DANIEL DE AVILA VIO

Ensaio sobre os Grupos de Subordinação, de Direito e de Fato, no Direito Societário Brasileiro

FACULDADE DE DIREITO DA UNIVERSIDADE DE SÃO PAULO

São Paulo

2014 
DANIEL DE AVILA VIO

N. ${ }^{\circ}$ USP 3109754

danielvio@usp.br

\section{Ensaio sobre os Grupos de Subordinação, de Direito e de Fato, no Direito Societário Brasileiro}

Tese de Doutorado apresentada ao Departamento de Direito Comercial, sob a orientação do Professor Doutor Erasmo Valladão Azevedo e Novaes França, como requisito parcial para a obtenção do título de Doutor em Direito Comercial.

São Paulo

2014 

Nome: Vio, Daniel de Avila

Título: Ensaio sobre os Grupos de Subordinação, de Direito e de Fato, no Direito Societário Brasileiro

Banca Examinadora: 
Ao pequeno Antonio, que cresceu ao lado destas páginas. 


\section{AGRADECIMENTOS}

Ao Professor Erasmo Valladão Azevedo e Novaes França, não apenas pela oportunidade de acesso ao Doutorado e pela inestimável e incansável orientação, mas também pelo exemplo inspirador de profunda dedicação ao estudo do Direito Comercial.

Ainda ao Professor Erasmo Valladão Azevedo e Novaes França e, outrossim, aos Professores Eduardo Secchi Munhoz e Francisco Satiro de Souza Junior, pelas correções, observações e sugestões apresentadas, inclusive por ocasião do exame de qualificação que, ainda que certeiras e essenciais, seguramente não livraram o ensaio de diversas falhas e imperfeições, pelas quais o candidato assume inteira responsabilidade.

A estes dois últimos, mas igualmente aos Professores José Alexandre Tavares Guerreiro e Mauro Rodrigues Penteado, pelas aulas ministradas e pelas oportunidades franqueadas ao debate ao longo do curso de Doutorado, imprescindíveis para o desenvolvimento do presente trabalho.

À Professora Érica Gorga, pela gentil autorização para a citação de artigo ainda em versão preliminar.

Nas pessoas de Jéssica e de Tânia, a todos bibliotecários, de mais de uma instituição, pelo indispensável auxílio no acesso aos textos e materiais empregados na pesquisa.

A diversos colegas, de vida acadêmica e profissional, pelo precioso apoio.

A Anna, Antonio, meus pais e minha irmã, por tudo. 


\section{RESUMO}

O trabalho tem por objeto a análise da disciplina jurídica, conforme fixada na Lei 6.404/1976, dos grupos de sociedades de subordinação, ou seja, aqueles pautados por relações hierarquizadas de controle societário, abrangendo tanto os grupos de fato (não formalizados por meio de convenção e regulados principalmente pelos artigos 245 e 246 da lei acionária) quanto os grupos de direito (sujeitos a convenção de grupo, estipulada consoante os artigos 265 e seguintes do referido diploma). A principal tese levantada, cuja verificação representa o objetivo central do estudo, é a de que o limitado uso dos grupos de direito na realidade brasileira se deve, sobretudo, à inefetividade da tutela judicial do conflito de interesses no âmbito dos grupos de fato. Como hipóteses de trabalho instrumentais a tal investigação, são analisadas questões como (i) a baixa difusão dos grupos de direito contraposta à ampla disseminação e à relevante função econômica dos grupos de fato na praxe empresarial brasileira, (ii) o alto nível de abuso do poder de controle (captura de benefícios privados do controle) na realidade do país e (iii) a inefetividade dos mecanismos judiciais de contraste ao abuso do poder de controle nas relações intersocietárias. A análise é amparada, principalmente, pelos métodos (i) histórico (investigação das origens da participação de sociedades no capital de outras sociedades), (ii) comparado (confronto pontual entre a disciplina brasileira e a de outros países, notadamente Alemanha, Itália e França) e (iii) dialético (confronto analítico de diferentes posições da doutrina). O estudo também toma por base dados empíricos extraídos de pesquisas de natureza econômica e de levantamentos oficiais, sem contudo empreender reelaboração estatística independente de tais informações. Os referidos dados trazem sólidos indícios que, argumenta-se, essencialmente confirmam as hipóteses de trabalho e a tese principal do estudo. Outros resultados e conclusões relevantes da pesquisa são: (i) a destacada função de fomento aos grupos e favorecimento da concentração econômica (Organisationsrecht) das normas brasileiras que tratam do fenômeno intersocietário, em contraposição ao objetivo de meramente proteger acionistas externos e credores (Schutzrecht); (ii) a rejeição da caracterização do grupo em si como uma sociedade de sociedades; (iii) a rejeição do conceito de interesse de grupo; (iv) a afirmação da natureza não apenas lícita, mas tipificada da organização da atividade empresarial na forma plurissocietária; (v) a obtenção de dados oficiais sobre a efetiva difusão dos grupos de direito, cujo número, apesar de baixo, excede as estimativas anteriores da doutrina; e (vi) a identificação da dificuldade de se comprovar em juízo o inadimplemento de deveres fiduciários de administradores e sociedades controladoras como elemento crítico por trás da inefetividade do sistema brasileiro de contraste ao abuso do poder de controle nas relações de grupo.

Palavras-chave: Grupo de sociedades. Grupo de subordinação. Grupo de direito. Grupo de fato. Empresa plurissocietária. Sociedade anônima. Poder de controle. 


\begin{abstract}
The scope of the research is to analyze the legal treatment, under Law 6,404/1976, of vertical groups of companies, i.e. those in which prevail hierarchical relations of corporate control. The analysis covers both de facto groups (that are not subject to a formal group agreement and are regulated mainly by articles 245 and 246 of Law 6,404/1976) and contractual groups (subject to a group agreement, executed in accordance with articles 265 et seq. of the same statute). The main thesis raised - confirmation of which is the central purpose of the research - is that the limited use of contractual groups in Brazil is, above all, the result of the ineffectiveness of judicial protection from conflicts of interest within de facto groups. As instrumental hypotheses supporting the analysis, the study comprises a review of issues such as: (i) the limited number of contractual groups, contrasting with the large diffusion and economic relevance of de facto groups within Brazilian businesses, (ii) the high level of abuse of corporate control (capture of private benefits of control) within the country and (iii) the ineffectiveness of judicial mechanisms aimed at contrasting abuse of corporate control in intercompany relations. The research is based mainly on the (i) historical (investigation of the origins of intercompany equity interests), (ii) comparative (comparison of Brazilian regulation of specific matters with that of other countries, mainly Germany, Italy and France) and (iii) dialectical (analytical opposition of different positions held by scholars) methods. The study is also based on factual data extracted from economical research and official assessments. However, such statistical information is not in any form independently processed. The collected data, it is argued, provides solid evidence confirming the main and supporting hypotheses of the study. Other material results and conclusions of the analysis are: (i) the significant function of promoting group formation and economic concentration (Organisationsrecht) of the Brazilian regulation of intercompany relation, as opposed to the purpose merely protecting external shareholders and creditors (Schutzrecht); (ii) the rejection of the qualification of groups themselves as companies formed by companies; (iii) the rejection of the concept of group interest; (iv) the defense of the lawful (but also expressly legally recognized) nature of the polycorporate business organization; (v) collection of official data on the effective use of contractual groups, which number is very limited but exceeds prior expectations of scholars; and (vi) identification of the difficulty to demonstrate in court the breach of fiduciary duties by managing officers and controlling companies as the critical cause of the lack of effectiveness of the Brazilian system of defense against abuse of corporate control in intercompany relations.
\end{abstract}

Keywords: Groups of companies. Vertical groups. Contractual groups. De facto groups. Polycorporate business enterprise. Corporations. Corporate Control. 


\section{RIASSUNTO}

La presente ricerca ha per oggetto l'analisi della disciplina giuridica, ai sensi della legge 6.404/1976, dei gruppi di società verticali, ovvero quei gruppi contraddistinti da rapporti gerarchizzati di controllo, siano essi gruppi di fatto (non formalizzati mezzo apposita convenzione di gruppo e regolati principalmente dal disposto negli articoli 245 e 246 della legge azionaria) o gruppi contrattuali (sottoposti a convenzioni di gruppo stipulate ai sensi degli articoli 265 e seguenti della stessa legge). La principale tesi articolata, la cui dimostrazione rappresenta l'obiettivo centrale dell'elaborato, è che il limitato uso dei gruppi contrattuali nella realtà brasiliana è dovuto, soprattutto, alla mancanza di effettività della tutela giudiziale del conflitto di interesse nell'ambito dei gruppi di fatto. Quali ipotesi di lavoro strumentali rispetto all'analisi principale, si valutano questioni come: (i) la modesta diffusione dei gruppi contrattuali contrapposta all'ampia utilizzazione e rilevante funzione economica dei gruppi di fatto nella prassi aziendale brasiliana, (ii) l'alto livello di abuso del potere di controllo (appropriazione di benefici privati del controllo) nella realtà del paese e (iii) la mancanza di effettività dei meccanismi giudiziali di contrasto all'abuso del potere di controllo nei rapporti tra società. L'analisi è basata principalmente sui metodi (i) storico (ricerca delle origini della partecipazione delle società nel capitale di altre società), (ii) comparato (confronto topico tra la disciplina brasiliana e le norme di altre nazioni, segnatamente Germania, Italia e Francia) e (iii) dialettico (confronto analitico tra le diversioni posizioni sostenute dalla dottrina). L'analisi fa leva anche su dati empirici derivati da ricerche economiche ed indagini ufficiali, senza però promuovere una rielaborazione statistica indipendente di tali informazioni. I summenzionati dati riportano solidi indizi che, così come si argomenta, nel corso dell'elaborato essenzialmente confermano le ipotesi di lavoro nonché la tesi principale della ricerca. Altri risultati e conclusioni rilevanti della ricerca sono: (i) la significativa funzione di stimolo alla formazione dei gruppi e di incentivo alla concentrazione economica (Organisationsrecht) delle norme brasiliane riguardanti il fenomeno intersocietario, in opposizione all'obiettivo di meramente tutelare azionisti esterni e creditori (Schutzrecht); (ii) l'opposizione alla qualificazione del gruppo di per sé come una società tra società; (iii) l'opposizione al concetto di interesse di gruppo; (iv) l'affermazione della natura non soltanto lecita bensì tipificata dell'organizzazione dell'attività aziendale attraverso la struttura plurisocietaria; (v) l'ottenimento di dati ufficiali in merito alla reale diffusione dei gruppi contrattuali, il cui numero, seppur contenuto, è superiore alle precedenti aspettative della dottrina; e (vi) l'identificazione della difficoltà della prova in giudizio dell'inadempimento da parte degli amministratori e società controllanti dei loro doveri fiduciari come elemento critico dietro l'assenza di effettività del sistema brasiliano di contrasto all'abuso del potere di controllo nei rapporti di gruppo.

Parole-chiave: Gruppo di società. Gruppo verticale. Gruppo contrattuale. Gruppo di fatto. Azienda plurisocietaria. Società per azioni. Potere di controllo. 


\section{Índice Analítico}

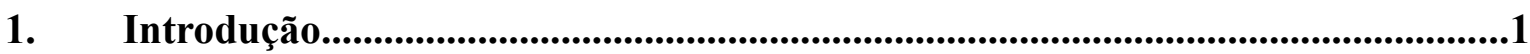

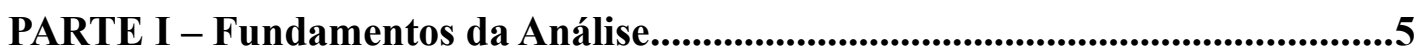

2. Desenvolvimento Histórico...........................................................................................5

2.1 Tardia Emergência dos Pressupostos Jurídicos dos Grupos.....................................5

2.2 Industrialização e Pressupostos Econômicos dos Grupos........................................18

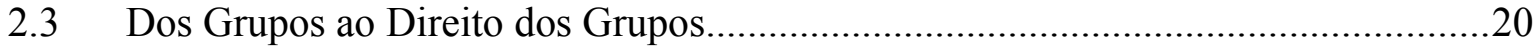

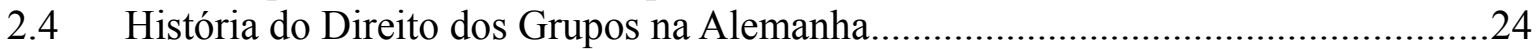

2.5 História do Direito Brasileiro dos Grupos............................................................29

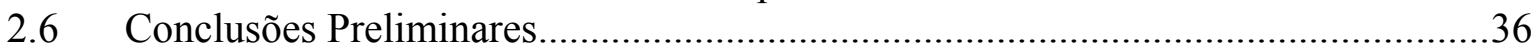

3. O Sentido Prático da Formação dos Grupos de Sociedades...............................38

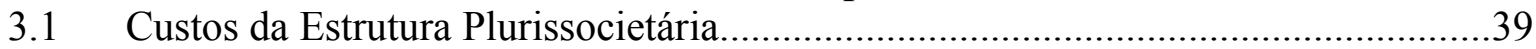

3.2 Funções e Benefícios Práticos da Estrutura Plurissocietária....................................42

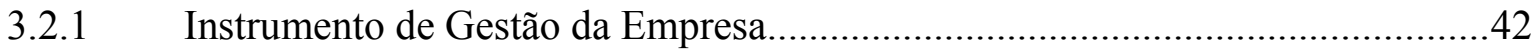

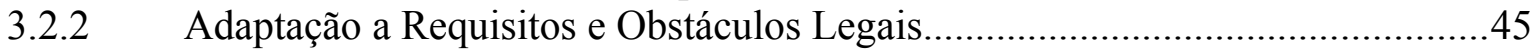

3.2.3 Acumulação de Poder com Investimento Reduzido...........................................47

3.2.4 Ambiente Institucional Adverso........................................................................52

3.2.5 Limitação da Responsabilidade e Compartimentação Patrimonial......................55

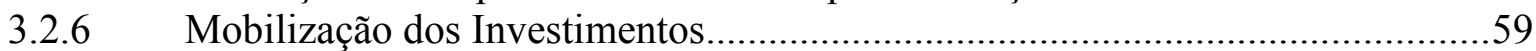

Conclusões Preliminares..............................................................................6

4. Fundamento Teleológico da Disciplina dos Grupos...............................................61

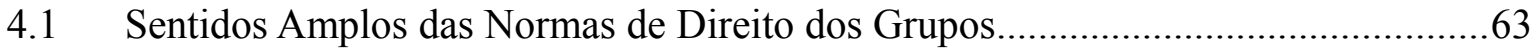

4.1.1 Grupos e Destinatário Substancial das Normas...................................................63

4.1.2 Tutela de Credores Hipossuficientes e Extracontratuais...................................67

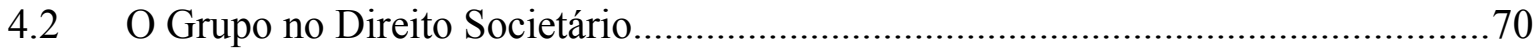

4.2.1 Representação da Situação Patrimonial da Sociedade...........................................71

4.2.2 Controle Societário e Conflito de Interesse nos Grupos.......................................75

4.2.3 O Conflito na Relação entre Sócios e Administradores.......................................78

4.2.4 O Conflito na Relação entre Credores e Sociedade............................................80

4.2.5 O Conflito na Relação entre Controlador e Minoritários.....................................83

4.3 Nota sobre Elemento Nacionalista da Disciplina dos Grupos...................................8

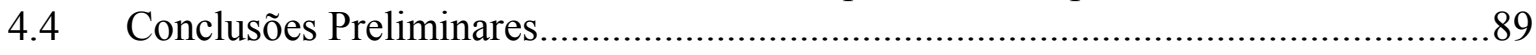

5. Notas sobre o Direito Estrangeiro Contemporâneo.............................................92

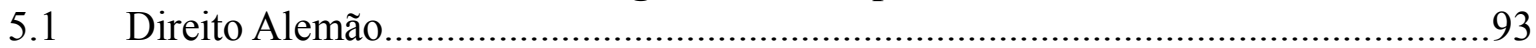

5.1.1 A Noção de Empresa (Unternehmen) para o Direito dos Grupos........................94

5.1.2 Categorias de Vínculos entre Empresas...............................................................97

5.1.3 A Operação de Integração (Eingliederung)......................................................102

5.1.4 Contratos de Empresa (Unternehmensvertäge) e Grupos de Direito.................104

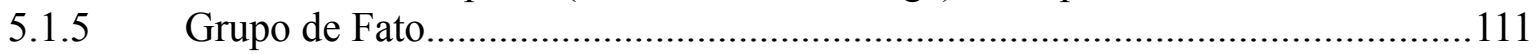

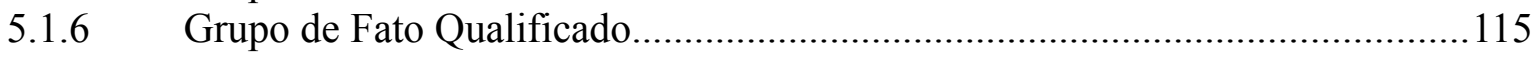




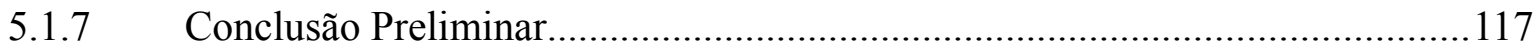

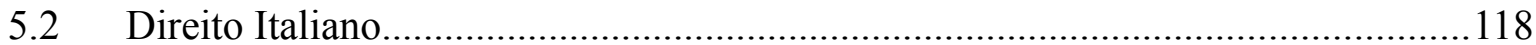

5.2.1 Atividade de Direção e Coordenação e Interesse Empresarial..........................119

5.2.2 Responsabilidade e Ação de Reparação..........................................................123

5.2.3 Deveres de Informação, Publicidade e Justificação............................................129

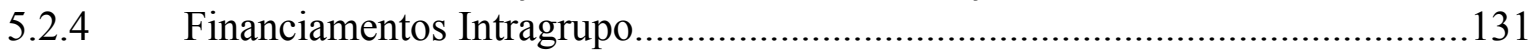

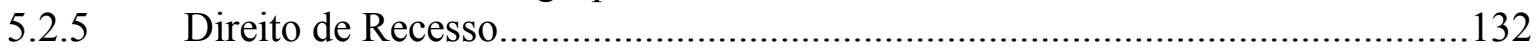

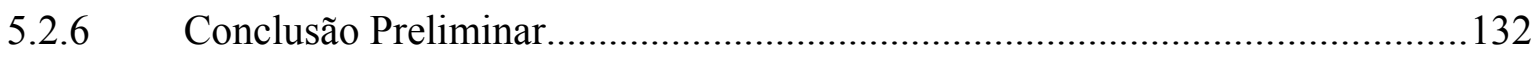

5.3 Breve Nota sobre Direito Francês e Doutrina Rozenblum......................................133

PARTE II - A Disciplina dos Grupos no Direito Societário Brasileiro.............139

6. Elementos Fundamentais das Técnicas Jurídicas de Agrupamento................139

6.1 Perfil Subjetivo do Grupo e Uso Efetivo do Controle.............................................141

6.2 Vínculos de Controle, Influência, Coligação e Direção Unitária............................151

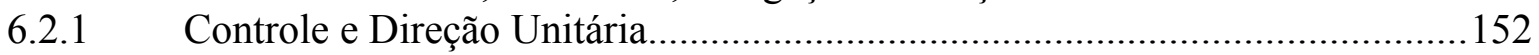

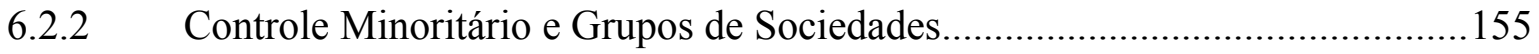

6.2.3 Controle Interno e Controle Externo................................................................158

6.2.4 Formação da Vontade na Sociedade Isolada e nos Grupos..............................161

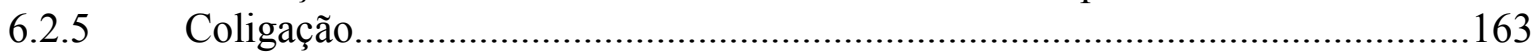

6.3 Fundamento Dogmático do Conceito de Grupo......................................................167

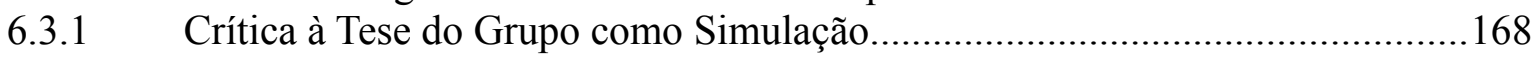

6.3.2 Crítica à Tese do Grupo como Sociedade de Sociedades....................................173

6.3.3 Tentativa de Definição Jurídica do Grupo........................................................ 179

6.4 Subordinação e Crítica ao Conceito de Interesse de Grupo....................................180

6.5 Breve Nota sobre os Consórcios de Sociedades....................................................188

6.6 Breve Nota sobre o Código Civil e Sociedades Não Acionárias............................190

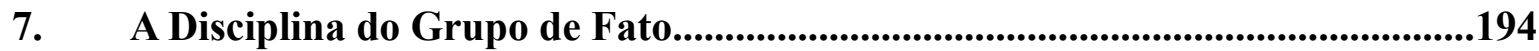

7.1 Disciplina dos Grupos de Fato e Interesse Social.................................................196

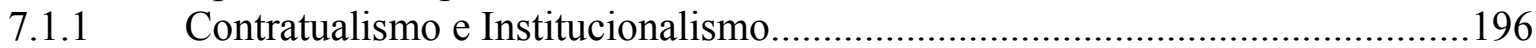

7.1.2 O Conflito de Interesses nas Operações Intragrupo.........................................201

7.2 Artigo 245 da Lei 6.404/1976 e a Posição dos Administradores.............................203

7.2.1 Autorização para Operações entre Partes Relacionadas....................................205

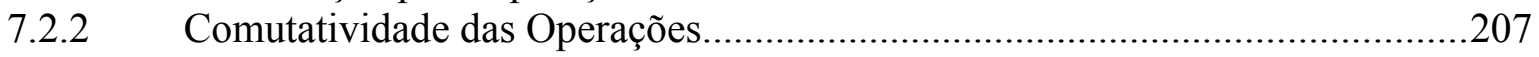

7.2.3 Pagamento Compensatório Adequado.........................................................2. 211

7.2.4 Responsabilização do Administrador.............................................................214

7.3 Artigo 246 da Lei 6.404/1976 e Sociedade Controladora......................................222

7.3.1 Remissão aos Artigos 116 e 117.....................................................................222

7.3.2 Natureza e Pressupostos da Ação de Responsabilização...................................224

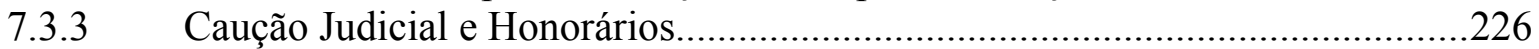

7.3.4 Prêmio sobre a Indenização........................................................................229

7.3.5 Legitimidade Passiva e Controle Indireto...................................................2232

8. A Disciplina do Grupo de Direito....................................................................236

8.1 Estrutura e Requisitos Essenciais do Grupo de Direito.......................................237

8.1.1 Controle Societário e Composição do Grupo...................................................237

8.1.2 Designação do Grupo e Uso da Expressão “Grupo".........................................242 
8.1.3 Nacionalidade da Sociedade de Comando e do Controle do Grupo.................244

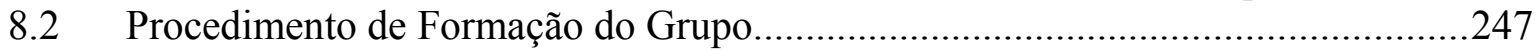

8.2.1 Aprovação pelos Sócios das Sociedades Convenentes......................................248

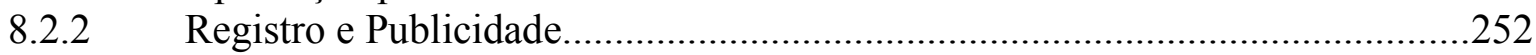

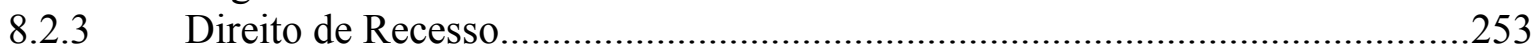

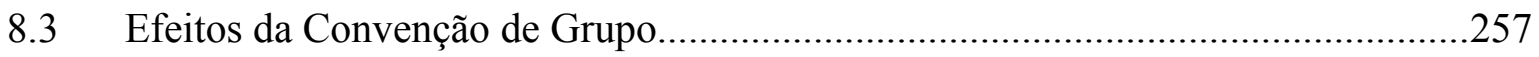

8.3.1 Legítima Subordinação de Interesses..........................................................258

8.3.2 Administração, Representação e Fiscalização.......................................................261

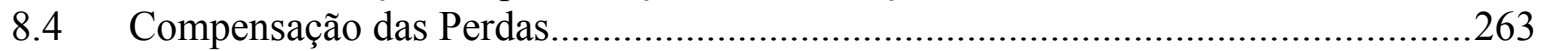

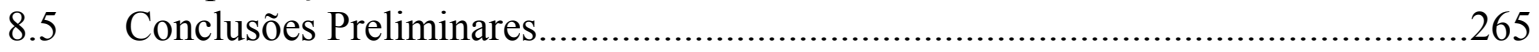

PARTE III - Crise da Disciplina Brasileira dos Grupos e Alternativas...........267

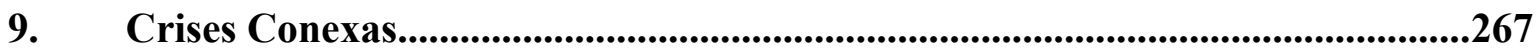

9.1 Crise de Desuso dos Grupos de Direito............................................................267

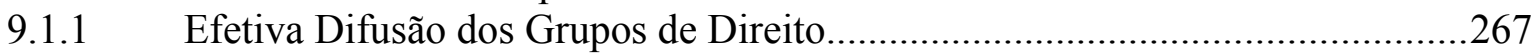

9.1.2 Possíveis Causas da Limitada Difusão dos Grupos de Direito.........................271

9.2 Crise de Efetividade da Disciplina dos Grupos de Fato........................................277

9.2.1 Difusão e Relevância Econômica dos Grupos de Fato......................................277

9.2.2 Evidências do Abuso de Controle nos Grupos de Fato.....................................280

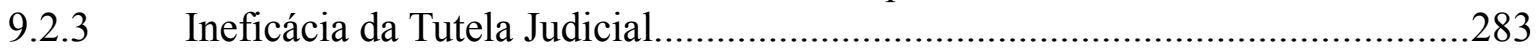

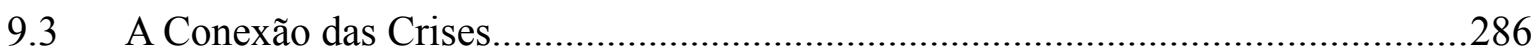

10. Anotações sobre Alternativas para a Disciplina dos Grupos..............................288

10.1 Crítica à Tese do Divórcio da Realidade...........................................................2290

10.2 Propostas e Mecanismos Julgados Inadequados...................................................292

10.2.1 Exclusão ou Relativização da Limitação da Responsabilidade...........................294

10.2.2 Vedação de Operações Intragrupo e Impedimento de Voto................................298

10.3 Alternativas para o Desenvolvimento do Direito dos Grupos...............................299

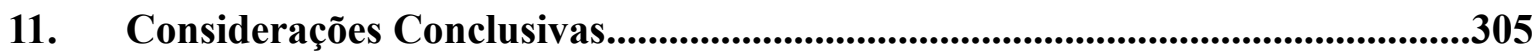

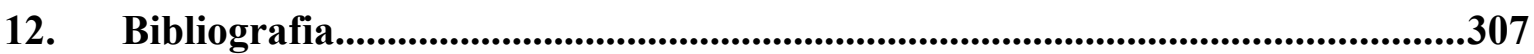


“... einen Drachen mit vielen Häuptern”"

Herbert Wiedemann

\section{Introdução}

Em interessante obra de caráter não acadêmico, Micklethwait e Wooldridge argumentam que a sociedade personificada possui a maior parte das prerrogativas legais das pessoas naturais e, ao mesmo tempo, por estar emancipada dos cruéis limites impostos pela biologia, goza de significativas vantagens, tais como, por exemplo, a imortalidade e a possibilidade de se "reproduzir" com ampla liberdade ${ }^{2}$.

Ressalvado o fato de que as normas jurídicas são, em última análise, sempre redutíveis a atos humanos ${ }^{3}$, cumpre reconhecer que, no momento em que duas ou mais sociedades são articuladas sob o domínio de um controlador final, emerge uma nova criatura, cujos benefícios comparativos sobre a pessoa natural podem facilmente eclipsar aqueles já existentes em favor da sociedade isolada. Com efeito, o grupo de sociedades sob vínculo de subordinação não apenas é potencialmente imortal - e definitivamente mais resiliente a adversidades do que a sociedade isolada -, mas é extremamente fluído, seus contornos, sua aparência e seu conteúdo podem rapidamente mudar de acordo com as circunstâncias e conveniências; apenas a preponderância da vontade do controlador final permanece como elemento estável e vínculo comum de ligação.

Trata-se de fenômeno em que a unicidade de domínio convive com a multiplicidade, fragmentarismo e mutabilidade de estruturas. O grupo é capaz, por exemplo, de assumir diferentes nacionalidades ou de movimentar a massa total de recursos que possui entre as diversas células societárias que o compõem com relativa facilidade.

1 Tradução livre: "[...] um dragão de muitas cabeças" in H. WIEDEMANN, Die Unternehmensgruppe im Privatrecht, p. 10.

2 "As sociedades provaram ser enormemente poderosas, não apenas porque elas aumentam a produtividade, mas também porque elas possuem a maior parte dos direitos legais do ser humano, sem as correspondentes desvantagens da biologia: elas não estão condenadas a morrer de velhice e podem criar uma prole essencialmente como bem entenderem". Tradução livre de: "Companies have proved enormously powerful not just because they improve productivity, but also because they possess most of the legal rights of a human being, without the attendant disadvantages of biology: they are not condemned to die of old age and they can create progeny pretty much at will." in J. MICKLETHWAIT, A. WOOLRIDGE, The Company - A Short History of a Revolutionary Idea, p. xv.

3 T. ASCARELLI, Saggi di Diritto Commerciale, p. 164-165. 
Esse potencial pode tanto ser utilizado para isolar riscos e agregar capitais, quanto para evadir deveres e obrigações. Desnecessário salientar que um ente com tais feições representa uma notável ferramenta para os empreendedores, um enorme desafio para o ordenamento e um tema de investigação quase inesgotável para a pesquisa jurídica.

A abordagem de matéria tão ampla e intrincada, que se sobrepõe e entrelaça com tantos temas extremamente relevantes para o Direito - como interesse, vontade e personalidade - exige notável esforço de delimitação. Nesse sentido, o primeiro recorte é de âmbito nacional: o presente trabalho tem como objetivo investigar a disciplina jurídica brasileira dos grupos de sociedades. Importante enfatizar, ademais, que o foco da análise é o grupo de sociedades, sob o ponto de vista exclusivo do direito societário. As diversas noções de grupos econômicos e grupos de empresas, previstas pelas normas tributárias, trabalhistas, ambientais e consumeristas serão abordadas apenas de forma incidental e com o único propósito de explicitar as principais idiossincrasias do conceito societário de agrupamento.

De qualquer forma, mesmo dentro dos limites mais estreitos do direito societário, o tema resta vasto e exige maior delimitação. De fato, em sua acepção mais ampla, o regime dos grupos compreende todas as questões relativas à titularidade, direta e indireta, de participação ou influência, por parte de uma sociedade em outra, ou ainda, de um mesmo sócio em diversas sociedades. Ou seja, diz respeito a temas como o consórcio de sociedades, a sociedade unipessoal, as participações recíprocas, todas as formas de coligação e controle, as sociedades sob controle comum e a transferência do controle, além de todos os deveres que derivam de tais situações, como o levantamento e a publicação de demonstrações financeiras consolidadas ou o impedimento à nomeação de membros do conselho fiscal.

Por outro lado, se considerada a concepção mais estreita possível, o objeto do estudo encontraria em seu núcleo os "grupos de direito", disciplinados pelos artigos 265 e seguintes da Lei 6.404/1976, cujas características estruturais e unicidade orgânica são explicitadas e formalizadas por meio da celebração de específica convenção, arquivada no Registro de Empresa.

$\mathrm{O}$ enfoque do trabalho encontra-se a meio caminho entre esses dois extremos. $\mathrm{O}$ tema principal é a relação entre grupos de direito e "grupos de fato" - expressão cunhada 
pela doutrina para indicar um conceito que se depreende da interpretação sistemática dos artigos $243, \S 2^{\circ}, 245$ e 246 da própria lei acionária -, com atenção especial para a crise de ambos os institutos enquanto mecanismos de tutela do conflito de interesse na empresa "plurissocietária" ". Nesse sentido e já em transição da apresentação do objeto para a indicação dos objetivos do estudo, a pesquisa se estruturará ao redor de uma tese principal: a de que a falência do modelo dos grupos de direito no Brasil deve necessariamente ser lida como um sintoma da ineficácia dos mecanismos existentes para a tutela do conflito de interesse nos grupos de fato. A pesquisa almeja demonstrar a conexão entre ambos os fenômenos e apontar algumas de suas possíveis causas profundas.

O trabalho se articula em três partes principais. A primeira delas trata dos pressupostos conceituais para o restante da análise e é composta pelos Capítulos 2 a 5 , que lidam, respectivamente, com (i) o processo de afirmação histórica dos grupos de sociedades e de seu estatuto jurídico específico, (ii) as razões práticas que compelem os empreendedores a adotar a forma plurissocietária, (iii) os fundamentos teleológicos da disciplina societária dos grupos e, enfim, (iv) o tratamento da matéria em algumas outras legislações selecionadas.

A segunda parte tem como objeto a disciplina brasileira, frise-se, societária e contemporânea, dos grupos de sociedades. O Capítulo 6 aborda conceitos gerais relevantes tanto para os grupos de fato quanto para os agrupamentos regulados por convenção. As questões específicas atinentes a cada uma destas duas fattispecie dos grupos societários são discutidas, respectivamente, nos dois capítulos seguintes.

O Capítulo 9 inaugura a parte terceira e final e do trabalho, trazendo alguns dados empíricos sobre a difusão e o peso econômico dos grupos em nossa realidade, para em seguida apontar os elementos que - argumenta-se - indicam uma forte crise no modelo de regulamentação de ambas as modalidades de agrupamento das sociedades. O Capítulo 10

4 Expressão muito difusa na doutrina portuguesa, que acabou sendo incorporada no Brasil e traduz convenientemente a noção de unidade de organização da atividade empresarial associada à multiplicidade de veículos societários. O Professor José Engrácia Antunes, que se dedicou extensivamente ao tema dos grupos, a emprega repetidamente em sua obra. Exemplo: J. ANTUNES, Estrutura e Responsabilidade da Empresa: O Moderno Paradoxo Regulatório, p. 35. O termo parece anterior e de uso mais difuso que outras alternativas, como "polissocietária" (D. ARAUJO, A Doutrina Rozenblum do Direito Francês; o Reconhecimento do Caráter Exoneratório dos Grupos de Sociedades em Matéria de Crimes de Abus de Biens Sociaux e a Consequente Influência do Direito Penal na Estruturação e no Funcionamento dos Grupos de Sociedade, p. 113) ou "multissocietária", por isso é a forma empregada neste trabalho. 
traz considerações sumárias sobre possíveis alternativas para o aprimoramento do sistema, enquanto que o Capítulo 11 contém as considerações conclusivas do trabalho. 


\section{PARTE I - Fundamentos da Análise}

\section{Desenvolvimento Histórico}

\subsection{Tardia Emergência dos Pressupostos Jurídicos dos Grupos}

Ao tratar das raízes históricas da sociedade em comandita, Goldschmidt relatou a existência, na zona do Mediterrâneo, já em meados do século XII, de um cenário complexo e articulado de entrelaçamento de participações, com sócios tractactor que recebiam fundos e bens de vários sócios capitalistas e os reinvestiam, valendo-se igualmente do negócio de commenda e confiando os respectivos recursos a diversos outros sócios "subcomanditados".

A natureza fortemente "internacional" - no sentido de envolver diferentes unidades políticas e geográficas, que evidentemente não correspondiam aos contemporâneos Estados nacionais - da atividade mercantil em tal período exigia, outrossim, a formação de sofisticadas redes de colaboração entre comerciantes, que eram muitas vezes a continuação de vínculos familiares ${ }^{6}$.

É célebre o exemplo do Banco Médici ${ }^{7}$, que mantinha presença em inúmeras cidades europeias por meio da constituição de diversas sociedades de pessoas, uma para cada praça ou empreitada de relevo, tendo como sócios os membros da família Médici e

5 "[...] especialmente em Gênova e Marselha, [havia] uma quase estonteante multiplicidade de acordos diversos, também no que diz respeito à participação nos custos e investimentos, e o capital social original se tornava frequentemente a parcela dos lucros do tractator, mesmo que inteiramente à custa de outras comendas contratadas simultaneamente, de modo que se formava uma crescente 'conta corrente de capital da sociedade'. Ocorria, ademais, que todos ou vários deles encontrassem paralelamente, por si sós ou por meio de tractatores alternativos, investidores e que o tractactor pudesse aplicar o capital recebido novamente em commendam (societatem), ou seja, entendia-se autorizada a estrutura 'subconsorcial'. Tudo isso já no Século XII." Tradução livre de: “...insbesondere in Genua und Marseille, eine fast verwirrende Mannigfaltigkeit abweichender Vereinbarungen, auch hinsichtlich der Beteheiligung an Kosten und Auslagen, und dem ursprünglich Gesellschaftskapital wird häufig der Gewwinnantheil des tractator, auch wohl aus anderen gleichzeitigen Kommenden hinzugeschlagen, so daß ein wachsendes „, Kapital Kapitalkonto der Sozietät“ besteht. Es begegnet ferner, daß alle oder doch mehrere Kapitaleinleger zugleich schlechthin oder alternativ tractatores find und daß der tractactor das empfangene Kapital weiter in commendam (societatem) geben darf, d.h. „Unterconsortialen “ anzunehmen befugt ist. All dies bereits in 12. Jahrhundert." in L. GOLDSCHMIDT, Universalgeschichte des Handelsrechts, p. 263-264.

6 F. BRAUDEL, Espansione Europea e Capitalismo - 1450-1650, p. 52-53.

7 "A família Medici criou, indisputavelmente, o primeiro caso histórico de grupo societário - e grupo multinacional - de que se tem notícia." in F. COMPARATO, Na Proto-História das Empresas Multinacionais: O Banco Medici de Florença, p. 261. 
parceiros do lugar ${ }^{8}$, mas sempre preservando o comando central dos primeiros a partir de Florença9 .

A referida estrutura chegou inclusive a suscitar questões de notável atualidade para a análise do direito dos grupos. Vale mencionar, por exemplo, processo movido por Damiano Ruffini contra Tommaso Portinari, um dos sócios dos Médici e responsável pela unidade do "grupo" em Bruges, no ano de 1453. Ruffini buscava o ressarcimento por quatro cargas de lã que havia comprado da unidade dos Médici estabelecida em Londres, mas que recebeu danificadas por terem sido embaladas inadequadamente. Portinari conseguiu se esquivar de qualquer responsabilidade afirmando, sob juramento, que a unidade de Bruges - ainda que inequivocamente vinculada à família Médici - representava uma sociedade distinta daquela inglesa e que não havia participado de qualquer modo na venda em questão ${ }^{10}$. Já aí o embrião da dicotomia entre autonomia jurídica das partes e unidade de comando do todo.

No entanto, apesar desses notáveis protótipos precoces de complexa organização empresarial, o moderno grupo de sociedades é um fenômeno relativamente recente na longa e tortuosa história do direito societário; um produto da Revolução Industrial que somente na segunda metade do século XIX assumirá seus contornos essenciais e apenas no século XX receberá tratamento legislativo específico e minimamente pormenorizado.

Essa maturação "tardia" do instituto se explica pelo fato de o grupo de sociedades, especialmente o grupo de subordinação na acepção contemporânea do conceito, ter como

8 "Em contraste com essas duas outras sociedades [as estruturas de uma só sociedade dos Bardi e dos Peruzzi], a casa bancária dos Médici não era formada por uma sociedade, mas uma combinação delas. Uma sociedade era formada para cada empreitada dos Médici [...] Ao se estudar a organização da casa bancária dos Médici, não se pode não perceber o quanto ela se assemelha a uma sociedade holding. A comparação é válida em mais de um aspecto. Os Médici controlavam a sociedade subsidiária por meio da propriedade de mais de 50 por cento do capital. [...]”. Tradução livre de: “In contrast with these two companies, the Medici banking house was not one partnership but a combination of partnerships. A separate partnership was formed for each of the Medici enterprises [...] In studying the organization of the Medici banking house, one cannot fail to notice how closely it resembles that of a holding company. The comparison is valid in more than one respect. The Medici controlled the subsidiary partnerships by owning at least 50 per cent of the capital. [...]" in R. ROOVER, The Medici Bank Organization and Management, p. 29. O controle era também reforçado pelo direito de dissolução da sociedade a qualquer tempo, bem como pela exclusividade no direito ao uso do nome ("marca") da família.

9 "O escritório principal do Banco Médici em Florença podia atuar tanto como representante quanto representado de qualquer uma de suas filiais." Tradução livre de: "The main office of the Medici Bank in Florence could act either as agent or as principal of any of its branches." in R. ROOVER, The Medici Bank Financial and Commercial Operations, p. 155.

10 R. ROOVER, The Medici Bank Organization and Management, p. 31 
pressupostos algumas das mais avançadas características do direito societário, ausentes nas sociedades em comandita ou em nome coletivo do período medieval e, mesmo quando presentes nas grandes companhias dos séculos XVII e XVIII, indisponíveis no mais das vezes para a aplicação quotidiana pelos empreendedores em suas iniciativas privadas.

Com efeito, tanto em seu uso - compartimentação do risco e ampliação do poder do empreendedor na posição de comando - quanto em seu abuso - prejuízo injusto a acionistas externos e credores -, o grupo apenas pode se materializar plenamente na presença de (i) autonomia patrimonial das sociedades que o compõem, (ii) limitação da responsabilidade dos sócios, (iii) deliberação pelo princípio majoritário e (iv) confirmação da possibilidade de participação de uma sociedade no capital de outra. A esses elementos estruturais ou essenciais é possível somar, também, a (v) facilidade prática na constituição da sociedade que reúna as características mencionadas acima, sem a qual o instituto não pôde alcançar o seu pleno potencial.

Em relação aos dois primeiros pontos, cumpre observar que se as peças elementares do grupo - as diversas sociedades que o integram - não tivessem uma existência jurídica própria, um grau mínimo de separação umas das outras, não haveria como se verificar na prática aquela contradição entre individualidade formal de cada sociedade e unicidade substancial de comando e coordenação do grupo como um todo, que é tão central à presente discussão. Tal entrechoque entre individualidade e unicidade, parte e todo, é um dos pilares da disciplina jurídica e da doutrina sobre este tema. Se a sociedade não dispõe de autonomia formal mínima, que crie em acionistas minoritários e em credores a expectativa legítima da persecução de um interesse próprio do ente societário, o qual possa se chocar com os anseios de quem comanda o grupo, não há então conflito a ser tutelado. $\mathrm{O}$ atrito entre a projeção pública de uma autonomia formal e a sujeição de fato a uma vontade "externa" que impõe unidade econômica é justamente a razão de ser do moderno direito dos grupos.

Além disso, se a sociedade ainda representasse pouco mais que uma mera soma de vínculos obrigacionais, mesmo que de natureza associativa, ela dificilmente poderia se tornar, simultaneamente, sujeito e objeto de intrincadas relações de propriedade - outro aspecto elementar dos atuais grupos de sociedades. Nesse sentido, a formação dos grupos parece ser indissociável do surgimento e da afirmação da sociedade personificada. 
A atribuição da personalidade jurídica às sociedades tem suas raízes conceituais remotas nas corporações eclesiásticas medievais, cujos bens eram a propriedade de Deus e não dos indivíduos que os administravam, o que permitia ao corpus mysticum perdurar intacto após a morte ou substituição dos membros de mosteiros e organizações assemelhadas ${ }^{11}$. A corporação possuía, portanto, existência jurídica autônoma, separada e independente daquela de seus integrantes.

A plena transposição dessa ideia para o campo das sociedades comerciais, porém, foi extremamente lenta. Os estatutos do primeiro Banco do Brasil, aprovados por meio do Alvará de 12 de outubro de 1808, já continham em seu artigo V referência à expressão "corpo moral"12. Ainda assim, mesmo o Código Comercial de 1850 evitou referências expressas a uma discussão julgada ainda não inteiramente pacificada e, dessa forma, a questão do reconhecimento da personalidade jurídica das sociedades só foi definitivamente resolvida no Brasil com a promulgação do Código Civil de $1916^{13}$.

Os mesmos argumentos se aplicam, ainda que em menor medida, à limitação da responsabilidade do sócio. Sem esta, o grupo não pode atingir o seu pleno potencial em termos de segregação e diversificação de risco e, portanto, de facilitação da associação de investidores ao redor de novos projetos. Por outro lado, se os sócios respondem, mesmo que apenas subsidiariamente, pelas dívidas de cada sociedade em todos os estágios da pirâmide societária, as obrigações podem eventualmente atingir pessoalmente aquele que se encontra em seu pináculo, limitando sobremaneira a possibilidade de abuso, mas igualmente as vantagens práticas decorrentes do recurso a essa estrutura. Também neste caso, para o bem e para o mal, é difícil vislumbrar efetivo grupo de subordinação se à personalidade jurídica não vier a se somar a limitação da responsabilidade dos sócios.

Com isso não se quer dizer que um grupo de subordinação não possa compreender, por exemplo, participações em sociedade em conta de participação ou em

11 O. GIERKE, Das Wesen der menschlichen Verbände, p. 14-15. A. LAMY FILHO, J. PEDREIRA, A Lei das S.A., vol. I, p. 30.

12 A redação completa do artigo, que estabelecia o princípio de não discriminação de acionistas estrangeiros, era a seguinte: "Art. V. É indifferente serem, ou não os accionistas nacionaes ou estrangeiros; e portanto toda e qualquer pessoa, que quizer entrar para a formação deste corpo moral o poderá fazer sem exclusão alguma, ficando unicamente obrigado a responder pela sua entrada".

13 Cujo artigo 16, pela primeira vez, confirmou de maneira peremptória a personalidade jurídica das sociedades civis (inciso I) e das sociedades mercantis (inciso II). E. TEIXEIRA, Das Sociedades por Quotas de Responsabilidade Limitada, p. 20. 
comandita por ações ${ }^{14}$. A questão é que se o grupo não tivesse como elemento constitutivo elementar a sociedade personificada com responsabilidade limitada dos sócios, os fatores justificadores de sua adoção prática (Capítulo 3) e da criação de sua disciplina jurídica (Capítulo 4) estariam presentes de forma anêmica ou meramente embrionária.

Sob tal perspectiva, cumpre recordar que a limitação da responsabilidade de todos os sócios surge apenas com as companhias coloniais e, conforme discutido adiante, somente adquire maior difusão com a superação do regime de privilégio legal na constituição das sociedades anônimas. Tal benefício, contudo, apenas estará disponível para empreendimentos de menor porte e uso massificado, ainda mais tarde, com a criação das sociedades não acionárias com responsabilidade limitada, entre o final do século XIX e início do século XX. O modelo da $G m b H$ alemã de 1892 apenas encontraria um correspondente nacional com a criação da sociedade por quotas de responsabilidade limitada, por meio do célebre Decreto 3.708/1919.

A noção de grupo, principalmente a de grupo de subordinação, está outrossim umbilicalmente ligada ao conceito de controle societário. Porém, há pouco ou nenhum sentido em se falar de controle sobre a sociedade, no sentido contemporâneo da expressão, sem o mecanismo de deliberação pelo voto da maioria. Em sua ausência, também não se pode cogitar da gradual separação entre propriedade e controle do capital ${ }^{15}$, fenômeno extremamente relevante para os grupos.

$\mathrm{Na}$ atualidade, pode parecer perfeitamente natural e óbvio que as decisões na sociedade sejam tomadas pelo voto da maioria, apurada em relação ao capital total ou entre os sócios presentes em determinado conclave. Afinal, o investimento total aportado na sociedade é uma expressão do risco assumido e deve, em alguma medida, ser proporcional à influência do sócio nas deliberações sociais. Além disso, a imobilidade decorrente das situações de impossibilidade de se alcançar decisão unânime é incompatível com o dinamismo típico dos negócios. Entretanto, a afirmação histórica do princípio majoritário foi lenta e gradual ${ }^{16}$. Trata-se, efetivamente, de regime fortemente contrário à lógica

14 Questão discutida no Capítulo 6.

15 A. BERLE, G. MEANS, The Modern Corporation and Private Property, p. 5-6.

16 "O principio majoritário não esteve, de forma alguma, sempre em vigor. Ele não se afirmou sem antes passar por longos embates históricos e, ao fazê-lo, sem percorrer diversos níveis de desenvolvimento." Tradução livre de: "Das Majoritätsprinzip hat keineswegs von jeher in Kraft gestanden. Es hat sich erst in langen geschichtlichen Ringen durchgesetzt und dabei sehr verschiedene Entwicklungsstufen 
garantista e individualista do Direito Privado romano, hostil a qualquer flexibilização do domínio inerente ao direito de propriedade ${ }^{17}$.

Em período histórico posterior, a deliberação majoritária se demonstraria, igualmente, pouco compatível com a responsabilidade solidária e ilimitada dos sócios no âmbito da sociedade medieval - que, ao contrário da societas romana, não tinha eficácia estritamente interna. De fato, é drástico e injusto que um sócio responda com todo o seu patrimônio - ainda que subsidiariamente - pelos efeitos de decisões tomadas contra a sua vontade. É por esta razão que existe forte vinculação, lógica e histórica, entre a limitação da responsabilidade do sócio e o princípio majoritário.

Esse fator explica porque o Código Comercial de 1850 ainda tratava a unanimidade como regra geral para todas as operações não previstas expressamente pelo contrato social (artigo 331), aplicando-se o critério da maioria por quinhão de capital às demais hipóteses (artigo 486). Mesmo o Código Civil de 2002, ao tratar da sociedade simples - mas a disciplina se estende às sociedades não acionárias pautadas pela responsabilidade ilimitada de ao menos uma classe de sócios - teve de contrapor ao princípio majoritário (artigo 1.010, caput) a possibilidade de retirada do sócio (nos termos do artigo 1.029), ad nutum na sociedade contratada por tempo indeterminado, por justa causa nas demais.

Como exemplos de resquício do princípio da unanimidade, é possível citar ainda (i) a deliberação de transformação da sociedade, sujeita à aprovação de todos os quotistas ou acionistas (artigo 221 da Lei 6.404/1976 e artigo 1.114 do Código Civil de 2002), uma vez que afeta aspectos fundamentais da estrutura societária; (ii) a distribuição desproporcional das ações resultantes do aumento de capital por incorporação de parcela cindida (Lei 6.404/1976, artigo 229. § 5º ou (iii) a mudança de nacionalidade da sociedade

durchlaufen." in O. GIERKE, Über die Geschichte des Majoritätsprinzips, p. 8.

17 "O princípio da maioria vigia no senado de Roma, bem como nos municipia, nos collegia e nos sodalitia, como indicado, mas é essencialmente desconhecido no Direito privado romano, no qual predominava o princípio da unanimidade"; e, ainda: "Outro campo no qual prevalece o princípio da unanimidade é o da administração da societas, ou seja, do contrato com o qual uma pluralidade de pessoas se obriga a desenvolver uma atividade comum por um fim comum". Tradução livre de: "Il principio di maggioranza vige nel senato di Roma, oltre che nei municipia, nei collegia e nei sodalitia, come si è detto, ma è pressoché sconosciuto al diritto privato romano, nel quale predomina il principio di unanimità."; e "Altro terreno nel quale domina il principio di unanimità è quello dell'amministrazione della societas, ossia del contratto con il quale più persone si impegnano a svolgere una comune attività per un fine comune." in F. GALGANO, La Forza del Numero e la Legge della Ragione, respectivamente, p. 56 e 58. 
(Decreto-Lei 2.627/1940, artigo 72, Código Civil de 2002, artigo 1.127). Resta claro, portanto, que a deliberação por unanimidade não é, tampouco, tema tão distante e perdido no passado remoto do direito societário quanto poderia se imaginar.

Mesmo após a afirmação da autonomia patrimonial, da personalidade das sociedades e consolidação do princípio majoritário, restava ainda por ser desatado o nó da participação da sociedade como sócia. Em princípio, tal possibilidade é uma decorrência perfeitamente lógica da personificação da sociedade. Reconhecido o status de pessoa, não haveria porque impedir a sociedade de ser titular de quota ou ações de outra e exercer, por meio de seus órgãos, os direitos inerentes a tal participação.

Ainda assim, a análise histórica e comparada traz exemplos de focos de resistência à ideia da sociedade como sócia, que atestam a nítida percepção de parte da doutrina e dos julgadores, vigente no final do século XIX e início do XX, de que tais arranjos representariam um grave desvirtuamento do instituto societário. O problema se divide essencialmente em dois, (i) a admissibilidade, em si mesma, da participação de uma sociedade em outra e (ii) a possibilidade de que uma sociedade exerça o poder de controle sobre outra. A ênfase sobre uma e outra questão depende do país e do momento histórico que se analisa.

Na Alemanha, ao contrário da maioria dos outros países, parece ter prevalecido a questão do controle intersocietário, muito mais do que a da simples participação, com a preocupação de que o domínio de uma sociedade sobre a outra representasse uma expropriação do poder da assembleia geral desta última e, consequentemente, delegação de fato da administração social a um terceiro, totalmente estranho em relação aos órgãos sociais formalmente estabelecidos. De acordo com Hommelhoff, tais questões relativas aos limites do exercício do poder de subordinação, sem a desnaturação da sociedade controlada - refletidas nas decisões judiciais emanadas nos casos "Rumänischen Eisenbahn" de 1881 e "Petroleum" de 1931 -, seriam apenas definitivamente assentadas com a promulgação da lei acionária de $1965^{18}$.

Nos Estados Unidos, a despeito de sua rápida industrialização e dinamismo econômico, a ideia dominante no período em questão era a de que a participação de uma

18 P. HOMMELHOFF, Die Konzernleitungspflicht, p. 2-3. 
companhia no capital social de outra, se não contemplada expressamente no respectivo estatuto - que, cumpre recordar, estava no mais das vezes sujeito à aprovação prévia das autoridades políticas do respectivo Estado - ou em lei específica (statute), representaria um ato ultra vires ${ }^{19}$.

Normas específicas ocasionalmente afastavam tal vedação para determinados setores estratégicos, nos casos em que - notadamente para as sociedades que construíam e administravam linhas ferroviárias e de telégrafo - a necessidade de atrair investimentos sobrepujava o arraigado receio em relação à estrutura plurissocietária.

É justamente em razão da necessidade de contornar tais restrições legais à existência da sociedade sócia, ou seja, à formação de sociedades holding, que diversos movimentos de concentração econômica nos Estados Unidos, na segunda metade do século XIX, encontraram no negócio jurídico do trust um dos principais instrumentos para a organização dos grupos ${ }^{20-21}$.

19 Escrevendo em 1903, Edward Harriman contestava com veemência tal argumento. "O exercício do direito de propriedade por uma companhia não pode nunca ser questionado com base no argumento de que a aquisição da propriedade é um ato ultra vires. Além disso, não é razoável se falar de um acionista como se ele exercesse a atividade empresarial desenvolvida pela companhia". Tradução livre de: "The exercise of the rights of an owner by a corporation can never be questioned on the ground that the acquisition of the property is ultra vires. Moreover, it is unsound to speak of a stockholder as engaging in the business carried on by the corporation." in E. HARRIMAN, Voting Trust and Holding Companies, p. 117.

20 O negócio jurídico de trust - que guarda algumas semelhanças com o mandato, com o fideicomisso e até mesmo com as fundações - é um tradicional instituto do direito anglo-saxão por meio do qual um sujeito (settlor) cede a titularidade sobre certos bens ou direitos a um determinado agente (trustee) para que, sob vínculo fiduciário, sejam administrados no melhor interesse de um terceiro (beneficiary). $\mathrm{O}$ instituto possui aplicação ampla, não se limitando ao direito societário ou à concentração econômica. E. SALOMÃO NETO, Trust e Deveres de Lealdade e Sigilo na Sociedade Anônima Brasileira, p. 295-296.

21 "Nos termos das leis de Ohio, a Standard Oil Company (de Ohio) não poderia ser titular de participação no capital de outras sociedades nem operar fora do Estado. Na verdade, porém, as sociedades Standard Oil eram administradas a partir da 26 Broadway, em Nova Iorque. Em 1879, uma primeira solução jurídica para esse problema foi encontrada, um acordo de trust [...] $O$ acordo de trust de 1879 resolveu o problema da propriedade de ações e da detenção de controle em outros estados, mas não era adequado para permitir a expansão da base de acionistas e, ao mesmo tempo, preservar o controle nas mãos dos Rockfeller. O advogado da Standard Oil, Samuel C. T. Dodd concebeu então o segundo acordo de trust, que era uma obra prima jurídica e foi extremamente influente. As ações de todas as sociedades Standard Oil foram colocadas em único trust com nove trustees, que exerciam o controle central sobre todas as sociedades Standard Oil, mas que formalmente não eram proprietários de nada". Tradução livre de: "Under the Ohio corporation law the Standard Oil Company (Ohio) could not own stock in other corporations and operate outside the state. In reality the Standard Oil Companies were run from 26 Broadway in New York. In 1879 a first legal solution to this problem was found, a trust agreement [...] The 1879 trust agreement solved the problem of interstate ownership and control but was not suitable for expanding the shareholder base while keeping control in Rockfeller hands. Standard's oil solicitor, Samuel C. T. Dodd, devised the second trust agreement, which was a legal masterpiece and extremely influential. The shares of all Standard Oil companies were placed in a single trust with nine trustees, who exerted central control over all Standard Oil companies but formally did 
O empresário John Davison Rockfeller foi um dos pioneiros no emprego desse instituto como ferramenta para a concentração econômica. Com efeito, a partir de 1882, a estrutura do trust teve um papel fundamental para permitir que a sua Standard Oil, criada em 1870, controlasse diversas outras sociedades e se tornasse um incontrastável império no setor de extração e refino do petróleo. O notável poder econômico acumulado pelo grupo constituído por Rockfeller acabou por atrair vigorosa reação das autoridades estadunidenses, movimento que teve como alguns de seus capítulos mais icônicos a promulgação do Sherman Antitrust Act, em 1890, e a divisão compulsória da Standard Oil, em $1911^{22}$.

Tal ofensiva legislativa, administrativa e judicial contra os trusts empresariais trouxe à tona novamente a necessidade de se encontrar uma via legal adequada para a formação e operação das empresas plurissocietárias nos ramos da economia em que as sociedades holding não eram ainda expressamente admitidas.

Não parece ser uma mera coincidência histórica, portanto, o fato de que em tal período, entre 1888 e 1893, novas leis societárias no Estado de Nova Jersey passassem a permitir, de forma generalizada - ou seja, independentemente do setor de atividade -, a participação de companhias no capital de outras ${ }^{23}$. Em função da peculiar competição regulatória existente entre os diversos Estados na realidade americana, a inovação rapidamente se alastrou pelo resto do país.

De acordo com Lamy Filho e Bulhões Pedreira, a praxe da participação de

not own anything." in M. BECHT, J. DELONG, Why has there been so little Block Holding in America?, p. 627.

22 Interessantíssimo relato histórico sobre as atividades e organização jurídica da Standard Oil pode ser colhido na defesa preparada pelos advogados John G. Johnson e John G. Milburn em processo movido pelo governo federal americano contra o conglomerado por práticas anticoncorrenciais. J. JOHNSON, J. MILBURN, United States of America vs. Standard Oil Company and Others - Brief on Behalf of Defendants Standard Oil Company and Others, p. 7-16.

23 P. BLUMBERG, The American Law of Corporate Groups, p. 307. Lamy Filho e Bulhões Pedreira confirmam a data de 1888. A. LAMY FILHO, J. PEDREIRA, A Lei das S.A., vol. I, p. 70. No mesmo sentido, Dettling. H. DETTLING, Die Entstehungsgeschichte des Konzernrechts im Aktiengesetz von 1965 , p. 18. Galgano, por outro lado, menciona o ano de 1896 como aquele determinante: "Nos Estados Unidos, a data de nascimento dos grupos é usualmente reconduzida a uma lei de Nova Jersey, de 1896, que foi a primeira a admitir a possibilidade de uma corporation adquirir ações de uma outra sociedade, precedentemente excluida enquanto ato ultra vires". Tradução livre de: "Negli Stati Uniti la data di nascita dei gruppi suole farsi risalire ad una legge del New Jersey del 1896 che, per prima, ammise la possibilità di una corporation di acquistare azioni di un'altra società, in precedenza esclusa perché atto ultra vires." F. GALGANO, Lex Mercatoria, p. 165. No mesmo sentido em F. GALGANO, Direzione e Coordinamento di Società - Art. 2497-2497 septies, p. 3. 
sociedade comercial no capital social de outra teria sido desconhecida pela maior parte do século XIX nos países da Europa Continental ${ }^{24}$.

Na França, a licitude da participação de uma sociedade no capital de outra foi definitivamente assentada apenas por meio de decisão judicial do ano de 1878 . O caso em questão envolvia a sociedade em nome coletivo "Brouilhet pére et fils" que se juntou a terceiro para constituir a "Demi-Brouilhet pére et fils", do mesmo tipo societário. Não tendo êxito a empreitada, credores da sociedade "filha" pleitearam em juízo o direito de se habilitar na falência da Brouilhet pére et fils. Tanto em sede de juízo de admissibilidade (Chambre des Requêtes) quanto na decisão final da Corte de Cassação, firmou-se expressamente o entendimento de que não havia óbice legal para que a sociedade fosse, também, sócia ${ }^{25}$.

Na Itália, o Decreto Real de 13 de novembro de 1931, $n^{\circ} 1.434$, antecipou o conceito que depois seria incorporado no artigo 2.361 do Código Civil de 1942 e autorizou as sociedades a deterem participação no capital social de outras ${ }^{26}$, mas desde que estas tivessem o mesmo objeto social da investidora ${ }^{27-28}$. O referido artigo 2.361 ainda hoje

24 A. LAMY FILHO, J. PEDREIRA, A Lei das S.A., vol. I, p. 70.

25 Em juízo de admissibilidade: "Uma vez que nenhum texto legal, nenhum princípio de direito veta às sociedades em nome coletivo já existentes de entrar como sócias em outras sociedades do mesmo gênero" e, na decisão final da Corte de Cassação: "Uma vez que nenhuma disposição legal se opõe ao fato que uma sociedade regularmente constituída entre como sócia de uma sociedade distinta, formada para um objetivo diferente". Traduções livres de, respectivamente: "Attendu qu'aucun texte de la loi, aucun principe de droit n'interdit aux sociétés en nom collectif existant déjà d'entrer comme associée dans d'autres sociétés du mémé genre" e "Attendu qu'aucune disposition de la loi ne s'oppose à ce qu'une société régulièrement constituée entre comme associée dans une société distincte formée pour un objet différent". Em ambos os casos, conforme o relato de Maurice Gégout: M. GÉGOUT, Filiales et Groupements de Sociétés, p. 21-23.

26 Em comentário a sentença justamente do ano de 1931, Ascarelli observou que: "Certamente se deve reconhecer que o nosso código disciplinou e previu a sociedade em nome coletivo como sociedade de pessoas fisicas, mas com isso não se demonstra que as disposições do código sejam todas inaplicáveis quando os sócios da sociedade sejam pessoas jurídicas. O código previu na própria sociedade anônima uma sociedade de pessoas fisicas, e ainda assim é, atualmente, opinião não contrastada aquela que admite a possibilidade de uma sociedade anônima entre diversas sociedades anônimas". Tradução livre de: "Certamente si deve riconoscere che il nostro codice ha disciplinato e previsto la società in nome collettivo come società di persone fisiche, ma con ciò non si dimostra affatto che le disposizioni del codice siano tutte inapplicabili quando i soci della società siano persone giuridiche. Il codice ha previsto nella stessa società anonima una società di persone fisiche, eppure è ormai opinione non contrastata quella che ammette la possibilità di società anonima tra più società anonime." in T. ASCARELLI, Studi in Tema di Società, p. 56.

27 F. GALGANO, Direzione e Coordinamento di Società-Art. 2497-2497 septies, p. 3.

28 Mas, em 1923, Vivante já asseverava que: "Uma sociedade pode participar de outras sociedades comerciais sejam de responsabilidade limitada sejam de responsabilidade ilimitada, e pode administrálas e supervisioná-las por meio de seus representantes [...] Somente no caso em que a sociedade anônima fosse simulada poder-se-ia, então, arrancar-lhe esse vão simulacro e considerar responsáveis ilimitadamente os acionistas que buscaram se subtrair ao peso da responsabilidade ilimitada". 
possui redação notavelmente restritiva, determinando que a participação em outras sociedades, prevista ou não no estatuto social, não será admissível se implicar alteração substancial no objeto social da participante.

Vale lembrar que mesmo o legislador brasileiro de 1976 entendeu ser prudente sublinhar o fato de que uma companhia pode participar de outras sociedades como sócia, ainda que na ausência de específica previsão estatutária (Lei 6.404/1976, artigo $2^{\circ}$, parágrafo $3^{\circ}$ ), inovando nesse sentido em relação ao dispositivo análogo do Decreto Lei $2.627 / 1940\left(\operatorname{artigo} 2^{\circ}\right)$.

De qualquer forma, como testemunho dos embriões históricos remotos de futuras estruturas mais complexas, cumpre assinalar o interessante registro de Cláudio Ganns, em notas à "Carta aos Credores" de Mauá, de que constava como acionista da "Companhia de Navegação a Vapor e Estrada de Ferro de Petrópolis", já em 29 de maio de 1852, a firma Carruthers \& Co., representada por Isaac Carruthers. Mais tarde, a ata de 12 de fevereiro de 1855 , relativa à mesma companhia, teria sido firmada por Mauá tanto em nome próprio quanto como representante da Mauá, Mac Gregor \& Cia., que conjuntamente detinham participação total de 6.537 ações $^{29}$.

A própria "Casa Mauá" - a referida sociedade em comandita denominada Mauá, Mac Gregor \& Cia., constituída antes que o Decreto 1.487/1854 viesse a expressamente proibir o fracionamento do capital em ações no âmbito de sociedades desse tipo - teve entre os 182 subscritores do seu capital social inicial de 6.000 contos, em julho de 1854 , diversas sociedades, brasileiras e estrangeiras, tais como: Loquai David \& Co.; Gomes \& Morais; Amaral \& Basto; Roberto Emery \& Co.; Flores, Filho \& Cia.; Joaquim da Fonseca Guimarães \& Cia.; Pereira \& Cia.; Hoggetdown \& Cia.; Debienne \& Cia.; Adet \& Cia ${ }^{30}$.

Na mesma linha, o Decreto 8.240 , de 3 de setembro de 1881 , que aprovou os

Tradução livre de: "Una società può prendere parte ad altre società commerciali siano a responsabilità limitata od illimitata, e può amministrarle e sorvegliarle per mezzo dei suoi rappresentanti [...] Soltanto nel caso che la società anonima fosse simulata solo allora si potrebbe strapparle questo vano simulacro e ritenere responsabili illimitatamente gli azionisti che tentarono di sottrarsi al peso della responsabilità illimitata." in C. VIVANTE, Trattato di Diritto Commerciale, vol. II, $\mathrm{n}^{\circ} 306$, p. 20. Por outro lado, conforme se discute mais adiante neste trabalho, ainda na década de 1930 Messineo entendia como simulação absoluta o controle de uma sociedade por ações por outra sociedade da mesma natureza. F. MESSINEO, Le Società di Commercio Collegate (c.d. Società a Catena), p. 12.

29 I. DE SOUSA, Autobiografia: Visconde de Mauá, nota de rodapé no 35, p. 131-132.

30 I. DE SOUSA, Autobiografia: Visconde de Mauá, nota de rodapé nº 152, p. 219-220. 
estatutos da "Companhia de Reboques e Salva-vidas, da Barra do Rio Grande do Sul, Província de S. Pedro", registrou em sua parte final a subscrição, em $1^{\circ}$ de fevereiro de 1881, de 600 ações (pelo valor de 60:000\$000), de um total de 1.750, por parte da sociedade “J. Maxwell Jones \& Comp.".

Evidentemente, não se tratava de participação, quanto menos controle, de sociedade acionária sobre sociedade acionária. Tampouco se pode falar em grupo de sociedades em qualquer moderna acepção do termo. Ainda assim, representam esses casos exemplos precoces (e brasileiros) de participação de uma sociedade no capital de outra e, enquanto tal, atestam passos importantes na direção da superação do último grande obstáculo jurídico que se colocava à formação dos grupos de sociedades.

Oportuno também notar, ainda a respeito da evolução legislativa brasileira nesse ponto, que o artigo 31 da Lei 3.150/1882 - princípio que foi repetido pelo artigo 40 do Decreto 434/1891, pelo artigo 15 do Decreto-Lei 2.627/1940 e, enfim, pelo artigo 30 da Lei 6.404/1976 - vedava à companhia negociar com as próprias ações. Conforme a doutrina do período, tal restrição se aplicava somente à aquisição das ações pela própria sociedade - o que significaria redução do capital - e não ao incentivo pela companhia à realização de tais negócios por (e por meio de) terceiros ${ }^{31}$. Nesse sentido, se houvesse no período em questão uma repulsa ampla e irrestrita à aquisição de participação societária por sociedade, o dispositivo em questão seria completamente inútil. Aliás, interpretação $a$ contrario sensu de tal norma parece sugerir exatamente o oposto ${ }^{32}$.

No que tange à facilidade de constituição da companhia, a grande variedade de

31 S. VAMPRÉ, Das Sociedades Anonymas, p. 125.

32 A despeito dessas evidências de antiga admissão da participação de sociedades no capital de outras sociedades, cumpre também reconhecer a persistência de elementos que denotam desatenção - de qualquer modo, superada na prática - quanto ao fato de que o papel de sócio seria desempenhado não apenas por pessoas naturais. É o caso, por exemplo, do artigo 13 do Decreto 3.708/1919 que atribuía a administração das sociedades por quotas de responsabilidade limitada aos sócios-gerentes e, portanto, ensejou a formação do conceito de gerente-delegado. "As sociedades comerciais não possuem apenas sócios pessoas naturais. São pessoas jurídicas, da mais variada espécie, que se reúnem para formar novas pessoas jurídicas a fim de permitir combinações industriais e mercantis dificilmente ajustáveis entre as pessoas fisicas. É comum, então, encontrarmos sociedades por quotas de responsabilidade limitada, constituídas, em maior parte, senão exclusivamente, por sócios - pessoas jurídicas. Surge, desde logo, a indagação: A quem caberá a gerência da sociedade por quotas se todos, ou pelo menos alguns sócios forem pessoas jurídicas?" in E. TEIXEIRA, Das Sociedades por Quotas de Responsabilidade Limitada, p. 149. Sobre a mesma questão: J. LUCENA, Das Sociedades Limitadas, p. 414. Similar pecadilho foi cometido pelo próprio Código Civil de 2002, que em seu artigo 1.075 prevê que a assembleia será presidida e secretariada - funções que, pelas suas próprias características, devem ser desempenhadas por pessoas naturais - por sócios escolhidos entre os presentes. 
arranjos e configurações que a empresa plurissocietária comporta apenas ganha sentido prático se o empreendedor tiver um grau mínimo de liberdade para utilizar as formas colocadas à disposição pela lei, o que não ocorria sob os regimes do privilégio legal e da autorização administrativa ${ }^{33}$.

Assim, apenas para trazer concretude histórica ao argumento, é corriqueira e já antiga a praxe de grupos estrangeiros constituírem sociedades controladas para desenvolverem suas atividades no Brasil. A alternativa da atuação direta em território nacional não apenas exigiria complexa autorização ministerial, nos termos do artigo 1.134 do Código Civil de 2002, mas privaria o investidor do benefício da responsabilidade limitada decorrente da existência da sociedade brasileira como anteparo entre controladora e credores locais.

Nos tempos do Visconde de Mauá, porém, diversos projetos destinados a serem implementados exclusivamente em território brasileiro, mas cuja viabilidade financeira reclamava o acesso ao mercado de capitais da Inglaterra, eram estruturados por meio da constituição de sociedades diretamente naquele país, sob regime jurídico local, que eram posteriormente autorizadas a atuar no Brasil ${ }^{34}$.

Abstraindo-se outros possíveis obstáculos à formação dos grupos naquele período, é de se observar que se tanto a constituição de uma companhia brasileira quanto a autorização para funcionamento de sociedade estrangeira no país estavam sujeitas a entraves burocráticos de similar gravidade - lei ou ato administrativo específicos -, não haveria razão prática para se buscar a constituição de duas sociedades ao invés de uma.

Ou seja, parece razoável afirmar que a mudança do regime de constituição teve

33 "A introdução da liberdade de constituição para as sociedades por ações teve um significado elementar não apenas para a formação dos cartéis, mas ainda mais para a formação dos grupos de sociedades". Tradução livre de: "Die Einführung der Gründungsfreiheit für Aktiengesellschaften war nicht nur für die Kartellbildung, sonder noch mehr für die Konzernbildung von elementarer Bedeutung." in $\mathrm{H}$. DETTLING, Die Entstehungsgeschichte des Konzernrechts im Aktiengesetz von 1965, p. 52.

34 Assim, por exemplo, a transferência da Cia. de Iluminação a Gás do Rio de Janeiro, constituída em 1853, para a Inglaterra, convertendo-se em The Rio de Janeiro Gas Company Limited, que foi autorizada a funcionar no Brasil por meio do Decreto 3.456/1865. I. DE SOUSA, Autobiografia: Visconde de Mauá, p. 119.-120. O artigo $2^{\circ}$ do estatuto impedia a companhia de alterar seus atos constitutivos sem autorização do governo imperial, sujeitando-a a verdadeiro e peculiar regime binacional. Outros, dentre tantos possíveis exemplos similares que podem ser colhidos na legislação imperial, são: The Amason Steam Navigation Company Limited (Decreto 5.020/1872), The Madeira and Mamoré Railway Company (Decreto 5.073/1872), Pernambuco Street Railway (Decreto 5.281/1873) e D. Pedro I Railway Company Limited (Decreto 5.237/1873). 
um papel determinante na adoção da estrutura de grupo como mecanismo típico para o investimento estrangeiro direto. Sem flexibilidade e liberdade no uso das formas, o grupo de sociedades não poderia florescer.

\subsection{Industrialização e Pressupostos Econômicos dos Grupos}

Conforme a lição magistral de Lamy Filho e Bulhões Pedreira, as instituições jurídicas são frequentemente a própria causa de mudanças estruturais na realidade econômica e não a mera resposta a estas últimas ${ }^{35}$. A "máquina jurídica" societária sobretudo em sua versão acionária - demonstrou ao longo da História ser uma tecnologia indispensável ao desenvolvimento econômico ${ }^{36}$. De qualquer forma, seria equivocado atribuir a tardia formação dos grupos de sociedades exclusivamente à retardatária disponibilidade de certas estruturas jurídicas.

O momento da gênese e desenvolvimento dos grupos parece ser determinado, em medida muito maior, pela longa prevalência de estruturas produtivas que, na prática, não tendiam a empregar vultosíssimos investimentos e, portanto, não reclamavam efetivamente a presença de tais institutos. Ou seja, trata-se, preponderantemente, de uma questão de ausência de demanda e não de oferta de soluções jurídicas.

Não é por mero acaso ou capricho da História que o surgimento dos grupos coincide com uma fase avançada da Revolução Industrial ${ }^{37}$. No capitalismo comercial ou mercantil, a produção ocorria no mais das vezes de forma descentralizada, no domicílio do próprio artesão ou em propriedades rurais, enquanto que o mercador se limitava a apresentar encomendas e - se tanto - fornecer matérias-primas. O capitalista (comerciante) era simplesmente o articulador de uma rede de produção e distribuição, mas não era ele mesmo um produtor. As necessidades de capital de tal modo de produção eram, em regra, plenamente atendidas pela sociedade isolada, sob controle familiar. Prevalecia uma relação de correspondência linear entre: um grupo de empreendedores (sócios), uma atividade e

35 “[...] nem sempre é a organização econômica que gera o direito, mas, muita vez, a ordem jurídica condiciona e promove a vida econômica." in A. LAMY FILHO, J. PEDREIRA, A Lei das S.A., vol. I, p. 20.

36 A. LAMY FILHO, J. PEDREIRA, A Lei das S.A., vol. I, p. 19. G. RIPERT, Aspects Juridiques du Capitalisme Moderne, p. 106.

37 Conforme assinala o Professor Comparato: "Ora, o conceito e a qualificação jurídica do controle dizem respeito, eminentemente, a essa nova realidade social oriunda da revolução industrial." in F. COMPARATO, C. SALOMÃO FILHO, O Poder de Controle na Sociedade Anônima, p. 107. 
uma sociedade.

Por outro lado, empreitadas de maior vulto - como as grandes navegações, a colonização e expedições militares - eram financiadas por parcerias ad hoc entre soberano e burguesia, que se valiam de instrumentos jurídicos de natureza predominantemente pública, como as grandes companhias do século XVII. Não havia, na prática, a necessidade premente ou sistemática da combinação de investimentos puramente privados de grande porte.

Esse cenário muda drasticamente com a disseminação das estratégias de produção em escala industrial ${ }^{38}$. As economias de escala e escopo decorrentes da concentração, coordenação e racionalização do trabalho em um único lugar trazem enormes ganhos de produtividade, mas também exigem que o antigo comerciante se torne capitão de indústria, adquirindo a propriedade dos meios de produção. Essa transição não poderia ter lugar sem um nível de concentração de capitais que não tinha precedentes. O desenrolar do processo levaria eventualmente a capacidade de autofinanciamento de empresas familiares ao limite e a implantação de novas redes de infraestrutura - como o telégrafo e sobretudo a ferrovia - tornaria absolutamente imperativa a adoção de instrumentos mais sofisticados para a captação e combinação de recursos ${ }^{39}$.

O volume de capitais imobilizados, o longo prazo de maturação dos investimentos

38 "O grande capital se transforma de capital comercial em capital industrial: o antigo modo de se obter mais valia, baseado em encomendas do comerciante ao artesão e ao camponês é substituído por um novo modo, baseado na propriedade capitalista dos meios de produção [...]". Tradução livre de: "Il grande capitale si trasforma da capitale commerciale in capitale industriale: all'antico modo di estrarre plus-valore, basato sulle commesse del mercante all'artigiano e al contadino, subentra un nuovo modo, basato sulla proprietà capitalistica degli strumenti di produzione [...]" in F. GALGANO, Lex Mercatoria, p. 121.

39 "Em termos gerais, a típica empresa da primeira metade do século [século XIX] era financiada de forma privada - ou seja, com patrimônio familiar - e se expandia reinvestindo lucros, [...] Contudo, o crescente tamanho e custo de empreendimentos como ferrovias, siderurgia e outras atividades que exigem pesados desembolsos iniciais, tornavam isso mais dificil. [...] mesmo na França e na GrãBretanha ocorreu conceber novas formas de mobilizar essas economias, de canalizá-las até os empreendimentos necessários. O terceiro quarto do século foi, portanto, um periodo fértil em experimentos com a mobilização de capitais para o desenvolvimento industrial." Tradução livre de: "By and large the characteristic enterprise of the first half of the century [século XIX] had been financed privately - e.g. from family assets - and expanded by reinvesting profits, [...] But the increasing size and cost of such undertakings as railways, metallurgical and other expensive activities requiring heavy initial outlays, made this more difficult. [...] even in Britain and France new ways of mobilizing these savings, of channelling them into the required enterprises, of organizing joint-stock rather than privately financed activities, had to be devised. The third quarter of the century was therefore a fertile period of experiments in the mobilization of capital for industrial development." in E. HOBSBAWN, The Age of Capital-1848-1875, p. 214. 
e as consequentes incertezas quanto ao retorno econômico e financeiro implicavam riscos intoleráveis, se assumidos individualmente apenas por um único empresário, núcleo familiar ${ }^{40}$ ou mesmo uma só companhia.

A sociedade anônima de capital aberto e o emergente mercado de capitais podiam resolver o problema do recurso à poupança popular e da liquidez (rápida e eficiente desmobilização) dos investimentos pessoais, por meio da subscrição e circulação de ações. Porém, apenas a formação de grupos poderia - conforme debatido de modo mais detido no próximo capítulo - (i) oferecer o isolamento eficiente dos riscos de cada um dos diversos projetos promovidos pela mesma empresa, (ii) permitir à companhia principal (holding) a alienação de forma eficiente de um conjunto de ativos quando reunidos sob a propriedade de uma sociedade controlada e (iii) assegurar a manutenção do controle com a titularidade de uma fração sempre menor do capital total investido na empresa, em particular por meio das estruturas piramidais. Elementos estes que estabelecem a estreita relação histórica entre industrialização avançada e grupo de $\operatorname{sociedades}^{41}$.

\subsection{Dos Grupos ao Direito dos Grupos}

O fato de existir um panorama legislativo que não mais impedia a formação do grupo de sociedades não significou que o fenômeno fosse, desde logo, objeto de normas que lhe estabelecessem disciplina própria. Existe uma clara linha de continuidade entre a afirmação das sociedades anônimas como estrutura jurídica fundamental para a condução da atividade empresarial, fato que marcou o século XIX, e a emergência dos grupos de sociedades, que se consolidou no século XX. Contudo, enquanto o primeiro fenômeno foi resultado direto de inovações legislativas, os grupos surgiram principalmente como fruto da liberdade contratual associada à criatividade dos empresários ${ }^{42}$.

40 “A empresa familiar não pôde se afirmar; em parte por questões sociais, [...], em parte porque o conceito de crescimento acelerado da indústria contemporânea compreende a exigência de duradoura provisão de capitais, que o clã familiar não está em condições de fornecer". Tradução livre de: "Das Familienunternehmen konnte sich nicht behaupten; teils aus gesellschaftlichen Gründen, [...], teils weil der Begriff neuzeitlicher Industrie beschleunigtes Wachstum enschließt, mithin dauernde Kapitalzufuhr fordert, die der Familienstamm nicht erschwingen kann." in W. RATHENAU, Vom Aktienwesen - Eine Geschäftliche Betrachtung, p. 123.

41 Em 1917, Rathenau já constatava que: "A empresa se expande para um conjunto, para um grupo; vivencia propagações de terceira e quarta geração". Tradução livre de: "Das Unternehmen erweitert sich zur Gruppe, zum Konzern, erlebt Fortpflanzungen im drittem und vierten Geschlecht." in W. RATHENAU, Vom Aktienwesen - Eine Geschäftliche Betrachtung, p. 138.

42 “A sociedade por ações foi uma criação legislativa; [...] O grupo de sociedades é, ao revés, fruto da criatividade empresarial, não uma criação do legislador, nasce da valorização de potencialidades 
Mais tarde, surgiriam em diversos países normas abertamente voltadas ao favorecimento da concentração empresarial e, portanto, à formação dos grupos - e, como veremos adiante, o Brasil não foi exceção. Contudo, em sua gênese, os grupos não parecem ter sido resultado de projeto deliberado do legislador, mas simplesmente uma consequência do senso de oportunidade dos empresários, que fizeram uso inovador das estruturas societárias que surgiam, uma vez superados os respectivos obstáculos jurídicos.

Nesse sentido, apenas quando os grupos efetivamente despontaram no horizonte da realidade econômica é que se acusou a necessidade de disciplinar as distorções mais visíveis e contundentes que sua existência enseja.

A relação entre poder estatal e grupos societários sempre foi ambígua. De um lado, o Estado sabe que a empresa plurissocietária é uma espécie de hidra do mundo dos negócios, capaz de estrategicamente escapar da aplicação da lei - ou diretamente fraudá-la - apresentando ao mundo, em cada ocasião, a cabeça que pareça mais conveniente. Ademais, a estrutura de grupo permite aos empresários uma notável acumulação de poder econômico, que pode se traduzir em influência política e não raro pode eclipsar a própria capacidade efetiva de ação da autoridade estatal.

Por outro lado, o grupo de sociedades é sabidamente um poderoso instrumento para a formação de conglomerados que permitem a concentração de capitais e a realização coordenada de investimentos de grande porte, fatores especialmente importantes em países que não possuem ambiente institucional favorável ou mercado de capitais altamente desenvolvido. Sob tal perspectiva, o grupo pode ser uma ferramenta imprescindível para as nações que buscam "queimar etapas" ou obter desenvolvimento econômico acelerado.

Esse flerte hesitante entre Estado e concentração empresarial ao longo da História é perfeitamente visível, por exemplo, na questão das companhias ferroviárias e de telégrafo dos Estados Unidos, ao longo do século XIX, conforme já apontado acima. O caráter estratégico dessas tecnologias, que exigem grandes investimentos iniciais e estão fortemente sujeitas a ganhos de escala e efeitos de rede, fez que com o legislador

implícitas na forma jurídica das sociedades por ações, as quais a criatividade empresarial levou às consequências extremas". Tradução livre de: "La società per azioni era stata una creazione legislativa; [...] Il gruppo di società è, all'opposto, frutto della inventiva imprenditoriale, non già creazione legislativa, nasce dalla valorizzazione di potenzialità implicite nella forma giuridica della società per azioni, che l'inventiva imprenditoriale porta alle estreme conseguenze." in F. GALGANO, Direzione e Coordinamento di Società - Art. 2497-2497 septies, p. 2. 
estadunidense superasse, ainda que pontualmente, a sua tradicional aversão aos grupos de sociedades.

Sob tal perspectiva, é importante ressaltar que regras mais amplas, específicas e estruturadas em matéria de grupos de sociedades não refletem necessariamente a intenção política de coibir mais intensamente o fenômeno. Com efeito, a análise histórica atesta com maior frequência a situação exatamente contrária. Foram justamente as nações que quiseram dar mais ampla margem de manobra à empresa plurissocietária - com ênfase absoluta para a Alemanha, mas também para Brasil, Portugal ${ }^{43}$ e alguns outros países - que criaram uma disciplina orgânica sobre o tema, em grande medida para excepcionar ou limitar a incidência de regras gerais do direito societário que poderiam criar embaraços ao funcionamento dos grupos. É a maior liberdade conferida aos grupos e maior clareza na delimitação de seu raio de ação que impõe a tentativa de "domá-los" por meio de arcabouço normativo mais estruturado.

Essa específica estratégia legislativa acabou por criar uma profunda separação entre tais países e todos os demais no que diz respeito à regulação do fenômeno dos grupos. Não se trata de uma contraposição entre países que possuem ou não possuem um direito dos grupos, como ocasionalmente se afirma de maneira simplista ${ }^{44}$. Virtualmente todos os Estados possuem regras elementares - de direito positivo ou jurisprudenciais sobre participações recíprocas, consolidação contábil ou desconsideração da personalidade jurídica em casos excepcionais de fraude ou abuso, as quais são - ao menos lato sensu típicas normas de direito dos grupos ${ }^{45}$.

Mesmo na questão específica do conflito de interesse, não havendo projeto político no sentido de se fomentar ou facilitar a concentração empresarial, podem ser

43 A partir de 1986, nos termos dos artigos $481^{\circ}$ a $508^{\circ}$ do Código das Sociedades Comerciais. Os artigos $493^{\circ}$ e seguintes regulam especificamente a questão da convenção de subordinação.

44 “A Alemanha é considerada no mundo inteiro como a 'Terra dos Grupos' ('Konzernland'). Isso se baseia simplesmente na concepção que tanto a França, quanto a Itália e a Inglaterra, bem como a maioria dos países dentro e fora da Europa, têm sobre si mesmos no que diz respeito a não possuírem um direito dos grupos - um fato por si só merecedor de análise". Tradução livre de: "Deutschland gilt weltweit als das 'Konzerland'. Das liegt zunächst einfach daran, daß gleichermaßen Frankreich, Italien wie England, aber auch die meisten übrigen inner- und außereuropäischen Rechtsordnungen von sich selber die Vorstellung haben, sie besäßen kein Konzernrecht - eine an und für sich schon analysewürdige Tatsache." in J. DRUERY, Das deutsche Konzernrecht aus der Sicht des übrigen Europa, p. 338.

45 Apenas como exemplos, o artigo 2.360 do Código Civil italiano de 1942 veda as participações recíprocas, restrição que foi introduzida no direito francês por meio do artigo $8^{\circ}$ da Lei ${ }^{\circ} 145$, de 4 de março de 1943. 
aplicados aos grupos, sem ressalvas ou discriminação, os mecanismos regulares do direito societário $^{46}$, como é o caso dos deveres fiduciários do direito anglo-saxão. Tais deveres consistem essencialmente em (i) respeito ao documento que estabelece os poderes do trustee, (ii) dever de cuidado e (iii) dever de lealdade, preceitos estes que têm como características fundamentais a amplitude e generalidade ${ }^{47}$.

O que torna especial o percurso legislativo seguido pelo Brasil e por outros países, na esteira da experiência alemã, é a complexidade, a especificidade e a organicidade da estrutura legal criada em torno da empresa plurissocietária, que contrastam com a experiência dos demais Estados. Não se trata, portanto, apenas de regular o grupo - fato corriqueiro em quase todos os países -, mas regular o grupo em si e como tal $^{48-49}$. Uma

46 "Mesmo em países que, até agora, renunciaram a uma codificação do direito dos grupos, existem grupos e, com estes, coloca-se o problema da proteção de credores e acionistas externos. Como inclusive demonstrado pelo direito alemão das sociedades limitadas, essas questões podem ser inteiramente reguladas pelo recurso ao direito societário geral; [...]". Tradução livre de: "Auch in Ländern, die bisher auf eine Kodifikation des Konzernrechts verzichtet haben, existieren Konzerne und die mit ihnen einher gehenden Problem des Gläubiger- und Außenseiterschutzes. Wie nicht zuletzt das deutsche GmbH-Recht zeigt, lassen sich diese Fragen allerdings durchaus unter Rückgriff auf das allgemeine Gesellschaftsrecht regeln; [...]" (negrito no original) in V. EMMERICH, M. HABERSACK, Konzernrecht, p. 19.

$47 \mathrm{Na}$ mesma parte do trabalho em que declinam tal tripartição dos deveres fiduciários no direito americano, Allen e Franco ainda acrescentam que: "Uma das características que torna os deveres fiduciários interessantes é o seu caráter inespecifico. Vistos de uma perspectiva ex ante os deveres fiduciários possuem natureza extremamente ampla [...]". Tradução livre de: "One of the characteristics that makes fiduciary duties interesting is their unspecified character. Viewed from an ex ante perspective fiduciary duties are extremely broad in character [...]" in W. ALLEN, B. FRANCO, The Corporate Directors Fiduciary Duty of Care and the Business Judgment Rule in U.S. Corporation Law, p. 544.

48 "A despeito do fato de que o grupo de sociedades desempenha nos Estados Unidos, como em praticamente todas as economias livres e industrializadas, um papel de organização e consolidação das empresas que é quase impossivel de se superestimar, não existe lá, nem, tampouco - ressalvadas algumas poucas exceções -, no resto do mundo, um direito societário dos grupos especial e fechado". Tradução livre de: "Obgleich der Konzern in denen USA wie in praktisch jeder freien industriellen Wirtschaft als Form der Organisation und Zusammenschlusses von Unternehmen eine kaum zu überschätzende Rolle spielt, existiert weder dort noch - von wenigen Ausnahmen abgesehen - sonst in der Welt ein spezielles, geschlossenes gesellschaftsrechtliches Konzernrecht." in H. DETTLING, Die Entstehungsgeschichte des Konzernrechts im Aktiengesetz von 1965, p. 6.

49 "[...] o fenômeno dos grupos obviamente existe e surge a questão do que devemos fazer em relação a ele. No Reino Unido, [...] não é que não tenhamos leis relativas aos grupos, mas sim que possuímos uma abundância de normas nesta área [...]. Existem leis relativas à consolidação contábil, dever de informar, tributação, atividades dos administradores no contexto dos grupos, opressão dos acionistas minoritários e insolvência. Uma característica importante dessas normas é que elas frequentemente não enfrentam o tema dos grupos como tal, mas, ao invés disso, lidam com alguns dos salientes problemas regulatórios do direito societário e, ao fazê-lo, cobrem também a questão dos grupos". Tradução livre de: "[...] the group phenomenon obviously exists, and the question arises as to what we are to do about it. In the UK [...] it is not that we do not have a law relating to groups, but that we have an abundance of law in this area [...]. There are laws relating to consolidation of accounts, disclosure, taxation, directors' dealings within the context of groups, minority shareholders oppression, and insolvency. An important feature of this legislation is that it often does not address the issue of groups as such, but rather deals with what are some of the salient regulatory problems of company law and in the process 
regulação que não tem como escopo apenas tutelar credores e acionistas, mas estabelecer as bases organizativas do grupo ${ }^{50}$. Nesse sentido, Karsten Schmidt enfatiza como o direito alemão observa o problema dos grupos a partir de "cima" - da perspectiva do exercício do poder de controle - e não de "baixo" - justamente, a proteção de credores e acionistas externos $^{51}$.

À luz dessa influência inequívoca e determinante da disciplina alemã na formação das disposições sobre os grupos constantes da Lei 6.404/1976, é oportuna uma breve análise da afirmação histórica do instituto no direito daquele país, antes de nos debruçarmos sobre a experiência brasileira.

\subsection{História do Direito dos Grupos na Alemanha}

A Alemanha é um país de unificação tardia, que ao contrário de seus pares na Europa Ocidental, como França e Inglaterra, despontou como potência europeia já na fase de consolidação do processo de colonização e, portanto, viu-se desprovida de domínios ultramarinos que pudessem alimentar sua economia com matérias-primas e mercados consumidores cativos. Além disso, o país teve, ao menos duas vezes, de reconstruir sua

also covering the issue of groups." (sem grifo no original) in D. PRENTICE, Some Comments on the Law of Groups, p. 371-372.

50 A esse respeito, extremamente oportunas as considerações de Emmerich e Habersack sobre o direito grupal alemão como norma de organização: "[...], foram sobretudo as questões da formação e do controle sobre a direção do grupo, no plano da empresa de comando [...], que causaram o desenvolvimento continuado do direito positivo. A última questão mencionada deve ser entendida sob o pano de fundo de uma discussão dos fundamentos do instituto, que diz respeito à função e ao objetivo das disposições de direito grupal, tais como as constantes dos $\$ \$ 291$ e seguintes, bem como dos $\$ \S 311$ e seguintes da lei acionária: elas são motivadas - partindo do modelo da sociedade independente - pela proteção a acionistas e credores sociais dos perigos da relação de dependência ou têm (também) como objeto a admissibilidade (e os seus limites) dos vínculos entre empresas e, assim, igualmente, a disciplina da organização de uma empresa vinculada a outra sociedade? Caso se observem primeiramente as disposições sobre os grupos regulados por convenção e sobre a operação de integração (Eingliederung), não pode haver dúvida de que tal vínculo entre empresas envolve uma profunda modificação da organização da sociedade controlada". Tradução livre de: "[...] war es vor allem die Frage einer Konzernbildungs- und Konzernleitungskontrolle auf der Ebene des herrschenden Unternehmens [...], die eine Fortbildung des geschriebenes Recht veranlasst hat. Die zuletzt angesprochene Frage ist vor dem Hintergrund einer Grundsatzdebatte zu sehen, bei der es um die Funktion und den Zweck konzernrechtlichen Vorschriften nach Art der $\$ \$ 291$ ff., 311 ff. AktG geht: Bezwecken diese, ausgehend vom Leitbild der unverbundenen Gesellschaft, den Schutz der Aktionäre und Gesellschaftsgläubiger vor den Gefahren der Abhängigkeit oder geht es ihnen (auch) darum, die (Grenzen der) Zulässigkeit von Unternehmensverbindungen und damit zugleich die Organisation einer mit einem anderen Unternehmen verbundenen Gesellschaft zu regeln? Betracht man zunächst die Vorschriften über den Vertragskonzern und über die Eingliederung, so kann nicht zweifelhaft sein, dass mit einer entsprechenden Unternehmensverbindung eine tiefgreifende Veränderung der Organisation der abhängigen Gesellschaft einhergeht." (negrito no original) in V. EMMERICH, M. HABERSACK, Konzernrecht, p. 7.

51 K. SCHMIDT, Gesellschaftsrecht, p. 489-490. 
estrutura produtiva quase que do zero em função das trágicas consequências de suas aventuras militares, para não mencionar os efeitos decorrentes do período de totalitarismo nazista. Trata-se, ademais, de nação que sofreu décadas de divisão territorial e política e enfrentou a Guerra Fria com proximidade e concretude extremas, provavelmente apenas superadas pela experiência de nações como Coreia e Vietnã.

Todos esses fatores contribuíram para imprimir um papel preponderante do Estado e dos conglomerados financeiros e industriais no desenvolvimento econômico alemão e determinar valor particularmente baixo para a concorrência e para a limitação do poder econômico nas ponderações relativas ao estímulo e racionalização da atividade produtiva.

Dettling identifica quatro principais fases no desenvolvimento do direito dos grupos na Alemanha: (i) o início da concentração econômica a partir de 1870, (ii) a intensificação de tal fenômeno durante a República de Weimar, (iii) a fase da ditadura nacional-socialista e (iv) o período pós Segunda Guerra Mundial, que culminou com a promulgação da lei acionária de $1965^{52}$.

Com a instauração do regime de liberdade de constituição das companhias, no âmbito da Confederação da Alemanha do Norte, em 11 de junho de $1870^{53}$, e com a unificação política da Alemanha, consequência da Guerra Franco-Prussiana de 1871, estavam lançadas as bases para um processo de forte concentração econômica. A orientação política economicamente liberal dos primeiros anos foi rapidamente substituída, em função da crise de 1873, por uma visão intervencionista e nacionalista que enxergava nos cartéis e acordos horizontais um instrumento de racionalização da produção e superação dos obstáculos conjunturais. Com o tempo, o remédio temporário acabou por se tornar um elemento estrutural da economia alemã $\tilde{5}^{54}$.

Após o fim da Primeira Guerra Mundial, o processo de concentração econômica

52 H. DETTLING, Die Entstehungsgeschichte des Konzernrechts in Aktiengesetz von 1965, p. 48. Hommelhoff, por outro lado, identifica três fases principais (i) anos 20 (maturação da jurisprudência), (ii) 1930-37 (primeiras codificações) e (iii) 1955-1965 (do $42^{\circ}$ Congresso de Juristas Alemães até a promulgação da lei acionária de 1965). P. HOMMELHOFF, Die Konzernleitungspflicht, p. 2.

53 H. DETTLING, Die Entstehungsgeschichte des Konzernrechts in Aktiengesetz von 1965, p. 50.

54 "Nascidos inicialmente como 'filhos da necessidade', os cartéis logo se estabeleceram na Alemanha como instituição permanente da vida econômica e se tornaram 'elemento central do modelo econômico' da atividade produtiva organizada". Tradução livre de: "Zunächst nur als 'Kinder der Not' geboren, etablierten sich die Kartelle in Deutschland bald als Dauereinrichtungen des Wirtschaftslebens und wurden 'zum Kernelement des neuen Wirtschaftstypus', der organisierten Wirtschaft." in H. DETTLING, Die Entstehungsgeschichte des Konzernrechts in Aktiengesetz von 1965, p. 51. 
se intensificou e a estrutura de cartelização começou a ser substituída pela formação de grupos verticais como instrumento preponderante para a limitação da concorrência. Verificou-se nesse período a consolidação de amplas doutrina e jurisprudência justificadoras da concentração empresarial, as quais deram ensejo à promulgação de normas, sobretudo de caráter tributário, que buscavam ativamente promover a criação dos grupos de sociedades. É o caso, por exemplo, do conceito de Organschaft, ou seja, do grupo formado por uma sociedade de comando e por outras empresas sem vontade própria, administrativa e financeiramente dependentes da primeira, que permitia a compensação entre ganhos e perdas nas operações entre seus integrantes e, portanto, sua neutralização em termos de incidência do imposto sobre o faturamento ${ }^{55}$.

A ausência de restrições à concentração do poder econômico e a densa rede de grupos e cartéis criaram solo fértil para o dirigismo econômico de cunho totalitarista, a partir de 1933. A lei acionária de 1937 aumentou significativamente o poder da administração das companhias e, em seu $\S 15$, estabeleceu pela primeira vez o conceito de grupo de sociedades (Konzern), definindo-o como empresas juridicamente autônomas reunidas sob direção comum.

Ao final da Segunda Guerra Mundial, como parte do projeto de reestruturação democrática da Alemanha Ocidental, os Aliados haviam planejado implementar um profundo programa de desconcentração da atividade econômica. A ideia subjacente era quase certamente a de evitar que as relações promíscuas entre os grandes conglomerados financeiros e industriais e o Estado alemão pudessem novamente contribuir para a afirmação de um modelo de desenvolvimento militarista e expansionista. $\mathrm{O}$ acirramento da Guerra Fria, contudo, provocou uma revisão de prioridades e o pretendido desmanche dos grandes grupos alemães foi abandonado logo após os seus primeiros e tímidos passos $^{56}$.

A tensa e próxima convivência com o bloco socialista impunha sobre a Alemanha Ocidental pressões contraditórias e dificilmente conciliáveis. A segurança do país repousava na sólida e acelerada reconstrução de sua economia e os grandes conglomerados poderiam, sem dúvida, ser um instrumento importante nesse processo. Porém, existia obviamente uma grande preocupação com a concentração do poder - e do poder

55 H. DETTLING, Die Entstehungsgeschichte des Konzernrechts in Aktiengesetz von 1965, p. 57 e 61. V. EMMERICH, M. HABERSACK, Konzernrecht, p. 14.

56 V. EMMERICH, M. HABERSACK, Konzernrecht, p. 3. 
econômico, em particular - vista como determinante para o militarismo e expansionismo alemão das fases anteriores. O grupo de sociedades era temido e necessário.

A esse caldeirão de exigências conflitantes somava-se a questão da competição de modelos (Wettbewerb der Systeme) com a Alemanha Oriental. O desenvolvimento na parte ocidental deveria não apenas se pautar pelas liberdades individual e de mercado, buscando a máxima eficiência, mas deveria ao mesmo tempo buscar uma repartição equânime da riqueza ${ }^{57}$.

Todas essas pressões convergiram para a emergência da política de Economia Social de Mercado (Soziale Marktswirtschaft), em grande parte inspirada pela filosofia ordoliberal, mas mais pragmática do que esta em relação à concentração empresarial. Na visão da Economia Social de Mercado, os conglomerados não eram, em si mesmos, nem bons nem ruins, e cabia à autoridade política mitigar os seus efeitos negativos e promover aqueles positivos ${ }^{58}$.

Nesse sentido, tanto a disciplina dos grupos de direito, regulados por convenção, quanto as regras gerais de cogestão (Mitbestimmung) ${ }^{59}$ - participação obrigatória dos trabalhadores na administração das grandes companhias -, introduzidas na Alemanha nesse período, podem ser vistas como a tentativa de criar freios internos ao exercício do poder econômico sem ter de promover o desmanche dos grandes conglomerados, o que significaria a renúncia às economias de escala e ganhos de eficiência que ensejam ${ }^{60}$. É sob esse pano de fundo histórico e político que foi concebida a lei acionária alemã de 1965.

Um dos aspectos centrais da disciplina alemã da empresa plurissocietária que emergiu em tal período é, com efeito, a distinção entre (i) os grupos de direito, aqueles cujos membros firmaram acordo de domínio (Beherrschungsvertrag) estabelecendo os termos e condições para a gestão de negócios internos ou de transferência total de lucros

57 H. DETTLING, Die Entstehungsgeschichte des Konzernrechts in Aktiengesetz von 1965, p. 2-3.

58 H. DETTLING, Die Entstehungsgeschichte des Konzernrechts in Aktiengesetz von 1965, p. 119-122.

59 H. DETTLING, Die Entstehungsgeschichte des Konzernrechts in Aktiengesetz von 1965, p. 135. Antes do período da Guerra Fria, as normas de cogestão eram limitadas a setores específicos da economia, como a mineração.

60 "Um segundo argumento político em favor da cogestão é o controle do poder ou, melhor formulado, a divisão do poder na grande empresa. O poder econômico, social e político ali existente deve ser repartido entre mais de uma das forças sociais". Tradução livre de: "Ein zweites politisches Argument für die Mitbestimmung ist die Machtkontrolle oder besser Machtverteilung in Großunternehmen. Die dort vorhandene wirtschaftliche, gesellschaftliche und politische Macht soll auf mehrere gesellschaftliche Kräfte verteilt werden." in H. WIEDEMANN, Gesellschaftsrecht, Band I, p. 596. 
(Gewinnabführungsvertrag), nos termos do $\S 291$, e (ii) os grupos de fato, cujo funcionamento não é disciplinado por nenhum acordo dessa natureza.

Durante breve período, nos anos que se seguiram à promulgação da Aktiengesetz de 1965, a articulada disciplina alemã dos grupos, constante da lei acionária, parecia fadada a servir como modelo para a regulamentação da empresa plurissocietária ao redor do mundo, especialmente entre os demais países europeus. De fato, os parlamentares franceses discutiram propostas de reforma legislativa que, se aprovadas, teriam incorporado diversos conceitos da lei alemã ${ }^{61}$. Além disso, as então aparentemente promissoras discussões para a criação de um regime comum dos grupos no âmbito da Comunidade Europeia - que deveriam desaguar na Nona Diretiva do Conselho em matéria de direito das sociedades - tinham as regras implementadas pela Alemanha como evidente ponto de referência.

O esperado triunfo da estratégia adotada pelo legislador alemão de 1965 em relação aos grupos, contudo, não se materializou. Como já se acenou, foram pouquíssimos os países que efetivamente acabaram por seguir esse percurso - o Brasil entre eles ${ }^{62}-\mathrm{e}$ seu peso econômico ou político não era particularmente relevante.

A França, após prolongados debates parlamentares de propostas que claramente se inspiravam no sistema alemão, abandonou a ideia de introduzir regras detalhadas sobre os grupos de sociedades ${ }^{63}$.

A Nona Diretiva nunca superou o estágio de minuta para discussão ${ }^{64} \mathrm{e}$ as regras comunitárias a respeito dos grupos ficaram limitadas essencialmente à Sétima Diretiva (Diretiva 83/349/EEC, de 13 de junho de 1983), relativa à consolidação contábil das sociedades com responsabilidade limitada ${ }^{65}$. Mesmo no que diz respeito a normas futuras

61 Objeto de diversas propostas de lei apresentadas pelo deputado Cousté. R. HOUIN, Les Groupes des Sociétés en Droit Français, p. 46. C. HANNOUN, Le Droit et les Groupes de Sociétés, p. 4

62 De acordo com Emmerich e Habersack, o modelo de ampla codificação dos grupos teria sido plenamente seguido apenas por Brasil, Portugal e Taiwan. Itália, Eslovênia, República Tcheca e Hungria seriam exemplos de codificação parcial. V. EMMERICH, M. HABERSACK, Konzernrecht, p. 18.

63 C. HANNOUN, Le Droit et les Groupes de Sociétés, p. 4-5.

64 V. EMMERICH, M. HABERSACK, Konzernrecht, p. 20.

65 Por meio de relatório de 21 de maio de 2003 (documento $\operatorname{COM(2003)~} 284$ final), a Comissão Europeia firmou o entendimento de que (versão oficial em português): "O Grupo de Alto Nivel de peritos no domínio do direito das sociedades salientou que os grupos de empresas, actualmente frequentes na maioria, senão em todos os Estados-Membros, devem ser considerados uma forma legítima de realizar actividades empresariais, muito embora apresentem riscos específicos para os accionistas e os credores sob diversos ângulos. A Comissão, com base na recomendação formulada pelo Grupo, entende que não 
no âmbito da União Europeia, o direito alemão perdeu favor para regras inspiradas na jurisprudência francesa e no sistema italiano ${ }^{66}$.

Mais surpreendente, porém, é o fato de que nem mesmo internamente, na própria Alemanha, o modelo de direito grupal da lei de 1965 parece ter vingado. Ele não foi recepcionado pelas reformas promovidas no regime das sociedades com responsabilidade limitada $(\mathrm{GmbH})$ daquele país. Tampouco foi acolhido pelos tribunais locais que, ao invés de aplicar tal disciplina analogicamente aos outros tipos societários, optaram, em muitos casos, por lidar com o problema do conflito de interesse em relações de grupo valendo-se de princípios gerais do direito societário, tal como o dever de lealdade ${ }^{67}$.

Ademais, foram poucas as companhias que formalizaram a sua relação de grupo por meio da celebração de convenção ${ }^{68}$. Os grupos de fato permaneceram a regra; o articulado regime de regulação contratual do conflito de interesse criado em torno da figura do grupo de direito permaneceu como exceção, conforme se discute no Capítulo 5, mais adiante.

\subsection{História do Direito Brasileiro dos Grupos}

Com a Crise de 1929, o financiamento da atividade produtiva no Brasil passou, ao longo das décadas de 1930 e 1940, a ocorrer predominantemente pela via dos empréstimos bancários, que suplantou o mercado de valores mobiliários. A essa tendência se associou uma forte concentração do controle sobre grandes companhias nas mãos de grupos familiares, movimento que foi facilitado pela possibilidade de emissão de ações

há qualquer necessidade de 'reactivar' o projecto de Nona Directiva relativa às relações de grupo, uma vez que não se afigura necessária a adopção de um acto legislativo distinto sobre os grupos, [...]"

66 Sintomático a respeito da impopularidade do regime alemão o comentário de Pierre-Henri Conac, em evento organizado pela Comissão Europeia em Bruxelas, em abril de 2011: "Antes que as críticas se derramem sobre mim como a chuva em Londres, ou melhor, a chuva vinda de Londres e de outros lugares da Europa, eu gostaria de indicar o que a proposta não é. A proposta não é 'um direito dos grupos'. A proposta não é uma nova $9^{\circ}$ Diretiva de Direito Societário atinente às relações de grupo. Deixe-me ser claro. Ela não é um Konzernrecht". Tradução livre de: "Before critics pour on me like rain in London, or I should rather say rain coming from London and may be from some other European places, I would like to indicate what the proposal is not. The proposal is not a 'law on groups'. The proposal is not a new 9th Company Law Directive on group relations. Let me be clear. It is not a Konzernrecht." (negrito no original, sem grifo no original) in P. CONAC, Groups of Companies and the Current European Company Law Framework, p. 1.

67 H. WIEDEMANN, Die Unternehmensgruppe im Privatrecht, p. 1.

68 Em 1982, Herbert Wiedemann mencionava a existência de pouco mais de uma centena de acordos de subordinação registrados na Alemanha sob a égide da lei acionária de 1965, a maioria dos quais referentes a alguns poucos grupos e tendo por objeto sobretudo vantagens fiscais. H. WIEDEMANN, The German Experience with the Law of Affiliated Enterprises, p. 28-29. 
preferenciais sem direito a voto, nos termos do artigo $1^{\circ}$, $\S 3^{\circ}$, do Decreto 21.536/1932.

Essa nova estrutura de controle concentrado fornecia melhores condições de atuação em um ambiente pautado pelo dirigismo econômico do Estado Novo ${ }^{69}$.

Nessa realidade anterior à promulgação da Lei 6.404/1976, eram, porém, parcas e esparsas as normas do Direito brasileiro que disciplinavam as relações de controle e coligação entre sociedades, especialmente no que diz respeito às disposições de caráter nitidamente societário.

O Decreto-Lei $2.627 / 1940$, com seu artigo $135, \S 2^{\circ}$, inovou em relação à Lei 3.150/1882, ao determinar que o relatório anual da administração contivesse informações sobre sociedades "controladas ou coligadas", expressão que seria já ao seu tempo compreendida pela doutrina como relativa a duas fattispecie diversas (controladas, de um lado, e coligadas, de outro) e não a uma noção única que tivesse o controle e a coligação como requisitos cumulativos ou alternativos ${ }^{70}$.

O legislador de 1940, porém, furtou-se a definir os referidos conceitos ou atribuirlhes consequências jurídicas mais precisas. A provável razão por trás de tal lacuna parece estar no fato de que a principal motivação que orientou a introdução das noções de

69 “A estrutura do financiamento das empresas no Brasil mudou radicalmente depois das décadas de 1930 e 1940 e os bancos suplantaram os mercados acionários e de títulos como principal fonte de financiamento [...]. A propriedade de grandes companhias acabou altamente concentrada porque ou as famílias ou o Estado tomaram controle do capital votante (o que se tornou relativamente fácil com a introdução de ações sem direito a voto em 1932). Os empreendedores brasileiros acabaram formando grandes e diversificados conglomerados (grupos) com propriedade altamente concentrada em função de razões estratégicas que dizem respeito tanto a questões econômicas - eles são úteis para superar muitas falhas de mercado - e politicas - eles são influentes máquinas de lobby com porte suficiente para fazer frente a poderosos sindicatos". Tradução livre de: "The structure of corporate finance in Brazil changed radically after the 1930s and 1940s and banks supplanted the stock and bond markets as the main source of corporate finance [...]. Ownership of large corporations ended up being highly concentrated because either families or the government seized full control of the voting equity (which became relatively easy with the introduction of nonvoting equity in 1932). Brazilian entrepreneurs ended up forming large, diversified conglomerates (grupos) with highly concentrated ownership for strategic reasons that have to do both with economics - they are helpful for overcoming many market failures and politics - they are influential lobbying machines with sufficient clout to counter the powerful labor unions." in A. MUSACCHIO, Experiments in Financial Democracy - Corporate Governance and Financial Development in Brazil-1882-1950, p. 236.

70 “Entre nós, desde antes do advento da lei de sociedades por ações de 1976, tem-se distinguido a simples coligação do controle, entendendo-se aquela como a participação de uma sociedade no capital de outra, com ou sem reciprocidade, em condição de explicitar uma certa influência econômica, sem que esta se torne preponderante ou dominadora. Neste sentido, interpretou-se o art. $135, \S 2^{\circ}$, do DecretoLei $n^{\circ}$ 2.627, quando falava em 'sociedades controladas ou coligadas', declarando-se que a conjunção ai era alternativa e não explicativa." in F. COMPARATO, C. SALOMÃO FILHO, O Poder de Controle na Sociedade Anônima, p. 68 
sociedades controladas e coligadas em tal lei acionária não foi a tutela dos interesses de credores e acionistas externos, mas sim a intenção - coerente com o espírito nacionalista e estatizante do período - de fornecer ao Estado os meios para monitorar a atuação dos grupos no Brasil, sobretudo os estrangeiros, conforme se depreende dos comentários de Trajano de Miranda Valverde, ilustre autor do respectivo anteprojeto, ao artigo 135, $\S 2^{\circ}$ do Decreto-Lei $2.627 / 1940^{71}$.

Com isso não se quer dizer que a doutrina da época era completamente alheia aos problemas derivados dos vínculos de controle que se estendiam por, e através de, mais de uma sociedade. A questão é simplesmente salientar (i) a preponderância de motivações extrassocietárias para a redação do dispositivo em questão e (ii) a inexistência, em tal período, de um arcabouço normativo, sistemático e estruturado, sobre o tema - tanto é assim que o próprio Trajano de Miranda, ao abordar o argumento, se valeu da ideia de justaposição de pessoa enquanto simulação, como mecanismo para fazer frente ao abuso do controle indireto ${ }^{72}$.

De qualquer modo, para uma avaliação justa e equilibrada, a norma deve ser julgada à luz de seu contexto histórico. O grupo de sociedades é um subtema e expressão particular do debate maior e mais amplo em torno do controle societário. Nesse sentido, em um período em que a maior parte dos países não disciplinava de forma específica o poder de controle ${ }^{73}$, a timidez das disposições do Decreto-Lei 2.672/1940 sobre tais aspectos é perfeitamente compreensível. Ademais, cumpre recordar que, a despeito de suas

71 "Visa também o preceito do $\S 2^{\circ}$ [do artigo 135 do Decreto-Lei 2.627/1940], notadamente com a obrigação que impõe aos diretores de no seu relatório darem precisas informações sôbre a situação das sociedades controladas ou coligadas, a fornecer à Administração Pública os elementos necessários para conhecer da existência dessas coligações ou do domínio de uma sociedade sôbre outras. ”; e ainda: "Interessa ao Estado, para coibir abusos e defender a economia nacional contra a expansão imperialista das grandes organizações internacionais, conhecer a ligação que existe, no país, entre as entidades que exploram certas indústrias-chaves." in T. VALVERDE, Sociedades por Ações, Vol. II, respectivamente p. 425 e 426.

72 "A interposição de pessoa já é ato de simulação, meio indireto de burlar um preceito proibitivo da lei." in T. VALVERDE, Sociedades por Ações, Vol. II, p. 325.

73 "Desconhecido pelo Código do Comércio de 1882, o fenômeno do 'controle' apareceu timidamente no horizonte do novo ordenamento com uma anêmica e pouco incisiva disposição [...] Ao 'controle' o novo código dedicou uma só disposição: aquela do artigo 2.359, com a qual o fenômeno é descrito na mais difusa e elementar conotação [...]". Tradução livre: "Ignoto al codice di commercio del 1882, il fenomeno del 'controllo' è timidamente apparso all'orizzonte del nuovo ordinamento con una scarna e poco incisiva disposizione [...] Al 'controllo' il nuovo codice ha dedicato una sola disposizione: quella dell'art. 2359, con la quale il fenomeno è stato descritto nella sua più diffusa ed elementare connotazione [...]" in A. LA ROSA, Tipologia dei Vincoli di "Controllo" e dei "Gruppi di Controllo", p. 581. 
limitações, surgiram na esteira da então nova lei acionária diversas normas que trataram da empresa plurissocietária em outros campos do Direito.

Em 1943, a Consolidação das Leis do Trabalho (Decreto-Lei 5.452/1943) incorporou o conceito de grupos econômicos em seu célebre artigo $2^{\circ}, \S 2^{\circ}$, que até hoje com diferentes graus de respeito ao contraditório, a despeito do Enunciado $n^{\circ} 205$ do Tribunal Superior do Trabalho - orienta decisões da justiça laboral e justifica a imputação de responsabilidade a sociedades unidas por vínculos de "direção, controle ou administração", sob o razoável fundamento de que o risco da atividade empresarial não deve recair sobre o trabalhador ${ }^{74}$.

A Lei 4.137/1962 estabeleceu como forma de abuso do poder econômico, nos termos de seu artigo $2^{\circ}$, inciso IV, a formação de grupo econômico, por agregação de empresas, que tivesse como objetivo a prática de preços discriminatórios ou vendas casadas.

A Lei da Reforma Bancária (Lei 4.595/1964) substituiu o Conselho da Superintendência da Moeda e do Crédito - SUMOC pelo Conselho Monetário Nacional CMN e, ao listar as competências do novo órgão, incluiu em seu artigo $4^{\circ}$, inciso $\mathrm{X}$, a autoridade para determinar "a percentagem máxima dos recursos que as instituições financeiras poderão emprestar a um mesmo cliente ou grupo de empresas".

A Lei 4.728/1965, cujo anteprojeto é da lavra de Bulhões Pedreira, instituiu, por meio de seu artigo 15, o consórcio de instituições financeiras para a colocação de valores mobiliários no mercado - introduzindo, assim, uma figura típica de grupo de coordenação no ordenamento brasileiro.

No campo tributário, diversas medidas favoreceram a formação dos grupos, em especial a substituição do regime cumulativo - que penalizava estruturas produtivas menos concentradas verticalmente em um único estabelecimento - pelo regime do valor adicionado. Isso ocorreu para o imposto de consumo, que depois se converteria em

74 "Com sua sensibilidade para os fatos e um certo desprezo pelos mitos jurídicos, a Consolidação das Leis do Trabalho foi, certamente, o primeiro diploma brasileiro a estabelecer a co-responsabilidade da holding e da empresa subsidiária no tocante aos ônus trabalhistas, referindo-se expressamente aos grupos industriais, comerciais e outros." in A. WALD, Caracterização do Grupo Econômico de Fato e suas Consequências quanto à Remuneração dos Dirigentes de suas Diversas Sociedades Componentes, p. 2. 
imposto sobre produtos industrializados - IPI, em 1958, e para o imposto sobre vendas em consignação, em 1966. Este último tributo foi substituído, logo em seguida, em 1967, pelo imposto de circulação de mercadorias - ICM, precursor do atual ICMS, que já nasceu sob a égide do sistema de valor adicionado ${ }^{75}$.

No que se refere à Lei 6.404/1976, o novo diploma foi um divisor de águas para todo o direito societário brasileiro e a questão dos grupos de sociedades certamente não representa uma exceção ${ }^{76}$. De um regime lacônico e minimalista, passamos a um tratamento legislativo amplo e pormenorizado das relações de participação entre sociedades.

A detalhada disciplina dos vínculos de controle e de participação constante da nova lei não representou acidente de percurso nem, tampouco, decorreu de intervenções tardias durante a fase de discussão do novo diploma no Parlamento, mas foi o reflexo do objetivo - profundamente enraizado no pensamento político e econômico que orientava as políticas do período - de abrir caminho para a consolidação da grande empresa nacional, conforme testemunham diversos "atos preparatórios" à promulgação do novo diploma.

O artigo 23 do Decreto-Lei 1.338/1974, inspirado pelo projeto político de favorecer a constituição de sociedades holding ${ }^{77}$ - e, por meio destas, a concentração empresarial e a competitividade da indústria brasileira -, eliminou a cobrança do imposto de renda retido na fonte sobre lucros, dividendos e bonificações pagos por uma pessoa jurídica a outra em decorrência de participação societária.

O II Plano Nacional de Desenvolvimento, aprovado pela Lei 6.151/1974, já incluía entre as "opções básicas" da estratégia econômica o favorecimento à formação de "estruturas empresariais poderosas" - ou seja, grandes empresas e conglomerados financeiros ou industriais e financeiros em setores-chave, inclusive por meio de fusões e

75 "A superioridade dos impostos sobre valor adicionado sobre os de incidência em cascata se manifesta em três pontos: os impostos em cascata estimulam a concentração vertical do processo produtivo (de modo a minimizar as passagens das mercadorias de um estabelecimento para outro) [...]" in $\mathrm{M}$. SIMONSEN, A Imaginação Reformista, p. 122.

76 "O direito brasileiro, nessa matéria, ganhou mais coerência interna e precisão conceitual com a Lei $n^{\circ}$ 6.404, de 1976. Até então, faziam-se alusões a 'grupos econômicos' ou 'grupos de empresas', sem que se esclarecesse, devidamente, o sentido técnico de tais expressões." in F. COMPARATO, C. SALOMÃO FILHO, O Poder de Controle na Sociedade Anônima, p. 43.

77 M. CARVAlHOSA, A Nova Lei de Sociedades Anônimas, p. 18. 
incorporações - como forma de aceleração do desenvolvimento ${ }^{78}$.

A Exposição de Motivos do Conselho de Desenvolvimento Econômico n ${ }^{\circ}$ 14, de 25 de junho de 1974, já indicava que seria tarefa da nova lei acionária promover a “regulação do grupo societário e participações recíprocas, de forma a possibilitar o esclarecimento de posição e defesa de direitos por parte do acionista minoritário"79.

O Ofício de 18 de abril de 1975, por meio do qual o anteprojeto que resultaria na Lei 6.404/1976 foi encaminhado para o Mistério da Fazenda, indicava como diretrizes que orientaram a elaboração da proposta, dentre outras, (i) a criação do modelo da grande empresa privada brasileira, (ii) permitir que as médias e pequenas empresas se associassem em joint-ventures e (iii) "disciplinar, de forma tentativa e sem pretensão de fazer obra definitiva [...] fenômenos novos e importantes, como as coligações e os grupos societários" $"$.

A ideia subjacente a essa recorrente preocupação com a questão dos grupos não era somente coibir abusos decorrentes da disseminação da estrutura plurissocietária. Muito pelo contrário, e com notáveis similaridades ao que ocorreu na Alemanha, o objetivo fundamental era estimular a formação de grupos como parte de um plano mais amplo de fomento da grande empresa nacional, tudo em nome do propósito maior de se reverter as ondas de desnacionalização e estatização então vividas pela economia brasileira.

O capitalismo industrial do período exigia investimentos em escala cada vez maior, que excediam a capacidade financeira individual mesmo das mais robustas empresas familiares brasileiras. No vácuo deixado pela iniciativa privada nacional, os grandes projetos de infraestrutura ou industriais do período estavam sendo desenvolvidos quase que exclusivamente pelo Estado - valendo-se de seus "instrumentos [...] de poupança forçada" ${ }^{\prime 1}$ - ou por grupos estrangeiros. No "tripé do desenvolvimento" de então - formado justamente pelo capital privado nacional, pelo capital estrangeiro e pela atuação

78 “Utilização, para a aceleração do desenvolvimento de certos setores, de estruturas empresariais poderosas, como a criação de grandes empresas, através da política de fusões e incorporações - na indústria, na infra-estrutura, na comercialização urbana, no sistema financeiro (inclusive na área imobiliária) -, ou a formação de conglomerados financeiros, ou industriais-financeiros." II Plano Nacional de Desenvolvimento, p. 47.

79 A. LAMY FILHO, J. PEDREIRA, A Lei das S.A., vol. I, p. 133.

80 A. LAMY FILHO, J. PEDREIRA, A Lei das S.A., vol. I, p. 133.

81 A. LAMY FILHO, J. PEDREIRA, A Lei das S.A., vol. I, p. 139. 
direta do Estado na economia - era a primeira perna aquela que fraquejava ${ }^{82}$.

A necessidade de se romper a dicotomia "desnacionalização versus estatização" era particularmente premente em função do momento político e ideológico vivido pelo país. O aumento da participação estrangeira na economia era significativamente delicado para um governo militar, que fomentava discursos ufanistas e planos de grandiosidade nacional $^{83}$. De outra parte, a crescente participação direta do Estado em atividades produtivas não apenas trazia legítimas preocupações em relação à eficiência geral do sistema econômico, mas - questão certamente não banal em tempos de Guerra Fria - era também vista como uma expressão típica das economias centralmente planificadas ${ }^{84}$.

O grupo de sociedades - enquanto facilitador da mobilização e agregação de investimentos (conforme discutido no Capítulo 3) - era visto como uma das principais armas no arsenal de políticas disponíveis para contrastar essa tendência ${ }^{85}$.

A centralidade da questão da concentração empresarial em geral e dos grupos de sociedades em particular no debate que se formou em torno da nova lei acionária é inclusive confirmada pelas mais ásperas críticas então formuladas contra o novo diploma. Em obra em que chegou inclusive a sustentar a inconstitucionalidade da nova lei, o

82 Merecem ser transcritas as considerações do Ministro Simonsen a esse respeito: "Por último, o problema do equilíbrio entre as micro-unidades da produção, a empresa privada nacional, a empresa estatal e a companhia estrangeira. Nesse tripé, como tem sido frequentemente observado, a parte mais débil parece residir na empresa privada nacional. A tecnologia moderna impõe dimensões cada vez maiores às empresas, e o setor privado nacional parece sentir dificuldades incessantes em se ajustar a essas dimensões. As alternativas são obviamente pouco confortáveis para um país que pretenda desenvolver-se sob o regime capitalista: a estatização ou a desnacionalização. Um exame sumário do problema mostra que esse desequilíbrio é quase paradoxal, pois as poupanças privadas nacionais excedem amplamente as do Governo mais as externas. O que parece existir é a falta de capacidade coesiva dessas poupanças, devida à tradição da sociedade anônima fechada, a obsessão pelo controle majoritário do capital votante das empresas e a aversão ao minoritarismo." in SIMONSEN, Mario Henrique, Os Desafios do Desenvolvimento, p. 176. No mesmo sentido, A. LAMY FILHO, J. PEDREIRA, A Lei das S.A., vol. I, p. 139-143.

83 "O Brasil pode, validamente, aspirar ao desenvolvimento e à grandeza" in II Plano Nacional de Desenvolvimento (II PND), aprovado pela Lei 6.151/1974, p. 23.

84 "A verificação de que o processo de estatização atualmente institucionalizado no Brasil conduz o País, inexoravelmente, na direção de um modelo de sistema econômico e político oposto àquele pelo qual optamos em toda a nossa história, e que mais se ajusta às idéias, crenças e valores do nosso sistema cultural, vem constituindo, nos últimos anos, motivo de crescente preocupação do Governo, das classes empresariais e da elite brasileira em geral.” in A. LAMY FILHO, J. PEDREIRA, A Lei das S.A., vol. I, p. 139-142.

85 Entre as políticas que visavam ao equilíbrio entre capital estrangeiro e nacional, estava a: "Emergência de Forte Expressão da Capacidade Empresarial Nacional, para formação de número significativo de grupos nacionais sólidos e, não raro, grandes, no Centro Sul, no Nordeste e demais áreas." in II Plano Nacional de Desenvolvimento (PND II), aprovado pela Lei 6.151/1974, p. 51. 
Professor Carvalhosa denunciava o objetivo explícito do legislador de estabelecer no Brasil regime equiparável ao dos conglomerados japoneses e alemães ${ }^{86}$.

O quadro que claramente emerge da análise histórica, portanto, é o de que as minuciosas disposições da Lei 6.404/1976 sobre a questão dos grupos de sociedades não refletem uma profunda preocupação com os interesses de acionistas externos e credores, mas são sobretudo expressão da intenção de estabelecer as bases para a organização e multiplicação dessa estrutura na realidade brasileira. Nesse sentido, o propósito da lei acionária de 1976 não foi restringir a formação dos grupos, mas - muito pelo contrário simplesmente disciplinar (poder-se-ia dizer, "civilizar" ou "domar") o seu funcionamento, com o mínimo de embaraço possível às suas operações.

\subsection{Conclusões Preliminares}

Enquanto expressão jurídica do fenômeno econômico da concentração empresarial, os grupos são fruto de uma fase já avançada da Revolução Industrial em que se verificou uma mudança da escala de grandeza dos investimentos exigidos pelos novos parques fabris e pela infraestrutura de comunicação e transportes.

A nova realidade econômica, em parte foi resultado da superação de uma série de obstáculos jurídicos e, em parte produziu ela mesma essas mudanças - notadamente, personalidade jurídica, autonomia patrimonial, responsabilidade limitada, deliberação majoritária, participação intersocietária e liberdade de constituição -, que abriram a estrada para uma nova era do direito societário.

A afirmação do novo fenômeno da empresa plurissocietária compeliu os diversos sistemas jurídicos a estabelecerem regras e mecanismos tendo por objetivo disciplinar o seu funcionamento e coibir as suas principais distorções. Nesse processo, verificaram-se dois principais percursos históricos: (i) o da regulação pontual e não sistemática de determinados aspectos dos grupos (com ênfase para participações recíprocas e consolidação contábil) e (ii) a estratégia alemã, de regulação geral e orgânica dos grupos

86 "Como num regime de despotismo esclarecido o anteprojeto reveste o controlador da figura de varão probo a que não só as companhias como o próprio país deve entregar a edificação da GRANDE EMPRESA e do próprio PODER NACIONAL." (maiúsculo no original) e ainda "Através deles [anteprojetos de Lei das S.A. e da CVM] institui-se claramente o regime do oligopólio a favor dos grandes grupos financeiros." in M. CARVALHOSA, A Nova Lei de Sociedades Anônimas, respectivamente p. 15 e 19. 
como tal e enquanto tal.

O Brasil foi o primeiro país no mundo a seguir o exemplo alemão. Tal escolha parece determinada tanto (i) pelo momento de promulgação da Lei 6.404/1976, durante fase em que o sistema alemão ainda despontava como promessa de referência primordial para regras uniformes europeias sobre a matéria, quanto (ii) pelo fato de que o legislador brasileiro buscou - tal como os autores da $A k t G$ de 1965 - não apenas proteger credores e acionistas externos, mas instaurar regime de organização (e promoção) dos grupos. $\mathrm{Ou}$ seja, tanto no Brasil quanto na Alemanha, analisou-se o fenômeno "de cima para baixo" e, à constatação de Karsten Schmidt a esse respeito ${ }^{87}$, pode-se acrescentar "de dentro para fora" - enxergando-se nos grupos de sociedades uma ferramenta política para o desenvolvimento econômico acelerado. O aspecto organizativo (Organisationsrecht) prepondera sobre a questão da proteção de credores e acionistas externos (Schutzrecht).

87 Já citado. K. SCHMIDT, Gesellschaftsrecht, p. 489-490. 


\section{O Sentido Prático da Formação dos Grupos de Sociedades}

Aspecto essencial para a adequada análise dos grupos de sociedades é a compreensão, ainda que nos seus contornos mais amplos, das razões práticas que compelem os empreendedores a organizar as suas atividades por meio de estruturas plurissocietárias, a despeito dos custos inerentes a tal estratégia.

Os destinatários de uma norma raramente são espectadores passivos dos esforços do legislador. Especialmente no campo empresarial, tendo em vista a sofisticação de parte dos agentes e os vultosos recursos à sua disposição, tentativas de regulação podem esbarrar em respostas estratégicas às novas restrições que eventualmente se mostrem ainda mais nocivas para a coletividade do que as condutas que se buscou originalmente disciplinar ${ }^{88}$. Esse onipresente risco será ainda maior se as estruturas de incentivo e desincentivo que pautam as ações dos empreendedores não forem esmiuçadas e tomadas em consideração quando se analisa o fato objeto da norma ou se propõe percurso alternativo para disciplinálo. É fundamental, portanto, investigar as razões práticas que incentivam a formação da empresa plurissocietária.

Cumpre esclarecer, desde logo, que essa parte da investigação não se confunde com o exame deontológico da disciplina legal dos grupos, objeto do próximo capítulo. $\mathrm{O}$ que se discute neste ponto são as razões, de fato, que tornam os grupos mais competitivos e atraentes do que outras estruturas; não os valores que orientam a atividade do legislador quando se debruça sobre esse fenômeno e sobre as suas consequências negativas. Ou seja, o que se propõe neste capítulo do trabalho é uma análise da motivação da conduta, não uma deontologia da norma que a disciplina. Neste momento, o foco está no uso, mais do que no abuso do grupo, ainda que, em termos práticos, os confins entre ambos sejam amiúde pouco nítidos.

Alguns estudos jurídicos a respeito dos grupos dedicaram grande atenção aos

88 "Intervenções estatais (sejam pelo Poder Judiciário ou por órgãos como a CVM) tendem a produzir piores resultados do que a atuação direta dos acionistas (ou de administradores desinteressados), por falta de conhecimento específico da companhia e da situação vivida pelos próprios acionistas.", Processos CVM RJ2006/7204 e RJ2006/7213, voto do Relator Diretor Pedro Oliva Marcilio de Sousa, 17 de outubro de 2006. 
procedimentos por meio dos quais o agrupamento se forma. Por exemplo, Volker Emmerich e Mathias Habersack citam como causas para a formação do grupo a cisão e a aquisição de controle de sociedades existentes ${ }^{89}$. Em seu clássico trabalho a respeito da concentração empresarial e do poder de controle, Champaud também reservou amplo espaço à descrição e à taxonomia das operações que conduzem à formação ou aquisição de uma posição de domínio sobre as decisões de uma sociedade ${ }^{90}$.

É evidente que o percurso de nascimento do grupo possui relevância, sobretudo para a análise jurídica: a constituição de uma subsidiária integral ex novo é menos complexa e envolve menos interesses do que a incorporação de ações de uma sociedade existente da qual participem acionistas externos. Ainda assim, tal discussão parece estar exageradamente circunscrita aos meios formais de criação do grupo, não às suas efetivas razões de existir, as quais representam o efetivo objeto do presente capítulo.

\subsection{Custos da Estrutura Plurissocietária}

Caso a criação e a manutenção de uma estrutura plurissocietária não tivessem um preço para o empreendedor, a análise da motivação prática por trás de sua formação seria menos crítica. De fato, se sua existência fosse economicamente neutra no plano dos custos - tanto em termos de desembolsos efetivos quanto no que diz respeito a custos de oportunidade - qualquer fator positivo, por mais tênue que fosse, já bastaria para explicar a grande disseminação dessa forma de organização dos negócios.

Essa, porém, não parece ser a realidade. Qualquer sociedade, por mais que seja uma holding pura, desprovida de estrutura administrativa própria, enseja custos fixos em seu nascimento e despesas recorrentes ao longo de sua vida. Exemplos de tais ônus são taxas públicas de registro, custos de publicação de documentos e honorários de diversos consultores, legais, fiscais e contábeis.

Em função da existência juridicamente autônoma e distinta, cada sociedade de um grupo tem de obter, em nome próprio, um rosário de inscrições, autorizações e registros, além de possuir ao menos uma conta bancária e um endereço para recebimento de correspondência.

89 V. EMMERICH, M. HABERSACK, Konzernrecht, p. 9.

90 C. CHAMPAUD, Le Pouvoir de Concentration de la Société par Actions, p. 165-194 e 244-258. 
Despesas dessa natureza, que se desdobram conforme se multiplicam as sociedades do grupo, não podem ser automaticamente tratadas como secundárias ou irrelevantes em contexto como o brasileiro, no qual, em média, cada empresa anualmente efetua nove pagamentos de impostos e emprega 2.600 horas de atividade profissional apenas para adimplir suas obrigações tributárias acessórias - o que coloca o Brasil na $150^{\mathrm{a}}$ pior posição a esse respeito em uma pesquisa promovida pelo Banco Mundial em que são avaliadas 183 nações ${ }^{91}$. A questão é particularmente crítica se considerarmos ainda, como exemplo adicional, que a abertura de um novo negócio exige cerca de 119 dias no Brasil, enquanto que no México - para nos atermos a uma comparação justa e razoável - bastam nove $\mathrm{e}^{92}$.

Além disso, a sociedade pode estar sujeita a tributos não dedutíveis, que incidem cumulativamente sobre uma cadeia de faturamento ou distribuição de lucros mais extensa. Surge, assim, uma desvantagem comparativa em relação a uma empresa baseada em uma única sociedade e que, portanto, concentra em si mesma todos esses fluxos de recursos, bens e serviços.

Efetivamente, operações que, para uma sociedade individual, são meramente internas - a coleta de uma peça no estoque, a remessa de fundos de uma conta para outra, a resposta a uma consulta por parte do departamento jurídico ou a transferência de um empregado de um setor para outro - quando verificadas entre duas sociedades de um mesmo grupo representam transações com repercussões externas relevantes - vale dizer, um contrato de fornecimento, um contrato de mútuo, um contrato de consultoria ou ainda a rescisão e celebração de novo contrato de emprego - todas potencialmente sujeitas a tributação e ônus específicos.

Ou seja, além dos custos transacionais decorrentes do gerenciamento do pagamento de impostos, a existência de várias sociedades pode frequentemente aumentar a própria carga tributária total. Não é por outra razão que, historicamente, os sistemas normativos que buscaram facilitar a formação dos grupos, com o objetivo de favorecer a concentração empresarial, incorporaram em seus esforços normas de natureza tributária,

91 Conforme estatísticas do Banco Mundial. WORLD BANK, Doing Business 2012 - Economy Profile: Brazil, p. 72.

92 WORLD BANK, Doing Business 2012 - Economy Profile: Brazil, p. 9. 
que muitas vezes aproximavam o tratamento do grupo ao da sociedade isolada ${ }^{93}$.

A estrutura de grupo, contudo, implica também custos menos óbvios e mais insidiosos. O grupo societário, por definição, é articulado em torno do conceito de controle $^{94}$. A aspiração de domínio sobre as decisões da sociedade pode, entretanto, trazer perdas de eficiência no que diz respeito à diversificação dos riscos de investimento ${ }^{95}$.

O revés da moeda de tal preferência pela estrutura de grupo - justamente porque baseada no controle sobre todas as sociedades envolvidas - é evidentemente uma aversão à posição de minoritário.

Um empreendedor com recursos finitos que tenha como política possuir uma participação de controle em todas as sociedades das quais seja sócio, evidentemente, poderá ser acionista de um número menor de companhias do que aquele que normalmente em razão de ambiente institucional que oferece maior proteção aos acionistas não controladores - está em condições de aceitar com tranquilidade a posição de minoritário. Este último, em contraste com o primeiro, terá seus recursos distribuídos de forma mais ampla e consistente e, portanto, estará mais abrigado contra oscilações de determinado setor de atividade econômica ou desaventuras de uma sociedade específica.

Tal atitude de aversão à condição de minoritário se traduz, também, em dificuldades na agregação de capitais para o financiamento de projetos de maior monta, o que sujeitaria a empresa plurissocietária a uma teórica desvantagem comparativa em relação, por exemplo, a uma companhia única, sob controle gerencial, capaz de mais facilmente absorver recursos de uma multidão de investidores pulverizados.

Os exemplos aduzidos acima parecem suficientes para demonstrar que a formação e a manutenção da forma plurissocietária implicam custos irrecuperáveis para o titular da respectiva empresa. Não são ambições deste trabalho estimar ou quantificar tais ônus,

93 Vide discussão do conceito de Organschaft, do direito tributário alemão, no Capítulo 2 deste trabalho.

94 Nos termos da lei acionária brasileira, o vínculo de coligação também releva para a caracterização do grupo de fato (Lei 6.404/1976, artigo 245), conforme se discute no Capítulo 6. Resta, porém, o fato de que o controle é essencial para que se imprima a todas as sociedades vinculadas uma política empresarial comum, expressão da vontade de um único sujeito.

95 "O controle não confere apenas beneficios, por vezes ele também envolve custos. A manutenção de um bloco de controle, por exemplo, força o maior acionista a ter seu investimento menos diversificado". Tradução livre de: "Control does not only confer benefits: sometimes it involves costs as well. Maintaining a controlling block, for instance, forces the largest shareholder to be not well diversified." in A. DYCK, L. ZINGALES, Private Benefits of Control: An International Comparison, p. 541. 
medir a eficiência da estrutura de grupo, nem tampouco promover qualquer forma de análise econômica do direito quanto a esse ponto. $\mathrm{O}$ aspecto mais importante, de fato, é que essa estratégia de organização da atividade empresarial não é economicamente neutra - muito ao revés -, o que justifica a investigação das razões por trás de sua adoção.

Verificando-se a existência dos referidos custos - e recusando-se como explicação a implausível hipótese de que empreendedores sofisticados ajam repetida e sistematicamente de forma irracional - é forçoso reconhecer que a formação do grupo deve, ao menos sob a perspectiva dos agentes que a promovem, trazer vantagens práticas ${ }^{96}$. O objeto do próximo tópico é justamente indagar sobre a natureza desses possíveis benefícios.

\subsection{Funções e Benefícios Práticos da Estrutura Plurissocietária}

\subsubsection{Instrumento de Gestão da Empresa}

Um dos fatores mais frequentemente citados como motivador da decisão de organizar a atividade econômica por meio de múltiplos veículos societários é a melhor organização da empresa, a partir do momento em que os recursos que esta movimenta atinjam determinadas dimensões críticas. Ou seja, argumenta-se que o grupo é uma ferramenta para a mais eficiente organização da macroempresa de forma descentralizada ${ }^{97-98}$.

96 "Pirâmides de controle devem ser valiosas para alguém ou então não seriam predominantes, como de fato são, em diversas economias". Tradução livre de "Control pyramids must be of value to someone or they would not predominate as they do in many economies." in R. MORCK, D. WOLFENZON, B. YEUNG, Corporate Governance, Economic Entrenchment, and Growth, p. 663.

97 O Professor Comparato cita como uma dentre quatro razões principais para a formação dos grupos: " $O$ aperfeiçoamento da gestão empresarial, transformando-se cada atividade em centro de custo e lucro, perfeitamente distinto." in F. COMPARATO, Os Grupos Societários na Nova Lei de Sociedades por Ações, p. 92. Na mesma passagem do referido artigo, o Professor Comparato cita ainda: (i) a expansão do poder de domínio com investimentos reduzidos (estruturais piramidais), (ii) a colaboração entre empresas (joint-ventures societárias) e (iii) adaptação formal à legislação dos vários países. Esses argumentos foram repetidos em artigo de 1994: F. COMPARATO, Die Konzerne in brasilianischen Aktiengesetz, p. 34. Curioso notar que não é mencionada a limitação (compartimentação) da responsabilidade, que parece ter um papel fundamental para a formação dos grupos e, de fato, mereceu amplo destaque em outra obra do ilustre jurista: F. COMPARATO, Na Proto-História das Empresas Multinacionais: o Banco Medici de Florença, p. 264. Bulhões Pedreira cita entre diversos outros fatores, alguns dos quais são objeto dos tópicos a seguir, a "otimização do uso dos recursos" e a "descentralização ou especialização de atividades." in J. PEDREIRA, Sociedades Coligadas, Controladoras e Controladas, p. 1933-1934.

98 "Dado que não existe nenhum limite para o tamanho de uma sociedade, as razões para a formação de entidades separadas devem ser outras e podem ser o resultado de motivos empresariais legítimos, como a criação de uma divisão com autonomia gerencial". Tradução livre de: "Since there is no limit to the size of a company, the reasons for forming separate entities lies elsewhere and may be for legitimate 
Em sua acepção mais ampla, tal afirmação é extremamente genérica e perde boa parte de seu poder explicativo, uma vez que passa a abarcar todas e quaisquer potenciais vantagens que os grupos oferecem para o desenvolvimento estruturado de uma atividade empresarial, inclusive os aspectos discutidos mais adiante neste capítulo, como a compartimentação do risco.

Em sentido estreito, por outro lado, o argumento diz respeito apenas à utilização da estrutura plurissocietária enquanto instrumento de gestão interna da empresa. Ou seja, traduz-se na ideia de que os agentes formariam os grupos de sociedades porque estes permitiriam a administração mais eficiente do quotidiano de grandes empresas, ao segmentá-las em unidades menores que podem ser mais facilmente supervisionadas e controladas.

É evidente que, em diversos cenários, a repartição de atividades entre múltiplas sociedades pode, efetivamente, ser conveniente à gestão da atividade econômica organizada, especialmente quando se trata de colaboração empresarial (joint-venture) que exija uma clara identificação e isolamento dos resultados da empreitada comum. Este elemento, porém, não tem as feições de força preponderante por trás da formação dos grupos e parece ter seu papel frequentemente sobrevalorizado.

A divisão de uma organização empresarial em unidades menores, com a atribuição de competências e poderes específicos a distintos gestores e departamentos, de acordo com critérios funcionais e territoriais, pode ocorrer de forma totalmente interna a uma única sociedade. É em tal âmbito estritamente "íntimo", com menor probabilidade de ofensa aos interesses de terceiros, que o direito societário oferece a mais ampla e desembaraçada liberdade aos sócios para a formatação da ordem social interna ${ }^{99}$.

Qualquer empresa monossocietária de médio ou grande porte organiza sua gestão

business reasons such as creating a division with managerial autonomy." in J. DINE, The Governance of Corporate Groups, p. 62.

99 “A diferenciação entre a esfera societária interna e as relações externas do grupo pertence à estrutura essencial de quaisquer normas que disciplinam coletividades e, portanto, também no que se refere ao direito societário. Nas relações internas, os vínculos jurídicos entre o ente associativo e seus membros e entre os associados devem ser disciplinados por eles próprios". Tradução livre de: "Die Unterscheidung zwischen der gesellschaftsinternen Binnensphäre und den Außenbeziehungen der Gruppe gehört zu den Seinsstrukturen jedes Gemeinschafts- und deshalb auch des Gesellschaftsrechts. Im Innenverhältnis gilt es die Rechtsbeziehungen zwischen dem Verband und seinen Mitgliedern und zwischen den Gesellschaftern selbst zu regeln." in H. WIEDEMANN, Gesellschaftsrecht, Band I, p. 83. 
interna através de cargos, comissões, regras, manuais e procedimentos que são claramente seguidos - amiúde temidos - por seus empregados e administradores, ainda que no mais das vezes sequer estejam refletidos em seus atos constitutivos.

Sob o manto de um mesmo veículo societário, uma empresa pode serenamente desmembrar-se em múltiplas unidades, não apenas geograficamente - ou seja, por meio do estabelecimento de filiais - mas também por setor, tanto no que diz respeito à atividade a ser realizada - setor de pesquisa, setor de produção, recursos humanos, departamento de vendas etc. - quanto aos respectivos mercados que busca atender - atacado versus varejo, produtos infantis versus produtos para adultos.

Tal fracionamento do monitoramento sobre a atividade é quase sempre complementado por uma complexa cadeia de comando, com precisa repartição de funções e competências. Não é por acaso que organogramas com especificação da hierarquia da empresa - frise-se, da empresa e não da sociedade - sejam, mais do que uma imagem frequente no universo empresarial, um absoluto lugar-comum, quase tão icônico quanto os gráficos de linha do desempenho econômico.

Essas formatação e projeção do poder interno não apenas prescindem da constituição de diversas sociedades como, amiúde, desconsideram a existência formalmente distinta das várias entidades, sobrepondo-se em termos práticos às respectivas regras estatutárias. É o caso, por exemplo, da grande multinacional que nomeia um profissional de médio nível hierárquico para ser formalmente o administrador de uma sociedade controlada. Tal administrador, mais cioso de seu emprego do que de seu cargo e estando, na maioria das vezes, a continuidade de ambas as posições permanentemente sujeita à vontade da sociedade controladora - tenderá a cumprir fielmente as diretrizes que receber e a não tomar iniciativas próprias individuais, não importando a autoridade que o estatuto social the possa formalmente conferir. Ou seja, a organização das funções no interior empresa pode ocorrer independentemente - e até mesmo a despeito - da estrutura plurissocietária.

Além da questão da cadeia de comando, é também comum a prática de se manter diversos registros contábeis separados e paralelos no âmbito de uma única sociedade, em função de suas diferentes finalidades, legais e gerenciais. Assim, especialmente com a difusão dos computadores pessoais, tornou-se praxe corriqueira manter registros separados 
sobre rentabilidade de uma específica linha de produtos ou performance financeira de uma determinada filial ${ }^{100}$.

Todos esses exercícios de segmentação da empresa para fins exclusivamente gerenciais podem, em princípio, ser implementados por meio de mecanismos internos, que não apenas prescindem da constituição de diversas sociedades como evitam embaraços legais tais como o dever de publicidade ou a tutela de credores - na ausência de acionistas externos - em situações de conflito de interesse.

A repartição da atividade empresarial em múltiplas sociedades pode certamente facilitar a sua gestão, uma vez adquirida certa dimensão extraordinária. Ela permite que o empreendedor se valha de mecanismos definidos pela própria lei para compartimentar as suas atividades. Ou seja, evita que o empresário tenha de riscar linhas divisórias já solidamente traçadas pelo direito positivo. Contudo, ainda que útil, a estrutura plurissocietária não é essencial para tal fim e a mera questão organizacional não parece capaz de justificar, por si só, a forte tendência à formação dos grupos de sociedades.

\subsubsection{Adaptação a Requisitos e Obstáculos Legais}

Uma razão prática mais determinante - e, portanto, mais convincente - do que a simples organização da empresa para justificar a formação dos grupos é a adaptação estratégica do empreendedor a requisitos e obstáculos legais.

Nessa seara, merece destaque a constituição, por parte de empresas que internacionalizam as suas atividades, de sociedades controladas regidas pelo direito de cada uma das praças em que decidem atuar de forma permanente. Com efeito, conforme já assinalado no capítulo anterior, desde os tempos do Banco Médici, o grupo de sociedades

100 Nos Estados Unidos, verifica-se inclusive o fenômeno da emissão de valores mobiliários atrelados a segmentos específicos de uma única sociedade-conglomerado (tracking stocks). Esse exemplo confirma o fato de que a compartimentação de atividades e ramos de negócios no âmbito exclusivamente interno de um único ente societário pode, em princípio, ser tão profunda e detalhada (inclusive no que diz respeito à contabilização de resultados) a ponto mesmo de produzir efeitos nas relações com terceiros, inclusive com desdobramentos sobre o mercado de capitais e a poupança popular. "[...] diversos conglomerados estadunidenses emitiram recentemente tracking stocks, que são ações cujos dividendos estão vinculados a uma única divisão do conglomerado.". Tradução livre de: "[...] many U.S. conglomerates have recently issued tracking stocks. These are stocks whose dividends are tied to a single division of the conglomerate." in R. MORCK, D. WOLFENZON, B. YEUNG, Corporate Governance, Economic Entrenchment, and Growth, p. 673. Sobre a introdução do instituto na Itália e suas vantagens: M. VENTORUZZO, Experiments in Comparative Law: The Recent Italian Reform and the Dubious Virtues of a Market for Rules in the Absence of Effective Regulatory Competition, p. 175. 
representa um dos instrumentos mais típicos da empresa multinacional.

A disponibilidade de um veículo societário plenamente integrado à realidade jurídica na qual o "forasteiro" dá seus primeiros passos traz consigo diversas vantagens. A primeira delas é a redução dos custos de transação nos negócios celebrados com empresários locais. Para nos atermos a banal exemplo, é muito mais fácil e menos dispendioso para um empresário brasileiro solicitar à competente Junta Comercial cópia dos atos constitutivos de uma sociedade limitada, controlada por grupo estrangeiro, para verificar se aquela existe, se está regularmente registrada e se foi adequadamente representada em determinado contrato, do que obter informações análogas relativas a uma sociedade estrangeira.

Além disso, a lei local pode exigir do investidor estrangeiro permissões especiais, tal como a já citada autorização do Poder Executivo, nos termos do artigo 1.134 do Código Civil de 2002, que podem ser facilmente contornadas por meio da constituição de uma sociedade controlada no país alvo.

A estruturação da atividade empresarial em uma rede de diversas sociedades, todas sob controle comum mas com sedes em diferentes jurisdições, permite, ademais, o aproveitamento estratégico dos tratados, regras físcais e benefícios de cada Estado (treaty shopping $)^{101}$. Assim, por exemplo, se uma companhia com sede no país $A$ deseja celebrar vultoso contrato com cliente estabelecido no país $C$, mas verifica que não existem convenções em matéria de bitributação entre tais Estados, ela pode preferir que a operação seja realizada por - ou com a intermediação de - sua sociedade controlada, do país $B$, que possui acordos válidos tanto com $A$ quanto com $C$.

Em alguns casos, determinado ramo dos negócios da empresa pode estar sujeito a rigorosa regulamentação, de forma que a segregação de atividades não sujeitas a tal controle estatal em uma entidade separada pode trazer flexibilidade e redução de custos,

101 "Estratégias internacionais de elisão regulatória envolvem, essencialmente, a escolha de um ordenamento conveniente no qual criar uma entidade jurídica, tal como uma companhia, sociedade de pessoas ou um trust, que pode ser usado como veículo para se deter ativos ou através do qual canalizar operações". Tradução livre de: "International regulatory avoidance strategies essentially entail choosing a convenient jurisdiction in which to create a legal entity, such as a corporation, partnership or trust, which can be used as vehicle to own assets or through which to channel transactions." in S. PICCIOTTO, Regulating Global Corporate Capitalism, p. 92. 
aumentando inclusive o valor de mercado da subsidiária ativa no setor livre de restrições ${ }^{102}$.

Tais vantagens, certamente determinantes em inúmeras situações, não são capazes de explicar, porém, a formação de grupos cuja atividade é limitada ao território de um único Estado - não raros em países como o Brasil, com dimensão continental - e em contextos em que não se vislumbra relevante pressão regulatória para adoção dessa estrutura. A adequação ao pano de fundo regulatório em que a empresa deverá atuar é, portanto, explicação possível, mas não exclusiva ou suficiente para a formação dos grupos.

\subsubsection{Acumulação de Poder com Investimento Reduzido}

A afirmação do princípio majoritário, tal como se acenou no capítulo anterior, ensejou situação em que determinados acionistas ou administradores - conforme o controle seja majoritário, minoritário ou gerencial - têm o poder-dever de gerir bens de terceiros vale dizer, bens da companhia que redundam, em última instância, em expectativas e direitos dos demais acionistas - como se próprios fossem ${ }^{103}$.

A estrutura de grupo permite levar essa dissociação entre propriedade e controle do capital às suas últimas consequências e, com efeito, é muitas vezes adotada com o

102 M. EISENBERG, The Structure of the Corporation - A Legal Analysis, p. 280. Apenas como exemplo, pode se mencionar o fato de as instituições financeiras no Brasil não podem voluntariamente adquirir imóveis não destinados ao uso próprio (Lei 4.595/1964) e, mesmo se para aplicação em suas atividades, não podem deter prédios e terrenos em valores superiores ao seu capital realizado e reservas. Se quiserem, portanto, investir em imóveis para uso de terceiros, os acionistas de um banco devem, em princípio, constituir uma nova sociedade. Galgano aponta a esse respeito, relativamente à experiência italiana: "Uma companhia de seguros não pode, enquanto tal, desenvolver atividade bancária, nem pode tampouco um banco desenvolver atividade de oferta de seguros, a estas, porém, é consentido o exercício indireto da atividade por meio de participação de controle tendo por objetivo a constituição de um conglomerado financeiro. É possível, deste modo, constatar como a empresa de grupo pode superar, ao menos no campo da conglomeração financeira, fronteiras não superáveis pela empresa isolada". Tradução livre de: "Una compagnia di assicurazione non può, in quanto tale, intraprendere l'esercizio diretto di attività bancaria, né può una banca intraprendere l'esercizio diretto di attività assicurativa; ad esse ne è, tuttavia, consentito l'esercizio indiretto, per il tramite di una partecipazione di controllo, rivolta a costituire una conglomerata finanziaria. É dato, a questo modo, di constatare come l'impresa di gruppo possa superare, quanto meno nel campo della conglomerazione finanziaria, frontiere non superabili dall'impresa singola." in F. GALGANO, Direzione e Coordinamento di Società - Art. 2497-2497 septies, p 216. No mesmo sentido, enfatizando o fracionamento societário como estratégia para lidar com restrições regulatórias no setor financeiro: $M$. EISENBERG, Megasubsidiaries: The Effect of Corporate Structure on Corporate Control, p. 1580.

103 “O controle é o direito de dispor dos bens alheios como um proprietário. Controlar uma empresa é deter o controle dos bens que lhe estão afeitos (direito de deles dispor como um proprietário) de tal sorte que se seja capaz de dirigir a sua atividade econômica". Tradução livre de: "Le contrôle est le droit de disposer des biens d'autrui comme un propriétaire. Contrôler une entreprise c'est détenir le contrôle des biens qui lui ont été affectés (droit d'en disposer comme un propriétaire) de telle sorte que l'on soit maître de diriger son activité économique" in C. CHAMPAUD, Le Pouvoir de Concentration de la Société par Actions, p. 161. 
objetivo específico de permitir o controle sobre a maior massa possível de recursos com o menor investimento de capitais próprios, especialmente em países - como o Brasil marcados pela alta concentração da propriedade acionária e mercados de capitais ainda não plenamente desenvolvidos ${ }^{104}$.

Um dos caminhos mais típicos por meio dos quais o grupo é utilizado para tal fim é o da constituição de estruturas piramidais ou em cascata ${ }^{105}$. Entre a companhia holding de comando e as sociedades efetivamente operacionais são interpostas diversas sociedades intermediárias, em cada uma das quais o controlador detém a parcela de capital estritamente necessária para determinar o seu voto na assembleia da sociedade controlada que está imediatamente "abaixo" na cadeia, atribuindo-se o restante das ações em cada um dos diversos degraus societários da estrutura grupal a acionistas externos.

Assim, detendo não mais do que metade mais uma das ações da companhia que se

104 Ainda que com ressalvas quanto à disponibilidade e à consistência dos dados a esse respeito, Khanna e Yafeh conjecturam que: "Uma possível justificação lógica para a superioridade e predominância da forma de grupo em mercados emergentes é que a estrutura de grupo isola o acionista controlador da pressão de investidores institucionais e de tomadas de controle e confere controle e influência econômica incontestáveis com limitado investimento de capital". Tradução livre de: "A possible rationale for the superiority and predominance of the group form in emerging markets is that the group structure insulates the controlling shareholder from institutional investor pressure and takeovers, and bestows control and economic influence undisputed with limited capital investment." in T. KHANNA, Y. YAFEH, Business Groups in Emerging Markets: Paragons or Parasites?, p. 341.

105 A praxe já era amplamente difundida nos Estados Unidos quando Berle e Means publicaram seu clássico estudo sobre o poder de controle: "No esforço de manter o controle sobre uma companhia sem a propriedade da maior parte de suas ações, foram desenvolvidos vários mecanismos legais. Destes, um dos mais importantes entre as sociedades de grande porte é o instrumento da 'estruturação piramidal'. Ele envolve a propriedade da maior parte do capital de uma sociedade que, por sua vez, detém a maior parte das ações de uma outra - um processo que pode ser repetido várias vezes. Por meio deste método, entrincheira-se legalmente uma participação correspondente a pouco mais do que um quarto, um oitavo, um dezesseis avos ou ainda menos do ente final a ser controlado. [...] O proprietário de fração majoritária do capital da sociedade no ápice da pirâmide pode ter um controle quase tão completo sobre toda a propriedade quanto o proprietário único, ainda que seja titular de participação inferior a um por cento do total". Tradução livre de: "In the effort to maintain control of a corporation without ownership of a majority of its stock, various legal devices have been developed. Of these, the most important among very large companies is the device of 'pyramiding.' This involves the owning of a majority of the stock of one corporation which in turn holds a majority of the stock of another $-a$ process which can be repeated a number of times. An interest equal to slightly more than a quarter or an eighth or a sixteenth or an even smaller proportion of the ultimate property to be controlled is by this method legally entrenched. [...] The owner of a majority of the stock of the company at the apex of the pyramid can have almost as complete control of the entire property as a sole owner even though his ownership interest is less than one per cent of the whole." in A. BERLE, G. GARDINER, The Modern Corporation and Private Property, p. 69. Sobre o mesmo tema: F. COMPARATO, Os Grupos Societários na Nova Lei de Sociedades por Ações, p. 92. "[...] a piramidação de sociedades é instrumento para concentrar o poder de controle de uma empresa (ou de um conjunto de empresas) com $o$ mínimo de aplicação de capital" in J. PEDREIRA, Sociedades Coligadas, Controladoras $e$ Controladas, p. 1924. 
encontra na posição de vértice, o controlador decide o voto de todas as ações que esta última detém na sociedade que controla imediatamente, o que por sua vez permite o direcionamento dos votos desta última em suas próprias controladas e assim por diante. Desse modo, o controlador pode determinar os rumos de enorme volume de recursos, tendo por base investimento extremamente baixo, em termos proporcionais.

É possível que se verifique, portanto, com apenas duas ou três repetições dessa manobra, uma desproporção entre o investimento total do controlador no negócio e a possibilidade de controle muito mais significativa do que aquela presente na companhia que emita ações preferenciais sem direito a voto até o limite legal de $50 \%$, nos termos do artigo 17 da Lei 6.404/1976 - a qual pode ser controlada por sócio que tenha apenas pouco mais de um quarto do capital total ${ }^{106-107}$.

Mesmo que todas as sociedades envolvidas tenham suas ações representadas exclusivamente por ações ordinárias, bastaria uma estrutura composta por quatro níveis (ou degraus) distintos para permitir ao controlador o domínio sobre a totalidade da empresa plurissocietária por meio do aporte de pouco mais de $6,25 \%$ dos recursos que nela foram imobilizados.

Os acionistas externos se tornam, ao mesmo tempo, uma grande maioria econômica e uma insignificante minoria política.

Além de ser uma ferramenta para a conquista de posição dominante sobre as sociedades agrupadas, a estrutura de grupo também pode servir como instrumento para a estabilização de um bloco de controle já existente ${ }^{108}$. Assim, por exemplo, podemos imaginar a sociedade $\alpha$, que tem como acionistas, de um lado, a sociedade $X$, detentora de $40 \%$ do capital social, e de outro as pessoas naturais e parentes entre si $A, B, C$ e $D$, cada um deles titular de $15 \%$ das ações da companhia.

Conjuntamente, as pessoas naturais $A, B, C$ e $D$ perfazem um bloco de controle. Porém, caso qualquer um deles (ou respectivos herdeiros) se alie à sociedade $X$, formar-se-

106 Ou mais de $16,66 \%$ do capital social para as sociedades anônimas constituídas anteriormente à reforma da Lei 6.404/1976 em 2001, nos termos da Lei Federal 10.303 do mesmo ano.

107 Para uma ilustração bastante elucidativa desse tipo de estrutura: R. MORCK, D. WOLFENZON, B. YEUNG, Corporate Governance, Economic Entrenchment, and Growth, p. 663.

108 T. CANELLAS, R. LEAL, Evolução e Estrutura de Controle das Empresas Ligadas na Bovespa entre 2004 e 2006, p. 13. 
á um novo bloco de controle. Para evitar qualquer "deserção" ou fragmentação de seu bloco de controle, $A, B, C$ e $D$ podem conferir suas ações representativas do capital social de $\alpha$ para a companhia $Y$, uma sociedade holding constituída especificamente para esse fim. Assim, cada uma das pessoas naturais terá $25 \%$ do capital social de $Y$, e esta última será inquestionavelmente a acionista controladora de $\alpha$.

O grupo pode também ser utilizado para resguardar politicamente a posição do acionista controlador por vias menos transparentes, muitas das quais já foram objeto de disciplina legal específica na maior parte dos Estados. É o caso, por exemplo, das participações recíprocas. Apenas como exemplo, um acionista que controle a maioria dos votos, mas não em número suficiente para alcançar quórum qualificado previsto no estatuto de companhia fechada para uma deliberação específica, poderia fazer com que uma controlada indireta subscrevesse as ações da holding e exercesse o voto no sentido por ele desejado.

Vale notar que, além da relação entre acionistas controladores e minoria social, o grupo também interfere no equilíbrio de poder entre acionistas em geral e administradores ${ }^{109}$. Se as atividades da empresa são fracionadas em diversas sociedades, muitas das decisões que caberiam diretamente aos acionistas em uma estrutura de conglomerado (sociedade única) - tais como todas as deliberações das controladas compreendidas no rol do artigo 136 da Lei 6.404/1976 - passam a ter como filtro inevitável a administração, uma vez que é o órgão administrador quem, em nome da companhia, exerce as prerrogativas de sócio, notadamente o direito de voto nas sociedades por ela controladas.

$\mathrm{Na}$ realidade brasileira, em que os administradores podem ser destituídos ad nutum a qualquer tempo e na qual não está disseminada a estrutura de controle gerencial ${ }^{110}$,

109 O Professor Comparato cita o interessante caso Aiple v. Twin City Barge \& Towing Co. (143 N.W.2d 374-1966), julgado nos Estados Unidos, em que os administradores buscaram contornar o quórum de deliberação correspondente a dois terços dos votos, posto como requisito para a aprovação de aumentos do capital social - uma vez que enfrentavam a resistência de minoritário detentor de mais de um terço das ações -, realizando através de uma sociedade controlada operações com o mesmo efeito econômico. F. COMPARATO, C. SAlOMÃO FILHO, O Poder de Controle na Sociedade Anônima, p. 145. Amparado no caráter extraordinário das operações de aumento do capital social, a Suprema Corte de Minnesota decidiu por maioria, em 22 de junho de 1966, manter a decisão do juiz a quo que reconheceu tal operação como fraude aos direitos atribuídos pela lei ao acionista minoritário.

110 Como salienta o Professor Eduardo Secchi Munhoz, os administradores ainda são, no Brasil, a longa manus do acionista controlador. E. MUNHOZ, Desafios do Direito Societário Brasileiro na Disciplina da Companhia Aberta: Avaliação dos Sistemas de Controle Diluído e Concentrado, p. 126. Assevera o 
essa questão é menos crítica, mas pode de qualquer forma ser relevante em contextos específicos.

Outro aspecto relevante a ser considerado é o fato de que o controlador pode utilizar a estrutura de grupo como verdadeira estratégia de divide et impera. $\mathrm{O}$ grupo desfavorece a coordenação da minoria política que representa a maioria econômica. Assim, por exemplo, comparados com os preferencialistas de uma única companhia, os acionistas externos de uma estrutura piramidal - segregados em cada uma das sociedades agrupadas possuem interesses menos homogêneos (possivelmente até conflitantes). Por serem investidores da mesma empresa, mas não da mesma companhia, não podem unir forças para se valer de prerrogativas como aquelas previstas nos artigos 105, 123, alínea “d”, 141, $\S 4^{\circ}$, II ou $157, \S 1^{\circ}$ da Lei $6.404 / 1976$. Pelas mesmas razões, seus interesses podem facilmente estar contrapostos em muitas situações concretas.

Também nas situações tratadas neste tópico, porém, a explicação para a formação dos grupos é convincente, mas não exaustiva ou determinante. A busca da potencialização do poder político não parece, por exemplo, justificar, por si só, a formação dos grupos sujeitos ao controle totalitário do mesmo acionista ou bloco de acionistas - apesar de, como apontado, ter um potencial impacto no raio de ação dos administradores das respectivas sociedades.

Em estudo de 2006, Heitor Almeida e Daniel Wolfenzon argumentam, com efeito, que a simples manutenção do poder de controle com investimentos reduzidos não parece explicar a intensidade e a difusão das estruturas piramidais de controle. Tal conclusão se baseia em observações estatísticas que indicam que (i) estruturas piramidais ocorrem mesmo em certos casos em que não parece existir acentuada dissociação entre controle e propriedade do capital e (ii) empreendedores que recorrem a tais estruturas não parecem utilizar com a frequência e intensidade esperadas determinados mecanismos (tais como as ações sem direito a voto), que seriam alternativas supostamente mais simples para a conservação do controle societário com o menor investimento possível ${ }^{111}$.

Professor Calixto Salomão Filho que "No Brasil é extrema a concentração acionária [...] Assim sendo, é impossível imaginar em hipóteses normais um controle administrativo sem sentido próprio, i.e., em ausência de um controlador ativo." in F. COMPARATO, C. SALOMÃO FILHO, O Poder de Controle na Sociedade Anônima, p. 75-76.

111 H. ALMEIDA, D. WOLFENZON, A Theory of Pyramidal Ownership and Family Business Group, p. 2638. 
Cumpre, portanto, analisar possíveis fundamentos práticos adicionais e complementares para a ampla difusão da empresa plurissocietária.

\subsubsection{Ambiente Institucional Adverso}

No campo da análise econômica, existe um número considerável de estudos que buscam estabelecer uma correlação entre a prevalência do grupo de sociedades principalmente em contraposição à propriedade acionária altamente dispersa, mas também em contraste à formação de conglomerados monossocietários - e ambientes institucionais que não oferecem adequada segurança em termos de respeito aos contratos, incluindo a proteção aos interesses de acionistas minoritários ${ }^{112}$.

De acordo com essa visão - que naturalmente comporta inúmeras variações e nuances, cuja catalogação foge do escopo deste trabalho -, em Estados nos quais a tutela da posição de investidores e financiadores é relativamente pouco eficaz, forma-se uma espécie de círculo vicioso. Acionistas controladores não apenas estão mais protegidos contra abusos de seus consócios, mas possuem eles próprios mais amplas oportunidades para capturar benefícios privados dos demais acionistas - prática conhecida como "tunneling"113. Em função disso, investidores externos passam a exigir prêmios de risco mais elevados como condição para aceitarem assumir a posição de acionistas minoritários ou mesmo conceder empréstimos em favor das companhias.

Por sua vez, o mercado financeiro desfavorável compele as empresas ao autofinanciamento de suas atividades - também chamado de "mercado de capitais interno" $" 114$-, o que apenas pode ser eficaz em estruturas de alta concentração empresarial, nas quais o mesmo grupo de acionistas controla empresas ativas em diferentes ramos de atividade e com distintos graus de maturação de seus respectivos investimentos e desloca recursos de um setor para o outro, de acordo com seus objetivos estratégicos. A titularidade de participação em várias empresas, somada ao grande número de operações entre partes

112 Apenas como exemplos: A. DYCK, L. ZINGALES, Private Benefits of Control: An International Comparison. T. KHANNA, Y. YAFEH, Business Groups in Emerging Markets: Paragons or Parasites?. R. MORCK, D. WOLFENZON, B. YEUNG, Corporate Governance, Economic Entrenchment, and Growth. H. ALMEIDA, D. WOLFENZON, A Theory of Pyramidal Ownership and Family Business Group.

113 R. MORCK, D. WOLFENZON, B. YEUNG, Corporate Governance, Economic Entrenchment, and Growth p. 678.

114 T. KHANNA, Y. YAFEH, Business Groups in Emerging Markets: Paragons or Parasites?, p. 303. 
relacionadas, aumenta o número de situações de conflito de interesse e o risco de prejuízo para os acionistas externos, o que alimenta e intensifica todo o processo.

O poder e a capacidade de mobilização de recursos do grupo podem ser utilizados para fazer frente a outras deficiências do mercado, não diretamente relacionadas à questão do financiamento. É o caso, por exemplo, de estruturas de treinamento comuns a todo o grupo, que buscam compensar a ausência de disponibilidade de mão de obra qualificada no país em que as diversas sociedades agrupadas atuam.

Outro aspecto extremamente relevante é o fato de que, em países com ambientes institucionais adversos, boas relações e conexões com as autoridades políticas podem ter um papel determinante no sucesso ou no fracasso das empresas. Contatos e trânsito nos canais adequados significam frequentemente a diferença entre a obtenção ou não de licenças, autorizações, renúncias físcais e financiamento público (crédito direcionado) ${ }^{115}$. Empresas de maior porte - como costuma ser o caso das empresas plurissocietárias costumam estar melhor posicionadas para ter maior poder de barganha em face do Estado e de outros agentes.

Aldo Musacchio argumenta, por exemplo, que a forte concentração da propriedade das companhias brasileiras, nas mãos de grupos familiares ou do Estado, a partir das décadas de 1930 e 1940 - subsequentemente à decadência do mercado de capitais vivida entre o final do Século XIX e o início do Século XX - teve como fundamento não apenas questões econômicas, mas a maior força política dessas novas estruturas empresariais, mais aptas a lidar com cenário de dirigismo econômico que então se desenhava ${ }^{116}$.

115 "[...] as empresas que mais doaram a candidatos vencedores conseguiram acesso preferencial a um recurso relativamente escasso no Brasil: capital financeiro. [...] Quem mais doou para a campanha de políticos vencedores conseguiu obter mais recursos financeiros em um período subsequente" e "Havendo restrição de financiamento e melhores condições de empréstimo em segmentos escolhidos, apenas uma fração dos empreendimentos privados verá a luz do dia. Isso afetará principalmente empresas de menor porte e sem acesso aos recursos direcionados." in S. LAZZARINI, Capitalismo de Laços: Os Donos do Brasil e suas Conexões, p. 47 e 49.

116 Trecho já citado. "Os empreendedores brasileiros acabaram formando grandes e diversificados conglomerados (grupos) com propriedade altamente concentrada em função de razões estratégicas que dizem respeito tanto a questões econômicas - eles são úteis para superar muitas falhas de mercado - e politicas - eles são influentes máquinas de lobby com porte suficiente para fazer frente a poderosos sindicatos". Tradução livre de: "Brazilian entrepreneurs ended up forming large, diversified conglomerates (grupos) with highly concentrated ownership for strategic reasons that have to do both with economics - they are helpful for overcoming many market failures - and politics - they are influential lobbying machines with sufficient clout to counter the powerful labor unions." in A. 
No fundo, parece que estamos diante de uma incidência específica dos princípios gerais já delineados por Coase: são os custos de transação que determinam as fronteiras entre o mercado e a empresa ${ }^{117}$. Quanto mais hostil - leia-se custoso - o ambiente externo de negócios, mais internalizadas serão as operações econômicas. Nessa equação, o grupo, de acordo com o seu maior ou menor grau de integração vertical, poderia ser considerado, do ponto de vista puramente econômico, como uma estrutura híbrida, em que as operações internas à empresa se revestem de feições de transações realizadas no mercado ${ }^{118-119}$.

Apesar de se verificar forte correlação entre ambiente institucional adverso e a existência dos grupos, parece que estamos diante fatores que não são, direta e imediatamente, causa e consequência um do outro.

As conclusões de tais estudos fornecem explicações plausíveis à tendência, amplamente observada, de concentração empresarial e de autofinanciamento da atividade

MUSACCHIO, Experiments in Financial Democracy - Corporate Governance and Financial Development in Brazil-1882-1950, p. 236.

117 "A principal razão pela qual é lucrativo estabelecer uma empresa parece ser o fato de que existe um custo na utilização do mecanismo de preços". Tradução livre de: "The main reason why it is profitable to establish a firm would seem to be that there is a cost of using the price mechanism." in R. COASE, The Nature of the Firm (1937), p. 21.

118 "A ubiquidade e diversidade dos grupos empresariais tornam fascinante o estudo dessa instituição. Conceitualmente, essa forma organizacional hibrida entre empresa e mercado pode trazer nova luz para a teoria da empresa e seus confins". Tradução livre de: "The ubiquity and diversity of business groups make the study of this institution fascinating. Conceptually, this hybrid organizational form between firm and market can shed new light on the theory of the firm and its boundaries." in T. KHANNA, Y. YAFEH, Business Groups in Emerging Markets: Paragons or Parasites?, p. 333.

119 O grupo como entidade que transita entre mercado (decisões pautadas pelo mecanismo do preço) e organização (decisões orientadas por coordenação hierárquica) é um conceito bastante presente nos estudos de Gunther Teubner: "[...] o direito dos grupos define os limites entre mercado e organização e, assim, (co)produz novos objetos de orientação [objetos de incidência de normas programáticas], aos quais, apenas a partir de então, poderá se vincular uma regulamentação externa." e "Por meio de uma proibição, reforçada por sanções, da adoção da forma híbrida do grupo de fato, buscou-se obrigar as empresas a uma clara separação entre mercado e organização: ou real autonomia da empresa dominada ou a sua absorção na unidade organizacional do grupo regulado por convenção ou, alternativamente, formado pela operação de integração [Eingliederung]”. Tradução livre de: “[...] definiert das Konzernrecht die Grenzen von Markt und Organisation und (ko-)produziert damit neue Steuerungsobjekte, an die externe Regulierungen überhaupt erst anknüpfen können."; e "Mit einem sanktionsbewehrten Verbot der hybriden Form des faktischen Konzerns hatte man die Unternehmen zur klaren Trennung von Markt und Organisation zwingen wollen: entweder reale Marktautonomie der abhängigen Unternehmen oder deren Aufgehen in der Organisationseinheit des Vertrags- bzw. Eingliederungskonzerns.” in G. TEUBNER, Die „Politik des Gesetzes “ im Recht der KonzernhaftungPlädoyer für einen sektoralen Konzernduchgriff, respectivamente, p. 264 e 268. Em trabalho posterior, Teubner argumenta que algumas estruturas de grupo representariam um terceiro gênero de condução da atividade produtiva, que emergiria de forma autopoiética e transcenderia tanto o mercado quanto a organização. É importante, porém, sublinhar que a análise do ilustre professor estava concentrada nos grupos fluídos e transitórios organizados na forma de rede e não nos grupos de subordinação sujeitos a controle estável. G. TEUBNER, The Many-Headed Hydra: Networks as Higher-Order Collective Actors, p. 47. 
produtiva em ambientes institucionais adversos. Tais análises, porém, não abordam - senão de forma indireta, mediata e secundária - a razão pela qual o referido processo de concentração, com todas as consequências que encerra, se articula preponderantemente por meio da empresa plurissocietária e não através de conglomerados monossocietários. Demonstrar que o ambiente adverso favorece a concentração econômica não significa elucidar a razão pela qual esta tende a ocorrer por meio da formação de grupos de sociedades. Conforme já se argumentou, não existe motivo a priori para que o aumento do tamanho da empresa conduza obrigatoriamente à adoção da estrutura plurissocietária.

Este aspecto, provavelmente menos relevante para a investigação puramente econômica, voltada sobretudo ao vago conceito de "firm", é, ao revés, extremamente importante para a análise jurídica e para o direito societário. Nesse sentido, resta a ser preenchido um anel da cadeia de explicações.

\subsubsection{Limitação da Responsabilidade e Compartimentação Patrimonial}

Dentre todas as razões comumente citadas como justificadoras da escolha pela estrutura plurissocietária, aquela que parece mais crítica, determinante e de aplicação geral

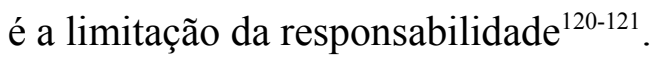

120 "O primeiro objetivo que se busca com a formação do grupo é a separação dos riscos conexos a cada setor ou a cada mercado: cada sociedade do grupo é, perante terceiros, um sujeito de direito distinto das outras sociedades do mesmo grupo, cada uma delas responsável pelas dividas que assumiu, não responsável pelas dividas assumidas pelas outras sociedades, para as quais estas são, juridicamente, dívidas de outrem. O benefício da responsabilidade limitada, próprio das sociedades por ações, é desse modo usufruido na medida mais ampla possivel." Tradução livre de: "Il primo obiettivo cui la formazione di un gruppo mira è la separazione dei rischi connessi a ciascun settore o a ciascun mercato: ogni società del gruppo è, di fronte ai terzi, un soggetto di diritto distinto da ogni altra società del medesimo gruppo, ciascuna responsabile dei debiti da essa assunti, non responsabile dei debiti assunti dalle altre società, che per esse sono, giuridicamente, debiti altrui. Il beneficio della responsabilità limitata, proprio della società per azioni, viene così fruito nella misura più estesa possibile." (sem grifo no original) in F. GALGANO, Lex Mercatoria, p. 165. "É justamente a independência patrimonial e a não-confusão de responsabilidades da controladora e das demais sociedades controladas que fazem desta forma de concentração empresarial [grupo] o instrumento para a redução dos riscos na expansão dos negócios." in V. PRADO, Conflito de Interesses nos Grupos Societários, p. 41.

121 No campo da análise econômica, tem-se como hipótese que: “A preferência pela forma do grupo também pode se dar em função de considerações jurídicas, particularmente em relação à responsabilidade societária e à possibilidade do acionista controlador de escolher não socorrer empresas do grupo que estejam em dificuldades. [...] Em contraste, a forma de conglomerado pode ser mais apropriada do que o grupo para o propósito de se obter uma redução da tributação por meio do nivelamento da renda através de suas divisões". Tradução livre de: "The group form may be preferred also because of legal considerations, especially in relation to corporate liability and the ability of the controlling shareholder to choose not to bailout ailing group firms [...] By contrast, the conglomerate form may be more appropriate than a business group for the purpose of tax reducing income smoothing across divisions." in T. KHANNA, Y. YAFEH, Business Groups in Emerging Markets: Paragons or 
O benefício da limitação da responsabilidade nasceu como forma de tutelar a posição dos investidores não envolvidos diretamente na gestão do negócio, fato ilustrado perfeitamente nas duas classes de sócios que caracterizam a estrutura das sociedades em comandita. Mais tarde, tal proteção seria estendida a todos os sócios, passando a representar uma barreira entre patrimônio pessoal do investidor e patrimônio destinado à atividade social.

Com a formação dos grupos se verifica uma nova e profunda mutação da função do preceito da limitação da responsabilidade, que é levado assim às suas consequências mais extremas. No âmbito da mesma empresa, determinadas parcelas do patrimônio total passam a estar sujeitas apenas a parte das obrigações contraídas. Partes dos bens empregados diretamente na atividade empresarial desenvolvida deixa de servir como garantia a parte das dívidas decorrentes do próprio negócio ${ }^{122}$.

De um lado, tal transformação representa uma efetiva subversão do princípio da limitação da responsabilidade do empresário. A limitação deixa de ser uma barreira apenas entre duas esferas patrimoniais bem precisas - aquela privada e aquela sujeita aos riscos da empresa $^{123}$ - para se converter em diversos pequenos cercados, constituídos (por exemplo, na cisão ou constituição de nova sociedade) ou levantados (incorporação e dissolução) de

Parasites?, p. 341. Também a esse respeito, R. MORCK, D. WOLFENZON, B. YEUNG, Corporate Governance, Economic Entrenchment, and Growth, p. 673.

122 "O benefício da responsabilidade limitada, típico da sociedade por ações, é fruído, desse modo, na medida mais extensa possível. Ele não serve apenas, como em suas origens, para separar o capital investido na sociedade do patrimônio pessoal do sócio, mas ser também a diversificar os riscos empresariais: não se trata mais da responsabilidade do sócio-investidor, mas é a responsabilidade de uma sociedade pelos débitos de uma outra sociedade [...]". Tradução livre de: "Il beneficio della responsabilità limitata, proprio della società per azioni, viene così fruito nella misura più estesa possibile. Esso non vale solo, come nelle origini, a separare il capitale investito nella società dal patrimonio personale del socio; ma vale anche a diversificare i rischi imprenditoriali: non è più la responsabilità limitata del socio-investitore, ma è la responsabilità di una società per i debiti di un'altra società [...]" in F. GALGANO, Direzione e Coordinamento di Società - Art. 2497-2497 septies, p. 4.

123 "O ente legal e o ente econômico eram idênticos; a companhia era a empresa. Todos os ativos do negócio estavam à disposição do pagamento dos débitos do próprio negócio e a limitação da responsabilidade protegia os investidores de perdas da atividade que excediam o valor do capital que subscreveram. Nos Estados Unidos, isso mudou dramaticamente, entre 1888 e 1893, com a adoção por Nova Jersey das primeiras leis autorizando companhias, de forma geral, a adquirir e manter participações no capital de outras companhias". Tradução livre de: "The legal entity and economic entity were identical; the corporation was the enterprise. All assets of the business were available for payment of the debts of the business, and limited liability protected the investors from losses of the business in excess of their capital subscription. In the United States, this changed dramatically in 188893 with the adoption by New Jersey of the first statutes authorizing corporations generally to acquire and hold stock in other corporations." in P. BLUMBERG, The American Law of Corporate Groups, p. 306-307. 
acordo com a conveniência do empreendedor.

Questão mais grave, porém, é o fato de que essas novas e menores áreas de compartimentação patrimonial não são estanques umas em relação às outras, mas representam "vasos comunicantes" 124 . Suas membranas de separação podem se tornar permeabilíssimas, quando e se assim quiser o controlador, que também poderá no mais das vezes determinar o sentido do fluxo patrimonial, em uma ou em outra direção. Desnecessário salientar que esse estado de coisas pode ensejar todo tipo de fraude e abuso.

Por outro lado, a limitação da responsabilidade por meio da estrutura plurissocietária tem inúmeros usos e resultados não apenas perfeitamente legítimos como também altamente desejáveis.

A possibilidade de controlar diversas sociedades, todas com personalidade jurídica e patrimônio próprios, associada à limitação da responsabilidade do sócio ao capital investido em cada uma delas, faz com que o empreendedor possa diversificar seus riscos e tomar novas iniciativas, estando ciente de que nem todos os ovos estarão na mesma cesta. $\mathrm{Na}$ felicíssima expressão do Professor Comparato, a limitação da responsabilidade associada à estrutura de grupo permite criar linhas de aceiro, que impedem a propagação de incêndios entre diferentes áreas e segmentos da empresa ${ }^{125}$. Sem tal prerrogativa, cada nova operação ou projeto poderia colocar em jogo a própria existência do conglomerado.

Uma compartimentação patrimonial clara e perfeitamente delimitada também representa um requisito essencial para a agregação de capitais e know-how em torno de novos projetos. Grande parte das vantagens de uma joint-venture societária, ou seja, do investimento realizado por dois ou mais empreendedores em colaboração, por meio de uma sociedade de propósito específico, deriva da limitação da responsabilidade no âmbito desta última. Sem ela, os parceiros não teriam a segurança de que os investimentos comuns não serão afetados por dívidas privadas de seus consócios. Além disso, a nova sociedade permite que o investimento seja realizado sem que nenhuma das partes envolvidas tenha de admitir terceiros no seio da própria sociedade holding.

124 F. COMPARATO, C. SALOMÃO FILHO, O Poder de Controle na Sociedade Anônima, p. 357-358. C. CHAMPAUD, Le Pouvoir de Concentration de la Société par Actions, p. 275.

125 F. COMPARATO, Na Proto-História das Empresas Multinacionais: o Banco Medici de Florença, p. 264. 
Outro aspecto importante a ser levado em consideração é o fato de que a limitação da responsabilidade não está, nem sempre nem exclusivamente, a serviço do empreendedor-devedor, mas também pode tutelar a posição de seus credores. A compartimentação da responsabilidade permite que o credor analise apenas a situação patrimonial da sociedade com a qual diretamente contrata, sem ter de investigar o status do grupo inteiro. O seu risco de crédito é mais facilmente mensurável, com redução dos custos de transação ${ }^{126}$.

Além disso, ressalvadas manobras abusivas da sociedade de comando, o patrimônio de uma companhia fica resguardado de débitos decorrentes de operações das demais participantes do grupo. Justamente porque a limitação da responsabilidade representa, ao menos em parte, uma via de duas mãos, o credor deixa de ter acesso ao inteiro patrimônio do grupo, mas, em contrapartida, tem a segurança de não concorrer com os credores particulares de outras sociedades agrupadas, em relação àquela específica parcela de bens - cristalizada sob a propriedade de uma sociedade do grupo juridicamente autônoma - que tomou como garantia para o seu crédito.

Todas essas vantagens parecem justificar a opção dos empreendedores pela estrutura de grupos, mesmo nas situações não alcançadas pelas explicações anteriormente analisadas neste capítulo. Apesar de o foco deste ponto do trabalho ser as motivações práticas dos empreendedores, possível entrever, desde logo, um interesse público na existência da compartimentação patrimonial do grupo, que não pode ser desconsiderado quando se discute o tratamento legislativo do tema.

126 "[...] os custos para negociar com o membro de um grupo aumentariam muito se existisse a responsabilidade de grupo. Em tal regime, a pessoa negociando com a sociedade que fosse parte do grupo teria que não apenas se satisfazer quanto à solvabilidade da sociedade isolada, mas também quanto à solvabilidade de todo o grupo". Tradução livre de: "[...] the costs to dealing with a member of a group would be greatly increased if there were to be group liability. In such a regime a person dealing with a company which was part of a group would not only have to satisfy himself as to the credit worthiness of the individual company but also as to the credit worthiness of the whole group." in D. PRENTICE, A Survey to the Law Relating to the Corporate Groups in the United Kingdom, p. 307. 


\subsubsection{Mobilização dos Investimentos}

Além dos benefícios intrínsecos da limitação da responsabilidade, a segregação patrimonial decorrente da alocação de determinadas atividades e bens a uma figura societária traz consigo também a vantagem da negociabilidade da empresa e maior facilidade de combinação de recursos e investimentos.

A organização da empresa de forma plurissocietária favorece, portanto, a venda de ramos de negócios, um benefício que não é perfeitamente replicado por meio de patrimônios separados ou de afetação. A transferência do controle sobre a pessoa jurídica, na forma de ações ou quotas, é muito mais simples e segura do que a venda de uma universalidade de bens. Assim, além de instrumento de investimento, o grupo representa também uma forma eficaz de desinvestimento. A perspectiva de mais fácil alienação de fração da empresa plurissocietária é um evidente estímulo para o investimento inicial ${ }^{127}$.

Se, com a possibilidade de participação no capital social, umas das outras, as sociedades se tornaram, simultaneamente, sujeitos e objetos de relações de propriedade, como discutido no capítulo anterior, com a disseminação dos grupos a própria sociedade ou, mais precisamente, o seu controle - torna-se mercadoria ${ }^{128}$. É graças à compartimentação patrimonial que se pôde formar um verdadeiro mercado de controle societário, que se reflete, entre outros elementos, na existência da contemporânea indústria de venture capital.

Para o empreendedor, isso se traduz em amplas possibilidades de monetizar partes da empresa plurissocietária quando e se necessário. Se, da perspectiva do controlador, essa maior liquidez é um importante benefício privado, do ponto de vista da coletividade ela é uma ferramenta essencial para a alocação mais eficiente dos recursos. É através das operações de transferência de controle que negócios potencialmente promissores, mas pobremente geridos ou capitalizados, podem ser assumidos por controladores que tenham à

127 C. SALOMÃO FILHO, A Sociedade Unipessoal, p. 38-39.

128 " [...] o novo não está apenas no como se produz; está também no que se produz; e está, outrossim, na circunstância particular de que o produtor é, ao mesmo tempo, sujeito e objeto da economia, ele próprio mercadoria de troca. [...] Delineia-se, assim, o aclamado fenômeno do 'mercado de controle"'. Tradução livre de: "[...] il nuovo non sta solo nel come si produce; sta anche nel che cosa si produce; $e$ sta, oltre a ciò, nella singolare circostanza che il produttore è, ad un tempo, soggetto ed oggetto dell'economia, esso stesso merce di scambio. [...] Si delinea il conclamato fenomeno del 'mercato del controllo'." in F. GALGANO, Direzione e Coordinamento di Società - Art. 2497-2497 septies, p. 11. 
sua disposição os elementos financeiros, técnicos e materiais ideais para o seu desenvolvimento.

A questão da mobilização dos investimentos tem, em função de quanto exposto acima, um papel muito relevante para explicar o porquê da escolha da estrutura de grupo na realidade prática, a despeito de seus custos. É forçoso reconhecer, contudo, que a possibilidade de eficiente cessão do controle está em relação de complementariedade com a limitação da responsabilidade - a qual, portanto, parece possuir um papel mais central neste tema. Sem a limitação da responsabilidade, não haveria a compartimentação patrimonial completa que está na base das operações de transferência de controle.

\subsection{Conclusões Preliminares}

São diversas, e muitas vezes complementares, as vantagens práticas para os empreendedores decorrentes da adoção da estrutura plurissocietária. Tais benefícios explicam a grande disseminação dos grupos, a despeito dos custos inerentes à sua formação.

Ainda assim, entre todas as potenciais explicações analisadas, destaca-se como a mais crítica e determinante a da compartimentação patrimonial, decorrente da limitação da responsabilidade dos sócios e, sobretudo, da sociedade enquanto sócia. Esta característica não apenas é pressuposto para outras das principais vantagens dos grupos - como, por exemplo, a mobilização dos investimentos - como representa aquela que menos facilmente se faz substituir por mecanismos alternativos.

Mesmo a análise da questão da limitação da responsabilidade sob a perspectiva exclusiva do empreendedor já permite divisar alguns primeiros traços de interesse público no instituto. De fato, se ao empreendedor fosse concedido o benefício da limitação de responsabilidade apenas em relação a uma única sociedade controlada, o incentivo para a diversificação de investimentos e participação em empreitadas de risco seria muito menor. 


\section{Fundamento Teleológico da Disciplina dos Grupos}

A pesquisa teleológica representa uma bússola hermenêutica fundamental tanto para a compreensão dos fenômenos disciplinados pela lei, quanto para a adequada aplicação da norma jurídica. Sem uma detalhada investigação do sentido ou função de um instituto, sua análise se converte em um inócuo exercício descritivo de características externas; uma mecânica morfologia de conceitos que não permite a verdadeira compreensão de sua estrutura.

Além disso, a aplicação cartesiana, literal e acrítica de uma disposição legal pode levar a resultados não apenas socialmente indesejáveis, mas diametralmente contrários aos objetivos originais do legislador e da comunidade política que legitimou as suas decisões ${ }^{129}$. Summum ius, summa iniura.

O problema central dos grupos de sociedades - e de qualquer norma que busque disciplinar esse fenômeno - é evidentemente a contradição entre, de um lado, unidade decisória e econômica e, do outro, multiplicidade jurídica de suas partes integrantes ${ }^{130}$. Grupo é expressão que, por si só, já indica a unidade na pluralidade ${ }^{131}$. Neutralizar ou mitigar as consequências negativas de tal dicotomia é, portanto, o objetivo natural e primordial de qualquer norma atinente à empresa plurissocietária.

Contudo, a transposição da análise teleológica desse plano mais geral e abstrato para indagações de natureza específica e concreta, tendo por objeto normas determinadas passo essencial para se alcançar conclusões válidas sobre os bens da vida efetivamente

129 "Toda a prescrição jurídica legal tem provavelmente um escopo, e presume-se que a este pretenderam corresponder os autores da mesma, isto é, quiseram tornar eficiente, converter em realidade o objetivo ideado. A regra positiva deve ser entendida de modo que satisfaça aquele propósito; quando assim não se procedia, construíam a obra do hermeneuta sobre a areia movediça do processo gramatical." in C. MAXIMILIANO, Hermenêutica e Aplicação do Direito, p. 124

130 H. DETTLING, Die Entstehungsgeschichte des Konzernrechts im Aktiengesetz von 1965, p. 8. “O fenômeno do grupo se caracteriza pelo fato de que, à unidade de direção administrativa e controle financeiro, corresponde uma pluralidade de organizações autônomas sob o aspecto econômico, técnico, administrativo e também jurídico". Tradução livre de: "Il fenomeno del gruppo si caratterizza per ciò che all'unità di direzione amministrativa e di controllo finanziario [...] corrisponde una pluralità di organizzazioni autonome sotto l'aspetto economico, tecnico, amministrativo e anche giuridico." in G. FERRI, Le Società, p. 698-699. F. GALGANO, Direzione e Coordinamento di Società - Art. 2497-2497 septies, p. 29-30. V. EMMERICH, M. HABERSACK, Konzernrecht, p. 55.

131 G. FERRI, Le Società, p. 699. 
tutelados pelas regras examinadas - definitivamente não representa uma tarefa simples.

As incontáveis normas que lidam com o fenômeno dos grupos são marcadas por uma diversidade assombrosa de objetivos imediatos, técnicas, estruturas e fundamentos dogmáticos. Se a sociedade isolada já representa uma forma de contrato notadamente capaz de afetar os interesses de terceiros ${ }^{132}$, é evidente que o grupo societário poderá fazêlo com muito mais intensidade e diversidade, pois é mais amplo o espectro potencial de sujeitos atingidos pela sua atuação.

O legislador, pragmático, sempre se movimentou neste campo com o objetivo de resolver, em cada contexto, dificuldades concretas, sem se fazer deter pelas preocupações de organização conceitual do jurista. O resultado final é um caleidoscópio de normas, fragmentário e desprovido de qualquer organicidade, que parece desafiar, à primeira vista, qualquer esforço de classificação e simplificação ${ }^{133}$.

Resta ao pesquisador buscar decantar e classificar, para fins exclusivos de análise, uma realidade complexa, ainda que se saiba de antemão que o retrato final será incompleto, uma mera aproximação, e que existirá inevitável sobreposição entre as diferentes categorias adotadas para organizar o argumento.

Reconhecendo o peso dessas dificuldades, o objetivo do presente capítulo é discorrer brevemente sobre os objetivos mais amplos e genéricos das normas que tratam dos grupos para, em seguida, identificar, em relação às normas grupais societárias - e, mesmo no âmbito destas, com foco apenas nas disposições da Lei 6.404/1976 -, (i) os bens da vida por elas tutelados, (ii) os sujeitos destinatários da proteção legal e, enfim, (iii) os valores que as orientam. Ao fazê-lo, espera-se trazer à tona alguns elementos caracterizadores das normas societárias dos grupos, que as apartam e contradistinguem de

132 E não é por outra razão, apenas como exemplo, que a sociedade nula deve ser liquidada (Lei 6.404/1976, art. 206, inciso II, alínea "a" e Código Civil, artigo 1.034, inciso I) - o que significa produzir efeitos jurídicos - e não simplesmente desconsiderada, como ocorreria em contrato bilateral típico. Justamente por se tratar de instituto que alcança a esfera de direitos, interesses e expectativas de terceiros, o retorno ao status quo ante não ocorre automaticamente com o reconhecimento da nulidade.

133 Hannoun expõe a questão com eloquência: "Heteróclito, contraditório, fragmentado entre os diversos ramos do direito, ele deixa uma impressão de mal-estar a quem com ele quer satisfazer o princípio da coerência. Importante demais para ser reduzido a um conjunto de casos específicos, o direito dos grupos é mais do que uma simples impureza nas águas claras do direito comum”. Tradução livre de: "Hétéroclite, contradictoire, éclaté dans les divers branches du droit, il laisse une impression de malaise à qui veut en saisir le principe de cohérence. Trop important pour être réduit à un ensemble de cas d'espèces, le droit des groupes est plus qu'une simple impureté dans les eaux claires du droit commun." in C. HANNOUN, Le Droit et les Groupes de Sociétés, p. 6. 
outras regras voltadas à empresa plurissocietária ou aos vínculos entre sociedades.

\subsection{Sentidos Amplos das Normas de Direito dos Grupos}

\subsubsection{Grupos e Destinatário Substancial das Normas}

Conforme já observado no Capítulo 3, a repartição das atividades de uma empresa entre mais de uma sociedade pode se prestar às mais diversas estratégias - com os mais distintos graus de legitimidade moral e jurídica - que tenham por objetivo evitar a incidência de determinados comandos legais ou contratuais.

Uma sociedade pode ser constituída em determinado Estado, apenas para assegurar acesso a tratados internacionais relativos à bitributação ou à resolução de conflitos que, em princípio, não alcançariam a nacionalidade de seus acionistas ${ }^{134}$. Se um contrato impõe a uma companhia o pagamento de royalties a terceiro, calculados com base em seu faturamento total, os seus acionistas podem tentar desenvolver parte da atividade em questão por meio de nova sociedade ${ }^{135}$. Existindo previsão de que sociedades com determinado número mínimo de empregados devem assegurar a representação destes últimos no conselho de administração (cogestão), o empregador pode contratar alguns deles por sociedade controlada interposta, de forma a assegurar que o limite crítico não seja excedido ${ }^{136}$. A mesma estratégia pode ainda ser adotada para evitar que uma

134 Esta segunda questão já foi enfrentada no caso ICSID ARB/98/7, julgado pelo Centro Internacional para a Arbitragem de Disputas sobre Investimentos, vinculado ao Banco Mundial, que contrapôs grupo empresarial canadense ao governo da República Democrática do Congo. Conforme extrato da decisão de $1^{\circ}$ de setembro de 2000: "O Tribunal não pode admitir que os requisitos de nacionalidade impostos pela Convenção de Washington sejam neutralizados por investidores que busquem se valer, de acordo com os próprios interesses em cada momento, simultânea ou sucessivamente, tanto da proteção diplomática quanto da arbitragem ICSID, tomando como base o fato de que uma das sociedades do grupo não possui a nacionalidade de um estado-membro da Convenção - e pode, portanto, se beneficiar da proteção diplomática em seu estado de origem - enquanto que uma outra controlada do grupo possui a nacionalidade de um estado-membro da Convenção e, assim, tem legitimidade ativa perante um tribunal ICSID". Tradução livre de: "The Tribunal cannot allow the requirements of nationality imposed by the Washington Convention to be neutralized by investors who are seeking to avail themselves, depending on their own interests at a given point in time, simultaneously or successively, of both diplomatic protection and ICSID arbitration, by playing on the fact that one of the companies of the group does not have the nationality of a Contracting State party to the Convention, and can therefore benefit from diplomatic protection by its home State, while another subsidiary of the group possesses the nationality of a Contracting State to the Convention and therefore has standing before an ICSID tribunal".

135 T. ASCARELLI, Problemas das Sociedades Anônimas e Direito Comparado, p. 493.

136 Não por acaso, encontra-se nas regras de alemãs de cogestão (Mitbestimmung) um dos embriões do direito dos grupos (Konzernrecht) daquele país. A primeira lei que estabeleceu o princípio da representação quase paritária no âmbito dos conselhos de supervisão (Aufsichtsrat) das companhias ativas nos setores da mineração, fundição e siderurgia (MontanMitbest $G$, de 1951) não continha regras 
convenção coletiva de trabalho particularmente vantajosa para os trabalhadores seja aplicada a todos os empregados do grupo ${ }^{137}$.

São, enfim, incontáveis os possíveis exemplos de utilização estratégica da estrutura societária unicamente (ou principalmente) para embaralhar as cartas e refugir a deveres e obrigações, apresentando-se ao mundo com a face que seja mais conveniente para a ocasião. Ocorre que o sistema normativo parece ainda, em certos casos, ter como premissa o fato de que o sujeito destinatário do comando legal seja uma pessoa, física ou jurídica, com vontade e interesses próprios.

Conforme discutido no tópico 3.2.2 deste trabalho, a resposta a obstáculos legais e regulatórios é uma das grandes razões práticas por trás da utilização da estrutura plurissocietária. A outra face dessa mesma moeda é representada pela missão do Estado de separar as estratégias legítimas das abusivas, reconhecendo a validade daquelas e coibindo estas.

Buscar os interesses últimos e efetivos por trás da rede de sociedades do grupo,

de agrupamento, questão que foi corrigida em 1956. "O conceito específico de cogestão econômica dos trabalhadores por meio de sua participação no conselho de supervisão [...], sobretudo nos grupos de sociedade, depara-se rapidamente com seus limites, uma vez que a concentração empresarial não significa, essencialmente, nada além do que a transferência de prerrogativas decisórias de dentro da empresa para terceiros, com a consequência de que a cogestão econômica dos trabalhadores resta esvaziada caso não se consiga, nas relações de grupo, estendê-la aos tomadores das decisões realmente importantes (que, no entanto, encontram-se fora da empresa). Já há tempo, o legislador se preocupou, portanto, em (complementarmente) reassentar a cogestão econômica no nivel em que, em última análise, as decisões serão tomadas, ou seja, no ápice do grupo". Tradução livre de: "Das Konzept speziell der wirtschaftlichen Mitbestimmung der Arbeitnehmer auf dem Weg über ihre Beteiligung am Aufsichtsrat [...] stößt vor allem in Konzernen schnell an seine Grenzen, da Unternehmenskonzentration der Sache nach nichts anderes als eine Verlagerung von Entscheidungskompetenzen aus dem Unternehmen heraus auf Dritte bedeutet - mit der Folge, dass die wirtschaftliche Mitbestimmung der Arbeitnehmer leerläuft, wenn es nicht gelingt, sie in Konzernzusammenhängen auf die eigentlich maßgeblichen, indessen unternehmensfremden Entscheidungsträger auszudehnen. Der Gesetzgeber bemüht sich deshalb seit langem darum, die wirtschaftliche Mitbestimmung (zusätzlich) auf derjenigen Ebene anzusiedeln, auf der letztlich die Entscheidungen falle, d.h. bei der Konzernspitze." (negrito no original) in V. EMMERICH, M. HABERSACK, Konzernrecht, p. 70.

137 "[...] foram relatados casos em que estruturas de grupo foram constituídas para escapar de determinadas regras relativas à democracia industrial. Ao dividir a empresa em diversas seções, diferentes convenções coletivas de trabalho se tornam aplicáveis, algumas mais favoráveis do que as outras. Ademais, alguns grupos podem, assim, ficar abaixo do limite para o estabelecimento de um conselho de empresa em cada uma das entidades que o compõem". Tradução livre de: "[...] cases have been reported in which group structures were set up to escape certain rules on industrial democracy. By splitting up the enterprise in several sections, different labour relation agreements may become applicable, some more favourable than others. Also, some groups may thus remain under the threshold for the enterprise council in each of the component enterprises." in E. WYMEERSCH, The Groups of Companies in Belgian Law, p. 336. 
desde que haja expressa previsão legal ou quando assim exigir uma prudente ponderação de valores fundamentais - além de ser, frequentemente, uma exigência para a eficácia prática da norma específica em questão -, não significa nada menos do que dar concretude ao princípio constitucional da igualdade perante a lei ${ }^{138}$, nos termos do caput do artigo $5^{\circ}$ da Constituição Federal de 1988. Seria efetivamente iníquo conferir a determinados sujeitos de direito a injustificada possibilidade de evadir deveres e direitos por meio de verdadeira polimorfia jurídica, enquanto que as demais pessoas permanecem inexoravelmente limitadas à própria e única identidade ${ }^{139}$.

Nessas situações, o ordenamento busca (i) conjugar novamente responsabilidade e poder decisório - ou seja, fazer com que o centro de tomada de decisões e o substrato de subjetividade jurídica sobre o qual estas repercutem voltem a coincidir - e/ou (ii) evitar que determinadas qualidades pessoais julgadas determinantes pelo legislador nacionalidade, faturamento, percentual de domínio sobre mercado relevante, ramo de atividade, prévia condenação, etc. - sejam falseadas por meio de anteparo societário.

Certamente não tão numerosos quanto as possibilidades de abuso da forma societária, são de qualquer forma muitos os exemplos de regras que perseguem exatamente esse efeito corretivo de determinação e fixação da identidade do destinatário substancial dos comandos legais.

É o caso do artigo $4^{\circ}, \S 7^{\circ}$ da Lei Federal 9.074/1995 $5^{140}$. O princípio da desverticalização do setor elétrico prevê a separação das atividades de geração e distribuição de energia. Para evitar que a restrição seja facilmente contornável por meio de banais arranjos societários, o dispositivo em questão veda às entidades que atuam na

138 Entendida como "igualdade na lei" e, portanto, como comando que se dirige tanto (e principalmente) ao legislador quanto à autoridade a quem incumbe julgar ou de qualquer outra forma aplicar a lei. J. SILVA, Curso de Direito Constitucional Positivo, p. 215-216.

139 “[...] o princípio da igualdade perante a lei é, também, como todas as fórmulas igualitárias, genérico. A communis opinio, de fato, o interpreta como uma prescrição da exclusão de qualquer discriminação arbitrária, seja da parte do juiz, seja da parte do legislador, onde por 'discriminação arbitrária' se compreende aquela introduzida ou não eliminada sem uma justificação e, mais sucintamente, uma discriminação não justificada (e, nesse sentido, 'injusta')". Tradução livre de: "[...] il principio dell'eguaglianza di fronte alla legge è anch'esso, come tutte le formule egualitarie, generico. La communis opinio infatti lo interpreta come prescrivente l'esclusione di ogni discriminazione arbitraria sia da parte del giudice sia da parte del legislatore, ove per 'discriminazione arbitraria' s'intenda quella introdotta o non eliminata senza una giustificazione, e, più brevemente, una discriminazione non giustificata (e in questo senso 'ingiusta')." (sem grifo no original) in N. BOBBIO, Eguaglianza $e$ Libertà, p. 21-22.

140 Incluído pela Lei Federal 10.848/2004. 
geração de energia a assunção da posição de controladora ou coligada de sociedades ativas no ramo da distribuição.

No âmbito do sistema de defesa da concorrência, atribui-se igualmente maior importância aos grupos econômicos, representantes mais fidedignos da realidade econômica subjacente, do que às sociedades individualmente consideradas. Apenas como exemplo, é o faturamento do grupo econômico como um todo e não o das sociedades diretamente envolvidas em cada operação que determina a necessidade de aprovação prévia dos atos de concentração econômica pelo Conselho Administrativo de Defesa Econômica (Lei Federal n 12.529/2011, artigo 88).

Já a Lei Complementar 123/2006, que trata do regime protetivo das micro e pequenas empresas, contém verdadeiras normas antigrupo, que visam a assegurar que as vantagens fiscais concedidas não sejam usufruídas por empresas efetivamente de maior porte, que busquem se apresentar ao mundo como entidades menores por meio do fracionamento dos seus ganhos entre diversas sociedades. É por essa razão que os incisos I, III e IV do artigo $3^{\circ}, \S 4^{\circ}$, da referida lei excluem do enquadramento como micro ou pequena empresa aquelas que tenham como sócios pessoas jurídicas, empresários ou sócios de outras sociedades incentivadas (cuja receita global ultrapasse os limites da lei), bem como sócios detentores de mais de $10 \%$ do capital de sociedades não incentivadas (também neste caso, cuja receita global ultrapasse os limites da lei). Além disso, à micro ou pequena empresa é, em princípio, vedado participar do capital de outras sociedades (artigo $3^{\circ}, \S 4^{\circ}$, inciso VII).

Em cada um dos exemplos discutidos acima, há um objetivo último perseguido pelo legislador - preservar a segregação das atividades de geração e distribuição de energia, evitar que empresas de maior se beneficiem dos benefícios destinados às microempresas, etc. - mas o sentido imediato comum das normas em questão parece ser o de tutelar a igualdade dos sujeitos de direito perante a lei. Nesse sentido, elas buscam dar efetividade a preceito constitucional fundamental e miram a um interesse eminentemente público.

Analisada a questão sob esta perspectiva intencionalmente genérica, torna-se difícil identificar destinatários específicos e individuais da proteção legal. Pode-se argumentar que, neste caso, beneficiária da tutela, é a própria coletividade. 


\subsubsection{Tutela de Credores Hipossuficientes e Extracontratuais}

Conforme se discute adiante, no Capítulo 6, todas as normas atinentes aos grupos têm em comum o fato de, a partir de determinados vínculos societários, administrativos ou econômicos, trasladarem ou imputarem características, direitos e obrigações de um sujeito de direito a outro.

Dentre a multiplicidade de técnicas adotadas pelo legislador em tal sentido, destaca-se como uma das mais importantes e frequentes a pura e simples imputação ou extensão de responsabilidades (ou solidarização passiva) originalmente atribuíveis a um determinado sujeito. Esse método é empregado, por exemplo, pelo artigo $2^{\circ}, \S 2^{\circ}$, da Consolidação das Leis do Trabalho - CLT ${ }^{141}$.

Ao definir os elementos constitutivos do grupo econômico no Direito do Trabalho, a CLT se refere a "empresa" e não a "sociedade", o que ensejou críticas da doutrina ${ }^{142} \mathrm{em}$ função da suposta imprecisão do texto, dada a ausência de personalidade jurídica da empresa em suas acepções funcional (atividade) e objetiva (patrimônio) ${ }^{143}$. A reprimenda não parece, contudo, inteiramente justificada.

A despeito da imprecisão, parece claro que o legislador buscou empregar a expressão em sua conotação subjetiva e com o propósito de tornar o conceito o mais amplo possível, capaz de abarcar tanto as sociedades quanto os empresários individuais ${ }^{144}$. Vale notar inclusive, que tal estratégia seria mantida, muito anos mais tarde, pelo legislador societário alemão, que mesmo em 1965 adotou a expressão "Unternehmen" (ou seja, empresa ou empreendimento) para definir os membros integrantes tanto dos grupos de fato quanto de direito ${ }^{145}$.

141 Também relevantes para o tema os artigos 10 (alteração da estrutura da empresa não afeta os direitos dos empregados) e 448 (mudança na titularidade ou estrutura da empresa não afeta os contratos de trabalho em vigor) da CLT.

142 "Passemos por alto as imperfeições terminológicas da norma, como a que se refere a 'personalidade jurídica' da empresa, quando em nosso direito a empresa, nem em sentido próprio, nem como 'estabelecimento', é 'pessoa jurídica'" in D. MARANHÃO, J. TEIXEIRA FILHO (atualiz.), Sujeitos do Contrato de Trabalho, p. 303.

143 A. ASQUINI, I Profili dell'Impresa, p. 9-10.

144 E, sob esta ótica, ao contrário do que argumentou Délio Maranhão, não seria necessária sequer uma interpretação extensiva ou baseada em princípios do dispositivo para se buscar a responsabilização do controlador pessoa física. "O legislador não disse tudo quanto pretendia dizer. Mas a lei deve ser aplicada de acordo com os fins sociais a que se dirige. [...] O controle sobre diferentes sociedades pode ser exercido por uma pessoa física, detentora da maioria de suas ações." in MARANHÃO, Délio, TEIXEIRA FILHO, João de Lima (atualiz.), Sujeitos do Contrato de Trabalho, p. 303.

145 Lei acionária alemã de 1965 (AktG 1965), § 16, subparágrafo 1. 
No que se diz respeito aos vínculos entre os integrantes do grupo, a legislação trabalhista adota critérios mais amplos e flexíveis do que as normas societárias, referindose a direção, controle (e, tudo leva a crer que se trate de controle na acepção de domínio) e administração.

A legislação consumerista, por sua vez, em dispositivo de questionável tecnicidade, determinou a responsabilidade subsidiária das sociedades "integrantes dos grupos societários e as sociedades controladas" ${ }^{146}$ - sem qualquer distinção entre grupos de fato e de direito e, portanto, sem esclarecer de que forma as sociedades controladas não estariam abrangidas no conceito de grupo societário, merecendo menção separada.

A despeito de o caput do artigo 28 do Código de Defesa do Consumidor - CDC atrelar, de forma muito clara, a desconsideração da personalidade jurídica a hipóteses de abuso ou quanto menos de culpa grave, o $\S 5^{\circ}$ do mesmo dispositivo admite a incidência de tal remédio extremo com grande liberalidade, determinando que "poderá ser desconsiderada a pessoa jurídica sempre que sua personalidade for, de alguma forma, obstáculo ao ressarcimento de prejuízos causados aos consumidores".

Essa redação tão ampla - ou melhor, genérica - foi quase literalmente replicada pelo artigo $4^{\circ}$ da Lei Federal 9.605/1998, que trata da responsabilidade pelo dano ambiental. Com efeito, além de inovar ao expressamente estender a responsabilidade penal às pessoas jurídicas (artigo $3^{\circ}$, caput), a Lei Federal 9.605/1998 determinou que poderá "ser desconsiderada a pessoa jurídica sempre que sua personalidade for obstáculo ao ressarcimento de prejuízos causados à qualidade do meio ambiente"147.

146 Lei Federal 8.078/1990, artigo 28, § $2^{\circ}$.

147 Ao votar para se conferir parcial provimento a recurso formulado pelo Ministério Público, com o qual o Parquet buscava, com fulcro no artigo $4^{\circ}$ da Lei Federal 9.605/1998, a desconsideração de personalidade jurídica de sociedade responsável por dano ambiental, o Exmo. Min. Rel. João Otávio de Noronha manifestou-se a favor da necessidade de caracterização de abuso para a aplicação de tal remédio extremo. No mesmo trecho de seu voto, o Relator ainda defendeu a natureza subsidiária da responsabilidade dos sócios e discorreu sobre o sentido da norma em questão: "A responsabilidade subsidiária tem sido empregada largamente pela Justiça do Trabalho, [...]. Nessa especialidade do direito, tal responsabilidade nasceu para proteger os trabalhadores que se consideravam vilipendiados nos seus direitos laborais quando contratados por empresas intermediárias de mão-de-obra (terceirização). Em direito ambiental, serve à proteção do meio ambiente degradado pela má-utilização de seus recursos por uns, em detrimento do restante da sociedade, verdadeira titular do direito. Naquela justiça especializada, o que se pretende é ressalvar os direitos dos trabalhadores, que servem à alimentação - em uma análise mais ampla: ressalvar o direito à vida. Em direito ambiental, o que se pretende também é o resguardo da vida humana, que não prescinde de um meio ambiente equilibrado." in STJ, RESP n ${ }^{\circ}$ 647.493-SC, 22 de maio de 2007. 
Não seria possível nem sequer oportuno discorrer criticamente sobre todos os dispositivos da legislação extravagante que tratam da responsabilidade de sociedades agrupadas pelos débitos e danos, umas das outras. O aspecto mais importante para o presente estudo é buscar os elementos comuns que unem essas hipóteses, de maneira a identificar os valores que orientaram a atividade do legislador.

É nítido o contraste entre a amplitude de tais normas setoriais de responsabilização - nos âmbitos consumerista, trabalhista e ambiental - e o princípio genérico de responsabilidade intersocietária constante do artigo 50 do Código Civil de 2002, que tem como pressuposto a demonstração de abuso, desvio de finalidade ou confusão.

Nesse sentido, o que se percebe prontamente é que, em todos os cenários ora discutidos, contrapõem-se à empresa plurissocietária (i) credores que jamais tiveram a chance de escolher assumir tal qualidade - caso dos titulares do direito de pleitear indenização por ato ilícito extracontratual, tal como as vítimas de contaminação ambiental - ou (ii) credores contratuais hipossuficientes, que não dispõem dos meios para medir adequadamente os riscos da celebração do contrato, negociar o seu conteúdo ou mesmo optar livremente por contrato alternativo.

Ou seja, os beneficiários dessas hipóteses alargadas de responsabilização são sujeitos que não reúnem as condições necessárias para fixar o grau de exposição ao risco da empresa - e é esse o conceito chave - que estão dispostos a assumir (ou a tolerar) por meio de negociações privadas. A eles evidentemente não se aplica, portanto, a ponderação constante da Exposição de Motivos do Projeto de Lei das S.A., no sentido de que: " $o$ Projeto absteve-se de criar a responsabilidade solidária presumida das sociedades do mesmo grupo, [...], pois a experiência mostra que o credor, em geral, obtém a proteção dos seus direitos pela via contratual, e exigirá solidariedade quando o desejar ${ }^{148}$.

Certamente não é por mera coincidência que a responsabilidade estrutural de grupo - vale dizer, a responsabilidade pela mera pertinência ao grupo de fato - esteja frequentemente associada a hipóteses de responsabilidade objetiva, tal como na esfera ambiental. A incidência de ambas as referidas estratégias facilitadoras da responsabilização

148 Exposição de Motivos n 196, de 24 de junho de 1976, do Ministério da Fazenda. Notas ao Capítulo XXI, Seção I, do Projeto. Sem grifo no original. 
e do ressarcimento do dano - todas as duas de natureza marcadamente extraordinária e excepcional em relação aos cânones do direito privado - é resultado da teoria do risco ${ }^{149}$, conceito de responsabilidade de afirmação histórica relativamente recente ${ }^{150}$.

A adoção do risco como fundamento para a responsabilização, bem como a amplitude dos grupos de potenciais destinatários da tutela legal nas hipóteses ora discutidas ${ }^{151}$, representam forte evidência do fato de que o movente do legislador, em todos estes casos, foi a internalização econômica dos efeitos externos nocivos (externalidades negativas) da empresa ${ }^{152}$.

\subsection{O Grupo no Direito Societário}

Ao se transpor o foco da análise de um plano mais geral para as normas de caráter nitidamente societário que tratam especificamente dos grupos de sociedades é possível discernir dois principais gêneros de regras. De um lado, aquelas que se concentram sobre a divulgação de informações sobre a empresa plurissocietária e, de outro, as que estabelecem padrões de conduta para os administradores e acionistas controladores das sociedades agrupadas.

Existem, entre os dois citados conjuntos de normas, evidentes sobreposições. Por exemplo, as regras sobre participações recíprocas buscam evitar um falseamento da

149 Positivada no direito brasileiro, nos termos do parágrafo único do artigo 927 do Código Civil.

150 "[...] o critério do 'risco' como princípio apto a fundar [...] uma categoria unitária e geral de responsabilidade objetiva, nascido no século passado, se afirmou apenas em época recente, se considerarmos que, ao final do Século XIX [...] não havia obtido amplo consenso, justamente porque o princípio 'nenhuma responsabilidade sem culpa' assegurava às empresas uma espécie de imunidade pelos danos provocados externamente - ao meio ambiente, aos confinantes, aos consumidores $-e$ internamente à empresa, ou seja, aos empregados". Tradução livre de: "[...] il criterio del 'rischio' come principio idoneo a fondare [...] una categoria unitaria e generale di responsabilità oggettiva, nato nel secolo scorso, si è accreditato solo in epoca recente, ove si consideri che, alla fine del XIX secolo [...] non aveva ottenuto larghi consensi, proprio perché il principio 'nessuna responsabilità senza colpa' assicurava alle imprese una sorta di immunità per $i$ danni provocati all'esterno - all'ambiente, ai confinanti, ai consumatori - e all'interno dell'azienda, e cioè ai dipendenti." in V. BUONOCORE, La Responsabilità dell'Impresa, p. 165.

151 É verdade que mais restritos e determináveis do que a inteira coletividade, como ocorre em relação às normas que tratam da igualdade perante a lei, discutidas no capítulo anterior, mas ainda assim estamos diante de conjunto de sujeitos - trabalhadores, consumidores, vítimas de dano ambiental - de natureza ampla, dinâmica (não estática) e difusa.

152 C. DERANI, Direito Ambiental Econômico, p. 162. Na realidade brasileira, não se verifica, portanto, ao menos não em termos gerais, a sobreposição e a prevalência de regras grupais societárias sobre as normas setoriais de responsabilização alargada, um fato que poderia representar um obstáculo à reparação dessas classes especiais de credores, tal denunciou Teubner em relação, por exemplo, à realidade dos créditos trabalhistas na Alemanha. G. TEUBNER, Die „Politik des Gesetzes“ im Recht der Konzernhaftung - Plädoyer für einen sektoralen Konzernduchgriff, p. 270-271. 
situação patrimonial, mas também se articulam por meio de proibições de comportamento. Por outro lado, o respeito aos deveres fiduciários que lhes incumbem, por parte de acionistas controladores e administradores, também passa pelo dever de informar.

Ainda assim, para fins exclusivos de análise e em função do elemento prevalente em cada um desses dois grupos de regras - informação ou enfrentamento direto da questão do conflito de interesse por meio de comandos, vedações e padrões de conduta - eles são tratados separadamente nos tópicos a seguir.

\subsubsection{Representação da Situação Patrimonial da Sociedade}

Conforme assinalou Ascarelli, um dos elementos justificadores do reconhecimento de autonomia patrimonial da sociedade e da limitação da responsabilidade de seus sócios é a manutenção e a publicidade de registros contábeis ${ }^{153}$, fator que, ao menos em princípio, traz transparência a respeito dos bens e direitos e da própria solvabilidade do ente social, permitindo, outrossim, certa rastreabilidade e controle de suas operações.

A estrutura de grupo, porém, torna muito mais complexa, em alguns casos até mesmo impossível, a observação da situação patrimonial da sociedade e o acompanhamento de suas atividades e investimentos, em prejuízo dos direitos e interesses de acionistas externos e controladores.

Como exemplo, pode-se pensar na hipótese de cisão parcial de uma companhia, com a criação de uma nova sociedade controlada e transferência de determinado ramo de negócios para esta última. Operações que antes estavam refletidas no balanço da sociedade controladora, desapareceriam em tese sob uma única rubrica, indicativa do valor histórico do investimento aportado na controlada - da qual os acionistas externos da controladora não são diretamente sócios, o que lhes priva da legitimidade para solicitar informações e documentos aos respectivos administradores.

A situação é ainda mais delicada quando a opacidade contábil não é meramente

153 "O sistema de publicidade da sociedade anônima, muito mais rigoroso e completo do que o da sociedade com sócios ilimitadamente responsáveis, encontra sua razão de ser na responsabilidade limitada dos acionistas e constitui, justamente, o caminho por meio do qual o direito, no seu desenvolvimento histórico, chegou a admitir, nesta hipótese, a constituição de um patrimônio separado." E "O balanço adquire, por isso, nas sociedades anônimas, uma especial importância, pois que, seja a sua redação periódica, seja a sua publicidade, serve para a verificação do patrimônio social e para a determinação dos lucros e das perdas." in T. ASCARELLI, Problemas das Sociedades Anônimas e Direito Comparado, respectivamente p. 323 e 331. 
efeito colateral de operações legítimas, mas é o próprio resultado buscado pelo acionista controlador. Conforme se discute no tópico a seguir, o poder de controle sobre todas as sociedades agrupadas confere ao controlador amplas oportunidades para abuso da forma societária e transferência de valor entre as diversas células componentes do grupo.

Em resposta a essas possíveis distorções, a legislação acionária instituiu mecanismos que buscam (i) impedir operações que poderiam vulnerar o princípio da intangibilidade do capital social e (ii) aprimorar a informação contábil, de forma a refletir da melhor forma possível os investimentos em sociedades controladas e coligadas.

A primeira e principal das obrigações previstas nesse sentido é aquela fixada no artigo 243 da Lei 6.404/1976, segundo o qual o relatório da administração deve indicar as participações detidas pela companhia em sociedades coligadas e controladas, esclarecendo ainda as alterações em tais investimentos verificadas ao longo do exercício social anterior. Ou seja, o legislador impõe à companhia o dever de declarar a sua titularidade de (e sua pertinência a) uma determinada empresa plurissocietária.

O conceito de sociedades controladas e coligadas, para os fins da lei acionária, não se confunde com a definição de "sociedades sob controle comum" constante da Lei Federal 11.638/2007, artigo $3^{\circ}$, parágrafo único, que disciplina a obrigatoriedade de auditoria independente para as "sociedades de grande porte" 154 . É natural que, neste caso, o legislador tenha aplicado critérios de agrupamento para a aferição da superação ou não dos critérios que ensejam tal ônus - ativo total superior a $\mathrm{R} \$ 240.000 .000,00$ (duzentos e quarenta milhões de reais) e/ou receita bruta excedente a $\mathrm{R} \$ 300.000 .000,00$ (trezentos milhões). De fato, esta é uma norma recente que confirma a estreita relação entre a devida consideração da empresa plurissocietária e (i) não discriminação e (ii) transparência patrimonial e contábil $1^{155}$.

Os outros principais exemplos de medidas desse gênero são: (i) as restrições a participações recíprocas, (ii) a determinação de apuração do valor de investimentos em sociedades participadas por meio da equivalência patrimonial (ou, método do patrimônio líquido) e (iii) a obrigação de elaboração de demonstrações financeiras consolidadas.

154 E. VALLADÃO FRANÇA, M. VON ADAMEK, Sociedades de Grande Porte (Lei 11.638/2007, art. $\left.3^{\circ}\right)$, p. 126-127.

155 Não fosse o critério de agrupamento haveria injusta distinção entre as empresas, conforme fracionassem ou não as suas atividades (bem como seus ativos e faturamento) entre diversas sociedades. 
Além de suas consequências políticas, as limitações legais à formação de participações recíprocas (Lei 6.404/1976, artigo 244) buscam evitar a diluição e falseamento do patrimônio das sociedades participantes-participadas ${ }^{156}$. Isso porque, em tal cenário e em termos puramente econômicos, pode-se afirmar que cada uma das sociedades investe parcialmente em si mesma, em operação que produz efeitos similares a uma restituição de fundos aos sócios.

É também por uma questão de adequação da informação contábil transmitida pela companhia a seus sócios e a terceiros que os investimentos relevantes em outras sociedades - definidos como aqueles realizados no capital de controladas, coligadas, integrantes do mesmo grupo (de direito) e sob controle comum - devem ser apurados contabilmente pelo método do patrimônio líquido ${ }^{157} \mathrm{ou}$, como é mais amplamente conhecido, da equivalência patrimonial (Lei 6.404/1976, artigo 248) ${ }^{158}$.

Por uma questão de prudência e objetividade, constitui regra geral a contabilização de bens e direitos pelo seu custo histórico, ressalvada apenas a aplicação de critérios de baixa e amortização fixados em regulamentação específica. A equivalência patrimonial representa uma exceção a esse princípio, que se justifica pela alta mutabilidade do conteúdo e do valor das participações societárias.

Com efeito, uma participação societária não representa um bem convencional, estático, mas sim um complexo feixe de direitos incidentes sobre o revestimento jurídico de uma atividade empresarial, ou seja, sobre a sociedade empresária, cujos próprios bens e direitos - e, portanto, a própria consistência patrimonial - estão sujeitos a mutação constante, em função das contingências ínsitas à sua presença no mercado ${ }^{159}$.

Se as participações detidas em outras sociedades representam fração relevante do patrimônio de uma companhia - típico caso das sociedades holding - a sua pura e simples

156 J. PEDREIRA, Sociedades Coligadas, Controladoras e Controladas, p. 1927.

157 “A expressão 'equivalência patrimonial' não consta das duas leis [Lei 6.404/1976 e Decreto-Lei 1.598/1997] - que se referem sempre à avaliação dos investimentos 'pelo valor do patrimônio líquido' mas está amplamente difundida." in J. PEDREIRA, Sociedades Coligadas, Controladoras e Controladas, p. 1956.

158 Matéria também regulamentada pela Instrução Normativa CVM n 247/1996.

159 "À vista, entretanto, da atividade da sociedade anônima, o seu patrimônio não é estático, não sofre alterações apenas ocasionais ou excepcionais; sofre, ao contrário, variações diárias, sendo continuamente diverso seja na sua composição, seja na sua importância." in T. ASCARELLI, Problemas das Sociedades Anônimas e Direito Comparado, p. 324. 
contabilização pelo valor histórico significaria tornar a contabilidade da participante um quadro extremamente incompleto e desatualizado do seu real estado patrimonial, uma vez que totalmente desconectado das vicissitudes e sucessos intercorrentes das participadas.

Os acionistas da sociedade participante apenas vislumbrariam reflexos do desempenho da sociedade participada por ocasião da distribuição (ou ausência de distribuição) de dividendos e não no momento em que o respectivo resultado fosse apurado. Esse estado de coisas, porém, significaria um desvio, de fato ainda que não formal, do regime de competência para o regime de caixa.

O método do patrimônio líquido visa a corrigir esta discrepância, por meio da atualização periódica, nas demonstrações financeiras da participante, do valor das quotas ou ações detidas nas participadas, conforme a evolução do patrimônio líquido destas últimas no mesmo período ${ }^{160}$.

A consolidação contábil (Lei 6.404/1976, artigo 249) possui objetivos similares aos da equivalência patrimonial - correção de distorções criadas pela estrutura plurissocietária na contabilidade tradicional -, mas mecânica bastante diferente. A consolidação representa um conjunto separado de demonstrações financeiras e diversamente da equivalência patrimonial - não possui impacto sobre as peças contábeis ordinárias, da sociedade individualmente considerada.

Essas demonstrações financeiras separadas, que diversamente da equivalência patrimonial abrangem apenas sociedades controladas e não coligadas $^{161}$, buscam representar a situação do grupo como se se tratasse de uma única entidade contábil, ou seja, como se as operações da empresa plurissocietária não estivessem fracionadas em diversas sociedades ${ }^{162}$.

Esse procedimento não ocorre pela simples soma de movimentações contábeis, mas sim pela neutralização das operações internas ao grupo ${ }^{163}$, o que significa

160 “[...] o principal objetivo do método do patrimônio líquido é reconhecer a participação da investidora nos resultados da controlada ou coligada segundo os princípios do regime de competência - em função do período em que esse resultado é ganho, e não da sua distribuição como dividendos." in J. PEDREIRA, Sociedades Coligadas, Controladoras e Controladas, p. 1954-1955.

161 O parágrafo único da Lei 6.404/1976 confere, contudo, à Comissão de Valores Mobiliários a autoridade necessária para expandir ou limitar o âmbito da consolidação contábil para as companhias abertas.

162 J. PEDREIRA, Sociedades Coligadas, Controladoras e Controladas, p. 1974.

163 “A essência da consolidação está na eliminação das relações endogrupais, por meio da qual se torna 
desconsiderar os créditos e débitos recíprocos das sociedades grupadas. Vale lembrar que a consolidação busca simular a hipótese de fusão das sociedades que integram o grupo e, em tal caso, os referidos créditos se extinguiriam automaticamente por confusão jurídica entre credor e devedor. Nesse sentido, as demonstrações financeiras consolidadas permitem uma análise da situação patrimonial da empresa plurissocietária que não seria possível por meio do exame do conjunto das demonstrações individuais das sociedades que a compõem.

Beneficiários da tutela legal, em todos os exemplos discutidos neste tópico, são naturalmente apenas os sujeitos que reúnem as condições necessárias para examinar a contabilidade da sociedade e dela extrair conclusões válidas para as suas decisões de investimento ou de celebração de contratos. Restringe-se, portanto, a acionistas (atuais ou futuros ${ }^{164}$ ) e credores sofisticados, com capacidade de negociação ou, ao menos, de análise de risco de crédito.

\subsubsection{Controle Societário e Conflito de Interesse nos Grupos}

Após a breve excursão sobre os objetivos de outras normas atinentes às sociedades grupadas, ao longo dos tópicos anteriores, cumpre analisar, enfim, o sentido dos dispositivos legais que representam o núcleo principal do presente trabalho, ou seja, os artigos 243, § $2^{\circ}, 245,246$ (disciplina dos grupos de fato) e 265 a 277 (disciplina dos grupos de direito) da Lei 6.404/1976.

Do exame de tais disposições legais, um dos primeiros dados que salta aos olhos, principalmente a partir da leitura dos artigos 245 e 276 é o fato de que os contratos, relações e atividades que têm lugar entre as sociedades pertencentes a um mesmo grupo, de direito ou de fato, não são considerados pelo legislador como operações normais, sujeitas

possível conhecer a real condição econômica e financeira do grupo como um todo. O resultado do grupo, se respeitados os princípios de consolidação, será diferente da soma dos resultados que emergem dos balanços individuais das sociedades do grupo". Tradução livre de: "L'essenza della consolidazione sta nella eliminazione dei rapporti endogruppo, per effetto della è resa possibile la conoscenza della reale condizione economica e finanziaria del gruppo complessivamente considerato. Il risultato del gruppo, se sono rispettati i principi di consolidazione, sarà diverso dalla somma dei risultati emergenti dai singoli bilanci delle società del gruppo." in F. GALGANO, Direzione e Coordinamento di SocietàArt. 2497-2497 septies, p.112-113.

164 É possível, teoricamente, fundar a consideração pelos interesses dos acionistas futuros e potenciais da companhia com base na diferença entre os conceitos de interesse de grupo e de interesse de série, conforme a lição de Pier Giusto Jaeger. O grupo diz respeito a determinados sujeitos que existem contemporaneamente, enquanto a série é relativa a todos que podem se revestir daquela categoria e, portanto, se projeta no tempo. O próprio Jaeger, porém, vislumbra na sociedade por ações uma relação de grupo e não de série de acionistas. P. JAEGER, L'Interesse Sociale, p. 10 e 163-167. 
às mesmas regras e princípios aplicáveis a transações entre partes completamente independentes.

Outra conclusão bastante evidente, que pode ser colhida de antemão, é o fato de que o legislador, ao estabelecer regime próprio para as referidas operações, entendeu que a simples informação ex ante não é suficiente para tutelar adequadamente os interesses de acionistas externos e credores. Trata-se de posição acertada, uma vez que a sociedade representa um "contrato incompleto" - ou seja, uma avença na qual seria antieconômico ou mesmo impossível ajustar previamente todos os detalhes e prever todas as possíveis contingências incidentes sobre as suas atividades já no momento de sua gênese ${ }^{165}$.

A principal razão, porém, da insuficiência da tutela por meio da mera informação não está na incompletude do contrato de sociedade, mas no fato de que as operações intragrupo são marcadas pela afirmação de uma única vontade preponderante, a do acionista controlador comum. Nelas não se verifica o típico contraditório de mercado entre partes realmente independentes que, de forma ativa e diligente, perseguem o próprio interesse e que, no mais das vezes, asseguram a comutatividade ou equitatividade das avenças assim formadas, à luz das condições vigentes no mercado. Por conseguinte, o controlador dispõe perenemente da capacidade de alterar unilateralmente o cenário original que terceiros tomaram por base para as suas decisões de investimento ou de concessão de crédito. Nesse sentido, por mais essencial que seja a qualidade e a extensão da informação disponível ex ante, ela não será suficiente, nem mesmo para agentes de mercado sofisticados.

Impõe-se, portanto, a formulação de regras que limitem o conteúdo do exercício do poder de controle ao longo da vida das sociedades e parece ser exatamente esse o

165 "A dificil tarefa enfrentada pelos elaboradores do texto de um contrato é antecipar e lidar adequadamente com as várias contingências que podem surgir durante o curso de sua relação comercial. Uma vez que pode ser proibitivamente custoso especificar, de forma válida e eficaz, as precisas ações que cada uma das partes deveria tomar em relação a cada eventualidade concebível, as partes, na prática, tendem a acabar por formular um contrato altamente incompleto". Tradução livre de: "The difficult task facing the drafters of a contract is to anticipate and deal appropriately with the many contingencies which may arise during the course of their trading relationship. Since it may be prohibitively costly to specify, in a way that can be enforced, the precise actions that each party should take in every conceivable eventuality, the parties are in practice likely to end up writing a highly incomplete contract." in O. HART, J. MOORE, Incomplete Contracts and Renegotiation, p. 755. "A experiência, breve, revelou que nos contratos de longa duração - como ocorre no caso das companhias - é imprescindivel, no interesse dos próprios contratantes, assegurar-se a possibilidade de revisões e atualizações contratuais." in A. LAMY FILHO, J. PEDREIRA, Estrutura da Companhia, p. 861. 
objetivo das normas centrais que disciplinam o grupo de fato e o grupo de direito em nossa lei acionária.

Nos termos do já citado clássico trabalho de Champaud ${ }^{166}$, o poder de controle se contradistingue pela notável capacidade de seu titular de dispor de bens alheios como se próprios fossem, aproximando-se, portanto, do instituto da propriedade, mas sem com este se confundir ${ }^{167}$. É justamente essa característica do poder de controle que, em última análise, sobretudo no âmbito da estrutura da macroempresa, permite um inédito grau de separação entre propriedade e gestão do capital, conforme a seminal investigação de Berle e Means ${ }^{168}$.

De um lado, tal separação - possível em face apenas da soma de personalidade jurídica, limitação da responsabilidade e deliberação majoritária - torna a sociedade anônima a estrutura ideal para a macroempresa, uma vez que é perfeitamente adaptada à administração profissional e à agregação de capitais dispersos. De outro, a possibilidade dada ao controlador de estabelecer o destino de bens que não lhe pertencem - mas, de propriedade da companhia, sobre os quais também se depositam as expectativas legítimas dos minoritários e que representam, enfim, a garantia dos credores sociais - cria ampla margem para comportamentos oportunistas, em diferentes frentes.

Ao abordar os mais importantes problemas de principal-agente (principal-agent problems) a serem enfrentados pelo direito societário, Hansmann e Kraakman identificaram três principais conflitos estruturais: (i) administradores versus sócios, (ii) sociedade versus credores e (iii) sócios majoritários versus minoritários ${ }^{169}$. O problema do

166 C. CHAMPAUD, Le Pouvoir de Concentration de la Société par Actions, p. 161.

167 "Tal poder empresarial - que não se confunde com o direito de propriedade, pois se caracteriza como gestão de bens alheios - é exercido não apenas sobre a 'célula econômica' [...] ou sobre a 'célula social' [...] mas, a rigor, sobre a vida e os bens de toda a sociedade, que existe em 'simbiose permanente com a empresa'." in A. LAMY FILHO, O Acionista Controlador na Nova Lei de S.A., p. 152.

168 A. BERLE, G. MEANS, The Modern Corporation and Private Property, p. 5-6. Cumpre anotar que, já em 1917, Rathenau apontava a tendência de absenteísmo dos acionistas, bem como a gestão tecnocrática das grandes companhias alemãs. W. RATHENAU, Vom Aktienwesen - Eine Geschäftliche Betrachtung, p. 142.

169 “"...] um 'problema de agência' - no sentido mais geral da expressão' - surge sempre que o bem estar de uma parte, denominada a 'principal', depende de ações tomadas por outra parte, designada o 'agente'. O problema reside em motivar o agente a agir no interesse do principal em vez de simplesmente atuar no interesse do próprio agente". Tradução livre de: "[...] an 'agency problem' - in the most general sense of the term - arises whenever the welfare of one party, termed the 'principal,' depends upon actions taken by another party, termed the 'agent'. The problem lies in motivating the agent to act in the principal's interest rather than simply in the agent's own interest." in H. HANSMANN, R. KRAAKMAN, Agency Problems and Legal Strategies, p. 21. A complexa questão do conceito de 
conflito de interesse nos grupos societários, de fato e de direito, tem desdobramentos que se projetam em todas essas três vertentes, conforme se discute, respectivamente, nos tópicos a seguir.

\subsubsection{O Conflito na Relação entre Sócios e Administradores}

$\mathrm{Na}$ relação entre administradores e sócios, a estrutura de grupo leva a um fortalecimento da influência daqueles, em prejuízo da capacidade de decisão e fisscalização destes. De fato, conforme já mencionado, no âmbito de uma estrutura piramidal, muitas das prerrogativas típicas dos sócios, tal como a nomeação dos administradores das sociedades controladas ou a aprovação de seus balanços, passam a ser exercidas por meio da intermediação dos administradores, cujo poder consequentemente aumenta de forma exponencial ${ }^{170}$, em prejuízo da influência de todos os acionistas ${ }^{171}$ - incluindo os sócios controladores da sociedade de comando.

Assim, por exemplo, bens que, em uma estrutura de conglomerado, pertenceriam à própria companhia, no âmbito da empresa plurissocietária restam fracionados nos patrimônios de diversas sociedades, mais distantes da supervisão dos acionistas da sociedade controladora.

Cumpre recordar que é o administrador que representa - ou melhor, presenta ${ }^{172}-\mathrm{a}$

interesse social é retomada ao longo deste trabalho, especialmente nos Capítulos 6 e 7, mas para os fins deste subcapítulo, em que importa apenas sublinhar os principais riscos vislumbrados pelo legislador, a tripartição de conflitos sugerida por Hansmann e Kraakman parece suficiente e adequada.

170 "Ao falarem em management control, Berle e Means tiveram em mente apenas as grandes companhias de capital aberto. A doutrina européia assinala, no entanto, que as participações recíprocas de capital, quando de elevado montante, podem esvaziar totalmente os poderes decisórios da assembléia geral, tornando os administradores das companhias autênticos controladores." in F. COMPARATO, C. SALOMÃo FILHO, O Poder de Controle na Sociedade Anônima, p. 73. No mesmo sentido, E. MUNHOZ, Desconsideração da Personalidade Jurídica e Grupos de Sociedades, p. $42-43$.

171 "Independentemente dos riscos de responsabilização que recaem sobre o controlador, cabe refletir em particular sobre o fato de que o exercício dos direitos de sócio (em especial o direito de voto) incorporados nas participações detidas pela sociedade controladora é atribuição dos órgãos sociais de administração. A formação do grupo tem, portanto, como consequência uma transferência de competência do nivel da sociedade controladora e demonstra ser um instrumento potencial para afastar a influência dos sócios sobre o patrimônio da sociedade controladora". Tradução livre de: "Auch unabhängig von den auf das herrschende Unternehmen zukommenden Haftungsrisiken ist nämlich zu bedenken, dass die Ausübung der in den Anteilen der herrschenden Gesellschaft verkörperten mitgliedschaftlichen Rechte (insbesondere des Stimmrechts) Sache des geschäftsführenden Organs ist; die Gruppenbildung hat mithin eine Kompetenzverlagerung auf der Ebene der herrschende Gesellschaft zur Folge und erweist sich somit als probates Mittel, die Gesellschafter von der Einflussnahme auf das Vermögen der herrschenden Gesellschaft auszuschließen" (negrito no original) in V. EMMERICH, M. HABERSACK, Konzernrecht, p. 100.

172 F. MIRANDA, Tratado de Direito Privado, tomo I, p. 347. 
sociedade controladora, em suas vestes de sócia, nas assembleias das sociedades controladas. É por meio dele que a sociedade exercerá todas as suas demais prerrogativas de quotista ou acionista em face das controladas ou coligadas. Cada degrau da pirâmide societária representará, nesse sentido, uma etapa adicional de intermediação, especialmente se não forem os mesmos indivíduos a ocupar os cargos de administração das sociedades por meio da qual é exercido o controle indireto.

É evidente que esse problema será mais grave nos países em que é altamente difuso o controle gerencial - nos quais, por outro lado, costumam ser muito menos frequentes as estruturas de grupo, como nos Estados Unidos e, em menor medida, no Reino Unido -, ou naqueles em que a lei assegura maior autonomia aos administradores em face da assembleia geral, como ocorre na Alemanha ${ }^{173}$.

No Brasil, na vasta maioria dos casos, o poder do acionista controlador é essencialmente incontrastável ${ }^{174}$. Em primeiro lugar, são raros entre nós os exemplos de controle minoritário, embrionárias as tentativas de coleta pública de mandatos ${ }^{175} \mathrm{e}$, ao que se sabe, inexistentes os casos de efetivo controle gerencial ${ }^{176}$. Ademais, a possibilidade de

173 Basta pensar no contraste entre o disposto no $\S 119$ da lei acionária alemã de 1965 e o artigo 121 da Lei 6.404/1976. Enquanto a lei alemã limita a competência da assembleia a um rol específico de matérias (§ 119(1)) e àquelas que forem expressamente suscitadas e submetidas à deliberação dos sócios pela Diretoria $(\S 119(2))$, a lei brasileira atribui à assembleia geral de acionistas "poderes para decidir todos os negócios relativos ao objeto da companhia e tomar as resoluções que julgar convenientes à sua defesa e desenvolvimento". Outro exemplo de diferença importante é o fato de que a destituição de membro do conselho de supervisão, mutatis mutandis equivalente ao conselho de administração no Brasil, exige maioria qualificada de três quartos dos votos, ressalvada disposição estatutária em contrário (§ 103(1)). A discussão sobre a obrigação ou não da Diretoria (Vorstand) de submeter à apreciação da assembleia uma operação de cessão de parte da atividade empresarial a uma sociedade controlada matéria que no direito brasileiro poderia ser livremente disciplinada no estatuto social ou em acordo de acionistas - foi o tema central do caso Holzmüller, julgado pela Corte Federal de Justiça Alemã (Bundesgerichtshof), decisão da Segunda Câmara Civil, de 25 de fevereiro de 1982 (BGHZ, S. 122). H. WIEDEMANN, Die Unternehmensgruppe im Privatrecht, p. 50-51.

174 "Nunca houve na gestação da lei societária brasileira real intenção de criar entidades separadas de seus controladores, aptas a serem geridas profissionalmente e apenas fiscalizadas por controladores ou terceiros. A característica funcional básica não é, portanto, a concentração acionária, mas a concentração de poderes em torno da figura do controlador." in C. SALOMÃO FILHO, O Novo Direito Societário, p. 83-84.

175 Questão disciplinada pelo artigo 22 e seguintes da Instrução Normativa CVM 481/2009. Pode-se citar como raro e vanguardista exemplo de tentativa de coleta de mandatos aquela promovida por Vinci Equities Gestora de Recursos Ltda., na qualidade de gestora de fundos de investimento acionistas da Valid Soluções e Serviços de Segurança em Meios de Pagamento e Identificação S.A., em abril de 2012. Fonte: <http://www.valid.com.br/noticias/comunicado-pedido-publico-procuracao-para-a-age>. Acesso em: 15 abr2013.

176 F. COMPARATO, C. SALOMÃO FILHO, O Poder de Controle na Sociedade Anônima, nota de texto 11, p. 75-76. E. MUNHOZ, Desafios do Direito Societário Brasileiro na Disciplina da Companhia Aberta: Avaliação dos Sistemas de Controle Diluído e Concentrado, p. 126. 
substituir administradores ad nutum, a qualquer momento, permite no mais das vezes um domínio efetivo e constante sobre as sociedades controladas, dado que qualquer insurreição dos administradores contra o controlador pode resultar em sua sumária destituição.

Ainda assim, o legislador brasileiro de 1976 houve por bem incluir em nossa lei acionária instrumentos que têm como objetivo específico assegurar a propagação e a eficácia da vontade do acionista controlador ao longo da pirâmide societária - o que ulteriormente atesta o fato de que a Lei 6.404/1976, em matéria de grupos, não se limitou à proteção dos acionistas externos (Schutzrecht), mas ativamente buscou facilitar a sua organização e operação (Organisationsrecht).

Os artigos 272 e 273 da Lei 6.404/1976 representam notáveis exemplos nesse sentido. O primeiro admite a criação de órgãos administrativos próprios para o grupo de direito, inclusive para fins de representação externa das sociedades filiadas, se assim estiver expressamente previsto na convenção de grupo. Por sua vez, o artigo 273 determina que compete aos administradores das sociedades filiadas seguir as orientações gerais estabelecidas pelos órgãos de administração do grupo, desde que não contrárias à lei ou à convenção. Percebe-se claramente que o legislador de 1976 buscou fornecer ao controlador os meios para adicionar eficácia jurídica ao domínio de fato exercido sobre a administração das sociedades filiadas.

\subsubsection{O Conflito na Relação entre Credores e Sociedade}

Em relação aos interesses dos credores, o principal risco da estrutura de grupo é a mobilidade interna de recursos e ônus no âmbito das sociedades agrupadas. Conforme se discutiu no capítulo anterior, propósito fundamental da empresa plurissocietária é a compartimentação patrimonial, fator chave para a adequada alocação de riscos e mobilização de investimentos.

Tal compartimentação, porém, não é estanque nem tampouco estática. É da essência da empresa e da atividade empresarial a celebração constante de contratos, a mutação constante de seu conteúdo patrimonial, em resumo, a criação da riqueza pela circulação do riqueza ${ }^{177}$.

177 F. GALGANO, Lex Mercatoria, p. 40-41. 
Outra característica fundamental e definidora da empresa é a sua coordenação vertical por uma vontade determinante, elemento que, de fato, a contradistingue da coordenação horizontal dos fatores pelo puro mecanismo de preços. É este elemento que, conforme a já citada clássica lição de Coase, traça as fronteiras entre o mercado e a empresa $^{178}$.

Contudo, a mutabilidade do conteúdo patrimonial e a afirmação de uma vontade dominante, quando incidentes sobre a estrutura plurissocietária, resultam na ampla possibilidade de manipulação estratégica e oportunista dos bens e direitos e da própria solvabilidade das sociedades envolvidas. Conforme já acenado no capítulo anterior, estas se tornam vasos comunicantes ${ }^{179}$, sendo que o volume e a direção dos fluxos entre os respectivos invólucros são determinados pela vontade dominante do acionista controlador.

Pode-se pensar na hipótese em que sociedade $A$ seja titular de participação de $99 \%$ no capital social da companhia $X$, cujas ações são todas ordinárias, e detenha também $50,1 \%$ das ações ordinárias com direito a voto de $Y$, que representam apenas $25,1 \%$ do capital social desta última, uma vez que metade das ações são preferenciais e destituídas do direito de voto. Para efeito de discussão, pode-se supor que o valor de mercado total de $X$ e $Y$ seja igual.

Caso a empresa plurissocietária capitaneada por $A$ se encontre, em seu todo, em graves dificuldades financeiras, é evidente que a controladora terá todo o incentivo para privilegiar a posição de $X$ em detrimento de $Y$, direcionando todos os ganhos e recursos para a primeira e todos os ônus e as dívidas para a segunda, que poderá ser sacrificada com menor dano pessoal para $A^{180}$. O desequilíbrio de incentivos será ainda mais grave caso $A$ tenha, por exemplo, prestado garantias pessoais em favor dos credores de $X$, sem ter feito o

178 R. COASE, The Nature of the Firm (1937), p. 21.

179 F. COMPARATO, C. SALOMÃO FILHO, O Poder de Controle na Sociedade Anônima, p. 357-358. "As relações econômicas mantidas entre as empresas societárias e os poderes exorbitantes derivados do controle, permitem aplicar aos seus patrimônios uma tradução contábil e financeira do princípio dos vasos comunicantes". Tradução livre de: "Les relations économiques entretenues entre les entreprises sociales et le pouvoirs exorbitants issus du contrôle, permettent d'appliquer à leurs patrimoines une traduction comptable et financière du principe des vases communiquants." in C. CHAMPAUD, Le Pouvoir de Concentration de la Société par Actions, p. 275.

180 "Os ativos e passivos de cada sociedade transformam-se em ativos e passivos de todo o grupo, sendo transferidos e alocados entre seus diversos integrantes, no exclusivo interesse deste, segundo a estratégia empresarial globalmente concebida para enfrentar as exigências econômicas de cada momento." in E. MUNHOZ, Desconsideração da Personalidade Jurídica e Grupos de Sociedades, p. 41. 
mesmo também em benefício de $Y$.

Ainda que os deveres fiduciários atribuíveis a $A$ sejam indistintamente válidos e aplicáveis tanto em relação a $X$ quanto a $Y$, é evidente que, na prática, a soma de incentivo econômico e domínio sobre as decisões de ambas as sociedades pode (e tende a) levar a tratamento discriminatório. Em tema de grupos societários, o aspecto crítico, com efeito, não é tanto a possibilidade de $A$ diretamente, com as suas próprias forças, favorecer $X-\mathrm{o}$ que, de qualquer forma, também é certamente relevante ${ }^{181}-$, mas sim a sua capacidade de fazer com que $Y$ atue contra o seu próprio interesse individual.

Uma das principais condutas que permitem o deslocamento de recursos internamente ao grupo - e que representa típico caso de abuso do poder de controle - é a celebração de contratos em condições de favorecimento, significativamente diversas daquelas que seriam negociadas por partes independentes. Assim, por exemplo, $A$ pode compelir $Y$ a comprar bens de $X$ acima do valor de mercado, ou a vender produtos a esta última muito abaixo de seu efetivo custo.

Naturalmente, esses são apenas alguns exemplos grosseiros e banais de operações prejudiciais aos acionistas externos, conhecidas como "tunnelling"182, que podem - e costumam - ter perfil muito mais sofisticado e intrincado, não apenas em função da própria complexidade da vida empresarial moderna, mas também em razão do deliberado propósito de ocultar sua verdadeira natureza e os danos delas decorrentes ${ }^{183}$. Pode-se

181 Exemplo interessante colacionado por Wiedemann: "Duas companhias controladas pertencentes ao mesmo grupo de fato planejam, de forma independente uma da outra, investimentos de modernização. Ambas necessitam de recursos externos adicionais, mas os créditos totais à disposição do grupo não são suficientes para o financiamento simultâneo de ambos os projetos. A instituição financeira associada ao grupo se decide pelo investimento de uma das controladas, enquanto que a outra é obrigada a desistir de seu projeto e limitar a sua produção". Tradução livre de: "Zwei faktisch konzernabhängige Aktiengesellschaften planen unabhängig voneinander Modernisierungsinvestititionen. Beide benötigen zusätzliche Fremdmittel; die der Unternehmensgruppe insgesamt zur Verfügung stehenden Kredite reichen nicht aus, beide Vorhaben gleichzeitig zu finanzieren. Die Hausbank entscheidet sich für die Investition bei einer Tochtergesellschaft, womit die anderen gezwungen wird, ihr Vorhaben abzugeben und die entsprechende Produktion einzuschränken." in H. WIEDEMANN, Die Unternehmensgruppe in Privatrecht, p. 47.

182 “[...] nós usamos o termo 'tunnelling', cunhado originalmente para caracterizar a expropriação de acionistas minoritários na República Checa (tal como na movimentação de bens por meio de um túnel subterrâneo), para descrever a transferência de ativos e lucros para fora das empresas, em benefício daquelas que as controlam". Tradução livre de: “[...] we use the term 'tunnelling,' coined originally to characterize the expropriation of minority shareholders in the Czech Republic (as in moving assets through an underground tunnel), to describe the transfer of assets and profits out of firm for the benefit of those who control them." in S. JOHNSON, R. LA PORTA, F. LOPEZ-DE-SILANES, A. SHLEIFER, Tunneling, p. 22.

183 A. DYCK, L. ZINGALES, Private Benefits of Control - An International Comparison, p. 537-538. 
cogitar, ilustrativamente, da interposição de terceiros ou ainda da usurpação de oportunidade comercial da controlada ${ }^{184}$. Elemento comum de todas elas é a erosão do patrimônio que serve de garantia aos credores sociais.

É em função de cenários dessa natureza que se pode afirmar que as vedações constantes dos artigos 117, § 1, alínea "f”, e 245 da Lei 6.404/1976 não existem apenas em benefício dos acionistas externos, mas também representam mecanismo de proteção aos seus credores.

Diversamente do que ocorre em relação aos acionistas externos, nos termos do artigo 246, a Lei 6.404/1976 não instituiu ação específica dirigida contra o controlador para a tutela dos credores, em face do esvaziamento patrimonial intencional da companhia. Contudo, pode-se afirmar que o legislador não o fez simplesmente porque neste caso não era necessário nem superar obstáculos de coordenação de interesses coletivos ou individuais homogêneos, nem estabelecer legitimação ativa extraordinária pela via da substituição processual, uma vez que o credor busca indenização por danos sofridos pessoal e diretamente.

O artigo $159, \S 7^{\circ}$, ressalvou expressamente o fato de que a ação ut singuli dos sócios contra os administradores não exclui aquela que couber aos acionistas ou terceiros diretamente prejudicados por eventuais atos abusivos. Não parece minimamente razoável deduzir ou intuir uma imunidade processual do controlador em face dos credores que não se revistam da qualidade de acionista a partir da mera ausência de uma ressalva análoga no corpo do artigo 246.

\subsubsection{O Conflito na Relação entre Controlador e Minoritários}

As mesmas dificuldades enfrentadas pelos credores das sociedades que integram o grupo se apresentam, amiúde de forma mais intensa, aos acionistas não controladores que, em última análise, são credores dos potenciais resultados positivos distribuíveis, seja como lucros seja como haveres de liquidação, da companhia de que participam.

184 “A sociedade controladora pode explorar a sua posição ulteriormente, para obter vantagens fiscais, ocupar postos de administração, esvaziar o mercado de produtos concorrentes ou simplesmente desviar para si mesma oportunidades de negócios e experiência". Tradução livre de: "Die Muttergesellschaft kann ihre Stellung weiter ausnutzen, um Steuervorteile zu gewinnen, Managementposten zu besetzen, Konkurrenzprodukte auszutrocknen oder einfach Geschäftschancen und Erfahrungen auf sich selbst umzuleiten." in H. WIEDEMANN, Die Unternehmensgruppe in Privatrecht, p. 44. 
Bastaria, com efeito, retomar o exemplo utilizado no tópico anterior para imediatamente se verificar que não apenas os credores da sociedade $Y$, mas também os seus acionistas minoritários, seriam fortemente prejudicados por operações abusivas orquestradas pelo controlador $A$.

Existem, entretanto, diversos aspectos que apartam a posição do acionista daquela de credor externo. A primeira diferença - e possivelmente a mais importante delas - é o grau de exposição ao risco de abuso por parte do acionista controlador. Enquanto o credor espera da sociedade integrante do grupo apenas uma determinada (ou ao menos determinável) e específica prestação, resultado de contrato bilateral, o acionista minoritário confia ao acionista controlador - por meio da interposição da própria companhia e de seus administradores - a gestão de parte de seu patrimônio.

O credor, em regra, está sujeito somente ao risco da hipótese limite de insolvência da companhia, enquanto que toda e qualquer contrapartida do investimento realizado pelo acionista, variável pela sua própria natureza, dependerá do bom desempenho da empresa.

Em sua relação bilateral, sociedade e credor estão sujeitos "apenas" ao respeito às normas cogentes e à cláusula implícita da boa-fé objetiva ${ }^{185}$. Ressalvados esses limites, ambos podem perseguir livremente os próprios interesses. Em contraste, o acionista controlador é órgão da companhia e, em função da natureza fiduciária da relação, deve exercer seu poder-função de controle no interesse desta (Lei 6.404/1976, artigo 115, caput) e considerando os seus fins (artigo 116, parágrafo único). Ao credor, basta ser honesto, o controlador deve ser leal (artigo 116, parágrafo único, parte final).

A boa-fé objetiva, que pode ser traduzida na fórmula "honestidade pública", pressupõe a devida consideração do interesse alheio ${ }^{186}$. O dever de lealdade dos acionistas controladores e dos administradores, ao revés, pela sua natureza fiduciária, implica a anteposição do interesse da companhia ao próprio $^{187}$.

185 Código Civil de 2002, artigo 422.

186 M. REALE, História do Novo Código Civil, p. 248-249.

187 "Os deveres fiduciários, [...] implicam a obrigação de que seu sujeito ultrapasse em um dado relacionamento a simples honestidade negocial, ficando a ele vedados o conflito de interesses e a aferição de qualquer tipo de vantagem em decorrência do exercício de suas funções, o que inclui também vantagens obtidas sem prejuizo para a sociedade ou os acionistas minoritários (dever de lealdade)." in E. SALOMÃO NETO, Trust e Deveres de Lealdade e Sigilo na Sociedade Anônima Brasileira, p. 305. 
Além disso, no plano formal e instrumental, o credor, se prejudicado, pleiteará individualmente indenização em nome próprio. Os acionistas minoritários são apenas mediata e indiretamente prejudicados, uma vez que é o patrimônio da sociedade a ser diretamente atingido pelos abusos do controlador. Contudo, é mais do que evidente que a sociedade e seus administradores, ambos sujeitos à influência determinante do controlador, não tomarão no mais das vezes medidas contra este último.

Por essa razão, o legislador criou, nos termos do artigo 246, mecanismos próprios para superar o problema da legitimidade processual e para mitigar a questão da coordenação dos interesses dos minoritários ${ }^{188}$. Assim, a lei conferiu aos minoritários, em caso de resistência da assembleia geral, a possibilidade de propor ação de indenização em nome próprio, mas em benefício da companhia, por substituição processual.

Essa prerrogativa, contudo, não é suficiente para permitir a superação das fortes externalidades positivas decorrentes da iniciativa de propor ação de apuração de responsabilidade contra a sociedade controladora. $\mathrm{O}$ acionista minoritário que toma a iniciativa de promover ação de responsabilidade contra ela incorre em significativos custos e riscos (por exemplo a sucumbência), mas os eventuais benefícios decorrentes de tal esforço reverterão, imediata e diretamente, em favor da sociedade.

Desse modo, as possíveis vantagens resultantes da ação apenas indiretamente serão aproveitadas pelo seu autor. Mais do que isso, os ganhos obtidos judicialmente tanto em termos de ressarcimento quanto de cessação de condutas lesivas - serão automaticamente compartilhados com todos os consócios, verdadeiros free-riders do risco e do empenho daquele que promoveu a ação. Vale lembrar, inclusive com certa redundância e ironia, que a própria sociedade controladora é beneficiária na medida em que, indiretamente, ao restituir recursos à companhia, indeniza parcialmente a si mesma.

De forma a contornar esse cenário desencorajador, a lei buscou criar benefícios diretos para o acionista que toma a iniciativa de questionar judicialmente a conduta da sociedade controladora. Os principais mecanismos adotados nesse sentido, consoante o parágrafo $2^{\circ}$ do artigo 246, são (i) um prêmio de cinco por cento sobre eventual valor de condenação aplicada à sociedade controladora e (ii) fixação de honorários advocatícios em

188 Dispositivo analisado de forma mais detida no Capítulo 7. 
vinte por cento sobre o montante da indenização.

Conforme já mencionado anteriormente, as preocupações do legislador brasileiro no que toca o direito societário dos grupos foram, porém, muito além da mera proteção aos acionistas minoritários. Se por um lado, a lei restringe a margem de manobra do acionista controlador, com as disposições dos artigos 116, 117 e 245 da Lei 6.404/1976, por outro lado, busca legitimar e viabilizar juridicamente a subordinação de interesses no âmbito dos grupos.

Em termos confessadamente simplistas e tecnicamente pouco rigorosos, pode-se argumentar que a tutela prudencial e conservadora dos interesses dos acionistas externos levaria, quase naturalmente, à gestão da empresa plurissocietária de acordo com critérios de eficiência paretiana, ou seja, alcançar-se-ia um equilíbrio na economia interna do grupo em que a melhoria da posição de um agente não poderia ocorrer sem a degradação da posição de outro. Isso significaria que o limite para a adoção de políticas comuns em favor do grupo, como um todo, seria o prejuízo individual de qualquer sociedade que o integrasse (e dos acionistas externos desta última) ${ }^{189}$.

O que o legislador buscou, ao instituir a exclusão de ilicitude em caso de "pagamento compensatório adequado", nos termos do próprio artigo 245 da Lei 6.404/1976, ou ainda ao permitir, pela via da celebração de convenção, a gestão centralizada e a subordinação de interesses no grupo de direito, consoante o artigo 276, é abrir espaço para a persecução de políticas orientadas por um equilíbrio de Kaldor-Hicks, no qual interesses individuais podem ser sacrificados em nome de uma maior utilidade total para o conjunto dos agentes ${ }^{190}$.

189 "Recorda-se que o parâmetro de eficiência de Pareto é alcançado quando pelo menos um indivíduo se beneficia e ninguém perde. Uma melhoria de Kaldor-Hicks ocorre quando os beneficiados obtêm um ganho de modo tal a contrabalancear as perdas sofridas pelos outros". Tradução livre de: "It will be remembered that the Pareto standard of efficiency is met when at least one individual gains and no one loses. A Kaldor-Hicks improvement occurs where those who benefit do so in a way that outweighs the loss to others." in J. DINE, The Governance of Corporate Groups, p. 118.

190 "Em todos os casos, portanto, em que uma certa política leva a um aumento da produtividade fisica e, portanto, da renda real total, a argumentação do economista em favor de tal política é substancialmente indiferente à questão da comparabilidade da satisfação individual, uma vez que é possível, em todos os referidos casos, tornar a situação de todos melhor do que antes ou, de qualquer forma melhorar a condição de alguns sem piorar a de ninguém. Não há qualquer necessidade de que o economista prove - como, de fato, jamais poderia provar - que como resultado da adoção de determinada medida ninguém na comunidade sofrerá". Tradução livre de: "In all cases, therefore, where a certain policy leads to an increase in physical productivity, and thus of aggregate real income, the economist's case for the policy is quite unaffected by the question of the comparability of individual satisfactions; since in all 
A constituição do grupo de direito encerra essencialmente uma permuta, proposta pelo legislador ao sócio controlador do grupo de fato. Em contrapartida da explicitação da existência e da formalização do funcionamento do grupo - ou seja, passagem do grupo de fato para grupo de direito -, o controlador da sociedade dominante, os administradores desta última e, principalmente, os administradores da sociedade dominada são colocados em uma "zona segura", ao resguardo das normas que tutelam o conflito de interesse e o abuso do poder de controle nos grupos.

O grupo de direito não é, e sequer foi pensado, ao menos não em sua essência, como um simples instrumento de gestão, como mera ferramenta em favor da mais conveniente administração do grupo de fato. A consequência mais importante da celebração da convenção não é a possibilidade de gestão unificada do grupo - efeito que, em termos práticos, deriva do próprio comando de fato sobre as sociedades em questão -, mas a mencionada realocação de responsabilidades individuais de acionistas e administradores por atos praticados em benefício do grupo, mas contra o interesse da própria sociedade.

De qualquer modo, é evidente que, mesmo sob a lógica de Kaldor-Hicks, o sacrifício imposto imediatamente à controlada $\mathrm{e}$, mediatamente, aos acionistas externos deve ser recompensado ${ }^{191}$. Porém, à luz da complexidade do funcionamento dos grupos e considerando a realidade do sistema judiciário brasileiro, este remédio parece - conforme se argumenta mais adiante - de duvidosa eficácia.

De fato, o legislador brasileiro parece ter se apoiado demasiadamente na regra de

such cases it is possible to make everybody better off than before, or at any rate to make some people better off without making anybody worse off. There is no need for the economist to prove - as indeed he never could prove - that as a result of the adoption of a certain measure nobody in the community is going to suffer." in N. KALDOR, Welfare Propositions of Economics and Interpersonal Comparisons of Utility, p. 550.

191 “A principal vantagem prática de nossa linha de abordagem é que ela fixa a atenção na questão da compensação. Toda a reforma econômica inflige uma perda em algumas pessoas; as reformas que estudamos são marcadas pela característica de permitirem uma compensação que contrabalanceará as perdas e, ainda assim, apresentar um ganho líquido."; e, ainda: "Se quisermos que medidas que promovem a eficiência tenham uma chance razoável, é extremamente desejável que elas sejam liberadas de complicações distributivas, tanto quanto possível". Tradução livre de: "The main practical advantage of our line of approach is that it fixes attention upon the question of compensation. Every simple economic reform inflicts a loss upon some people; the reforms we have studied are marked out by the characteristic that they will allow of compensation to balance that loss, and they will still show a net advantage." " "If measures making for efficiency are to have a fair chance, it is extremely desirable that they should be freed from distributive complications as much as possible." in J. HICK, The Foundations of Welfare Economics, respectivamente p. 711 e 712. 
conflito, deixando sobre os ombros do acionista minoritário o ônus de detectar abusos, comprová-los e contra eles se insurgir judicialmente, no mais das vezes enfrentando aguda assimetria econômica e informação e tendo de contar com tribunais pouco propensos a avaliar o mérito de decisões comerciais. Se no plano conceitual a exigência de compensação - fixada no artigo 245 , no que tange os grupos de fato, e presumivelmente negociada caso a caso nas convenções dos grupos de direito - tutela a posição dos acionistas externos, em termos práticos a posição destes é extremamente vulnerável.

\subsection{Nota sobre Elemento Nacionalista da Disciplina dos Grupos}

Uma das mais insistentes críticas endereçadas ao anteprojeto de Lei de S.A. que resultou na promulgação da Lei 6.404/1976, por ocasião dos debates públicos que antecederam a sua aprovação parlamentar, foi o suposto favorecimento dos grupos estrangeiros, que aceleraria o processo de desnacionalização da economia brasileira ${ }^{192}$.

Tais críticas parecem particularmente injustas se tomarmos em conta as referências à promoção do "interesse nacional" e à tutela da "economia nacional", constantes do artigo 117, $\S 1^{\circ}$, alínea "a": dispositivo que forma parte de um sistema de atribuição de responsabilidade social à grande empresa, fosse ela brasileira ou estrangeira.

Mesmo no âmbito dos grupos, contudo, a Lei 6.404/1976 apresentou clara direção nacionalista e não apenas com a exigência de indicação da nacionalidade do grupo, nos termos do artigo 269, VII e parágrafo único. Com efeito, com o artigo 245, a lei acionária estabeleceu - conforme já discutido acima - uma nítida vedação à subordinação de interesses nos grupos de fato. O sacrifício dos interesses da sociedade controlada, na arquitetura conceitual da lei, apenas é possível se contraposto a adequado pagamento compensatório ou precedido da celebração da convenção de grupo, hipótese em que a atuação dos administradores das sociedades controladas sujeita-se ao disposto no artigo 273. Ocorre que, nos termos do artigo $265, \S 1^{\circ}$, a sociedade controladora ou de comando do grupo deve necessariamente ser brasileira ${ }^{193}$.

O controle da sociedade de comando, enquanto pináculo do grupo, está fora do

192 A. LAMY FILHO, J. PEDREIRA, A Lei das S.A., vol. I, p. 167.

193 “Mas, como esse interesse não poderia opor-se ao do país, só permitiu formação de grupos [de direito] com empresa controladora brasileira [...]” in A. LAMY FILHO, J. PEDREIRA, A Lei das S.A., vol. I, p. 167. 
âmbito da convenção de grupo, que se aplica a partir de tal companhia "para baixo". Em outras palavras, a convenção de grupo não regula a subordinação de interesses da sociedade de comando em favor de sua controladora pois, se assim fizesse, esta última se tornaria a sociedade de comando.

Assim, fosse o artigo 245 aplicado com toda a força de suas disposições literais, as consequências de tal requisito de nacionalidade seriam dramáticas e significariam nada menos que uma vedação geral à subordinação de interesses de sociedade brasileira por parte de controladores estrangeiros.

Se a sociedade estrangeira pode participar do grupo de direito apenas como controlada, e não como sociedade de comando, e se somente nos limites internos de tal grupo regulado por convenção é possível a prevalência dos interesses gerais sobre os interesses individuais de cada sociedade, é forçoso concluir que - ao menos na concepção original da norma - a matriz estrangeira não poderia impor uma relação de subordinação às controladas brasileiras.

A disciplina da Lei 6.404/1976 não atingiu tal resultado prático simplesmente em função da pouca eficácia concreta das restrições previstas no artigo $245^{194}$, mas a análise não deixa de revelar uma mens legis fortemente protetiva da empresa nacional. De fato, qualquer dúvida a esse respeito se dissipa imediatamente com a leitura da Exposição de Motivos de nossa lei acionária, em sua seção atinente ao conceito de subsidiária integral, na qual se afirma que: “[...] o Projeto não admite a companhia brasileira subsidiária integral de companhia estrangeira, para deixar claro que a lei veda a subordinação do interesse da sociedade nacional ao da estrangeira [...]"195.

\subsection{Conclusões Preliminares}

Como em uma espécie de lente de distância focal variável ou zoom, buscou-se nas páginas anteriores vislumbrar os possíveis destinatários das diversas normas de direitos dos grupos a partir da posição ampla e geral possível para, em seguida, buscar os sujeitos, ou mais precisamente, as posições e categorias jurídicas mais específicas e determinadas.

194 Questão discutida no Capítulo 9.

195 Exposição de Motivos n 196, de 24 de junho de 1976, do Ministério da Fazenda. Comentários ao capítulo XX, Seção V. 
Tal percurso se iniciou, portanto, com normas que parecem estar endereçadas à própria coletividade como um todo e que prestigiam um princípio de caráter tão geral quanto o da própria igualdade perante a lei. Tais normas se baseiam principalmente na técnica da imputação aditiva ou substitutiva de características de um sujeito a outro, para o preenchimento da fattispecie de determinada norma, cujo método será discutido de forma mais detida no Capítulo 6.

O passo seguinte foi tratar das normas que tutelam os interesses de trabalhadores, consumidores e vítimas de danos ambientais. Os dois primeiros representam conjuntos de credores contratuais hipossuficientes; estas últimas credores extracontratuais. Traço comum a todas as três categorias é a impossibilidade de se aferir, por ato consciente e voluntário, o grau de exposição do credor aos riscos da empresa plurissocietária. Não por acaso, portanto, é justamente na questão do risco que a lei ancorou hipóteses alargadas de responsabilização em todos estes microssistemas jurídicos.

Na passagem para o direito societário, a densa regulamentação sobre a prestação de informações é forte indício do fato de que a atenção do legislador se desloca gradualmente para agentes mais sofisticados, que - caso sejam dotados dos instrumentos e subsídios necessários - poderão tomar decisões informadas sobre os próprios rumos no ambiente empresarial.

Não cabe à lei afastar de tais sujeitos, ainda que estejam na posição mais vulnerável de acionistas minoritários, os riscos inerentes à atividade empresarial, que são a contrapartida e a justificação dos ganhos potenciais decorrentes das relações de crédito e investimento. Nestes casos, o principal risco a ser enfrentado é o de comportamento desleal e oportunista por parte daqueles que administram os fundos sociais: os próprios administradores e o acionista controlador.

Entretanto - e esta é provavelmente a conclusão mais interessante e menos óbvia da análise teleológica -, é possível identificar diversas normas, sobretudo no que se refere à possibilidade de compensação das perdas no grupo de fato, e a autorização expressa para a subordinação de interesses no grupo de direito, cuja existência não se explica pela simples tutela de acionistas externos e credores sociais. Nelas resta evidente a intenção do legislador de criar meios para permitir e facilitar a propagação do poder de controle ao 
longo da empresa plurissocietária ${ }^{196}$. Como consequência, o próprio controlador é alçado à condição de beneficiário da tutela jurídica do direito societário dos grupos no Brasil, ensejando uma contraditória convivência de normas de proteção e preceitos de organização em nosso sistema.

196 “[...] o Anteprojeto, ao invés de tentar destruir o empresário-empreendedor [...], adotou, como diretriz, reconhecer sua importância na economia aberta, centrar um grupo de normas em torno de sua figura, assegurar-lhe maior número de opções para organizar a empresa [...]” in A. LAMY FILHO, J. PEDREIRA, A Lei das S.A., vol. I, p. 187. 


\section{Notas sobre o Direito Estrangeiro Contemporâneo}

O presente capítulo tem como objeto a análise da disciplina jurídica dos grupos em algumas poucas legislações selecionadas, julgadas de especial interesse para a condução do trabalho. O objetivo não é, porém, realizar detida análise de direito comparado, mas apenas colher subsídios para o confronto, ao longo do resto deste estudo este sim, esforço comparativo - da praxe estrangeira a respeito de questões específicas dos grupos com as normas de direito brasileiro. Por diferentes razões, a seguir declinadas, os países escolhidos para tanto são Alemanha, Itália e França.

Após os breves apontamentos, constantes do subcapítulo 2.4, sobre o contexto histórico em que foi gestado o Konzernrecht na Alemanha é absolutamente irrenunciável discorrer sobre as principais características da disciplina contemporânea alemã do direito dos grupos, considerando seu papel vanguardista na promulgação de um sistema de normas societárias tendo por objeto específico as relações de grupo. Por outro lado, tendo em vista a complexidade da disciplina dos grupos em tal país, a riqueza de suas discussões doutrinárias e a vastidão do arcabouço judicial construído desde a promulgação da lei acionária de 1965, é igualmente inevitável que tal análise seja realizada em apertada síntese.

Um exame do direito italiano se justifica por se tratar de um dos países que mais recentemente promulgou amplas e articuladas disposições legais tendo por objeto precipuamente o fenômeno dos grupos de sociedades e, portanto, pôde colher inspiração nas experiências legislativas de outras nações, bem como nos amplos debates travados em função da (até agora) malfadada tentativa de construir uma disciplina comum europeia sobre o tema. Aspecto interessante do novo sistema italiano é o fato de representar uma estrutura híbrida, a meio caminho entre os ordenamentos que disciplinam o grupo como tal e a vasta maioria dos países que possuem inúmeras regras sobre os efeitos dos grupos, sem atribuir ao próprio conceito de grupo e ao conflito de interesses no grupo um papel central na própria legislação ${ }^{197}$.

197 “A reforma italiana de 2003 transita por um caminho intermediário entre a fragmentação inicial e o regramento excessivo alemão". Tradução livre de: "La reforma italiana del 2003 transita un camino intermedio entre la fragmentación inicial y el reglamentarismo alemán.” in H. ROITMAN, Francesco 
Enfim, a questão dos grupos na França é merecedora de breve comentário, justamente por representar um exemplo de nação que possui uma longa tradição doutrinária em matéria de grupos, mas que não criou um sistema orgânico de normas a respeito do tema. Neste caso, porém, a análise será centrada sobretudo na doutrina Rozenblum, que é quase certamente o aspecto de direito grupal francês que encontrou maior projeção nas discussões de direito comparado.

\subsection{Direito Alemão}

O direito alemão dos grupos está positivado principalmente nos $\S \S 15$ a 19 e 291 a 327 da lei acionária (Aktiengesetz ou simplesmente $A k t G$ ) de 1965. O primeiro bloco de normas contém definições gerais sobre os vínculos de associações possíveis entre as sociedades e empresas, enquanto que os $\S \S 291$ a 337 formam o Livro Terceiro da $A k t G$ 1965, especificamente destinado à disciplina da formação, extinção e operação dos agrupamentos de empresas que tenham como controladas as sociedades por ações (verbundene Unternehmen) $^{198}$.

É importante anotar que a lei que trata das sociedades de responsabilidade limitada no direito alemão (Das Gesetz betreffend die Gesellschaften mit beschränkter Haftung ou $G m b H G$ ), promulgada em 1892, mas que desde então sofreu diversas modificações, não lida especificamente com a questão dos grupos formados por sociedades de tal tipo. Repetidos planos para criar uma disciplina específica de direito dos grupos aplicáveis a esta forma societária foram abandonados e, no espaço vago deixado pelo legislador, formou-se densa jurisprudência ${ }^{199}$, que em alguns casos se apropriou de conceitos constantes da lei acionária ${ }^{200}$, mas em diversos outros trilhou um caminho

Galgano y su obra, p. 193.

198 "Enquanto os $\S \S 291$ a 328 da lei acionária são, em geral, aplicáveis diretamente apenas quando o vínculo entre empresas diz respeito a sociedades por ações ou em comandita por ações e, além disso, quando estas estão no papel de empresa controlada, os $\$ \S 15$ a 22 contém, por assim dizer, a 'parte geral' do direito alemão dos grupos, por meio da definição dos conceitos mais importantes para as regras de grupo". Tradução livre de: “Während die $\$ \oint 291$ bis 328 AktG in der Regel unmittelbar nur anwendbar sind, wenn an der Unternehmensverbindung eine AG oder KG .a.A., und zwar gerade in der Rolle als abhängiges Unternehmen beteiligt ist, enthalten die $\$ \oint 15$ bis 22 AktG sozusagen den 'allgemeinem Teil' des deutschen Konzernrechts durch eine Definition der wichtigsten konzernrechtlichen Begriffe [...]” in V. EMMERICH, M. HABERSACK, Konzernrecht, p. 24.

199 V. EMMERICH, M. HABERSACK, Konzernrecht, p. 6-7.

200 Por exemplo, no célebre caso Autokran, o Tribunal de Justiça Federal da Alemanha decidiu que o mecanismo de absorção e compensação anual de perdas sofridas pela sociedade controlada que integra grupo de direito poderia, em hipóteses de grave deterioração patrimonial, ser aplicado às sociedades de responsabilidade limitada: "Em caso de esvaziamento patrimonial de uma sociedade controlada de 
próprio $^{201}$.

Conforme argumenta Hoffmann-Becking, pode-se afirmar que o legislador alemão de 1965 vislumbrou três níveis distintos de entrelaçamento entre decisões e atividades das sociedades vinculadas, que em grau crescente de suposta autonomia residual reservada para as sociedades controladas seriam: (i) as sociedades integradas (Eingliederung), (ii) o grupo de direito e (iii) o grupo de fato. A essas categorias, a doutrina e a jurisprudência fizeram acrescentar um nível híbrido, qual seja (iv) o grupo de fato qualificado $^{202}$.

O presente subcapítulo parte de uma análise do específico conceito de empresa utilizado nesta seara para, em seguida, abordar as diversas definições estruturantes do grupo no direito alemão e, enfim, se debruçar sobre cada um dos níveis de agrupamento descritos acima.

\subsubsection{A Noção de Empresa (Unternehmen) para o Direito dos Grupos}

O regime alemão dos grupos, conforme estabelecido na lei acionária de 1965, é estruturado a partir do complexo encadeamento de uma série de conceitos, associados por

responsabilidade limitada, cabe considerar a responsabilidade subsidiária da empresa controladora do grupo, pela correspondente aplicação dos $\S \S 303,322$, subparágrafos 2 e 3 da lei acionária, nas hipóteses em que a controladora conduz ela própria, de forma ampla e duradoura, os negócios da sociedade de responsabilidade limitada controlada e é incapaz de comprovar que um administrador diligente de uma sociedade de responsabilidade limitada independente teria agido do mesmo modo". Tradução livre de: "Bei Vermögenslosigkeit einer abhängigen GmbH kommt eine Ausfallhaftung des herrschenden Konzernunternehmens in entsprechender Anwendung der $\S \S 303,322$ II und III AktG in Betracht, wenn dieses die Geschäfte der abhängigen GmbH dauernd und umfassend selbst geführt hat und nicht dartun kann, daß der pflichtgemäß handelnde Geschäftsführer einer selbständigen GmbH die Geschäfte ebenso geführt hätte." conforme a ementa da decisão do Tribunal de Justiça Federal da Alemanha II Câmara Civil, de 16 de setembro de 1985 (BGHZ 122, S. 123).

201 “A proteção de uma sociedade limitada controlada em face de ataques de seu único sócio não segue o sistema de responsabilidade do direito grupal previsto pelas normas aplicáveis às sociedades por ações (\$\$ 291 e seguintes, 311 e seguintes da lei acionária), mas, ao revés, está limitada à preservação de seu capital social e à garantia dos direitos adquiridos, o que exige a adequada consideração das exigências próprias das sociedades de responsabilidade limitada". Tradução livre de: "Der Schutz einer abhängigen GmbH gegen Eingriffe ihres Alleingesellschafters folgt nicht dem Haftungssystem des Konzernrechts des Aktienrechts ( $\$ 2291 \mathrm{ff}$., $311 \mathrm{ff}$. AktG), sondern ist auf die Erhaltung ihres Stammkapitals und die Gewährleistung ihres Bestandsschutzes beschränkt, der eine angemessene Rücksichtnahme auf die Eigenbelange der GmbH erfordert." conforme decisão, no caso "BremerVulkan", do Tribunal de Justiça Federal da Alemanha II Câmara Civil, de 17 de setembro de 2001 (BGHZ 149, S. 10).

202 Fala-se em categoria híbrida, apenas em função da atribuição de efeitos típicos do grupo de direito a uma situação não formalizada expressamente por meio de contrato de empresa. No que toca, porém, ao grau de entrelaçamento de atividades e subordinação de interesses, o grupo de fato qualificado está no limite do que poderia ser admitido mesmo dentro do próprio grupo de direito. M. HOFFMANN-BECKING, Der qualifizierte faktische AG-Konzern - Tatbestand und Abwehransprüche, p. 69. 
sua vez a diversas presunções legais. No plano subjetivo, a célula elementar de tal estrutura não é propriamente a sociedade, mas o conceito mais amplo de Unternehmen, ou seja, "empresa" tomada na acepção de ente ou sujeito titular da organização da atividade produtiva. É com base em tal conceito que todas as demais definições são articuladas, conforme discutido no próximo tópico.

O fundamento para a limitação da incidência das normas grupais apenas aos sujeitos que se qualifiquem como empreendedores reside na valoração realizada pelo legislador alemão no sentido de que o efetivo problema dos grupos não é o conflito de interesses em geral, mas o conflito - julgado como mais crítico ${ }^{203}$ - entre os interesses da sociedade e um interesse empresarial e externo às suas atividades ${ }^{204}$.

Assim, buscou-se expressamente excluir do campo de aplicação do Konzernrecht o investidor privado (Privatgesellschafter), concebido como o sujeito que eventualmente detenha participações em mais de uma sociedade, mas o faça simplesmente como investimento pessoal, vale dizer como exercício de administração do próprio patrimônio, mas (i) sem exercer uma atividade empresarial por meio dos entes societários e (ii) sem que tal gestão se transforme, per se, em uma atividade empresarial ${ }^{205}$.

203 "No direito federal alemão, a seu turno, reconheceu-se apropriadamente que a dependência de um empresário (consócio) controlador é potencialmente mais prejudicial para a sociedade do que aquela estabelecida em relação a um controlador que seja investidor privado". Tradução livre de: "Im bundesdeutschem Recht wurde demgegenüber zutreffend erkannt, daß die Abhängigkeit von einem herrschenden (Mitglieds)Unternehmen die Gesellschaft potentiell mehr gefährdet als diejenige von einem herrschenden Privatgesellschafter." (negrito no original) in H. WIEDEMANN, Gesellschaftsrecht, Band I, p. 347.

204 "A doutrina anterior à aprovação da nova lei acionária repetidamente solicitou que o âmbito de aplicação do direito dos grupos se estendesse a qualquer sujeito controlador, sem se considerar a sua qualidade de empresário. Os autores da lei, porém não seguiram tal caminho, porque em sua opinião apenas em relação a um sócio-empresário existiria o perigo de utilização dos direitos decorrentes de sua participação em prejuízo da sociedade e em favor de seus outros interesses empresariais (o assim chamado conflito de grupo), enquanto que no que diz respeito a acionistas privados não se verificaria a ameaça de um risco comparável". Tradução livre de: "In Schrifttum war vor Verabschiedung des neuen Akt $G$ wiederholt gefordert worden, den Anwendungsbereich des Konzernrechts auf jede herrschende Person zu erstrecken, ohne Rücksicht auf ihre Unternehmensqualität. Dem sind die Gesetzesverfasser indessen nicht gefolgt, weil sie der Meinung waren, allein bei einem Unternehmensgesellschafter bestehe die Gefahr, dass er die Rechte aus der Beteiligung zum Nachteil der Gesellschaft für seine sonstigen unternehmerischen Interessen nutzbar macht (sog. Konzernkonflikt), während bei einem Privatgesellschafter eine vergleichbare Gefahr nicht drohe." (negrito no original) in V. EMMERICH, M. HABERSACK, Konzernrecht, p. 24. H. WIEDEMANN, Die Unternehmensgruppe im Privatrecht, p. 39.

205 "[...] o legislador, como mencionado, criou uma distinção entre o acionista-empresário e outros acionistas. De um acionista relevante, cuja atividade econômica se limite a uma empresa, espera-se que, em geral, veja o interessa da empresa como o seu próprio ou, em qualquer caso, que não persiga nenhum interesse especial a ele contrário. Em relação a tal acionista, portanto, pôde o legislador avaliar que o risco de sacrificio do bem-estar da sociedade em nome de seus interesses pessoais era 
É em parte surpreendente que o legislador alemão, a despeito de ter disciplinado de forma exageradamente minuciosa e articulada alguns aspectos do direito dos grupos, tenha deixado aos tribunais a delimitação dos precisos contornos do conceito de empresa. Em termos práticos, partindo de uma avaliação teleológica da norma, doutrina e jurisprudência acabaram por ampliar notavelmente a extensão do conceito de empresário para os fins do direito dos grupos, de forma que a figura do investidor privado acabou por se tornar uma definição residual; a exceção e não a regra. Houve, portanto, uma inversão de perspectiva, por meio da qual se busca avaliar em que ocasiões um acionista age puramente como um particular que se restringe a zelar pelo próprio patrimônio e não o contrário $^{206}$.

Nesse sentido, a qualificação jurídica do sócio não tem qualquer relevância para o reconhecimento de sua posição de empresário para os fins do direito dos grupos na Alemanha, sendo possível que se revistam de tal qualidade sociedades de pessoas e até mesmo não personificadas, associações, fundações e empresários individuais ${ }^{207}$. Releva apenas a existência de um interesse econômico-empresarial externo à sociedade, conceito no qual não se incluem atividades beneficentes ou caritativas ${ }^{208}$.

menor e considerou que as regras gerais de proteção dos minoritários, nomeadamente o $\$ 117$ bem como o $\$ 243$, subparágrafo 2, da lei acionária, eram suficientes para se contrapor a tal risco. Por outro lado, é de se presumir tal perigo em relação ao acionista que tenha atividade empresarial externa à sociedade, de forma que as situações especiais de conflito exigem também precauções normativas especiais [...]". Tradução livre de: “[...] daß der Gesetzgeber, wie erwähnt, zwischen Unternehmensaktionären und anderen Aktionären unterschieden hat: Von einem Großaktionär, dessen wirtschaftliche Tätigkeit sich auf das eine Unternehmen beschränkt, wird erwartet, daß er im Regelfall das Interesse dieses Unternehmens als sein eigenes betrachten oder jedenfalls keine ihm zuwiderlaufenden Sonderinteressen verfolgen wird; bei ihm konnte daher der Gesetzgeber die Gefahr, er werde das Wohl der Gesellschaft solchen individuellen Interessen opfern, geringer veranschlagen und zu ihrer Abwehr den allgemeinen Minderheitenschutz, den namentlich $\S 117$ sowie $\$ 243$ Abs. 2 AktG bieten, für ausreichend erachten. Dagegen ist diese Gefahr bei einem Aktionär, der sich auch außerhalb der Gesellschaft unternehmerisch betätigt, typischerweise vorauszusetzen, so daß die besondere Konfliktslage auch besondere gesetzliche Vorkehrungen erforderte [...].” conforme decisão do Tribunal de Justiça Federal da Alemanha, II Câmara Civil, de 13 de outubro de 1977, no caso VEBA/Gelsenberg (BGHZ 69, S. 334).

206 V. EMMERICH, M. HABERSACK, Konzernrecht, p. 25-26.

207 “[...] uma empresa pode ser representada não pelo(s) titular(es) de uma atividade desenvolvida por meio de uma sociedade ou empresa individual, mas inclusive por um indivíduo na qualidade de particular. Neste último caso, a questão relevante é se a pessoa possui interesses econômicos não apenas na companhia em que detém participação mas também em outras companhias". Tradução livre de: "[...] an undertaking may consist not only of the owner(s) of a business carried on in partnership or by a sole trade, but even of a private individual. In the latter case the relevant question is whether that person has economic interests not only in the company in which he has a holding but also in other companies." in U. IMMENGA, The Law of Groups in the Federal Republic of Germany, p. 95.

208 V. EMMERICH, M. HABERSACK, Konzernrecht, p. 27. 
Assim, por exemplo, entende-se atualmente que o Estado, enquanto acionista, está sempre sujeito às normas relativas aos grupos, uma vez que, por definição, não atua nas vestes de mero investidor privado, mas age sempre de forma estritamente vinculada e em função do interesse público - o qual, para todos os efeitos, é um interesse externo ao da sociedade controlada e que pode conduzir a medidas que lhes sejam prejudiciais. $\mathrm{O}$ fato de o Estado poder assumir as vestes de empresário (e de empresa controladora) para os fins das regras de direito dos grupos restou confirmado com o caso VEBA/Gelsenberg, de outubro de 1977, no qual à própria República Federativa da Alemanha foi atribuída a qualidade de acionista empresário dominante ${ }^{209}$.

\subsubsection{Categorias de Vínculos entre Empresas}

O uso da expressão Konzern para designar os grupos empresariais, bem como do termo Konzernrecht para indicar o conjunto de normas que os disciplinam, representa, ao mesmo tempo, uma imprecisão e um exercício de metonímia. Com efeito, o Konzern é apenas uma entre várias categorias previstas pelo direito alemão dos grupos ${ }^{210} \mathrm{e}$, em sua acepção stricto sensu (ou seja, na definição estrita do § 18, subparágrafo 1, da lei acionária

209 "[...] em relação ao campo industrial ora sob análise, a República Federativa da Alemanha exibe em relação à sociedade na qual detém participação relevante todas as características de um empresário dominante."; e ainda "Que o governo federal, de fato, não concebe suas participações como puro investimento patrimonial, mas sim como participação ativa e para fins de planificação econômica por meio de sua administração dos eventos da sociedade, é questão fora de dúvida e, ademais, prevista na lei". Tradução livre de: "[...] in dem hier in Frage kommenden industriellen Bereich weist die Bundesrepublik Deutschland gegenüber den Gesellschaften, an denen sie maßgeblich beteiligt ist, alle Merkmale eines herrschenden Unternehmens auf."; " "Daß der Bund in der Tat die Beteiligungen nicht als bloße Vermögensanlage betrachtet, sondern auch wirtschaftlich planend durch seine Verwaltungen das Geschehen in den Gesellschaften aktiv mitbestimmt, kann nicht zweifelhaft sein und ist überdies gesetzlich vorgesehen." conforme decisão do Tribunal de Justiça Federal da Alemanha, II Câmara Civil, de 13 de outubro de 1977, no caso VEBA/Gelsenberg (BGHZ 69, S. 334).

210 "É difusa e também utilizada no âmbito deste manual a expressão direito dos grupos [Konzernrecht], ainda que - em vista do disposto no $\S 18$, subparágrafo 1, sentença 1 da Lei Acionária, de acordo com o qual o grupo [Konzern] representa apenas uma entre diversas formas de vinculação entre empresas ela possa ser imprecisa". Tradução livre de: "Es wird verbreitet und auch in Rahmen dieses Lehrbuch als Konzernrecht bezeichnet, mag dies auch in Hinblick auf $\S 18$ Abs. 1 S. 1 AktG, dem zufolge der Konzern nur eine von mehreren Formen der Unternehmensverbindung darstellt, unscharf sein." in V. EMMERICH, M. HABERSACK, Konzernrecht, p. 1. "[...] não se pode esquecer a esse respeito que o 'direito dos grupos' não vigora apenas para os 'grupos' [Konzerne] de verdade (vide $\S 18$, subparágrafo I, da lei acionária), nem, tampouco, está limitado apenas aos casos de dependência (vide $\S 18$, subparágrafo II, da lei acionária). Ele é descrito nos parágrafos 15 e seguintes da lei acionária, com precisão, como o direito das 'empresas vinculadas' e compreende, indo-se ainda mais além - caso incluamos, por exemplo, as associações -, o direito 'dos entes jurídicos vinculados"'. Tradução livre de: [...] dar darüber nicht vergessen werden, daß das »Konzernrecht "nicht nur für echte »Konzerne" gilt (vgl. § 18 I AktG) noch auch nur auf Abhängigkeitsfälle beschränkt ist (vgl. \& 18 II AktG). Es wird in den $\S \xi 15 \mathrm{ff}$. AktG treffend als Recht der »verbundenen Unternehmen « bezeichnet und umfaßt sogar, wenn wir etwa Vereine mit einbeziehen, noch weitergehend das Recht der "verbundenen Rechtsträger «." in K. SCHMIDT, Gesellschaftsrecht, p. 487-488. 
alemã), certamente não é a mais importante.

A categoria mais ampla adotada pelo direito societário alemão a este respeito é a das empresas vinculadas (verbundene Unternehmen, expressão definida pelo $\S 15$ ), que abrange as subcategorias de (i) participação majoritária, (ii) domínio e dependência, (iii) empresas de grupo (Konzern propriamente dito), (iv) participações recíprocas e (v) partes de convenção de grupo.

Da situação de "participação majoritária" no capital de uma empresa ${ }^{211}$ (Mehrheitsbesitz, conforme o $\S 16$, subparágrafo 1) decorre a presunção de "influência dominante" (beherrschende Einfluss, de acordo com § 17, subparágrafo 2) da participante sobre as atividades da participada. Se uma empresa é capaz de exercer a referida influência dominante sobre outra, seja pela participação majoritária em seu capital, seja por outros mecanismos jurídicos ${ }^{212}$, elas se encontram, respectivamente, em situação de "domínio e de dependência" (abhängige und herrschende Unternehmen, § 17, subparágrafo 1). Este parece ser o conceito mais próximo da definição de controle nos termos da legislação brasileira $^{213}$.

Um dos aspectos mais idiossincráticos do direito alemão é sabidamente o amplo direito de cogestão (Mitbestimmung), que permite aos trabalhadores a nomeação de significativo número de representantes para o conselho de supervisão das companhias. Tal prerrogativa é regulada em três principais diplomas: (i) a lei da cogestão nas companhias atuantes nos setores da siderurgia e mineração (MontanMitbestG), (ii) a lei geral de cogestão (Mitbest $G$ ) e a (iii) lei da cogestão relativa à participação de um terço no conselho

211 Definida como a titularidade da (i) maior parte do capital social ou (ii) maioria dos direitos de voto nas deliberações de uma determinada sociedade. Não são computadas no cálculo de tais participações as quotas ou ações pertencentes à própria sociedade participada ( $§ 16$, subparágrafo 2 , parte 3 ). Por outro lado, existe um critério de apuração de participações indiretas, tratando-se as ações, as quotas ou direitos de voto pertencentes a sociedades em regime de dependência (o que denota uma certa recursividade ou circularidade na definição) ou detidas por terceiros em nome e por conta da empresa participante como se fossem propriedade desta última ( $§ 16$, subparágrafo 3 ).

212 Mas, como se discute a seguir, a despeito da fórmula relativamente aberta adotada pela lei alemã, houve uma significativa restrição jurisprudencial quanto à admissibilidade do controle externo como vínculo caracterizador do grupo de sociedade.

213 "Presume-se que uma sociedade na qual outra possua uma participação majoritária seja dependente da acionista majoritária. Essa definição corresponde em termos gerais à definição de controle de outros sistemas legais". Tradução livre de: "A company in which another owns a majority share is presumed to be dependent on the majority shareholder. This definition corresponds roughly to the definitions of control in other legal systems." in U. IMMENGA, The Law of Groups in the Federal Republic of Germany, p. 107. F. COMPARATO, C. SALOMÃO FILHO, O Poder de Controle na Sociedade Anônima, p. 81. 
de supervisão $(\text { DrittelbG })^{214}$. Enquanto esta última assegura, como já indicado pela sua própria denominação, a nomeação de um terço dos membros do conselho de supervisão, as duas outras normas permitem a representação paritária dos trabalhadores no referido órgão colegiado. Esse peso relevante dos trabalhadores no conselho de supervisão poderia ensejar dúvidas a respeito do exercício do controle efetivo de um sócio sobre as decisões da sociedade e, portanto, da possibilidade de caracterização da influência dominante nos termos do $\S 17$. Entretanto, a influência dos trabalhadores é limitada somente às matérias de competência do conselho de supervisão e, em várias hipóteses, existem disposições que asseguram a prevalência da posição dos representantes dos sócios em tal órgão, o que torna o efetivo poder dos trabalhadores apenas quase (e não totalmente) paritário ${ }^{215}$. A cogestão, portanto, não descaracteriza, por si só, a influência política do acionista dominante, cuja presença é necessária para a configuração do grupo.

Caso uma empresa em posição de domínio associe à sua influência dominante sobre uma ou mais empresas dependentes também a "direção unitária" de suas atividades (einheitlichen Leitung) ${ }^{216}$ estará, então, formado um "grupo" (Konzern) e todas as empresas em questão serão consideradas "empresas de grupo" (Konzernunternehmen, §18, subparágrafo 1). Presume-se que entre empresas em posição de domínio e dependência exista também a relação de grupo (§ 18, subparágrafo 1, parte final).

Nesse sentido, apenas como exemplo, caso a sociedade $X$ detenha mais da metade do capital social da sociedade $Y$, satisfazendo os requisitos do $\S 16$, subparágrafo 1 , existirá

214 A MontanMitbest $G$ se aplica a empresas constituídas sob a forma de sociedades por ações ou sociedade de responsabilidade limitada que atuem nos setores da mineração, do ferro e do aço e tenham mais de 1.000 empregados. A MitbestG é aplicável a sociedades por ações que não estejam sujeitas à MontanMitbest $G$ e tenham mais de 2.000 empregados. Estão, enfim, sujeitas à DrittelbG as sociedades por ações com mais de 500 e menos de 2.000 empregados. B. GRUNEWALD, Gesellschaftsrecht, p. 256-257.

215 V. EMMERICH, M. HABERSACK, Konzernrecht, p. 40. B. GRUNEWALD, Gesellschaftsrecht, p. 257. A respeito da relação entre cogestão e direito dos grupos, é oportuno mencionar também o $\S 32$ da lei geral de cogestão (Mitbest $G$ ) que assegura que, em certos casos, a deliberação do conselho de supervisão para o exercício, pela sociedade, das prerrogativas de sócia em outras sociedades controladas seja tomada apenas pelos representantes nomeados pelos sócios, conforme: V. EMMERICH, M. HABERSACK, Konzernrecht, p. 73.

216 Com a devida vênia, parcialmente circulares e tautológicas e, portanto, pouco esclarecedoras, as considerações de Immenga a esse respeito: "Há controvérsia a respeito do que precisamente constitui a direção unitária. O critério decisivo é se existem indicações de fato de que as companhias em questão são tratadas como um negócio unificado e, portanto, estão sujeitas a direção externa ou a decisões de sujeitos externos". Tradução livre de: "There is controversy on what precisely constitutes unified direction. The decisive criterion is that there are de facto indications that the companies concerned are treated as a unified business and are thus subject to external direction or the decisions of outsiders" in U. IMMENGA, The Law of Groups in the Federal Republic of Germany, p. 97. 
a presunção de que, como verdadeiros círculos concêntricos, (i) a sociedade $X$ domina a sociedade $Y$ e esta é dependente daquela, (ii) $X$ dirige de forma unitária as atividades de $Y$ e, enfim, (iii) $X$ e $Y$ são membros de um Konzern.

Em termos práticos, porém, os cenários podem ser menos lineares e mais complexos do que o descrito acima. Torna-se inteiramente irrelevante a verificação da existência de relações de participação majoritária nas hipóteses - discutidas mais detalhadamente a seguir - em que as empresas em questão (i) sejam signatárias de acordo de domínio - vale dizer, de convenção de grupo de subordinação (Beherrschungsvertrag, $\S$ 291) - ou (ii) uma delas seja objeto de operação de "integração" (Eingliederung, § 319) promovida pela outra. Em tais casos, por força de presunção absoluta, entende-se que a sociedade controlada está sujeita à direção unitária da respectiva empresa controladora e, portanto, ambas são integrantes de um mesmo grupo.

De forma similar, mas com efeitos práticos diametralmente contrários, a presunção de relação de domínio-dependência em caso de participação majoritária, estabelecida pelo $\S 17$, subparágrafo 2 , é simples e pode ser elidida pela demonstração da existência de circunstâncias especiais que impeçam a empresa acionista majoritária de nomear a maioria dos representantes do conselho de supervisão da sociedade participada. Trata-se de cenário raro, mas que pode, de qualquer forma, se concretizar inter alia na presença de (i) quóruns qualificados de deliberação, (ii) limitações estatutárias ao exercício do direito de voto $^{217}$ ou ainda por meio da (iii) celebração de acordos de exclusão do poder de domínio (Abhängigkeitsauschlussvertrag ou Entherrschungsvertrag) ${ }^{218}$.

Os acordos de exclusão de domínio encerram uma renúncia parcial ou limitação voluntária do exercício do direito de voto por parte do acionista majoritário. Para serem válidos, devem ser celebrados com terceiros independentes, consócios da sociedade participada. Mais recentemente, admite-se também a eventual estipulação do acordo com a própria sociedade participada. Como requisitos adicionais de validade, o contrato de exclusão de domínio deve (i) impedir a influência significativa do sócio majoritário na composição do conselho de supervisão, (ii) ter um prazo mínimo de cinco anos, (iii) ser passível de rescisão antecipada apenas em face de justa causa, (iv) excluir tantos votos do

217 V. EMMERICH, M. HABERSACK, Konzernrecht, p. 50-51.

218 P. HOMMELHOFF, Die Konzernleitungspflicht, p. 80-81. V. EMMERICH, M. HABERSACK, Konzernrecht, p. 51-52. 
acionista majoritário quantos sejam necessários para assegurar que ele detenha menos da metade dos votos válidos nas assembleias gerais, de acordo com os índices médios de presença dos demais acionistas e, enfim, (v) forma escrita e disciplina detalhada dos pontos relacionados anteriormente ${ }^{219}$.

É importante também mencionar que, na aferição da existência de relação de dependência, não se admite o controle puramente externo ou contratual. A influência exercida sobre determinada sociedade deve ser, necessariamente, intermediada pelo direito societário para que possa caracterizar a relação de domínio, conforme definida pelo $\S 17$ da lei acionária de $1965^{220}$. Contratos de financiamento, fornecimento, licença ou franquia que implicam grande influência de uma parte sobre a outra - podem fortalecer o domínio exercido a partir da titularidade de posição minoritária no capital social, mas não são meios idôneos per se para fundar relação de influência significativa e, portanto, caracterizar a formação de um Konzern ${ }^{221}$.

Situação mais delicada é aquela na qual a relação de controle (Abhängigkeit) já está plenamente configurada, mas busca-se, não obstante, demonstrar que tal influência dominante não se traduz em direção unitária dos negócios da sociedade dependente (ou seja, afirma-se que não está presente a einheitliche Leitung). Hommelhof afirma que esse pode ser um dos efeitos do contrato de limitação do domínio ${ }^{222}$. Porém, como bem ressaltam Emmerich e Habersack, trata-se de demonstração extremamente complexa e dificilmente alcançável na prática ${ }^{223}$.

219 V. EMMERICH, M. HABERSACK, Konzernrecht, p. 52.

220 "Assim, o controle substantivo no sentido legal existe apenas se o controle econômico é reforçado por uma posição influente como acionista da sociedade". Tradução livre de: "Accordingly substantive control in the legal sense exists only if the economic control is reinforced by an influential position as shareholder of the company." in K. HOPT, Legal Elements and Policy Decisions in Regulating Groups of Companies, p. 93.

221 "Uma influência dominante nos termos do $\$ 17$ da lei acionária deve ser determinada ou, quanto menos, intermediada por direitos de sócio. Uma dependência econômica puramente baseada em relaçães comerciais, por exemplo, em contrato de crédito, não basta neste caso. Através dela, pode-se simplesmente fortalecer uma influência societária interna, transformando-a em influência dominante". Tradução livre de: "Ein beherrschender Einfluß im Sinne von $\$ 17 \mathrm{AktG}$ muß gesellschaftsrechtlich bedingt oder zumindest vermittelt sein. Eine durch Austauschbeziehungen, zum Beispiel einen Kreditvertrag, begründete rein wirtschaftliche Abhängigkeit reicht hierfür nicht aus. Durch sie kann sich lediglich ein ohnehin schon bestehender gesellschaftsinterner Einflu $\beta$ zu einem beherrschenden Einflu $\beta$ verstärken." conforme ementa oficial da decisão do Tribunal de Justiça Federal da Alemanha, II Câmara Civil, de 26 de março de 1984 (BGHZ 90, S. 381).

222 P. HOMMELHOFF, Die Konzernleitungspflicht, p. 80.

223 "A presunção da existência da relação de grupo pode ser elidida quando se demonstra que a sociedade controlada, de fato, dispõe livremente de seus recursos. Quanto à dificuldade de uma prova dessa natureza, não se deve ter nenhuma ilusão. A experiência confirma que, em termos práticos, o 
Como já acenado, nas hipóteses de celebração de acordo de domínio (Beherrschungsvertrag) ou de realização de operação de integração (Eingliederung), sequer há espaço para discussão da configuração ou não de direção unitária. Nestes casos, por definição, está presente a direção unitária e a caracterização da relação de grupo é inafastável.

Por outro lado, estando presente o requisito da administração unitária, resta de todo modo configurado o grupo societário, ainda que entre as respectivas sociedades não existam vínculos de subordinação ( $§ 18$, subparágrafo 2). Este cenário específico administração unitária sem sujeição a vínculo de dependência domínio - caracteriza o grupo horizontal ou grupo de coordenação (Gleichordnungskonzern ou Koordinierungskonzern $)^{224}$, equivalente mutatis mutandis ao consórcio de sociedades do direito brasileiro, previsto pelos artigos 278 e 279 da Lei 6.404/1976.

Como se vê, a complexa articulação das presunções e conceitos fixados pela lei alemã permite iterações a partir da presença ou ausência dos vários requisitos previstos para a caracterização de cada categoria de vínculo entre empresas, o que enseja exercício assemelhado à operação matemática de análise combinatória. Em face da complexidade desse sistema, parecem mais do que justas e razoáveis as críticas a ele levantadas pelo Professor Comparato ${ }^{225}$.

\subsubsection{A Operação de Integração (Eingliederung)}

Regulada pelos $\S \S 319$ a 327, a operação de Eingliederung representa um conceito criado ex novo pela lei de $1965^{226}$ e guarda similaridades com os institutos da incorporação de ações e da subsidiária integral do direito brasileiro. Trata-se de uma das formas mais

afastamento da presunção da existência da relação de grupo é raramente buscado e, ainda mais raramente, coroado de sucesso". Tradução livre de: "Die Konzervermutung ist widerlegt, wenn nachgewiesen werden kann, das die abhängige Gesellschaft tatsächlich frei über ihre Mittel verfügen kann. Über die Schwierigkeiten solchen Beweise dar man sich keine Illusionen hingeben. Dies wird durch die Erfahrung bestätigt, dass in der Praxis eine Widerlegung der Konzervermutung nur selten versucht wird und noch seltener gelingt." in V. EMMERICH, M. HABERSACK, Konzernrecht, p. 63.

224 P. HOMMELHOFF, Die Konzernleitungspflicht, p. 388.

225 "Na verdade, tais disposições, pela sua falta de clareza e simplicidade, figuram entre as menos felizes da Lei Acionária alemã de 1965, como reconhecem os próprios juristas germânicos." in F. COMPARATO, Os Grupos Societários na Nova Lei de Sociedades por Ações, p. 94. Ainda: “A crítica mais grave que se possa fazer a esse sistema [direito dos grupos na lei acionária alemã de 1965] é a da rigidez da tipologia legal. O legislador cedeu, aí, à natural propensão dos germânicos pelo formalismo lógico ou arquitetura de conceitos" in F. COMPARATO, Consórcios de Empresas, p. 7.

226 V. EMMERICH, M. HABERSACK, Konzernrecht, p. 6. 
estreitas de vinculação entre duas sociedades, provavelmente a que mais se aproxima da efetiva incorporação de um ente pelo outro. Não é por outra razão que a doutrina alemã se refere à estrutura resultante desta forma de reorganização societária como uma divisão empresarial personificada ${ }^{227}$.

A Eingliederung pode ter lugar apenas entre duas sociedades por ações com sede no território alemão. Além disso, é requisito essencial para a operação que a sociedade controladora (neste caso, denominada "Hauptgesellschaft" ou "sociedade principal") detenha (i) a totalidade das ações da sociedade controlada (hipótese em que se aplica o $\S 319$ ) ou (ii) ao menos 95\% do seu capital social (operação disciplinada pelo § 320).

Nesta segunda hipótese, consoante o $§ 320 \mathrm{~b}$, cabe aos minoritários da sociedade a ser integrada trocar as próprias ações pelo número de ações da sociedade principal a que teriam direito em caso de incorporação efetiva daquela por esta. Caso a sociedade principal seja, em si mesma, uma sociedade controlada, os acionistas externos da sociedade a ser integrada terão a opção de receber uma indenização em dinheiro, baseada no valor da empresa na data em que a sociedade principal aprovou a operação de integração. Tal indenização não exclui, contudo, a pretensão ao ressarcimento de danos ulteriores.

O aperfeiçoamento da operação de integração autoriza a sociedade controladora a emitir instruções juridicamente vinculantes aos administradores da sociedade integrada (tal como se existisse contrato de domínio entre as duas partes, consoante o $§ 308$, subparágrafo 2), restando, outrossim, expressamente afastada a aplicação tanto das regras sobre vedação da subordinação de interesses quanto daquelas relativas à obrigatoriedade de ressarcimento das respectivas perdas.

Em contrapartida, e esta é claramente uma outra diferença crucial em relação a institutos análogos do direito brasileiro - as já citadas incorporação de ações e subsidiária integral -, a sociedade controladora responde solidariamente (na qualidade de Gesamtschuldner) pelas obrigações da sociedade a ela integrada que sejam decorrentes de

227 "A integração se assemelha à fusão, porém, as sociedades integradas mantêm a sua autonomia". Tradução livre de: "Die Eingliederung ähnelt bereits der Verschmelzung, jedoch behält die eingegliederte Gesellschaft ihre rechtliche Selbständigkeit" in K. SCHMIDT, Gesellschaftsrecht, p. 947. "É possivel, portanto, descrever a sociedade integrada como uma efetiva divisão de negócios juridicamente autônoma". Tradução livre de: "Man kann deshalb die eingegliederte Gesellschaft geradezu als rechtlich selbständige Betriebsabteilung bezeichnen." in V. EMMERICH, M. HABERSACK, Konzernrecht, p. 148. 
fatos ou eventos posteriores à concretização da operação de integração (§ 322).

\subsubsection{Contratos de Empresa (Unternehmensvertäge) e Grupos de Direito}

Estabelecendo percurso que seria posteriormente seguido pelo legislador brasileiro, em 1976, e pelo ordenamento societário português, dez anos mais tarde ${ }^{228}$, a lei acionária alemã cria nítida distinção entre os grupos de fato e os grupos de direito.

Diversamente do que prevê a norma brasileira, o legislador germânico não se limitou a especificar de modo amplo o conteúdo possível e típico das convenções de grupo - vale dizer, a possibilidade de subordinação de interesse, a criação dos órgãos de administração grupal e a representação conjunta das sociedades agrupadas -, mas fixou nos $\S \S 291$ e 292 da lei de 1965 uma taxonomia relativamente rígida dos tipos de acordos de empresa (Unternehmensverträge) ${ }^{229}$ que podem ser firmados pelas sociedades por ações ou em comandita por ações: (i) acordo de domínio (Beherrschungsvertag), (ii) acordo de transferência ou atribuição de lucros (Gewinnabführungsvertrag), (iii) acordo de compartilhamento de lucros (Gewinngemeinschaft), (iv) acordo de atribuição parcial de lucros (Teilgewinnabführungsvertrag) e (v) acordo de arrendamento ou de cessão temporária de estabelecimento/empresa (Betriebspachtvertrag e Betriebsüberlassungsvertrag).

Importante observar que a lista dos acordos de empresa não representa um rol numerus clausus de possíveis avenças intragrupo nem significa evidentemente uma vedação implícita a outras formas de relacionamento contratual entre empresa controladora e sociedade controlada, até mesmo porque, se assim fosse, não se explicaria a existência de diversas regras relativas à responsabilidade da primeira por perdas apuradas pela segunda no âmbito do grupo de fato ${ }^{230}$.

O que o legislador alemão parece ter buscado foi simplesmente sujeitar a estipulação de algumas formas particulares de cooperação intragrupo a especial regime de aprovação e transparência. Com efeito, esses contratos específicos - pelo seu caráter

228 Decreto-Lei ${ }^{\circ} 262 / 1986$, de 2 setembro, artigo $493^{\circ}$.

229 "Contratos de empresa não são contratos ordinários sujeitos ao direito das obrigações, mas são contratos de organização regidos pelo direito societário". Tradução livre de: "[...] company association contracts are not ordinary contracts falling under the law of obligations, but organization contracts falling under company law." in U. IMMENGA, The Law of Groups in the Federal Republic of Germany, p. 100.

230 H. WIEDEMANN, Die Unternehmensgruppe im Privatrecht, p. 47. 
invasivo e por representarem efetiva alteração do objeto da sociedade controlada dificilmente poderiam ser validamente celebrados e acomodados no seio do direito das obrigações sem expresso amparo de norma especial.

O acordo de domínio tem por objeto a sujeição de uma sociedade à direção (Leitung) de outra empresa. Ele apenas pode ser estipulado entre sociedades unidas por vínculo de dependência - caso contrário, tratar-se-ia efetivamente de fenômeno diverso, nomeadamente, de grupo de mera coordenação, ou Gleichordnungskonzern. Dentre os diversos contratos de empresa, este é o único que, per se, enseja a presunção - neste caso, considera-se presunção jure et de jure - de existência de um grupo (Konzern), nos termos do $\S 18$, subparágrafo 1 , da lei acionária alemã $\tilde{2}^{231}$.

Os contratos de atribuição de lucros e atribuição parcial de lucros têm por objeto a transferência, pela sociedade por ações ou em comandita por ações, dos lucros que apurar, em benefício da respectiva contraparte contratual. Conforme já ressaltado pelas respectivas denominações, a diferença entre ambas as espécies contratuais diz respeito a uma questão de amplitude e grau. Na primeira, por definição, todos os lucros da sociedade são transferidos para terceiro, enquanto que nesta última a canalização externa dos resultados diz respeito apenas aos lucros auferidos por um determinado estabelecimento (Betrieb) ou a uma certa fração dos seus ganhos totais.

Em relação ao acordo de atribuição de lucros, existe uma verdadeira troca do risco (e do prêmio pelo risco) assumido pelo acionista, que em lugar dos lucros reais e efetivos apurados pela sociedade da qual participa, terá apenas os ganhos resultantes da aplicação do mecanismo de compensação de perdas, previsto no $\S 304$ e discutido mais adiante.

A seu turno, o acordo de compartilhamento dos lucros tem como escopo a alocação dos resultados das diversas partes em fundo comum, comunhão ou pool (justamente uma Gewinngemeinschaft) para posterior repartição. Também nesta hipótese é possível vislumbrar uma troca de riscos: cada uma das partes troca o risco individual de suas atividades pelo risco médio de todas as empresas que integram a avença de partilha dos lucros.

Enfim, o arrendamento de estabelecimento (Betriebspachtvertrag) representa

231 V. EMMERICH, M. HABERSACK, Konzernrecht, p. 54. 
forma especial do gênero contrato de locação, regulado pelos $\S \S 581-581$ do Código Civil alemão. $\mathrm{O}$ contrato de cessão temporária de estabelecimento (Betriebsüberlassungsvertrag) implica a condução das atividades empresariais relativas a uma dada unidade produtiva pelo cessionário em nome do cedente - baseado na outorga de poderes de representação -, mas por conta e risco do próprio cessionário. Nestes casos, o lucro é substituído por um aluguel contratualmente estabelecido entre as partes.

Todos os mencionados contratos estão sujeitos a formalidades especiais, como condição essencial para a validade de sua celebração e para sua eficácia. Nos termos do $\S 293$, é necessária, com efeito, a prévia aprovação da assembleia geral, por meio do voto afirmativo dos titulares de ao menos três quartos do capital social votante ${ }^{232}$ e desde que o estatuto não estabeleça quórum de deliberação superior. Os mesmos critérios se aplicam ao aditamento do contrato. Cabe ademais à Diretoria da sociedade arquivar no Registro do Comércio declaração a respeito da assinatura do contrato, da sua espécie, bem como da identidade das respectivas contrapartes (§ 294 e, quanto à rescisão do acordo, § 298).

Além dos requisitos incidentes sobre a formação do vínculo contratual, a lei alemã estabeleceu instrumentos especiais para a defesa dos interesses de acionistas externos e credores ao longo da vigência dos acordos de empresa. As regras gerais sobre manutenção das reservas mínimas legais ( $§ 150)$ são, neste caso, substituídas pelas disposições do $\S 300$. Estas preveem diversos ajustes que asseguram que, por exemplo, a atribuição de lucros a uma contraparte contratual do acordo de empresa não impeça a amortização de perdas acumuladas nos exercícios anteriores e, portanto, não cause uma recomposição mais lenta das reservas mínimas. No mesmo sentido, o $§ 301$ fixa o limite máximo dos lucros

232 Ulrich Immenga defende a realização de conclave separado entre acionistas minoritários para a aprovação do contrato de empresa - essencialmente, um impedimento de voto para a empresa controladora -, uma vez que, em sua opinião, a aprovação pela assembleia geral seria no mais das vezes inócua, a despeito do elevado quórum qualificado previsto pela lei: “A experiência demonstra, contudo, que a empresa dominante apenas conclui um contato de domínio se ela já detiver a maioria necessária de três quartos dos votos na assembleia geral. Assim, a companhia controladora decide sozinha se e em que condições o contrato será celebrado". Tradução livre de: "Experience has shown, however, that the dominant company usually concludes a control contract only if it already holds the necessary majority of three-quarters of the votes at the general meeting. Thus, the dominant company alone decides whether and on what conditions a contract will be concluded." in U. IMMENGA, The Law of Groups in the Federal Republic of Germany, p. 100. É de se imaginar, porém, que o já baixo número de grupos de direito criados na Alemanha seria ainda menor se fosse estabelecida tal exigência de aprovação em conclave separado. Além disso, uma participação correspondente a 75\% do capital social é certamente muito relevante, não estando muito distante do quinhão de $95 \%$ que autorizaria a empresa controladora a promover a integração (Eingliederung) da sociedade controlada e o consequente squeeze-out dos minoritários. 
que podem ser anualmente retirados da sociedade.

A estipulação e a vigência de um contrato de empresa desencadeiam também obrigações específicas de informação e fiscalização. A diretoria da sociedade que seja parte de um acordo de empresa deve preparar um relatório detalhado ( $§ 293 b$ ) sobre as disposições do contrato celebrado, sobre as dificuldades que este pode ensejar para o ente societário e seus acionistas e, em particular, sobre a espécie e a magnitude dos mecanismos de compensação de perdas a serem estabelecidos em respeito ao disposto no $\S 304$. O relatório em questão deve ainda indicar os critérios propostos para exercício do direito de retirada, nos termos do $\S 305$, com minuciosa justificação econômica.

Os acordos de domínio e de atribuição total de lucros são vistos como particularmente críticos pelo legislador alemão, em função do alto risco de prejuízo para credores e acionistas externos e, por isso, em complementação aos mecanismos de proteção mencionados acima, estão ainda sujeitos a regras especiais de: (i) absorção de perdas anuais (§ 302), (ii) equalização de ganhos (§ 304) e (iii) forma particular de exercício de direito de retirada por parte dos acionistas externos (Abfindungsrecht, prevista pelo $\S 305)$.

O detalhado regramento da reparação das perdas causadas às sociedades controladas, em função de sua sujeição à política comum das empresas agrupadas, é um dos aspectos mais marcantes da disciplina do grupo de direito alemão e é a principal razão para explicar a construção da figura jurisprudencial de grupo de fato qualificado, discutida mais adiante.

Nos termos do $\S 302$, subparágrafo 1, a contraparte do acordo de domínio ou de atribuição de lucros deve arcar com todas as perdas sofridas pela companhia (ou sociedade em comandita por ações) durante a vigência do respectivo contrato, que não sejam compensadas pelos montantes transferidos para as reservas de lucro da própria sociedade durante o período em questão ${ }^{233}$.

233 Conforme ressalta Bloß, o dispositivo em questão pode ser aplicado também aos grupos formados apenas por sociedades de responsabilidade limitada:"A disciplina do $\S 302$ da lei acionária é expressão do principio geral de acordo com o qual quem quer que possa determinar o destino da sociedade e obter todos os seus ganhos também responderá por suas perdas, encontrando assim correspondente aplicação para os grupos de direito formados por sociedades de responsabilidade limitada". Tradução livre de: "Die Regelung des $\$ 302$ AktG ist Ausdruck des allgemeinen Prinzips, daß derjenige, der die Geschicke der Gesellschaft bestimmen kann oder ihnen ganzen Gewinn erhält, auch für die Verluste 
Reconhecendo o fato de que os efeitos da integração profunda entre as atividades de controladora e controlada, com a sujeição perene e estável desta às políticas e instruções daquela, são incompatíveis com um dever de indenização pontual e una tantum, o $§ 304$ fixa como conteúdo obrigatório do acordo de domínio e do acordo de atribuição de lucros o pagamento anual de uma adequada compensação.

O valor mínimo de tal compensação - que no caso do acordo de domínio tem a forma de uma partilha de lucros - deve corresponder ao montante de dividendos que, com base na performance passada da sociedade controlada, teriam sido razoavelmente distribuídos aos seus acionistas, considerando os efeitos de depreciação contábil e reservas de depreciação ( $§ 304$, subparágrafo 2). Trata-se, evidentemente, de uma operação contrafatual, ou seja, que tem por referência um cenário hipotético de projeção de resultados passados e que, portanto, é em grande medida complexa e subjetiva. A compensação apenas pode ser dispensada caso a sociedade controlada seja uma subsidiária integral, desprovida de acionistas externos, no momento da celebração do contrato de empresa.

De forma similar ao que ocorre na operação de Eingliederung, o legislador alemão também se valeu da estratégia de retirada, assegurando aos acionistas externos descontentes a possibilidade de transferir onerosamente suas ações à empresa controladora, nos termos fixados no respectivo acordo de domínio ou de atribuição de lucros $(\S 305$, subparágrafo 1). A contrapartida em função de tal transferência de ações depende do status da empresa controladora. Caso a controladora seja uma sociedade por ações ou em comandita por ações com sede no território da União Europeia ${ }^{234}$ e não esteja sujeita ao controle de outras empresas - em outras palavras, desde que a empresa controladora não esteja, ela própria, sujeita a vínculo de dependência nos termos do $\S 17$, subparágrafo 1 - o pagamento será feito com ações da própria controladora. Na hipótese em que a controladora preencha todos os requisitos anteriores, mas seja controlada por uma outra sociedade, a qual por sua vez satisfaça as referidas exigências ${ }^{235}$, o pagamento pela

einzustehen hat und findet daher entsprechende Anwendung in GmbH-Vertragskonzern." in H. BLOSS, Die Unternehmensgruppe im englischen und deutschen Recht der Kapitalgesellschaften, p. 26.

$234 \mathrm{Ou}$ ainda os países que não são membros da União Europeia, mas integram o Espaço Econômico Europeu; atualmente: Islândia, Noruega e Liechtenstein.

235 Ter sede no território da União Europeia ou de outro país que integre o Espaço Econômico Europeu e, ainda, ser constituída sob o tipo societário de sociedade por ações ou em comandita por ações. 
participação do acionista externo na controlada poderá ser feito em: (i) em ações da controladora imediata, (ii) ações da controladora indireta ou (iii) dinheiro. Em todas as demais hipóteses, o pagamento deverá ser realizado exclusivamente em dinheiro.

Havendo permuta de ações da controlada, devem ser aplicados os mesmos critérios que seriam utilizados em caso de incorporação daquela pela sociedade controladora. Possíveis frações resultantes da aplicação da respectiva relação de troca de ações podem ser liquidadas em dinheiro. Toma-se como referência temporal para a apuração do valor de mercado da sociedade controlada a data de celebração do respectivo acordo de empresa. Os valores a serem pagos em dinheiro estão sujeitos a juros a partir da data em que o acordo de empresa se torna eficaz. Uma eventual disputa entre os acionistas externos e a empresa controladora, se limitada ao valor da indenização a ser paga, não justifica a anulação da assembleia que aprovar a celebração do acordo de empresa em questão (§ 305, subparágrafo 5).

Dentre todos os contratos de empresa, o único que tem o condão de efetivamente fundar um grupo de direito é o acordo de domínio, cuja celebração enseja a aplicação de regras especiais sobre a coordenação das atividades da sociedade controlada e subordinação de seus interesses, previstas nos $\S \S 308$ a 311 da lei acionária.

O $\S 308$, subparágrafo 1 , autoriza expressamente o empresário controlador amparado por acordo de empresa dessa natureza a emitir instruções aos administradores da sociedade controlada, inclusive as que eventualmente sejam prejudiciais a tal companhia, desde que (i) sejam úteis ao próprio controlador ou às sociedades filiadas e (ii) não violem as disposições do respectivo acordo de domínio ${ }^{236}$.

A diretoria da sociedade controlada está obrigada a seguir tais instruções. Mesmo que o respectivo estatuto social exija uma aprovação prévia do conselho de supervisão para a prática do ato solicitado e caso tal permissão não seja tempestivamente concedida, a diretoria deverá implementar a instrução recebida na hipótese em que, após relatar a situação ao empresário controlador, este reitere as suas ordens. Ou seja, nos termos do $\S 308$, subparágrafo 3, o acordo de domínio pode até mesmo prevalecer sobre, e derrogar, o

236 Ou seja, a regra geral parece ser a da subordinação completa de interesses, que será restringida apenas na exata medida em que o acordo de domínio assim previr expressamente. 
estatuto social da companhia controlada ${ }^{237}$.

Aos administradores da empresa controladora (ou ao titular da empresa individual, se for o caso) subscritora do acordo de domínio é imposto, nos termos do $\S 309$, dever de atuar de forma diligente e cuidadosa ao emitir instruções vinculantes para a sociedade controlada. Na hipótese de violação de tal dever, respondem pelas perdas causadas à sociedade controlada. Além disso, pesa contra tais administradores o ônus de provar que sua conduta foi correta ( $§ 309$, subparágrafo 2, parte final).

A respectiva ação de ressarcimento pode ser movida pela própria sociedade ou na forma ut singuli pelos acionistas externos, hipótese na qual eventual indenização verterá exclusivamente em benefício da controlada. Ao contrário da lei brasileira (Lei 6.404/1976, artigo 246), a norma alemã não estipulou neste caso nenhum prêmio ou benefício específico para os minoritários que tomam a iniciativa de promover a ação de responsabilidade.

O credor social da companhia dominada também é legitimado a promover ação contra os administradores da empresa controladora que agem abusivamente, mas apenas na medida em que a própria controlada não seja capaz de ressarcir as suas perdas.

É peculiar e questionável o fato de que a lei acionária alemã discipline, neste caso, ação de responsabilidade direcionada contra os administradores da empresa controladora e não contra a própria controladora - como corretamente fez a lei brasileira nos termos do artigo 246 -, seja porque o núcleo real do poder está nas mãos da empresa controladora, seja porque esta, normalmente, possui capacidade econômica (e, portanto, possibilidade de recomposição das perdas sofridas por acionistas externos e credores) muito superior àquela do administrador pessoa física.

De acordo com Wiedemann, o $\S 283$ do anteprojeto de lei que resultou na AktG 1965 previa, justamente, a responsabilidade expressa da contraparte do acordo de domínio, ou seja, da própria empresa controladora. Tal disposição foi, contudo, suprimida do texto ao longo do processo legislativo, sendo substituída pela responsabilização dos administradores. Tal decisão foi tomada sob o argumento de que a empresa controladora já

237 Parece evidente que este dispositivo da legislação alemã serviu de inspiração para o artigo 273 da Lei 6.404/1976. A norma brasileira, porém, foi mais razoável e cautelosa, ressalvando o dever de respeito a disposições do estatuto ou contrato social. 
responde por abusos perante a sociedade controlada nos termos das regras gerais de direito, de forma que uma disposição específica não seria necessária ${ }^{238}$. Eventual demanda de ressarcimento contra a empresa controladora deverá, portanto, estar calcada na violação direta do acordo de domínio ou, com base no $§ 276$ do Código Civil alemão, pelo dolo ou omissão no desempenho de sua função de empresa dominante, nos termos de tal contrato $^{239}$.

Os administradores da sociedade controlada, incluindo tanto os membros da diretoria quanto do conselho de supervisão, responderão solidariamente com os administradores da controladora - e estarão igualmente sujeitos a inversão do ônus da prova - caso também tenham violado os próprios deveres ( $\$ 310)$.

Apesar de sua articulada disciplina - e, provavelmente, ao menos em parte, exatamente em função dela - o grupo de direito é um instrumento que não vingou na realidade alemã. Foram poucos os grupos que formalizaram a relação de subordinação de interesses das respectivas sociedades controladas ${ }^{240}$ e, aparentemente, no mais das vezes a decisão de fazê-lo foi motivada por considerações de natureza tributária e não pela necessidade de conciliar os interesses de credores e acionistas minoritários com as exigências práticas da empresa plurissocietária ${ }^{241}$.

\subsubsection{Grupo de Fato}

Os $\S \S 311$ a 318 da lei acionária de 1965 tratam do exercício do poder de controle nas companhias que não são firmatárias de acordo de domínio. É oportuno ressaltar que o vínculo crítico e determinante tomado como base para a disciplina do grupo de fato não é a

238 H. WIEDEMANN, Gesellschaftsrecht, Band I, p. 351-352.

239 Wiedemann entende não ser aplicável in casu a responsabilidade da pessoa jurídica pelos atos de seus órgãos de administração, consoante o $§ 31$ do Código Civil alemão, porque esta exigiria um pressuposto fático autônomo de responsabilidade do ente social. H. WIEDEMANN, Gesellschaftsrecht, Band I, p. 352 .

240 "Foi estimado que, entre 1970 e 1980, foram celebrados contratos de empresa (i.e. acordos de domínio e acordos para a atribuição de lucros) em relação a 130 companhias. [...], resta claro que a grande maioria das sociedades controladoras escolheu 'união estável sem certificado de matrimônio"”. Tradução livre de: "It has been estimated that between 1970 and 1980 enterprise contracts (i.e. control agreements or agreements to transfer profits) were concluded in respect of 130 corporations. [...], it is clear that the great majority of parent companies have chosen 'cohabitation without marriage certificates'." in K. HOPT, Legal Elements and Policy Decisions in Regulating Groups of Companies, p. 95. H. WIEDEMANN, Die Unternehmensgruppe im Privatrecht, p. 7.

241 U. IMMENGA, The Law of Groups in the Federal Republic of Germany, p. 100. V. EMMERICH, M. HABERSACK, Konzernrecht, p. 186. H. WIEDEMANN, The German Experience with the Law of Affiliated Enterprises, p. 28-29. 
caracterização do Konzern em sua acepção stricto sensu (§ 18), a qual é relevante sobretudo para fins contábeis, mas sim a relação de domínio e dependência prevista no $\S 17^{242}$.

O $\S 311$ - que tem como claro equivalente no direito brasileiro o artigo 245 da Lei 6.404/1976 - determina que, na ausência de acordo de domínio, a empresa controladora não deve utilizar a sua influência para fazer com a que a controlada tome medidas que lhe sejam prejudiciais, a menos que as respectivas perdas sejam devidamente compensadas ${ }^{243}$. Tanto nos casos de integração, quanto nas hipóteses de formação de grupo de direito, discutidos anteriormente, existe uma forte limitação, para não se falar em verdadeira supressão, da autoridade da diretoria da sociedade controlada, o que torna justo e razoável um proporcional redimensionamento de sua responsabilidade. No grupo de fato, isto não ocorre e o poder-dever dos administradores consignado no $\S 76$, subparágrafo 1 resta, teoricamente, intacto.

Na concepção original da lei acionária alemã, o grupo de fato seria compatível apenas com formas mais tênues e pontuais de exercício da influência da empresa controladora sobre a sociedade controlada, com menor integração das atividades de $\operatorname{ambas}^{244}$.

242 Confirmando, portanto, que: "Conceito central do direito acionário dos grupos não é, como se tenderia talvez a acreditar à primeira vista, o grupo [Konzern] (conforme $\$ 18$ da lei acionária), mas sim - por modo de dizer, um nível antes - a dependência [controle] (enquanto grupo potencial, conforme o $\$ 12$, subparágrafo 2 da lei acionária)". Tradução livre de: "Zentralbegriff des Aktienkonzernrechts ist nicht etwa, wie man auf den Ersten Blick vielleicht anzunehmen geneigt ist, der Konzern (s. § $18 \mathrm{AktG}$ ), sondern - gleichsam eine Stufe früher - die Abhängigkeit (als potenzieller Konzern, s. \& 17 Abs. 2 $A k t G)$." in (negrito no original) in V. EMMERICH, M. HABERSACK, Konzernrecht, p. 39.

243 E o mecanismo em questão parece compartilhar a relativa inefetividade da norma análoga brasileira: "Como se poderia esperar, a rígida abordagem alemã ensejou poucos grupos de sociedades que praticam a indenização espontânea. Na prática, as sociedades controladoras de sociedades de grupos de capital fechado ignoram as exigências de indenização, que apenas são rigorosamente aplicadas quando os credores de sociedades limitadas $(\mathrm{GmbH})$ insolventes buscam recuperar ativos faltantes de seus sócios controladores. No caso de sociedades por ações (AG), não há essencialmente jurisprudência a respeito de indenização, o que sugere ser pouco provável que as disposições alemãs tenham sido eficazes". Tradução livre de: "As one might expect, Germany's rigid approach produces few selfindemnifying corporate groups. In practice, the parent companies of closely held German groups often ignore the indemnification requirements, which are rigorously enforced only when the creditors of insolvent closely held firms (GmbH) seek to recover missing assets from controlling shareholders. In the case of public companies $(A G)$ there is virtually no case law on indemnification, which suggests that the German provisions are unlikely to have been effective." in G. HERTIG, H. KANDA, Related Party Transactions, p. 125.

244 "O grupo de direito é permitido, o grupo de fato é tolerado". Tradução livre de: "Der Vertragskonzern ist erlaubt, der faktischen Konzern geduldet." in H. WIEDEMANN, Die Unternehmensgruppe im Privatrecht, p. 46. "A exigência essencial é sempre que qualquer prejuizo causado por operações ou medidas adotadas seja passível, em primeiro lugar, de quantificação e que, em seguida, possa ser 
Por outro lado, seria exagerado vislumbrar no $§ 311$ uma efetiva vedação de toda e qualquer forma de subordinação dos interesses da controlada, pois - como no direito brasileiro - existe a expressa previsão da possibilidade de compensação das perdas. Nesse sentido, havendo adequada compensação, não existirá ilícito, o que é estruturalmente diferente - inclusive para fins de aferição dos deveres fiduciários de administradores e controladores - da hipótese de ressarcimento de um dano ilícito.

O dever de compensação dos prejuízos é fixado de forma bem mais detalhada do que no direito brasileiro, com a previsão de que os termos e condições do pagamento ressarcitório devem ser estabelecidos no próprio exercício social em que forem verificadas as respectivas perdas ( $\$ 311$, parágrafo único).

Tal como ocorreu posteriormente no sistema brasileiro, o legislador reconhece a ilegitimidade da subordinação de interesses no grupo de fato - o que, em princípio, tonaria de rigor a sua administração de acordo com critérios paretianos -, mas busca, por meio da compensação das perdas, deixar aberta a porta para operações que tragam ganhos totais de eficiência, ainda que ensejem prejuízos tópicos para algumas das sociedades controladas ${ }^{245}$.

Os $\S \S 312$ a 315 regulam o dever de prestação de informações relativas à "economia interna" do grupo de fato. Cumpre à diretoria da sociedade controlada preparar um relatório, nos primeiros três meses de cada exercício social, especificando (i) todos os negócios jurídicos celebrados no exercício anterior entre, de um lado, a própria sociedade controlada e, de outro, a empresa controladora ou outras empresas a ela vinculadas e (ii) todas as medidas que a sociedade controlada tomou, ou deixou de tomar, em função de instruções recebidas da empresa controladora ou em nome dos interesses desta última.

Enquanto que o cumprimento da exigência de listagem dos contratos celebrados na esfera interna é, ao menos teoricamente, passível de aferição objetiva -, o segundo requisito é muito mais complexo. Com efeito, tendo em vista a maneira completamente informal por meio da qual o poder de controle pode se projetar ao longo das sociedades agrupadas, a eficácia das instruções da empresa controladora não está sujeita a qualquer

compensado. Nestas bases, apenas um agrupamento relativamente frouxo é possível". Tradução livre:

"The essential requirement is always that any detriment caused by transactions or by measures adopted must be capable first of being quantified and then of being compensated. On this basis only a relatively loose grouping is possible." in U. IMMENGA, The Law of Groups in the Federal Republic of Germany, p. 109.

$245 \mathrm{O}$ que denota a busca pela eficiência em termos de Kaldor-Hicks, conforme se discutiu no tópico 4.2.5. 
formalização ou suporte documental. Uma vez que o próprio administrador da controlada responsável pela elaboração do relatório está sujeito à influência da empresa controladora, é natural que ele busque justificar cada uma de suas ações, ou omissões, com base em motivações comerciais aparentemente legítimas, evitando referências expressas a instruções ou comandos recebidos. Buscando contrabalancear essa tendência, o § 318, subparágrafo 1, determina que os membros da administração (tanto da diretoria quanto do conselho de supervisão) serão corresponsáveis - sujeitos inclusive a inversão do ônus da prova - pelas perdas sofridas pela sociedade controlada que não tenham sido mencionadas no relatório. Existe, portanto, uma conexão direta entre cumprimento do dever de informação e responsabilidade do administrador.

O referido relatório deve ser submetido ao conselho de supervisão da sociedade controlada, ao qual cabe eventualmente levantar objeções sobre os negócios mantidos com as sociedades integrantes do grupo e incluir as suas observações no próprio relatório anual endereçado aos acionistas. Caso a sociedade controlada esteja sujeita a auditoria obrigatória, o relatório da diretoria sobre as operações intragrupo também será submetido à análise dos auditores externos (§ 313).

Apesar de, por si só, não ter o efeito legitimador da subordinação de interesses que é próprio do acordo de domínio - e, portanto, não converter plenamente o grupo de fato em grupo de direito -, a celebração de um acordo de atribuição de lucros entre a empresa controladora e a sociedade controlada torna, por força do disposto no $\S 316$, desnecessária a prestação das informações e a realização de auditoria, nos termos dos $\S \S 312$ a 315 .

Qualquer acionista pode solicitar a revisão das relações entre a sociedade controlada e a empresa controladora por parte de um perito judicial nas hipóteses em que (§ 315): (i) os auditores externos tenham se recusado a exprimir parecer sobre o relatório da diretoria relativo às operações intragrupo ou o tenham feito com ressalvas, (ii) o conselho de supervisão tenha exprimido objeções quanto a tal relatório da diretoria e/ou (iii) a própria diretoria indique que a sociedade controlada sofreu prejuízos em razão de determinados negócios ou operações.

Enfim, o $§ 317$ e o já acenado $§ 318$ tratam, respectivamente, da responsabilidade (i) da empresa controladora e seus representantes legais e (ii) dos administradores da 
sociedade controlada. A empresa controladora responde perante a sociedade controlada pelas perdas decorrentes dos negócios que a induzir a celebrar e das medidas que a fizer tomar, ou deixar de tomar. Os danos pessoais e diretos causados aos acionistas externos também estão sujeitos a reparação. Exclui-se a responsabilidade da empresa controladora na hipótese em que se conclua que mesmo um administrador independente, diligente e leal teria incorrido na conduta incriminada. Por fim, os administradores da empresa controladora que tomaram parte no ato lesivo respondem solidariamente pelas perdas que se verificarem.

\subsubsection{Grupo de Fato Qualificado}

O conceito de grupo de fato qualificado (qualifizierter faktisch Konzern), que nasceu no âmbito de discussões relativas à reforma do regime das sociedades de responsabilidade limitada, no início dos anos de $1970^{246}$, diz respeito a situações em que o domínio da empresa controladora sobre as atividades da sociedade controlada - exercido sem qualquer amparo em contratos de empresa - é particularmente amplo e profundo. Nos termos da paradigmática decisão do Tribunal de Justiça Federal da Alemanha no caso "Autokran", mencionado anteriormente, o grupo de fato qualificado se contradistingue pela influência abrangente (umfassend), além de contínua e duradoura (dauernd), exercida sobre as atividades da controlada por parte da empresa controladora, em contexto em que esta última não é capaz de demonstrar que um administrador independente teria agido do mesmo modo ${ }^{247}$.

Consoante levantamento doutrinário promovido por Hoffmann-Becking, pode-se chegar uma definição de grupo de fato qualificado sob três perspectivas distintas: (i) pela natureza dos seus efeitos sobre a controlada, (ii) pela forma de organização da empresa que resulta do exercício de tal influência e (iii) pela possibilidade, ou não, de se controlar ou remediar as suas consequências. De acordo com tais critérios, o grupo de fato qualificado se caracteriza, respectivamente, (i) pelo prejuízo reiterado e permanente aos interesses da controlada, (ii) pela gestão da sociedade controlada de forma análoga a uma divisão interna (Betriebsabteilung) da empresa controladora e (iii) pela ineficácia, em termos práticos, do

246 V. EMMERICH, M. HABERSACK, Konzernrecht, p. 455.

247 Decisão do Tribunal de Justiça Federal da Alemanha II Câmara Civil, de 16 de setembro de 1985 (BGHZ 122, S. 123). 
mecanismo de ressarcimento de perdas constante do $§ 311$ da lei acionária alemã ${ }^{248}$.

É justamente este último aspecto que é enfatizado na análise do tema realizada por Herbert Wiedemann ${ }^{249}$. No grupo de fato qualificado, a influência negativa da empresa controladora sobre as atividades da sociedade controlada é tão ampla, profunda, contínua e permanente que a eficácia dos mecanismos de proteção previstos na lei acionária para os grupos de fato "normais" - notadamente o mecanismo de responsabilidade por prejuízos previsto no $\S 311$ - resta comprometida.

Cumpre recordar que o $\S 311$, em contraste com a lei brasileira, impõe limites temporais claros ao dever de ressarcimento da empresa controladora no grupo de fato. A compensação deve ocorrer no curso do próprio exercício social em que se verificou o prejuízo aos interesses da controlada ou, alternativamente, durante tal período devem ao menos ser fixados os termos e condições para o pagamento ressarcitório. A própria referência a exercício social já tem em si, implícita, a ideia de possibilidade de reiteração dos referidos pagamentos.

A inadequação do sistema de responsabilização previsto no $\S 311$ relativamente às hipóteses de profunda subordinação de interesses - a qual justificou a formulação do conceito de grupo de fato qualificado - não está, portanto, puramente no aspecto temporal ou em uma suposta qualidade una tantum do ressarcimento, mas sim no atrelamento do direito à indenização a medidas e instruções, individuais e específicas da empresa controladora $^{250}$. Em cenário em que as ordens prejudiciais advindas da empresa

248 M. HOFFMANN-BECKING, Der qualifizierte faktische AG-Konzern - Tatbestand und Abwehransprüche, p. 73.

249 "Configura-se um agrupamento qualificado de empresas, quando o interesse próprio de uma sociedade controlada é continuamente prejudicado como resultado do exercício da influência - ampla em termos de matérias afetadas e duradoura no aspecto temporal - do empresário dominante. Em um grupo de empresas de tal gênero, dirigido de forma centralizada, a compensação das perdas prevista no § 311 da lei acionária torna-se impraticável, porque, após anos e anos, não é mais possível reconstruir qual seria a situação da sociedade livre da estrutura de grupo". Tradução livre de: "Ein qualifizierter Unternehmensverbund liegt vor, wenn das Eigeninteresse der abhängigen Gesellschaft infolge eines von dem herrschenden Unternehmen - sachlich umfassend und zeitlich andauernd - ausgeübten Einflusses nachhaltig beeinträchtigt wird. In einer solchen zentral gesteuerten Unternehmensgruppe wird der $\S 311$ Akt G vorgesehene Nachteilsausgleich undurchführbar, weil die abhängige Gesellschaft nach Jahr und Tag als konzernfrei nicht mehr rekonstruiert werden kann." in H. WIEDEMANN, Die Unternehmensgruppe im Privatrecht, p. 46.

250 "Em outras palavras: um mecanismo de compensação de perdas que vincula pretensões ressarcitórias a instruções ou medidas individuais do empresário controlador não tem mais como funcionar em um agrupamento de empresas plenamente estabelecido". Tradução livre de: "Anders ausgedrückt: ein Ausgleichsmechanismus, der an einzelne Weisungen oder Maßnahmen des herrschenden Unternehmens Schadenersatzansprüche anknüpft, kann in einem durchgeführten Unternehmensverbund nicht mehr 
controladora deixam de ser a exceção para se converter em perene regra, não tem sentido esperar que os administradores da controlada possam listar todas as instruções prejudiciais emanadas pela empresa controladora, como prevê o $§ 312$. Justamente porque se trata de situação em que o domínio é abrangente e profundo, buscar remédio para o conflito de interesse em tal regra significaria, em princípio, pretender que todos os mais minuciosos aspectos da vida da companhia fossem declinados em tal relatório dos administradores; medida irrazoável e inaplicável.

A principal consequência da plena caracterização do grupo de fato qualificado, como se verificou no caso Autokran, é a aplicação analógica da regra constante do $\S 302$ da lei acionária alemã - que, em princípio, estaria circunscrita aos grupos de direito - de acordo com a qual a empresa controladora deve assumir as perdas gerais sofridas pela controlada, conforme apuradas em balanço, e não simplesmente indenizar os danos individuais que comprovadamente causar ${ }^{251}$.

Sempre por meio de aplicação analógica do regime dos grupos de direito, outros potenciais desdobramentos do reconhecimento da relação de grupo de fato qualificado são a possibilidade de se exigir ressarcimento de danos, consoante o $\S 304$, e de exercício de direito de retirada (Abfindung), nos termos do $\S 305^{252}$.

\subsubsection{Conclusão Preliminar}

O sistema jurídico alemão certamente encerra em seu direito positivo, em sua doutrina e em sua jurisprudência a mais rica, avançada e articulada tentativa de que se tem registro de regulação específica do fenômeno dos grupos de empresa no âmbito do Direito Privado. Contudo, o legislador alemão de 1965 parecer ter incorrido no pecado perfeitamente perdoável à luz do vanguardismo da norma - de buscar fazer com que a infinita diversidade da realidade da atividade empresarial se adequasse aos seus rígidos parâmetros conceituais, e não o contrário. O direito alemão dos grupos parece ser, com efeito, desnecessária e exageradamente complexo.

A modesta difusão dos grupos de direito - cavalo de batalha da disciplina

funktionieren." in H. WIEDEMANN, Die Unternehmensgruppe im Privatrecht, p. 47. No mesmo sentido: V. EMMERICH, M. HABERSACK, Konzernrecht, p. 457 e 461.

251 V. EMMERICH, M. HABERSACK, Konzernrecht, p. 462-463.

252 V. EMMERICH, M. HABERSACK, Konzernrecht, p. 464. 
construída em 1965 - é o principal indício do grave insucesso do modelo adotado, ao menos à luz de suas ambições originais. Reforça essa conclusão, o fato que, ao contrário de todas as expectativas iniciais, o modelo alemão não ter sido seguido nem ao nível da Comunidade (e, posteriormente União) Europeia nem, individualmente, pelas outras principais nações industrializadas daquele continente ${ }^{253}$.

De qualquer forma, seria exagero dizer que do edifício construído pelo legislador alemão restaram apenas ruínas. Diversos instrumentos extremamente válidos podem ser colhidos em tal esforço de regulação dos grupos, tal como, por exemplo, o Abfindungsrecht, que contrariamente ao direito de recesso cria uma via de saída da sociedade que não necessariamente representa seu esvaziamento patrimonial. Além disso, não se pode deixar de observar que, por meio da doutrina dos grupos de fato qualificados ${ }^{254}$, muitos dos mecanismos concebidos para a tutela da minoria social e dos credores nos grupos de direito acabaram encontrando um novo percurso de aplicação prática, menos formal e mais flexível, pragmático e aderente à realidade da organização da empresa plurissocietária do que por meio da assinatura de contratos de empresa.

\subsection{Direito Italiano}

O núcleo central da disciplina italiana do direito societário dos grupos é bastante recente, sendo formado pelos artigos 2.497 a 2.497-septies do Código Civil daquele país, resultado da reforma introduzida pelo artigo $5^{\circ}$ do Decreto Legislativo de 17 de janeiro de $2003, \mathrm{n}^{\circ} 6$, que entrou em vigor em $1^{\circ}$ de janeiro de 2004 .

Esses sete artigos tratam, respectivamente, (i) da responsabilidade pelo exercício incorreto da atividade de direção e coordenação de sociedades, (ii) do dever de publicidade, (iii) do dever de motivação específica de decisões, (iv) do direito de recesso,

253 Conforme apontado no subcapítulo 2.4.

254 “A batalha jurídica defensiva não é mais conduzida contra o grupo de fato, nem por meio da busca pela caracterização de sua ilegalidade, nem tampouco por meio de sua migração forçada para o grupo convencional, motivada por ponderações de responsabilização. Ao contrário, o grupo de fato efetivamente se afirmou sobre o grupo convencional em todos os campos. Atualmente, apenas o grupo de fato qualificado - vale dizer, um grupo de fato extremamente centralizado - está na mira". Tradução livre de: "Die juristische Abwehrschlacht wird nicht mehr gegen den faktischen Konzern geschlagen, sei es über dessen Illegalisierung, sei es über seine haftungsrechtlich motivierte Abdrängung in den Vertragskonzern. Vielmehr hat sich faktisch der faktisch Konzern gegenüber dem Vertragskonzern auf ganzer Linie durchgesetzt. Heute ist nur noch der qualifizierte Konzern, also ein extrem zentralisierter faktischer Konzern, in Visier." in G. TEUBNER, Die „Politik des Gesetzes" im Recht der Konzernhaftung - Plädoyer für einen sektoralen Konzernduchgriff, p. 268. 
(v) dos financiamentos intragrupo, (vi) da presunção de existência de direção e coordenação e (vii) da atividade de coordenação sem participação de controle, por meio de acordos ou disposições estatutárias.

Decididamente, os mais importantes são os dois primeiros, nos quais estão articulados os principais conceitos de uma disciplina que representa um sistema híbrido entre o dualismo alemão - grupos de fato e grupos de direito - e a simples ausência de normas que tratem especificamente dos grupos como tal; característica comum à maioria dos ordenamentos nacionais.

\subsubsection{Atividade de Direção e Coordenação e Interesse Empresarial}

Aspecto notável da nova disciplina italiana dos grupos é a ausência de definição expressa do próprio conceito de grupo $^{255}$. Em estratégia legislativa que guarda similaridades com o regramento do grupo de fato no direito brasileiro, nos termos do artigo 245 da Lei 6.404/1976, o conceito de grupo no direito italiano deve ser dessumido a partir da definição de um ilícito civil, qual seja: o exercício da atividade de direção e coordenação de sociedade, impelido por interesse empresarial próprio ou de outrem, em violação dos princípios de correta gestão societária e empresarial (artigo 2.497, $\S 1^{\circ}$, do Código Civil italiano $)^{256}$.

No plano subjetivo, diversamente do sistema brasileiro, que reserva papel central à "sociedade controladora", ou da lei acionária alemã, que coloca em primeiro plano a “Unternehmen" (empresa), o Código Civil italiano faz menção a "sociedades ou entes" (società o enti) que agem "no interesse empresarial próprio ou de terceiros" (interesse imprenditoriale proprio o altrui $)^{257}$.

255 De acordo com Galgano, a omissão é intencional, uma vez que sublinha a natureza do grupo como fenômeno fatual, que não é criado pelo direito, mas que por ele é apenas descoberto. F. GALGANO, Direzione e Coordinamento di Società - Art. 2497-2497 septies, p. 4. "Mais especificamente, em tal contexto normativo: [...] não é nunca utilizada a expressão 'grupo', nem se fornece uma definição explícita de tal fenômeno". Tradução livre de: "Più in particolare, in tale contesto normativo:[...] non è mai utilizzata l'espressione 'gruppo', né si fornisce una esplicita definizione di tale fenomeno, [...]" U. TOMBARI, Diritto dei Gruppi di Imprese, p. 5-6.

256 G. SCONAMIGLIO, Danno Sociale e Azione Individuale nella Disciplina della Responsabilità da Direzione e Coordinamento, p. 948.

257 Interessante e oportuna a observação de Valzer no sentido de que, sob uma perspectiva clássica e conservadora, anterior à reforma de 2003, o simples agir do sócio controlador impelido por um interesse externo, empresarial ou não, já poderia ser considerado, em si mesmo, violação do princípio de correta gestão. A. VALZER, Il Potere di Direzione e Coordinamento di Società tra Fatto e Contratto, p. 851. 
Também na Itália, portanto, a exemplo do sistema alemão, o legislador houve por bem excluir do campo de sujeição aos mais intensos deveres derivados da relação de grupo o acionista preponderante que não é titular, direta ou indiretamente, de outros interesses empresariais e externos à companhia. Também, neste caso, consequentemente, encontra-se subjacente à opção legislativa adotada uma prévia valoração a respeito da suposta maior criticidade, para os sócios externos e credores, do conflito entre interesses empresariais em relação ao conflito de interesses em geral.

A principal consequência é que apenas estarão submetidos aos comandos e à responsabilidade previstos no artigo 2.497 os sujeitos que possam ser, direta ou indiretamente, titulares ou portadores (em nome e em lugar de terceiros) de interesses em determinada atividade empresarial externa à sociedade. Titulares de um interesse próprio serão as capogruppo ou holdings de vértice (controladoras finais), enquanto que as portadoras de interesses de terceiros serão, em geral, as holdings intermediárias, que exercem simultaneamente os papéis de participantes e participadas na estrutura do grupo ${ }^{258}$.

Galgano não exclui sequer a possibilidade de que se revistam de tal condição de holding de vértice os acionistas pessoas naturais. Será sempre necessário, porém, averiguar - tal como ocorre na praxe alemã para fins de qualificação de uma pessoa física como Unternehmen - se a participação é detida com o mero propósito de gestão de um portfólio pessoal de ações ou se, ao revés, o controle societário é o mecanismo por meio do qual se exerce a atividade de controle e direção motivada por um interesse empresarial. Um indício relevante para fixar a distinção seria, de acordo com o saudoso estudioso, a existência de uma estrutura de escritórios e empregados dedicados a tal atividade ${ }^{259}$.

258 F. GALGANO, Direzione e Coordinamento di Società - Art. 2497-2497 septies, p. 58.

259 "Quando, na posição de controle em relação a uma ou mais sociedades se encontre uma pessoa fisica, coloca-se o problema de verificar se esta não seja nada além de um acionista que administra o próprio portfólio ou então um sujeito que desenvolve, por intermédio do controle acionário, uma verdadeira e própria função empresarial de direção e coordenação do grupo, que seja portanto impelido por um 'interesse empresarial' [...] A responsabilidade da holding pessoa fisica não é, portanto, excluída". Tradução livre de: "Ove, in posizione di controllo rispetto a una o più società si trovi una persona fisica, si pone il problema di accertare se questa sia null'altro che un azionista che gestisca il proprio portafoglio azionario oppure un soggetto che svolge, per il tramite del controllo azionario, la vera e propria funzione imprenditoriale di direzione e coordinamento del gruppo, che sia mosso cioè da un 'interesse imprenditoriale', [...] La responsabilità della holding persona fisica non è però esclusa." (sem grifo no original) in F. GALGANO, Direzione e Coordinamento di Società - Art. 2497-2497 septies, p. 59. Em sentido contrário: "[...] a responsabilidade pelo mau exercício da atividade de direção e coordenação foi limitada aos sujeitos distintos das pessoas físicas". Tradução livre: "[...] la responsabilità per il cattivo esercizio dell'attività di direzione e coordinamento è stata limitata ai soggetti diversi dalle persone fisiche." in F. ABATE, A. DIMUNDO, L. LAMBERTINI, L. PANZANI, 
Aplicando a mesma lógica a outros sujeitos de direito, Galgano entende que fundações e associações, bem como entes da administração pública local, também podem assumir a qualidade de exercentes da função de coordenação e direção de sociedades, consoante o artigo 2.497, $\S 1^{\circ}$, desde que desenvolvam, direta ou indiretamente, atividades econômicas que tenham por escopo financiar ou realizar os seus próprios fins não lucrativos $^{260}$. O ilustre estudioso se recusa, porém, a atribuir tal condição de empresarialidade ao próprio Estado, uma vez que este último seria - por definição sempre impelido por um interesse último político e não empresarial ${ }^{261}$.

Quanto ao vínculo político existente entre ente dominante e sociedade dominada, em lugar de se referir ao conceito de controle, a lei italiana é baseada na relativamente vaga noção de "direção e coordenação" (direzione e coordinamento) de sociedades ${ }^{262}$, definitivamente mais próxima da concepção de direção unitária (Einheitliche Leitung) do direito alemão. A noção de controle societário ingressa na equação apenas por via indireta, em função da presunção, fixada no artigo 2.497 sexies - e se trata expressamente de presunção simples -, de existência da atividade de direção e coordenação quando preenchidos os requisitos do artigo 2.359, o qual define, por sua vez, os conceitos de

A. PATTI, Gruppi, Trasformazione, Fusione, Scissione, Scioglimento e Liquidazione, Società Estere (artt. 2484-2510), p. 244. No mesmo sentido, Marco Ventoruzzo assevera que: "[...] a regra se aplica apenas quando o acionista controlador é, ele próprio, uma sociedade ou pessoa jurídica, não quando é um indivíduo" (tradução livre de: "[...] the rule applies only when the controlling shareholder is itself a corporation or a legal entity, not when it is an individual"), mas corretamente ressalva (nota de rodapé $\mathrm{n}^{\circ}$ 127) que a pessoa física pode ser responsabilizada nos termos do artigo 2.497, $\S 2^{\circ}$. M. VENTORUZZO, Experiments in Comparative Law: The Recent Italian Reform and the Dubious Virtues of a Market for Rules in the Absence of Effective Regulatory Competition, p. 199.

260 "Este conceito de objetiva 'economicidade' é, portanto, o critério ao qual se deve recorrer para se decidir quando um particular - seja ele um indivíduo, uma associação ou uma fundação - assume, em razão da atividade econômica exercida, a qualidade de empreendedor e, esteja, portanto sujeito a todas as consequências que o ordenamento jurídico vincula à assunção de tal qualidade". Tradução livre de: "Questo concetto di 'obiettiva economicità' è, dunque, il criterio al quale dovrà farsi ricorso per decidere quando un privato - sia esso un singolo oppure una associazione o una fondazione - assuma, in ragione dell'attività economica esercitata, la qualità di imprenditore e sia, pertanto, assoggettabile a tutte le conseguenze che l'ordinamento giuridico ricollega a all'assunzione di tale qualità" in $\mathrm{F}$. GALGANO, Direzione e Coordinamento di Società - Art. 2497-2497 septies, p. 64.

261 F. GALGANO, Direzione e Coordinamento di Società - Art. 2497-2497 septies, p. 65.

262 "[...] as novas regras se aplicam apenas em caso de 'direção e coordenação' da companhia por uma sociedade controladora ou holding. O significado de tal expressão é consideravelmente elusivo". Tradução livre de: "[...] the new rules apply only in case of 'direction and coordination' of the corporation by a controlling or holding company. The meaning of this term is rather elusive." in M. VENTORUZZO, Experiments in Comparative Law: The Recent Italian Reform and the Dubious Virtues of a Market for Rules in the Absence of Effective Regulatory Competition, p. 199. 
sociedades controladas $^{263}$ e coligadas ${ }^{264}$.

A esse respeito, cumpre recordar que a direção unitária, pressuposto da caracterização do Konzern em sentido estrito, ocupa um papel relativamente secundário no direito alemão, pois nele a responsabilidade por abusos é desencadeada pelo mero controle ou, mais precisamente, pela qualidade de "herrschendes Unternehmen", consoante o § 311 da lei acionária alemã, que se apoia portanto no $\S 17$ do mesmo diploma, e não no $\S 18$, que trata da direção unitária ${ }^{265}$. O sistema italiano conferiu, portanto, maior peso ao elemento dinâmico da direção - com efeito, o artigo 2.497 do Código Civil italiano se refere expressamente a exercício e a atividade - em prejuízo do aspecto estático do poder de controle. Essa escolha parece impossibilitar a caracterização da direção e coordenação de sociedade como um poder-dever, restringindo enormemente o espaço para a imputação de responsabilidade por omissão ao acionista dominante ${ }^{266}$.

Se, por um lado, a natureza juris tantum da presunção constante do artigo 2.497 sexies permite, teoricamente, afastar a caracterização da relação de atividade e coordenação de sociedade ainda que diante da firme presença do controle societário, por outro, é possível vislumbrar cenários simetricamente reversos, em que restará configurado o exercício de tal atividade - e as responsabilidades que enseja - mesmo que não se demonstre a clara satisfação dos pressupostos fáticos para a configuração do controle, consoante o artigo 2.359, $\S 1^{\circ}$. É o caso, por exemplo, da hipótese de interlocking directorates. Essa potencial disjunção entre controle societário formal e atividade de

263 Consideram-se sociedades controladas no direito italiano aquelas nas quais, direta ou indiretamente, uma outra sociedade disponha (i) da maioria dos votos em assembleia, (ii) de votos suficientes para o exercício de uma influência dominante ou (iii) de influência dominante resultante de vínculos contratuais.

264 Definidas como aquelas nas quais uma sociedade detenha "notável influência" (influenza notevole), a qual pode ser presumida nos casos em que a sociedade participante detenha ao menos (i) um quinto dos votos ou (ii) um décimo do capital social da participada.

265 Conforme já citado no subcapítulo anterior. V. EMMERICH, M. HABERSACK, Konzernrecht, p. 39.

266 “[...] em essência, assume relevância não a mera possibilidade de exercer uma 'influência dominante' sobre uma ou mais sociedades ('controle societário'), mas o efetivo exercício de tal influência [...]". Tradução livre de: "[...] in sostanza, assume rilevanza non la mera possibilità di esercitare una 'influenza dominante' su una o più società ('controllo societario'), ma l'esercizio effettivo di tale influenza [...]" in U. TOMBARI, Diritto dei Gruppi di Imprese, p. 18. "A conduta do sujeito dominante é indicada como comissiva (age) e nem poderia ser diferente, se levarmos em consideração a natureza diretiva e, por assim dizer, intrusiva da atividade que ele desenvolve [...]". Tradução livre: "La condotta del soggetto dominante è indicata come commissiva (agisce), né avrebbe potuto essere diversamente, tenuto conto della natura direttiva e, se si vuole, intrusiva dell'attività da esso svolta [...]" in F. ABATE, A. DIMUNDO, L. LAMBERTINI, L. PANZANI, A. PATTI, Gruppi, Trasformazione, Fusione, Scissione, Scioglimento e Liquidazione, Società Estere (artt. 2484-2510), p. 250. 
direção e coordenação é resultado do fato de que, como salienta Tombari, para o direito italiano esta última é, ao contrário daquele, uma questão puramente de fato. Justamente porque inspirada em um princípio de efetividade, a configuração da direção e coordenação seria, na opinião do autor, completamente independente da natureza ou mesmo da própria licitude da fonte do exercício de tal poder ${ }^{267}$.

Confirmando tais conclusões, o artigo 2.497 septies complementa as previsões constantes do artigo 2.497 sexies ao determinar que, mesmo fora da esfera das presunções fixadas neste último dispositivo, poderá se configurar atividade de direção e coordenação com base em disposições contratuais ou estatutárias.

\subsubsection{Responsabilidade e Ação de Reparação}

É interessante notar que a lei italiana não faz menção às noções de favorecimento ou de subordinação de interesses como os fatores imediatamente determinantes do dever de indenização pelas perdas eventualmente causadas a credores e acionistas, mas sim ao conceito mais amplo (porém, também mais vago) de violação do princípio de correta gestão empresarial e societária.

Umberto Tombari identifica, por meio da interpretação a contrario sensu do dever de correta gestão estipulado no artigo $2.497, \S 1^{\circ}$, do Código Civil italiano, mais do que a mera intenção de tutela das minorias ou dos credores sociais (Schutzrecht), uma tentativa de se resguardar o espaço para a formação e organização dos grupos (Organisationsrecht $^{268}$. Com efeito, a disciplina introduzida pela reforma de 2003

267 “[...] é de se enfatizar, em primeiro lugar, que as disposições contidas nos artigos 2497 e seguintes do Código Civil são inspiradas em um 'princípio de efetividade', disciplinando um fato e, em particular, a atividade de direção e coordenação de sociedades, independentemente da fonte do poder (participação social, contrato, interlocking directorates, etc.), por meio do qual tal atividade é exercida e da valoração (legitimidade/ilegitimidade) do próprio fato. Desta perspectiva, não é relevante, portanto, o perfil estático do 'controle societário' (conforme artigo 2.359 do Código Civil), mas o perfil dinâmico [...]". Tradução livre de: “[...] è da sottolineare, in primo luogo, che disposizioni contenuti negli artt. 2497 ss., c.c., sono ispirate ad un 'principio di effettività', disciplinando un fatto e, più in particolare, l'attività di direzione e coordinamento di società, a prescindere dalla fonte del potere (partecipazione sociale, contratto, interlocking directorates, ecc.), in forza del quale tale attività viene esercitata e della valutazione (legittimità/illegittimità) del fatto medesimo. In questa prospettiva, non rileva, dunque, il profilo statico del 'controllo societario' (cfr. art. 2359, c.c.), ma il profilo dinamico [...]" in U. TOMBARI, Diritto dei Gruppi di Imprese, p. 18.

268 U. TOMBARI, Diritto dei Gruppi di Imprese, p. 35-36. Em sentido contrário, apesar de no resto do seu texto buscar compilar elementos organizativos do novo ordenamento italiano dos grupos, Valzer indica que a feição de proteção prevaleceria sobre aquela de Organisationsrecht: A. VALZER, Il Potere di Direzione e Coordinamento di Società tra Fatto e Contratto, p. 836-837. 
confirma a legitimidade da direção do grupo - ou seja, a imposição de políticas e práticas orientadas por estratégias comuns -, desde que obedecidos os princípios de correta gestão.

A confirmação da legitimidade da consideração de interesses externos à própria sociedade, na tomada de decisões e medidas pelos membros da administração, conduz logicamente à pontual derrogação parcial de preceitos gerais de responsabilidade, tal como as regras consignadas no artigo 2.391 do Código Civil italiano ${ }^{269}$, relativas à divulgação de interesses conflitantes com os da sociedade e ao dever de abstenção de voto do administrador.

Uma vez que, como já assinalado, é pouco claro o conteúdo do dever de correta gestão, as formas concretas de violação de tal obrigação serão tão variadas quanto a própria vagueza da norma. Fato indiscutível, porém, é que a sociedade sujeita a atividade de direção não pode ser administrada de forma a ser completamente privada da possibilidade de auferir lucros ${ }^{270}$.

Além de tal limite mínimo, cumpre notar, como salienta Galgano, que o dever de correta gestão é duplamente qualificado pela norma italiana, desdobrando-se em correção societária e empresarial ${ }^{271}$.

Como exemplos de má gestão societária, o célebre doutrinador cita a prática de induzir a sociedade controlada a adquirir participações em sociedades com objeto social de todo incompatível com as suas próprias atividades (violação do artigo 2.361 do Código Civil italiano) ou não tomar as medidas necessárias para recompor ou reduzir o capital social em casos de perdas apuradas ao final do exercício social (artigos 2.446 e 2.447).

A inadequada gestão empresarial, por outro lado, estará refletida nas próprias modalidades escolhidas para a consecução do objeto social, com a assunção de riscos exagerados e a tomada de decisões incompatíveis com os cânones de diligência e prudência ditados pelas boas práticas de administração. Nesta segunda ordem de questões

269 “O grupo deve poder funcionar e para que isso possa ocorrer é necessário em alguma medida derrogar a regra pela qual os administradores das sociedades do grupo devem perseguir o interesse da própria sociedade e apenas ele". Tradução livre de: "Il gruppo deve poter funzionare e perché ciò possa accadere è necessario in qualche misura derogare alla regola per quale gli amministratori delle società del gruppo devono perseguire l'interesse della propria società e solo quello." in R. PENNISI, La Disciplina delle Società soggette a Direzione Unitaria ed il Recesso nei Gruppi, p. 892-893.

270 U. TOMBARI, Diritto dei Gruppi di Imprese, p. 39.

271 F. GALGANO, Direzione e Coordinamento di Società - Art. 2497-2497 septies, p. 107. 
(violação da correta gestão empresarial), é importante considerar que (i) a má gestão não restará configurada apenas nas hipóteses de condutas específicas frontalmente contrárias à lei $i^{272}$ e (ii) a aferição do inadimplemento passará inevitavelmente por uma avaliação do mérito de decisões comerciais tomadas pelos administradores ${ }^{273}$.

A posição prevalente na doutrina italiana é a de que o dever de indenização, nas hipóteses ora sob análise, tenha a natureza de responsabilidade pelo fato ilícito - artigo 2.043 do Código Civil italiano -, decorrente do desrespeito ao dever legal de administrar corretamente a sociedade ${ }^{274}$. Há, porém, quem sustente se tratar de responsabilidade contratual, uma vez que resultante da violação de um poder-dever funcional ${ }^{275}$.

Nos termos textuais do artigo $2.497, \S 1^{\circ}$, são potenciais beneficiários do direito a indenização os sócios e os credores da sociedade controlada. No caso dos sócios, o fundamento da reparação e a medida do dano sofrido serão dados pela desvalorização e pela perda de rentabilidade da participação detida. Em relação aos credores, o critério é a lesão causada à integridade do patrimônio da sociedade.

É importante salientar que, no que diz respeito ao dano sofrido pelo credor, a pretensão ressarcitória contra o ente que exerce a atividade de direção e coordenação não se confunde com o crédito subjacente detido em face da sociedade controlada em função do contrato que com ela celebrou. Os pressupostos e a natureza jurídica dos débitos são distintos e a própria área de legitimação passiva é diversa ${ }^{276}$.

Ainda no que tange ao dano, é extremamente relevante a parte final do artigo 2.497, $\S 1^{\circ}$, na qual se determina que apenas existirá uma perda sujeita a ressarcimento caso a lesão não tenha sido neutralizada (i) por medidas compensatórias específicas ou

272 “[...] poderá ser considerada imprópria também a gestão que não se demonstre textualmente ilícita, mas ainda assim contrária a principios de sana gestão”. Tradução livre de: “[...] potrà considerarsi scorretta anche una gestione che non appaia testualmente illecita, bensì contraria a principi di sana gestione." in F. GALGANO, Direzione e Coordinamento di Società-Art. 2497-2497 septies, p. 106.

273 "A correção devida na gestão se estende, de fato, até compreender a 'razoabilidade' das escolhas de administração [...]". Tradução livre de: "La correttezza dovuta nella gestione si estende, infatti, fino a comprendere la 'ragionevolezza' delle scelte gestionali." in F. GALGANO, Direzione e Coordinamento di Società-Art. 2497-2497 septies, p. 107.

274 F. GALGANO, Direzione e Coordinamento di Società - Art. 2497-2497 septies, p. 96.

275 F. ABATE, A. DIMUNDO, L. LAMBERTINI, L. PANZANI, A. PATTI, Gruppi, Trasformazione, Fusione, Scissione, Scioglimento e Liquidazione, Società Estere (artt. 2484-2510), p. 247.

276 G. SCONAMIGLIO, Danno Sociale e Azione Individuale nella Disciplina della Responsabilità da Direzione e Coordinamento, p. 954. 
(ii) pelo resultado geral e total da respectiva atividade de direção e coordenação ${ }^{277}$. Neste ponto, parecem ecoar no direito italiano algumas das conclusões da doutrina Rozenblum, desenvolvida na França, a respeito da legitimidade de políticas que tenham por objeto o assim chamado interesse de grupo $^{278}$. De qualquer forma, a neutralização do dano pelos benefícios da política de grupo deve ser objetivamente demonstrada e medida, sem se limitar a referências genéricas a sinergias e vantagens decorrentes da relação grupal.

Questão digna de nota na nova disciplina italiana sobre os grupos é o fato de que a responsabilidade imputada ao ente que (mal) exerce a atividade de direção e coordenação de uma determinada sociedade é direta, não apenas em face dos credores sociais, mas sobretudo dos próprios sócios da companhia controlada. Por conseguinte, direta será também a ação de ressarcimento a ser promovida por ambos os grupos de destinatários da norma. Este segundo aspecto é particularmente importante, pois implica o exercício de ação em nome próprio (sem substituição processual) e para benefício pessoal e direto do sócio autor, em notável desvio em relação à tradicional ação social de responsabilidade ( $u t$ singuli), disciplinada nos artigos 2.393 e 2.393 bis do próprio Código Civil italiano.

Esta opção legislativa cria significativas vantagens e desvantagens. O principal benefício reside no fato de que a coincidência entre legitimidade ativa processual e titularidade da pretensão ressarcitória material cria mais incentivo à proposição de medidas judiciais, uma vez que o acionista não se vê na incômoda posição de incorrer em despesas pessoais, imediatas e prolongadas - para o custeio da ação - tendo como contrapartida ganhos eventuais, futuros e difusos, já que direcionados à própria companhia e compartilhados com todos demais consócios ${ }^{279-280}$.

277 G. SCONAMIGLIO, Danno Sociale e Azione Individuale nella Disciplina della Responsabilità da Direzione e Coordinamento, p. 953.

278 C. HANNOUN, Le Droit et les Groupes de Sociétés, p. 80. Conceito analisado criticamente no Capítulo 6.

279 M. VENTORUZZO, Experiments in Comparative Law: The Recent Italian Reform and the Dubious Virtues of a Market for Rules in the Absence of Effective Regulatory Competition, p. 196.

280 Por outro lado e com a devida vênia, pouco convincente o argumento declinado por Galgano no sentido de que a ação direta teria ainda a vantagem adicional, em relação à ação ut singuli, de ser imune a transação ou desistência por parte da própria sociedade, aprovada em assembleia orquestrada e capitaneada pelo próprio controlador (F. GALGANO, Direzione e Coordinamento di Società - Art. 2497-2497 septies, p. 107). Em um sistema que estabeleça efetiva possibilidade de substituição processual, é o autor que pleiteia interesse de terceiro em nome próprio e, como tal, fixa os rumos da respectiva ação. Além disso, em deliberação relativa a transação ou desistência de medida judicial tendo por objeto a responsabilidade do controlador, este último estaria, em princípio, impedido de votar, nos termos do artigo $2.373, \S 2^{\circ}$, do Código Civil italiano. 
Entretanto, as facetas positivas da ação direta são, neste caso, neutralizadas - e suas facetas negativas elevadas exponencialmente - pela regra constante do $\S 3^{\circ}$ do artigo 2.497, dispositivo que, compreensivelmente ensejou grande perplexidade na doutrina italiana. O referido parágrafo determina, com efeito, que o credor ou sócio lesados pelo ente que exerce a atividade de direção e coordenação apenas poderão mover ação contra este último caso os respectivos débitos não tenham sido satisfeitos pela própria sociedade. A norma parece estabelecer, assim, ao menos em primeira leitura, um princípio de subsidiariedade que implicaria tornar a vítima direta e imediata da má gestão, ou seja, a sociedade controlada, a responsável em primeira linha pelo ressarcimento ${ }^{281}$.

O legislador da reforma de 2003 parece ter, desconsiderado, outrossim, o fato de que o sócio que é ressarcido pela sociedade na qual tem interesse econômico não deixa de, parcial e proporcionalmente, indenizar indiretamente a si mesmo ${ }^{282}$.

Buscando contornar essas dificuldades e incoerências, a doutrina tentou distinguir os efeitos do $\S 3^{\circ}$ do artigo 2.497 em relação a credores e a sócios, argumentando que apenas haveria beneficium ordinis em relação aos primeiros ${ }^{283}$. Além disso, mesmo em tal hipótese, parece mais razoável concluir que a prévia excussão da sociedade controlada deverá ocorrer apenas em fase executiva; não se exige ação cognitiva preliminar contra esta última.

Tombari sugere ainda interpretação para o $\S 3^{\circ}$ do artigo 2.497 segundo a qual a norma seria simplesmente uma confirmação por parte do legislador, uma espécie de reiteração do conceito já esboçado na parte final do $\S 1^{\circ}$, a respeito do fato de que, uma vez sanado eventual dano diretamente pela própria sociedade controlada, possivelmente por meio de recursos aportados ou transferidos pelo ente que exerce atividade de direção e

281 G. SCONAMIGLIO, Danno Sociale e Azione Individuale nella Disciplina della Responsabilità da Direzione e Coordinamento, p. 955-956.

282 "[...] não se pode, efetivamente, não compartilhar a visão de que a atribuição do ressarcimento do dano a cargo da controlada obriga, de fato, o seu sócio 'externo' a sofrer a perda em medida proporcional ao montante da própria participação". Tradução livre de: "[...] non può infatti non condividersi il rilievo che l'aver posto il risarcimento del danno a carico della dominata costringe in fatto il suo socio 'esterno' a subirlo in parte proporzionale all'entità della propria partecipazione." in R. SANTAGATA, Autonomia Privata e Formazione dei Gruppi nelle Società di Capitali, nota de rodapé n 26, p. 811 . Oportuno recordar que, em função da dissociação entre, de um lado, participação majoritária e controle societário e, de outro, o exercício da atividade de direção e coordenação, conforme discutido acima, a participação do sócio externo na sociedade controlada pode, eventualmente, ser extremamente significativa em termos proporcionais.

283 G. SCONAMIGLIO, Danno Sociale e Azione Individuale nella Disciplina della Responsabilità da Direzione e Coordinamento, p. 954. U. TOMBARI, Diritto dei Gruppi di Imprese, p. 50. 
coordenação, não haveria mais uma perda indenizável a ser remediada por meio de ação contra este último ${ }^{284}$.

Cumpre notar que, mesmo que se adote o referido percurso hermenêutico "corretivo", restam graves distorções resultantes da ação direta e individual, atribuída pela norma em questão ao próprio sócio, mas tendo por objeto a reparação de dano que não sofreu direta e pessoalmente. Com efeito, caso o sócio obtenha do ente que exerce a atividade de direção e coordenação uma indenização pela desvalorização e perda de rentabilidade de sua participação, não parece razoável que a sociedade controlada possa, em seguida, pleitear reparação do mesmo sujeito passivo em função dos mesmos eventos lesivos subjacentes. Haveria, com efeito, nítido bis in idem.

Neste caso, porém, com o ressarcimento já vertido diretamente em favor do sócio e preclusa para sociedade a possibilidade de buscar, ela própria, indenização, haverá um efetivo esvaziamento patrimonial desta última - uma restituição indireta (triangular) de capital -, em prejuízo dos outros sócios e dos credores sociais, cuja garantia é também reduzida. Trata-se, claramente, de solução que não privilegia nem a integridade patrimonial da sociedade controlada, nem os interesses coletivos da totalidade dos sócios externos.

Como consolo, resta o fato de que o direito de ação estatuído no âmbito do artigo 2.497 do Código Civil italiano não afasta nem preclui - satisfeitos, naturalmente, os próprios e respectivos requisitos de direito material e processual - o recurso a outros instrumentos de tutela da posição dos sócios, tais como aqueles previstos nos artigos 2.393 (responsabilidade dos administradores em face da sociedade), 2.393bis (ação de reparação ut singuli), 2.394 (responsabilidade dos administradores em face dos credores sociais) e 2.395 (ação direta do sócio ou credor pelo dano direto) do mesmo diploma ${ }^{285}$.

Nos termos do artigo $2.497, \S 2^{\circ}$, respondem solidariamente pelas perdas sofridas por credores e sócios externos os sujeitos que, conscientemente, tenham participado dos respectivos atos lesivos e assim obtido ganhos pessoais. A referida responsabilidade é limitada ao benefício ilegitimamente auferido.

Considerando-se todos os elementos acima, o percurso para a obtenção de efetivo

284 U. TOMBARI, Diritto dei Gruppi di Imprese, p. 42-43.

285 U. TOMBARI, Diritto dei Gruppi di Imprese, p. 38 
ressarcimento, nos termos do artigo 2.497, parece decididamente tortuoso e sujeito a percalços. Além dos pressupostos gerais aplicáveis a qualquer causa que tenha por objeto uma pretensão de reparação (inter alia dano efetivo e nexo causal), ao credor ou sócio externo que se sintam prejudicados pela relação de grupo será necessário demonstrar, em juízo, que o réu (i) exercia a atividade de direção e coordenação da sociedade em questão ${ }^{286}$, (ii) agiu em violação aos (extremamente vagos) princípios de correta gestão empresarial e societária e (iii) o fez movido por um interesse de natureza empresarial estranho à própria sociedade. Ademais, conforme a interpretação que se atribua ao artigo 2.497 ter, deverão os autores atestar a incapacidade da sociedade controlada em reparar direta e pessoalmente o dano sofrido. Mesmo que sejam satisfeitos todos os pressupostos acima, o réu - que naturalmente tem acesso a informações muito mais detalhadas sobre as atividades da respectiva empresa societária - poderá ainda se esquivar do dever de reparação se puder demonstrar que os efeitos positivos - a partir de uma perspectiva geral e ampla - para a sociedade controlada resultantes da aplicação prática da política de grupo superaram o impacto negativo das lesões levantadas no respectivo processo judicial ${ }^{287}$.

\subsubsection{Deveres de Informação, Publicidade e Justificação}

A lei italiana não reproduziu a dicotomia entre grupos de fato e grupos de direito, inaugurada pelo direito alemão e replicada com nuances no Brasil e em Portugal $^{288}$, mas claramente nela colheu inspiração para a disciplina do dever de publicidade das sociedades que estejam sujeitas à atividade de direção e coordenação por parte de outrem.

286 Tal prova, evidentemente, não será necessária caso o exercício da atividade de direção e coordenação tenha sido formalmente declarado, nos termos do artigo $2.497 \mathrm{bis}$.

287 M. VENTORUZZO, Experiments in Comparative Law: The Recent Italian Reform and the Dubious Virtues of a Market for Rules in the Absence of Effective Regulatory Competition, p. 200.

288 "[...] a nova disciplina italiana do grupo de empresas se desenvolveu por meio de percurso tendencialmente diferente daquele adotado pelo principal modelo de regulamentação proveniente da experiência comparatística: a referência é, em particular, ao direito alemão dos grupos, codificado no direito acionário de 1965. Mais especificamente, o modelo alemão contido no direito acionário e fundado na distinção entre 'grupos de fato' e 'grupos contratuais' - ainda que tenha certamente representado um imprescindivel ponto de referência para o legislador - não foi, contudo, recepcionado em nosso ordenamento, no qual se escolheu uma via distinta para a regulamentação do fenômeno". Tradução livre de: "[...] la nuova disciplina italiana del gruppo di imprese si è mossa lungo binari tendenzialmente autonomi rispetto al principale modello di regolamentazione proveniente dall'esperienza comparatistica: il riferimento è, in particolare, al diritto tedesco dei gruppi, codificato nel diritto azionario del 1965. Più in particolare, il modello tedesco contenuto nel diritto azionario e fondato sulla distinzione tra 'gruppi di fatto' e 'gruppi contrattuali' - se certamente ha costituito un imprescindibile punto di riferimento per il legislatore - non è stato tuttavia recepito nel nostro ordinamento, ove è stata scelta una via diversa per la regolamentazione del fenomeno" in U. TOMBARI, Diritto dei Gruppi di Imprese, p. 7-8. 
$\mathrm{O} \S 1^{\circ}$ do artigo 2.497 bis determina que os administradores da sociedade devem indicar em seus atos e correspondências o ente a cuja atividade de direção e coordenação ela está sujeita. Além disso, a identificação do ente diretor deve também ser formalizada por meio de anotação própria no Registro das Empresas - em seção específica, criada nos termos do $\S 2^{\circ}$ deste mesmo artigo.

O cumprimento de tais formalidades não enseja, porém, a formação de grupo de direito. Com efeito, trata-se de dever legal autônomo que não altera o regime de responsabilidade da sociedade ou os deveres de seus administradores, nem tampouco amplia as prerrogativas de implementação de políticas comuns de grupo, asseguradas pela lei, ainda que a contrario sensu (artigo 2.497), ao ente que exerce a atividade de direção. Tal registro tem eficácia declaratória, não constitutiva.

O sentido da norma claramente é o de alertar potenciais investidores e credores a respeito do fato de que a sociedade está sujeita a decisões tomadas em função das necessidades do grupo ao qual pertence e não exclusivamente de seu próprio interesse ${ }^{289}$. Além disso, a divulgação da relação de domínio pode cientificar os sócios externos a respeito do início da relação de direção e coordenação, permitindo-lhes o exercício do direito de recesso, nos termos do artigo 2.497 quater, $\S 1^{\circ}$, alínea "c".

Na hipótese de inadimplemento do dever de registro e de indicação da relação de dependência em atos e correspondência, os administradores respondem pelos danos que tal omissão possa causar aos sócios e a terceiros.

A sociedade também deve incluir, como parte das notas explicativas às suas demonstrações financeiras (nota integrativa, definida no artigo 2.427 do Código Civil italiano) um relatório resumido dos dados essenciais do balanço social mais recente do ente que, sobre ela, exerce a atividade de direção e coordenação. Complementarmente, o

289 " $A$ ratio da disciplina publicitária, especialmente em relação a atos e correspondência da sociedade, é a de tornar conhecido a quem entre em contato com a controlada que essa não é um ser isolado, mas a sua atividade é parte do campo mais amplo da estratégia empresarial elaborada por uma sociedade controladora, a qual exercita poderes tão intensos que incidem de maneira penetrante em seus objetivos e em sua gestão". Tradução livre de: "La ratio della disciplina pubblicitaria, specie per quanto riguarda atti e corrispondenza della società, è quella di render noto a chi entri in contatto con la dominata che essa non è una monade, ma che la sua attività rientra nel più ampio campo di strategia imprenditoriale elaborata da una società dominante, la quale esercita poteri tali da incidere in maniera penetrante sui suoi obbiettivi e sulla sua gestione." in A. VALZER, Il Potere di Direzione e Coordinamento di Società tra Fatto e Contratto, p. 854-855. 
relatório anual da administração (relazione sulla gestione, artigo 2.428) deve indicar (i) as relações mantidas com tal ente e com outras sociedades que também estejam sob a sua influência (artigo 2.497 bis, $\S 5^{\circ}$ ) e (ii) a motivação detalhada de todas as decisões da sociedade tomadas sob influência exercida pela respectiva holding.

A despeito de suas feições organizativas (Organisationsrecht), cumpre reconhecer que o novo ordenamento italiano dos grupos - ao contrário do alemão e do brasileiro - não criou mecanismos aptos a tornar juridicamente vinculantes as instruções transmitidas pelo ente que exerce a atividade de direção e coordenação aos administradores da sociedade que a ela estão sujeitos. O poder de determinar os rumos da administração da sociedade permanece meramente um dado de fato ${ }^{290}$, mesmo em face da formalização (declaratória e não constitutiva) dos vínculos de grupo por meio do cumprimento do disposto no artigo 2.497 bis.

\subsubsection{Financiamentos Intragrupo}

O artigo 2.497 quinquies do Código Civil italiano estende a todas as operações de financiamento entre sociedades sujeitas a atividade de direção e coordenação, independentemente de seu tipo societário, e dos entes que respectivamente exercem tal atividade, o mecanismo de contraste à subcapitalização, previsto no artigo 2.467 do mesmo diploma, que em princípio seria aplicável apenas às sociedades de responsabilidade limitada ${ }^{291}$.

O referido dispositivo determina que todos os financiamentos concedidos por um sócio à sociedade, em situações (i) de forte desequilíbrio entre o patrimônio líquido desta e seu endividamento total ou (ii) que de outra forma tornariam aconselhável um aumento de capital social, apenas podem ser pagos após a satisfação de todos os demais credores. Além disso, qualquer reembolso dos empréstimos recebidos pelo sócio - ou, in casu, ente que exerce atividade de direção e coordenação - no ano anterior à declaração de falência da

290 "O fato é que a atividade de 'direção e coordenação' [...] é destinada a se desenvolver em um espaço vazio de direito. [...] o poder de dar instruções resta um mero dado de fato". Tradução livre: "Il fatto è che l'attività di 'direzione e coordinamento' [...] è destinata a svolgersi entro uno spazio vuoto di diritto. [...] il potere di direttiva resta un mero dato di fatto." in F. GALGANO, Direzione e Coordinamento di Società - Art. 2497-2497 septies, p. 132-133. No mesmo sentido: R. SANTAGATA, Autonomia Privata e Formazione dei Gruppi nelle Società di Capitali, p. 812.

291 F. GALGANO, Direzione e Coordinamento di Società - Art. 2497-2497 septies, p. 174. U. TOMBARI, Diritto dei Gruppi di Imprese, p. 64-65. 
sociedade deverá ser restituído.

\subsubsection{Direito de Recesso}

O sócio da sociedade sujeita a atividade de direção e coordenação pode exercer direito de recesso, com base no artigo 2.497 quater, em três hipóteses distintas: (i) aprovação de transformação do tipo societário ou alteração do objeto social do ente controlador, que representem mudança significativa nas condições econômicas e patrimoniais da empresa, (ii) condenação do respectivo ente que exerce atividade de direção e coordenação nos termos do artigo 2.497 e (iii) início ou cessação de atividade de direção ou coordenação, mas desde que esse evento represente uma alteração no risco de investimento. Esta última hipótese de recesso não será aplicável, tampouco, se a sociedade dominada for de capital aberto ou caso se realize uma oferta pública de compra de suas ações ou quotas.

A primeira das hipóteses de recesso listadas anteriormente se destaca por autorizar a retirada de acionista em função de eventos que, em princípio, atingem diretamente apenas a estrutura da controladora - ou seja, do ente que exerce a atividade de direção e coordenação ${ }^{292}$.

Em todos os casos apontados acima, a efetivação do recesso se processará, mutatis mutandis, de acordo com as regras gerais constantes dos artigos 2.437 bis a 2.437 sexies.

\subsubsection{Conclusão Preliminar}

O saldo final da avaliação das normas relativas aos grupos, conforme introduzidas pela reforma do direito societário italiano de 2003, definitivamente não é positivo. Recheado de conceitos vagos e em parte contraditórios, o regime italiano parece um compromisso precário entre posições radicalmente contrastantes, sem que o resultado final tivesse um grau adequado de coerência interna. Trata-se de desfecho relativamente melancólico para um país com tamanha riqueza em termos de tradição jurídica e que, ao desenvolver seu novo regime, ainda teve a oportunidade de se valer de décadas de observação da experiência comparada, sobretudo em relação à disciplina alemã.

292 F. GALGANO, Direzione e Coordinamento di Società - Art. 2497-2497 septies, p. 159. 
Ainda assim, há méritos a serem colhidos nas regras instauradas pelos artigos 2.497 a 2.497 septies do Código Civil italiano e que podem servir de inspiração para outros países. Uma das ideias mais interessantes é provavelmente a obrigação de identificação e divulgação do controlador ou, mais precisamente, da sociedade ou ente que exerce atividade de direção e coordenação (artigo 2.497 bis). De fato, uma vez que se conclua que a titularidade de uma dada prerrogativa não pode estar de todo desconectada da responsabilidade pelas consequências de seu exercício, é lógico e natural que se exija o mais alto grau possível de transparência em relação à identidade do sujeito que detém o respectivo poder.

\subsection{Breve Nota sobre Direito Francês e Doutrina Rozenblum}

Em debates promovidos em maio de 1971, tendo por objeto a disciplina dos grupos no direito francês, Paillusseau já fazia notar a nítida incompatibilidade existente entre uma interpretação rigorosa de determinadas normas do direito societário penal daquele país e as práticas - correntes, difusas e, pode-se mesmo dizer definidoras da própria empresa plurissocietária - adotadas pela grande maioria dos grupos de sociedades $^{293}$.

Em um sistema legislativo marcado pela relativa escassez de normas de Direito Privado especificamente direcionadas a contrastar ou mitigar o conflito de interesses no âmbito dos grupos ${ }^{294}$, foi justamente a partir dessa fricção entre direito penal e praxe empresarial que emergiram algumas das principais contribuições da França para o debate em torno da melhor forma de se regular o fenômeno das sociedades juridicamente

293 "Se o direito atual das sociedades e, particularmente, as suas disposições penais, fossem aplicados, os grupos não poderiam funcionar! Como se poderia conciliar as disposições atuais de direito societário: disposições dos artigos 101 e seguintes da lei de 24 de julho de 1966, delitos de abuso dos bens e crédito da sociedade, etc., com as necessidades práticas da vida dos grupos [...]?”. Tradução livre de: "Si le droit actuel des sociétés et, particulièrement, ses dispositions pénales étaient appliquées, les groupes ne pourraient sans doute fonctionner! Comment pouvez-vous concilier les dispositions actuelles du droit des sociétés : conventions des articles 101 et suivants de la loi du 24 juillet 1966, délits d'abus des biens eu du crédit de la société, etc., avec les nécessités pratiques de la vie des groupes [...]?" in ASSOCIATION FRANÇAISE DES JURISTES D'ENTREPRISE, CENTRE DE DROIT DES AFFAIRES DE RENNES, Droit des Groupes des Sociétés - Analyse - Propositions, p. 192.

294 “Os grupos de sociedades são tão comuns e poderosos na França quanto em todos os outros países com um sistema econômico desenvolvido. Eles não são, contudo, objeto de uma legislação especial $e$ sistemática". Tradução livre de: "Gesellschaftsgruppen sind in Frankreich ebenso verbreitet und mächtig wie in allen anderen Ländern mit entwickelter Wirtschaftsordnung. Sie sind allerdings nicht Gegenstand einer speziellen und in sich geschlossen Gesetzgebung." in Y. GUYON, Das Recht der Gesellschaftsgruppe in Frankreich, p. 76. 
autônomas sujeitas a um centro único de decisões econômicas.

Os artigos 425 e 437 da antiga lei francesa sobre as sociedades comerciais de $1966^{295}$ estatuíam, respectivamente para as sociedades de responsabilidade limitada e para as sociedades anônimas, a figura do delito de abuso de bens sociais. Mais especificamente, os pontos 4 e 5 do artigo 425 - relativos às sociedades de responsabilidade limitada -, com redação análoga àquela dos pontos 3 e 4 do artigo 437 - atinente às sociedades anônimas -, vedavam respectivamente aos administradores: (i) a utilização em má-fé de bens e créditos da sociedade ou (ii) o emprego dos poderes e votos inerentes às suas funções, de forma sabidamente contrária aos interesses da sociedade e para fins pessoais ou para favorecer outra sociedade ou empresa, nas quais tivessem interesse, direto ou indireto. A violação de qualquer dos dispositivos em questão ensejava pena de reclusão por até cinco anos, além de multa correspondente a Fr. 2.500.000,00 (dois milhões e quinhentos mil francos).

Os elementos fundamentais de tais tipos penais seriam posteriormente transpostos para os artigos L241-3, parágrafos $4^{\circ}$ e $5^{\circ}$ (sociedades de responsabilidade limitada) e L242-6, parágrafos $3^{\circ}$ e $4^{\circ}$, do Code de Commerce, sem com isso sofrer alterações que os desnaturassem. A cominação pecuniária foi atualizada para o montante de $€ 375.000$ (trezentos e setenta e cinco mil euros), mantendo-se a pena máxima de prisão pelo prazo de cinco anos.

Conforme ressalta Guyon, ecoando a advertência de Paillusseau, uma aplicação literal e inflexível de tais dispositivos impediria a formação de um "mercado interno de capitais" no seio dos grupos de sociedades franceses ${ }^{296}$. Uma das grandes vantagens das operações intragrupo se comparadas àquelas que têm lugar entre partes independentes reside no fato de, nas primeiras ao contrário destas últimas, as contratantes terem acesso -

295 Lei n ${ }^{\circ} 66-537$, de 24 de julho de 1966.

296 "Frequentemente, uma sociedade do grupo dispõe de meios financeiros suficientes, enquanto outra tem necessidade de liquidez. Caso nos atenhamos rigorosamente à autonomia jurídica das sociedades integrantes do grupo, impõe-se exigir que uma sociedade possa conferir recursos a outra apenas nos termos da taxa de juros usual do mercado de capitais. Consequentemente, qualquer auxilio financeiro em favor da sociedade - de fato ou contratualmente - dominante caracterizaria o delito de 'abus des biens sociaux' (abuso dos recursos da sociedade)". Tradução livre de: "Oft verfügt eine Gesellschaft der Gruppe über ausreichende Finanzmittel, während eine andere liquide Mittel benötigt. Hielte man strikt an Grundsatz der rechtlichen Selbständigkeit der gruppenzugehörigen Gesellschaften fest, müßte man verlangen, daß eine Gesellschaft einer anderen ein Darlehn nur zu dem am Kapitalmarkt üblichen Zinsen gewähren darf. Dann würde jede günstigere Finanzhilfe an die vertraglich oder faktische herrschende Gesellschaft das Delikt des 'abus des biens sociaux' (Mißbrauch von Gesellschaftsmitteln) erfüllen." in Y. GUYON, Das Recht der Gesellschaftsgruppe in Frankreich, p. 82. 
pela óbvia razão de serem dirigidas pelo mesmo controlador - a informação mais completa sobre a solvência e as intenções de suas respectivas contrapartes e, por isso, poderem avaliar melhor o risco da concessão de crédito, restando, portanto, em condições de exigir umas das outras juros mais baixos do que os de mercado (os quais refletem a taxa média de risco de operações entre desconhecidos). Além disso, o financiamento de uma sociedade do grupo pelas suas pares também evita a incidência dos custos decorrentes da remuneração de eventual intermediário financeiro. Por essas razões, a realocação de excedentes de caixa entre as sociedades agrupadas pode, frequentemente, ser mais eficiente do que o recurso ao mercado financeiro ou de capitais ${ }^{297}$.

Porém, a aplicação rigorosa das disposições acerca do delito de abuso dos bens sociais imporia a realização de qualquer financiamento entre as sociedades sob controle comum de acordo com as condições prevalentes no mercado, em operações realizadas entre partes independentes. Em tal caso, contudo, a operação perderia muito de seu sentido, pois o principal benefício das operações internas é - como mencionado - obter acesso a recursos em condições mais vantajosas do que as disponíveis no mercado. A alternativa, por outro lado, seria incorrer no risco de celebrar contrato de financiamento de legalidade duvidosa, com exposição dos administradores envolvidos à possibilidade de condenação criminal $^{298}$.

Em 1984, a regulamentação bancária francesa foi alterada, de forma a permitir a concessão de empréstimos recíprocos de curto prazo entre entidades não qualificadas como instituições financeiras, desde que pertencentes ao mesmo grupo. Essa mudança incrementou significativamente as oportunidades de financiamento intragrupo e, portanto, aumentou o peso da restrição representada pelo delito de "abus des biens sociaux"

A semente do percurso hermenêutico que conduziria a uma solução para esse estado de coisas foi originalmente lançada pelo Tribunal Correctionnel de Paris, em maio

297 Aspecto prático extremamente relevante dos grupos, especialmente nos países com mercado de capitais pouco desenvolvido, conforme se discutiu no item 3.2.4.

298 "Qualquer transferência financeira interna ao grupo seria então ou desnecessária - porque as mesmas condições também poderiam ter sido contratadas com terceiros - ou perigosa - porque a estrutura do grupo teria sido aplicada para neutralizar a eficácia de leis do mercado". Tradução livre de: "Jeglicher finanzielle Transfer innerhalb der Gruppe würde also entweder unnötig - weil zu denselben Bedingungen auch mit Dritten abgeschlossen werden könnte - oder gefährlich - weil die Gruppenstruktur verwendet würde, um Marktgesetze außer Kraft zu setzen." in Y. GUYON, Das Recht der Gesellschaftsgruppe in Frankreich, p. 82.

299 Lei bancária de 24 de janeiro de 1984. C. HANNOUN, Le Droit et les Groupes de Sociétés, p. 86-87. 
de 1974, em decisão tomada no célebre caso Willot, no qual o assim chamado "interesse de grupo" foi levantado como possível excludente da ilicitude de operações realizadas entre sociedades sujeitas ao domínio de um mesmo sujeito.

O reconhecimento da legitimidade de tais operações foi condicionado pelo tribunal de Paris à verificação de três principais blocos de requisitos: (i) existência de grupo fortemente estruturado, em bases não artificiais, cujos elementos concorram para a realização do "objeto social" do próprio grupo; (ii) que os sacrifícios solicitados a uma determinada sociedade sejam realizados (a) em nome do interesse do grupo, para a manutenção de seu equilíbrio, ou (b) para se perseguir uma política global coerente e não no interesse pessoal de seus dirigentes; e (iii) que os sacrifícios em questão não façam com que a respectiva sociedade corra riscos demasiadamente importantes - sem contrapartidas adequadas - que a sujeitem, bem como a seus credores e sócios, a potenciais dificuldades graves, já previsíveis no momento em que é tomada a respectiva decisão incriminada ${ }^{300}$.

A referida posição do tribunal de Paris seria, em seus contornos gerais, confirmada pela Corte de Cassação, muitos anos mais tarde, em fevereiro de 1984, em decisão que ficaria conhecida como arrêt Rozenblum. Ao apreciar e rejeitar o recurso de um administrador de várias sociedades distintas, condenado nas instâncias inferiores por abuso dos bens sociais, a Corte de Cassação lançou mão dos conceitos de: interesse de grupo, política comum de grupo, adequada compensação, equilíbrio entre prestações e respeito à capacidade financeira da sociedade prejudicada pela operação em concreto $^{301}$.

Hannoun buscou sumarizar as considerações levantadas pelo tribunal de Paris e

300 C. HANNOUN, Le Droit et les Groupes de Sociétés, p. 89.

301 Diz a ementa da decisão em questão: "Para escapar às previsões dos artigos $425\left(4^{\circ}\right)$ e $437\left(3^{\circ}\right)$ da lei de 24 de julho de 1966, a contribuição financeira transposta pelos administradores de fato ou de direito de uma sociedade a uma outra empresa do mesmo grupo no qual detêm interesse, direto ou indireto, deve ser ditada por um interesse econômico, social ou financeiro comum, a ser aferido em relação a uma política elaborada para o conjunto do grupo, e não deve ser desprovida de contrapartidas ou romper o equilibrio entre as respectivas prestações das sociedades envolvidas, nem exceder as possibilidades financeiras daquela que arca com o ônus". Tradução livre de: "Pour échapper aux prévisions des articles $425\left(4^{\circ}\right)$ et $437\left(3^{\circ}\right)$ de la loi du 24 juillet 1966, le concours financier apporté par les dirigeants de fait ou de droit d'une société, à une autre entreprise d'un même groupe dans laquelle ils sont intéressés directement ou indirectement, doit être dicté par un intérêt économique, sociale ou financier commun, apprécié au regard d'une politique élaborée pour l'ensemble de ce groupe, et ne doit ni être démuni de contrepartie ou rompre l'équilibre entre les engagements respectifs des diverses sociétés concernées, ni excéder les possibilités financières de celle qui en supporte la charge." conforme decisão da Corte de Cassação Francesa, Câmara Criminal, audiência pública de 4 de fevereiro de 1985, recurso $n^{\text {o } 84-91581, ~ p r e s i d e n t e ~ M . ~ E s c a n d e . ~}$ 
pela Corte de Cassação, quanto às condições que asseguram a licitude da condução da empresa plurissocietária, nos seguintes termos: (i) existência de grupo estruturado para a convergência de esforços na realização de um "objeto social único", (ii) auxílio financeiro ditado pelo interesse do grupo e (iii) existência de adequada contraprestação e ausência de riscos demasiadamente importantes para as sociedades que suportam o peso do auxílio prestado $^{302}$.

A doutrina Rozenblum acabou recebendo grande projeção e repercussão fora da França, sendo inclusive citada por Emmerich e Habersack como um dos novos pontos de referência para a eventual construção de uma disciplina dos grupos da União Europeia, após a gradual perda de consenso em torno do modelo dualista alemão ${ }^{303}$. Além disso, a decisão da Corte de Cassação mereceu, entre os doutrinadores brasileiros, as detalhadas considerações de Viviane Muller Prado ${ }^{304}$, Danilo Borges dos Santos Gomes de Araujo ${ }^{305}$ e Eduardo Secchi Munhoz ${ }^{306}$.

O interesse despertado pela referida construção da jurisprudência francesa provavelmente se deve ao fato de esta despontar como alternativa para a legitimação jurídica de operações que sejam tópica e pontualmente prejudiciais às sociedades do grupo, mas que façam sentido a partir de uma perspectiva mais ampla do funcionamento da empresa plurissocietária; isso, sem exigir a rigidez e a complexidade dos grupos de direito $^{307}$. A lição mais importante dos julgados em questão parece ser a de que, no grupo, deve-se analisar, tanto quanto possível, o todo, sem limitar o olhar a operações individuais.

A despeito do inegável valor da experiência francesa condensada na doutrina

302 C. HANNOUN, Le Droit et les Groupes de Sociétés, p. 90-91.

303 V. EMMERICH, M. HABERSACK, Konzernrecht, p. 20. A doutrina também foi citada por Wiedemann. H. WIEDEMANN, Die Unternehmensgruppe im Privatrecht, p. 80. G. HERTIG, H. KANDA, Related Party Transactions, p. 125.

304 V. PRADO, Conflito de Interesses nos Grupos Societários, p. 131-137 e 190-200.

305 D. ARAUJO, A Doutrina Rozenblum do Direito Francês; o Reconhecimento do Caráter Exoneratório dos Grupos de Sociedades em Matéria de Crimes de Abus de Biens Sociaux e a Consequente Influência do Direito Penal na Estruturação e no Funcionamento dos Grupos de Sociedade, p. 83.

306 E. MUNHOZ, Estrutura de Governo dos Grupos Societários de Fato na Lei Brasileira: Acionista Controlador, Administradores e Interesse de Grupo, p. 288.

307 "'...] na decisão ROZENBLUM, em matéria de abuso de bens sociais, [...] na qual pudemos detectar a vontade da Corte de Cassação de deixar o direito societário desempenhar o seu papel, ainda que as práticas concretas não correspondam àquelas descritas pelas formas jurídicas". Tradução livre de: "[...] dans l'arrêt ROZENBLUM, en matière d'abus de biens sociaux, [...] où l'on a pu repérer la volonté de la Cour de Cassation de laisser au droit des sociétés jouer son rôle même si les pratiques concrètes ne correspondent pas à celles décrites par les formes juridiques." in C. HANNOUN, Le Droit et les Groupes de Sociétés, p. 244. 
Rozenblum, tanto a sua análise quanto eventuais transposições de conceitos para outros países ou mesmo para outros campos do direito, devem ser operadas com cautela. Acima de tudo, não se pode perder de vista o fato que se trata de uma tese gestada no âmbito do direito penal, tendo como objetivo a tutela de um bem da vida tão essencial como a liberdade individual. É evidente que existe uma enorme distância entre não ser um criminoso e ser um bom administrador. Ser criminalmente inocente, não significa - ao menos não necessariamente - ser civilmente diligente e isento da responsabilidade de indenizar as perdas que causou.

Apenas como exemplo, ao confrontar os critérios de responsabilização civil fixados no artigo 2.497 do Código Civil italiano, com os elementos de tipificação do crime de infidelidade patrimonial, disciplinados no artigo 2.634 do mesmo diploma, Tombari prontamente reconhece que as "estimáveis vantagens compensativas" que excluem a ilicitude da conduta no âmbito penal podem ter significado muito diferente, e mais restritivo, na esfera civil ${ }^{308}$.

Não se pode, ademais, deixar de observar criticamente o caráter vago de muitos dos conceitos subjacentes às decisões tomadas pelos tribunais franceses nos casos Willot $\mathrm{e}$ Rozenblum, tais como as noções de "estrutura não artificial", "equilíbrio", "objeto social de grupo" ou "interesse de grupo"309. Não se trata aqui simplesmente do inevitável problema de se lidar com pressupostos fáticos de contornos amplos, que conferem ampla discricionariedade ao juiz - aspecto inevitável ao se lidar com matérias como conflito de interesse ou desvio de finalidade - mas de falta de clareza no próprio plano conceitual relativamente ao uso das referidas expressões, que não parecem se traduzir em fórmulas minimamente operativas.

308 U. TOMBARI, Diritto dei Gruppi di Imprese, p. 43-44.

309 Noção que será objeto de crítica mais detida no próximo capítulo. A esse respeito, Guyon observou que: "Não se compreende exatamente o que se deve entender pelo conceito de 'interesse de grupo' - o que, de resto, não causa surpresa, uma vez que não existe definição de aceitação geral para o conceito de interesse social". Tradução livre de: "Man versteht nicht genau, was unter dem Begriff des 'Gruppeninteresses' zu verstehen ist - was in übrigen nicht verwunderlich ist, da schon keine allgemein anerkannte Definition für den Begriff des Gesellschaftsinteresses existiert." in Y. GUYON, Das Recht der Gesellschaftsgruppe in Frankreich, p. 82-83. 


\section{PARTE II - A Disciplina dos Grupos no Direito Societário Brasileiro}

\section{Elementos Fundamentais das Técnicas Jurídicas de Agrupamento}

Em seus termos mais amplos e gerais, quase todas as normas que disciplinam o fenômeno dos grupos de sociedades se valem de uma entre duas estratégias fundamentais: (i) a técnica de imputação (ou transladação) de características ou atributos originalmente pertencentes ou atribuíveis a um sujeito a outra pessoa, de forma a se obter o preenchimento ou a satisfação do pressuposto fático de determinadas normas ${ }^{310}$ e (ii) a atribuição de efeitos particulares, especificamente "grupais"- ou seja, que não são ordinariamente aplicáveis a sujeitos de direito isolados, independentemente de suas características pessoais -, uma vez configurada a relação de grupo.

Um típico exemplo de aplicação da técnica de imputação é a extensão da qualidade de "estrangeira" à sociedade brasileira controlada por sujeito domiciliado ou residente no exterior, nos termos de leis que regulamentam setores estratégicos nacionais, tais como (i) a propriedade de imóveis rurais em faixas de fronteira ${ }^{311}$ ou (ii) o transporte aéreo $^{312}$. A imputação não atua necessariamente pela via da substituição de qualidades por exemplo, a referida substituição tópica da qualidade de brasileira pela de estrangeira mas pode ter lugar de forma aditiva ou cumulativa. É o caso do disposto na Lei 12.529/2012, artigo 88, em que o faturamento de todas as sociedades que integram um determinado grupo é somado para fins de apuração da necessidade ou não de submissão de atos de concentração à prévia avaliação do Conselho Administrativo de Defesa Econômica $^{313}$. Trata-se, essencialmente, da mesma técnica empregada pela Lei Federal

310 H. WIEDEMANN, Die Unternehmensgruppe im Privatrecht, p. 5.

$311 \mathrm{O} \S 1^{\circ}$ do artigo $1^{\circ}$ da Lei 5.709/1971 determina: "Fica, todavia, sujeita ao regime estabelecido por esta Lei a pessoa jurídica brasileira da qual participem, a qualquer título, pessoas estrangeiras fisicas ou jurídicas que tenham a maioria do seu capital social e residam ou tenham sede no Exterior".

312 Lei 7.565/1986, artigo 185.

313 Oportuno recordar, conforme a lição do Professor Calixto Salomão, que os conceitos de grupo do direito societário stricto sensu e do direito concorrencial não necessariamente coincidem: "É certo, por outro lado, que os conceitos comerciais não são perfeitamente coincidentes com os utilizados no direito societário propriamente dito. [...] As diferenças são marcadas a ponto de se falar hoje na existência de um direito societário concorrencial." in F. COMPARATO, S. CALIXTO, O Poder de Controle na Sociedade Anônima, nota de texto n ${ }^{\circ}$ 4, p. 43. 
11.638/2007, a respeito da auditoria externa obrigatória das demonstrações financeiras das sociedades de grande porte, cujo artigo $3^{\circ}$, parágrafo único, leva em consideração o faturamento e o ativo de todas as sociedades "sob controle comum" 314.

Uma variante importante da técnica de imputação é aquela que determina a desaplicação de determinadas normas na presença do grupo. É o caso, por exemplo, dos já citados incisos I, III e IV do artigo $3^{\circ}, \S 4^{\circ}$, da Lei Complementar 123/2006, que trata do regime de proteção às micro e pequenas empresas. Nem sempre, porém, a caracterização da relação de agrupamento terá consequências gravosas. A vedação geral aos acordos horizontais de restrição à competição, prevista pelas normas da União Europeia, não se aplica, por exemplo, à colaboração dessa natureza estabelecida entre controladora e controlada ou àquela que tenha lugar entre sociedades sob controle comum ${ }^{315}$.

Por outro lado, como exemplos de normas que partem de uma noção de grupo para diretamente atribuir obrigações de caráter especificamente grupal, não aplicáveis a sujeitos de direito isolados, é possível citar as regras tributárias sobre preços de transferência - baseadas na definição de pessoa vinculada, do artigo 23, III, da Lei Federal 9.430/1996 - ou ainda as regras sobre consolidação contábil, constantes da própria lei acionária (artigos 249 e 250).

Independentemente da estratégia utilizada, há sempre um pressuposto fático preliminar, vale dizer a própria existência do vínculo (normalmente, político ou econômico) caracterizador do grupo. É nessa norma preliminar, que qualifica determinadas relações para a incidência diferenciada dos efeitos de outras normas de caráter geral ou para a aplicação de disposições especificamente grupais, que parece se encontrar a essência das diversas definições de grupo, em cada microssistema jurídico que a utilize. O objetivo

314 E. VALLADÃO FRANÇA, M. VON ADAMEK, Sociedades de Grande Porte (Lei 11.638/2007, Art. $3^{\circ}$ ), p. 126.

315 O parágrafo 11 das "Orientações sobre a aplicação do artigo 101. ${ }^{\circ}$ do Tratado sobre o Funcionamento da União Europeia aos acordos de cooperação horizontal" (documento $n^{\circ}$ 2011/C 11/01), norma oficial sobre direito concorrencial da União Europeia, determina, na versão oficial em português, que: "As empresas que fazem parte da mesma 'empresa', na acepção do artigo 101. ${ }^{\circ}, n{ }^{\circ} 1$ [do próprio TFUE, ou Tratado sobre o Funcionamento da União Europeia], não são consideradas concorrentes para efeitos das presentes orientações. $O$ artigo $101 .^{\circ}$ aplica-se exclusivamente aos acordos entre empresas independentes. Quando uma empresa exerce uma influência decisiva sobre outra empresa, constituem em conjunto uma única entidade económica e, por conseguinte, fazem parte da mesma empresa. $O$ mesmo é válido no que se refere às empresas-irmãs, ou seja, empresas relativamente às quais a mesma empresa-mãe exerce uma influência decisiva. Por conseguinte, estas empresas não são consideradas concorrentes, mesmo que desenvolvam ambas actividades nos mesmos mercados do produto e geográfico relevantes". 
dos Subcapítulos 6.1 e 6.2, que seguem, é justamente analisar os elementos constitutivos da noção de grupo adotada pela Lei 6.404/1976 para que se possa, no Subcapítulo 6.3, buscar uma definição de tal conceito.

Os demais subcapítulos tratam de outras questões que também são relevantes tanto para o grupo de fato quanto para o grupo de direito, nos termos da disciplina brasileira do tema, quais sejam: (i) o conceito de interesse de grupo, (ii) a distinção entre grupos de subordinação e de coordenação e (iii) a articulação entre as disposições da Lei $6.404 / 1976$ e outras normas relativas aos grupos, notadamente no que diz respeito ao Código Civil de 2002 e às sociedades não acionárias.

\subsection{Perfil Subjetivo do Grupo e Uso Efetivo do Controle}

Antes de passar o foco da análise para a questão da natureza dos vínculos políticos que unem os integrantes de um grupo - objeto do próximo subcapítulo -, cumpre verificar quais sujeitos de direito ou entes jurídicos não personificados podem eventualmente integrar formalmente o grupo. De qualquer forma, é importante ter presente, desde logo, que os dois temas - as características pessoais dos integrantes do grupo, de um lado, e os vínculos de influência que os unem, de outro - são sobrepostos e estreitamente vinculados, especialmente na realidade brasileira.

Como se anotou no capítulo anterior, no direito societário alemão, a incidência das normas especificamente atinentes ao grupo de sociedades está circunscrita aos sujeitos de direito ou entes não personificados que possam se revestir da qualidade de empresário (Unternehmen). O requisito em questão se aplica tanto ao vértice do grupo quanto aos entes sobre os quais aquele exerce influência dominante $(\S \S 15$ a 19 da lei acionária alemã).

A razão para essa distinção entre empresários e não empresários reside em uma valoração do legislador estrangeiro sobre a suposta - e questionável - maior periculosidade do conflito entre dois interesses empresariais, se comparado com o conflito de interesses em geral. Assim, buscou-se afastar da sujeição às mais gravosas regras de responsabilidade decorrentes do direito dos grupos aquelas pessoas que não sejam titulares de um interesse empresarial externo à própria sociedade. Ou seja, que se limitariam à gestão, tendencialmente passiva, de um patrimônio pessoal. 
Essa questão do interesse empresarial externo à sociedade - apenas implícita na legislação alemã, tendo sido deduzida e desenvolvida por doutrina e jurisprudência -, foi expressamente positivada no texto do artigo 2.497 do Código Civil italiano, com a redação que lhe foi atribuída pela reforma levada a cabo em 2003, o qual se refere a "sociedade ou ente" que age no "interesse empresarial, próprio ou de terceiros".

No direito societário brasileiro, uma distinção similar, com propósitos confessadamente semelhantes ${ }^{316}$, foi construída por meio do desdobramento das definições de "acionista controlador", constante do artigo 116 da Lei 6.404/1976, e daquelas de "sociedade controlada" e "controladora", previstas no $\S 2^{\circ}$ do artigo 243 do mesmo diploma. Os pressupostos fáticos de ambas as definições têm diversos elementos em comum, de aplicação geral: (i) a titularidade de direitos de sócio, (ii) a preponderância, de modo permanente, nas deliberações sociais e (iii) o poder de eleger a maioria dos administradores.

Entretanto, as normas definidoras de uma e de outra fattispecie em exame, divergem em três pontos cruciais. O primeiro diz respeito à própria natureza jurídica do titular do poder de controle. Enquanto o caput do artigo 116 se refere a "pessoa natural ou jurídica", a incidência do artigo $243, \S 2^{\circ}$, tanto no que se refere à "controlada" quanto à “controladora", está evidentemente limitada aos entes qualificáveis como sociedade. A segunda importante distinção reside na ausência de referência, no corpo do artigo $243, \S 2^{\circ}$, ao uso efetivo do poder de controle para dirigir as atividades sociais e orientar o funcionamento da companhia, requisito este que, ao revés, está consignado expressamente na alínea "b" do artigo 116. Enfim, a terceira diferença diz respeito ao controle indireto, expressamente presente no artigo $243, \S 2^{\circ}$, e apenas incorporado por referência ao conceito de "sob controle comum" no artigo 116, no qual prevalece para todos os fins a relação direta de controle ${ }^{317}$.

316 " $A$ razão do art. 116 é que ele se reporta a pessoas fisicas, que, muita vez, por ausência, ignorância, omissão ou herança, não sabem ou não podem exercer o controle. Para essas pessoas, seria injurídico atribuir-lhes responsabilidades de controlador que de fato não eram. Já as pessoas jurídicas controladoras - como sociedades comerciais que são - têm o poder e o dever estatutário de exercer seu objeto, são, pois, necessariamente controladoras, e, como tal, respondem se detêm a maioria. Não precisava, e não devia a lei, inclui-las na definição para as pessoas fisicas (art. 116, b) [...] porque têm o dever, como sociedade mercantil, de realizar seu objeto estatutário e administrar o seu patrimônio. Em outras palavras, quando têm o poder [...] têm o correlato dever de exercer o controle, com as responsabilidades de controlador" in A. LAMY FILHO, Financiamentos Bancários a Empresa Associada, p. 332-333.

317 Afirma o Professor Comparato: “Ou seja, na hipótese de incidência definida no art. 116, o controle é 
Ao se analisarem as razões históricas e teleológicas para o referido desdobramento de conceitos, é possível verificar que a primeira das citadas diferenças - a natureza jurídica do titular do poder - existe justamente em função da necessidade de se delimitar a segunda questão - presença ou ausência do uso efetivo de tal poder. Com efeito, a exigência de "uso efetivo" do poder de controle foi concebida pelos ilustres autores do Anteprojeto de lei acionária brasileira como um mecanismo de proteção ao acionista pessoa física que, pelas mais variadas razões - incapacidade, ignorância, menoridade, etc. -, não fosse de fato capaz de exercê-lo, a despeito de formalmente reunir as prerrogativas para tanto, por exemplo, por meio da titularidade da maioria do capital votante da companhia ${ }^{318}$.

O que se percebe, nesse sentido, é que o requisito do uso efetivo do poder de controle existe para tutelar uma situação jurídica bastante específica e se justifica apenas em função da presumível vulnerabilidade de determinados sujeitos. Trata-se, portanto, de exceção, não regra geral. O fato de que não tenha sido repetida no corpo do artigo 243 , $\S 2^{\circ}$, a exigência de exercício ativo da direção das atividades sociais não é, portanto, acidente ou lapso do legislador ${ }^{319}$, mas reflexo da expressa opção legislativa de se de atribuir consequências jurídicas diversas para situações fáticas distintas. Desse modo, não se pode concordar com a interpretação extensiva que, por exemplo, Waldecy Lucena e Modesto Carvalhosa ${ }^{320}$, buscam atribuir ao requisito do exercício efetivo, colocando-o

sempre direto e as sociedades sob controle comum são tidas, em conjunto, por controladoras. No art. 243, $\S 2^{\circ}$, despreza-se o escalão intermédio, buscando-se a sociedade controladora em último grau." in F. COMPARATO, C. SALOMÃO FILHO, O Poder de Controle na Sociedade Anônima, p. 85.

318 "O requisito de que a pessoa (ou grupo de pessoas) exerça efetivamente o poder de dirigir as atividades sociais e orientar o funcionamento dos órgãos da companhia se explica porque a definição do artigo 116 da Lei abrange pessoas naturais que, embora sejam titulares da maioria dos votos, não exercem efetivamente o poder de controle, como no caso da viúva do empresário que o sucede na maioria dos direitos de voto mas deixa a administração da companhia entregue aos administradores profissionais em que o marido confiava, sem exercer efetivamente o poder de controle. Cabe destacar que a Lei não incluiu esse requisito na definição de sociedade controladora, constante no $\S 2^{\circ}$ do artigo 243 , porque a sociedade existe para realizar seu objeto e, se este inclui a participação em companhias, ela exerce seus direitos de sócio." in A. LAMY FILHO, J. PEDREIRA, Estrutura da Companhia, p. 817.

319 Ao contrário do que haviam presumido Teixeira e Guerreiro: "Note-se, porém, que ao contrário do que exige a alínea b desse último dispositivo [artigo 116 da Lei 6.404/1976], na definição de controle de sociedades ministrada pelo $\S 2^{\circ}$ do art. 243, não se requer que a sociedade controladora use efetivamente seu poder para dirigir as atividades sociais e orientar o funcionamento dos órgãos da companhia. Cremos ter havido, nesse particular, flagrante omissão do texto legislativo." (sem grifo no original) in E. TEIXEIRA, J. GUERREIRO, Das Sociedades Anônimas no Direito Brasileiro, vol. II, p. 702.

320 J. LUCENA, Das Sociedades Anônimas - Comentários à Lei, vol. III, p. 739-740. “A aptidão de comandar não configura controle. O que identifica essa posição de privilégio e responsabilidade legal (arts. 117 e 245) é o efetivo exercício desse poder de impor a política e os quadros de administração das sociedades, direta ou indiretamente, controladas. Ou seja, não é a possibilidade de exercício majoritário ou minoritário de comando que caracteriza o controle, mas a sua efetividade." in M. 
como condição para a atribuição das responsabilidades típicas decorrentes da titularidade de posição de controle para acionistas de toda espécie ${ }^{321}$. Na maioria dos casos, não há sentido ou razoabilidade em se premiar o detentor do controle empresarial pela sua eventual inércia.

Existe, portanto, um claro paralelo entre a disciplina brasileira do controle e as disposições de direito alemão e italiano, nas quais que se buscou resguardar os "acionistas privados" que se limitassem a meramente administrar o próprio patrimônio, sem exercer um papel ativo, na qualidade de empresário. A ideia subjacente em todas essas hipóteses é atenuar a posição de quem apenas tangencia o meio empresarial, sem desempenhar no mercado um papel ativo e central. À posição passiva e reativa da pessoa natural que se encontra no papel de mera prestadora de capital - ainda que sua participação na companhia encerre em si o potencial para ser convertida em base jurídica para o efetivo exercício de poder empresarial - o legislador preferiu não fazer recair toda a gama de deveres e responsabilidades imputados ao empresário que exerce o controle-domínio.

No direito alemão, como já se teve a oportunidade de apontar, o conceito aberto de empresa (Unternehmen) acabou criando espaço para interpretações notadamente

CARVALHOSA, Comentários à Lei de Sociedades Anônimas, $4^{\circ}$ vol., tomo II, p. 63. Aparentemente no mesmo sentido: N. EIZIRIK, A. GAAL, F. PARENTE, M. HENRIQUES, Mercado de Capitais Regime Jurídico, p. 391-392. Tal posição parece ignorar o fato de que o exercício do poder empresarial frequentemente prescinde de canais formais de deliberação, o que torna, na prática, muito difícil comprovar a diferença entre, por exemplo, o acionista majoritário passivo - que na visão de Lucena e Carvalhosa não seria controlador - e o controlador que discretamente se vale de suas prerrogativas. Como lembra Galgano: "As instruções são, repito, instruções confidenciais; são o exercício de um poder de fato e, todavia, a controladora está em condições de poder lhes transmitir graças à força persuasiva ou, se for o caso, dissuasiva que lhe é atribuida pelas faculdades inerentes ao direito real sobre as ações". Tradução livre de: "Le direttive sono, ripeto, direttive confidenziali; sono l'esercizio di un potere di fatto, e tuttavia la controllante è nella condizione di poterle impartire grazie alla forza persuasiva o, se del caso, dissuasiva che le è attribuita dalle facoltà inerenti al diritto reale sulle azioni." in $\mathrm{F}$. GALGANO, Direzione e Coordinamento di Società - Art. 2497-2497 septies, p. 131. Além disso, a universalização da exigência de uso efetivo do poder de controle consagraria em diversas situações a irresponsabilidade do controlador por omissão, o que vai contra a própria natureza de poder-dever do controle.

321 Opinião extremamente oportuna e razoável de lege ferenda, mas não inteiramente amparada pela interpretação literal das normas em questão, é aquela (do Professor Comparato) de acordo com a qual o requisito do exercício efetivo seria aplicável apenas ao controlador minoritário: "A exigência do uso efetivo do poder 'para dirigir as atividades sociais e orientar o funcionamento dos órgãos da companhia' somente se compreende, como elemento integrante da definição de controlador, em se tratando de controle minoritário." F. COMPARATO, C. SALOMÃO FILHO, O Poder de Controle na Sociedade Anônima, p. 87. Trata-se de posição parcialmente diversa daquela defendida anteriormente, na qual se vislumbrava na ausência de referência ao uso efetivo no artigo 243 uma "omissão" sem "maior significação, pois esse uso efetivo do poder de controle é algo sempre suposto, como resultado necessário da preponderância nas deliberações sociais." in F. COMPARATO, Os Grupos Societários na Nova Lei das Sociedades por Ações, p. 96. 
ampliativas, que permitiram imputar os deveres decorrentes do Konzernrecht aos mais variados tipos de sujeitos, incluindo-se pessoas físicas e o próprio Estado.

No direito italiano, conforme a posição que se adote em relação à interpretação da expressão "ente ou sociedade", pode-se afirmar que existe (i) ou apenas um critério aberto, atinente unicamente à titularidade de interesse empresarial externo à companhia (muito próximo, portanto, à posição que veio a prevalecer na Alemanha) (ii) ou critério misto, de acordo com o qual o interesse empresarial externo deve se somar à qualidade de pessoa jurídica ("ente o società") do acionista.

Nessa seara, o legislador brasileiro optou por um critério misto - sem prejuízo, obviamente, da exigência dos demais requisitos para a configuração do controle, que são de aplicação geral - de acordo com o qual é irrelevante qualquer ação ou outra característica pessoal do titular do poder: (i) o uso efetivo do poder e/ou (ii) a qualidade de sociedade ensejam a plena submissão aos deveres e responsabilidades inerentes à posição de controlador.

Do ponto de vista puramente conceitual, uma das principais vantagens da opção adotada pelo legislador brasileiro é a de - em contraste com a estratégia alemã e italiana não enfatizar diretamente a questão do conflito de interesses puramente empresariais. Com efeito, o conflito de interesses é questão de fato que apenas pode ser adequadamente apurada na prática, caso a caso. É possível vislumbrar inúmeras situações em que o entrechoque entre interesse não empresarial do sócio - apenas como exemplos, aspirações de natureza religiosa, política, afetiva ou familiar ${ }^{322}$ - e o melhor interesse da companhia possa ter consequências extremamente negativas para esta última. Em termos práticos, um benefício comparativo do regime brasileiro é a possibilidade de aferição mais objetiva da incidência ou não das normas de grupo, sem a necessidade de realizar complexa indagação a respeito da existência de um interesse empresarial externo.

Por outro lado, o critério predominantemente formal adotado pelo legislador brasileiro, ao eleger como elemento determinante a natureza de sociedade do ente

322 Pode-se pensar, por exemplo, na hipótese em que o acionista controlador pessoa natural seja candidato a cargo eletivo e, por isso, decida não encerrar as atividades de uma unidade fabril fortemente deficitária da companhia para, desse modo, evitar a perda de popularidade na região que se seguiria à demissão dos respectivos empregados. Ou ainda, o acionista controlador que decida suspender determinada linha de produtos da companhia em função de incompatibilidade com religião para a qual tenha se convertido. 
controlador $^{323}$, tem efeitos muito mais restritivos sobre o perímetro máximo possível de incidência das normas de direito dos grupos do que aquilo que se verifica em relação às regras congêneres de direito estrangeiro. Efetivamente, atendo-se a uma interpretação literal do artigo 243, $\S 2^{\circ}$ da Lei 6.404/1976, estão em princípio excluídos do âmbito de aplicação dos principais dispositivos que tratam dos grupos - tais como os artigos 245, 246 e 265 do mesmo diploma - todos os sujeitos que não se qualifiquem como sociedade. Dessa perspectiva, o direito grupal brasileiro é rigorosamente direito do grupo de sociedades, não direito do grupo de empresas ${ }^{324}$.

Esse fato enseja legítimo questionamento sobre o possível papel reservado pelas nossas normas de direito dos grupos para uma série de agentes econômicos não constituídos como sociedade - ou cuja natureza societária é colocada em discussão por parte da doutrina ${ }^{325}$-, muitos dos quais têm relevância fundamental no panorama

323 "[...] o Capitulo XXI, embora contendo algumas normas especiais sobre a companhia, foi redigido para ser aplicado a qualquer tipo de sociedade que participe de uma convenção de grupo." in J. PEDREIRA, Dispositivos da Lei das S.A. Revogados pela Lei $n^{\circ} 7.958 / 89$, p. 359.

324 "A nova lei de sociedades por ações [Lei 6.404/1976] só regula os grupos de sociedades, não os grupos de empresas de modo geral. Nesse ponto, aparta-se da orientação seguida pelo legislador alemão de 1965, que admitiu pudesse o Konzern ser composto não só de sociedades, mas também de empresários individuais e até mesmo do próprio Estado." in F. COMPARATO, Os Grupos Societários na Nova Lei de Sociedades por Ações, p. 91. "[...] a Lei Acionária somente reconheceu grupos de sociedades e não grupos dos quais participem empresas, como faz o modelo do Konzern alemão." in V. FRANCO, Concentração de Poder Econômico e Grupos não Acionários perante a Ótica do Código Civil, p. 221. "Qualquer que seja o ângulo sob o qual se configure o relacionamento intersocietário (convencional ou não), é importante assinalar que são contempladas pela lei apenas as vinculações entre sociedades. Assim sendo, não se tem coligação, controle, subsidiária integral, grupo ou consórcio baseados na participação de pessoas fisicas." in E. TEIXEIRA, J. GUERREIRO, Das Sociedades Anônimas no Direito Brasileiro, vol. II, p. 697. "Uma das diferenças que existem entre a lei alemã e a brasileira é que aquela prevê o grupo de empresas, admitindo que no topo da pirâmide, por exemplo, figure um empresário individual, enquanto que esta só admite o grupo de sociedades." in E. VALLADÃO FRANÇA, Dever de Informar dos Administradores de Companhias Abertas. Inexistência de Submissão ao Acionista Controlador, p. 362. No mesmo sentido: V. PRADO, Conflito de Interesses nos Grupos Societários, p. 56. A exclusão das pessoas naturais do conceito de grupo implica, por sua vez e desde logo, a não consideração do controle gerencial como vínculo de influência interno ao grupo de direito ou de fato.

325 É o caso, por exemplo, da empresa individual de responsabilidade limitada - EIRELI. Em debate cujo deslinde extrapola os limites do presente trabalho, a doutrina discute se a EIRELI (criada pela Lei Federal 12.441/2011, que inseriu o artigo 980-A no Código Civil de 2002) seria uma forma de sociedade unipessoal ou um novo ente jurídico personificado. Caso se aceite sua natureza societária, estará a EIRELI diretamente sujeita ao direito dos grupos, nos termos mutatis mutandis aplicáveis às sociedades limitadas (consoante remissão constante do artigo 980-A, $\S 6^{\circ}$ do Código Civil e conforme discutido no subcapítulo 6.6, mais adiante), independentemente do recurso à analogia. Em favor da qualificação da EIRELI como sociedade: E. VALLADÃO FRANÇA, M. VON ADAMEK, Empresa Individual de Responsabilidade Limitada (Lei $n^{\circ}$ 12.441/2011): Anotações, p. 44-45. Defendendo a sua natureza não societária: A. GONÇALVES NETO, Direito de Empresa - Comentários aos Artigos 966 a 1.195 do Código Civil, p. 123. Também sustentam a natureza não societária da EIRELI o Enunciado ${ }^{\circ} 3$ da I Jornada de Direito Comercial e o Enunciado $n^{\circ} 469$ da V Jornada de Direito Civil, ambas promovidas pelo Centro de Estudos Judiciários do Conselho da Justiça Federal. Qualquer que seja a posição que se 
empresarial brasileiro $^{326}$. A discussão diz respeito não apenas às pessoas naturais - que, cumpre recordar, podem inclusive ter a qualidade de empresário individual -, mas envolve também, por exemplo, fundações e associações e pessoas jurídicas de direito público interno e internacional.

Uma interpretação literal do artigo $243, \S 2^{\circ}$ e dos demais dispositivos que se apoiam em suas definições não parece dar margem para a extensão do conceito de sociedade a tais entes não societários. Em tal hipótese, verificar-se-ia, entretanto, uma grave desconexão entre as reais composição e dimensão da empresa única conduzida por meio de diversos entes e estruturas e o perímetro jurídico possível do grupo. Estar-se-ia furtando eficácia a mecanismos cuja função precípua é aquela de introjetar no campo do direito ao menos parte da unidade de fato da empresa plurissocietária ${ }^{327}$. Tal aspecto, associado à consideração das específicas - e altamente circunscritas - razões que motivaram o desdobramento, no direito positivo brasileiro, dos conceitos de "acionista controlador" e "sociedade controladora", parece sugerir a existência de amplo espaço - e aguda necessidade - para a incidência analógica (artigo $4^{\circ}$, Decreto-Lei $n^{\circ} 4.657 / 1942$ ) das normas acionárias relativas aos grupos aos sujeitos e entes que, embora não dotados da qualidade de sociedade, desempenham função quase idêntica na economia e política internas do grupo empresarial. Na verdade, a extensão analógica da incidência das normas de grupo é caminho que já há muito vem sendo trilhado pela doutrina e pela jurisprudência, sobretudo no que diz respeito à ação ut singuli disciplinada no artigo $246, \S 1^{\circ}$ da Lei $6.404 / 1976^{328}$.

adote a esse respeito, é de se lamentar que ainda não se tenha admitido no Brasil, de forma irrestrita, a constituição e a operação de sociedades unipessoais, independentemente de seu tipo societário.

326 "A realidade é que, estando disseminados em diversas empresas e, ao mesmo tempo, ativos nas estruturas do controle, os fundos [de pensão] tornaram-se pivôs nas mais diversas aglomerações locais corporativas." in S. LAZZARINI, Capitalismo de Laços: Os Donos do Brasil e suas Conexões, p. 38.

$327 \mathrm{Na}$ verdade, neste caso, a expressão "plurissocietária" é imprecisa porque restritiva. Mais do que confrontados com uma empresa conduzida por meio de diversas sociedades, estamos diante de empresas conduzidas por meio de diversos entes e estruturas jurídicas, algumas das quais não personificadas, como os fundos de investimento.

328 A esse respeito, o Professor Comparato argumenta que: "A lei das sociedades por ações de 1976, ainda aí, não obstante consagrar a instituição do acionista controlador, deixou de contemplar a disciplina do instituto com o aparelhamento de côngruas sanções, a começar pelo mecanismo da ação social ut singuli, tradicionalmente prevista para os casos de responsabilidade administrativa. Diante da omissão legislativa, porém, parece irrecusável a aplicação analógica do direito positivo [...] Qualquer acionista, em nosso entender, é parte legítima para propor ação de perdas e danos, no interesse da companhia contra o controlador, observado no que couber, os dispositivos do art. $246, \xi 1^{o}$." in F. COMPARATO, C. SAlOMÃO FILHO, O Poder de Controle na Sociedade Anônima, p. 384. Em posição divergente, mais conservadora, no sentido de que nem os benefícios, nem as exigências constantes do artigo 246 seriam aplicáveis à ação movida contra o acionista controlador que não seja 
Não se vislumbra razão para excluir da disciplina dos grupos as empresas públicas $^{329}$ e as sociedades de economia mista. O artigo 269, parágrafo único, alínea "b", da Lei 6.404/1976 sugere exatamente o contrário ${ }^{330}$. Resta, porém, margem para dúvida especialmente na pendência da devida regulamentação do artigo $173, \S 1^{\circ}$, da Constituição Federal - sobre onde se encontra o preciso ponto de equilíbrio entre o disposto nos artigos 245 e 238 (segunda parte) da lei acionária.

Para além da questão da articulação entre as normas do Código Civil de 2002 e a lei acionária - discutida no Subcapítulo 6.6, a seguir -, parece claro que todas as sociedades não acionárias personificadas podem tranquilamente integrar tanto os grupos de fato quanto aqueles regulados por convenção, tanto na posição de controladas-filiadas quanto como sociedade controladora ou de comando ${ }^{331}$. Com efeito, cumpre recordar que o artigo 270 da Lei 6.404/1976 prevê que a convenção de grupo deve ser aprovada de acordo com os mesmos critérios aplicáveis à alteração do estatuto ou contrato social, o que ilustra o fato de que a disciplina ali declinada não está limitada à sociedade anônima e à comandita por ações.

A despeito de sua limitada difusão e diminuta relevância prática, cumpre recordar que as sociedades em nome coletivo não estão autorizadas, no regime instituído pelo Código Civil de 2002 (artigo 1.039), a ter pessoas jurídicas em seu quadro de sócios. Nesse sentido, e considerando também o fato de que os artigos 116 e 243 , $\S 2^{\circ}$, da Lei 6.404/1976 se referem a "direitos de sócio" - e, portanto, conforme discutido mais adiante, excluem o

sociedade controladora: P. ARAGÃO, Aspectos Processuais da Legislação Societária, p. 71.

329 Defendem a impossibilidade de participação em grupo da empresa pública, dada a sua natureza não societária, os Professores Fábio Konder Comparato (F. COMPARATO, Controle Conjunto, Abuso no Exercício do Voto Acionário e Alienação Indireta de Controle Empresarial, p. 83) e Viviane Muller Prado (V. PRADO, Conflito de Interesses nos Grupos Societários, p. 56). Com a devida vênia, desde que - nos termos da faculdade expressamente consignada no artigo $5^{\circ}$, II, do Decreto 200/1967 - à empresa pública seja dada uma forma societária, não parece haver motivo para exclúíla de antemão do perímetro do grupo de fato ou de direito, especialmente se levarmos em conta sua sujeição às regras disciplinadoras das empresas privadas, consoante o artigo $173, \S 1^{\circ}$, inciso II, da Constituição Federal. Como exemplo de empresa pública constituída sob a forma de sociedade anônima é possível mencionar a Empresa de Transporte Ferroviário de Alta Velocidade S.A. - ETAV, criada nos termos do Decreto 7.755/2012. Uma vez que seu capital deve necessariamente pertencer exclusivamente à União, é natural que a posição da empresa pública no grupo seja aquela de vértice.

330 E. TEIXEIRA, J. GUERREIRO, Das Sociedades Anônimas no Direito Brasileiro, vol. II, p. 773.

331 “A sociedade controladora não precisa ser sociedade anônima. Pode perfeitamente ser sociedade por quotas de responsabilidade limitada ou sociedade de outro tipo qualquer." e "Note-se, também, que podem convencionar o grupo quaisquer tipos de sociedades. A lei não reservou o instituto às anônimas, nem tampouco exige que a sociedade de comando seja companhia. Igualmente não se requer que a sociedade de comando e as sociedades filiadas pertençam ao mesmo tipo." in E. TEIXEIRA, J. GUERREIRO, Das Sociedades Anônimas no Direito Brasileiro, vol. II, respectivamente p. 703 e 772. 
controle externo ou puramente contratual -, pode-se concluir que sociedades de tal espécie não podem se sujeitar ao controle de uma outra sociedade. Dessa forma, apenas poderão participar do grupo na qualidade de controladoras últimas ou sociedade de comando ${ }^{332}$. Uma vez que os sócios comanditados também devem necessariamente ser pessoas naturais (Código Civil de 2002, artigo 1.045) e que a eles incumbe com exclusividade a administração, as mesmas ponderações também se aplicam mutatis mutandis às sociedades em comandita simples.

A sociedade simples, por outro lado, pode claramente ter como sócios pessoas jurídicas ${ }^{333}$ - de outro modo, não se explicaria as referências a "denominação" e "sede" na redação do artigo 997, inciso II, do Código Civil de 2012. Além disso, a deliberação por meio de maioria de participação no capital (1.010) reforça a possibilidade de serem objeto de posição de controle, nos termos do artigo 1.089 do próprio Código Civil ou da lei acionária.

No que diz respeito às sociedades cooperativas, o princípio da singularidade de voto - artigo $4^{\circ}$, inciso V, da Lei 5.764/1971 e artigo 1.094, inciso VI, do Código Civil de 2002 - também parece tornar altamente improvável a possibilidade de controle de tais entes por outra sociedade, de modo que sua posição no grupo também seria, tendencialmente, apenas aquela de vértice ${ }^{334}$.

Ao se analisar a redação do artigo 243 , $\S 2^{\circ}$, da Lei $6.404 / 1976$ não se pode olvidar o fato de que, por ocasião da promulgação da lei acionária, o uso da expressão

332 "Mas, voltando à generalidade dos grupos, dele podem participar, para fins acadêmicos, tanto sociedades em nome coletivo, como em comandita simples e limitadas. É linear que dada a vedação da participação de pessoas jurídicas nas duas primeiras (arts. 1.039 e 1.046 do CC/2002), tanto a sociedade em nome coletivo, como a em comandita simples, somente poderão participar de grupos quando na posição de sociedade 'controladora' ou, em princípio (a ser objeto de discussão) de comando." in V. FRANCO, Concentração de Poder Econômico e Grupos não Acionários perante a Ótica do Código Civil, p. 223-224. Com a devida vênia, parece cabível um pequeno reparo às observações da ilustre Professora Vera Helena de Mello Franco quanto à suposta vedação de sócios pessoas jurídicas nas sociedades em comandita simples. Nos termos do artigo 1.045 do Código Civil de 2002, a restrição não parece alcançar a classe dos comanditários.

333 E. VALLADÃO FRANÇA, Sociedade em Comum, nota de rodapé no 48, p. 124.

334 A respeito desta mesma questão no direito italiano, Galgano observou que: "Uma cooperativa não pode controlar outras cooperativas, dado o princípio de 'um voto por cabeça' que caracteriza este tipo societário. [...] Na Itália, contudo, os grupos cooperativos foram, de todo modo, constituídos, na forma de uma sociedade cooperativa que controla sociedades de capital". Tradução livre de: "Una cooperativa non può controllare altre cooperative, atteso il principio 'una testa un voto' che caratterizza questo tipo societario. [...] In Italia, tuttavia, i gruppi cooperativi si sono ugualmente costituiti, nella forma di una società cooperativa che controlla società di capitali." in F. GALGANO, Direzione e Coordinamento di Società - Art. 2497-2497 septies, p. 76. 
"sociedade" ainda não havia sido adequadamente disciplinado e uniformizado pelo Código Civil de 2002, em seus artigos 44, II, e 981. Na vigência do Código Civil de 1916, ainda era possível, por exemplo, lançar mão de expressões como "sociedade sem fins lucrativos" ou "sociedade universal" 335 . Esse aspecto histórico poderia dar ensejo a visões ampliativas da lei, tendo por fim a aplicação direta - e não pela via analógica apontada acima - das normas acionárias de grupo a entes que possuem natureza associativa, ainda que não societária, notadamente as próprias associações. Contudo, o artigo 243, § $3^{\circ}$ parece encontrar suas raízes no artigo $135, \S 2^{\circ}$, do Decreto-Lei $2.627 / 1940$, que já se referia a sociedade enquanto ente capaz de deter participações e, ao mesmo tempo, ser participado. Assim, parece que mesmo do ponto de vista histórico, o legislador buscou utilizar a expressão "sociedade" em sentido estrito, o que excluiria a sua extensão - ressalvada a já citada via analógica - às associações.

Questão, enfim, que merece ser mencionada, mas que - pela sua complexidade não pode ser adequadamente enfrentada ou esmiuçada nestas páginas, é a da relação entre os grupos e as sociedades não personificadas, caso da sociedade em conta de participação e da sociedade em comum ${ }^{336}$. É importante recordar a esse respeito que a principal função da disciplina dos grupos é a tutela de credores e acionistas externos. Desse modo, apenas haverá sentido em se discutir a incidência do direito grupal a tais formas de sociedade se, e na medida em que, projetarem efeitos externos para além da esfera dos próprios sócios ${ }^{337}$

335 "Antes de o Código Civil de 2002 entrar em vigor, o tratamento jurídico da sociedade civil e da associação era comum, o que fez com que uma parte da doutrina sustentasse não existir critério legal para separação entre elas. Agora, a distinção legal é nítida não permitindo mais essa discussão. [...] Sociedade sem fins lucrativos não é mais sociedade, mas associação." in A. GONÇALVES NETO, Direito de Empresa - Comentários aos Artigos 966 a 1.195 do Código Civil, p. 143.

336 A complexidade decorre tanto da multiplicidade de formas que as sociedades não personificadas podem assumir, especialmente a sociedade em comum (vide os doutos comentários do Professor Erasmo Valladão França, a respeito das três vias para a formação de tal sociedade; E. VALLADÃO FRANÇA, A Sociedade em Comum, p. 122-123) quanto da dificuldade em se transpor o conceito de controle fundamental para o grupo - para esses tipos societários, nem sempre regidos pelo princípio majoritário.

337 Da experiência comparada, é possível mencionar decisão italiana - anterior à reforma do direito dos grupos de 2003 - que determinou a falência de sociedade em comum entre pessoas físicas que, na visão do tribunal, operava como holding gestora de participações em sociedades personificadas: " $A$ confusão entre patrimônio dos sócios e das sociedades de capital das quais participam, bem como o desenvolvimento pelos sócios de uma atividade autônoma de coordenação, direção e financiamento das referidas sociedades, denunciam a existência de uma holding líder do grupo [capogruppo] que tem por objeto principal o controle tirânico das sociedades investidas [...]". Tradução livre de: "La confusione dei patrimoni dei soci e delle società di capitali da questi partecipate, nonché lo svolgimento da parte dei soci di un'autonoma attività di coordinamento, direzione e finanziamento delle società medesime, denunciano l'esistenza di una holding capogruppo avente ad oggetto principale il controllo tirannico delle partecipate [...]" conforme decisão do Tribunal de Messina, de 08 de abril de 1999 (GCo 1999, II, 581). 
aspecto inevitavelmente fatual, cuja aferição apenas pode ser efetivamente realizada com base nos elementos de cada caso concreto. De qualquer maneira, a experiência brasileira com os fundos de investimento ${ }^{338}$ serve de prova a respeito do profundo impacto que entes não personificados podem ter sobre a economia, deixando pouco ou nada a dever em termos de vulto e sofisticação dos investimentos realizados e das estruturas internas de deliberação.

\subsection{Vínculos de Controle, Influência, Coligação e Direção Unitária}

Tanto em termos econômicos quanto jurídicos, "empresa" é noção que pressupõe a titularidade dos meios - quaisquer que sejam eles, de fato ou de direito - para direcionar o emprego de determinados fatores de produção, imprimindo sobre a sua utilização uma destinação comum. Em termos elementares, e, como tais, quase tautológicos, não há empresa sem o poder de empreender.

É justamente por isso que, a par do aspecto subjetivo, ou seja, as sociedades aptas a estarem agrupadas, o segundo elemento constitutivo dos grupos são os vínculos de poder que unem estas últimas e por meio dos quais sobre elas se afirma, predominante, uma única vontade, portadora de um determinado projeto econômico ${ }^{339}$. Retomando-se repisada metáfora, segundo a qual os grupos seriam as moléculas e as sociedades isoladas que os compõem os átomos do direito societário ${ }^{340}$, pode-se dizer que os vínculos de influência entre estas últimas seriam as suas ligações iônicas. Sem tais liames, não se forma a matéria tangível dos grupos.

Para assegurar que vontade e projeto se transformem em alteração da realidade material, em efetivo direcionamento de recursos e esforços no sentido almejado, é evidente

338 Sobre a possibilidade de fundos de investimento se qualificarem como sociedades não personificadas: E. VALLADÃO FRANÇA, A Natureza Jurídica dos Fundos de Investimento, Conflito de Interesses Apurado pela Própria Assembleia de Quotistas. Quorum Qualificado para Destituição de Administrador de Fundo, p. 194.

339 “É, portanto, característica indissociável dos grupos societários a integração da atividade empresarial das sociedades que o compõem. Essa integração é absolutamente natural aos grupos, pois, sem ela, a concentração por via da formação de grupos societários não se justifica economicamente." in E. MUNHOZ, Estrutura de Governo dos Grupos Societários de Fato na Lei Brasileira: Acionista Controlador, Administradores e Interesse de Grupo, p. 270 e 271.

340 F. COMPARATO, C. SAlOMÃo FILHO, O Poder de Controle na Sociedade Anônima, p. 358. E. TEIXEIRA, J. GUERREIRO, Das Sociedades Anônimas no Direito Brasileiro, vol. II, p. 696. J. ANTUNES, Estrutura e Responsabilidade da Empresa: O Moderno Paradoxo Regulatório, p. 31. Arnoldo Wald e Nelson Eizirik atribuem a autoria do modo de dizer em questão ao Professor René Rodière. A. WALD, N. EIZIRIK, A Designação "Grupo de Sociedades” e a Interpretação do Art. 267 da Lei das $S / A$, p. 56. 
que o domínio em questão deve ser amplo e reunir feições de incontrastabilidade, ou de soberania ${ }^{341}$. Em função dessas densidade e extensão da influência exercida, Champaud argumentou, em sua clássica obra sobre a matéria, que o poder de controle está mais próximo do direito de propriedade do que de qualquer outro instituto e que se contradistingue pela possibilidade de disposição dos bens alheios como se próprios fossem $^{342}$.

A noção de controle, em sua acepção de controle-domínio, está expressamente absorvida, nos termos do artigo 243, $\S 2^{\circ}$ da Lei 6.404/1976, nos conceitos de "sociedade controlada" e "sociedade controladora", os quais, por sua vez, são elementos essenciais e definidores tanto dos grupos de fato (artigos 245 e 246) quanto daqueles de direito (artigo 265). O poder de controle é, portanto, pedra angular de toda a disciplina dos grupos verticais que, não por acaso, são denominados grupos de subordinação.

O controle é provavelmente a grande questão do direito societário e não seria possível ou oportuno conduzir análise detalhada e exaustiva sobre o tema no âmbito do presente trabalho. Ainda assim, é indispensável discorrer brevemente sobre qual o conteúdo mínimo e as feições de tal poder, quando se tem como foco exclusivo a sua relação com os grupos societários.

\subsubsection{Controle e Direção Unitária}

Diversos e ilustres doutrinadores argumentam que o verdadeiro vínculo determinante da existência dos grupos seria a direção unitária, não o poder de controle ${ }^{343}$.

341 Afirma o Professor Comparato: "Ora, quando se fala em controle no sentido de dominação, na sociedade anônima, alude-se a um poder que transcende as prerrogativas legais da própria assembleia. Dai por que uma certa doutrina o aproxima, com razão, da noção de soberania." in F. COMPARATO, C. SALOMÃO FILHO, O Poder de Controle na Sociedade Anônima, p. 32.

342 C. CHAMPAUD, Le Pouvoir de Concentration de la Société par Actions, p. 161. A. LAMY FILHO, O Acionista Controlador na Nova Lei de S.A., p. 152. Professor Comparato: "Trata-se [o controle], portanto, de uma noção concorrente da propriedade que só pode ser definida em função desta." in F. COMPARATO, C. SALOMÃO FILHO, O Poder de Controle na Sociedade Anônima, p. 121.

343 "Um grupo sem uma direção unitária não constitui uma entidade particular, nem do ponto de vista jurídico, nem do ponto de vista econômico". Tradução livre de:"Un groupe sans une direction unifiée ne constitue une entité particulière ni du pont de vue juridique, ni du pont de vue économique." in A. PETITPIERRE-SAUVAIN, Droit des Sociétés et Groupes de Sociétés, p. 35. "A direção unitária ocuparia, desse modo, o centro da atenção do ordenamento jurídico dos grupos" in E. PEREIRA NETO, Anotações sobre os Grupos de Sociedades, p. 30. Asseverou o Professor Comparato: "É por isso que, contrariamente a uma opinião assaz difundida, a melhor doutrina considera a unidade de direção o único critério geral de identificação de todos os grupos econômicos, e não a unidade de controle, que só ocorre no grupo econômico de subordinação, muito embora este seja, de fato, o mais importante." in F. COMPARATO, C. SAlOMÃO FILHO, O Poder de Controle na Sociedade Anônima, p. 43. Em 
Com a devida vênia, tal posição não parece compatível com o direito positivo brasileiro atual, nem desponta como oportuna proposta de lege ferenda.

A discussão do conceito de direção unitária como vínculo político-funcional caracterizador dos grupos ${ }^{344}$ está diretamente relacionada com o tema do exercício efetivo do poder de controle, já enfrentado no subcapítulo anterior. Com efeito, a noção de direção unitária tem como pressuposto não a mera prerrogativa potencial de domínio, mas sim uma conduta ativa, a qual se traduz na gestão - mais ou menos centralizada, mais ou menos detalhada - das atividades das sociedades agrupadas.

A esse respeito, cumpre recordar que a exclusão do requisito do exercício efetivo do poder, constante do artigo 116 da Lei 6.404/1976, é a principal particularidade dos conceitos de "sociedade controladora" e "sociedade controlada", que estão na base da disciplina brasileira dos grupos; as definições são, de fato, retomadas, entre outros, nos artigos 245, 246 e 265 da mesma lei. Ou seja, foi justamente em relação aos grupos que o legislador brasileiro houve por bem explicitar a desnecessidade de efetivo exercício do domínio, priorizando desse modo o aspecto estático de poder-dever da posição de controle. Assim, oportuna e corretamente se preservou o espaço para a responsabilização do

artigo anterior, o Professor Comparato vislumbrava no controle e na direção, respectivamente, os elementos unificadores do grupo de fato e do grupo de direito. F. COMPARATO, Os Grupos Societários na Nova Lei das Sociedades por Ações, p. 98. O Professor Eduardo Secchi Munhoz afirma que "Em termos jurídicos, o requisito da integração empresarial é traduzido pelo conceito de direção unitária."; e "A doutrina atual converge, porém, para o reconhecimento de que a direção unitária constitui o elemento central dos grupos societários. Não se trata de um conceito unívoco (são análogos, por exemplo, os conceitos de influência dominante e de controle, disciplinados de forma distinta nas leis dos diversos países), mas ele é útil para identificar, de forma ampla o grupo de sociedades. Por direção unitária, entende-se o exercício do poder dos diversos membros do grupo societário, que passam a seguir, assim, uma política global." in E. MUNHOZ, Estrutura de Governo dos Grupos Societários de Fato na Lei Brasileira: Acionista Controlador, Administradores e Interesse de Grupo, p. 270 e 271. No mesmo sentido: E. MUNHOZ, Empresa Contemporânea e Direito Societário: Poder de Controle e Grupos de Sociedades, p. 109. Os conceitos de controle e influência dominante dizem respeito ao poder, enquanto que direção unitária reflete - como apontado pelo Professor Munhoz - o exercício do poder. Assim, não obstante sua evidente afinidade, é preciso cautela ao tratá-los como análogos.

344 Após criticar a ambiguidade da maioria das definições de direção unitária propostas pelos doutrinadores à época (ambiguidade que atribui a uma busca orientada por critérios jurídico-formais e não econômicos), Embid Irujo assevera que "[...] a direção unitária - e o grupo como tal - tem como pressuposto a perda da independência das sociedades que formam parte do grupo. Isso significa que uma série de competências necessárias para decidir sobre os setores ou âmbitos que integram a atividade de uma empresa [...] foram 'transferidos' à sociedade dominante do grupo". Tradução livre de: “[...] la dirección unitaria - y el grupo como tal - tiene como presupuesto la pérdida de la independencia económica de las sociedades que forman parte del grupo. Ello significa que una serie de competencias necesarias para decidir sobre los sectores o ámbitos integrantes de la actividad de una empresa [...] han sido 'transferidos' a la sociedad dominante del grupo, [...]. J. IRUJO, Algunas Reflexiones sobre los Grupos de Sociedades y su Regulación Juridica, p. 21. 
controlador por omissão.

No que diz respeito ao direito comparado, conforme apontado no item 5.1.2 deste trabalho, o conceito de direção unitária (Einheitliche Leitung) está positivado no $§ 18$ da lei acionária alemã de 1965 e representa um pressuposto para a caracterização do Konzern em sentido estrito. Contudo, estas - Einheitliche Leitung e Konzern - não são definições centrais para o direito dos grupos da Alemanha (que ainda assim é, ironicamente, denominado Konzernrecht). De fato, a presença da direção unitária é relevante sobretudo para desencadear determinadas obrigações contábeis acessórias ou para caracterizar, quando ausente a influência dominante, o grupo horizontal de coordenação (Gleichordnungskonzern).

O verdadeiro eixo da disciplina alemã dos grupos societários de subordinação é, dessarte, o conceito de influência dominante (beherrschende Einfluss, previsto no $\S 17)^{345}$, este sim análogo à noção de controle do direito brasileiro ${ }^{346}$. Cumpre observar que o comando relativo à proibição da subordinação de interesses, constante do $\S 311$, se dirige ao titular da influência dominante, não ao exercente da direção unitária. Além disso, nos termos do $2^{\circ}$ subparágrafo do $\S 291$, a relação de influência dominante é requisito essencial para a válida estipulação de acordo de domínio e, portanto, para a formação de um grupo de direito.

Percurso radicalmente diferente foi adotado pelo direito italiano, no qual o vínculo relevante para a responsabilização por abuso, nos termos do artigo 2.497 do Código Civil daquele país, é o (mau) exercício da atividade de coordenação e direção. O controle, definido no artigo 2.359 do mesmo diploma, releva sobretudo para fins contábeis e para a incidência de normas específicas sobre a aquisição e alienação de participações recíprocas ou no capital social de partes relacionadas. Além disso, da existência de controle decorre presunção simples (artigo 2.497 sexies) de exercício da atividade de direção e coordenação. As principais consequências - argumenta-se, ambas negativas - da centralidade da atividade de direção e coordenação no sistema italiano são: (i) a impossibilidade de

345 V. EMMERICH, M. HABERSACK, Konzernrecht, p. 39.

346 U. IMMENGA, The Law of Groups in the Federal Republic of Germany, p. 107. Ressaltando, porém, diferenças e nuances entre os conceitos de controle, do direito francês e inglês, e de influência dominante do direito alemão: V. EMMERICH, M. HABERSACK, Konzernrecht, p. 40. "A noção de 'influência dominante' é amplíssima e parece corresponder à própria noção de poder de controle, [...]" in F. COMPARATO, C. SALOMÃO FILHO, O Poder de Controle na Sociedade Anônima, p. 81. 
responsabilização do acionista dominante por omissão ${ }^{347}$ e (ii) a intensificação do já relevante ônus probatório atribuído aos credores ou acionistas externos prejudicados, aos quais caberá demonstrar não apenas a posição de domínio do réu, mas também o seu efetivo exercício, consubstanciado no elusivo conceito de direção unitária ${ }^{348}$.

Quanto a este segundo aspecto, é importante reiterar que o poder de controle pode, amiúde, ser exercido de forma não ostensiva, por meio de instruções informais e confidenciais aos administradores, ao invés de deliberações aprovadas em assembleia ou outros atos formais. Isso para não mencionar a hipótese em que os administradores espontaneamente ajustam a própria conduta ao comportamento que julgam ser esperado pelo controlador ${ }^{349}$. Nesse sentido, parece adequado e pragmático o atual modelo brasileiro $^{350}$, voltado à questão do poder e não do seu exercício efetivo ${ }^{351}$.

\subsubsection{Controle Minoritário e Grupos de Sociedades}

O controle minoritário, sempre presente em discussões doutrinárias e em esforços de regulamentação da Lei $6.404 / 1976^{352}$, é tema que ganhou atualidade na realidade

347 F. ABATE, A. DIMUNDO, L. LAMBERTINI, L. PANZANI, A. PATTI, Gruppi, Trasformazione, Fusione, Scissione, Scioglimento e Liquidazione, Società Estere (artt. 2484-2510), p. 250.

348 M. VENTORUZZO, Experiments in Comparative Law: The Recent Italian Reform and the Dubious Virtues of a Market for Rules in the Absence of Effective Regulatory Competition, p. 199.

349 H. WIEDEMANN, Gesellschaftsrecht, Band I, p. 351.

350 Conforme aponta Engrácia Antunes, a adoção do controle como critério chave, em lugar da direção unitária, permite uma concepção mais ampla do grupo: "Uma outra noção é baseada no conceito de controle [...]: haverá um grupo sempre que uma companhia controlar outra companhia ou companhias. [...] Neste último caso, emerge uma concepção mais ampla de grupo: uma vez que o critério decisivo ou parâmetro se relaciona ao mero controle, considerando, portanto, a administração unificada como irrelevante ou desnecessária, presume-se ou entende-se existir um grupo pelo simples fato de que uma companhia seja titular de uma maioria estável de votos na assembleia de outra ou detenha outro instrumento de controle". Tradução livre de: "Another notion is based on the concept of control [...]: there is group whenever a corporation controls another corporation or corporations. [...] In this later case, a broader concept of group emerges: since the decisive criterion or parameter relates to mere control, thereby considering unified management as irrelevant or unnecessary, a corporate group is deemed or presumed to exist by the simple fact that a corporation owns a stable majority voting in the annual meeting of another or any other relevant controlling instrument." in J. ANTUNES, The Governance of Corporate Groups, p. 28.

351 O próprio Professor Comparato, a despeito dos comentários favoráveis à noção de direção unitária, ao discutir o controle majoritário em oposição ao minoritário, asseverou que: “[...] ainda que o controlador afete desinteressar-se dos negócios sociais, não pode arredar o fato de que o poder de comando se exerce em seu nome, ou por delegação sua, o que a tanto equivale." in F. COMPARATO, C. SALOMÃO FILHO, O Poder de Controle na Sociedade Anônima, p. 87.

352 "Além disso, a lei admite o controle minoritário, ou seja, o controle exercido por sociedade que detém pequena quantidade de ações, no conjunto do capital social, mas que, face ao absenteísmo ou a inabilitação para o voto por parte dos demais acionistas, tem, na prática, assegurada a preponderância nas deliberações sociais e o poder de eleger a maioria dos administradores." in E. TEIXEIRA, J. GUERREIRO, Das Sociedades Anônimas no Direito Brasileiro, vol. II, p. 703. Oportuno mencionar também a célebre Resolução do Conselho Monetário Nacional - $\mathrm{CMN} \mathrm{n}^{\circ} 401$, de 22 de dezembro de 
brasileira dos últimos anos, com o significativo aumento do número de companhias abertas que não possuem acionista individualmente titular de mais da metade do capital social votante $^{353}$. Ainda que o número efetivo de companhias abertas brasileiras sujeitas a controle minoritário tenha de ser visto com certa cautela ${ }^{354}$, trata-se de questão que efetivamente tende a ganhar importância com o gradual - e esperado - amadurecimento de nosso mercado de capitais e que, com efeito, já ensejou relevantes movimentos e debates em torno de novos temas como a poison pill à brasileira e sua estabilização por meio de cláusulas pétreas ${ }^{355}$.

Oportuno, portanto, analisar a questão do controle minoritário a partir da perspectiva dos grupos de sociedades. O primeiro passo, nesse sentido, é refutar a posição de acordo com a qual simplesmente não existiria controle minoritário ${ }^{356}$. Cumpre a esse respeito recordar que o controle é uma questão de fato e que se, em certa situação concreta, a titularidade de direitos de voto inferiores à maioria absoluta assegura o domínio efetivo sobre a companhia, não existe razão para fechar os olhos a tal realidade e falsamente presumir que a sociedade opere em um suposto limbo político ${ }^{357}$. Se em determinada companhia que não apresente bloco majoritário de acionistas é possível observar, de todo modo, teor mínimo de estabilidade e coerência na condução dos negócios sociais ao longo do tempo, é porque existe, de forma oculta ou explícita, alguma unidade de comando subjacente $^{358}$. Nesse sentido, o único efeito prático da negação do controle nestes casos

1976, já revogada, cujo ponto IV fixava, nas companhias abertas, a prevalência em três assembleias gerais sucessivas como critério de aferição da posição de controlador, relativamente aos acionistas ou grupo de acionistas que não detivessem maioria absoluta dos votos.

353 Estudo de Érica Gorga, de 2008, mostra que de 92 companhias listadas no Novo Mercado, 65 não tinham um acionista com participação majoritária e, em tais sociedades, o maior acionista possuía na média apenas 26,23\% do capital social. E. GORGA, Changing the Paradigm of Stock Ownership from Concentrated towards Dispersed Ownership? Evidence from Brazil and Consequences for Emerging Countries, p. 88.

354 Walfrido Warde Jr. observa como o grupo de sociedades pode ser usado para camuflar como estrutura de capital disperso um controle majoritário indireto. W. WARDE JR., O Fracasso do Direito Grupal Brasileiro: a Institucionalização do Controle Oculto e de sua Sub-Reptícia Transferência, p. 132.

355 Ensejando, inclusive, manifestação da Comissão de Valores Mobiliários, nos termos do Parecer de Orientação n 36, de 23 de junho de 2009.

356 M. CARVALHOSA, Comentários à Lei de Sociedades Anônimas, $2^{\circ}$ vol., p. 572-573.

357 Conforme a clássica lição do Professor Comparato: "Surpreende ainda, como novidade, a idéia simples de que não há sociedade sem controle, assim como não existe empresa sem empresário." in F. COMPARATO, C. SALOMÃO FILHO, O Poder de Controle na Sociedade Anônima, p. XVII.

358 Como salientam Lamy Filho e Bulhões Pedreira, se não se formassem nas companhias com capital pulverizado blocos de minoritários com votos suficientes para determinar os rumos dos negócios sociais, nem tampouco, em alternativa, emergisse controle gerencial, haveria mudanças frequentes na administração, ao sabor de maiorias ocasionais em cada assembleia: "Transformar-se-ia, assim, a utópica 'empresa de todos', na 'empresa de ninguém'.” in A. LAMY FILHO, J. PEDREIRA, Estrutura 
seria sancionar a irresponsabilidade do controlador minoritário, o que é tanto mais grave pelo fato de os seus interesses estarem, tendencialmente, mais desalinhados em relação aos da companhia do que os de um controlador majoritário ${ }^{359}$.

Como bem salienta o Professor Calixto Salomão Filho, na discussão sobre a suficiência ou aceitabilidade do controle minoritário, deve-se sempre ter conta a norma específica a ser aplicada ${ }^{360}$. Prevalecendo a análise de condutas individuais ou de atividades com duração determinada - caso da maior parte das hipóteses previstas no $\S 1^{\circ}$ do artigo 117 - não há razão para não se equiparar, sem maiores questionamentos, o controle minoritário ao controle majoritário. Por outro lado, quando se trata de apurar a existência de posições jurídicas consolidadas, tal como ocorre em relação à verificação da necessidade de oferta pública por alienação de controle, nos termos do artigo 254-A da Lei 6.404/1976, são legítimas maiores indagações sobre a estabilidade do domínio exercido sobre a companhia.

Transposta para a questão dos grupos, tal linha de argumentação se traduz na aceitação de diferentes níveis de permanência e estabilidade para o controle minoritário conforme se trate de (i) apurar responsabilidade da sociedade controladora nos termos do artigo 246 ou (ii) confirmar a satisfação do requisito do controle, para fins de válida celebração de convenção de grupo, nos termos do artigo 265, caput. No primeiro caso,

da Companhia, p. 782.

359 "Quando uma pessoa exerce autoridade de modo a afetar o patrimônio de outra, interesses podem divergir. Quanto menor a participação dos gestores na empresa, tanto mais divergirão os interesses de tais gestores dos interesses daqueles que contribuíram com capital". Tradução livre de: "When one person exercises authority that affects another's wealth, interests may diverge. The smaller the managers' share in the enterprise, the more the managers' interests diverge from the interests of those who contributed capital." in F. EASTERBROOK, D. FISCHEL, The Economic Structure of Corporate Law, p. 91. Recorda-se que cada centavo injustamente subtraído à companhia pelo controlador pesa indiretamente sobre tal acionista dominante na medida da sua própria participação. Quanto menor a sua participação proporcional no capital social, maiores as oportunidades de uso de seu poder para a expropriação dos consócios. É por essa razão que, por exemplo, não se admite no Novo Mercado da BMF\&Bovespa companhias com capital social representado por ações preferenciais sem direito de voto (Regulamento do Novo Mercado, item 3.1(viii)).

360 Professor Calixto Salomão Filho: [...] é fundamental adotar noção de controle tendo em conta a situação de fato. A maioria das hipóteses do art. 117, $\S 1^{\circ}$, refere-se a atos específicos ou atividade de duração determinada. [...] Diferente deve ser a concepção do controle quando a disciplina, para sua aplicação coerente, requer a consolidação de uma posição jurídica. Exemplo claro é a disciplina da alienação de controle e oferta pública. Só há sentido em aplicá-la em relação a posições jurídicas que possam ser avaliadas como tal, inclusive do ponto de vista patrimonial. [...] Conclui-se, portanto, que a discussão controle majoritário-minoritário, mais que uma definição de hipótese legal de incidência, relaciona-se à disciplina a ser aplicada." in F. COMPARATO, C. SALOMÃO FILHO, O Poder de Controle na Sociedade Anônima, nota de texto ${ }^{\circ}$ 9, p. 70-71 
parece evidente que a exigência de estabilidade será menor do que no segundo. Basta, por exemplo, a prevalência em uma única assembleia para tomar medidas de favorecimento a partes relacionadas em prejuízo da companhia. Por outro lado, a institucionalização e formalização do domínio, inclusive com legitimação da subordinação de interesses, que se verificam no grupo de direito, parecem pressupor uma estrutura política minimamente duradoura, que não seja resultado de "supremacia fortuita e aritmética de votos"361-362. Não se pode esquecer, ademais, que a formação do grupo de direito com base em controle minoritário exigiria, de qualquer forma, o concurso dos acionistas não controladores, de forma a se satisfazer o critério de maioria qualificada constante do artigo 136, V, da lei acionária.

\subsubsection{Controle Interno e Controle Externo}

Uma vez que a aderência das formas jurídicas à realidade econômica representa um tema recorrente na doutrina relativa aos grupos, é natural que uma crítica frequentemente endereçada à lei acionária brasileira de 1976 diga respeito ao fato de o diploma não ter disciplinado o controle exercido por outros meios que não a titularidade de direitos de sócio $^{363}$ - requisito expressamente constante do artigo 116, alínea "a" e artigo $243, \S 2^{\circ}-$, ou seja, o controle externo ${ }^{364}$.

361 E. TEIXEIRA, J. GUERREIRO, Das Sociedades Anônimas no Direito Brasileiro, vol. I, p. 295.

$362 \mathrm{Na}$ ausência de critérios legais sobre a permanência e estabilidade do controle, é frequentemente citado o parâmetro - de fato, bastante razoável - de prevalência do acionista em três assembleias sucessivas, constante da revogada Resolução do Conselho Monetário Nacional n 401/1976. N. EIZIRIK, A Lei das S/A Comentada, vol. III, p. 363.

363 Recorda, a esse respeito, o Professor Comparato: "A lei fala, sabiamente, em 'titular de direitos de sócio' e não apenas em 'acionistas' porque, [...], a natureza jurídica de coisa dos valores mobiliários enseja a possibilidade de dissociação entre a titularidade, ou pertinência subjetiva das ações, e a titularidade de direitos destacados dela, como o de voto, segundo ocorre no usufruto ou na alienação fiduciária em garantia. Em tais hipóteses, controlador é quem tem os votos decisivos, não o proprietário das ações." in F. COMPARATO, C. SALOMÃO FILHO, O Poder de Controle na Sociedade Anônima, p. 85.

364 "É mister, no entanto, ressaltar que o controle enquanto elemento unificador do grupo econômico de subordinação, não precisa manifestar-se, necessariamente, sob a forma de participação acionária em todas as sociedades controladas. Há casos de aguda dependência externa, no suprimento de matériaprima ou no escoamento de produção, por exemplo, os quais provocam a integração de uma sociedade em um grupo, sem participação de capital." in F. COMPARATO, C. SALOMÃO FILHO, O Poder de Controle na Sociedade Anônima, p. 45. "Tenho entendido que todo o grupo empresarial - seja ele de fato ou de direito, de subordinação ou coordenação, com controle interno ou externo - consubstancia uma relação societária." (sem grifo no original) in F. COMPARATO, Grupo Societário Fundado em Controle Contratual e Abuso de Poder do Controlador, p. 277. "O reconhecimento da situação de controle externo como típica relação de controle empresarial, ainda estranho ao nosso direito positivo e ainda reticente em nossa jurisprudência, constitui uma necessidade premente em nosso ordenamento, no âmbito do qual a tutela aos abusos desta modalidade de controle ainda reside na mera possibilidade de reparação por perdas e danos sob a regência da lei civil." in R. MACEDO, Limites de Efetividade do Direito Societário na Repressão ao Uso Disfuncional do Poder de Controle nas Sociedades Anônimas, 
Tal visão não deixa de encontrar guarida no direito comparado. No ordenamento italiano, por exemplo, como já se viu, optou-se por um modelo normativo em que a fonte do poder exercido sobre a sociedade é completamente irrelevante para a incidência das normas de responsabilização daquele que exerce o domínio sobre os negócios sociais ${ }^{365}$.

$\mathrm{Na}$ Alemanha, por outro lado, onde o legislador deixou inteiramente ao intérprete a missão de fixar os contornos precisos do conceito de influência dominante (beherrschende Einfluss) consignado no $§ 17$ da lei acionária de 1965, acabou por prevalecer na jurisprudência a ideia de que as normas relativas aos grupos apenas devem incidir em relações que sejam se não determinadas ao menos intermediadas por vínculos societários. As principais razões que ampararam tal conclusão são (i) a grande dificuldade em se encontrar fórmulas práticas para definir o controle externo e distingui-lo das meras relações contratuais bilaterais ${ }^{366}$ e (ii) o fato de que a disciplina dos grupos representa instrumento societário de contraste a abusos de prerrogativas de natureza também societária, pouco adequada portanto às vicissitudes das relações contratuais bilaterais ${ }^{367}$.

O legislador brasileiro foi peremptório ao exigir a titularidade de direitos de sócio como requisito para a caracterização do poder de controle, nos termos e para os fins da legislação societária ${ }^{368}$, de forma que apenas o controle interno pode desencadear todo o

p. 208.

365 U. TOMBARI, Diritto dei Gruppi di Imprese, p. 18.

366 Nas palavras de Emmerich e Habersack, o direito dos grupos restaria em tal hipótese desprovido de confins ou margens (uferlos), resultando em evidente insegurança jurídica. V. EMMERICH, M. HABERSACK, Konzernrecht, p. 41.

367 "Não é tarefa do direito das empresas vinculadas, e sim do Direito Civil, do Direito Concorrencial e do Direito das Condições Gerais dos Negócios, oferecer aos prejudicados a necessária proteção jurídica em face dos riscos gerais de manipulação econômica, na medida em que, em tal campo, se verifique a exigência de tutela em face de inescrupuloso exercício do poder.". Tradução livre de: "Die allgemeinen Risiken einer marktwirtschaftlichen Betätigung zu erfassen und, soweit in diesem Bereich ein Schutzbedürfnis gegenüber rücksichtsloser Machtausübung auftritt, dem Betroffenen den nötigen Rechtsschutz zu gewähren, ist dagegen nicht die Aufgabe des Rechts der verbundenen Unternehmen, sondern des Zivilrechts, des Wettbewerbsrechts und des Rechts der allgemeinen Geschäftsbedingungen." conforme parágrafo 36 da decisão do Tribunal de Justiça Federal da Alemanha, II Câmara Civil, de 26 de março de 1984 (BGHZ 90, S. 381). Na referida decisão, o tribunal asseverou que vínculos contratuais particularmente profundos - tais como contratos de licença, fornecimento ou licenciamento - podem reforçar a dependência societária, mas não substituí-la por completo.

368 Para o direito concorrencial, ao revés, no qual o foco está no poder econômico, tendo em vista a possibilidade de manipulação do mercado, admite-se tranquilamente o controle externo. $\mathrm{O}$ mesmo conceito se aplica a regulamentações setoriais, tais como no campo das telecomunicações. N. EIZIRIK, A. GAAL, F. PARENTE, M. HENRIQUES, Mercado de Capitais - Regime Jurídico, p. 389-391. Conforme o Professor Calixto Salomão Filho: "É certo, por outro lado, que os conceitos concorrenciais não são perfeitamente coincidentes com os utilizados no direito societário propriamente dito. Para caracterizar a concentração, substitui-se o conceito de controle pelo conceito mais amplo de influência dominante. [...] As diferenças são marcadas a ponto de se falar hoje na existência de um direito 
espectro de consequências atribuídas pela Lei 6.404/1976 à posição jurídica de controlador $^{369}$.

É importante considerar, igualmente, que, desde a promulgação da lei acionária de 1976, verificaram-se significativas mudanças no tratamento jurídico dos contratos bilaterais, que parecem tornar menos premente a necessidade de transposição ou "empréstimo", para tal campo, dos mecanismos de proteção de partes vulneráveis, originalmente concebidos no direito societário. Efetivamente, vivemos na vigência de um Código Civil ajustado, cuja reforma de 2002 se pautou explicitamente pelos princípios da socialidade, eticidade e operabilidade ${ }^{370}$. Em sua redação atual, o diploma positivou conceitos como a boa-fé objetiva (artigo 422) e a onerosidade excessiva (artigo 478). Além disso, várias espécies de contratos bilaterais de longa duração particularmente propensos à formação de situações de dependência econômica receberam regulamentação específica, no mais das vezes altamente protetiva, tal como, por exemplo, a concessão comercial de veículos automotores (Lei 6.729/1979) ou a franquia empresarial (Lei Federal 8.955/1994). A Lei Federal 12.529/2011 tipifica, ademais, como infração administrativa de natureza objetiva, uma série de condutas tradicionalmente associadas à opressão contratual em arranjos de longa duração (vide, por exemplo, incisos XI e XII do artigo $36, \S 3^{\circ}$ de tal diploma).

societário concorrencial." in F. COMPARATO, C. SALOMÃO FILHO, O Poder de Controle na Sociedade Anônima, nota de texto 4, p. 43. Ascarelli, com seu peculiar vanguardismo, já assinalava a possibilidade e a oportunidade de adoção de critérios mais flexíveis para a análise dos vínculos de coligação e controle nas "normas contra os monopólios". T. ASCARELLI, Problemas das Sociedades Anônimas e Direito Comparado, p. 486-487.

369 "Tal modalidade de 'controle externo', exercido não mediante o poder de controle acionário, mas mediante vínculos contratuais ou situações fáticas não previstas na Lei das S.A., não se caracteriza como controle acionário; assim, da sua configuração, não decorre qualquer consequência na esfera do direito societário, muito menos a responsabilidade pela eventual infração a qualquer das modalidades de abuso de poder previstas no artigo 117 da Lei das S.A." in N. EIZIRIK, A. GAAL, F. PARENTE, M. HENRIQUES, Mercado de Capitais - Regime Jurídico, p. 390. A regra do artigo 249, alínea "a", sobre a inclusão nas demonstrações financeiras consolidadas de sociedades financeira ou administrativamente dependentes reforça, ao invés de contradizer, o entendimento a respeito da prevalência e da exclusividade do controle interno, pois atesta que o legislador considerou o fenômeno do controle externo e fez uma escolha política de discipliná-lo de modo distinto. Poder-se-ia tentar extrair um indício de aceitação do controle externo na referência a controle exercido "mediante acordo", constante do $\S 1^{\circ}$ do artigo 265, aparentemente posta como alternativa à titularidade de direitos de sócio. Entretanto, vale notar que, além de partir das definições de "controladora" e "controlada", que em si já encerram a noção de controle interno, o dispositivo em questão usa a expressão "mediante acordo com outros sócios ou acionistas. Ou seja, ambas as partes do acordo em questão devem ser titulares de direitos de sócio. Parece, portanto, como discutido no Capítulo 8, que se trata apenas de referência a acordo de voto, em linha com o que dispõe o caput do artigo 116.

370 M. REALE, História do Novo Código Civil, p. 37-40. 
Nesse novo cenário, as partes sujeitas a dependência econômica em relação a terceiros, em função de vínculos contratuais não societários, já não se encontram mais completamente órfãs de adequada tutela jurídica, a justificar um alargamento contra legem do conceito de controle constante das normas acionárias. O ponto não é que as situações de forte dependência econômica normalmente classificadas como controle externo não mereçam tutela jurídica, pois em diversos casos o reequilíbrio da situação pelo legislador ou pelos tribunais é legítimo e absolutamente indispensável. A questão é em que medida a melhor maneira de fazê-lo seria realmente por meio da sugerida equiparação da parte contratual economicamente forte ao acionista controlador.

De resto, não sem certo cinismo, pode-se argumentar que em uma realidade como a brasileira, na qual claramente não se soube sequer equacionar adequadamente a questão do disseminado abuso de direitos e do conflito de interesses no âmbito dos grupos sujeitos a inequívoco controle interno e majoritário ${ }^{371}$, a questão do controle externo deve ser tratada, no mínimo, como prioridade menor.

Com essas considerações, contudo, não se quer obviamente excluir do campo do direito dos grupos as situações em que o controle seja fraudulentamente camuflado ou ocultado.

\subsubsection{Formação da Vontade na Sociedade Isolada e nos Grupos}

É evidente que a formação do grupo tem profundo impacto sobre a estrutura política das sociedades envolvidas. Como já se mencionou anteriormente, a estrutura plurissocietária transfere poder em favor dos administradores e torna mais opaca justamente porque mais intermediada pelos sistemas de deliberação e documentação de eventos de cada sociedade individual - a circulação das informações, dos fluxos financeiros e das instruções. Contudo, é oportuno analisar criticamente uma afirmação recorrentemente constante das obras que tratam deste tema, no sentido de que a formação do grupo levaria a um deslocamento do eixo de tomada das decisões para fora das sociedades controladas ${ }^{372}$.

371 Discute-se a ineficácia da disciplina brasileira dos grupos na Parte III deste trabalho.

372 "O fenômeno mencionado é a transposição, para dentro da controlada, de decisões tomadas acima dela, no interior da controladora". Tradução livre de: "Il fenomeno menzionato è la trasposizione, entro la controllata, di decisioni prese al di sopra di essa, all'interno della controllante." in F. GALGANO, Direzione e Coordinamento di Società - Art. 2497-2497 septies, p. 128. "[...] empresas juridicamente autônomas, cuja gestão é influenciada de maneira relevante, mais do que isso, determinante por um 
Dizer que, na presença do grupo, o núcleo decisório se desloca para fora da sociedade - ou seja, afirmar que o grupo é a causa eficiente de tal mudança na estrutura política da sociedade - significa afirmar a contrario sensu que, ausente a estrutura plurissocietária, a formação da vontade ocorrerá no seio do próprio ente societário ${ }^{373}$. Esta, porém, representa uma visão idealizada dos processos de decisão da sociedade isolada, que parece refletir valores da já há muito superada concepção democrática, ou fícção assemblear, das deliberações sociais ${ }^{374}$.

centro decisório a elas externo". Tradução livre de: "[...] imprese giuridicamente autonome, la cui gestione è influenzata in maniera rilevante ed anzi determinante da un centro decisionale ad esse esterno." in G. SCONAMIGLIO, Danno Sociale e Azione Individuale nella Disciplina della Responsabilità da Direzione e Coordinamento, p. 950. "De fato, essa forma específica de organização da empresa [o grupo de sociedades] trouxe um novo e decisivo fato para a dissolução do papel estatutário do referido órgão social [a assembleia geral]: a criação de uma fonte exógena de governo dos negócios sociais externa à própria sociedade controlada (gestão unificada do grupo". Tradução livre de: "As a matter of fact, this particular form of enterprise organization [o grupo de sociedades] brought a new and decisive factor to the dissolution of the statutory role of such a corporate organ [a assembleia geral]: the creation of an alien source of corporate governance external to the subsidiary corporation itself (unified group management)." in E. ANTUNES, Liability of Corporate Groups Autonomy and Control in Parent-Subsidiary Relationships in US, German and EU Law - An International and Comparative Perspective, p. 100-101. "Quanto à responsabilidade do sócio pelos atos de heterogestão, se parece claro que subjacente ao principio geral do qual a nova fattispecie é expressão esteja a intenção de tomar nota, e consequentemente disciplinar, o fenômeno da 'alienação do governo' da sociedade ou, em outras palavras, da translação dos poderes de gestão para fora da sua estrutura organizativa; [...]". Tradução livre de: "Quanto poi alla responsabilità del socio per atti di eterogestione, se pare indubbio che sotteso al principio generale di cui la nuova fattispecie è espressione vi sia l'intento di prendere atto, e conseguentemente disciplinare, il fenomeno della 'alienazione del governo' della società o, altrimenti detto, della traslazione dei poteri gestori al di fuori della sua struttura organizzativa; [...]" in R. SANTAGATA, Autonomia Privata e Formazione dei Gruppi nelle Società di Capitali, p. 814.

373 Por vezes, a afirmação é direta e não a contrario sensu: "A disciplina do direito societário é calcada na idéia de entes juridicamente autônomos, devendo a vontade social ser formada dentro da própria estrutura da sociedade e depurada de influências exteriores." in V. PRADO, Conflito de Interesses nos Grupos Societários, p. 166. A referida assertiva não parece válida em relação às normas acionárias brasileiras, que se ancoram nos conceitos de poder de controle, dever de lealdade e conflito de interesse, sinais inegáveis de uma tomada de consciência quanto à superação do ideal democrático-assemblear de deliberação social.

374 Palavras do Professor Comparato: "Até há pouco tempo, o modelo legal, ao qual ainda aderiam doutrina e jurisprudencia, concebia as companhias como destituídas de mando ou controle predeterminado, admitindo que os negócios sociais fossem decididos em assembléia, por uma maioria formada ad hoc, após amplos debates e momentânea deliberação. Daí decorria a disciplina da assembléia geral e do exercício do voto como um verdadeiro direito eleitoral, quando a realidade quotidiana não cessava de desmentir essa 'concepção parlamentar" (sem grifo no original) in F. COMPARATO, C. SALOMÃO FILHO, O Poder de Controle na Sociedade Anônima, p. XVII. "Uma assembléia geral - repita-se o que se disse alhures - é uma reunião de 'sacos de dinheiro que votam', e não uma festa cívica." in A. LAMY FILHO, J. PEDREIRA, Estrutura da Companhia, p. 779. " $\underline{A 0}$ definir a figura do acionista, permitindo a identificação do poder de controle acionário, a Lei das S.A. superou a 'ficção democrática' da sociedade anônima, que acarretava a diluição das responsabilidades pelas deliberações sociais, uma vez que prevalecia até então a noção de que as decisões eram tomadas pela comunhão dos acionistas, como se não existissem acionistas controladores e minoritários." (sem grifo no original) in N. EIZIRIK, A. GAAL, F. PARENTE, M. HENRIQUES, Mercado de Capitais Regime Jurídico, p. 389-391. 
Independentemente da existência ou não da estrutura de grupo, a assembleia geral da sociedade isolada - por exemplo, aquela que tenha somente pessoas físicas como sócias - não é, ao menos não na quase totalidade dos casos, o palco de amplos debates que desempenham um papel fundamental no convencimento - que se consumaria apenas naquele momento e naquele foro - dos acionistas, os quais agiriam sobretudo considerando o interesse do próprio ente societário. Sabidamente, as companhias (agrupadas ou não) operam com base em deliberações já tomadas de antemão e as assembleias gerais são, no mais das vezes, instâncias de ratificação formal de maiorias pré-constituídas.

Esse fenômeno de sujeição a uma vontade externa não é, portanto, "privilégio" da sociedade grupada. Ele não se deve à estrutura de grupo, mas sim à afirmação histórica do princípio majoritário, sobretudo em sua variante de maioria de capital, como mecanismo de governo das sociedades, associado ao reconhecimento da personalidade jurídica destas.

Com isso, é importante frisar, não se quer afirmar que a questão do controle não tenha importantes particularidades no âmbito dos grupos de sociedades - muitas das quais já apontadas anteriormente -, mas simplesmente reconhecer o fato de que não se trata de um problema ontologicamente diverso daquele que se verifica no processo de formação das decisões de qualquer sociedade isolada.

A desconexão entre personalidade jurídica, interesse e vontade - que, idealmente, deveriam estar reunidos no próprio sujeito de direito, ainda que historicamente e efetivamente muitas vezes não estejam - não é resultado da emergência dos grupos, mas sim da mais ampla e profunda questão do poder de controle. Essa constatação - a de que o problema do poder nos grupos é apenas expressão particular das dificuldades ensejadas pelo controle societário em geral - é extremamente relevante tanto para a análise dos grupos de sociedades, quanto para a sugestão de novas propostas de regulamentação do fenômeno.

\subsubsection{Coligação}

No regime anterior à Lei 6.404/1976, o artigo 135, § 2º do Decreto-Lei 2.627/1940 fazia apenas referência genérica à obrigação de fornecer informações sobre "sociedades controladas e coligadas", sem trazer definições precisas de tais conceitos ${ }^{375}$.

375 L. LEÃES, Sociedades Coligadas e Consórcios, p. 137. 
A partir da vigência da lei acionária de 1976, a expressão passou a designar especificamente uma situação intermediária entre (i) a simples participação de uma sociedade no capital social de outra e (ii) a titularidade do poder de controle.

De acordo com a redação original da Lei 6.404/1976 a definição básica de coligada estava vinculada a dois critérios cumulativos: (i) um positivo e puramente quantitativo, na forma de titularidade de mais de dez por cento do capital social da sociedade participada; e (ii) outro negativo e qualitativo, com a exigência de que tal posição não pudesse conferir ao seu titular o poder de controle sobre a sociedade participada $^{376}$.

Dentro do gênero sociedade coligada, a lei acionária previa ainda uma espécie de coligação qualificada, nos termos do artigo 248 , que ensejava não apenas a sujeição ao disposto no artigo 245, relativo ao conflito de interesse nos grupos de fato e também aplicável à coligação "ordinária", mas também a obrigação da avaliação do investimento detido na respectiva participada pelo método do patrimônio líquido (equivalência patrimonial), bem como a inclusão de detalhes sobre tal investimento nas notas explicativas ao balanço (artigo 247). Os critérios para a caracterização dessa modalidade especial de coligação eram, alternativamente, (i) o exercício de influência sobre a administração da participada e/ou (ii) titularidade de mais de vinte por cento de seu capital social.

A Lei Federal 11.638/2007 alterou a redação do artigo 248 e substituiu o critério de influência na administração pelo conceito de "influência significativa". A Medida Provisória 449/2008, cujas alterações restaram confirmadas pela Lei Federal 11.941/2009, promoveu uma unificação da definição de sociedade coligada, excluindo portanto o anterior desdobramento do conceito em sociedades sujeitas e não sujeitas à disciplina contábil prevista pelos artigos 247 e 248 da Lei 6.404/1976. Além disso, foram acrescidos dois parágrafos ao artigo $243\left(\S \S 4^{\circ}\right.$ e $\left.5^{\circ}\right)$, respectivamente (i) para definir o conceito de influência significativa como o "poder de participar nas decisões das políticas financeira ou operacional da investida, sem controlá-la" e (ii) para fixar presunção ${ }^{377}$ de existência de

376 "Coligação e controle são realidades repelentes. [...] Logo, se a investidora for controlada da investida, não se há de cogitar de coligação, precisamente porque esta é um minus em relação ao controle." in E. VALLADÃO FRANÇA, M. VON ADAMEK, O Novo Conceito de Sociedade Coligada na Lei Acionária Brasileira, p. 377.

377 A toda evidência se trata de presunção absoluta, não sujeita a prova contrária. "Tal como já ocorria na 
tal poder, nas hipóteses de titularidade de mais de vinte por cento do capital social votante $^{378}$ da sociedade participada.

A reforma do conceito de coligada parece ter tomado em consideração apenas a sua aplicação contábil, sem dar devida atenção à sua relevância no campo da tutela do conflito de interesses no do direito dos grupos. A nova disciplina foi objeto de diversas detalhadas e merecidas - críticas por parte de Erasmo Valladão França e Marcelo von Adamek, as quais podem ser apertadamente resumidas em: (i) houve adoção de múltiplos e discrepantes conceitos, para fins diferentes, sob a mesma designação; (ii) a natureza fluída e indeterminada do novo conceito de coligada desconsidera sua utilização para fora da esfera contábil e cria notável insegurança jurídica; bem como (iii) os novos critérios, ao invés de ampliar o universo das sociedades qualificáveis como coligadas, o esvazia, na medida em que (a) a presunção de coligação exige níveis superiores de investimento proporcional, se comparados aos da legislação anterior, (b) o novo regime substituiu critérios claros e objetivos por requisitos fluídos e abertos e (c) se colocou em dúvida a bilateralidade da coligação $0^{379}$.

No que diz respeito especificamente às normas grupais, o conceito de coligação releva sobretudo para os grupos de fato, nos termos da interpretação sistemática dos $\S \S 1^{\circ}$, $4^{\circ}$ e $5^{\circ}$ do artigo 243, combinados com o artigo 245 da Lei 6.404/1976. Na delimitação dos contornos externos do grupo de fato, é importante levar em consideração dois aspectos dos

antiga definição legal, o percentual escolhido pelo legislador é arbitrário e, em realidade, é até muito elevado em companhias abertas. De toda a forma, a presunção legal é aqui absoluta; juris et de jure; portanto, insuscetivel de prova noutro sentido." in E. VALLADÃO FRANÇA, M. VON ADAMEK, $O$ Novo Conceito de Sociedade Coligada na Lei Acionária Brasileira, p. 372. Com efeito, uma participação superior a vinte por cento do capital social enseja diversos e relevantes direitos de minoria, tal como a nomeação de representantes para o conselho de administração, nos termos do artigo 141 da Lei 6.404/1976. Poderia se indagar, na esteira da praxe alemã dos acordos de exclusão de domínio (Entherrschungsvertrag), a respeito da possibilidade de celebração de acordo de acionistas tendo por objeto a renúncia expressa à influência significativa. Contudo, essa prática não parece ter sido incorporada à realidade brasileira e, de qualquer forma, esbarraria no caráter cogente e não passível de renúncia de muitas das normas que instituem prerrogativas em defesa dos acionistas minoritários.

378 A esse respeito, pode-se levantar legítima dúvida: “O que se deve entender por 'capital votante' na espécie? Eis mais um ponto obscuro na nova conceituação legal. No direito italiano, a regra faz expressa referência aos votos em assembleia ordinária [...]. No direito brasileiro, a dúvida que se coloca é se as preferenciais com voto restrito (LSA, art. 111, caput) entram ou não no cômputo do 'capital votante'. [...] Evidentemente, é algo chocante supor que, para positivar a presunção de influência significativa, se tenha que tautologicamente verificar se ações concedem... influência significativa." in E. VALLADÃO FRANÇA, M. VON ADAMEK, O Novo Conceito de Sociedade Coligada na Lei Acionária Brasileira, nota de rodapé $\mathrm{n}^{\circ}$ 12, p. 372.

379 E. VALLADÃO FRANÇA, M. VON ADAMEK, O Novo Conceito de Sociedade Coligada na Lei Acionária Brasileira, p. 382-383. 
vínculos de coligação: (i) a ausência de colateralidade e (ii) sua bilateralidade ou, alternativamente, seu caráter unilateral-assimétrico, conforme a interpretação que se faça da nova redação dada aos artigos 243 e 248 Lei 6.404/1976.

Ao contrário do poder de controle, a influência significativa não se projeta através ou para além de cada sociedade participada. Nesse sentido, entende-se por não colateralidade o fato de que o vínculo de coligação esteja adstrito a cada par de sociedades investidora e investida, de modo que duas sociedades sujeitas à influência significativa de uma terceira (e, portanto, coligadas com esta última) não são, reciprocamente, coligadas entre $\mathrm{si}^{380}$.

Já a questão da bilateralidade-simétrica versus unilateralidade-assimétrica consiste em aferir se, presente o vínculo de influência significativa, tanto a investida quanto a investidora serão consideradas coligadas, uma reciprocamente em relação à outra, ou apenas uma delas. A questão perdeu clareza com as alterações introduzidas na lei acionária em 2008. A redação original do $\S 1^{\circ}$ do artigo 243 deixava evidente que, satisfeitos os critérios para a existência de vínculo de coligação, ambas as sociedades, investidora e investida, seriam consideradas "coligadas". Na nova disciplina, a interpretação literal de tal dispositivo sugere que apenas a sociedade investida será considerada coligada. São relevantes as potenciais consequências dessa redação pouco adequada para a delimitação do perímetro do grupo de fato.

A sociedade meramente coligada não pode ser parte da convenção de grupo e, portanto, não pode integrar o grupo de direito, em função do expresso requisito da sujeição ao poder de controle, direto ou indireto, da sociedade de comando. Enquanto o grupo de direito exige o controle, o vínculo de coligação o repele. Nesse sentido, pode-se dizer que, na visão do legislador de 1976, a coligação representa por definição um campo de exclusão da subordinação legítima de interesses (ínsita à convenção de grupo) - ou, mais precisamente, a subordinação será tolerada apenas se e, na medida em que, for acompanhada de específico "pagamento compensatório adequado" (artigo 245).

380 "[...] não se concebe coligação por vínculo colateral: a coligação se estabelece exclusivamente entre a sociedade que tem influência significativa e a sociedade sujeita a tal poder, mas não entre as sociedades sujeitas à influência de uma mesma sociedade. Portanto, se A tem influência significativa sobre $B$ e também sobre $C, B$ e C não são entre si coligadas." in E. VALLADÃO FRANÇA, M. VON ADAMEK, O Novo Conceito de Sociedade Coligada na Lei Acionária Brasileira, p. 382. No mesmo sentido: J. LUCENA, Das Sociedades Anônimas - Comentários à Lei, vol. III, p. 713-714. 
É de se questionar, a esse respeito, em que medida o vínculo que tenha como elemento caracterizador a exclusão do poder de controle possa efetivamente servir como instrumento para a subordinação de interesses. Pela sua natureza, a coligação parece se prestar muito mais a abusos tópicos - operações, deliberações e contratos específicos - do que a qualquer forma de desequilíbrio duradouro e estrutural, traço típico do controle intersocietário. Assim, por exemplo, a participante coligada pode incorrer em abuso de minoria ao recusar a aprovação de deliberação sabidamente benéfica para a sociedade participada, mas sujeita a quórum qualificado por disposição estatutária. Ela não terá, porém, os meios para determinar os rumos e as atividades da participada, fazendo com que esta atue de modo permanente em seu próprio benefício. Afinal, se pudesse fazê-lo, não seria mais coligada, mas controladora minoritária.

Essas ponderações são úteis para se abordar uma segunda indagação: sociedades unidas apenas por vínculos de coligação, sem qualquer relação de controle, formam um grupo de fato? Ou seja, se a sociedade $A$ detém participação de trinta por cento no capital das companhias $B$ e $C$, sem controlá-las, estamos diante de um grupo de fato? A resposta, inevitavelmente, deve ser dada em partes e depende da perspectiva adotada. Pode-se afirmar com segurança que o conjunto formado por $A, B$ e $C$ não representa uma empresa plurissocietária capitaneada por $A$, uma vez que esta última não tem as prerrogativas necessárias para dirigir as atividades de suas coligadas. Nesse sentido, por não ser controladora, $A$ também não está sujeita ao disposto nos artigos 116, 117 e 246 da Lei 6.404/1976. Por outro lado, $A$ deve exercer seu direito voto nas deliberações de $B$ e $C$ em pleno respeito ao disposto no artigo 115 do mesmo diploma, e os administradores de $B$ e $C$ que, por qualquer razão, favorecerem $A$ nas relações com tais companhias estarão plenamente sujeitos ao disposto no artigo 245 , dispositivo que representa parte do núcleo da disciplina legal dos grupos de fato.

\subsection{Fundamento Dogmático do Conceito de Grupo}

Como discutido anteriormente, existe aparente consenso quanto ao fato de que o grupo representa um conjunto de sociedades juridicamente autônomas sujeitas a uma unidade de comando, a qual, por sua vez, se traduz em integração econômica. Menos claro, porém, é o possível enquadramento jurídico de tal dado da realidade ${ }^{381}$. No presente

381 "A dificuldade em se estabelecer uma definição jurídica para os grupos também pode ser apontada 
subcapítulo, são analisadas criticamente duas teses a esse respeito, a do grupo como simulação e a do grupo como sociedade de sociedades, para se discutir, em seguida, uma definição jurídica alternativa de tal conceito.

\subsubsection{Crítica à Tese do Grupo como Simulação}

Em sua obra pioneira sobre o tema, de 1932, Francesco Messineo não empregou meias palavras ao classificar a relação de controle de sociedade personificada por outra sociedade personificada não apenas como uma expressão de simulação, mas de simulação absoluta $^{382}$. É importante ter em mente que o ilustre doutrinador italiano teve a prudência de sublinhar o fato de que a simulação não se identifica automaticamente com a fraude, nem a esta pode ser reduzida, uma vez que inúmeras operações simuladas podem se prestar a fins perfeitamente legítimos ${ }^{383}$.

Ainda assim, na visão de Messineo, a constituição de uma sociedade controlada ou "sociedade instrumental" conforme a denominação então julgada mais rigorosa pelo jurista - teria como escopo, intrínseco e inexorável, a disponibilidade de um "homem de palha" que fosse "indefinidamente dócil". De acordo com tal perspectiva, a controlada não seria nada mais do que um alter ego, um indevido desdobramento da personalidade da controladora que, desse modo, estaria em condições de celebrar um contrato consigo mesma, transmitindo, porém, ao mundo exterior, a aparência de alteridade subjetiva ${ }^{384}$. E isso sem incorrer nos principais riscos e inconvenientes tradicionalmente decorrentes do

como uma das causas da inexistência de uma regulação específica sobre a matéria na maioria dos países, a despeito de sua forte presença, há várias décadas, na realidade empresarial." in E. MUNHOZ, Empresa Contemporânea e Direito Societário: Poder de Controle e Grupos de Sociedades, p. 109.

382 "Com a criação de uma sociedade filha, a sociedade mãe persegue o escopo preciso de obter o fictício desdobramento permanente da própria subjetividade jurídica, ainda que permanecendo economicamente como um centro único de interesses. Um caso que eu não hesito em qualificar como simulação absoluta". Tradução livre de: "Con la creazione di una società-figlia, la società-madre persegue lo scopo preciso di conseguire il fittizio sdoppiamento permanente della propria soggettività giuridica, pur restando economicamente un unico centro di interessi. Un caso che io non esito a qualificare di simulazione giuridica." in F. MESSINEO, Le Società di Commercio Collegate (c.d. Società a Catena), p. 12. Ascarelli afirmou que a posição de Messineo a esse respeito restou isolada, uma vez que mesmo os demais defensores da tese da simulação se referiam a simulação relativa. T. ASCARELLI, Problemas das Sociedades Anônimas e Direito Comparado, nota de rodapé n 114, p. 133.

383 "É um velho erro dogmático, que corresponde a um preconceito, associar simulação e atividade fraudulenta". Tradução livre de: " $\dot{E}$ un vecchio errore dogmatico che corrisponde ad un pregiudizio, quello di associare simulazione ad attività fraudolenta." in F. MESSINEO, Le Società di Commercio Collegate (c.d. Società a Catena), p. 13. No mesmo sentido, mas esclarecendo que sequer se poderia falar em simulação, uma vez que ambas as sociedades poderiam coexistir: T. ASCARELLI, Problemas das Sociedades Anônimas e Direito Comparado, nota de rodapé n 107, p. 130.

384 F. MESSINEO, Le Società di Commercio Collegate (c.d. Società a Catena), p. 12. 
recurso a um prestanome ("testa de ferro", "laranja") de carne e osso, quais sejam: (i) o risco de rebelião de tal sujeito contra seu mandante-cúmplice ou (ii) a penhora dos bens que lhe foram confiados para a satisfação de seus credores pessoais.

No momento histórico em que Messineo se debruçou sobre a questão, quando ainda prevaleciam no direito societário conceitos especificamente forjados para a sociedade isolada, tal visão exacerbadamente conservadora sobre a natureza jurídica dos vínculos de grupo era, ao menos em parte, compreensível e minimamente defensável.

Conforme sublinha Ascarelli, o percurso histórico da criação e afirmação de diversos institutos jurídicos frequentemente passa pela adaptação e pela profunda remodelação de instrumentos típicos preexistentes, atribuindo-lhes finalidades completamente diversas daquelas para as quais foram originalmente concebidos ${ }^{385}$. É plausível supor que, em sua gênese histórica, a empresa plurissocietária tenha representado um negócio indireto, por meio do qual se buscava uma ulterior compartimentação patrimonial, não expressamente contemplada pelas normas societárias então vigentes.

Atualmente, porém, a tese de Messineo é nitidamente obsoleta, datada e inadequada. Ressalvadas as hipóteses de emprego efetivamente abusivo e fraudulento do instituto, a empresa plurissocietária não representa um mero anteparo artificial para encobrir uma distinta e verdadeira estrutura jurídica e econômica subjacente ${ }^{386}$. Ela é, em si mesma, parte integrante da realidade econômica. A estrutura de grupo não é um simulacro. Ela é, e abertamente é apresentada para o mundo como, um importantíssimo, autônomo e específico instrumento para a organização da atividade produtiva.

Nos dias que correm, a típica parte que celebra um contrato economicamente relevante com uma das tantas sociedades pertencentes a um dos grandes grupos transnacionais, por exemplo, não tem qualquer ilusão de ter como contraparte uma

385 "O negócio indireto representa, então, como que uma ponte de passagem histórica; novas exigências, de início satisfeitas, apenas indiretamente, mediante negócios disciplinados à vista de exigências diversas, acabam por poderem ser satisfeitas, diretamente, por meio de novos negócios que as levam, diretamente, em conta" in T. ASCARELLI, Problemas das Sociedades Anônimas e Direito Comparado, p. 118.

386 Nesse sentido, com a devida vênia, cumpre discordar do Professor Leães, que em texto de 1973, em referência ao trabalho de Messineo, asseverou que: "Com efeito, a forma jurídica, nas coligações $e$ controles societários, não corresponde à substância que se propõe revestir, porque, se formalmente as sociedades se apresentam autônomas, substancialmente elas se integram, formando um grupo." in L. LEÃES, Sociedades Coligadas e Consórcios, p. 142. 
sociedade isolada e independente, livre de todas e quaisquer influências externas, nem tampouco de estar, automaticamente, vinculada contratualmente a toda a constelação de sociedades de tal grupo, como se este fosse um sujeito de direito único. No mais das vezes, é perfeitamente sabido e inequívoco que se contrata com uma sociedade controlada, titular de uma esfera patrimonial própria, mas sujeita a uma vontade externa. A estrutura de grupo não surge para camuflar uma realidade econômica diversa da apresentada, mas justamente para viabilizar a segmentação de riscos, a separação entre propriedade e controle do capital, a associação de capitais e a mobilização de investimentos.

Vertente moderada da posição defendida por Messineo, é a afirmação de que, apenas no caso da holding pura - ou seja, sociedade cujos resultados econômicos seriam auferidos unicamente a partir de participações societárias - haveria simulação ou, de qualquer forma, grande risco de abuso, uma vez que tal sociedade não exerceria nenhuma atividade própria, mas se limitaria a exercer mediata e indiretamente a atividade de suas controladas. Trata-se de posição sustentada por Cesare Vivante, em meados da década de 1930, por ocasião da discussão da reforma da disciplina das sociedades anônimas no direito italiano, mas que parece ter deixado vestígios em manifestações mais recentes da doutrina nacional ${ }^{387}$. Em artigo de 1935, o grande mestre italiano defendia, com efeito, notáveis restrições às participações intersocietárias ${ }^{388}$ e sugeria regras particularmente rígidas para as sociedades por ele definidas como financeiras (società finanziarie), nas quais os investimentos em outras sociedades fosse prevalente em relação à atividade industrial ou comercial "própria". Para Vivante, estas últimas eram particularmente propensas a abusos e distorções e estruturalmente incompatíveis com a disciplina das sociedades por ações. Os pontos críticos vislumbrados eram (i) os efeitos irreversíveis da

387 "Ascarelli, ao invés de simulação, fala em negócio indireto, que ocorre quando as partes recorrem a um determinado tipo de negócio jurídico, não para alcançarem o escopo que lhe é peculiar, mas sim para obterem resultados que normalmente não são próprios da estrutura jurídica adotada. Especialmente na holding pura, a sociedade assumindo um papel puramente financeiro, não se destina a exercer atividade própria nenhuma." (sem grifo no original) in L. LEÃES, Sociedades Coligadas e Consórcios, p. 142. "Tem a sociedade holding como característica diferencial e objeto principal a participação em uma atividade econômica de terceiros ao invés do exercício de atividade produtiva ou comercial própria. [...] Sua finalidade é comercial, indiretamente exercida." in M. CARVALHOSA, Sociedade "Holding" - Bens Excluídos do Giro de seus Negócios, p. 37.

388 Como condições à válida participação de uma sociedade no capital social de outra, sem com isso se considerar a primeira "società finanziaria", o grande jurista sugeria: (i) que a atividade dominante fosse exercida pela controladora, (ii) que o capital investido pela controladora nas controladas não superasse $o$ montante destinado à sua própria atividade e (iii) que existisse coordenação e afinidade do ponto de vista técnico, entre as atividades de controladora e controlada, para se evitar o agrupamento de atividades heterogêneas. C. VIVANTE, Proposte per la Riforma delle Società Anonime, p. 15-16. 
subordinação de interesses sobre a estrutura empresarial dos entes associados, (ii) a confusão patrimonial entre eles e, enfim (iii) a emissão de ações pela controladora com base na participação detida na controlada e, portanto, supostamente em "duplicidade", uma vez que tendo lastro em acervo patrimonial real já representado pelas ações da controlada $^{389}$.

À luz da praxe empresarial e tratamento legislativo dos grupos na atualidade, essa segunda posição, intermediária, também merece ser refutada ${ }^{390}$.

Apenas como exemplo, quando uma sociedade de investimentos - detida, a seu turno, por um fundo de private equity ou banco de investimentos - repetidamente adquire ou cede a participação de controle sobre sociedades diversas, ela não busca camuflar uma sua suposta completa identidade econômica mantida com estas últimas. $\mathrm{Na}$ verdade, em tais casos, a investidora simplesmente está tratando as sociedades controladas como mercadoria - uma solução que seria quase certamente inviável com a adoção de qualquer outra estrutura alternativa. É justamente pelo fato de a estrutura de grupo permitir a redução das participações de controle a mercadoria ${ }^{391}$, criando uma inédita mobilidade de recursos, que se pode afirmar que a gestão e a disposição de tais investimentos - ou seja a atividade da holding - representam, em si mesmas, uma atividade própria e autônoma da sociedade controladora, que não se decanta em mero exercício intermediado do objeto da controlada ${ }^{392}$.

389 C. VIVANTE, Proposte per la Riforma delle Società Anonime, p. 18-19.

390 Extremamente interessantes e permeadas da riqueza de metáforas que lhe são peculiares, as considerações de Ripert a esse respeito: "Existem, de fato, sociedades que não possuem nenhuma empresa para administrar. As holdings não têm outra atividade além da boa gestão dos títulos que possuem. Os economistas denunciam, por vezes, tal má utilização da sociedade. O mecanismo lhes parece girar no vazio inutilmente. É possivel, mas se vê admiravelmente em tal tipo a diferença entre a sociedade e a empresa; vê-se a máquina jurídica funcionar para a simples gestão dos capitais". Tradução livre de: "Il existe d'ailleurs des sociétés qui n'ont aucune entreprise à gérer. Les holding n'ont d'autre activité que la bonne gestion des titres qu'elles possèdent. Les économistes dénoncent parfois cette mauvaise utilisation de la société. Le mécanisme leur paraît tourner à vide et inutilement. C'est possible, ma on voit admirablement dans ce type la différence entre la société et la entreprise; on y voit la machine juridique fonctionner pour la simple gestion des capitaux." in G. RIPERT, Aspects Juridiques du Capitalisme Moderne, p. 107.

391 Conforme já discutido no item 3.2.6 deste trabalho. F. GALGANO, Direzione e Coordinamento di Società - Art. 2497-2497 septies, p. 11.

392 Ascarelli, como sempre à frente de seu tempo, observa que os sócios da holding constituem fundo comum para a gestão coletiva das participações societárias por ela detidas - que se encontram em posição instrumental em relação à atividade de gestão desenvolvida - e subsequente repartição de lucros, o que permite concluir que se trata efetivamente de sociedade e não de comunhão de fruição. $\mathrm{O}$ ilustre Mestre italiano argumenta ainda que a sociedade holding desenvolve atividade própria de natureza econômica e empresarial. T. ASCARELLI, Saggi di Diritto Commerciale, p. 320-322. 
No que se refere à suposta duplicidade de emissão de ações com base nos mesmos bens, é importante recordar a lição de Ascarelli quanto à natureza de bens de "segundo grau" - muito diversa dos bens ordinários - das ações representativas do capital da sociedade anônima ${ }^{393}$. Tal faceta das ações permite instaurar uma hierarquização das pretensões de acionistas, conforme as diversas posições que ocuparem na cadeia societária, e de terceiros credores sobre determinados ativos, mas que nem por isso consiste em fraude ou simulação. Como observa o Professor Comparato, complementando as palavras de Ascarelli, o objeto patrimonial de tais títulos - o efetivo valor que representam - não é estritamente um acervo de bens estático, mas a própria empresa, no sentido de organização econômica capaz de gerar lucros ${ }^{394}$.

Nesse sentido, excluídos cenários de patologia, o grupo não é, em si mesmo e por si mesmo, a cobertura - ou simulação - de outros fenômenos. O grupo simplesmente é. $\mathrm{O}$ grupo existe e é inclusive amplamente reconhecido pelo Estado. A análise da grande quantidade de normas que tratam da empresa plurissocietária - e, podemos tomar como exemplo dos mais significativos o artigo $2^{\circ}, \S 3^{\circ}$, da Lei 6.404/1976, além obviamente dos artigos $243, \S 2^{\circ}$, e 265 do mesmo diploma - permite, com efeito, concluir que esta representa uma forma não apenas lícita, mas essencialmente tipificada de condução de atividades econômicas. Como forma própria e específica de organização da empresa, o

393 "As ações não materializam a titularidade do acionista sobre bens (ou créditos) em contraposição aos bens pertencentes à sociedade, mas direitos e poderes de acionista na coletividade social e, por isso, em via definitiva, em relação aos bens da sociedade. [...] A materialização de tal posição nas ações, por sua vez concebidas como coisas [...] leva à constituição de bens que eu denominei de segundo grau". Tradução livre: "Le azioni non materializzano l'appartenenza all'azionista di beni (o crediti) in contrapposizione ai beni appartenenti alla società, ma diritti e poteri dell'azionista nella collettività sociale e perciò, in via definitiva, in relazione ai beni della società. [...] La materializzazione di questa posizione nelle azioni, a loro volta concepite come cose [...] porta alla costituzione di beni che ho chiamato di secondo grado." in T. ASCARELLI, Saggi di Diritto Commerciale, p. 239-240. Ascarelli demonstra, outrossim, que a estrutura de grupo não leva a uma adição de patrimônios, mas simplesmente a uma distinção da posição de distintas séries de credores. T. ASCARELLI, Saggi di Diritto Commerciale, p. 243.

394 "Pois as ações de sociedade anônima não são bens iguais aos que, tradicionalmente, constituíam objeto de propriedade. Ascarelli denominava as ações de companhias 'bens de segundo grau', porque se referem, sempre, a elementos componentes de outro patrimônio. Mais do que isso, diríamos nós, referem-se a uma organização econômica de pessoas e bens, destinada à produção, circulação de mercadorias ou prestação de serviços no mercado, com intuito lucrativo. As ações de sociedade anônima, em uma palavra, dizem respeito à empresa. Assim, não se trata de bens possuídos ou usufruídos por si mesmos, mas como instrumento, veículo ou título de legitimação à posse, usufruto ou disposição de outros bens, componentes do patrimônio social. [...] E se, por hipótese, as ações em causa representam o controle de uma sociedade matriz de grupo econômico, com sociedades controladas em cadeia, ou coligadas em leque, aqueles títulos constituirão bens de graus sucessivos, correspondentes ao encadeamento societário." in F. COMPARATO, O Direito de Subscrição em aumento de Capital, no Fideicomisso Acionário, p. 125-126. 
grupo é indispensável para o funcionamento de qualquer economia de mercado moderna e minimamente sofisticada. Seu objetivo não é ocultar os resultados econômicos típicos de outras estruturas, mas alcançar as consequências que lhe são lícitas e peculiares.

\subsubsection{Crítica à Tese do Grupo como Sociedade de Sociedades.}

Visão bastante antiga e muito difundida na doutrina, nacional e estrangeira, é aquela segundo a qual o grupo de sociedades representaria, em si mesmo, uma sociedade; ainda que não personificada, uma "sociedade de sociedades" 395 ou "sociedade de segundo grau" ${ }^{396}$. Houve quem sugerisse, inclusive, a atribuição de personalidade jurídica a tal suposta sociedade grupal ${ }^{397}$.

Tal concepção, em todas as suas vertentes, tem como fundamento principal a ideia de que as sociedades agrupadas contribuem reciprocamente para o exercício de uma determinada atividade econômica, o que implicaria suposta subsunção perfeita ao conceito de contrato de sociedade ${ }^{398}$, tal como atualmente definido no direito brasileiro nos termos

395 Ao tratar dos pressupostos conceituais da jurisprudência francesa em matéria de abuso de bens sociais, Hannoun afirma que: "O grupo é percebido como uma sociedade de sociedades que dispõe de um objeto social que é a soma dos objetos das sociedades que o compõem". Tradução livre de: "Le groupe est perçu comme une société de sociétés disposant d'un objet social somme de divers objets des sociétés le composant." in C. HANNOUN, Le Droit et les Groupes de Sociétés, p. 91. "Indiscutivelmente, os vínculos societários identificadores da coligação e do controle traduzem a existência de uma associação de sociedades, ou sociedades de sociedades, também denominados grupos de fato, por oposição aos grupos de direito, regulados pela lei nos arts. 265 e seguintes." (sem grifo no original) in E. TEIXEIRA, J. GUERREIRO, Das Sociedades Anônimas no Direito Brasileiro, vol. II, respectivamente p. 708. " $A$ convenção grupal é um autêntico contrato de sociedade" e "O grupo constitui, na realidade, uma sociedade, nada importando o reconhecimento ou não, de sua personalidade jurídica." in F. COMPARATO, Os Grupos Societários na Nova Lei das Sociedades por Ações, respectivamente p. 98 e 122. M. VARGAS, Grupo de Sociedades, p. 2062. Edmur Nunes Pereira Neto defende de lege ferenda a natureza de sociedade de grupo, mas a coloca em questão de lege lata em razão da ausência de patrimônio comum, resultado, por sua vez, da inexistência de responsabilidade legal de uma sociedade grupada pelos débitos da outra, ainda que de forma subsidiária. E. PEREIRA NETO, Anotações sobre os Grupos de Sociedades, p. 32-34.

396 E. PEREIRA NETO, Anotações sobre os Grupos de Sociedades, p. 32.

397 "Se, hoje, a maioria admite que há, ao lado da pessoa física ou de existência visivel, a pessoa jurídica ou moral [...] porque [sic] não aceitar, também, a existência dos grupos de sociedades como entidades personificadas, já que o grupo de sociedades e as sociedades, que o compõem, não são entidades idênticas, mas diferentes, como diferente é o todo em relação à parte em que se decompõe?" in J. LOBO, Direito dos Grupos de Sociedades, p. 113.

398 Ainda de acordo com o Professor Comparato: "A nosso ver, o grupo econômico constitui, em si mesmo, uma sociedade. Os três elementos fundamentais de toda a relação societária - a saber, a contribuição individual com esforços ou recursos, a atividade para lograr fins comuns e a participação em lucros ou prejuízos - encontram-se em todo grupo. Ainda que o legislador não reconheça a personalidade jurídica dessa sociedade de segundo grau, que é um grupo personalizado, a relação societária que se estabelece entre as empresas ou sociedades agrupadas implica, necessariamente, uma unidade de direção e uma intercomunicação patrimonial." (sem grifo no original) in F. COMPARATO, S. CALIXTO, O Poder de Controle na Sociedade Anônima, p. 360. "Efetivamente, a interpretação do 
do artigo 981 do Código Civil de $2002^{399}$.

É importante observar, entretanto, que no grupo de subordinação - ao contrário do que ocorre no de mera coordenação ${ }^{400}$ - não se verifica qualquer encontro de vontades. $\mathrm{O}$ que efetivamente tem lugar é a atuação e a afirmação de uma única vontade preponderante, aquela da sociedade controladora. A vontade da controlada em si - projeção da vontade da controladora - é, em si mesma, um produto da estrutura de grupo. Não se pode pretender, portanto, que a formação do grupo dependa de uma prévia livre manifestação de tal vontade subordinada ${ }^{401}$.

Essa constatação permite excluir de plano a formação de sociedade, inclusive de sociedade em comum, no âmbito do grupo de fato, disciplinado pelo artigo 245 da Lei $6.404 / 1976^{402}$. Em tal hipótese, não se exige qualquer manifestação de vontade ou ato, ainda que tácito ou implícito, tampouco qualquer específica conduta por parte das sociedades controladas e coligadas, para que esteja plenamente configurado o grupo de

grupo societário como autêntica sociedade - sociedade de fato, nos grupos de fato, e sociedade de direito, mas despida de personalidade jurídica, nos grupos convencionais - é a que melhor dá conta do fenômeno." in F. COMPARATO, Abuso de Controle em Grupo Societário de Fato: Remédio Jurídico Cabivel, p. 313. No mesmo sentido: F. COMPARATO, Os Grupos Societários na Nova Lei das Sociedades por Ações, p. 98.

399 "Chama a atenção, desde logo, a semelhança entre os termos utilizados nesse dispositivo legal [artigo 265 da Lei 6.404/1976] e aqueles empregados pelo art. 1.363 do Código Civil, de 1916, e pelo art. 981 do Código Civil de 2002, ao tipificarem o contrato de sociedade. Essa similitude corrobora o entendimento de Fábio Konder Comparato de que os grupos se qualificam juridicamente como sociedade de segundo grau, não personificadas." in E. MUNHOZ, Empresa Contemporânea e Direito Societário: Poder de Controle e Grupos de Sociedades, p. 282.

$400 \mathrm{O}$ consórcio de sociedades é, inclusive, considerado sociedade não personificada típica. A própria exposição de motivos do projeto que resultou na atual Lei 6.404/1976 mencionava expressamente a questão, indicando, nos comentários ao Capítulo XXII do novo texto legislativo, que o "Projeto [...] regula o consórcio, como modalidade de sociedade não personificada".

401 Interessante assinalar que Messineo, ao argumentar - conforme discutido no tópico anterior - que a estrutura de grupo representaria acordo de simulação, houve por bem precisar que tal acordo não poderia ser celebrado entre a controladora e a controlada, mas apenas entre aquela (controladora) e terceiros, uma vez que esta última (controlada) seria o objeto, e não parte da simulação. "O acordo simulado não era celebrado entre sociedade-mãe e sociedade-filha, porque esta última é, ao contrário, fruto do acordo celebrado ao invés disso entre a sociedade-mãe e aqueles que cooperaram com ela para a criação da sociedade anônima fictícia". Tradução livre de: "L'accordo simulatorio non passava fra società-madre e società-figlia, perché quest'ultima è, al contrario frutto dell'accordo simulatorio passato invece fra la società-madre e coloro che hanno cooperato con essa alla creazione dell'anonima fittizia." in F. MESSINEO, Le Società di Commercio Collegate (c.d. Società a Catena), p. 25-26.

402 O Professor Erasmo Valladão França identifica na restrição à colaboração, constante do artigo 245 da Lei 6.404/1976, o elemento chave para se recusar a qualidade de sociedade em comum ao grupo de fato: "[...], quanto aos grupos societários, não partilhamos da opinião de que os mesmos constituam sociedades. Comparato defende essa solução relativamente aos grupos de direito, mas não aos grupos de fato. E certamente não há nenhuma sociedade nos grupos de fato, até porque a combinação de recursos e esforços em prol de outra sociedade ou do grupo é expressamente vedada (art. 245 da LSA)." in E. VALLADÃ̃ FRANÇA, Sociedade em Comum, p. 173. 
fato.

Em nada socorre a defesa da suposta qualidade de sociedade dos grupos em si o fato de que o contrato de sociedade tenha sabidamente natureza consensual, cuja validade interna dispensa ulteriores formalidades ${ }^{403}$. Mesmo o contrato consensual exige, naturalmente, "manifestação do consentimento de forma hígida"404, da qual não se vislumbra traço na formação do grupo de fato. Nem há sentido em conjecturar a respeito de assentimento por meio do silêncio (Código Civil de 2002, artigo 111), até porque nenhum hipotético protesto ou oposição por parte da sociedade participada poderia impedir a sociedade participante de subscrever ou adquirir as suas ações, formando assim uma posição de controle ou de coligação, nos termos do artigo $243, \S \S 2^{\circ}$ e $4^{\circ}$ da Lei $6.404 / 1976$.

Uma vez que o próprio artigo 981 do Código Civil de 2002 define a sociedade como contrato, não se pode cogitar de sua formação em situação jurídica que prescinde inteiramente da vontade de um dos sujeitos envolvidos ${ }^{405}$. Em tal cenário, frise-se, coligadas e controladas são o objeto e não os sujeitos de uma determinada vontade. $\mathrm{O}$ elemento definidor da relação de grupo de fato não é qualquer forma de colaboração em favor de um objetivo compartilhado - o que pode eventualmente ocorrer - mas o simples estado de sujeição a um poder. O grupo de fato, portanto, não representa, em si e por si, uma sociedade.

O mesmo pode se argumentar em relação ao grupo de direito. Nesse caso, porém, em função da celebração de convenção de grupo, o percurso que conduz à mesma conclusão - ou seja, da inexistência de contrato sociedade - é decididamente mais delicado

403 E. VALLADÃO FRANÇA, $A$ Sociedade em Comum, p. 109.

404 E. VALLADÃO FRANÇA, $A$ Sociedade em Comum, p. 116.

405 Fran Martins refuta a tese do grupo como sociedade não personificada, por entender que, no direito brasileiro, as únicas formas de sociedades sem personalidade jurídica seriam a sociedade em conta de participação e a sociedade em comum, não se enquadrando o grupo em nenhuma dessas duas categorias. O grupo não pode ser sociedade em conta de participação, pois não possui sócios ocultos: todas as sociedades agrupadas podem manter relações com terceiros. Tampouco pode ser considerado sociedade em comum, uma vez que não existe responsabilidade solidária entre as suas integrantes. F. MARTINS, R. PAPINI (atualiz.), Comentários à Lei das Sociedades Anônimas, nota de rodapé n 12, p. 1115. O argumento parece, entretanto, demasiadamente formal e pouco convincente. Não se poderia excluir, em tese, que a Lei 6.404/1976, lei ordinária de caráter especial, pudesse ter criado nova forma de sociedade não personificada - precipuamente como se argumenta ter feito o legislador em relação ao consórcio de sociedades. Nesse sentido, parece preferível rejeitar a natureza de sociedade do grupo com base em sua incompatibilidade estrutural com o contrato de sociedade. 
e complexo ${ }^{406}$.

É evidente que a convenção, firmada pela sociedade de comando e pelas filiadas, representa negócio jurídico lícito, expressamente disciplinado pelo legislador. É igualmente inegável, outrossim, que a sociedade de comando e a sua filiada podem celebrar entre si os mais diversos contratos, inclusive com o objetivo de constituir outra sociedade em que ambas tenham participação. Não se tem dúvida, também, quanto ao fato de que esse novo ente poderá, a seu turno, aderir à convenção de grupo (tornando-se filiada) ou permanecer na condição de simples controlada e/ou coligada (integrando, assim, um grupo de fato). A vontade da sociedade de comando exerce, direta ou indiretamente, um papel determinante na formação de todos mencionados vínculos obrigacionais mas, nem por isso, os respectivos negócios jurídicos restam desnaturados.

Ocorre, porém, que o objeto da convenção de grupo é estruturalmente incompatível com o vínculo contratual de sociedade. A convenção de grupo é celebrada em função de um objetivo prático principal: a legítima subordinação de interesses ${ }^{407}$, não a mera colaboração para o exercício de atividade econômica comum, que dispensaria tal formalidade. $\mathrm{O}$ aspecto determinante do grupo de direito não é uma finalidade comum às partes, mas a legitimação do emprego dos recursos do grupo em prol dos objetivos da sociedade de comando ${ }^{408}$. A subordinação do próprio interesse não constitui, porém,

406 De fato, a própria exposição de motivos da Lei das S.A. vislumbrava no grupo de direito uma sociedade de sociedades, ainda que tenha tido o cuidado de utilizar a expressão entre aspas, possivelmente denotando dúvida quanto à sua tecnicidade: "O grupo de sociedades é uma forma evoluída de interrelacionamento de sociedades que, mediante aprovação pelas assembléias gerais de uma 'convenção de grupo' dão origem a uma 'sociedade de sociedades". Exposição de Motivos $\mathrm{n}^{\circ}$ 196, de 24 de junho de 1976, do Ministério da Fazenda. Notas ao Capítulo XXI, Seção I, do Projeto. Sem grifo no original.

407 Ao lado de outras prerrogativas acessórias, tais como criação de uma estrutura de representação e gestão comum para todo o grupo. No direito alemão, também se afirma que a essência do acordo de domínio está na atribuição, à controladora, de um direito de emanar instruções vinculantes (Weisungsrecht) à controlada. V. EMMERICH, M. HABERSACK, Konzernrecht, p. 187.

408 Wiedemann compara a subordinação da sociedade filiada àquela do empregado e observa que: " $A$ sociedade dependente trabalha, por conseguinte, não mais em favor do interesse de todos os sócios e de seus próprios empregados, mas em prol do interesse da empresa dominante". Tradução livre de:"Die abhängige Gesellschaft arbeitet dementsprechend nicht mehr zugunsten aller Gesellschafter und in ihrer eigenen Arbeitnehmer, sondern im Interesse des herrschenden Unternehmer." in H. WIEDEMANN, Gesellschaftsrecht, Band I, p. 22. Em comentários às ponderações de Wiedemann, o Professor Erasmo Valladão França, com razão, indaga: "Como imaginar uma sociedade, nessas condições?" in E. VALLADÃO FRANÇA, Sociedade em Comum, nota de rodapé n 207, p. 173. No mesmo sentido: “ $A$ partir do momento em que age exclusivamente no interesse de sua controladora [...] a sociedade controlada que integra uma relação grupal deixa de perseguir seu próprio (e individual) interesse social, e é de se indagar: onde afinal, se divisa o fim comum, que [...] é característica essencial ao contrato de sociedade? [...] o grupo de sociedades, no Brasil, não é, a princípio, pelo menos, uma sociedade de sociedades, ou uma sociedade de segundo grau." in L. CASTELLÕES, Grupos de 
matéria sobre o qual a sociedade filiada possa livremente dispor, da mesma forma que não se admite que a administração de um ente associativo fixe livremente as suas finalidades estatutárias.

Na opinião de Lacerda Teixeira e Tavares Guerreiro, a subordinação de interesses decorrente da celebração de convenção de grupo é questão tão relevante para a estrutura da sociedade que representa efetiva alteração do seu objeto social ${ }^{409}$. Tal decisão cabe, lógica e unicamente, aos acionistas. Não é por outra razão que a lei acionária de 1976 colocou a expressa aprovação dos sócios, por meio de maioria qualificada, como requisito indispensável à válida celebração da convenção de grupo, inclusive conferindo aos minoritários discordantes o direito de recesso.

Em linha com tal argumento, a doutrina alemã vislumbra no acordo de domínio um contrato de organização - não um mero contrato bilateral, é verdade, mas tampouco um contrato de sociedade - que tem por efeito uma alteração temporária dos atos constitutivos da sociedade controlada, sendo este precisamente o motivo pelo qual a lei daquele país também teria condicionado a celebração de tal avença à prévia aprovação pela assembleia

Sociedades, p. 134-135. Ainda que escorada no discutível conceito de affectio societatis, tão central para o direito societário francês, Sabine Vacrate alcança conclusão análoga - ou seja, de que o grupo em si não pode ser considerado sociedade em comum - amparada por argumentos muito similares. Com efeito, a doutrinadora também toma por base, principalmente, a incompatibilidade do elemento de subordinação hierárquica, típico dos grupos verticais, com a combinação efetivamente voluntária de recursos que, ao revés, caracteriza a sociedade: "O fato de que uma sociedade controladora e sua controlada possam constituir uma sociedade em comum é dificilmente admissível em razão do vínculo de subordinação econômica existente entre elas. Tal sujeição se opõe ao caráter igualitário que pressupõe a affectio societatis em todas as sociedades". Tradução livre de: "Le fait qu'une société-mère et sa filiale puisse constituer une société créée de fait est difficilement admissible du fait du lien de subordination économique qui existe entre elles. Cet assujettissement s'oppose au caractère égalitaire que suppose l'affectio societatis dans toutes les sociétés." in S. VACRATE, La Société Créée de Fait, Essai de Théorisation, p. 154.

409 "Ora, tendo em vista as próprias características do grupo de sociedades, no bojo do qual se admite a subordinação dos interesses de uma sociedade a outra e a existência de um escopo peculiar ao grupo, distinto do objeto de cada sociedade filiada, era preciso se resguardassem os direitos dos acionistas contrários à associação. Esta equivale, por assim dizer, a uma alteração do objeto social da sociedade filiada. Por isso mesmo, o parágrafo único do art. 270 assegura aos sócios ou acionistas dissidentes da deliberação de se associar a um grupo o direito ao reembolso de suas ações ou quotas." (sem grifo no original) in E. TEIXEIRA, J. GUERREIRO, Das Sociedades Anônimas no Direito Brasileiro, vol. II, p. 779. No mesmo sentido: M. VARGAS, Grupo de Sociedades, p. 2065. Tal posição é corroborada pela própria Exposição de Motivos da lei acionária: "A integração de sociedade em grupo equivale à mudança de seu objeto social. Daí os requisitos do artigo 271, para sua aprovação pelos sócios ou acionistas, o direito de retirada dos sócios dissidentes (art. 271, par. único) e a aprovação pela autoridade competente, no caso de companhia que, por seu objeto, depende de autorização para funcionar (art. 269)." conforme Exposição de Motivos n 196, de 24 de junho de 1976, do Ministério da Fazenda. Comentários ao capítulo XXI, Seção II. 
geral da sociedade dependente, inclusive por maioria qualificada ${ }^{410}$.

O próprio fato de que tais exigências e formalidades - aprovação pela assembleia e recesso - não se apliquem, em regra, à constituição de uma sociedade ex novo tendo como acionistas a controladora e a controladora é, por si só, um forte indício das diferenças estruturais existentes entre o contrato de sociedade e a convenção de grupo. Enquanto na sociedade se verifica a colaboração das partes em nome de uma finalidade comum $^{411}$, no grupo de direito se legitima a subordinação de interesses, que por definição se traduz no alinhamento dos esforços de todas as sociedades em favor do interesse próprio e particular da sociedade de comando.

De resto, como argumento de segunda ordem, cumpre questionar o fato de que, se o grupo de direito fosse em si mesmo uma sociedade não personificada, não se compreenderia quais bens formariam o seu patrimônio especial, dado que cada sociedade grupada conserva a titularidade dos próprios bens, não se formando comunhão entre as filiadas ${ }^{412}$. Além disso, cabe recordar que a lei não fixou regras de representação externa do grupo em si, mas apenas regras de representação conjunta das sociedades associadas ao redor da convenção de grupo ${ }^{413}$.

À luz dos referidos argumentos, a convenção de grupo pode ser considerada como espécie própria de contrato de organização, que teria feições - em termos confessadamente imprecisos e grosseiros - de "acordo de acionistas intersocietário", que trata de prerrogativas e interesses próprios dos sócios controladores do grupo e dos acionistas

410 "Pode-se descrever, portanto, o acordo de domínio e o acordo de atribuição de lucros como contratos de organização; decisiva, porém, é a constatação que eles [...] conduzem, de fato, a uma (temporária) alteração do estatuto social da sociedade dependente. Encontra-se sobretudo neste ponto, em última análise, a explicação para a necessidade de uma aprovação pela assembleia geral da sociedade dependente (\$293, subparágrafo 1, da lei acionária), por maioria qualificada (compare-se com o 179 da lei acionária)". Tradução livre de: "Man mag deshalb Beherrschungs- und Gewinnabführungsverträge als Organisationsverträge bezeichnen; entscheidend ist jedoch die Einsicht, dass sie [...] der Sache nach auf eine (befristete) Änderung der Satzung der abhängigen Gesellschaft hinauslaufen. Vor allem die Notwendigkeit eines Zustimmungsbeschlusses der Hauptversammlung der abhängigen Gesellschaft mit qualifizierter Mehrheit (\$293 Abs. 1 AktG) findet hierhin letztlich ihre Erklärung (vgl. \& 179 AktG)." (negrito no original) in V. EMMERICH, M. HABERSACK, Konzernrecht, p. 192-193.

411 T. ASCARELLI, Problemas das Sociedades Anônimas e Direito Comparado, p. 271.

412 E. TEIXEIRA, J. GUERREIRO, Das Sociedades Anônimas no Direito Brasileiro, vol. II, p. 776.

413 "Não tem o grupo representação legal, nem se preocupou o legislador com defini-la [...] Daí ter-se limitado a lei a disciplinar a representação das sociedades perante terceiros, o que fez no parágrafo único do artigo 272. Ainda quando essa representação caiba convencionalmente aos administradores do grupo, é sempre em nome das sociedades que eles agem." in E. TEIXEIRA, J. GUERREIRO, Das Sociedades Anônimas no Direito Brasileiro, vol. II, p. 783. 
externos, mas que, por exigências práticas, é firmado por meio de pessoas interpostas, especificamente a sociedade controladora e as suas controladas, de forma muito similar ao que se verifica em relação ao protocolo de incorporação ou de fusão ${ }^{414}$. Ora, se considerarmos que, aos olhos do legislador de 1976, o grupo de direito representaria um caminho em direção à integração completa das sociedades associadas, justamente por meio das referidas operações de reorganização societária, podemos concluir que as semelhanças não são mera coincidência ${ }^{415}$.

\subsubsection{Tentativa de Definição Jurídica do Grupo}

Tomando como subsídio as observações anteriores sobre a composição subjetiva do grupo (subcapítulo 6.1) e os vínculos políticos que o caracterizam (subcapítulo 6.2), bem como tendo refutado, nos termos deste subcapítulo, a qualificação dessa forma de organização da empresa como simulação ou sociedade - o que implica também recusar-lhe subjetividade jurídica - é possível empreender uma, confessadamente hesitante e preliminar, tentativa de definição jurídica de tal conceito.

Como mencionado anteriormente, o grupo é comumente descrito como conjunto de sociedades juridicamente autônomas, mas economicamente integradas. Uma definição jurídica e societária da expressão deve, contudo, preferencialmente, prescindir do conceito inevitavelmente vago e extrajurídico de integração econômica. Em nossa realidade, contribui para a possibilidade de se satisfazer tal critério o fato de que o legislador brasileiro tenha limitado o grupo apenas às sociedades e tenha também privilegiado o aspecto estático da titularidade do poder, e não o elemento dinâmico do exercício de tal poder.

Sob essa perspectiva, seria possível concluir que o grupo de fato representa o perímetro intersocietário de sujeição ao poder de uma determinada sociedade. Ou seja, ele consiste em conjunto de sociedades alcançadas pela influência de uma sociedade

414 De fato, não cabe aos administradores de uma sociedade decidir autonomamente se ela deve continuar a existir ou, ao contrário, deve ser absorvida por uma outra sociedade. Uma decisão de tal natureza compete exclusivamente aos sócios, mas por questão de exigências práticas o documento de base da operação é negociado e firmado pelos administradores, para posterior aprovação dos sócios.

415 "Em suma: o grupo [de direito] são sociedades associadas a caminho da integração, que se opera mediante incorporação ou fusão; mas, até lá, as sociedades grupadas conservam a sua personalidade jurídica, e podem voltar à plenitude da vida societária, desligando-se do grupo". Exposição de Motivos $\mathrm{n}^{\circ}$ 196, de 24 de junho de 1976, do Ministério da Fazenda. Notas ao Capítulo XXI, Seção I, do Projeto. 
dominante, além da própria sociedade dominante. Em seu núcleo, tal conjunto é formado pelas sociedades sujeitas a um poder mais profundo, que tem feições de soberania - o poder de controle. Em sua periferia, estão as sociedades coligadas, nas quais a influência da sociedade participante não é única nem incontrastável ${ }^{416}$.

O grupo de direito se assenta, necessariamente, sobre o núcleo interno de um grupo de fato, uma vez que limitado às sociedades unidas por vínculo de controle. Sua característica peculiar é a celebração de contrato de organização, que legitima e disciplina o exercício de um poder ainda mais vertical e profundo, que se traduz na lícita subordinação de interesses. Assim, o grupo de direito poderia ser juridicamente definido como conjunto de sociedades sujeitas não apenas ao poder de controle de determinada sociedade controladora (que também integra o grupo), mas à subordinação legítima dos próprios interesses em favor dos objetivos desta última, nos termos de contrato de organização (convenção de grupo) celebrado especificamente para esse fim.

\subsection{Subordinação e Crítica ao Conceito de Interesse de Grupo}

De acordo com a clássica lição de Carnelutti, o "interesse" pode ser descrito, do ponto de vista jurídico, como o vínculo de complementaridade entre um sujeito que experimenta uma necessidade e o bem ou ente apto a satisfazer tal necessidade ${ }^{417}$. Por representar um denso entrelaçamento e uma profunda sobreposição de relações jurídicas, aspirações e pretensões de inúmeros e discrepantes sujeitos, é evidente que o grupo

416 "Grupo de sociedades é o conjunto de sociedades formado por uma sociedade controladora e uma ou mais sociedades sob seu controle." in J. PEDREIRA, Sociedades Coligadas, Controladoras e Controladas, p. 1929.

417 “[...] o interesse, noção fundamental para o estudo do direito, a qual é fruto da noção de valor: [...] eu a defini como uma posição favorável à satisfação de uma necessidade”. Tradução livre de: “[...] l'interesse, nozione fondamentale per lo studio del diritto, la quale è un germoglio della nozione del valore: [...] l'ho definito come una posizione favorevole per la soddisfazione di un bisogno." in F. CARNELUTTI, Teoria Generale del Diritto, p. 32. O ilustre jurista também enfrenta as noções de necessidade e bem, esta baseada naquela: "O estímulo age por meio de uma sensação penosa enquanto estiver ausente a combinação e de uma sensação agradável quando se verifica a combinação. Essa tendência à combinação de um ente vivo com um ente complementar é uma necessidade. A necessidade se satisfaz com a combinação. $O$ ente apto a satisfazer é o bem; bonum quod beat, porque faz bem". Tradução livre de: "Lo stimolo agisce per via di una sensazione penosa fin che la combinazione manca e di una sensazione piacevole quando la combinazione si produce. Questa tendenza alla combinazione di ente vivo con un ente complementare è un bisogno. Il bisogno si soddisfa con la combinazione. L'ente, che è atto a soddisfare il bisogno è un bene; bonum quod beat, perché fa del bene." in F. CARNELUTTI, Teoria Generale del Diritto, p. 59. Definição retomada também por Jaeger. P. JAEGER, L'Interesse Sociale, p. 3. E. VALLADÃO FRANÇA, Conflito de Interesses nas Assembléias de S.A., p. 15-16. Discutir-se-á o conceito específico de interesse social no Capítulo 7, também ali, porém, sem pretensões de fazê-lo de maneira exaustiva. 
representa campo dos mais férteis para a colisão dos diversos interesses que se depositam nele e em suas partes componentes.

Seja ao descrever os referidos $\operatorname{conflitos}^{418}$, seja ao procurar um ponto de equilíbrio ou síntese entre as inúmeras necessidades contrastantes, diversos e respeitados doutrinadores recorreram à, pouco feliz, fórmula do "interesse de grupo" ${ }^{419}$. Nessa esteira, um conjunto de estudiosos encarregado pela Comissão Europeia, entre 2010 e 2011, de formular propostas para a regulamentação de questões societárias no âmbito da União Europeia, ao tratar dos grupos apontou a doutrina do "interesse de grupo" como o principal caminho para o desenvolvimento de nova regulamentação, supostamente apta à conciliação

418 Apesar de lançar mão da criticável expressão "interesse do grupo", Champaud ao menos teve o cuidado de reconhecer que se tratava, essencialmente, de uma abreviação para o interesse do acionista controlador: "O interesse próprio de uma sociedade controlada encontra-se mais ou menos subordinado àquele dos controladores. Uma vez que tal controle é a manifestação da unidade de direção econômica de um grupo, a noção de interesse social se vê suplantada por aquela de interesse do grupo". Tradução livre de: "L'intérêt propre d'une société contrôlée se trouve plus ou moins subordonné a celui des contrôlaires. Lorsque ce contrôle est la manifestation de l'unité de direction économique d'un groupe, la notion d'intérêt social se voit supplantée par celle d'intérêt du groupe." in C. CHAMPAUD, Le Pouvoir de Concentration de la Société par Actions, p. 276. Ou seja, Champaud utilizou a expressão para constatar um fato: a frequente subordinação de interesses das sociedades controladas pelo acionista controlador nos grupos, mas não para sugerir um critério operacional de governo de tais relações.

419 "No reino da empresa plurissocietária, o interesse global do grupo prevalece sobre os interesses individuais de cada companhia que o integra". Tradução livre de: "Within the realm of the polycorporate enterprise, the global interest of the group ranks before the particular interests of each constituent corporation." in J. ANTUNES, Liability of Corporate Groups, p. 106. "Ao lado do que se costuma denominar 'interesse do grupo' - que, sem prejuizo de sua correspondência aos fins das sociedades nele integradas, é sensivelmente influido pela sociedade dominante - coexistem interesses singulares das sociedades dependentes". Tradução livre de: "Al lado de lo que se suele denominar 'interés del grupo' - que sin perjuicio de su correspondencia con los fines de las sociedades integradas en él, es sensiblemente influido por la sociedad dominante - coexisten intereses singulares de las sociedades dependientes." in J. IRUJO, Algunas Reflexiones sobre los Grupos de Sociedades y su Regulación Juridica, p. 25. "O interesse do grupo não substitui, mas se sobrepõe ou acresce ao interesse social de cada membro do grupo: é o interesse do conjunto das sociedades de, mediante cooperação, otimizar os resultados de cada uma na realização do seu fim e objeto e participar dos beneficios criados pela atividade comum." in J. PEDREIRA, Sociedades Coligadas, Controladoras e Controladas, p. 1937. Afirma o Professor Comparato: "[...] o direito não pode descurar os relevantes interesses econômicos globais do grupo societário, que devem, mesmo, sobrepor-se ao interesse particular das sociedades que o compõem" (sem grifo no original) in F. COMPARATO, C. SALOMÃO FILHO, O Poder de Controle na Sociedade Anônima, p. 406. "Já no grupo de sociedades [grupo de direito], reconhece a lei a existência de interesses que transcendem a esfera especifica da sociedade, [...] Esses interesses são os interesses do grupo, no qual pode ser identificado um escopo peculiar e distinto do objeto de cada sociedade participante. Trata-se, por assim, dizer, dos interesses da empresa, entendida como atividade negocial exercida através de mais de uma pessoa jurídica, de caráter instrumental, portanto." (sem grifo no original) in E. TEIXEIRA, J. GUERREIRO, Das Sociedades Anônimas no Direito Brasileiro, vol. II, p. 698-699. No mesmo sentido: L. LEÃES, Proibição de Voto e Conflito de Interesse nas Assembléias Gerais, p. 179. C. LOBO, Conflito de Interesses entre a Companhia e seu Administrador, p. 28. Não se pode concordar com a referida ideia de "interesses da empresa". A expressão empresa pode designar patrimônio, atividade ou sujeito que exerce uma atividade. Apenas nesta última acepção poder-se-ia atribuir à empresa a titularidade de um interesse e, como se argumentou, o grupo não é sujeito de direito. 
da realidade econômica dos grupos com os deveres atribuídos pela legislação dos diversos países-membros aos administradores e acionistas controladores ${ }^{420}$. Trata-se, porém, tal como se argumenta e se almeja demonstrar neste subcapítulo, de expressão significativamente imprecisa e potencialmente perigosa.

Conforme discutido nos pontos anteriores, o grupo é essencialmente o perímetro de alcance de um determinado poder; um conjunto de sociedades que têm como elemento comum determinante a sujeição à influência de determinada outra sociedade. O grupo não é, em si mesmo, sujeito de direito ${ }^{421}$, nem parece reunir os elementos mínimos necessários (por exemplo, uma autonomia patrimonial imperfeita) para o reconhecimento de formas intermediárias e mais tênues de subjetividade jurídica, tal como faz a doutrina italiana em relação às sociedades de pessoas não personificadas ${ }^{422}$. Nesse sentido, é difícil se vislumbrar no grupo - sobretudo no grupo de fato, que carece das mais elementares formas de institucionalização - um possível titular de quaisquer necessidades ou aspirações próprias e, portanto, o portador de um interesse grupal ${ }^{423}$.

Além disso, como se argumentou, o grupo não se enquadra no conceito de sociedade, tanto por (ao menos no que diz respeito ao grupo de fato) não apresentar a convergência de vontades que caracteriza a noção de contrato, quanto por (seja o grupo de fato, seja o grupo de direito) não ser orientado por uma finalidade comum, compartilhada por todos os seus integrantes. Com efeito, enquanto expressão da afirmação de um poder, a

420 "Portanto, se a doutrina do interesse de grupo fosse reconhecida, o seu efeito seria o de operar como 'porto seguro' para os administradores de sociedades da União Europeia, tanto de controladoras quanto de controladas, contra a responsabilidade (civil e criminal) caso eles tomem medidas relativas a uma companhia do grupo levando em consideração a existência do grupo como uma unidade empresarial, especialmente na hipótese de instruções da controladora para tomar medidas no interesse do grupo como um todo, mas que, discutivelmente, não sejam do interesse daquela sociedade especifica." Tradução livre de: "Therefore, if the doctrine of the group interest is recognized, the effect of this would be that it could operate as a 'safe harbour' for the managers of both EU parent and subsidiary companies against liability (civil and criminal) if they take action for a group company taking into consideration the existence of the group as a unitary business entity, particularly in the case of instructions from a parent company to take action that is in the interests of the group as a whole but arguably not in the interests of that particular company." in J. ANTUNES, T. BAUMS, B. CLARKE, P. CONAC, L. ENRIQUES, A. HANAKA, J. HANSEN, H. DE KLUIVER, V. KNAPP, N. LENOIR, L. LINNAINMAA, S. SOLTYSINSKI, E. WYMEERSCH, Report of the Reflection Group on the Future of EU Company Law (April 5, 2011), p. 62.

$421 \mathrm{E}$, assim, cabível a mesma crítica tradicionalmente levantada ao institucionalismo clássico, de acordo com a qual não se pode aceitar "um interesse destituído de sujeito". E. VALLADÃO FRANÇA, Conflito de Interesses nas Assembléias de S.A., p. 25. Também nesse sentido: V. PRADO, Conflito de Interesses nos Grupos Societários, p. 240.

422 F. CORSI e F. FERRARA JR., Gli Imprenditori e Le Società, p. 194.

423 V. PRADO, Conflito de Interesses nos Grupos Societários, p. 240. 
característica fundamental do grupo é a projeção das finalidades próprias da sociedade controladora sobre outros sujeitos - fato que permite uma integração econômica com coesão interna suficientemente forte para formar a empresa plurissocietária - e não a persecução de um fim comum ${ }^{424}$, tal como se verifica nos contratos plurilaterais ${ }^{425}$.

O grupo, convém reiterar, não possui fins próprios, sendo o veículo para a afirmação dos propósitos de quem o controle ${ }^{426}$. Também deste ponto de vista, portanto, não parece convincente ou conveniente se falar em interesse de grupo, ainda que como mera metáfora ou suposta síntese do interesse coletivo das sociedades agrupadas, pois, no mais das vezes, a expressão representará mero anteparo para encobrir o interesse próprio de quem exerce o poder de controle - e é exatamente em tal ponto que a imprecisão do termo se transmuta em perigo.

Mesmo que se adote a perspectiva mais recente do contrato associativo ${ }^{427}$, o que se verifica é que, ao contrário do contrato de sociedade, a formação do vínculo de grupo não tem como objetivo precípuo estabelecer uma nova organização - no sentido indicado pelo Professor Calixto Salomão Filho de "coordenação da influência recíproca de atos" no âmbito do feixe de relações envolvidas na sociedade ${ }^{428}$-, mas sim absorver a controlada na organização erigida para a satisfação das necessidades da controladora. Tampouco em tais conceitos se vislumbra, portanto, possível fundamento para um suposto interesse de grupo.

Com isso não se quer dizer que o grupo será, sempre e por definição, nocivo para os interesses das sociedades controladas, dos acionistas externos ou credores. Muito pelo

424 Conforme assinala o Professor Comparato: “[...] o interesse social não é redutível a qualquer interesse dos sócios e sim, unicamente, ao seu interesse comum de realização do escopo social." (sem grifo no original) in F. COMPARATO, C. SALOMÃO FILHO, O Poder de Controle na Sociedade Anônima, p. 381. "O interesse social da companhia é definido, objetivamente, a partir do seu fim e do seu objeto social: é o interesse do conjunto dos acionistas, como membros da sociedade, [...]" (sem grifo no original) in J. PEDREIRA, Sociedades Coligadas, Controladoras e Controladas, p. 1937.

425 "A pluralidade corresponde a circunstância de que os interêsses contrastantes das várias partes devem ser unificados por meio de uma finalidade comum; os contratos plurilaterais aparecem como contratos com comunhão de fim." in T. ASCARELLI, Problemas das Sociedades Anônimas e Direito Comparado, p. 271.

426 Em sentido contrário: “[...] por meio das diversas formas de tal organização, aparece um verdadeiro 'objetivo social': o objetivo do grupo é a coordenação econômica de seus membros". Tradução livre de: “[...] à travers les diverses formes de cette organisation un véritable 'but social' apparaît : le but du groupe est la coordination de l'activité économique des membres." in A. PETITPIERRE-SAUVAIN, Droit des Sociétés et Groupes de Sociétés, p. 35.

427 Ferro-Luzzi critica os conceitos de plurilateralidade e de escopo comum, por não se aterem ao aspecto funcional do contrato de sociedade. P. FERRO-LUZZI, I Contratti Associativi, nota de rodapé $\mathrm{n}^{\circ}$ 16, p. $76-78$.

428 C. SALOMÃo FILHO, O Novo Direito Societário, p. 43. 
contrário, da pertinência ao grupo - de fato ou de direito - decorrem, na maioria dos casos, diversas e concretas vantagens para as sociedades controladas. Basta pensar em ganhos de imagem, reputação, crédito e acesso a redes de suprimentos e distribuição de produtos ${ }^{429}$. A concentração empresarial cria ganhos de escala e escopo que representam um sobrevalor em relação à mera soma das partes da empresa plurissocietária. Não há razões para se supor que a sociedade controlada não possa colher parte desses benefícios - em parte já discutidos no Capítulo 3.

É evidente, ademais, que, no bojo da estrutura de grupo, operações isoladas podem adquirir um significado completamente novo. O grupo impõe a valoração da comutatividade por prisma diverso. Seria, apenas como exemplo, desarrazoado esperar que uma sociedade isolada e independente concedesse licença de uso gratuita de suas marcas a um terceiro ou assumisse a condição de garantidora das dívidas deste último sem contragarantias ou contraprestações imediatas. No âmbito dos grupos, porém, tanto nos de fato quanto nos de direito, operações dessa natureza são corriqueiras e podem ser perfeitamente justificadas ${ }^{430}$ pela continuidade e pela intensidade das relações recíprocas internas ao grupo, as quais ensejam a perspectiva concreta de compensação de eventuais perdas tópicas em função de operações futuras em sentido inverso ${ }^{431}$.

É exatamente essa tolerância a uma aparente perda imediata e em curto prazo que sob uma perspectiva de longo prazo pode se revelar, em verdade, um investimento altamente recompensador para a sociedade isolada - que permite ao grupo superar a eficiência meramente paretiana e perseguir resultados orientados por uma lógica de Kaldor-Hicks, conforme já discutido no Capítulo 4.

Nestes casos, não se verifica, entretanto, uma ponderação entre suposto interesse de grupo e interesse da sociedade controlada ${ }^{432}$, mas simplesmente se faz uma avaliação

429 F. GALGANO, Direzione e Coordinamento di Società - Art. 2497-2497 septies, p. 134.

430 Mas frequentemente não o são, o que caracterizaria, no grupo de fato, a ilegítima subordinação de interesses.

431 E. MUNHOZ, Estrutura de Governo dos Grupos Societários de Fato na Lei Brasileira: Acionista Controlador, Administradores e Interesse de Grupo, p. 289. No mesmo sentido a jurisprudência falimentar: "Verificando-se, ainda, que fiadora e afiançada são empresas do mesmo grupo econômico, com controlador comum e área de atuação semelhante, não há como considerar que a obrigação tenha sido firmada a título gratuito, posto que, de certo modo, o financiamento concedido, direta ou indiretamente, beneficiava a ambas." (sem grifo no original) Tribunal de Justiça do Estado de São Paulo, Apelação no 497.528 4/5-00, Acórdão no 01611082, voto do Rel. Des. Grava Brazil, de 12 de fevereiro de 2008.

432 “Em uma sociedade vinculada a um grupo, os interesses representados pela holding não pesam sobre a 
mais flexível e mais ampla da concretização dos interesses desta última - mais ampla tanto em termos cronológicos, quanto no que diz respeito à quantidade de operações e relações levadas em consideração. O que permite uma nova leitura da comutatividade dessas relações intragrupo não é, por conseguinte, uma relação dialética entre hipotético interesse de grupo e interesse da sociedade isolada, mas sim um confronto entre interesses de curto e de longo prazo da própria controlada. Nesse sentido, parece muito mais adequado se falar em "interesses no grupo" do que em "interesse de grupo".

A confirmar o fato de que não existe um interesse de grupo que se anteponha (ou sobreponha) ao interesse da sociedade isolada ou justifique o sacrifício deste ${ }^{433}$, verifica-se que, em qualquer hipótese, será sempre necessária a compensação, efetiva ou potencial, em favor da sociedade isolada. No grupo de direito, a compensação não é expressa e inequivocamente imposta pelo legislador, mas claramente pressuposta. Com efeito, optouse por deixar às partes a negociação de mecanismos de compensação, tendo como evidente contrapartida o não exercício de direito de recesso pelos acionistas externos. Conforme se discute de forma mais detida no Capítulo 8 , a redação do artigo 276, $\S 2^{\circ}$, é claro indício de que, na mens legis, a convenção sempre incluiria regras de neutralização de perdas ${ }^{434}$. No

balança da justiça nem mesmo um miligrama mais do que o interesse do pequeno acionista da sociedade controlada, que não quer que sua sociedade seja sacrificada em nome de um suposto interesse superior do grupo à racionalização da produção ou ao redimensionamento das instalações e assim por diante". Tradução livre de: "In una società collegata in un gruppo, gli interessi rappresentati dalla holding non pesano sulla bilancia della giustizia neppure un milligrammo più dell'interesse del piccolo azionista della società controllata, che non vuole che la sua società sia sacrificata in nome di un preteso interesse superiore del gruppo alla razionalizzazione della produzione o al ridimensionamento degli impianti e via dicendo." in L. MENGONI, Conflitto di Interessi in Materia Sociale, p. 444-445.

433 "Chega-se, assim, ao ponto de atribuir relevância jurídica ao 'interesse de grupo' enquanto interesse em nome de cuja satisfação a controlada pode agir e concretamente age. A tal orientação se replicou que afirmar que o interesse de grupo pode ser perseguido na medida em que não incida sobre o interesse das sociedade individuais, que ele deve ser ulterior, mas não conflitante em relação ao interesse social das controladas, significa, na verdade, asseverar a irrelevância do interesse de grupo no direito societário vigente. Em outras palavras, sustentar a legitimidade do interesse de grupo mas desde que este permaneça externo, sem influência e separado em relação ao interesse das sociedades individuais, equivale a afirmar a legitimidade da persecução de qualquer interesse extrassocial, desde que ele não incida sobre o interesse social, em sua acepção tradicional." Tradução livre de: "Si arriva così a dare giuridica rilevanza anche all"interesse di gruppo' quale interesse per il conseguimento del quale la controllata può agire e concretamente agisce. A tale orientamento si è però replicato che affermare che l'interesse di gruppo in tanto può essere perseguito in quanto non incida sull'interesse delle singole società che esso deve essere ulteriore ma non confliggente, rispetto all'interesse sociale delle controllate, significa in realtà asserire l'irrilevanza dell'interesse di gruppo nell'ambito del diritto societario vigente. Sostenere, in altre parole, la legittimità dell'interesse di gruppo a condizione che esso rimanga esterno, ininfluente e separato rispetto all'interesse delle singole società, equivale ad affermare la legittimità del perseguimento di qualunque interesse extrasociale, purché questo non incida per nulla sull'interesse sociale, tradizionalmente inteso." (sem grifo no original) in P. JAEGER, L'Interesse Sociale Rivisitato (Quarant'Anni Dopo), p. 810.

434 C. SALOMÃO FILHO, O Novo Direito dos Grupos, p. 196-197. 
grupo de fato, por sua vez, a lei prevê expressamente o "pagamento compensatório adequado" como requisito para a exclusão de ilicitude de operações que, de outro modo, poderiam representar favorecimento indevido da controladora ou de coligada.

A ideia aparentemente subjacente à doutrina do interesse de grupo é a de trazer mais flexibilidade à gestão da empresa plurissocietária, ao se renunciar a uma leitura excessivamente restritiva e pontual da comutatividade de cada operação individual levada a cabo entre os membros do grupo ${ }^{435}$. Desse modo, ter-se-iam normas mais aderentes à realidade da organização das empresas no mundo contemporâneo. Tal resultado, porém, como se apontou acima, prescinde da nebulosa e potencialmente nociva concepção de interesse de grupo e pode, inclusive, ser alcançado por meio de uma interpretação sistemática do direito brasileiro atualmente em vigor ${ }^{436}$.

Com efeito, a vedação legal da subordinação de interesses no grupo de fato não se traduz na obrigação de conduzir a administração da sociedade isolada tal como se, irrealisticamente, não existissem as relações de grupo ${ }^{437}$. Cumpre recordar que a lei busca contrastar a atuação em conflito de interesses, ou seja, a situação de colisão direta em que a satisfação de necessidade do controlador se dá, necessariamente, em prejuízo da controlada. Não há restrição nos casos em que os interesses em jogo estejam em relação de

435 "No caso das sociedades de grupo, a presença de um interesse de grupo poderá ser demonstrada, como o relatório da lei delegante indicava, 'avaliando-se o interesse social não apenas com referência a uma operação considerada isoladamente, mas com referência ao quadro geral, de grupo, justamente no qual se desenvolve a empresa social". Tradução livre de: "Nel caso delle società di gruppo la presenza di un interesse di gruppo potrà essere dimostrata, come la relazione della legge delega precisava, 'valutando l'interesse sociale non solo con riferimento ad una operazione isolatamente considerata, ma con riferimento al quadro generale, di gruppo, appunto, nel quale si svolge l'impresa sociale."' in F. GALGANO, Direzione e Coordinamento di Società - Art. 2497-2497 septies, p. 137.

436 Nesse sentido, a despeito da discordância veemente em relação à premissa a respeito do interesse do grupo, pode-se concordar com a conclusão do ilustre Professor Eduardo Secchi Munhoz sobre a flexibilidade ínsita às normas constantes da lei acionária: "[...] o estudo sistemático das normas da lei brasileira evidencia sua plena adequação à teoria do interesse do grupo, de que antes se cuidou, ao analisar-se a experiência europeia [...] Infere-se de tais passagens [artigos 117, § $1^{\circ}$, alínea "a" e 245 da Lei 6.404/1976] que a lei brasileira não adotou uma visão estrita do interesse social nos grupos de fato." in E. MUNHOZ, Estrutura de Governo dos Grupos Societários de Fato na Lei Brasileira: Acionista Controlador, Administradores e Interesse de Grupo, p. 289.

437 Em sentido contrário: "As sociedades do grupo não convencional ou de fato mantêm integra a individualidade de seus objetivos operacionais. Não tem a controladora ingerência direta sobre a politica de prioridades das controladas. Devem os administradores, de cada uma das sociedades, observar estritamente o disposto no art. 154. Pressupõe a lei que a holding de controle tem posição receptiva de resultados patrimoniais das companhias operacionais que controla, sem impor aos seus administradores qualquer política empresarial e, mesmo, de distribuição de dividendos." in $\mathrm{M}$. CARVALHOSA, Comentários à Lei de Sociedades Anônimas, $4^{\circ}$ Vol., Tomo II, p. 44. 
indiferença ou instrumentalidade (solidariedade) $)^{438}$. A lei certamente não veda a realização de operações pela sociedade controlada nas quais a sociedade controladora tenha algum interesse ou até mesmo envolvimento direto e pessoal. O simples fato de a sociedade controladora auferir benefícios em tais operações não representa, tampouco, um ilícito.

A interpretação a contrario sensu do artigo 117, $\S 1^{\circ}$, alínea "f", da Lei 6.404/1976 confirma, efetivamente, a possibilidade de celebração de contratos entre controladora e controlada, desde que não haja indevido favorecimento ${ }^{439}$. Em sentido análogo, a alínea "a" do mesmo dispositivo parece condicionar, outrossim, a responsabilidade por desvio de finalidade ou o favorecimento a outras sociedades ao efetivo prejuízo sofrido por acionistas minoritários. Já a alínea "c" não apenas incorpora como requisitos do pressuposto fático que ali está definido o conceito de perda, como também, cumulativamente, a intenção de causá-la (com a expressão "que visem a causar prejuízo"). O aspecto crítico reside, portanto, no fato de que, da conduta da sociedade controladora, não devem derivar perdas para a sociedade controlada. Considerando-se a natureza fiduciária do exercício do poder de controle, parece prudente que se aplique, neste caso, um conceito amplo de perda, para abarcar inclusive os lucros cessantes e a perda de chance, pois de outro modo abrir-se-ia amplo espaço para a usurpação de oportunidades comerciais pela acionista controladora.

Em complemento a esse perímetro de livre atuação - ou seja, o raio de operação integrada do grupo, mas sem penalização da controlada - e confirmando, portanto, a inclinação da lei acionária em favor da afirmação e efetividade do poder empresarial, o artigo 245 prevê ainda que, mesmo diante de evidentes perdas sofridas pela sociedade controlada, restará excluída a ilicitude do comportamento da sociedade controladora em caso de "pagamento compensatório" $"$, nitidamente elevado pela lei a substituto da

438 E. VALLADÃO FRANÇA, Conflito de Interesses nas Assembléias de S.A., p. 17.

439 E. MUNHOZ, Estrutura de Governo dos Grupos Societários de Fato na Lei Brasileira: Acionista Controlador, Administradores e Interesse de Grupo, p. 289.

440 Ao tratar da relação entre o dever de justificar as operações intragrupo e o princípio da compensação das perdas (vantaggi compensativi), conforme positivado no direito italiano (artigo $2.497, \S 1^{\circ}$, do Código Civil italiano), Renato Santagata enfatiza que a neutralização do dano é apurada à luz do interesse da sociedade isolada, não em nome de um suposto interesse de grupo: “[...] tem como consequência a sua [dos administradores] obrigação de evidenciar os motivos subjacentes a uma possível escolha de abdicar, em relação a uma decisão individual, à própria autonomia e exprimir o interesse da sociedade, considerada de forma atomística, a efetuar a operação prejudicial. Nem seria correto, por outro lado, vislumbrar na cláusula das vantagens compensadoras (nos termos do art. $2.497, \S 1^{\circ}$, último periodo) a causa justificadora de eventuais políticas de grupo lesivas para a controlada, com a consequente 
comutatividade contratual em operações específicas. Ou seja, mesmo nos grupos de fato, o legislador consente ao controlador ultrapassar o campo dos interesses indiferentes ou solidários, para adentrar na perigosa arena dos interesses em conflito, mas desde que cada passo dado em tal direção - na direção da subordinação de interesses - seja objeto de compensação específica, restando, portanto, neutralizada a subordinação tópica e pontual do interesse da controlada ${ }^{441}$.

Pano de fundo dessa flexibilidade buscada pela lei não parece ser, pelas razões expostas, um suposto interesse de grupo, mas sim a promoção dos interesses da controladora e das controladas no grupo.

\subsection{Breve Nota sobre os Consórcios de Sociedades}

Tanto na doutrina quanto na própria estrutura da Lei 6.404/1976, o grupo de mera coordenação é visto como figura próxima ao grupo de subordinação ${ }^{442}$. Com efeito, uma e outra figuras envolvem o alinhamento dos recursos e esforços de diferentes sociedades, ensejando algum grau de integração econômica, mas com a preservação da existência juridicamente autônoma de suas integrantes ${ }^{443}$.

irresponsabilidade do administrador que se conforma à instrução danosa para a sociedade, mas vantajosa para o grupo a que pertence". Tradução livre de: “[...] ne consegue il loro [dos administradores] obbligo di palesare i motivi sottesi ad una possibile scelta di abdicare, rispetto ad una singola decisione, alla propria autonomia e di estrinsecare l'interesse della società, atomisticamente considerata, ad effettuare quell'operazione pregiudizievole. Né sarebbe corretto, d'altro canto, scorgere nella clausola dei vantaggi compensativi (di cui all'art. 2497, comma $1^{\circ}$, ult. periodo) la causa di giustificazione di eventuali politiche di gruppo lesive per la controllata, con la conseguente irresponsabilità dell'amministratore ottemperante alla direttiva dannosa per la società ma vantaggiosa per il gruppo di appartenenza." (sem grifo no original) in R. SANTAGATA, Autonomia Privata e Formazione dei Gruppi nelle Società di Capitali, p. 813-814.

441 Mecanismo similar ao previsto no artigo 2.497, $\S 1^{\circ}$, do Código Civil italiano, que por sua vez ecoa o disposto no artigo $2.634, \S 3^{\circ}$ do mesmo diploma, relativo à exoneração de responsabilidade penal do administrador. F. GALGANO, Direzione e Coordinamento di Società - Art. 2497-2497 septies, p. 138. O exame mais detido do conceito de "pagamento compensatório adequado", nos termos da lei brasileira, é desenvolvido no Capítulo 7, relativo à disciplina dos grupos de fato.

442 "Perante regimes legais que disciplinam o fenômeno grupal em sua inteireza, como é o caso da Lei 6.404/1976, é possível vislumbrar o quadro mais amplo em que se inserem os grupos de sociedades, abrangendo não apenas aqueles estruturados segundo relações de subordinação (grupos de subordinação), mas também as combinações societárias em que as empresas participantes se encontram em pé de igualdade, sem que uma exerça o controle sobre a outra (grupos de coordenação). $O$ consórcio de empresas, em princípio, inclui-se entre estes últimos." in M. PENTEADO, Consórcio de Empresas, p. 39.

443 A lei acionária alemã de 1965 consagra a figura do grupo horizontal (doutrinariamente conhecido como “Gleichsordnungskonzern"), definindo-a como a coordenação de empresas sob uma direção unificada, mas sem vínculos de domínio-dependência ( $§ 18$, subparágrafo 2). O conceito alemão, porém, parece muito diverso da definição do consórcio de sociedades do direito brasileiro. De fato, como ressaltam Emmerich e Habersack: "Da necessidade de uma 'direção unitária' das empresas, vinculadas mas entre si independentes, resulta que a coordenação da política dos negócios das empresas associadas, neste 
É importante, contudo, atentar para as notáveis diferenças estruturais entre ambos os institutos, dos pontos de vista funcional, político e jurídico, que parecem justificar ao menos uma relativização da sua suposta afinidade.

Ao contrário do grupo, caracterizado pelo fato da posição de controle, vale dizer, pela afirmação de uma vontade, o consórcio tem como marca fundamental o encontro de vontades $^{444}$. Nesse sentido, a ele sim é efetivamente cabível a classificação de sociedade não personificada, tal como, aliás expressamente mencionado na própria Exposição de Motivos da lei acionária ${ }^{445}$.

Por outro lado, a colaboração voluntária ao redor de projeto determinado não tem o condão de criar integração econômica tão profunda e coesa quanto aquela viabilizada pelo vínculo de subordinação. Está ausente no grupo de coordenação aquela unidade de investimento e de centro decisório que, no dizer de Galgano, permitiria a um economista afirmar com segurança que se encontra diante de uma única empresa ${ }^{446}$. O escopo restrito da colaboração no âmbito do consórcio de sociedades é enfatizado pela própria lei, ao determinar, no artigo 278, que o seu objeto deve consistir na execução de "determinado

caso como no grupo de subordinação não deve se limitar a aspectos individuais da política empresarial [...]. Ela deve, ao contrário, abranger fundamentalmente as empresas participantes em sua totalidade [...]". Tradução livre de: “Aus der Notwendigkeit einer 'einheitlichen Leitung' der verbundenen, aber voneinander unabhängigen Unternehmen im Gleichordnungskonzern folgt, dass sich die Koordinierung der Geschäftspolitik der verbundenen Unternehmen hier ebenso wie im Unterordnungskonzern nicht auf einzelne Aspekte der Unternehmenspolitik [...] beschränken darf [...]. Sie muss vielmehr grundsätzlich die beteiligten Unternehmen in ihrer Gesamtheit erfassen [...]" (negrito no original) in V. EMMERICH, M. HABERSACK, Konzernrecht, p. 65. No sistema brasileiro, em contraste, o consórcio deve se limitar a "determinado empreendimento" (Lei 6.404/1976, artigo 278, caput).

444 "A essência do grupo em sentido horizontal está, portanto, no fato de que a atividade de direção e coordenação de uma sociedade não é, como nos grupos em sentido vertical, a mera consequência de um fato, qual seja a relação de controle entre elas existente; é, ao revés, o efeito de um ato de vontade das sociedades que a ele se sujeitam, que resulta ou de um contrato celebrado entre elas e a sociedade ou ente encarregado de exercer tal atividade ou de especificas cláusulas constantes de seus estatutos sociais, nos quais se enuncia a sua sujeição à atividade de direção e coordenação por terceiros". Tradução livre de: "L'essenza del gruppo in senso orizzontale sta dunque in ciò, che l'attività di direzione e coordinamento di una società non è, come nei gruppi in senso verticale, la mera conseguenza di un fatto, qual è il rapporto di controllo fra essi esistente; è, invece, il portato di un atto di volontà delle società che vi sono sottoposte, risultante o da un contratto intercorrente fra esse e la società o ente incaricato di esercitarla oppure da apposite clausole dei loro statuti, nei quali è enunciata la loro soggezione all'altrui attività di direzione e coordinamento." in F. GALGANO, Direzione e Coordinamento di Società - Art. 2497-2497 septies, p. 211-212.

445 "Completando o quadro das várias formas associativas de sociedades, o Projeto, nos artigos 279 e 280 , regula o consórcio, como modalidade de sociedade não personificada que tem por objeto a execução de determinado empreendimento. Sem pretensão de inovar, apenas convalida, em termos nítidos, o que já vem ocorrendo na prática, principalmente na execução de obras públicas e de grandes projetos de investimento." in Exposição de Motivos n 196, de 24 de junho de 1976, do Ministério da Fazenda. Notas ao Capítulo XXII do Projeto.

446 F. GALGANO, Direzione e Coordinamento di Società - Art. 2497-2497 septies, p. 19-20. 
empreendimento".

Assim, em termos simplistas, pode-se argumentar que, ao celebrar contrato de consórcio, as consorciadas criam uma nova sociedade não personificada - o consórcio que desenvolverá atividade empresarial própria, uma nova empresa ${ }^{447}$. Em contraste, quando uma sociedade se torna controladora de outra ela passa a dispor dos mecanismos necessários para tornar a controlada veículo de sua atividade, ou seja, absorver a controlada em uma única empresa, a empresa plurissocietária. Nesse sentido, forçoso concluir que estamos diante de fenômenos estruturalmente distintos ${ }^{448}$.

\subsection{Breve Nota sobre o Código Civil e Sociedades Não Acionárias}

$\mathrm{Na}$ concepção original de seus formuladores, o projeto de novo Código Civil brasileiro - que se converteria na Lei Federal 10.406 em 2002, mas que começou a ser gestado na segunda metade do século passado - deveria disciplinar todas as principais matérias do direito privado, inclusive o regime das sociedades por ações, seguindo, portanto, a estrutura do Código Civil italiano de 1942, evidente modelo de inspiração para a reforma do diploma brasileiro.

Contudo, em decisão de 1974, o governo Geisel optou por excluir as sociedades por ações dos esforços coordenados pelo Professor Miguel Reale e, especificamente em

447 Ressalvado o fato, porém, de que o consórcio pode desenvolver atividade sem fim lucrativo, em cujo caso ensejaria uma associação e não uma sociedade. E. VALLADÃO FRANÇA, A Sociedade em Comum, p. 171-172.

448 "No grupo de coordenação - afirma-se - a direção unitária é o resultado de acordo paritário e livre das sociedades agrupadas, as quais cedem voluntariamente parte de suas competências ao órgão ou sociedade encarregados de dirigir o grupo. Sem dúvida, não por isso se pode dizer que o grupo de coordenação constitua uma unidade econômica, pois a inexistência de relações de dependência econômica entre as sociedades que o compõem nega aquela possibilidade. Se é assim, dificilmente se poderá afirmar que o chamado grupo de coordenação, a despeito de seu caráter 'articulado', constitua efetivamente uma empresa [...] a categoria dos chamados grupos de coordenação parece se encontrar assim diante de uma contradição dificilmente superável e que consiste em querer tornar compativel a estrutura do grupo com a ausência de subordinação ou de dependência econômica entre as sociedades deste último". Tradução livre de: "En el grupo por coordinación - se afirma - la direción unitária [sic] es el resultado del acuerdo paritario y libre de las sociedades agrupadas, las cuales ceden voluntariamente parte de sus competencias al órgano o sociedad encargados de la dirección del grupo. Sin embargo, no por ello se puede decir que el grupo por coordinación constituya una unidad económica, pues la inexistencia de relaciones de dependencia económica entre las sociedades que formam [sic] parte del mismo niega aquella posibilidad. Si esto es así, dificilmente se podrá afirmar que el llamado grupo por coordinación, a pesar de su carácter 'articulado', constituya efectivamente una empresa [...] la categoría de los llamados grupos por coordinación parece encontrarse así ante una contradicción dificilmente salvable y que consiste en querer hacer compatible la estructura del grupo con la ausencia de subordinación o de dependencia económica entre las sociedades del mismo." in J. IRUJO, Algunas Reflexiones sobre los Grupos de Sociedades y su Regulación Juridica, p. 24. 
matéria comercial, pelo Professor Sylvio Marcondes ${ }^{449}$, atribuindo a Alfredo Lamy Filho e José Luiz Bulhões Pedreira a missão de reformar o regime das sociedades por ações ${ }^{450}$. A decisão se mostraria acertada, não apenas pela inegável excelência do texto de nossa lei acionária, mas pelo fato de que a tramitação da reforma do Código Civil sofreria, no entretempo, inúmeros percalços, que adiariam a sua implementação por diversas décadas.

Convém reconhecer, de qualquer forma, que os ilustres autores do Anteprojeto de Lei das S.A. ultrapassaram o escopo original de sua tarefa e introduziram no texto do diploma de 1976 normas reguladoras de matérias de relevância geral e transversal para o direito societário, que certamente não dizem respeito apenas à sociedade anônima e à sociedade em comandita por ações ${ }^{451}$. Apenas como exemplos, é possível citar a disciplina das operações de cisão, fusão, incorporação e transformação, além da própria questão do poder de controle, bem como dos grupos, de direito e de fato. Como exemplo de evidência da intenção do legislador de fazer alcançar outros tipos societários pelas disposições de direito dos grupos da Lei 6.404/1976, pode-se mencionar a referência a "contratos sociais" no artigo 273.

Também neste caso, o saldo histórico final da "intromissão" da lei acionária em tais áreas parece muito positivo, uma vez que ofereceu regramento detalhado sobre diversas questões não tratadas pelo Código Comercial de 1850 que, de outro modo, teriam ficado "órfãs" de disciplina própria na pendência da longa gestação do Código Civil de 2002. Por outro lado, é evidente que a disciplina de questões gerais em uma lei especial cria dificuldades de delimitação do perímetro de incidência de tal diploma e de articulação de suas disposições com outras normas, especialmente quando se trata de tipos societários que estão fora de seu escopo principal.

Na vigência do Decreto 3.708/1919, essa questão era menos crítica, uma vez que

449 O Professor Sylvio Marcondes atribui tal decisão de separação da disciplina das sociedades por ações a dois principais fatores: (i) o reconhecimento da sociedade anônima como instrumento de ação do Estado sobre a economia (incompatível, portanto, com a estrutura de instituto pertencente ao Direito Privado) e (ii) o caráter vanguardista e experimental de muitas das disposições do Anteprojeto formulado por Lamy Filho e Bulhões Pedreira, pouco conciliável com a codificação, que pressupõe noções decantadas pelo tempo e pela prática. S. MARCONDES, Questões de Direito Mercantil, p. 26-27.

450 A. LAMY FILHO, J. PEDREIRA, A Lei das S.A., vol. I, p. 132-133.

451 "Assim, verifica-se que o Projeto de Código Civil regula vários institutos genéricos, relativos a todas as sociedades comerciais, como lhe compete, embora também interesse às anonimas; o Anteprojeto da reforma das anônimas inclui, em seu âmbito, os mesmos institutos que não lhe dizem respeito." in R. REQUIÃO, Anteprojeto de Lei de Sociedades por Ações, p. 112. 
o notório laconismo de tal lei, associado à remissão geral ao regime das sociedades por ações constante de seu artigo 18, diminuíam significativamente - mas certamente não eliminavam - o espaço para dúvidas e hesitações em relação à possibilidade de incidência, ainda que mutatis mutandis, das disposições da Lei 6.404/1976.

Entretanto, com a entrada em vigor da Lei Federal 10.406/2002, que estabeleceu disciplina muito mais ampla e detalhada para as sociedades não acionárias - com destaque obviamente para a sociedade limitada, sucessora da sociedade por quotas de responsabilidade limitada ${ }^{452}$-, o problema da articulação entre tais normas e o regime da lei acionária se tornou muito mais complexo.

O novo Código Civil introduziu definições novas dos vínculos de participação entre sociedades. A terminologia adotada não é, entretanto, perfeitamente rigorosa nem compatível com aquela que já era empregada há décadas pela Lei 6.404/1976. Nos termos do artigo 1.097, a expressão "coligada" é utilizada para definir um gênero que compreende as espécies "controladas", "filiadas" e "de simples participação". Por outro lado, o artigo 1.098 se refere a "coligadas" e "filiadas" como sinônimos para representar a situação de participação relevante (superior a dez por cento do capital sem direito de voto) sem exercício de controle. Nos termos do artigo 46 da Lei 11.941/2009, é esse o conceito de coligada que deve ser usado em relação a leis especiais, de forma que a definição constante do artigo 243 da lei acionária será empregada exclusivamente para os fins desse próprio diploma $^{453}$. O artigo 1.098 define "sociedade controlada", inclusive no caso de controle indireto, mas não contém a definição de controladora.

Além de conter definições próprias de conceitos relevantes para o direito dos grupos, o Código Civil de 2002, por meio de seu artigo 1.053, alterou os parâmetros para a

452 De acordo com estatísticas do Departamento Nacional de Registro do Comércio - DNRC, entre 1985 e 2005, de um total de 4.569.288 novas sociedades constituídas no país, 4.300 .257 (cerca de $94,11 \%$ do total) eram sociedades limitadas (ou por quotas de responsabilidade limitada). Dados disponíveis em: $<$ http://www.dnrc.gov.br/Estatisticas/caep0101.htm>. Acesso em: 07out2012. A predominância da sociedade limitada se explica pelos menores custos de constituição e operação e pela inexistência, em nosso sistema, ao contrário da Alemanha e da Itália, de requisitos de capital social mínimo, elementos que relegaram os tipos societários que não preveem a responsabilidade limitada de todas as classes de sócios a uma curiosidade histórica de nossa legislação.

453 Técnica legislativa confusa, oportunamente criticada por Erasmo Valladão França e Marcelo von Adamek. E. VALLADÃO FRANÇA, M. VON ADAMEK, O Novo Conceito de Sociedade Coligada na Lei Acionária Brasileira, p. 370-371. A comprovar as preocupações dos doutos juristas, verifica-se que, em alguns casos, a legislação especial faz referência expressa e específica aos $\S \S 1^{\circ}$ e $2^{\circ}$ do artigo 243 da Lei 6.404/1976, tal como ocorre no artigo 23, III, da Lei Federal 9.430/1996. 
aplicação supletiva da lei acionária às sociedades limitadas. O principal regime de referência de tal tipo societário se tornou a sociedade simples e a eventual aplicação da Lei 6.404/1976 - ressalvada a via da analogia - foi condicionada à expressa previsão de tal possibilidade no contrato social. Trata-se de percurso hermenêutico relativamente tortuoso, que ensejou justificadas críticas da doutrina ${ }^{454}$.

Em termos práticos e estritamente no que diz respeito aos grupos de sociedade, importa identificar critérios operacionais que permitam estabelecer quando e como serão aplicáveis as regras da Lei 6.404/1976 e quando, ao revés, determinada situação fática estará sujeita apenas ao Código Civil de 2002.

Uma vez que o artigo 1.089 do Código Civil de 2002 ressalva a incidência de lei especial às sociedades anônimas, parece lícito concluir que estruturas de grupo que contem com a presença de sociedades anônimas serão regidas pela Lei 6.404/1976 em função da especialidade de tal diploma ${ }^{455}$.

Além disso, mesmo em cadeias piramidais de controle que não contenham membros com a qualidade de sociedades por ações parece legítimo que se admita, de qualquer forma, a aplicação das disposições grupais da Lei 6.404/1976 quando ao menos uma das integrantes do grupo seja uma sociedade limitada com características prevalentes de sociedade de capitais e com previsão expressa de regência supletiva pela lei acionária consignada no respectivo contrato social, consoante o previsto no parágrafo único do artigo 1.053 do Código Civil de 2002.

454 "Conforme se verifica, o NCC colocou o intérprete do direito societário no lugar de um jogador de corrida de obstáculos, que deve percorrer a pista em busca de uma saída em infindáveis idas e vindastarefa que é inteiramente fruto da péssima técnica legislativa de que se revestiu aquele diploma legal. $O$ resultado na maioria das vezes será um 'Frankenstein jurídico', [...]" in H. VERÇOSA, Curso de Direito Comercial, vol. 2, p. 372. Lucena, por sua vez, se valeu da expressão "dança remissiva". J. LUCENA, Das Sociedades Limitadas, p. 788.

455 "Tem-se em vista que a presença de uma sociedade anônima neste contexto autorizaria que fosse invocada a disciplina estatuída na Lei Acionária, como lei especial. Isto é claro, sem indagar quanto às eventuais mazelas embutidas na redação duvidosa da norma do art. 1.101, parágrafo único, do CC/2002, quando menciona 'ações ou quotas'." in V. FRANCO, Concentração de Poder Econômico e Grupos não Acionários perante a Ótica do Código Civil, p. 225. Essa posição era defendida pelo Professor Comparato mesmo antes da promulgação do Código Civil de 2002: “[...] o fenômeno grupal só mereceu regulação quando, no conjunto das sociedades agrupadas, pelo menos uma delas é anônima; [...]" in F. COMPARATO, Os Grupos Societários na Nova Lei das Sociedades por Ações, p. 94. 


\section{A Disciplina do Grupo de Fato}

A Lei 6.404/1976 não define expressamente o conceito de grupo de fato. Nos termos de tal diploma, "grupo" seria, em rigor, exclusivamente o grupo de direito, formalizado por meio de convenção e disciplinado pelos artigos 265 e seguintes da lei acionária ${ }^{456}$. A expressão "grupo de fato" é, portanto, uma construção doutrinária ${ }^{457}$. O termo "fato" usado para designá-lo e, bem assim, a ausência de expressa definição legislativa do conceito não devem, porém, fazer pensar que estamos diante de figura extrajurídica, nem tampouco que a Lei 6.404/1976 não encerre em si todos os elementos constitutivos de tal instituto.

Como já apontado no capítulo anterior, a definição de grupo de fato decorre de uma interpretação sistemática das disposições dos conceitos de coligada, controladora e controlada, definidos nos parágrafos do artigo 243 da lei acionária, e de sua contraposição ao disposto nos artigos 265 e seguintes do mesmo diploma. O grupo de fato emerge, assim, como o conjunto de controladora, controladas e coligadas que não esteja sujeito às disposições relativas ao grupo de direito, por não ter seus vínculos formalizados por meio de convenção.

Além disso, é de se ter em conta que os pressupostos de caracterização do grupo de fato não têm natureza puramente fática ${ }^{458}$, mas são, ao contrário, o resultado da

456 "Indiscutivelmente, os vínculos societários identificadores da coligação e do controle traduzem a existência de uma associação de sociedades, ou sociedades de sociedades, também denominados grupos de fato, por oposição aos grupos de direito, regulados pela lei nos arts. 265 e seguintes. Tecnicamente, porém, à vista do que dispõe o parágrafo único do artigo 267, será absolutamente impróprio falar em grupo de sociedades para designar a realidade ora considerada." in E. TEIXEIRA, J. GUERREIRO, Das Sociedades Anônimas no Direito Brasileiro, vol. II, p. 700.

457 "Trata-se da distinção, sob certo aspecto radical, entre grupos de fato e grupos de direito. A lei, na verdade, não contém essas expressões, de origem doutrinária. Mas elas parecem muito sugestivas e apropriadas para a compreensão do sistema legal." in F. COMPARATO, Os Grupos Societários na Nova Lei das Sociedades por Ações, p. 94.

458 Ao discorrer sobre os problemas e complexidades conceituais da referida distinção entre questão de fato e questão de direito, Castanheira Neves asseverou que: "Pensamos naquelas distinções entre entidades (ou objectivações) juridicamente conformadas e conceitualizadas, mas em que um dos termos distinguidos recebe a designação 'de facto' por razões particulares (juridicamente particulares), fundamentalmente diferentes das razões pelas quais, usando da mesma expressão, se poderá opor o jurídico ao puro não-jurídico; pois a designação 'de facto' traduz agora apenas uma específica estrutura jurídica de certas relações e instituições concretas, quando postas em confronto com aquelas outras que mereçam, também nesta perspectiva, a predicação 'de direito', e para significar que em umas relativamente às outras se verificaria uma divergência na indole dos fundamentos das suas respectivas juridicidades - as primeiras de uma juridicidade que elas si mesmas exibem e impõem, as segundas de uma juridicidade que lhes vai formal e antecipadamente reconhecida [...] É deste modo que se fala de 
satisfação de silogismos legais precedentes, que se consubstanciam na prévia qualificação dos sujeitos em questão como "sociedade" e nos vínculos que os unem como "controle" ou “coligação". Nesse sentido, a denominação dessa figura jurídica, quase certamente importada da praxe alemã ${ }^{459}$, parece simplesmente refletir a ausência de expressa formalização da estrutura de grupo por meio de convenção, em contraste ao grupo convencional, ou "grupo de direito" - também esta uma expressão doutrinária, uma vez que a lei se refere simplesmente a "grupo" ou "grupo de sociedades".

A esse respeito, também é oportuno notar que o rigor na interpretação do sentido da expressão "grupo", de forma a se compreendê-la única e exclusivamente como "grupo de direito" sempre que empregada pela lei acionária, tem sido, ao menos na jurisprudência administrativa, ocasionalmente mitigado. Efetivamente, em mais de uma ocasião, ainda que com naturais oscilações decorrentes de variações em sua composição, o Colegiado da Comissão de Valores Mobiliários concluiu que a existência de grupo de fato desencadeia a incidência de impedimento para nomeação ao Conselho Fiscal, nos termos do artigo 162, $\S 2^{\circ}$, o qual exclui como legítimos candidatos para tal órgão de supervisão, entre outros, os sujeitos que sejam "membros de órgãos de administração e empregados da companhia ou de sociedade controlada ou do $\underline{\text { mesmo grupo" }}^{\text {"460 }}$. Ou seja, o órgão máximo da autarquia concluiu que, por uma questão de tutela da independência do Conselho Fiscal, os grupos de fato podem ser subsumidos ao conceito legal de "mesmo grupo", conforme empregado em tal passagem da lei acionária.

Se considerarmos que os deveres de informação e as regras contábeis consignados

'universalidade de facto', de 'sociedade de facto', da posse como 'situação jurídica de facto' [...]" in A. NEVES, A Distinção entre a Questão-de-Facto e Questão-de-Direito e a Competência do Supremo Tribunal de Justiça Como Tribunal de "Revista", p. 502-508.

$459 \mathrm{Na}$ doutrina alemã em matéria de direito societário, fala-se efetivamente em "faktischer Konzern" (grupo de fato) em oposição ao "Vertragskonzern" (grupo contratual), termos que - como no Brasil - não foram expressamente empregados no texto da lei acionária. Note-se, porém, que o sistema alemão não é binário, mas tripartido, uma vez que a terceira e mais coesa forma de agrupamento é a "Eingliederung" (integração de empresas). H. DETTLING, Die Entstehungsgeschichte des Konzernrechts im Aktiengesetz von 1965 , p. 275. Vale lembrar que a subsidiária integral do direito brasileiro é espécie do gênero sociedade controlada e não uma modalidade completamente distinta de vinculação entre sociedades, tal como aquela resultante da operação de Eingliederung.

460 Nos processos RJ 2000/4860, RJ 2000/4755 e RJ 2009/6720 (ao que consta, o mais recente), prevaleceu a interpretação ampliativa, baseada sobretudo na similaridade substancial dos riscos derivados das outras hipóteses indubitavelmente compreendidas no escopo do artigo 162, $\S 2^{\circ}$ da Lei 6.404/1976 e aqueles decorrentes da situação em que o conselheiro fiscal atua como empregado ou administrador de sociedade integrante do grupo de fato da própria companhia. No Processo Administrativo Sancionador CVM RJ 2007/3822, prevaleceu ao revés a interpretação mais literal e histórica do dispositivo em questão, que buscou circunscrever o âmbito de sua aplicação aos grupos de direito. 
nos artigos 243 e 247 a 250 da Lei 6.404/1976 são de caráter geral, aplicando-se indistintamente aos grupos de fato e de direito, podemos vislumbrar o núcleo da disciplina societária típica, idiossincrática, dos grupos de fato no disposto nos artigos 245 e 246, cuja incidência sobre os grupos de direito será - argumenta-se - residual e contingente em relação ao conteúdo das respectivas convenções, conforme se discute no próximo capítulo.

O artigo 245 da lei acionária representa comando de direito material, dirigido aos administradores e que, processualmente, parece se escorar implicitamente nas disposições do artigo 159. O artigo 246, por outro lado, possui natureza predominantemente processual, tem como destinatária a sociedade controladora e, quanto ao seu conteúdo material, apoia-se na referência expressa às disposições dos artigos 116 e 117. Questão subjacente comum a ambos os dispositivos é a tutela da autonomia e do interesse próprio da sociedade isolada. Nesse sentido, o próximo subcapítulo trata do tema do interesse social para, nos subcapítulos seguintes, passar à análise mais detida de cada um dos referidos artigos.

\subsection{Disciplina dos Grupos de Fato e Interesse Social}

\subsubsection{Contratualismo e Institucionalismo}

No subcapítulo 6.4 deste trabalho, já foram colacionados os ensinamentos de Carnelutti a respeito das definições de interesse, necessidade e bem ${ }^{461}$. Cumpre agora enfrentar - mas apenas de forma limitada e instrumental à própria análise e sem qualquer ambição de exaurir o tema - a mais complexa e tormentosa questão do interesse social. Nesse campo, a grande discussão parece claramente ser o embate entre as visões contratualistas e institucionalistas do interesse da sociedade ${ }^{462}$. Vale dizer, conforme o

461 F. CARNELUTTI, Teoria Generale del Diritto, p. 59.

462 Discussão que, aliás, definitivamente, não está superada. Em 2000, Hansmann e Kraakman afirmaram que: "O triunfo do modelo de companhia orientado pelos interesses do acionista sobre os seus principais competidores está agora assegurado, ainda que ele fosse problemático tão recentemente quanto há vinte e cinco anos atrás". Tradução livre de: "The triumph of the shareholder-oriented model of the corporation over its principal competitors is now assured, even if it was problematic as recently as twenty-five years ago." in H. HANSMANN, R. KRAAKMAN, The End of History for Corporate Law, p. 32. Que o título, confessadamente provocativo, do trabalho de Hansmann e Kraakman e, bem assim, o seu argumento relativo ao suposto triunfo definitivo da visão contratualista (nos termos da doutrina do "shareholder-oriented model) eram, quanto menos, exagerados - sem prejuízo da validade de muitos dos argumentos construídos pelos ilustres estudiosos - é algo que se demonstra pelo simples fato de que os autores em questão se viram compelidos a revisitar, esclarecer e defender suas afirmações cerca de uma década mais tarde (H. HANSMANN, R. KRAAKMAN, Reflections on the End of History for Corporate Law). 
critério de distinção proposto por Jaeger ${ }^{463}$, se o conceito de interesse social deve (consoante prega o institucionalismo) ou não (na concepção contratualista) abarcar também os interesses de terceiros não sócios ${ }^{464}$.

Ao discutir a relação entre Direito e poder político, Bobbio propôs metáfora extremamente oportuna, sugerindo que se veja o ordenamento jurídico como uma pirâmide, em cuja base o poder claramente serve ao sistema normativo, mas na qual, conforme se avance na direção de seu ápice, verifica-se uma inversão de tal relação, de forma que, no cume da estrutura, a norma é produto e está a serviço do poder constituído $^{465}$. Ou seja, o mesmo ente jurídico, observado por ângulos diversos, tal como um prisma, reflete a luz de maneiras distintas.

Uma relatividade similar, conforme argumentou o Professor Erasmo Valladão França, parece se impor também em relação à questão do interesse social ${ }^{466}$, particularmente no que diz respeito ao ordenamento brasileiro, em que foram positivados tanto conceitos que refletem a visão contratualista da sociedade quanto comandos portadores de valores típicos do institucionalismo. Cumpre recordar que, de um lado, o Código Civil de 2002, nos termos de seu artigo 981, claramente ancorou a sociedade no campo dos contratos. Por outro lado, não se pode ignorar nem reduzir a reclamos genéricos sem conteúdo jurídico as disposições do parágrafo único do artigo 116 da Lei 6.404/1976, que se referem expressamente à necessidade de tutela da posição dos trabalhadores e da comunidade em que a companhia atua.

Nesse sentido, não parece oportuno ou sequer coerente tomar como base posições

463 P. JAEGER, L'Interesse Sociale, p. 3.

464 Ao revisitar o argumento, décadas mais tarde, Jaeger identifica na doutrina do shareholder value uma particular síntese entre fortes elementos contratualistas e institucionalistas. De um lado, está presente a ênfase no fato de que a função primordial da atividade da empresa está no resultado econômico auferido para os sócios, típico traço contratualista. Tal ganho econômico, porém, tendencialmente se concretiza apenas por ocasião da perda da qualidade de sócio, uma vez que a prioridade reside no aumento do valor de venda de sua participação e não na realização de distribuições periódicas de dividendos. Desse modo, e por outro lado, existe a superação da dicotomia entre distribuição de lucros e autofinanciamento da empresa. O foco, como no institucionalismo, está no crescimento da empresa em detrimento do caráter de renda, de fruição, da participação societária. P. JAEGER, L'Interesse Sociale Rivisitato (Quarant'Anni Dopo), p. 812.

465 N. BOBBIO, Teoria dell'Ordinamento Giuridico, p. 42-46.

466 "Se fosse lícito utilizar uma imagem, poder-se-ía dizer que o confronto entre os partidários das duas teorias sugere visões de observadores colocados em pontos distintos: um, o institucionalista, olhando a sociedade anônima de fora (ab extra), pelo que ela representa para a comunidade e para a economia, [...] outro, o contratualista, vendo-a de dentro (ab intus), sob o ângulo exclusivo dos sócios" in E. VALLADÃO FRANÇA, Conflito de Interesses nas Assembléias de S.A., p. 52. 
extremadas ou apriorísticas do conceito de interesse social, de maneira totalmente independente do uso que se faz de tal noção e das características concretas das sociedades - e, especialmente, das empresas - objeto da respectiva análise. Não se trata de se esquivar do problema ou recusar tomada de posição, mas reconhecer o caráter híbrido da sociedade - especialmente a sociedade anônima, instrumento predominantemente de Direito Privado que pode ter gigantesco impacto sobre a coletividade, movimentando massa ingente de capitais e recursos - e a natureza assaz discrepante das tarefas nas quais o conceito de interesse social é costumeiramente empregado, que compreendem desde a avaliação puramente acadêmica ou abstrata das normas societárias até a resolução de conflitos concretos e específicos.

Partindo-se dessa premissa, pode-se afirmar que a perspectiva institucionalista adquire relevância conforme aumente o impacto das atividades da sociedade sobre a esfera jurídica de terceiros e da coletividade em geral, o que geralmente coincidirá com as dimensões econômicas da empresa por ela desenvolvida. Em seu clássico texto sobre o tema, como forma de apontar as discrepâncias de uma visão puramente contratualista do direito societário, Rathenau assinalava a irrazoabilidade e a inviabilidade prática de uma eventual liquidação do Deutsche Bank em função de interesses particulares de seus acionistas $^{467}$. Por outro lado, seria igualmente desarrazoado impor a microempresário a manutenção de atividade fortemente deficitária em função de suposto interesse público ${ }^{468}$.

No que tange à aplicação dada em cada caso ao conceito de interesse social, podese dizer que, em termos gerais, a importância da visão institucionalista será menor em análises atinentes à relação interna entre sócios e sociedade e será maior quando se observa a interação do ente societário com o mundo ao seu redor. Ela será, ademais, maior no âmbito de discussões de política legislativa, que tenham como escopo reformas estruturais do equilíbrio de poder nas companhias, mas será significativamente menos relevante quando se trate de, por exemplo, apurar em situação concreta o cumprimento de deveres

467 W. RATHENAU, Vom Aktienwesen - Eine Geschäftliche Betrachtung, p. 155.

468 "Com efeito, ignorar a diferença entre uma companhia fechada, do tipo familiar, que emprega um diminuto número de operários, e uma macrocompanhia de capital aberto, com patrimônio líquido ascendendo a centenas de milhões de dólares, e de cuja gestão regular depende a subsistência de milhares de trabalhadores, bem como a segurança de inúmeros investidores que nas ações da companhia aplicaram suas poupanças, e bem assim o equilibrio da própria economia nacional, e pretender que ambas possuam a mesma natureza, é sem dúvida fechar os olhos à realidade." in E. VALLADÃO FRANÇA, Conflito de Interesses nas Assembléias de S.A., p. 49. 
fiduciários, ou seja, quando se busca simplesmente aplicar a regra de conflito ${ }^{469}$.

É evidente que o grupo de sociedades é uma estrutura fortemente associada à macroempresa e à concentração empresarial, o que confirma relevante interesse público na disciplina do fenômeno. Ao se discutir, portanto, mudanças na disciplina dos grupos de sociedade, especialmente aquelas que tenham um papel instrumental na eficácia de outros microssistemas jurídicos ${ }^{470}$, é natural e necessário adotar uma visão alargada de interesse social e trazer para o primeiro plano uma leitura institucionalista de tal conceito.

Quando se trata, porém, de analisar a incidência de normas postas, que têm por escopo fundamental valorar a conduta de determinados agentes na qualidade de "gestores de patrimônio alheio" - ou seja, deveres fiduciários - parece natural a prevalência de uma perspectiva contratualista, na qual se tome por referência o interesse social em sua acepção stricto sensu, de interesse da companhia, traduzível em termos de aspiração pela melhor eficiência da empresa, que se reflita na maximização dos resultados econômicos, tanto em termos de lucros (resultados para a própria sociedade), quanto de dividendos (resultados diretos para o próprio acionista $)^{471}$.

$\mathrm{Na}$ análise dos artigos 245 e 246 da Lei 6.404/1976, parece ser exatamente essa a concepção de interesse social mais adequada para se tomar como referência. Convém notar que o artigo 245 se concentra unicamente nos padrões de conduta que devem ser adotados pelos administradores na celebração de contratos intragrupo. Os seus comandos legais estão, portanto, concentrados em aspectos patrimoniais e em uma relação nitidamente

469 Crítico a respeito da centralidade da regra de conflito nos sistemas em que prevalece o contratualismo, o Professor Calixto Salomão Filho vislumbra nessa segunda função uma verdadeira capitis diminutio do conceito. C. SALOMÃO FILHO, O Novo Direito Societário, p. 94-95.

470 Por exemplo, apesar de imperfeita, a disciplina introduzida pela Lei Federal 11.638/2007 - que contém disposição de natureza claramente grupal, nos termos de seu artigo $3^{\circ}$, parágrafo único - facilita a supervisão da empresa plurissocietária por parte de toda coletividade, servindo como potencial instrumento de incremento da efetividade, entre outras, de normas tributárias, concorrenciais e trabalhistas, ao tornar mais nítida a estrutura real da empresa e dificultar o ocultamento de bens.

471 "Pode-se concluir, assim, que o interesse da companhia (ou interesse social stricto sensu), na Lei 6.404, constitui um conceito típico e especifico, consistente no interesse comum dos sócios à realização do escopo social, abrangendo, portanto, qualquer interesse que diga respeito à causa do contrato de sociedade, seja o interesse à melhor eficiência da empresa, seja à maximização dos lucros, seja à maximização dos dividendos. Em face desse conceito, portanto, qualquer outro interesse comum ou individual dos sócios pode ser classificado como extra-social." in E. VALLADÃO FRANÇA, Conflito de Interesses nas Assembléias de S.A., p. 62-63. "[...] o interesse geral de todo acionista, no mecanismo jurídico societário, é um só e sempre igual a si mesmo: a participação nos lucros e no acervo da companhia, refletida no valor de suas ações. [...] Ao falar em 'interesse da companhia', a lei se refere ao interesse comum dos acionistas [...]" in F. COMPARATO, Controle Conjunto, Abuso no Exercicio do Voto Acionário e Alienação Indireta de Controle Empresarial, p. 88. 
interna - vale dizer, deveres de diligência e lealdade do administrador em face da companhia.

Em relação ao artigo 246, cumpre reconhecer que a remissão expressa aos artigos 116 e 117 traz, forçosamente, para discussão as disposições marcadamente institucionalistas constantes de tais dispositivos - notadamente o parágrafo único do artigo 116 como um todo e as referências ao interesse nacional, dos trabalhadores e dos investidores nas três primeiras alíneas do $\S 1^{\circ}$ do artigo 117. Contudo, uma análise da função e da estrutura do artigo 246 parece confirmar, também neste caso, o cabimento de uma abordagem contratualista. É importante, com efeito, atentar para o fato de que a legitimação ativa promovida pelo dispositivo em questão alcança apenas os acionistas, sem se estender aos credores sociais ${ }^{472} \mathrm{e}$, principalmente, aos trabalhadores ${ }^{473}$. Ademais, e principalmente, trata-se de norma voltada unicamente para a recomposição de perdas patrimoniais sofridas pela própria companhia, com pouquíssimo ou nenhum espaço, portanto, para a viabilização de qualquer forma de internalização de interesses extrassociais nos processos decisórios do ente societário ${ }^{474}$.

Por essas razões, para os fins do presente capítulo, parece suficiente e justificado tomar como norte a noção do interesse social stricto sensu no exame dos artigos 245 e 246. De fato, nas hipóteses tipicamente disciplinadas por esses dispositivos, não se pode sequer excluir o risco de que o reclamo a posições institucionalistas seja feito pelos administradores ou pelo acionista controlador com o mero objetivo de legitimar e camuflar os interesses privados conflitantes deste último ${ }^{475}$.

472 Ao contrário, por exemplo, do que ocorre no ordenamento italiano, cujas normas especificamente grupais preveem, expressamente, uma responsabilidade por má gestão do ente ou sociedade que exerce a atividade de direção e coordenação em face dos credores da sociedade controlada (Código Civil italiano, artigo $\left.2.497, \S 1^{\circ}\right)$.

473 Cuja posição, não obstante, é tutelada pelo artigo $2^{\circ}, \S 2^{\circ}$ da Consolidação das Leis do Trabalho.

474 "[...] paralelamente às obrigações com a empresa, o acionista também tem obrigações com os terceiros que com ela se relacionam. $O$ referido artigo abrange, tanto um, como outro feixe de direitos e interesses. O art. 117, que dá corpo ao princípio contido no art. 116, naturalmente deve ser também interpretado com a mesma amplitude. $\underline{O}$ art. 246, por sua vez, materializa o exercício da pretensão que nasce do descumprimento apenas de um, desses dois feixes de direitos. Ou seja, fala apenas das obrigaçães do acionista controlador perante a sociedade." (sem grifo no original) conforme Voto-Vista da Ministra Nancy Andrighi, Superior Tribunal de Justiça, Recurso Especial n ${ }^{\circ}$ 633.338-DF (Rel. Min. Ari Pargendler), $1^{\circ}$ de junho de 2006.

475 "Sobre a utilidade desse tipo de declaração genérica [artigo 116, parágrafo único, da Lei 6.404/1976], que não encontra tradução em regras organizativas, existem muitas dúvidas. Pode-se questionar se não acaba servindo, como ocorreu na Alemanha, para justificar atuações dos acionistas majoritários e seus representantes no interesse próprio, em nome de um mal definido interesse social." in C. SALOMÃO FILHO, O Novo Direito Societário, p. 37. 


\subsubsection{O Conflito de Interesses nas Operações Intragrupo}

Tomando-se como premissa a observação do grupo de fato pelas lentes do interesse social stricto sensu, conforme discutido acima, restam, desde logo, evidentes os potenciais riscos para os acionistas externos decorrentes da influência da sociedade controladora sobre o restante do grupo. De fato, há diversas situações em que a maximização do retorno econômico da posição de controle não coincide com a maximização do valor e dos ganhos para todos os demais acionistas ${ }^{476}$. Conforme já se acenou preliminarmente no item 4.2.5 deste trabalho, o domínio exercido sobre o grupo permite a busca de benefícios privados da posição de controle, ou seja, ganhos desproporcionalmente elevados em relação ao investimento aportado na companhia e que não são compartilhados com os demais acionistas ${ }^{477}$.

São incontáveis os possíveis exemplos de conflito de interesse entre sociedade controladora e controladas. Pode-se pensar, como banal ilustração, na hipótese em que a sociedade $A$ detenha $51 \%$ do capital social da companhia $B$ e $99 \%$ das ações emitidas pela companhia $C$. É evidente que, em quaisquer contratos celebrados entre $B$ e $\mathrm{C}, A$ estará sob forte tentação de utilizar a sua influência sobre ambas - que, a despeito da diferença de participação proporcional, é igualmente incontrastável em relação a todas as duas - para fazer com que primeira favoreça a segunda, uma vez que, em tal caso, os possíveis ganhos para a controladora serão muito maiores.

Não existe nas relações entre $B$ e $C$ um "contraditório de mercado", ou seja, uma relação dialética entre sujeitos que buscam de forma independente o melhor resultado possível para si e cuja síntese - ressalvadas anomalias como erro, coação ou estado de necessidade - pode ser presumida como correspondente aos termos e condições "justos" para aquele bem ou serviço, naquele determinado contexto temporal e geográfico. De fato, nada disso se verifica nos contratos celebrados por sociedades submetidas à influência de um mesmo sujeito. Não há, nesta última hipótese o "equilíbrio natural obtido pela contraposição de interesses opostos ${ }^{\$ 478}$. Os contratos celebrados no seio do grupo de fato estão sujeitos a permanente e estrutural conflito de interesse. A vontade última incidente

476 E. GORGA, Direito Societário Atual, p. 57.

477 A. DYCK, L. ZINGALES, Private Benefits of Control - An International Comparison, p. 541.

478 P. ARAGÃO, O Parecer de Orientação 35/2008 da CVM e a Incorporação de Companhia Fechada por sua Controladora Companhia Aberta, p. 522. 
sobre os dois polos contratantes é essencialmente a mesma, o que aproxima as referidas operações da figura do negócio consigo mesmo ${ }^{479}$, com a agravante, porém, da multiplicidade dos interesses afetados.

Daí porque, conforme já mencionado, Champaud se referia à existência de "vasos comunicantes ${ }^{\$ 40}$ entre as sociedades agrupadas e a mais recente doutrina econômica utiliza a expressão "tunnelling", derivada da ideia de furto mediante a construção de um túnel ${ }^{481}$ : o acionista controlador - in casu, sociedade controladora - dispõe dos meios para direcionar e alocar recursos entre as sociedades do grupo, produzindo ganhos em algumas e prejuízos em outras, de acordo com a sua melhor conveniência, por meio da simples manipulação dos termos e condições dos contratos celebrados entre elas ${ }^{482}$.

A questão, de todo modo, é muito mais vasta e não se limita apenas aos contratos bilaterais celebrados entre as sociedades agrupadas, mas abarca também todos os fluxos de informações e decisões que se estabelecem no seio do grupo de fato. Retomando-se o exemplo anterior, pode-se cogitar a hipótese em que pesquisas confidenciais custeadas e desenvolvidas pela sociedade $B$ indiquem promissor novo produto e que $A$, buscando maximizar os próprios ganhos e valendo-se de seu domínio de fato sobre a administração de ambas as sociedades, opte por explorar tal oportunidade comercial por meio de $C$. Também neste caso, um interesse extrassocial de $A$ - seus ganhos resultantes da participação detida em $C$ - conduzem a uma diminuição dos lucros potenciais auferíveis pelos demais acionistas de $B$.

O caráter insidioso e multiforme das modalidades de favorecimento, bem como o fato de que tais estratégias abusivas possam ser compostas de passos individuais que sejam, em si mesmos, perfeitamente lícitos - tais como nas típicas hipóteses de fraude à lei -, tornam irrenunciável o recurso pelo legislador a conceitos abertos e centrados na questão

479 F. MIRANDA, Tratado de Direito Privado, tomo III, p. 368-369.

480 C. CHAMPAUD, Le Pouvoir de Concentration de la Société par Actions, p. 275.

481 S. JOHNSON, R. LA PORTA, F. LOPEZ-DE-SILANES, A. SHLEIFER, Tunneling, p. 22.

482 A criticidade das operações intragrupo levou inclusive ao desenvolvimento do conceito contábil de "partes relacionadas" - que é mais amplo do que as definições de controladora, controladas e coligadas -, originalmente definido pela Deliberação CVM n 26/1986, mas atualmente disciplinado pela Deliberação CVM n ${ }^{\circ}$ 560/2008, que aprovou o Pronunciamento Técnico CPC 05. Este, por sua vez, busca internalizar no Brasil a regra contábil internacional IAS 24. As normas em questão determinam a divulgação das relações e operações com partes relacionadas com maiores detalhes e rigor do que o previsto na regulamentação contábil ordinária. V. PRADO, Transações com Partes Relacionadas: Estratégias Jurídicas, p. 86-87. 
da intenção do agente, tais como o abuso de poder e o desvio de finalidade. Nessa esteira e de forma a buscar integrar tais conceitos e lhes dar concretude, o legislador também lança mão de padrões de conduta, de deveres fiduciários ${ }^{483}$. Trata-se de estratégia que não deixa de ser expressão da incompletude do contrato de sociedade e que se encontra claramente impressa nas disposições nos artigos 245 e 246 da lei acionária.

\subsection{Artigo 245 da Lei 6.404/1976 e a Posição dos Administradores}

É natural que a Lei 6.404/1976 contenha disposição dirigida especificamente aos administradores das sociedades que compõem o grupo de fato, pois eles são filtros obrigatórios e necessários para a projeção do poder da sociedade controladora ao longo da cadeia formada por controladas e coligadas. O controle indireto não é exercido pela sociedade controlada em primeira mão, mas apenas através das sociedades controladascontroladoras intermediárias, presentadas por seus respectivos administradores ${ }^{484}$.

No Brasil, adotou-se uma visão organicista da administração das companhias ${ }^{485}$, de modo que o administrador, no âmbito de sua esfera de competência, deve agir de forma independente, levando em consideração apenas os interesses da própria sociedade, sem privilegiar as pretensões dos acionistas que o elegeram - fato expressamente ressalvado no $\S 1^{\circ}$ do artigo 154 da lei acionária ${ }^{486}$. Nesse sentido, também é natural que o legislador, nos termos do artigo 245, tenha elevado os administradores a guardiões da comutatividade dos contratos celebrados no âmbito do grupo do fato.

483 Eduardo Salomão Neto se refere aos standards como "tipos de frequência com conteúdo normativo", que refletem qualidades normalmente presentes em determinadas classes de sujeitos, ainda que não em sua totalidade. E. SALOMÃO NETO, Trust e Deveres de Lealdade e Sigilo na Sociedade Anônima Brasileira, p. 310.

484 "O controle indireto é exercido através dos órgãos das companhias." in J. PEDREIRA, Acordo de Acionistas sobre Controle de Grupo de Sociedades, p. 244. "[...] os atos da sociedade controladora se confundem com os dos administradores, já que o acionista controlador age por intermédio dos administradores, não podendo [...] agir diretamente na sociedade." in F. MARTINS, R. PAPINI (atualiz.), Comentários à Lei das Sociedades Anônimas, p. 1014.

485 "No direito brasileiro, parece igualmente estar definitivamente superada a configuração jurídica do administrador como simples mandatário, [...] Para demonstrar a inadequação do mandato como vínculo entre o administrador e a sociedade, bastaria, a rigor, lembrar que a função administrativa é indelegável [...]" in J. GUERREIRO, Responsabilidade dos Administradores de Sociedades Anônimas, p. 72. No mesmo sentido: E. VALLADÃO FRANÇA, Dever de Informar dos Administradores de Companhias Abertas. Inexistência de Submissão ao Acionista Controlador, p. 367.

486 “Não só não estão [os administradores] obrigados a seguir instruções [do controlador], como não podem fazê-lo, em face de seu dever de independência, que ressalta clara e explicitamente do disposto no artigo 154, e seu respectivo $\S 1^{\circ}$, da Lei 6.404/1976 [...]" in E. VALLADÃO FRANÇA, Dever de Informar dos Administradores de Companhias Abertas. Inexistência de Submissão ao Acionista Controlador, p. 371. 
Porém, pode-se argumentar que a exigência de conduta efetivamente autônoma por parte de diretores e membros do conselho de administração é, em certa medida, irrealista e contraditória (quase esquizofrênica) no sistema brasileiro, considerando a forte concentração de poder nas mãos do acionista controlador. O nítido contraste resultante de uma comparação da repartição interna de poderes na companhia brasileira com a disciplina alemã a esse respeito - que carrega traços da doutrina da Unternehmen an sich - é altamente esclarecedor. Enquanto membros do conselho de administração de uma companhia brasileira podem ser destituídos ad nutum, a qualquer momento - aspecto sublinhado pelo artigo 122, II da Lei 6.404/1976 - e por maioria simples, uma decisão análoga - destituição de membro do conselho de supervisão - apenas pode ser tomada no sistema alemão por maioria qualificada de três quartos (§ 103, subparágrafo 1 da lei acionária de 1965). No que diz respeito à diretoria, na Alemanha, seus membros são sempre nomeados pelo conselho de supervisão e apenas podem ser removidos antes da expiração de seu mandato em face de justa causa ( $(83$, subparágrafo 3 ).

Além disso, enquanto o artigo 121 da lei acionária brasileira assegura à assembleia a possibilidade de decidir "todos os negócios relativos ao objeto da companhia" - o que implica a possibilidade de avocar para si essencialmente qualquer questão relativa à sociedade - o $\S 119$, subparágrafo 1, da lei alemã de 1965 fixa um rol taxativo de matérias que - somadas àquelas expressamente previstas no estatuto social exigem manifestação dos acionistas. A assembleia da Aktiengesellschaft apenas pode se exprimir sobre outras questões, não previstas em tal elenco exaustivo, em face de expressa solicitação da diretoria ( $§ 119$, subparágrafo 2$)^{487}$.

Em nossa realidade, a despeito da filiação ostensiva à teoria organicista da administração, continua-se a tratar o administrador como mandatário e, muita vez, fato particularmente grave, mandatário do acionista que o elegeu e não da própria companhia, como nitidamente ilustrado por disposições como os $\S \S 8^{\circ}$ e $9^{\circ}$ do artigo 118 da Lei 6.404/1976, com a redação que lhes foi atribuída pela reforma de 2001.

Desse modo, não é de se surpreender - conforme se argumenta no Capítulo 9 que as disposições relativas aos deveres fiduciários dos administradores tenham, entre nós,

487 E foi justamente a excepcional ampliação pretoriana desse rol que fez com que o caso Holzmüller, já citado anteriormente, tivesse grande destaque na Alemanha. H. WIEDEMANN, Die Unternehmensgruppe im Privatrecht, p. 50-51. 
limitada efetividade prática. A lei acionária não equipou os administradores das companhias brasileiras para que, no mais das vezes, possam oferecer séria resistência às pretensões do acionista controlador ou representar um contraponto efetivo às suas aspirações. Premidos entre, de um lado, a imediata e segura perda de sua posição e, de outro, apenas eventual e incerta responsabilização civil e administrativa, a prática parece demonstrar que tendencialmente os administradores são compelidos a aderir às instruções ilegítimas do controlador.

\subsubsection{Autorização para Operações entre Partes Relacionadas}

Uma leitura a contrario sensu do artigo 245 da lei acionária desperta, ao menos em primeira análise, certa perplexidade. Com efeito, se há um comando legal que expressa e especificamente atribui ao administrador o dever de não celebrar, com sociedades controladas, controladoras ou coligadas, contratos que não guardem estrita comutatividade, seria legítimo dessumir que, ausentes os referidos vínculos de controle e coligação, tornarse-iam admissíveis contratos não pautados por termos equitativos? Em palavras pobres, estaria em tal hipótese o administrador autorizado a celebrar contratos sabidamente gravosos para a companhia?

Em caso de resposta afirmativa, estar-se-ia diante de nítida incompatibilidade entre tal conclusão e os deveres gerais de diligência, persecução do melhor interesse da sociedade - especificamente, o seu interesse stricto sensu - e de lealdade, respectivamente declinados nos artigos 153, 154 e 155 da Lei 6.404/1976.

Porém, uma vez que se admita - como parece ser inegável - que a busca leal e responsável por condições mais favoráveis ou, quando menos, equilibradas em todos os negócios da companhia é dever do administrador mesmo nas relações estabelecidas com sociedades que não mantenham com ela vínculo de controle ou coligação, qual seria então o objetivo do artigo 245? O que ele acrescentaria - e com foco específico nos grupos de fato - em relação aos deveres gerais de correta, eficiente e diligente gestão dos negócios sociais, inerentes à posição fiduciária do administrador? Nesse sentido, qual seria a exata diferença entre os deveres fiduciários dos administradores atinentes a operações intragrupo (sujeitas ao artigo 245) e aqueles relativos a contratos negociados e celebrados com terceiros independentes (sujeitos somente às regras gerais dos artigos 153 e seguintes)? 
Respeitando-se o cânone de que a lei, em princípio, não contém palavras inúteis ${ }^{488}$, é necessário buscar um significado prático válido para o disposto no artigo 245 que, ao mesmo tempo, seja coerente com uma interpretação sistemática dos demais comandos constantes da Lei 6.404/1976.

Uma possível primeira resposta, seria afirmar que a norma em questão tem o objetivo de meramente reforçar, em contexto específico, as disposições gerais relativas aos deveres fiduciários dos administradores. Com efeito, a própria Exposição de Motivos da lei acionária reconheceu a preocupação de declinar de forma "pedagógica" os padrões de conduta impostos aos administradores, ainda que sob o risco de redundância ${ }^{489}$.

Outra possibilidade interpretativa seria afirmar que o artigo 245 buscou fixar uma diferença de grau, ou seja, de intensidade, entre os deveres fiduciários atribuíveis aos administradores em relação a contratos entre partes independentes, de um lado, e aqueles celebrados entre partes relacionadas, de outro. Tal distinção é perfeitamente razoável à luz da criticidade das operações entre partes sujeitas ao mesmo controlador, já apontada acima.

Não é singela, entretanto, a tarefa de inferir consequências práticas de tal constatação. Pode-se, afirmar, em termos genéricos, que os administradores devem certamente tomar maiores cautelas nas operações sujeitas a conflito de interesse, documentando cada elemento justificador de sua realização. Parece exagerado buscar no artigo 245 uma presunção de irregularidade das operações intragrupo. Ainda assim, existe uma expressa diferenciação legislativa dos negócios celebrados pela companhia, conforme as respectivas contrapartes pertençam ou não ao mesmo grupo de fato, que não deve ser ignorada e que pode servir como base, por exemplo, para uma correspondente distinção de tratamento em outros campos, particularmente em matéria probatória, seja em termos de

488 Ao discorrer sobre o brocardo "Verba cum effectu, sunt accipienda" - ressaltando o caráter não absoluto do preceito -, Carlos Maximiliano asseverou que "As expressões do Direito interpretam-se de modo que não resultem frases sem significação real, vocábulos, ociosos, inúteis. [...] Dá-se valor a todos os vocábulos e, principalmente, a todas as frases, para achar o verdadeiro sentido de um texto; porque este deve ser entendido de modo que tenham efeito todas as suas provisões, nenhuma parte resulte inoperativa ou supérflua, nula ou sem significação alguma." in C. MAXIMILIANO, Hermenêutica e Aplicação do Direito, p. 204.

489 "Os artigos 154 a 161 [que se tornariam os artigos 153 a 160 da Lei 6.404/1976] definem, em enumeração minuciosa, e até pedagógica, os deveres e responsabilidades dos administradores. É Seção da maior importância no Projeto porque procura fixar os padrões de comportamento dos administradores, cuja observância constitui a verdadeira defesa da minoria e torna efetiva a imprescindivel responsabilidade social do empresário." (sem grifo no original) Exposição de Motivos $n^{\circ}$ 196, de 24 de junho de 1976, do Ministério da Fazenda. Notas ao Capítulo XII, Seção IV, do Projeto. 
maior flexibilidade na aceitação de indícios, seja na efetiva inversão do ônus da prova.

Porém, caso se deixe de lado, por um momento, uma leitura do artigo 245 a partir da perspectiva da proteção de minoritários e credores (Schutzrecht), analisando-o sob a ótica da estruturação da empresa de grupo (Organisationsrecht), pode-se claramente vislumbrar em tal dispositivo uma confirmação - respeitadas as condições ali consignadas - da possibilidade jurídica de estipulação de acordos entre partes relacionadas ${ }^{490}$, cuja celebração poderia, de outro modo, ser posta em dúvida ${ }^{491}$.

\subsubsection{Comutatividade das Operações}

O artigo 245 da lei 6.404/1976 contém uma cláusula geral de vedação da subordinação de interesses no âmbito dos grupos de fato, fixando limites para o exercício dos poderes da administração relativamente aos contratos e operações intragrupo. Ao contrário do dispositivo análogo da lei acionária alemã de 1965 (o § 311), o artigo 245 se dirige primordialmente aos administradores de cada sociedade e não à sociedade controladora (ou, na praxe alemã, empresa dominante). Outra diferença importante reside no fato de que a lei brasileira se apoia no conceito de comutatividade para buscar exprimir e dar concretude à noção de vedação de subordinação de interesses, enquanto que a norma germânica busca fazer o mesmo usando como base a noção de "desvantagem" "492.

490 “O artigo 245 é, portanto, norma especial da disciplina dos grupos de sociedades, que, em vez de vedar ao administrador o voto ou a intervenção, na suposição de interesse conflitante, veda o favorecimento de outra sociedade do grupo em prejuizo da companhia. Permite as operações inter companies, mas responsabiliza o administrador se, em tais operações, não forem observadas condições estritamente comutativas, ou, não havendo comutatividade, a sociedade não receber pagamento compensatório adequado." (sem grifo no original) in C. LOBO, Conflito de Interesses entre a Companhia e seu Administrador, p. 33.

491 Em parecer que versava sobre a incorporação de controlada, mas em que citou expressamente o artigo 245 da lei acionária, Lamy Filho apontou que: "Como se vê, o direito brasileiro regulou, expressamente, a matéria, e ao fazê-lo afastou a discussão doutrinária sobre a eficácia da 'self-dealing transaction' por isso que previu a incorporação de controlada pela controladora, isto é, de empresas sob o mesmo controle." (sem grifo no original) in A. LAMY FILHO, Temas de S.A. - Exposições Pareceres, p. 258. Importante recordar, a esse respeito, que o Decreto-Lei 2.627/1940 não tratava da figura do controlador, mas continha norma extremamente restritiva em relação às operações entre administrador e sociedade, nos termos de seu artigo 120. Pode-se ler, portanto, no artigo 156, $\S 1^{\circ}$, da lei acionária atual, uma confirmação da possibilidade de realização das operações entre companhia e administradores, análoga àquela que se argumenta estar implícita no artigo 245, relativamente a controladora, coligadas e controladas.

492 Discute-se na doutrina alemã a diferença entre "dano" (Schaden) e "desvantagem" (Nachteil), sobretudo em função do critério temporal de apuração: "O conceito de desvantagem não coincide com o de dano: enquanto a determinação do dano a ser compensado se verifica ex post $e$, portanto, com base em curso dos eventos que então já se desenrolou, a magnitude da desvantagem é medida no momento em que é executada a medida que se estima prejudicial ao patrimônio ou ao faturamento da sociedade". Tradução livre de: "Der Begriff des Nachteils deckt sich somit nicht mit dem des Schadens: Während die 
O termo "comutatividade" parece ter sido empregado no artigo 245 da Lei 6.404/1976 essencialmente com o mesmo significado das expressões condições “equitativas" e condições de (não) "favorecimento" utilizadas em outros dois dispositivos da própria lei acionária. Com efeito, o artigo $117, \S 1^{\circ}$ alínea "f”, refere-se à vedação da celebração de contratos entre o controlador e a companhia "em condições de favorecimento ou não equitativas". O artigo 156, $\S 1^{\circ}$, a seu turno, de forma mais detalhada e esclarecedora, determina que a estipulação de contratos entre o administrador e a sociedade apenas é legítima se realizada em "condições razoáveis ou eqüitativas, idênticas às que prevalecem no mercado ou em que a companhia contrataria com terceiros" ${ }^{\prime 493}$.

Por comutatividade ou equitatividade, entende-se, em geral, o equilíbrio ou proporcionalidade entre a onerosidade das prestações do contrato. Não se trata, porém, de um equilíbrio econômico objetivo ou externo, mas eminentemente subjetivo ${ }^{494}$, enquanto decorrente da livre e autônoma apreciação de cada uma das partes do valor das obrigações de dar ou fazer que assumem e que esperam receber da contraparte ${ }^{495}$. A esse respeito, o Código Civil francês define, em seu artigo 1.104, a comutatividade de um contrato como a situação em que ambas as partes consideram as contraprestações devidas pela outra como equivalentes àquelas que lhes cabem. O elemento essencial, portanto, está na síntese entre duas vontades dialeticamente contrapostas ${ }^{496}$.

Contudo, o aspecto caracterizador do grupo de fato é, como já se apontou acima, a presença e a afirmação de uma única vontade preponderante, o que impede a formação de juízo isento sobre a equivalência econômica das prestações. Não deixa de ser irônico, portanto, o fato de que o recurso pelo legislador ao conceito de comutatividade se imponha

Bestimmung des auszugleichenden Schadens ex post und damit auf der Grundlage des nunmehr bekannten Geschehenablaufs zu erfolgen hat, bemisst sich die Höhe des Nachteils nach der im Zeitpunkt der Vornahme der Maßnahme abzusehenden Beeinträchtigung der Vermögens- oder Ertragslage der Gesellschaft." (negrito no original) in V. EMMERICH, M. HABERSACK, Konzernrecht, p. 427. V. PRADO, Conflito de Interesses nos Grupos Societários, p. 180.

493 Em relação às companhias abertas, aplica-se ainda o disposto na Instrução Normativa CVM 323/2000, que contém diversos dispositivos relativos aos contratos e operações intragrupo e cujos incisos V e VII de seu artigo $1^{\circ}$ tratam da vedação de contratos em "condições desvantajosas ou incompatíveis às de mercado".

494 L. CARDOSO, A Onerosidade Excessiva no Direito Civil Brasileiro, p. 95.

495 "[...] o equilíbrio contratual, assentado na equivalência das prestações. Equivalência essa, não como a possa eventualmente entender o juiz, mas como a avaliaram os contratantes." (sem grifo no original) conforme Voto do Rel. Min. Eduardo Ribeiro, Superior Tribunal de Justiça, Recurso Especial n ${ }^{\circ}$ 5.723MG, 25 de junho de 1991.

496 N. EIZIRIK, A Lei das S/A Comentada, vol. III, p. 357 
justamente nas situações em que tal qualidade, por definição, não pode emergir naturalmente, mas tem de, forçosamente, ser reconstruída com base no hipotético comportamento de partes independentes que negociassem uma operação análoga procedimento, com efeito, expressamente declinado na parte final do $\S 1^{\circ}$ do artigo 156 da Lei 6.404/1976 e, ainda que não explicitamente reiterado, também necessário no que tange a qualquer tentativa de aplicação do artigo 245 do mesmo diploma.

Reconhecendo a dificuldade prática da valoração da presença da comutatividade nas operações intragrupo e buscando fixar critérios para tal avaliação, Modesto Carvalhosa se apoia no teste de fairness (justiça ou razoabilidade) da praxe estadunidense ${ }^{497}$ - que também se traduz na comparação com negócios hipotéticos ou com operações anteriores entre a própria companhia e terceiros não vinculados ao controlador -, para em seguida declinar a necessidade de observância estrita dos critérios de oportunidade e conveniência em todos os contratos celebrados no âmbito do grupo de fato ${ }^{498}$. Vale dizer, não basta analisar apenas os termos e condições intrínsecos do contrato ou operação em questão, que podem ser em si mesmos justos e razoáveis, mas cumpre aferir se sua celebração era efetivamente necessária, adequada ou aconselhável - se atendiam ao interesse da companhia, conforme discutido acima - no contexto e no momento em que foi realizada.

A exigência expressa de comutatividade parece deixar claro o fato de que a

497 "Um controlador tem, de fato, um dever fiduciário em face de sua controlada quando houver operações entre ambas. Contudo, esse fato por si só não evoca o critério da equitatividade intrínseca. Tal critério apenas será aplicado quando o dever fiduciário é acompanhado de um contrato consigo mesmo - a situação na qual um controlador está de ambos os lados de um negócio com a sua controlada. $O$ negócio consigo mesmo ocorre quando o controlador, por meio de seu domínio sobre a controlada, faz com que esta aja de modo a que o controlador receba algo da controlada em exclusão e em detrimento dos acionistas minoritários de tal sociedade". Tradução livre de: "A parent does indeed owe a fiduciary duty to its subsidiary when there are parent-subsidiary dealings. However, this alone will not evoke the intrinsic fairness standard. This standard will be applied only when the fiduciary duty is accompanied by self-dealing - the situation when a parent is on both sides of a transaction with its subsidiary. Selfdealing occurs when the parent, by virtue of its domination of the subsidiary, causes the subsidiary to act in such a way that the parent receives something from the subsidiary to the exclusion of, and detriment to, the minority stockholders of the subsidiary." conforme opinião do Juiz C. J. Wolcott, Supremo Tribunal de Delaware, Sinclair vs. Levien, 280 A.2d 717; 1971 Del. LEXIS 225, decisão 18 de junho de 1971. "A falta de equitatividade em uma operação com partes relacionadas pode ser identificada por meio de uma ou duas maneiras, entre si relacionadas: pela comparação do negócio com uma hipotética operação com terceiro independente ou por meio da comparação com operações reais em um mercado competitivo que funcione adequadamente". Tradução livre de: "Unfairness in a self-dealing transaction may be identified in one or both of two related ways: by comparison of the transaction to a hypothetical other-dealing transaction or by comparison to actual transactions in a well-functioning competitive market." in R. CLARK, Corporate Law, p. 147.

498 M. CARVALHOSA, Comentários à Lei de Sociedades Anônimas, $4^{\circ}$ vol., tomo II, p. 63-65. 
responsabilidade potencial dos administradores, neste caso, extrapola em muito os limites do conceito de dano emergente. Justamente porque a aferição da violação do artigo 245 se baseia sempre no confronto com um cenário hipotético, parece natural que a respectiva perda ressarcível diga respeito ao custo de oportunidade, ou seja, não compreende apenas o que a companhia efetivamente perdeu - um mero retorno ao status quo ante -, mas também, tudo o que razoavelmente deixou de ganhar, ao não empregar de modo diverso os recursos mobilizados na respectiva operação com a controladora, controlada ou coligada ${ }^{499}$.

Os comandos legais relativos à comutatividade e à vedação de favorecimento indevido a sociedades vinculadas à companhia não se traduzem na obrigação do administrador de sempre obter resultados positivos em tais operações. O risco é inerente à atividade empresarial e representa um pressuposto do lucro. O honesto e escusável erro de avaliação do mercado por parte do administrador não pode ser visto como favorecimento $^{500}$. Digamos que a sociedade controlada $X$ venda, a preços correntes de mercado e como parte de suas atividades normais, grande quantidade de determinado insumo agrícola para a sua controladora $Y$. Caso, imediatamente após a operação, o preço do insumo suba drasticamente por fatores imprevisíveis e fora do controle dos administradores de $X$, tais como quebra de safra ou bloqueios sanitários, é evidente que o montante que a companhia deixou de ganhar - e o correspondente benefício de sua controladora - não representam favorecimento ou dano, mas simples flutuação de mercado.

Com a exceção dos abusos mais grosseiros, salta aos olhos a complexidade e a alta dose de subjetividade inerentes à aferição do caráter equitativo de determinada operação intragrupo, ainda que se trate de contrato isolado, una tantum. Tratando-se, porém, de relação continuada e de longo prazo - como frequentemente são os contratos efetivadores da "economia interna" do grupo de fato - a questão adquire complexidade exponencialmente maior ${ }^{501}$. Outros exemplos de fatores que potencialmente agravam a dissecção de tais operações são a interposição de terceiros, o recurso a estruturas

499 N. EIZIRIK, A Lei das S/A Comentada, vol. III, p. 361.

500 "Investido, para o bom exercício da função, de poderes 'discricionários' para lograr os fins societários, obrigado a decidir questões às vezes de grande relevância em questão de minutos, o administrador é levado a cometer erros, e o que distingue o mau do bom administrador é o fato de acertar mais do que erra." in A. LAMY FILHO, Responsabilidade do Administrador por Ato Praticado no Exercício da Função - A Dificil Caracterização do Risco Envolvido, p. 410.

501 N. EIZIRIK, A Lei das S/A Comentada, vol. III, p. 360. 
contratuais pouco usuais e o envolvimento de ativos dificilmente precificáveis, como direitos de propriedade intelectual. Esses aspectos, somados à posse das respectivas informações e documentos pelos próprios administradores - e, portanto, com amplas possibilidades de ocultamento intencional de dados - tornam a questão da detecção e da prova da ilícita subordinação de interesses um elemento crítico da efetividade desta norma $^{502}$. Esse quadro de assimetria parece justificar plenamente uma abordagem mais flexível, tanto pelos tribunais de lege lata, quanto pelo legislador de lege ferenda em relação à formação, à aquisição, à valoração da prova do inadimplemento da obrigação de contratar em bases equitativas ${ }^{503}$.

\subsubsection{Pagamento Compensatório Adequado}

O artigo 245 determina que o administrador apenas será civilmente responsável pelo favorecimento de outras sociedades do grupo de fato se os prejuízos resultantes para a companhia não forem neutralizados por meio de "pagamento compensatório adequado".

Como mencionado anteriormente, esse dispositivo representa um ponto de conexão com a doutrina Rozenblum do direito francês e guarda semelhança conceitual com o previsto na parte final do artigo $2.497, \S 1^{\circ}$, do Código Civil italiano - o qual, por sua vez, ecoa o disposto no artigo 2.634, $\S 3^{\circ}$, do mesmo diploma, relativo à exoneração de responsabilidade criminal do administrador -, que determina a ausência de responsabilidade do ente que exerce a atividade de direção e coordenação nas hipóteses em que o dano causado à sociedade controlada não se materializa (i) em função do resultado geral da atividade da influência daquele sobre esta ou (ii) por meio de operações

502 O § 309, subparágrafo 2 , da lei acionária alemã de 1965, prevê expressamente a inversão do ônus da prova contra os representantes legais da empresa controladora. Na prática, a doutrina entende que cabe aos autores da ação de reparação aduzir uma relação causal entre perdas causadas à companhia e supostas instruções emitidas por tal representante, ou violações de seus deveres de diligência e cuidado, antes que tenha lugar a efetiva inversão do ônus da prova. V. EMMERICH, M. HABERSACK, Konzernrecht, p. 404-405. Em Delaware, a inversão do ônus da prova é a principal consequência da incidência do intrinsic fairness test: "Quando a situação envolve uma controladora e sua controlada, com a controladora dominando o negócio e determinando os seus termos, o teste da equitatividade intrínseca, com a sua consequente inversão do ônus da prova, é aplicado". Tradução livre de: "When the situation involves a parent and a subsidiary, with the parent controlling the transaction and fixing the terms, the test of intrinsic fairness, with its resulting shifting of the burden of proof, is applied." conforme opinião do Juiz C. J. Wolcott, Supremo Tribunal de Delaware, Sinclair vs. Levien, 280 A.2d 717; 1971 Del. LEXIS 225, decisão de 18 de junho de 1971.

503 Matéria já, preliminarmente, debatida em trabalho anterior do candidato: D. VIO, Prova Difícil e Inadimplemento da Obrigação de Contratar em Condições Equitativas nos Termos da Lei das S.A., p. $253-259$. 
especificamente voltadas à compensação da perda sofrida. Galgano cita como exemplo a operação em que uma sociedade holding faz com que uma sociedade financeira do grupo conceda crédito em condições mais vantajosas do que as disponíveis no mercado a uma outra controlada em dificuldades. Para evitar lesão aos interesses dos acionistas externos da sociedade financeira, a holding pode efetuar a esta um pagamento correspondente ao custo de oportunidade da operação, ou seja, a diferença entre os juros praticados e os juros de mercado $^{504}$.

A lei acionária alemã de 1965 também contém disposição similar ${ }^{505}$, como parte do seu já mencionado $\S 311$, que trata dos limites para o exercício de influência dominante sobre uma sociedade dependente no grupo de fato, ou seja, na ausência de celebração de acordo de domínio (Beherrschungsvertrag). A parte final do subparágrafo 1 de tal dispositivo determina que a influência exercida será ilegítima apenas se eventuais perdas assim causadas não forem compensadas. O subparágrafo 2, por sua vez, determina que se as perdas não forem compensadas ao longo do exercício social em curso, caberá ao menos determinar a forma e o prazo para sua efetivação antes do fim do exercício ${ }^{506}$.

A lei brasileira é menos rigorosa do que a alemã ao não estabelecer um prazo fixo para a efetivação da neutralização das perdas. Por outro lado, o conceito de "pagamento compensatório adequado" parece ser muito mais restritivo do que as noções de compensação genérica previstas nas legislações alemã ${ }^{507}$ e italiana, bem como na jurisprudência francesa. De fato, à primeira vista, a norma brasileira encerraria inelutável dever de ressarcimento específico e em dinheiro para a sociedade controlada prejudicada pela políticas da controladora para o grupo de fato. Conforme discutido no subcapítulo 6.4 deste trabalho, é apenas através de uma leitura sistemática dos artigos 117 e 245 da Lei 6.404/1976, baseada mais na exclusão da ilicitude em face da inexistência de perda efetiva

504 F. GALGANO, Direzione e Coordinamento di Società - Art. 2497-2497 septies, p. 138.

505 O Professor Leães vê plena identidade entre o requisito brasileiro de "pagamento compensatório adequado" e a regra alemã. L. LEÃES, Proibição de Voto e Conflito de Interesse nas Assembléias Gerais, p. 179.

506 V. EMMERICH, M. HABERSACK, Konzernrecht, p. 437.

507 “A natureza da vantagem por meio da qual a perda é compensada não é disciplinada pela lei. Admite-se qualquer vantagem pecuniária, que seja em termos gerais apta a neutralizar as perdas no balanço. Em particular, as vantagens não precisam ter qualquer relação com as desvantagens". Tradução livre de: "Die Art des Vorteils, durch den der Nachteil auszugleichen ist, ist nicht gesetzlich geregelt. In Betracht kommt jeder geldwerte Vorteil, der generell geeignet ist, die Nachteile in der Bilanz zu neutralisieren. Die Vorteile brauchen namentlich keinen Bezug auf die Nachteile zu haben." (negrito no original) in V. EMMERICH, M. HABERSACK, Konzernrecht, p. 437. 
do que propriamente na extensão e flexibilização do conceito de pagamento compensatório, que se pode alcançar conclusão favorável à possibilidade de implementação de políticas comuns de grupo no âmbito do grupo de fato, em função das quais determinadas desvantagens momentâneas sejam neutralizadas por benefícios supervenientes.

Cumpre indagar se o pagamento compensatório implica exclusão da própria ilicitude da conduta ou simplesmente representa uma referência à potencial neutralização do dano indenizável. Apesar de, em ambas as hipóteses, a consequência imediata ser a inexistência de dever de reparação, a questão não tem relevância meramente acadêmica, pois - conforme a linha de interpretação que se adote - é possível chegar a conclusões opostas sobre o cumprimento, por parte dos respectivos administradores, de seus deveres fiduciários - vale dizer, estar desobrigado de indenizar, não significa ser um bom e leal administrador. A redação do artigo 245 parece claramente elevar o adequado pagamento compensatório a alternativa em relação à comutatividade da operação, tornando-o, portanto, mecanismo idôneo para afastar a pecha de ilicitude da conduta do administrador.

Para que se alcance tal efeito legitimador dos atos dos administradores, entretanto, parece claro que o pagamento compensatório deverá ser realizado tempestiva e espontaneamente. Assim, por exemplo, se a companhia obtiver indenização diretamente do controlador por abuso de controle que também seja passível de subsunção ao artigo 245, em ação social ut singuli movida pelos acionistas minoritários, o administrador cúmplice por uma simples questão de bis in idem, a despeito do disposto no artigo $117, \S 2^{\circ}$ - não estará obrigado a reparar duplamente a perda já ressarcida. Entretanto, os valores desembolsados pelo controlador a título de ressarcimento certamente não poderão ser considerados "pagamento compensatório", nos termos do próprio artigo 245, e não restará cancelada a ilicitude da conduta do administrador que, caso se trate de companhia aberta, permanecerá inclusive passível de responsabilização na esfera administrativa.

É importante também considerar que o pagamento compensatório deve se consubstanciar em ganho econômico efetivo, específico e mensurável para a companhia prejudicada, não se admitindo referências genéricas a benefícios de sinergia, imagem ou perspectivas de lucratividade ${ }^{508}$. Uma vez que a presença de tal vantagem neutralizadora

508 “A este propósito, as considerações desenvolvidas anteriormente induzem a considerar que seja 
das perdas representa fato desconstitutivo do dever de indenizar que, de outro modo, seria imputável ao administrador, é a este último que caberá a demonstração cabal de tais benefícios, nos termos do artigo 333, II, do Código de Processo Civil; solução, aliás, bastante razoável, em princípio, tendo em vista seu presumível conhecimento do negócio e disponibilidade de documentos e informações.

\subsubsection{Responsabilização do Administrador}

Ainda que o artigo 245 da Lei 6.404/1976 não contenha remissão expressa às disposições do artigo 159 do mesmo diploma, não há nenhuma razão para se afirmar que não serão estas últimas a regular a ação de apuração de responsabilidade do administrador por indevido favorecimento de controladora, controladas e coligadas ${ }^{509}$.

Por conseguinte, a respectiva ação poderá ser promovida, conforme o caso: (i) diretamente pela sociedade (ut universi), (ii) por qualquer acionista (ação ut singuli por substituição processual derivada) ou (iii) por acionistas que detenham mais de cinco por cento do capital social (ação ut singuli por substituição processual originária). Nas duas primeiras situações, a propositura da ação estará condicionada à prévia deliberação da assembleia geral em favor da responsabilização do administrador, hipóteses nas quais este restará impedido de exercer suas funções, nos termos do $\S 2^{\circ}$ do artigo $159^{510}$. Requisito adicional aplicável à segunda hipótese - ação ut singuli por substituição processual derivada, consoante o $\S 3^{\circ}$ do artigo 159 - é a inércia dos demais administradores em dar

necessário identificar uma compensação efetiva, e não meramente 'virtual', de forma a garantir a satisfação de um interesse patrimonial de titularidade dos sócios das sociedades (controladas) prejudicadas". Tradução livre de: "A questo proposito, le considerazioni svolte precedentemente inducono a ritenere che sia necessario individuare una compensazione effettiva, e non meramente 'virtuale', cosi da garantire la soddisfazione di un interesse patrimoniale facente capo ai soci delle società (controllate) pregiudicate." in P. JAEGER, L'Interesse Sociale Rivisitato (Quarant'Anni Dopo), p. 813.

509 "A aplicação ao caso das regras de legitimação ativa do art. 159 me parece irrecusável, sob pena de se condenar o texto do art. 245 à total inefetividade." in F. COMPARATO, Os Grupos Societários na Nova Lei das Sociedades por Ações, p. 97. "Parece-nos não haver dúvidas possíveis quanto ao cabimento da aplicação do art. 159, $\S 4^{\circ}$ à hipótese do art. 245, embora este último não traga qualquer indicação a respeito." in E. TEIXEIRA, J. GUERREIRO, Das Sociedades Anônimas no Direito Brasileiro, vol. II, p. 709.

510 Como ressalta o Professor Leães, a deliberação assemblear a respeito da responsabilização dos administradores não é petição inicial. Não deve ela, necessariamente, conter em detalhes todos os pontos e causas de pedir da futura ação a ser movida contra o administrador. L. LEÃES, Ação Social Derivada de Responsabilidade Civil dos Administradores, p. 707. O objetivo da deliberação assemblear prévia é simplesmente o de dar à maioria social a oportunidade para indicar, assumindo a responsabilidade pela sua decisão, se ainda confia no administrador suspeito ou se julga oportuna a apuração de sua responsabilidade. No mesmo sentido: N. EIZIRIK, A Lei das S/A Comentada, vol. II, p. 410. 
início ao processo, decorridos três meses da deliberação da assembleia a esse respeito.

A via da substituição processual, seja ela derivada ou originária (discutida a seguir), comporta uma não coincidência entre as partes do processo (administrador e sócio) e os sujeitos da relação de direito material controvertida (administrador e companhia) ${ }^{511}$. Trata-se de hipótese sempre excepcional, que apenas tem lugar quando expressamente autorizada por lei, conforme o disposto no artigo $6^{\circ}$ do Código de Processo Civil. Cumpre anotar que para Modesto Carvalhosa apenas haveria substituição processual na hipótese do artigo $159, \S 3^{\circ}$ da lei acionária ${ }^{512}$. Na modalidade prevista no $\S 4^{\circ}$ do mesmo dispositivo e, como se verá, também em relação ao artigo 246 -, Carvalhosa vislumbra a atuação extraordinária da minoria societária como órgão corporificador - presentador - da companhia, com exclusão expressa de qualquer forma de substituição processual ${ }^{513}$. Melhor razão parece assistir, in casu, a Marcelo von Adamek que afirma ser justamente na hipótese do artigo 159, § $3^{\circ}$, da Lei 6.404/1976 - aquela na qual Carvalhosa vislumbra substituição processual - a única em relação à qual se poderia argumentar que o minoritário age como órgão, por estar respaldado em prévia deliberação da maioria e, portanto, atuar com base na presumível vontade da sociedade ${ }^{514}$. Mesmo do ponto de vista

511 A. ALVIM, Notas Atuais sobre a Figura da Substituição Processual, p. 20. J. GUERREIRO, Responsabilidade dos Administradores de Sociedades Anônimas, p. 82. Celso Agrícola Barbi denomina a substituição processual "legitimação anômala". C. BARBI, Comentários ao Código de Processo Civil, vol. I, p. 72.

512 "Deixando a administração de propor a ação social, dentro do prazo máximo previsto na norma contado da deliberação favorável da assembleia geral, caberá a qualquer acionista, independentemente do percentual que detenha no capital social, propor em nome próprio a medida que caberia à companhia, nos termos do art. $6^{\circ}$ do Código de Processo Civil." (sem grifo no original) in $\mathrm{M}$. CARVAlHOSA, Comentários à Lei de Sociedades Anônimas, $4^{\mathrm{a}}$ ed., $3^{\circ}$ vol., p. 460.

513 "Na ação social ut singuli o acionista ingressa em juízo em nome da companhia, na defesa do patrimônio social e do restabelecimento da observância da lei ou do estatuto. Não há, portanto, substituição processual, tal como prevista no art. $6^{\circ}$ do Código de Processo Civil." (sem grifo no original) in M. CARVALHOSA, Comentários à Lei de Sociedades Anônimas, $4^{a}$ ed., $3^{\circ}$ vol., p. 468. Em parecer de 1993, o Professor Leães transmite a impressão de aderir a tal posição: "Trata-se da chamada ação social minoritária, ou seja, a ação social exercida por um grupo de sócios a que a lei atribui a condição de órgão subsidiário da companhia, legitimado a representá-la na propositura da ação social uti singuli." in (sem grifo no original) L. LEÃES, A Prévia Deliberação Assemblear Como Condição de Legitimatio ad Causam na Ação Social, p. 463. Contudo, em parecer de 1996, o Professor Leões confirma sua plena adesão à tese da substituição processual, mesmo na hipótese do artigo $159, \S 4^{\circ}$ : " $A o$ exercer a ação com base no $\S 4 .^{\circ}$ do art. 159 da Lei $n .6 .404$, o acionista age em nome próprio mas no interesse da companhia, cujo patrimônio visa a defender. Tem-se, no caso, a legitimação extraordinária, a excepcionar o princípio insculpido no art. $6 .^{\circ}$ do Código de Processo Civil, sob forma de substituição processual. O acionista é, parte, mas apenas no sentido formal, já que a sociedade preserva a sua condição de parte em sentido material, [...]" (sem grifo no original) in L. LEÃES, Ação Social Derivada de Responsabilidade Civil dos Administradores, p. 706.

514 "No entanto, na hipótese em que a ação social é proposta de forma derivada, contra a vontade manifestada pela maioria dos acionistas em assembléia geral, não há como se supor possa a minoria ser propriamente órgão da sociedade, sob pena de ter-se de admitir a existência de conflitos intra- 
prático, é de se questionar como seriam reguladas questões como a desistência da demanda, caso não se reconhecesse a titularidade do direito de ação - ou seja, a qualidade de parte em sentido formal - aos acionistas minoritários.

A terceira hipótese - ação ut singuli por substituição processual originária, nos termos do artigo 159, $\S 4^{\circ}$-, ao revés, tem como pressuposto a prévia decisão da assembleia geral contrária à imputação de responsabilidade ao administrador, o que inclui deliberações intencionalmente evasivas e procrastinatórias ${ }^{515}$. Neste caso, exige-se que os acionistas promotores da ação tenham ao menos cinco por cento do capital social da companhia, votante ou não, de forma a se assegurar representatividade mínima e se contrastar o abuso de minoria.

Não é necessário que apenas um acionista detenha individualmente a referida participação no capital, admitindo-se que vários minoritários reúnam suas forças para tanto, formando litisconsórcio ativo. A tentativa de aglutinação de participações para compor o índice mínimo exigido pela lei é, certamente, razão legitimadora da solicitação da lista de acionistas da companhia, nos termos do artigo $100, \S 1^{\circ}$ da Lei 6.404/1976 ${ }^{516}$.

Existe discussão sobre em que momento essa participação é exigível - data do ajuizamento da ação ou data em que os supostos danos foram causados - e se sua titularidade deve ou não ser mantida ao longo de todo o processo. Quanto ao primeiro ponto, parece prevalecer a posição que toma como referência a data de propositura da ação. O risco inerente à posição contrária é o de que se verifique um significativo hiato entre a data em que os danos forem causados e o momento de sua detecção, intervalo durante o qual o quadro de acionistas pode sofrer relevantes alterações o que - adotando-se o

orgânicos na disléxica manifestação da vontade social" in M. VON ADAMEK, Responsabilidade Civil dos Administradores de S/A e as Ações Correlatas, p. 373-374.

515 "Compreendem-se como negativa da Assembléia Geral as deliberações evasivas, manifestamente protelatórias, certo que a maioria não pretende permitir em concreto qualquer responsabilidade, nem eventualmente instauração de procedimento judicial, nenhum seriam os direitos essenciais dos sócios e os da minoria, se não podem cuidar sequer de apurar fatos graves apontados." conforme decisão do Tribunal de Justiça do Rio Grande do Sul, Agravo de Instrumento n 31.353, 8 de novembro de 1978, Rel. Des. Milton dos Santos Martins.

516 "Assim, entendo que o disposto no $\S 1^{\circ}$ do art. 100 autoriza o fornecimento da lista integral de acionistas nas hipóteses em que os acionistas devem atuar conjuntamente para defender algum direito comum, em razão de a lei ou o estatuto estabelecer quorum mínimo para a postulação diante do Poder Judiciário, da Administração Pública ou dos órgãos da companhia." conforme o voto do DiretorRelator Eli Loria, Processo Administrativo CVM n RJ2009/5356, Rio de Janeiro, 08 de dezembro de 2009. 
referido critério temporal ${ }^{517}$ - inviabilizaria a obtenção da participação necessária ao ajuizamento da ação de responsabilização. Em relação à necessidade ou não de manutenção do bloco de cinco por cento ao longo de toda a tramitação do processo, soa pouco razoável uma exigência desse gênero à luz da duração média dos processos no Brasil e considerando que se discute uma indenização que verterá para a própria companhia e não para o acionista ou ex-acionista (que, neste segundo caso, terá interesse apenas no reembolso das despesas do processo que antecipou $)^{518}$.

Nos termos do artigo 291, caput, da Lei 6.404/1976, a Comissão de Valores Mobiliários está expressamente investida de autoridade para reduzir o percentual de participação mínima indicado no artigo $159, \S 4^{\circ}$, relativamente às companhias abertas. Ao que consta, a autarquia se valeu de tal prerrogativa apenas em relação à solicitação de instalação do conselho fiscal (Instrução Normativa CVM n ${ }^{\circ} 324 / 2000$ ) e para o requerimento de voto múltiplo para a formação do conselho de administração (atualmente, Instrução Normativa CVM n ${ }^{\circ}$ 164/1991), mas não para a fattispecie em exame. Com as notícias a respeito do aumento da dispersão de capital em algumas companhias abertas brasileiras, seria oportuno que a Comissão de Valores Mobiliários considerasse seriamente a possibilidade de redução do requisito de participação constante do $\S 4^{\circ}$ do artigo $159^{519}$, pois cinco por cento pode ser uma fração extremamente significativa do capital em determinados cenários.

517 Ementa de decisão do Tribunal de Justiça do Rio de Janeiro afirma: "[...] Percentual do artigo 159, § 4 da Lei 6.404. Verificação no momento em que ocorreu a lesão [...]”. Tribunal de Justiça do Rio de Janeiro, Agravo de Instrumento ${ }^{\circ}$ 2007.002.33.363, Rel. Des. Bernardo Moreira Garcez Neto, decisão de 21 de maio de 2008. Importante observar, quanto ao referido caso, que a decisão foi tomada em favor de minoritário que, simultaneamente, por meio de processo separado, questionava exatamente a diluição de sua participação para nível inferior ao limite de cinco por cento; fator que certamente foi levado em consideração pelos julgadores.

518 No sentido de que a participação não deve ser obrigatoriamente mantida após o ajuizamento da ação: “ $O$ fato de os agravados terem, no decorrer da ação, exercido o direito de recesso, não os torna parte ilegítima para figurar no polo ativo, nas circunstâncias, isto é, depois de terem deixado de contar com 5\% do capital social." Tribunal de Justiça de São Paulo, Agravo de Instrumento ${ }^{\circ}$ 320.676-4/2-00, Acórdão n 00679266, voto do Rel. Des. José Geraldo de Jacobina Rabello, de 18 de março de 2004. Na edição de 2003 de seus célebres comentários à lei acionária, Modesto Carvalhosa defendia a suspensão do processo até que fosse recomposto o percentual de cinco por cento entre os litisconsortes ativos (M. CARVAlHOSA, Comentários à Lei de Sociedades Anônimas, $3^{\mathrm{a}}$ ed., $3^{\circ}$ vol., p. 381). Contudo, na edição de 2011 da mesma obra, o ilustre jurista reviu sua posição para sustentar que o processo não é suspenso ou extinto caso os autores da ação percam de forma superveniente a qualidade de acionistas, esclarecendo ainda que não há requisito processual de recomposição do percentual de participação mínima (M. CARVALHOSA, Comentários à Lei de Sociedades Anônimas, $4^{\mathrm{a}}$ ed., $3^{\circ}$ vol., p. 470).

519 Idealmente, de forma escalonada e, de um lado, proporcional ao porte da companhia e, de outro, inversamente proporcional ao seu free-float. 
É de se questionar se a exigência em questão é aplicável mesmo nas hipóteses em que o acionista controlador - ou bloco de controle - detenha mais de noventa e cinco por cento do capital social, nas quais, portanto, seria impossível alcançar o percentual de cinco por cento, mesmo com a mobilização de todos os acionistas externos. Parece mais justa a resposta negativa, pois, caso contrário, conferir-se-ia verdadeira imunidade judicial ao administrador que age em conluio com o controlador $^{520}$. Uma possível solução para o problema seria autorizar o ajuizamento da demanda pelo minoritário que não conta nem com participação relevante no capital, nem com respaldo de prévia deliberação assemblear (favorável à responsabilização), mediante prestação de caução de custas e verbas de sucumbência, por meio da aplicação analógica do artigo 246, § $1^{\circ}$, alínea "b".

Não é de se excluir, de antemão, que a assembleia geral possa aprovar a propositura da ação de responsabilidade do administrador por violação do disposto no artigo 245 da lei acionária ${ }^{521}$. Pode-se pensar, por exemplo, na hipótese em que $A$ seja acionista controlador da companhia $X$ e, ao mesmo tempo, administrador da companhia $Y$, uma coligada de $X$, mas controlada pelo acionista $B$. O administrador $A$ terá incentivo para fazer com que $Y$ atue de modo a favorecer $X$ e, em tal caso, o controlador da companhia prejudicada terá todo interesse em tomar as medidas judiciais cabíveis para remediar a situação.

$\mathrm{Na}$ realidade brasileira em que, como se discutiu acima, os administradores costumam ser a longa manus do acionista controlador, é mais provável que a ação seja promovida pelos minoritários, nos termos do $\S 4^{\circ}$ do artigo 159 , até mesmo porque a aprovação da propositura da medida judicial pelo controlador poderia ser interpretada- em alguns casos, injustamente - como o reconhecimento de falha no exercício de seu poder-

520 Questão já enfrentada pelo Superior Tribunal de Justiça, que decidiu a favor dos minoritários: "Na espécie, somente cerca de $1 \%$ das ações com direito a voto e do capital social não pertencem à controladora. Indaga-se, nessa circunstância, sobre a possibilidade e legitimidade dos acionistas minoritários em promoverem ação de responsabilidade civil contra o administrador e contra a sociedade controladora, pleiteando, em nome próprio, indenização para a controlada [...] o co-réu [...] era administrador e acionista majoritário dessa empresa controladora. Destarte, despiciendo seria exigir-se, neste caso, a convocação de assembléia geral para deliberar sobre a propositura de processo judicial destinado a apurar responsabilidades do administrador, [...] Tal assembléia, in casu, além de impregnada de absoluto contrassenso, teria resultado certo e induvidoso, pelo que sem sentido a sua realização." conforme decisão do STJ, Recurso Especial n 16.410-0 SP, Rel. Min. Sálvio de Figueiredo, 23 de junho de 1992.

521 Para a discussão de interessante caso prático nesse sentido: M. VON ADAMEK, Responsabilidade Civil dos Administradores de S/A e as Ações Correlatas, nota de rodapé n 65, p. 130-131. 
dever de nomear profissionais competentes $\left(117, \S 1^{\circ}\right.$, alínea “d") para a gestão da companhia.

Com estas considerações não se quer afirmar, porém, que as ações sociais $u t$ singuli por substituição processual originária sejam comuns. Muito pelo contrário, são bastante raras na prática, o que se atribui principalmente à posição desfavorável do acionista minoritário, que tem, no mais das vezes, de promover com recursos próprios uma longa e desigual batalha contra os administradores (e acionista controlador), que têm acesso aos recursos, econômicos e de informação, da própria companhia ${ }^{522}$.

Tratando-se de hipótese de substituição processual, é evidente que os eventuais ganhos obtidos por meio de condenação do administrador fluirão em benefício (ao menos direto e imediato) da própria companhia (artigo $159, \S 5^{\circ}$ ) e não do minoritário autor da respectiva demanda judicial. Além disso, o artigo 159 da Lei 6.404/1976, ao contrário do artigo $246, \S 2^{\circ}$, não previu qualquer prêmio ao acionista minoritário que patrocina a ação social, nem fixou, desde logo, os honorários advocatícios em patamar elevado. Desse modo, mesmo em caso de vitória total, ao minoritário caberá apenas o reembolso de suas despesas - e, ainda assim, no limite da condenação aplicada ao administrador -, além do benefício indireto e proporcional decorrente dos valores recebidos pela própria companhia. Tais recursos, porém, continuarão sob a gestão indireta do mesmo acionista controlador e, portanto, sujeitos a novos abusos. Enfim, é importante considerar que, para as companhias de grande porte, o patrimônio pessoal de um administrador pessoa natural, ainda que abastada, será amiúde insuficiente para cobrir as perdas decorrentes de eventual conduta de indevido favorecimento a outras sociedades do grupo de fato. A ação social ut singuli coloca o acionista minoritário diante de riscos e custos efetivos e imediatos, cuja contrapartida tende a ser, nos melhores casos, uma vitória de Pirro e, nos piores, elevadas despesas sucumbenciais ${ }^{523}$. Todos esses elementos tornam perfeitamente compreensível a

522 "Convenhamos que, nesses termos, a tutela é por demais precária, por reclamar raro aguerrimento e, mesmo, substancial disponibilidade econômica do acionista prejudicado, para desencadear uma batalha judicial da qual os administradores e o acionista controlador soem participar lançando mão de recursos da própria empresa [...]" in M. PENTEADO, Dissolução e Liquidação de Sociedades, p. 203204. E. MUNHOZ, Empresa Contemporânea e Direito Societário: Poder de Controle e Grupos de Sociedades, p. 280.

523 No direito inglês, nos termos do paradigmático caso Wallersteiner versus Moir, de 1975, entende-se que, se o juiz der autorização para o prosseguimento da ação derivada - o que implica uma valoração prima facie sobre a razoabilidade e verossimilhança da demanda - os respectivos custos devem ser suportados pela própria companhia, mesmo em caso de indeferimento do pedido ressarcitório: "[...] uma consequência do fato de que a ação derivativa se destina a defender direitos da companhia é que, caso 
parca utilização deste mecanismo de responsabilização dos administradores ${ }^{524}$.

Vistos os procedimentos de responsabilização, cumpre analisar brevemente as hipóteses de exoneração do dever de indenizar por parte dos administradores. Conforme já se acenou anteriormente, o simples desempenho insatisfatório da companhia não pode ser considerado, em si mesmo, fato ilícito ${ }^{525}$. O risco é inerente à atividade empresarial e o administrador não é imune a erros de avaliação ou mesmo prognóstico. $\mathrm{O}$ artigo 159 , $\S 6^{\circ}$ busca preservar o raio de ação do administrador, ao excluir a sua responsabilidade em caso de sólidas evidências quanto à sua boa-fé e quanto à persecução sincera do melhor interesse da companhia ${ }^{526}$.

Ademais, nos termos do artigo 134, § $3^{\circ}$, a aprovação das demonstrações financeiras e das contas do exercício social implicam exoneração de responsabilidade dos administradores. Pressupõe-se, neste caso, que os acionistas concordaram com o modo de atuação dos administradores. De acordo com a posição prevalente na doutrina, caso se constate a existência de irregularidades posteriormente à aprovação das contas pela assembleia, a responsabilização dos administradores estará condicionada à prévia anulação das deliberações tomadas no conclave por erro (ou, se cabível, por dolo, fraude, simulação ou coação), dentro do prazo decadencial previsto no artigo $286^{527}$.

a permissão seja concedida, a sociedade normalmente será responsável pelos custos do processo, mesmo - e, de fato, especialmente -, na hipótese em que a demanda seja em última análise mal sucedida. [...] Essa é uma disposição muito importante porque, sem ela, o desincentivo financeiro para que o acionista promovesse uma ação derivada seria muito forte [...]". Tradução livre de: "[...] a consequence of the derivative claim being to enforce the company's rights is that, where permission is given, the company should normally be liable for the costs of the claim, even, in fact especially, where the litigation is ultimately unsuccessful. [...] This is a very important provision because, without it, the financial disincentive for a shareholder to bring a derivative claim would be very strong [...]" in DAVIES, Paul Lyndon, Gower and Davies' Principles of Modern Company Law, p. 622.

524 M. VON ADAMEK, Responsabilidade Civil dos Administradores de S/A e as Ações Correlatas, p. 368369. L. LEÃES, A Prévia Deliberação Assemblear Como Condição de Legitimatio ad Causam na Ação Social, p. 706.

525 N. EIZIRIK, A Lei das S/A Comentada, vol. II, p. 349.

526 Para Nelson Eizirik, que vislumbra em tal preceito a internalização da doutrina da business judgement rule no ordenamento brasileiro, os requisitos para a exoneração de responsabilidade do administrador, nos termos do artigo 159, § $6^{\circ}$, da Lei 6.404/1976, são: (i) conduta ativa do administrador (não há proteção em relação à omissão), (ii) inexistência de interesses conflitantes, (iii) coleta diligente de informações anteriormente à tomada da decisão, (iv) persecução do interesse social e (v) a boa-fé. N. EIZIRIK, A Lei das S/A Comentada, vol. II, p. 357. Em relação aos grupos, porém, convém recordar que, nos termos da decisão tomada no caso Sinclair vs. Levien (Supremo Tribunal de Delaware, 280 A.2d 717; 1971 Del. LEXIS 225, decisão de 18 junho de 1971), nas hipóteses de contratos celebrados entre partes relacionadas (self-dealing) a business judgement rule é substituída pelo intrinsic fairness test, que enseja inversão do ônus da prova em desfavor dos administradores e acionista controlador.

527 N. EIZIRIK, A Lei das S/A Comentada, vol. II, p. 164-165. 
A disciplina do quitus representa passagem particularmente infeliz de nossa lei acionária, em grave dessintonia com o direito comparado ${ }^{528}$. Neste ponto, o legislador brasileiro parece ter, em enorme medida, de um lado, (i) sobrestimado as informações que podem ser efetivamente apreendidas e a fiscalização que pode ser exercida por meio dos números globais agregados constantes das demonstrações financeiras e de discussões assembleares e, de outro, (ii) subestimado as dificuldades que decorrem desse sistema para o acionista minoritário, que terá de buscar a anulação de tal deliberação com base em erro, promover nova assembleia tendo como objeto a responsabilização dos administradores e, apenas em seguida, promover a competente ação na qualidade de substituto processual $^{529}$. De todo modo, de lege lata, parece imperativo interpretar restritivamente o artigo 134, $\S$ $3^{\circ}$, de forma que o efeito exoneratório da aprovação das contas se limite às contas efetivamente prestadas, ou seja, às informações verdadeira e inequivocamente fornecidas aos acionistas. Não deve o quitus abarcar dados apenas implícitos em contas agregadas. Caso contrário, cria-se situação em que, quanto menos informarem - quanto mais sintéticas e crípticas forem as demonstrações e contas do exercício - maior será a probabilidade de os administradores obterem um verdadeiro cheque em branco da assembleia social.

O $\S 7^{\circ}$ do artigo 159 da lei acionária ressalva, enfim, a responsabilidade do administrador pelos danos causados diretamente a acionistas ou terceiros. Nesse caso, não se trata de perda meramente reflexa, indireta, resultante de prejuízo causado à sociedade, mas prejuízo que impacta o próprio patrimônio da parte. Pode-se imaginar, por exemplo, a situação em que um acionista apenas decida não exercer direito de recesso e aprove a relação de troca proposta para uma operação de incorporação, por outra companhia, das ações da sociedade de que participa em função de informações sabidamente falsas divulgadas pelos administradores ${ }^{530}$. Em tal hipótese, a sociedade que se tornou subsidiária

528 Apenas como exemplo, não poderia ser maior o contraste entre o artigo 134 , $\S 3^{\circ}$, da lei acionária brasileira e o disposto no artigo $74^{\circ}$ do Código das Sociedades Comerciais de Portugal, de acordo com o qual a aprovação das contas apenas tem efeito exoneratório (i) em relação aos fatos expressamente levados a conhecimento dos sócios anteriormente à aprovação e (ii) desde que não se verifique a oposição de sócios representando ao menos dez por cento do capital social.

529 Merecidas, portanto, as detalhadas e percucientes críticas levantadas por Marcelo von Adamek contra a norma em questão. M. VON ADAMEK, Responsabilidade Civil dos Administradores de S/A e as Ações Correlatas, p. 249-257. São particularmente oportunas as considerações do autor a respeito da gravidade dos obstáculos práticos representados pela necessidade de anulação da assembleia para a responsabilização dos administradores (M. VON ADAMEK, Responsabilidade Civil dos Administradores de $S / A$ e as Ações Correlatas, nota de rodapé n ${ }^{\circ}$, p. 253).

530 Marcelo von Adamek colaciona diversos outros exemplos, como o indevido impedimento do ingresso de acionista em assembleia ou a obstrução do exercício do direito de preferência na subscrição de novas 
integral não sofreu, por si mesma, qualquer perda patrimonial e, portanto, não tem qualquer pretensão a ressarcimento. A parte lesada, em tal caso, é pessoalmente o acionista, que terá ação direta - sem substituição processual, na qualidade de parte formal e substancial - contra o administrador, independentemente de qualquer prévia deliberação da assembleia.

\subsection{Artigo 246 da Lei 6.404/1976 e Sociedade Controladora}

\subsubsection{Remissão aos Artigos 116 e 117}

O artigo 246 da Lei 6.404/1976 contém importantíssima remissão ao disposto nos artigos 116 e 117 da mesma lei ${ }^{531}$, pois sem essa referência cruzada poderia pairar alguma dúvida sobre a incidência dos poderes-deveres típicos do "acionista controlador" à "sociedade controlada", conceito este que, de tal forma, estaria sob o risco de ser relegado apenas aos seus significados contábeis e ao disposto no artigo 245. Trata-se, de fato, de importantíssima equiparação entre as duas definições para fins de imputação de deveres e responsabilidades ${ }^{532}$.

Feita essa observação, cumpre constatar que o conteúdo "puramente grupal” do artigo 246 é mínimo - contido na própria circunscrição de sua incidência à sociedade controladora - e não se compreende porque o legislador não estendeu o seu campo de aplicação a todos os acionistas controladores, independentemente de revestirem ou não a qualidade de sociedade ${ }^{53}$. Na verdade, é na lista exemplificativa ${ }^{534}$ de condutas ilícitas do

ações. M. VON ADAMEK, Responsabilidade Civil dos Administradores de $S / A$ e as Ações Correlatas, p. 203-204.

531 “O artigo 117, parágrafo único, alínea a, define um dos casos mais freqüentes de 'abuso de controle' qual seja o do controlador de várias sociedades que, para atender aos seus próprios interesses, sacrifica os de uma companhia para favorecer outra em que tem maior participação. A norma deve ser entendida em consonância com o disposto no Cap. XX da Lei (arts. 243 a 264), que trata das sociedades coligadas, controladoras e controladas [...]" (sem grifo no original) in A. LAMY FILHO, Responsabilidade do Acionista Controlador Estrangeiro, p. 213.

532 "O legislador societário equipara a sociedade controladora [...] ao acionista controlador, a quem a Lei das S.A. atribui expressamente determinados deveres, visando a prevenir e a reprimir a prática de abusos." in N. EIZIRIK, A Lei das S/A Comentada, vol. III, p. 518.

533 Deixando, conforme já mencionado, à doutrina e à jurisprudência a tarefa de identificar a via processual cabível para a responsabilização do controlador que não seja sociedade. A favor da plena aplicabilidade do artigo 246 em tal caso: F. COMPARATO, C. SALOMÃO FILHO, O Poder de Controle na Sociedade Anônima, p. 384. Defendendo a possibilidade de ação contra o controlador, mas sem as exigências (caução ou cinco por cento de participação) e benefícios (prêmio e honorários fixados em vinte por cento) do artigo 246: P. ARAGÃO, Aspectos Processuais da Legislação Societária, p. 71.

534 “A caracterização do 'acionista controlador' é definida no parágrafo único do artigo 116 e pressupõe, além da maioria dos votos, o efetivo exercicio do poder de controle para dirigir a companhia. Exemplificando, no artigo 117, modalidades mais freqüentes de exercício abusivo do poder pelo 
acionista controlador, constante do artigo $117, \S 1^{\circ}$, que se pode encontrar referências a questões efetivamente de direito material de natureza intersocietária, tais como (i) levar a companhia a favorecer outra sociedade, em prejuízo das prerrogativas econômicas dos minoritários (alínea "a") e (ii) e celebrar contratos com a companhia em condições não equitativas ou de favorecimento, ainda que por meio da interposição de "sociedade na qual tenha interesse" (alínea "f") $)^{535}$. Naturalmente, com isso não se quer dizer que outras modalidades de abuso de poder ou desvio de finalidade, previstas na lista do $\S 1^{\circ}$ do artigo 117 ou apenas implícitas na fórmula aberta de seu caput, não encontrem nos grupos campo fértil de aplicação.

Aspecto extremamente relevante de muitas das condutas abusivas previstas no artigo $117, \S 1^{\circ}$, é a sua natureza extra-assemblear, a confirmar que - conforme já discutido anteriormente - o legislador brasileiro de 1976 superou definitivamente a ficção democrática das deliberações sociais, demonstrando lucidez e pragmatismo quanto às reais modalidades, informais e não documentadas, de afirmação e projeção do poder de controle, tanto na companhia isolada, quanto ao longo da cadeia societária do grupo de fato.

Com isso, obviamente, não se quer dizer que o domínio da sociedade controladora sobre a assembleia geral dos acionistas não seja tema importantíssimo. Ao contrário, podese afirmar com segurança que a própria disseminação dos grupos de sociedades na realidade econômica, somada aos perenes conflitos formais de interesse que prevalecem em suas relações internas, mas que nem sempre se traduzem em conflitos substanciais, representou um dos principais fatores para a reformulação, em chave restritiva, das doutrinas e normas relativas ao impedimento de voto ${ }^{536}$.

controlador, o Projeto não exclui outras hipóteses, que a vida e a aplicação da lei se incumbirão de evidenciar." conforme a Exposição de Motivos no 196, de 24 de junho de 1976, do Ministério da Fazenda. Notas ao Capítulo X, Seção IV, do Projeto. Sem grifo no original. No mesmo sentido: A. LAMY FILHO, J. PEDREIRA, A Lei das S.A., vol. I, p. 324. F. MARTINS, R. PAPINI (atualiz.), Comentários à Lei das Sociedades Anônimas, p. 1015.

$535 \mathrm{Na}$ esfera das companhias abertas, e para fins de responsabilidade administrativa do controlador, a referida lista é complementada pelo rol, também exemplificativo, do artigo $1^{\circ}$ da Instrução Normativa CVM 323/2000.

536 Oportunas as considerações de Luigi Mengoni, tendo por referência a experiência italiana: “Não existe, portanto, em nosso ordenamento, um princípio que proíba ao acionista perseguir na assembleia uma política de interesses inspirada em fins estranhos aos da sociedade. A renúncia do legislador a introduzir um princípio dessa natureza é essencial no sistema econômico moderno, caracterizado por um processo de concentração industrial e pelo respectivo fenômeno de encaixotamento das sociedades"; e "O fenômeno das participações acionárias de controle exige certamente cautelas jurídicas mais penetrantes do que as atualmente existentes [...] Mas, enquanto não se quiser considerá-lo ilícito, o que seria impensável, não se pode precluir à sociedade controladora o direito de voto nas deliberações 


\subsubsection{Natureza e Pressupostos da Ação de Responsabilização}

Modesto Carvalhosa, reiterando o argumento de que lançou mão na análise do artigo $159, \S 4^{\circ}$, afirma que a ação prevista no artigo 246 da Lei 6.404/1976 não consiste em hipótese de substituição processual consoante o artigo $6^{\circ}$ do Código de Processo Civil, mas se traduz, ao revés, na representação da companhia pelos minoritários, limitadamente ao ajuizamento e condução do processo, na qualidade de órgão social. Vale dizer, a minoria social corporificaria - presentaria - a companhia, a qual compareceria assim em juízo como parte em sentido formal e material, sem qualquer forma de legitimação anômala ${ }^{537}$.

Pelas mesmas razões já levantadas anteriormente e com a devida vênia, não parece in casu assistir razão ao ilustre estudioso. O minoritário que propõe ação nos termos do artigo 246 o faz sem respaldo de deliberação assemblear prévia e, portanto, não parece adequado vê-lo como portador de qualquer vontade social. Na esfera do artigo 246, contudo, existem razões adicionais para que se argumente que efetivamente estamos diante de substituição processual e não representação orgânica da companhia pela minoria social. Afinal, se o minoritário atuasse realmente como órgão social ele não seria pessoalmente responsável por seus atos regulares de gestão, nos termos do artigo 158, caput da própria lei acionária. Como consequência, a responsabilidade perante a controladora ré pelas

referentes às relações entre ela e a sociedade controlada, apenas porque em tais relações a controladora se encontra formalmente em uma posição de potencial conflito de interesses com a controlada". Tradução livre de: "Non esiste perciò, nel nostro ordinamento, un principio che proibisca all'azionista di perseguire nell'assemblea una politica di interessi ispirata da fini estranei alla società. La rinuncia del legislatore a introdurre un simile principio è essenziale nel sistema economico moderno, caratterizzato dal processo di concentrazione industriale e dal connesso fenomeno dell'inscatolamento delle società."; e "Il fenomeno delle partecipazioni azionarie di controllo esige certamente delle cautele giuridiche più penetranti di quelle attualmente predisposte [...]. Ma fino a quando non lo si voglia considerare illecito, il che è impensabile, non si può precludere alla società controllante il diritto di voto nelle deliberazioni concernenti i rapporti con essa della società controllata, solo perché in tali rapporti la controllante si trova formalmente in una posizione di potenziale conflitto di interessi con la controllata." in L. MENGONI, Conflitto di Interessi in Materia Sociale, respectivamente, p. 444 e 451 452. E. LEÃES, Proibição de Voto e Conflito de Interesse nas Assembléias Gerais, p. 181. E. VALLADÃO FRANÇA, Conflito de Interesses e Benefício Particular: Uma Distinção que se Impõe Definitivamente Dirimir, p. 42.

537 "No caso específico desse artigo [artigo 246, Lei 6.404/1976] a minoria tem legitimidade plena e única de representação da companhia, ativamente em juizo, em ação social ut universi, contra a controladora ou controladoras (controle comum). [...] Portanto, a legitimidade é dos minoritários, como órgão da sociedade que se tornam para esse específico fim."; e ainda "Os minoritários, portanto, corporificam a vontade da controlada em juízo, representando-a organicamente. Não se aplica à hipótese o art. $6^{\circ}$ do Código de Processo Civil. Não se trata de legitimação sui generis, extraordinária ou anômala. A parte que entra em juízo é a companhia controlada, como titular do direito material e processual objeto da ação." in M. CARVALHOSA, Comentários à Lei de Sociedades Anônimas, 4 vol., tomo II, respectivamente p. 67 e 71. 
verbas de sucumbência em caso de desfecho negativo (improcedência) da ação social seria, em tal hipótese, unicamente da própria companhia, que apenas poderia exercer direito de regresso para recuperar tais valores do "minoritário-órgão" em caso de culpa ou dolo deste último ou expressa violação da lei ou do estatuto (artigo 158, caput, I e II), fatos a serem apurados em ação autônoma. Nesse caso, porém, não se explicaria a expressa exigência de caução e a inequívoca imputação de responsabilidade, perante a controladora ré, pelas verbas de sucumbência, consoante a alínea " $b$ " do $\S 1^{\circ}$ do artigo 246. Também não estaria claro em tal hipótese o enquadramento jurídico do prêmio previsto no $\S 2^{\circ}$ do artigo 246 , devido pela sociedade controladora ré diretamente ao acionista minoritário autor da ação social.

A propositura de ação nos termos do artigo 246 não está sujeita - e nem haveria sentido que estivesse ${ }^{538}$ - à previa deliberação da assembleia. Neste caso, diversamente do que ocorre em relação às ações previstas no artigo 159, o polo passivo da ação será composto pela própria acionista controladora e é descabido esperar que esta vote em favor da responsabilização de si mesma por conduta ilícita ${ }^{539}$. A diversidade de sujeitos justifica, portanto, a diversidade de procedimentos prévios à ação.

Os principais requisitos definidores da legitimidade ativa do acionista minoritário para a propositura da ação ut singuli contra a sociedade controladora são, consoante o $\S 1^{\circ}$ do artigo 246, (i) a titularidade de ao menos cinco por cento do capital social da companhia ou, alternativamente, (ii) prestação de caução por custas e honorários de advogado. No que diz respeito à participação no capital, as questões que emergem e os possíveis critérios a serem aplicados são essencialmente os mesmos já discutidos acima, no âmbito da análise do artigo $159, \S 4^{\circ}$. Ou seja, é indiferente se se trata de capital votante ou não, o critério pode ser satisfeito por meio da soma da participação de diversos minoritários e, em termos gerais, considera-se suficiente a titularidade da participação na data da propositura da ação.

A participação de cinco por cento no capital social - que também pode ser, mas

538 E. TEIXEIRA, J. GUERREIRO, Das Sociedades Anônimas no Direito Brasileiro, vol. II, p. 711.

539 Não se pode excluir a hipótese de que a própria companhia promova a ação ut universi contra a (antiga) sociedade controladora em caso de mudança do controle societário ou de falência. Seria, de fato, inadequado interpretar o $\S 1^{\circ}$ do artigo 246 como uma exclusão do direito de ação da própria parte lesada. Convém lembrar que a substituição é a exceção; a ação direta a regra. Nelson Eizirik argumenta que, por aplicação analógica do artigo 159, seria necessária prévia deliberação dos acionistas em tal caso. N. EIZIRIK, A Lei das S/A Comentada, vol. III, p. 368-369. 
até hoje não foi, reduzida pela Comissão de Valores Mobiliários relativamente às companhias abertas, nos termos do artigo 291 da Lei 6.404/1976 - serve como barreira para o abuso de minoria, evitando que "aventureiros", que não tenham um significativo entrelaçamento dos próprios interesses com os da companhia, ajuízem ações contra o controlador. Cumpre recordar que, à luz do disposto no artigo 36 da lei acionária, até os concorrentes da companhia - ou seus representantes - podem, em princípio, se tornar acionistas.

A título de nota, é de se observar que o artigo 246 - ao contrário do artigo 159, $\S 7^{\circ}$ - não ressalva expressamente a responsabilidade (tampouco a respectiva ação de apuração) da sociedade controladora pelos danos causados diretamente aos acionistas externos da controlada ou seus credores. Não seria razoável, porém, derivar desse silêncio uma supressão da responsabilidade aquiliana da controladora ${ }^{540}$.

\subsubsection{Caução Judicial e Honorários}

Ausente a referida participação mínima correspondente a cinco por cento do capital social, é realmente prudente, de certo ponto de vista, a exigência de caução, pois neste caso - ao contrário da hipótese prevista no artigo $159, \S 3^{\circ}$ - o acionista, além de não possuir interesse proporcionalmente significante no patrimônio da companhia, age sem respaldo de prévia deliberação assemblear. Não obstante, esse requisito pode certamente agravar o já crítico desequilíbrio de forças entre acionistas minoritários e sociedade controladora.

A lei não fixa o valor da caução, mas é possível argumentar que o seu montante não deve ser módico, a ponto de incentivar lides temerárias ou ser incapaz de fazer frente às eventuais verbas de sucumbência, mas também não pode representar negação de acesso à Justiça, nem tampouco frustrar o próprio sentido da norma em questão ${ }^{541}$. Tendo vista a

540 "Os parágrafos desse art. 246 só tratam da ação social uti singuli, sem aludir à ação individual dos acionistas para haver perdas e danos. Mas tampouco aqui considero aceitável uma interpretação restritiva do texto legal, deixando de levar em consideração que a ação de indenização do acionista por prejuizo individual, sofrido em razão de abuso de poder, pode encontrar assento tanto nos arts. $116 \mathrm{e}$ 117, quanto no princípio geral do art. 159 [equivalente ao artigo 186 do Código Civil de 2002] do Código Civil." in F. COMPARATO, Os Grupos Societários na Nova Lei das Sociedades por Ações, p. 97-98. "Não há limitação 'a forfait' da responsabilidade civil do acionista controlador, regendo-se a hipótese pelas normas gerais do Código Civil (art. 159)." in A. LAMY FILHO, Responsabilidade do Acionista Controlador Estrangeiro, p. 214.

$541 \mathrm{O}$ que se pode observar, desde logo, é que o legislador dispensou a prestação de caução em todos os casos em que os acionistas minoritários autores da ação social detivessem mais de cinco por cento do 
potencial assimetria de poderio econômico e os valores que costumam estar em jogo, o tema não é banal ou secundário e os tribunais pátrios dele se ocuparam em mais de uma ocasião.

Não se pode deixar de observar, nesta seara, que um excessivo rigor na imposição da caução judicial acabaria por criar situação em que a sociedade controladora seria premiada pela própria torpeza. Em outras palavras, quanto maior a perda ilicitamente causada, maiores as barreiras econômicas para o exercício de pretensão ressarcitória por parte dos acionistas minoritários ${ }^{542}$. O próprio fato de que a lei tenha atribuído à Comissão de Valores Mobiliários competência para reduzir o percentual de participação no capital que determina a desnecessidade da garantia é forte indício de que é admissível uma dose de flexibilidade nesta matéria ${ }^{543}$.

Uma das principais questões discutidas a esse respeito é se se poderia tomar como referência para o cálculo do valor da garantia o proveito econômico indireto e proporcional a ser obtido pelo acionista-autor em caso de procedência da ação. Assim, em demanda ajuizada contra a sociedade controladora, tendo por objeto ressarcimento à companhia no valor total de $\mathrm{R} \$ 100.000,00$, promovida por acionista titular de um por cento do capital social, a caução seria calculada tomando por base o montante de $\mathrm{R} \$ 1.000,00$. Contra tal possibilidade, pesa tanto a interpretação literal da alínea "b", $\S 1^{\circ}$, do artigo 246 da lei acionária, quanto a qualidade de substituto processual do acionista, pois afinal, o objeto da ação é a reparação do dano sofrido pela companhia e não pelo sócio.

Nesse sentido, como aparente solução de acomodação, a jurisprudência tem combinado o conceito indicado acima, com (i) o comando constante do artigo 20, $\S 4^{\circ}$, do Código de Processo Civil, bem como com (ii) uma interpretação teleológica da lei

capital social, além de atribuir competência à Comissão de Valores Mobiliários para reduzir tal percentual em relação às companhias abertas. Assim, fixou-se um grau de comprometimento econômico com a companhia e com a demanda judicial a partir do qual se pressupõe que o acionista não age de forma temerária. Pode-se argumentar, portanto, que em nenhuma hipótese será lícito exigir caução superior ao valor da participação que dispensaria tal garantia.

542 "[...] será frustrar o direito que a lei outorga ao acionista, subordinar o valor da caução que deve prestar, ao valor certo e previsível da total reparação, - tornando assim a propositura da ação, tanto mais inalcançável ao pequeno investidor de poupança, quanto maior a lesão. Será a impunidade dos amus [sic, leia-se: “maus"], se improbos em grandes cifras." conforme Voto-Vista do Min. Clóvis Ramalhete, Supremo Tribunal Federal, Recurso Extraordinário n ${ }^{\circ}$ 94.720-5 RJ, $1^{\text {a }}$ Turma, 06 de outubro de 1981.

543 “Tal porcentual mínimo não constitui 'cláusula pétrea', tanto que pode ser reduzido pela Comissão de Valores Mobiliários.” in N. EIZIRIK, A Lei das S/A Comentada, vol. III, p. 370. 
acionária, para admitir que, em função do caráter inestimável do valor da causa, a caução seja temporariamente determinada com base no proveito econômico indireto esperado para o acionista $^{544}$.

Ao aplicar essa linha de argumentação em decisão de 2010, o Superior Tribunal de Justiça permitiu que o parâmetro de referência para o cálculo de caução exigida de acionista minoritário na lide em questão despencasse, em caráter provisório, da quantia de R\$ 1 bilhão, para apenas R \$ 65.000,00, uma vez que a participação do autor da ação no capital da sociedade controlada - uma companhia aberta de telecomunicações - estava circunscrita a cerca de $0,000065 \%$ do capital social total ${ }^{545}$.

No bojo dessa decisão, o tribunal também enfatizou que a cifra do valor da causa assim reduzida deverá ser, igualmente, adotada como referência para o cálculo de honorários advocatícios em caso de procedência da ação ${ }^{546}$. Ao proceder dessa maneira,

544 Essa parece ser a linha que prevalece, atualmente, no Superior Tribunal de Justiça, mas seus principais elementos conceituais já haviam sido levantados no início da década de 1980 pelo Supremo Tribunal Federal. De fato, ainda no regime anterior à Constituição Federal de 1988, em recurso não acolhido por falta de prequestionamento, o Min. Clóvis Ramalhete, do Supremo Tribunal Federal, trouxe importantes considerações a respeito do tema: "A ação do acionista minoritário para obter a reparação de danos causados pelo Controlador à SA de que participe, merece certas considerações do aplicador da lei. A primeira é que o acionista intenta ação de valor inestimável. - Neste caso, por isso, os honorários não se subordinam ao valor da causa, nem são arbitrados por peritos. São deixador [sic] à 'apreciação equitativa do juiz' (CPC, art. $\left.20, \S 4^{\circ}\right)$. A segunda está em que, para o acionista minoritário, o interesse financeiro dele só seria proporcional à porcentagem do valor de suas ações, em relação ao capital da SA; [...] Não há de, pois, fazê-lo arcar, sem razão, com o ônus relativo ao total de eventual reparação, a obter pela ação; porque não a ele, mas à SA controlada, de que é acionista, irá ter o montante da eventual indenização. A terceira, e relevante, é que na aplicação desta norma, quando se tem em vista o fim social dela, que consiste em uma dotação legal de poder ao acionista minoritário, que não o teria sem a lei, na sua confrontação com a poderosa controladora, o Juiz não deve frustrá-lo." (grifos no original) conforme Voto-Vista do Min. Clovis Ramalhete, Supremo Tribunal Federal, Recurso Extraordinário n ${ }^{\circ}$ 94.720-5 RJ, $1^{\text {a }}$ Turma, 06 de outubro de 1981.

545 "No caso, a manutenção do valor da causa em ( $R \$ 1.000 .000 .000,00$ - um bilhão de reais), frustraráo direito que a lei outorga ao acionista, tornando a propositura da ação inalcançável ao pequeno investidor, motivo pelo qual deve ser readequada, com vistas a permitir o depósito da caução prevista no artigo 246, § 1o, alínea ' $b$ ', da Lei das Sociedades Anônimas." conforme voto do Rel. Min. Luis Felipe Salomão, Recurso Especial n ${ }^{\circ} 1.220 .272-R J, 14$ de dezembro de 2010. Com base em tal premissa e no caráter então meramente estimatório do valor da causa, o Min. Relator autorizou sua fixação com base no proveito econômico indireto vislumbrado para o acionista minoritário, naquele momento correspondente a apenas R \$65.000,00. Também a respeito dessa questão: Superior Tribunal de Justiça, Agravo Regimental no Agravo de Instrumento n 1.136.981- SP, Rel. Min. Luis Felipe Salomão, 29 de setembro de 2009.

$546 \mathrm{Na}$ verdade, a questão é mencionada apenas en passant no voto do Ministro Relator Luis Felipe Salomão: "Ademais, é de se ressaltar que o valor da causa terá impacto, também, no momento de fixação dos honorários para o vencedor da demanda.", que havia já mencionado a possibilidade de futura adequação do valor da causa em liquidação de sentença, deixando margem para honorários mais elevados. Em seu voto-vista, porém, dedicado especificamente ao tema, o Ministro Aldir Passarinho Júnior houve por bem consignar: "Penso que devemos fazer essa ressalva para evitar, o absurdo que seria, por exemplo, entrar com a ação, ganhar como acionista, substituindo a empresa, mas, como o 
contudo, cria-se o risco de se permitir a superação do obstáculo da caução, apenas para, em seguida, romper a possibilidade de paridade de armas entre a sociedade controladora e o acionista minoritário. Significa, sob certo ponto de vista, dar com uma mão, para tirar com a outra. De fato, é importante recordar que a prefixação dos honorários em vinte por cento representa incentivo essencial para que o minoritário possa se valer da assistência de equipe de advogados especializados, aptos a se contrapor aos patronos da sociedade controladora.

Não se pode, com efeito e com a devida vênia, concordar com a tese de Nelson Eizirik, de acordo com a qual a indicação de honorários de vinte por cento do valor da causa, prevista no $\S 2^{\circ}$ do artigo 246 , seria apenas uma referência para o julgador, que de todo modo teria discricionariedade de fixar a verba honorária nos termos gerais do artigo 20, $\S 3^{\circ}$, do Código de Processo Civil ${ }^{547}$. Tal interpretação implicaria, em essência, negar qualquer significado útil à disposição da Lei 6.404/1976, pois se não fosse a intenção da lei acionária fixar, desde logo e objetivamente ${ }^{548}$, os honorários em vinte por cento, como incentivo à sofisticação e à tecnicidade da defesa dos interesses do minoritário nos autos da ação social, não se explicaria esta sua intromissão no campo processual.

\subsubsection{Prêmio sobre a Indenização}

A propositura de ação social ut singuli contra a sociedade controladora é conduta marcada por significativas externalidades positivas, ou seja, benefícios para terceiros que o acionista autor da medida judicial, que incorre nos respectivos riscos e custos, não é capaz de capturar ou internalizar. De fato, uma vez formado o bloco de participação de cinco por cento do capital social (artigo $246, \S 1^{\circ}$, alínea “a”), ou prestada a garantia do juízo para as

resultado reflexo é para todo mundo da empresa, os honorários advocatícios serem fixados sobre o valor da condenação considerando o todo. Nem lá nem cá. Essa via tem mão dupla." e ainda "Portanto, o valor da causa será fixado levando-se em consideração apenas a parte autora, o que a beneficia, pois terá de arcar com custas menores. Mas, da mesma forma, se ela sair-se vitoriosa, também a sucumbência a seu favor terá o mesmo limite, ou seja, não deverá recair sobre os valores dos demais acionistas." (Rel. Min. Luis Felipe Salomão, Recurso Especial n 1.220.272-RJ, 14 de dezembro de 2010).

547 "O dispositivo contém previsão de honorários de 20\% (vinte por cento) sobre o valor da indenização, tratando-se, na realidade, de padrão normativo que não vincula o julgador, assim, os honorários, embora devendo representar reconhecimento do esforço do minoritário e de seu patrono em favor do interesse social, serão fixados na decisão judicial, que aplicará os critérios previstos no Código de Processo Civil." (sem grifo no original) in N. EIZIRIK, A Lei das S/A Comentada, vol. III, p. 370.

548 "A disposição constante do $\S 2^{\circ}$ do art. 246 da Lei $n^{\circ} 6.404$ é de caráter objetivo, isto é, não leva em consideração os fatores de graduação da condenação em honorários, previstos pela lei adjetiva civil." in E. TEIXEIRA, J. GUERREIRO, Das Sociedades Anônimas no Direito Brasileiro, vol. II, p. 712. 
verbas de sucumbência (artigo 246, $\S 1^{\circ}$, alínea “a”), os demais acionistas externos não teriam, em princípio, qualquer motivo ou incentivo para aderir à iniciativa. Em caso de procedência da ação, beneficiar-se-iam indiretamente de todo modo, na mesma medida dos demais acionistas, pela recomposição das perdas sofridas pela sociedade controlada. Em caso de improcedência, não serão responsáveis pelas verbas de sucumbência. No entretempo e independentemente do resultado, graças à sua inércia, livram-se do ônus de ter de arcar com o custeio de uma quase sempre prolongada disputa judicial. Existe, portanto, forte incentivo para que todos os acionistas externos permaneçam inertes, esperando que, na posição de free-riders, possam se beneficiar da iniciativa tomada por um de seus consócios.

Além disso, é de se registrar que as potenciais externalidades positivas decorrentes da iniciativa do minoritário que promove a ação social não se limitam aos demais acionistas externos, mas alcançam também os credores da sociedade controlada cuja garantia é reforçada pela recomposição do patrimônio desta - e, até mesmo, toda a coletividade, uma vez que a fiscalização promovida pelo sócio pode desvendar fraudes e trazer à luz condutas de relevância administrativa e criminal. A mera perspectiva - desde que realística - de ter sua atuação contestada pelos minoritários, pode fazer com que a sociedade controladora busque aplicar critérios mais rigorosos de gestão e de documentação das decisões tomadas no âmbito do grupo de fato ${ }^{549}$. O prêmio atribuído ao minoritário adquire, assim, feições de interesse público.

Por todas essas razões, o inovador conceito de prêmio sobre o valor da indenização ${ }^{550}$, atribuído ao autor da ação que age como substituto processual e não à companhia, representa um importante, razoável e justificado instrumento de contraste ao abuso do poder de controle e ao desvio de finalidade nos grupos de fato ${ }^{551}$.

O prêmio em questão parece, com efeito, também possuir uma natureza

549 E. GORGA, M. HALBERSTAM, Litigation Discovery and Corporate Governance: The Missing Story About the "Genius of American Corporate Law" [no prelo], p. 29.

550 O Professor Comparato qualificou o prêmio de cinco por cento do valor da condenação como "inovação do maior alcance em nosso sistema jurídico". F. COMPARATO, Os Grupos Societários na Nova Lei das Sociedades por Ações, p. 98.

551 "Trata-se de um justo prêmio ao acionista que se prontifica a agir em beneficio da companhia e, por extensão, de todos os demais acionistas, atuando em busca da reparação de dano social, expondo-se a elevada sucumbência [...] e tendo de, durante toda a morosa tramitação da ação, financiar os custos da demanda." in M. VON ADAMEK, Responsabilidade Civil dos Administradores de S/A e as Ações Correlatas, p. 410. 
intencionalmente punitiva para a sociedade controladora. À luz dos obstáculos de legitimação e da complexidade da prova que normalmente se exige do minoritário, em cenário tipicamente marcado por forte assimetria informacional, pode-se afirmar que suas chances de sucesso em ações promovidas nos termos do artigo 246 serão, na maioria dos casos, bastante limitadas. Esse estado de coisas pode favorecer a conduta irresponsável da sociedade controladora. Ao determinar que as consequências de uma conduta ilícita podem exceder a simples neutralização das perdas causadas, o legislador parece buscar uma alteração - em favor da prudência - da ponderação de risco realizada pela controladora, no momento em que decide se implementará, ou não, políticas que possam ser consideradas abusivas.

Por outro lado, não se pode desconsiderar o fato de que a sociedade controladora condenada a reparar as perdas causadas à sociedade controlada, em parte e indiretamente, está ressarcindo a si mesma. É importante, ademais, ter em conta que o problema de coordenação de interesses, que o legislador buscou enfrentar por meio do prêmio de cinco por cento, está circunscrito à minoria social e não diz respeito ao próprio bloco de controle. Como resultado, em situações em que sejam poucos os acionistas minoritários e seja ínfima a sua participação total no capital social, o prêmio em questão pode se tornar proporcionalmente exagerado e ensejar distorções, em prejuízo da sociedade controladora.

Pode-se pensar, por exemplo, na situação em que a sociedade $A$ detenha 99,99\% das ações da sociedade $B$, que tenha como único outro sócio Tício, titular de apenas uma ação, correspondente justamente ao restante $0,01 \%$ do capital social. Caso $A$ seja condenada a ressarcir perdas causadas a $B$, é evidente que a maior parte do valor da indenização reverterá mediata e indiretamente para a esfera patrimonial da própria sociedade controladora, na forma de - consoante o dizer ascarelliano - bens de segundo grau. Além disso, é claro que não havia in casu nenhuma necessidade de coordenar os interesses de Tício com os de outros minoritários free riders, pois estes simplesmente inexistiam. Em cenário extremo como esse, parece justo argumentar, de lege ferenda, que o prêmio atribuído a Tício poderia sofrer uma prudente redução equitativa, por estarem ausentes alguns dos elementos justificadores de tal incentivo.

A redução, porém, não deveria em nenhuma hipótese significar a substancial supressão do prêmio, nem tampouco ser linearmente proporcional ao free float da 
sociedade controlada - ou seja, à parcela do capital social não detida, direta ou indiretamente pela sociedade controladora -, justamente porque, conforme se argumentou anteriormente, suas funções extrapolam a mera coordenação dos interesses dos minoritários. Mesmo no exemplo construído acima, o prêmio atribuível a Tício ainda se justificaria com base em seu caráter punitivo e pela dimensão pública da sua atividade de fiscalização da conduta da controladora $A$.

\subsubsection{Legitimidade Passiva e Controle Indireto}

Tema que, surpreendentemente, parece ter recebido pouca atenção por parte da doutrina e da jurisprudência, a despeito de sua extrema relevância para o direito dos grupos, diz respeito ao perímetro exato do polo passivo na ação de reparação proposta pelo acionista minoritário nos termos do artigo 246 da Lei 6.404/1976.

Uma primeira e mais simples faceta do problema diz respeito aos terceiros, coniventes com os atos abusivos praticados pela sociedade controladora ou ainda por eles favorecidos. Pode o acionista minoritário, agindo na qualidade de substituto processual, dirigir a pretensão ressarcitória também contra os referidos sujeitos ou o disposto no artigo $6^{\circ}$ do Código de Processo Civil impõe uma leitura restritiva da legitimação extraordinária prevista no artigo 246 da lei acionária, de forma a se concluir que o minoritário pode ajuizar a demanda única e exclusivamente em face da sociedade controladora? A questão já foi enfrentada pelo Superior Tribunal de Justiça, que decidiu a favor dos minoritários e entendeu prevalecer em tal hipótese a responsabilidade solidária decorrente do direito material - nos termos do artigo 1.518 do Código Civil de 1916, correspondente ao artigo 942 do Código Civil em vigor - de modo a se reconhecer a legitimidade passiva de - e, portanto, a possibilidade de figurarem como corrés na ação social ao lado da sociedade controladora - sociedades sem vínculo direto com a controlada lesada, mas que alegadamente se beneficiaram dos abusos contra esta perpetrados ${ }^{552-553}$.

A esse respeito, convém recordar que um importante ponto de conexão entre a disciplina da responsabilidade dos administradores e da sociedade controladora no grupo

552 Superior Tribunal de Justiça, Recurso Especial n 78.850, Rel. Min. Sálvio de Figueiredo Teixeira, 24 de março de 1998.

553 Uma vez que se admite a inclusão no polo passivo da sociedade cúmplice que não tenha vínculo societário com a sociedade controladora, não parece haver qualquer óbice para se ajuizar a ação de ressarcimento também contra suas outras controladas ou coligadas que tenham se beneficiado de operações não comutativas. 
de fato reside na solidariedade passiva estatuída pelo $\S 2^{\circ}$ do artigo 117 da Lei 6.404/1976. À luz da supramencionada decisão do Superior Tribunal de Justiça, parece legítimo concluir que, tratando-se de apuração de responsabilidade solidária entre sociedade controladora e administrador, pode o acionista minoritário ajuizar ação única, nos termos do artigo 246 da lei acionária, dispensando-se, assim, as demais formalidades constantes do artigo 159 .

O segundo aspecto a ser discutido no campo da legitimidade passiva, contudo, é mais delicado e tem como elemento central o próprio conceito de sociedade controladora, conforme empregado no artigo 246 da Lei 6.404/1976. Com efeito, a questão se refere à possibilidade, ou não, de se promover a ação social contra a controladora indireta que não detenha, pessoal e imediatamente, qualquer participação no capital social da sociedade controlada prejudicada pelos eventos de abuso de poder ou de desvio de finalidade aduzidos na demanda judicial. Assim, por exemplo, se $A$ controla $B$, que controla $C$, que controla $D$, podem os acionistas minoritários desta última propor ação com fulcro no artigo 246 diretamente contra $A$ ou estão necessariamente adstritos a ter como parte adversa apenas a controladora direta $C$ ?

Não se pode olvidar o fato de que a definição de "sociedade controladora" do artigo 243, $\S 2^{\circ}$, na qual a toda evidência se apoia o caput do artigo 246, compreende expressa e inequivocamente o controle indireto, exercido "através de outras controladas". Por outro lado, o dispositivo em questão não afirma que em cada grupo de fato apenas a sociedade que se encontra na posição de vértice terá a qualidade de controladora ${ }^{554}$. Desse modo, retomando o exemplo anterior, parece possível afirmar - como em um jogo de bonecas russas (matrioshka) - que (i) $C$ é sociedade controladora de $D$, (ii) $B$ é sociedade controladora seja de $C$ seja de $D$ e (iii) $A$ é sociedade controladora de todas as anteriores.

Nesse sentido, se nos termos do $\S 2^{\circ}$ do artigo 243 o legislador não fez ressalva quanto à necessidade de controle direto para a atribuição da qualidade de sociedade controladora - muito pelo contrário -, não parece oportuno instituir tal distinção

554 Essa é, contudo, a visão do Professor Comparato: "Vale dizer, toda vez que deparamos com um controle em cadeia (a sociedade A controla $\mathrm{B}$, que por sua vez controla $\mathrm{C}$ e esta última controla $\mathrm{D}$ ), controladora é, tão só, a que detém o poder de comando em última instância. Todas as demais são controladas, direta ou indiretamente." in F. COMPARATO, Abuso de Controle em Grupo Societário de Fato: Remédio Jurídico Cabivel, p. 311. 
relativamente ao artigo $246^{555}$. Foi exatamente com base em tal argumento que os julgadores membros da Décima Sexta Câmara Cível do Tribunal de Justiça do Rio de Janeiro, em recentíssimo acórdão, deliberaram por unanimidade reverter a decisão de primeira instância e permitir a inclusão no polo passivo de ação de reparação, intentada por acionista minoritária de uma companhia brasileira, duas sociedades estrangeiras, controladoras indiretas desta última ${ }^{556}$.

A decisão em questão parece justa e correta. Com efeito, permitir que a sociedade controladora indireta se furte do dever de indenizar perdas causadas, em última análise, pelas suas próprias decisões simplesmente em função da interposição de controladas intermediárias significaria caminhar em direção diametralmente contrária ao espírito das normas ora examinadas, que buscam precipuamente (re)conjugar poder e responsabilidade $^{557}$. Não parece adequado, outrossim, no que se refere às controladascontroladoras intermediárias, permitir que uma sociedade atue acriticamente como canal de passagem de instruções abusivas e lesivas dos interesses de suas próprias controladas, sem com isso incorrer em nenhuma forma de responsabilidade.

Pode-se contra-argumentar, com razão, que - retornando ao exemplo original - a responsabilização da sociedade $B$ pelos danos causados à controlada $D$ representaria uma perda indireta para os acionistas minoritários externos daquela, que em nada influíram para

555 Aparentemente, essa posição é corroborada por Nelson Eizirik: "Este artigo trata de controle direto ou indireto, embora, na prática de nosso mercado, dada a concentração do controle acionário, a maioria dos casos de controle por sociedade seja indireto. Assim, se A controla B que, por sua vez, controla C, temos o controle indireto, pois o controlador final é A. Porém, se B não tem controlador definido, por estar seu capital votante disperso no mercado, seu controle sobre $C$ pode ser caracterizado como direto. Na primeira hipótese, de controle indireto, a responsabilidade pelos eventuais abusos será de $A$. controlador final, e de B, a 'sociedade controladora' mencionada no caput deste artigo. Já na segunda, de controle direto por $B$, que não tem acionista controlador, será ela, $B$, a responsável pela prática de abuso do poder de controle." (sem grifo no original) in N. EIZIRIK, A Lei das S/A Comentada, vol. III, p. 365.

556 "[...] as sociedades controladoras indiretas e os controlados agrupados de forma hierarquizada ou não, tem legitimidade passiva 'ad causam' para estar no polo passivo de que vise apurar as suas responsabilidades em face de danos à sociedade." conforme decisão do Tribunal de Justiça do Estado do Rio de Janeiro, Décima Sexta Câmara Cível, Rel. Des. Lindolpho Morais Marinho, Agravo de Instrumento $\mathrm{n}^{\circ}$ 71.940-06/2012-0000, 05 de março de 2013.

557 Neste ponto, ousa-se andar na direção contrária à do magistério de Lamy Filho, para quem a referida responsabilização do controlador indireto apenas poderia advir de fraude e desconsideração da personalidade jurídica: "Em termos estritos, a lei brasileira não cogitou de 'controlador de controlador'. ou 'holding de $2^{\circ}$ grau' para efeito de apuração de responsabilidade. Mas, é oportuno ressalvar que, em direito vigora o principio 'fraus omnia corrumpit' o que vale dizer: se a constituição da companhia é feita para fraudar a lei, o juiz pode desconsiderar sua existência." (sem grifo no original) in A. LAMY FILHO, Responsabilidade do Acionista Controlador Estrangeiro, p. 210. 
os prejuízos apurados por esta. É verdade. Porém, a potencial responsabilidade de $B$ por seus atos ilícitos é um risco que todos os seus acionistas assumiram ao tomarem sua decisão de investir em tal companhia e a desvalorização da participação de seus sócios minoritários também ocorreria, ilustrativamente, se a tal sociedade fosse imputada contaminação ambiental ou dano consumerista. Além disso, caso a sociedade $B$ se veja obrigada a pagar indenização à companhia $D$ em função de abusos originalmente arquitetados por $A$, ela certamente terá direito de regresso contra a sua controladora, que poderá ser exercido por iniciativa de seus minoritários, com amparo no próprio artigo 246. 


\section{A Disciplina do Grupo de Direito}

Em função do relativo ocaso a que o instituto dos grupos de direito foi relegado pela praxe brasileira ${ }^{558}$, muitas das numerosas, complexas e interessantes questões relativas à constituição e ao funcionamento de tais estruturas nunca adquiriram relevância prática e, portanto, não foram jamais efetiva e amplamente esmiuçadas pela jurisprudência nacional, merecendo apenas modesta atenção por parte da doutrina.

Estudar os detalhes da disciplina dos grupos de direito representa, por conseguinte, uma espécie de "arqueologia do que não houve". Uma análise do direito posto, mas jamais significativamente aplicado. Ainda assim, trata-se de exercício não apenas irrenunciável como também potencialmente profícuo para qualquer estudo que tenha a disciplina brasileira dos grupos como objeto. Qualquer que tenham sido os seus resultados práticos, o regime dos grupos de direito constante da lei acionária em vigor representou, no momento de sua promulgação, uma tentativa vanguardista e inovadora de lidar com um problema bastante complexo. Merece, portanto, a devida atenção.

A dissecção das regras e princípios do Capítulo XXI da lei acionária pode, com efeito, permitir a melhor compreensão da lógica adotada pelo legislador de 1976 e de suas motivações. Tal análise é capaz, outrossim, de trazer lições importantes para qualquer iniciativa de se construir um regime alternativo para a disciplina do fenômeno do controle intersocietário. Não se trata, portanto, de esforço meramente histórico ou perfunctório.

Na mens legislatoris de 1976, o grupo de direito deveria representar uma forma intermediária entre as sociedades independentes e a empresa totalmente integrada, organizada em torno de uma única sociedade; um verdadeiro caminho preparatório para a absorção futura da controlada pela controladora, por meio de incorporação ou fusão ${ }^{559}$. Esse fato, somado à concepção do agrupamento em si mesmo como uma sociedade ${ }^{560}$, ensejou a criação de uma série de regras típicas das sociedades personificadas para o grupo de direito - principalmente, a adoção de uma designação e o estabelecimento de órgãos de

558 A análise da real difusão dos grupos de direito na realidade brasileira é objeto do próximo capítulo.

559 "Em suma: o grupo são sociedades associadas a caminho da integração, que se opera mediante incorporação ou fusão; mas, até lá, as sociedades grupadas conservam a sua personalidade jurídica, e podem voltar à plenitude da vida societária, desligando-se do grupo." in Exposição de Motivos nº 196, de 24 de junho de 1976, do Ministério da Fazenda, Capítulo XXI, Seção I.

560 Já discutida e criticada no Capítulo 6. 
administração -, ausentes na disciplina alemã do acordo de domínio (Beherrschungsvertrag), que a toda evidência serviu de inspiração ao legislador brasileiro.

O presente capítulo parte justamente da análise dos elementos constitutivos ou estruturais do grupo de direito, que carregam essa forte influência do regime das sociedades personificadas, para em seguida abordar o seu procedimento de formação e, enfim, discutir as consequências de sua adoção para a condução da empresa plurissocietária.

\subsection{Estrutura e Requisitos Essenciais do Grupo de Direito}

\subsubsection{Controle Societário e Composição do Grupo}

As questões gerais relativas ao conceito de sociedade e aos vínculos de influência definíveis como controle para os fins do direito societário dos grupos já foram enfrentadas nos subcapítulos 6.1 e 6.2. Cumpre agora analisar como tais noções se articulam especificamente com a disciplina própria do grupo de direito.

O artigo 265 da Lei 6.404/1976 define que o grupo pode ser formado pela sociedade controladora e suas controladas. É relevante o fato de que o artigo em questão não empregue a expressão "sob controle comum", tal como utilizada no artigo 116. Devem, portanto, necessariamente integrar o grupo a própria sociedade controladora e suas controladas, não se admitindo a celebração de convenção grupal apenas entre estas últimas. Em outras palavras, se a sociedade $A$ controla diretamente as sociedades $B, C$ e $D$ - sendo que estas últimas não detêm participação, umas no capital das outras - não será possível a formação de grupo de direito somente entre $B, C$ e $D$ sem a participação de $A$.

Na dicção do $\S 1^{\circ}$ do artigo 265 , a sociedade controladora na posição de vértice do grupo de direito é designada "sociedade de comando" e as demais integrantes do grupo "filiadas" 561 . A redação desse dispositivo não deixa de ser tautológica e pleonástica, ao

561 De acordo com o Professor Comparato, a aquisição da qualidade de "filiada", por meio da formação do grupo de direito, determinaria a perda da qualidade de "controlada": "Não é 'sociedade controlada', na sistemática legal, [...], tampouco as sociedades integrantes do 'grupo de sociedades' regulado no Capitulo XXI. Para estas últimas, a lei reserva a expressão 'sociedades filiadas'. A referência a 'sociedades controladas', no texto do art. 265, explica-se como indicação de um pressuposto da constituição do 'grupo de direito': o fato de que ele só pode existir entre sociedades unidas por vínculo de subordinação ou controle. Em outras palavras, as 'sociedades controladas', uma vez celebrada a convenção grupal, passam a ser 'filiadas'." (sem grifo no original) in F. COMPARATO, Abuso de Controle em Grupo Societário de Fato: Remédio Jurídico Cabivel, p. 311. Com a devida vênia, em 
determinar que a controladora deve exercer o controle ${ }^{562}$. Elemento particular desta passagem da lei, não presente nas definições constantes do artigo $243, \S 2^{\circ}$, é a referência à necessidade de a sociedade controladora ser "titular de direitos de sócio ou acionista, ou mediante acordo com outros sócios ou acionistas". Ainda que a construção da frase pareça sugerir plena alternatividade entre (i) a titularidade de direitos de sócio ou (ii) a celebração de acordos, o que representaria, em última análise, aceitação do controle externo, é importante atentar para a menção à exigência de que o acordo em questão seja celebrado com "outros sócios ou acionistas", a qual denota o fato de que ambas as partes da avença devem ter a qualidade de sócias. Nesse sentido, a parte final do $\S 1^{\circ}$ do artigo 265 parece simplesmente fazer referência - em redação não muito feliz - aos acordos de voto, conceito já presente no artigo 116, caput, da lei acionária. Assim, pode-se cogitar que a intenção do legislador foi simplesmente confirmar que a posição de influência, dominante e permanente, adquirida pela sociedade de comando pode ser o resultado de acordo de acionistas e de bloco de controle. Ou seja, seria um aval legislativo ao reforço de uma posição de controle minoritário por meio de acordos de acionistas.

De fato, ao analisar esse trecho da norma, o Professor Comparato não cogitou de controle externo, mas sugeriu que o objetivo da alternatividade constante do $\S 1^{\circ}$ do artigo 265 seria simplesmente determinar que, excepcionalmente, para os fins do grupo de direito, o controle obtido mediante acordo seja tratado sempre como controle isolado atribuível unicamente à sociedade de comando - e não controle conjunto, como seria, ao revés, nos termos dos artigos 116 e $243, \S 2^{\circ 563}$.

relação a este específico ponto a razão não parece estar com o ilustre jurista. De fato, caso tal posição fosse aceita e levada às últimas consequências, poder-se-ia concluir, apenas como exemplo, que não seria aplicável na contabilidade individual das sociedades integrantes do grupo de direito o método da equivalência patrimonial, nos termos do artigo 248 da Lei 6.404/1976, em relação aos investimentos que umas realizassem nas outras, por não se tratarem mais de "controladas". Além disso, para todas as questões não expressamente disciplinadas na convenção, continuarão aplicáveis os artigos 245 e 246 da lei acionária, o que permite dizer que o grupo de direito não deixa de ser - nos silêncios da convenção grupo de fato. Parece mais razoável argumentar, portanto, que os predicados de "sociedade de comando" e "sociedade filiada" se somam, respectivamente, às qualidades de "sociedade controladora" e "sociedade controlada".

562 "Isso tudo [as disposições dos artigos 116 e $243, \S 2^{\circ}$ ] nos leva a considerar talvez como desnecessária a repetição contida no $\S 1^{\circ}$ deste art. 265 , da regra que a sociedade controladora ou de comando no grupo societário, deve 'exercer, direta ou indiretamente, e de modo permanente, o controle das sociedades filiadas como titular de direitos de sócio ou acionista ou mediante acordo com outros sócios ou acionistas'. Tal não acontecesse, a sociedade de comando não seria controladora das demais sociedades do grupo.” in F. MARTINS, R. PAPINI (atualiz.), Comentários à Lei das Sociedades Anônimas, p. 1112.

563 "Aqui, cuidando-se de grupo convencional de sociedades, cujos atos constitutivos são arquivados no Registro do Comércio, dispõe a lei que a sociedade de comando deve exercer o controle 'como titular de 
É natural que a coligação não tenha sido levada em consideração para a delimitação do perímetro do grupo de direito. O propósito principal do grupo convencional é disciplinar a subordinação de interesses, a qual pressupõe a afirmação de uma única vontade. A exigência do controle societário assegura que os grupos de direito se formarão sempre no seio de uma única estrutura hierarquizada, evitando que os administradores das sociedades filiadas estejam simultaneamente sujeitos a mais de um centro decisório. A coligação, por definição, exclui o controle. Se não existe domínio sobre as sociedades participadas, não deveria existir permanente subordinação de interesses a ser legitimada por meio da convenção. Se existe domínio sobre as atividades daquelas, não se trata mais de coligação, mas sim de controle minoritário.

Em função da centralidade do conceito de controle para o grupo disciplinado por convenção, pode-se concluir que todo grupo de direito está sempre contido em um grupo de fato lógica e cronologicamente antecedente; este pode ser mais extenso do que aquele, mas nunca o contrário.

Não parece lícito dessumir do artigo 265 qualquer exigência de que todas as sociedades controladas pela sociedade de comando devam obrigatoriamente fazer parte do grupo de direito eventualmente constituído. O próprio artigo 265 confirma que a convenção pode ter por objeto apenas empreendimento determinado, o que significa que ela pode abranger somente um setor de atividade, no qual nem todas as sociedades filiadas estejam envolvidas. Além disso, o artigo 269, V, determina que a convenção de grupo indique as condições para admissão e retirada do grupo, o que parece sugerir flexibilidade e variações em sua composição.

Nessa esteira, cabe também indagar se deve haver necessária contiguidade entre os vínculos de controle direto e a pertinência de cada sociedade ao grupo de direito. Em outras palavras, se a sociedade de comando $A$ controla diretamente $B$, que controla $\mathrm{C}$, a qual por sua vez controla $D$, seria possível a constituição de grupo de direito tendo como

direitos de sócio ou acionista, ou mediante acordo com outros sócios ou acionistas'. A alternativa é de ser ressaltada: já não se fala, no art. $265, \S 1^{\circ}$, de 'grupo de pessoas, vinculadas por acordo de votos, que é titular de direitos de sócio'; mas de um poder fundado na titularidade desses direitos, ou então em acordo com outros sócios ou acionistas. Vale dizer que, em se tratando de grupo de sociedades do Capítulo XXI, o legislador admitiu, explicitamente, que uma sociedade, pelo fato de poder determinar o conteúdo do voto de outras, seja considerada, isoladamente, como controladora." in F. COMPARATO, Titularidade do Poder de Controle e Responsabilidade pela Concessão Abusiva do Crédito, p. 70-71. 
membros apenas $A, C$ e $D$, mas não $B$, a despeito de a sociedade de comando não possuir qualquer participação direta no capital daquelas suas controladas indiretas?

Convém reconhecer que as definições de controle intersocietário constantes dos artigos 243, § $2^{\circ}$, e 265 são enfáticas em relação à admissão dos vínculos indiretos, ou seja, o exercício da influência em uma sociedade intermediado pela participação em sociedades interpostas. Nesse sentido, uma interpretação literal do artigo 265 conduziria à conclusão de que é possível a celebração de convenção de grupo entre sociedade de comando e uma sua controlada indireta, sem a participação das controladas-controladoras intermediárias.

Essa conclusão, porém, não parece encontrar amparo em uma análise sistemática e teleológica do instituto do grupo de direito. É sempre delicado buscar identificar restrições onde o legislador não o fez explicitamente, porém é importante ter em mente que a função primordial do instituto grupo de direito é disciplinar e legitimar a subordinação de interesses entre sociedades.

Assim, tornando ao exemplo mencionado acima, a convenção de grupo firmada por $A, C$ e $D$ poderia incluir em seu bojo medidas de relevante impacto sobre a esfera patrimonial destas últimas, em benefício da sociedade de comando. Como consequência, os interesses de $B$, em sua qualidade de acionista majoritária de $C$, também seriam afetados. Contudo, uma vez que tal sociedade não integra formalmente o grupo de direito em questão, aos sócios de $B$ nunca teria sido dada a oportunidade de aprovar ou rejeitar em assembleia a celebração da respectiva convenção de grupo e aos seus acionistas externos teria sido injustamente subtraída a ocasião de exercer o direito de retirada nos termos do artigo 137 da Lei 6.404/1976, em combinação com o disposto no artigo 136, V. Por essas razões, não parece oportuna ou inteiramente compatível com o espírito da norma a formação de grupo de direito sem contiguidade nos vínculos diretos de controle.

Ainda no que diz respeito à composição do grupo de direito, não se vislumbra nenhum obstáculo ao fato de que ele seja formado exclusivamente pela sociedade de comando e por subsidiárias integrais. Nesta hipótese, não haveria interesses conflitantes de acionistas externos a serem tutelados ${ }^{564}$, mas ainda assim um arranjo dessa natureza poderia

564 No que se refere puramente à subordinação de interesses da filiada pela sociedade de comando, a convenção de grupo apenas teria efetivo significado caso se adotasse uma concepção institucionalista do interesse próprio da subsidiária ou uma visão contratualista de série, e não de grupo, para assim abarcar seus (potenciais) acionistas externos futuros. O Professo Calixto Salomão Filho vê na sociedade 
ter alguma utilidade prática, na forma da vinculação dos administradores das filiadas às instruções recebidas dos administradores do grupo (artigo 273) e da possibilidade de representação coletiva conjunta de todas as sociedades do grupo (artigo 272, parágrafo único).

Outro aspecto relevante a ser considerado é a possibilidade de sobreposição de diferentes grupos de direito. Neste caso, desde que não exista insuperável contradição entre os diferentes instrumentos firmados pelas diversas sociedades filiadas - hipótese na qual eventuais conflitos deveriam, tendencialmente, ser superados por meio dos cânones normais do direito dos contratos - não parece haver razão para se objetar a celebração de mais de uma convenção grupal pela mesma sociedade de comando, cada uma tendo por objeto matérias diferentes ou mesmo filiadas distintas - respeitado o critério de contiguidade defendido anteriormente. A ausência de expressa vedação, somada à já mencionada possibilidade de se constituir grupo de direito para empreendimentos e não apenas atividades comuns (artigo 265, caput), propugna pela resposta afirmativa ${ }^{565}$.

Com efeito é possível imaginar a formação de grupos de direito especializados, reunindo as filiadas ativas em cada uma das áreas de investimento de uma única sociedade de comando holding. Outra possibilidade seria uma estrutura de grupos de direto sobrepostos como círculos concêntricos, em cujo núcleo estariam aquelas filiadas sujeitas a um grau mais intenso de subordinação de interesses - e, como tal, subscritoras de mais de uma convenção - e em cuja periferia estariam as filiadas com maior autonomia (potencialmente, com participação proporcional mais relevante de acionistas externos), firmatárias apenas de uma convenção mais amena.

Assim, por exemplo, a sociedade controladora $A$ poderia celebrar uma convenção com suas controladas $B, C$ e $D$, ativas no ramo industrial, e um outro acordo similar, em separado, para as suas controladas $X, Y$ e $Z$, do setor comercial. Em sobreposição a estes

unipessoal campo ideal para uma leitura do valor organizativo do contrato de sociedade. C. SALOMÃO FILHO, O Novo Direito Societário, p. 48-49. Uma possível estratégia de utilização prática da formação de grupo de direito - se houvesse utilização prática do instituto, evidentemente - com controladas subsidiárias integrais seria justamente aprovar a convenção em preparação para a admissão de sócios externos. Assim, estes já ingressariam em sociedade dotada da qualidade de filiada, estando excluída a possibilidade de exercício de direito de retirada.

565 É de se questionar como ficaria a denominação das sociedades duplamente convenentes. Em princípio, teriam de acrescentar a designação de ambos os grupos de direito à própria denominação, nos termos do artigo 271, § $3^{\circ}$. Por exemplo, “Alpha Confecções Ltda. - Grupo X Grupo Y”. 
arranjos, uma terceira convenção poderia ser estipulada pela sociedade de comando, envolvendo apenas as sociedades $B$ e $X$, com um grau mais profundo de subordinação de interesses, em função da participação proporcionalmente menor de acionistas externos em tais sociedades - o que tornaria a hipótese de exercício de recesso por parte de tais sócios menos onerosa.

\subsubsection{Designação do Grupo e Uso da Expressão "Grupo"}

O artigo 267 da Lei 6.404/1976 determina que os grupos de direito devem ser identificados por designação - e não denominação - que contenha necessariamente a expressão "grupo" ou "grupo de sociedades". O regime da Lei 6.404/1976 sobre a matéria é ainda composto pelas disposições do artigo $271, \S 3^{\circ}$, de acordo com as quais tanto a sociedade de comando quanto as filiadas devem acrescentar às respectivas denominações a designação do grupo ${ }^{566}$. Ou seja, a sociedade filiada "Alpha Comércio Ltda.", uma vez formalmente completa a constituição do respectivo grupo de direito designado "Grupo Beta”, deve passar a adotar a denominação "Alpha Comércio Ltda. - Grupo Beta”.

A lei acionária não chegou a especificar se o ato da sociedade filiada que aprova a formação do grupo (artigo 271, inciso II) poderia já prever a futura automática adoção da nova denominação ou se seria necessária ulterior alteração contratual ou estatutária, posterior ao arquivamento, no registro da sede da sociedade de comando, de todos os documentos previstos no caput do artigo 271.

O legislador de 1976 claramente colheu inspiração em critérios típicos das sociedades personificadas ao estabelecer as regras para a designação do grupo. A própria (burocrática) exigência de atribuição de designação é sinal de que se buscou dar feições mais institucionais a essa estrutura do que ocorreu no direito alemão, que não contém qualquer exigência desse tipo, a despeito de ser muito mais generoso na proteção dos interesses dos acionistas minoritários ${ }^{567}$. Partindo de uma concepção societária, o legislador brasileiro parece ter visualizado no grupo de direito um ator - ainda que não personificado - no mercado, com uma identidade e uma reputação próprias a serem tuteladas ${ }^{568}$.

566 Disposições reiteradas pelo artigo 13 da Instrução Normativa DNRC nº 116/2011.

567 O § 294 da lei acionária alemã de 1965 não exige sequer que o próprio "contrato de empresa" (Unternehmensvertrag) seja arquivado no Registro Comercial, mas apenas uma declaração dos administradores a respeito de sua celebração, com identificação de sua espécie e respectivas contrapartes.

568 Wald e Eizirik enfatizam a função da designação de estabelecer a distinção entre grupos de fato e de 
Quanto à obrigatoriedade de adoção da designação do grupo na própria denominação da sociedade de comando e das filiadas, o seu presumível sentido é alertar terceiros de boa-fé que venham a estabelecer relações com qualquer das convenentes, seja na qualidade de contrapartes contratuais, seja como futuros investidores, de que estão diante de um ente que não necessariamente age de forma autônoma e - tratando-se de filiada - cujos interesses poderão ser subordinados às necessidades da sociedade de comando. Trata-se de exigência similar àquela imposta pelo artigo $2.497 \mathrm{bis}$, $\S 1^{\circ}$, do Código Civil italiano, que exige a identificação, na correspondência e nos atos da sociedade controlada, do ente ou sociedade a cuja atividade de direção e coordenação está sujeita $^{569}$. A lei italiana, porém, não se ocupou de identificar o próprio grupo como tal.

O parágrafo único do artigo 267 determina ainda que apenas os grupos de direito organizados de acordo com as disposições do Capítulo XXI da lei acionária podem incluir na própria denominação as expressões "grupo" e "grupo de sociedades"

Não deixa de ser uma disposição problemática em termos práticos, pois "grupo" é vocábulo genérico de emprego extremamente frequente, ao contrário de expressões compostas como "sociedade limitada" (ou "Ltda.”) e "sociedade anônima" (ou "S.A.”), que geralmente não se prestam a outros usos fora de seu escopo societário e técnico de aplicação. Em artigo publicado em 1984, Arnoldo Wald e Nelson Eizirik defenderam uma interpretação restritiva de tal limitação, afirmando que o comando legal contrasta apenas o falseamento, perante terceiros, da estrutura da empresa - ou seja, a hipótese em que se busca transmitir a ideia da presença de um grupo de direito, sem que ele verdadeiramente exista $^{571}-$, sem com isso representar uma vedação geral do emprego do termo "grupo" em

direito: "A importância em se identificar os grupos societários, disciplinados no capítulo XXI da Lei das Sociedades Anônimas como sendo 'grupos de direito', decorre da necessidade de se fazer uma distinção entre estes e os 'grupos de fato', [...]" in A. WALD, N. EIZIRIK, A Designação do "Grupo de Sociedades" e a Interpretação do Art. 267 da Lei das S/A, p. 58.

$569 \mathrm{Na}$ lei italiana, a exteriorização do vínculo de direção e coordenação tem ainda a função adicional de alertar os acionistas externos para a possibilidade de exercício de direito de recesso, uma vez que o estabelecimento de tal relação não está sujeito à deliberação prévia dos sócios. F. GALGANO, Direzione e Coordinamento di Società - Art. 2497-2497 septies, p. 121-122.

570 Questão regulamentada pelo artigo 13 da Instrução Normativa ${ }^{\circ} 116 / 2011$, do Departamento Nacional de Registro do Comércio - DNRC. Na versão original da Lei 6.404/1976, conforme publicada no Diário Oficial em 17 de dezembro de 1976, a expressão estava, provavelmente por simples erro material, no singular (ou seja, "grupo de sociedade").

571 "Podemos, assim, concluir que não há, no Direito brasileiro, uma vedação geral de usar a palavra 'grupo', mas sim uma impossibilidade para o conglomerado de contratar com terceiros pretendendo ser o que ele não é - um grupo de direito. Qualquer outra interpretação ampliativa ou extensiva carece completamente de amparo legal. Trata-se de norma de efeitos e alcance limitados que visa a proteção 
outros contextos.

Fran Martins também faz uma leitura restritiva de tal proibição, ressaltando a ausência de sanções ou mecanismos administrativos de coerção que amparem a vedação do uso da expressão "grupo" fora do âmbito dos grupos convencionais ${ }^{572}$.

\subsubsection{Nacionalidade da Sociedade de Comando e do Controle do Grupo}

Como já discutido anteriormente (subcapítulo 4.3), existe evidente tendência nacionalista na Lei 6.404/1976, ao determinar, na primeira parte do $\S 1^{\circ}$ do artigo 265 , que a sociedade de comando do grupo deve ser brasileira ${ }^{573}$. Uma vez que, na concepção original da lei, a subordinação de interesses é admissível apenas nos limites fixados pela convenção de grupo, tal disposição se traduz em efetiva vedação da subordinação dos interesses das sociedades aos desígnios e pretensões de suas eventuais controladoras estrangeiras. A subordinação lícita de interesses, em tese, ocorreria apenas a partir da sociedade de comando brasileira "para baixo", ao longo da cadeia societária. Da sociedade de comando "para cima", todas as relações deveriam ser pautadas pela autonomia administrativa daquela e pela plena comutatividade dos contratos intragrupo.

Entretanto, importante frisar que a nacionalidade da sociedade de comando, necessariamente a brasileira, não se confunde com a identidade nacional do próprio grupo e de seus controladores últimos. Conforme bem salienta o Professor Comparato, o requisito

da boa fé dos terceiros que contratam com a empresa ou o conglomerado e devem saber qual é a sua verdadeira estrutura." in A. WALD, N. EIZIRIK, A Designação "Grupo de Sociedades" $e$ a Interpretação do Art. 267 da Lei das S/A, p. 66.

572 "O preceito deve ser entendido em termos. A lei não tem poderes para impedir que um ajuntamento de sociedades se intitule 'grupo' e como tal exerça suas atividades. Legalmente, não se trata de grupo, pois a constituição regular deste exige o cumprimento das regras estipuladas neste Capítulo XXI da lei [...] Mas isso não significa que, de fato, algumas sociedades ligadas por interesses comuns se intitulem de 'grupo de sociedades', ou 'grupo $\mathrm{X}^{\prime}$. A lei não dá a nenhum órgão poderes para fazer com que, se tal acontecer, os administradores desses grupos de fato, ou as sociedades que participam dos mesmos, sejam compelidos a não usar os nomes 'grupo' ou 'grupo de sociedades'." in F. MARTINS, R. PAPINI (atualiz.), Comentários à Lei das Sociedades Anônimas, p. 1117. Cumpre recordar, porém, que negócios jurídicos tendo por objeto o uso da expressão "grupo" fora do contexto dos grupos de direito poderiam eventualmente ser considerados nulos, nos termos do artigo 166, VII, do Código Civil de 2002. Além disso, as Juntas Comerciais, ainda que de forma completamente errática, costumam recusar o registro de atos de sociedades que incluam a expressão "grupo" na própria denominação. A vedação, de qualquer forma, deve ser interpretada de modo restritivo, não parecendo razoável a recusa de registro de atos de sociedades cuja denominação contenha termos próximos ("ajuntamento", "conjunto", "agrupamento" etc.) ou traduções com grafia diversa ("group", "Gruppen”, "groupement” etc.) da expressão em questão.

573 “[...] o grupo pressupõe uma sociedade de comando, necessariamente brasileira, a qual deve exercer direta ou indiretamente, e de modo permanente, o controle das sociedades participantes ou filiadas" in E. TEIXEIRA, A. GUERREIRO, Das Sociedades Anônimas no Direito Brasileiro, vol. II, p. 772. 
da nacionalidade incide de maneira distinta sobre dois níveis diversos de controle: (i) o controle imediato do próprio grupo pela sociedade de comando e (ii) o controle último e final da sociedade de comando ${ }^{574}$.

Nos termos do artigo 269, inciso VII, da lei acionária, a convenção de grupo deve obrigatoriamente declarar a nacionalidade do controle do grupo. O parágrafo único do mesmo artigo determina, por outro lado, que o grupo apenas poderá ser considerado brasileiro se seus controladores finais, ainda que por meio de controle indireto, sejam pessoas naturais residentes ou domiciliadas no Brasil ou pessoas jurídicas de direito público interno.

De acordo com o Professor Manoel Vargas, as normas em questão refletiriam inequívoca proibição da constituição de grupo de direito sob controle, direto ou indireto, estrangeiro $^{575}$. Na opinião de Vargas, a declaração prevista no inciso VII do artigo 269, em combinação com a restrição constante do artigo $265, \S 1^{\circ}$, não teria como função meramente informar o país de origem dos controladores do grupo em formação, mas sim atestar, ou seja, certificar e confirmar, o cumprimento do suposto requisito de nacionalidade exclusivamente brasileira, nos termos do parágrafo único do próprio artigo 269.

Porém, e com a devida vênia, a melhor interpretação da norma em questão parece ser aquela apontada por Egberto Lacerda Teixeira e José Alexandre Tavares Guerreiro, de acordo com os quais - em linha com a posição do Professor Comparato - o sentido da regra é simplesmente diferenciar os grupos de direito que podem ostentar o título de "sob controle brasileiro" dos demais, sem, porém, vedar a existência destes últimos ${ }^{576}$.

574 “'Sociedade brasileira', no art. $265, \S 1^{\circ}$, significa sociedade sob controle brasileiro, tal como definido no parágrafo único do art. 269? Entendo que não. Estamos, de fato, diante de dois niveis de controle, que a lei deseja se mantenham distintos. A nacionalidade brasileira de uma sociedade por ações continua a ser dada pela regra do art. 60 do Decreto-lei 2.627, ainda em vigor [...]" in F. COMPARATO, Os Grupos Societários na Nova Lei das Sociedades por Ações, p. 99.

575 "O fim da lei é somente admitir que seja controlador, direto ou indireto, da sociedade de comando do grupo constituído nos termos do Capitulo XXI da LSA pessoas que estejam permanentemente submetidas à jurisdição do Estado brasileiro, de modo que este tenha condições de fiscalizar e cobrar do controlador do grupo a observância das leis brasileiras."; e "Se o controle não for brasileiro, o grupo de sociedades de direito não poderá ser formado, pois esse requisito não será atendido." in M. VARGAS, Grupo de Sociedades, respectivamente p. 2060 e 2061.

576 "Não importa que seu controle seja detido por pessoas fisicas ou jurídicas residentes ou domiciliadas no exterior: cumpridos os requisitos do mencionado art. 60 do Decreto-lei $n .^{\circ} 2.627$, a sociedade controladora ou de comando do grupo será considerada brasileira. A Lei $n .{ }^{\circ} 6.404$, no entanto, se preocupa com a declaração da nacionalidade do controle do grupo, ou seja, com a procedência do 
$\mathrm{O} \S 1^{\mathrm{o}}$ do artigo 265 não se refere ao controlador indireto e final do grupo de direito, mas simplesmente à sua sociedade de comando, cuja nacionalidade brasileira decorrerá simplesmente (i) da sua constituição de acordo com as leis do país e (ii) o estabelecimento de sua sede no território nacional ${ }^{577}$. A restrição legal constante do artigo $265, \S 1^{\circ}$, tem como alvo a posição de ápice do grupo de direito - ou seja, a sociedade de comando. Não vai a norma, contudo, além de tal ponto, não abarcando sociedade que controle a sociedade de comando mas não seja parte da convenção de grupo $^{578}$, nem controladores diretos ou indiretos que sejam pessoas naturais ${ }^{579}$.

Não parece justificável uma interpretação ampliativa das restrições impostas pela lei a esse respeito. Fosse a intenção do legislador vedar a constituição de grupos de direito sob controle último estrangeiro, não haveria porque endereçar o artigo $265, \S 1^{\circ}$, especificamente à sociedade de comando (ao invés do controlador indireto final do grupo). Também não haveria razão para que o artigo 269, inciso VII, exigisse a indicação da nacionalidade do grupo no texto da convenção; um requisito que traz, implícito, o fato de que a informação solicitada pela norma pode ter mais de um conteúdo. Se não fosse admissível o grupo de direito sob controle indireto estrangeiro, o texto da lei poderia se limitar à imposição de uma declaração expressa de cumprimento de tal preceito. Vale dizer, em tal caso, a norma exigiria a declaração de controle brasileiro, não declaração da nacionalidade do controle.

O objetivo da norma parece, portanto, ser simplesmente o de estabelecer uma distinção geral entre duas espécies do gênero grupo de direito, cujas possíveis consequências práticas - por exemplo, o acesso ou não a incentivos fiscais ou a

capital da sociedade de comando. Note-se que o texto legal não fala em nacionalidade do grupo, mas em nacionalidade do controle do grupo, sendo digno de menção o fato de que o diploma em questão não impõe quaisquer restrições aos grupos cujo controle seja de nacionalidade estrangeira. Assim, a finalidade da declaração exigida é de caráter meramente informativo." in E. TEIXEIRA, A. GUERREIRO, Das Sociedades Anônimas no Direito Brasileiro, vol. II, p. 778. No mesmo sentido: “[...] apesar de a lei exigir que a sociedade de comando do grupo de sociedades seja brasileira, permite que essa sociedade tenha controle estrangeiro, o que faz com que o grupo, observando-se o $n^{\circ}$ VII e o parágrafo único do art. 269, seja considerado sob o controle estrangeiro." in F. MARTINS, R. PAPINI (atualiz.), Comentários à Lei das Sociedades Anônimas, p. 1112.

577 Nos termos do artigo 60 do Decreto-Lei 2.627/1940, que não foi revogado pela Lei 6.404/1976 (conforme artigo 300 desta última), bem como do artigo 1.126 do Código Civil de 2012.

578 Até mesmo porque, se fosse parte da convenção, tornar-se-ia, automaticamente, a efetiva sociedade de comando do respectivo grupo de direito.

579 Os quais, nos termos da legislação brasileira, não formam grupo de fato (artigo 245 da Lei 6.404/1976) nem, tampouco, possuem legitimidade para ser parte de convenção de grupo de direito (artigo 265, caput). 
possibilidade de atuação em setores estratégicos, considerados críticos para a tutela do interesse nacional - seriam previstas em outras normas, e não no corpo da própria lei acionária, como já ocorria - e ocorre - em relação ao conceito de nacionalidade da sociedade isolada, nos termos do Decreto-Lei 2.267/1940 (artigo 60) e do Código Civil de 2002 (artigo 1.126).

Em resumo, e por isso se falava em dois níveis de controle, a lei fixa, de um lado, nacionalidade obrigatória (brasileira) para a sociedade de comando e, de outro, estabelece os critérios para a aferição da nacionalidade do próprio grupo (brasileira ou estrangeira). Assim, a sociedade de comando deve necessariamente ser constituída de acordo com as leis brasileiras e ter sua sede no território nacional - e a contrario sensu as filiadas podem ser sociedades estrangeiras ${ }^{580}$. Além disso, se a sociedade de comando for controlada por um cidadão alemão, residente na Alemanha, o grupo de direito em questão terá a nacionalidade alemã - frise-se, para os fins e sob a perspectiva do direito societário brasileiro - e tal fato deverá ser expressamente indicado na respectiva convenção.

\subsection{Procedimento de Formação do Grupo}

O artigo 269 da Lei 6.404/1976 traz elenco com os itens que constituem o conteúdo mínimo da convenção de grupo. Além da designação do grupo e a declaração da nacionalidade de seu controle (incisos I e VII), já discutidos acima, o dispositivo estabelece a necessidade de declinação: (i) da identidade da sociedade de comando e de cada uma das filiadas, (ii) termos e condições de participação no grupo, (iv) prazo de duração (que pode ser indeterminado) e condições de extinção, (v) condições de admissão e retirada de integrantes, (vi) estrutura de administração do grupo e (viii) condições para a alteração da convenção.

Essas disposições são essencialmente repetidas, com poucas variações ${ }^{581}$, pela

580 Assim, por exemplo, integram o Grupo Itautec, as sociedades Itautec America, Inc. (estadunidense) e a Itautec Portugal, S.A. (portuguesa), nos termos da convenção de grupo registrada perante a Junta Comercial do Estado de São Paulo e disponível em: <http://www.itautec.com.br/media/ 764768/20120516\%20-\%20d\%C3\%A9cimo\%20segundo\%20aditamento\%20a\%20conven\%C3\%A7\%C $3 \% \mathrm{~A} 3 \mathrm{o} \% 20 \mathrm{do} \% 20$ grupo\%20itautec.pdf $>$. Acesso em 08 set 2013 .

581 Mas, ainda assim, em alguns pontos, tais desvios em relação ao texto da lei são pouco felizes. Por exemplo, o caput do artigo $3^{\circ}$ da mencionada Instrução Normativa DNRC n ${ }^{\circ} 73 / 1998$ repete o conceito do caput do artigo 270 da Lei 6.404/1976, no que tange à necessidade de aprovar a convenção de grupo pelos mesmos critérios que se aplicam à alteração do contrato social ou estatuto da respectiva sociedade. $\mathrm{O}$ conceito é detalhado e especificado no parágrafo único de tal artigo $3^{\circ}$ da instrução normativa em questão, mas essa passagem da norma regulamentadora, além de ser voltada apenas às sociedades por 
Instrução Normativa do Departamento Nacional de Registro do Comércio n $73 / 1998$, que ainda especifica alguns aspectos do procedimento de registro em seu artigo $4^{\circ}$.

\subsubsection{Aprovação pelos Sócios das Sociedades Convenentes}

Conforme já discutido no item 6.3.2 deste trabalho - ao se argumentar que é inadequado considerar o grupo de direito uma sociedade de sociedades -, a convenção de grupo consiste em negócio jurídico suis generis, tanto em função de suas partes, quanto - e principalmente - pelo seu objeto. A convenção visa principalmente à instrumentalização da sociedade filiada, permitindo-lhe excepcionalmente - sempre na medida e nos limites estreitos do que for expressamente pactuado - abdicar da persecução dos próprios fins sociais para se tornar um meio de realização dos objetivos fixados pela sociedade de comando $^{582}$. Nesse sentido, verifica-se um realinhamento e uma compressão dos deveres fiduciários dos administradores das sociedades filiadas, aos quais se autoriza (e se impõe) também de forma excepcional e limitada - dar efeito às instruções recebidas da sociedade de comando, ainda que prejudiciais ao ente que administram.

Todos esses efeitos obviamente extrapolam os limites da administração ordinária das sociedades convenentes. Pode-se argumentar, inclusive, que as drásticas consequências da celebração de convenção de grupo alteram o conteúdo patrimonial da participação societária. A titularidade de ações de companhia não filiada, supostamente engajada unicamente na persecução de seus próprios interesses, é estruturalmente diferente do investimento em sociedade integrante do grupo de direito, sujeita à legítima subordinação de interesses. Nesse sentido, a estipulação da convenção de grupo, conforme o seu conteúdo, tem feições de ato de disposição patrimonial.

Seria, portanto, descabido permitir aos administradores da sociedade filiada que

ações, não levou em consideração a possibilidade de redução do quórum de deliberação correspondente a, ao menos, metade das ações com direito a voto, por decisão da Comissão de Valores Mobiliários, nos termos do artigo $136, \S 2^{\circ}$, da Lei $6.404 / 1976$.

582 Neste caso, mais do que nunca, é perfeitamente cabível a expressão "sociedade instrumental”, cunhada por Francesco Messineo para designar as sociedades controladas por outras sociedades: "[...] preferiria e gostaria que fosse adotado o termo sociedades 'instrumentais' para fixar especialmente o conceito de que elas nascem e funcionam sobretudo para servir objetivos alheios que são, ao revés, próprios de uma outra sociedade e que, justamente em tal ponto, reside a razão prática de sua criação". Tradução livre de: "[...] preferirei adoperare e vorrei si adoperasse il termine di società 'strumentali' per fissare specialmente il concetto che esse nascono e funzionano soprattutto per servire a scopi alieni che sono piuttosto propri di un'altra società e che appunto in questo consiste la ragione pratica della loro creazione." in F. MESSINEO, Le Società di Commercio Collegate (c.d. Società a Catena), p. 7. 
fizessem juízo de oportunidade e conveniência a respeito dos limites e das finalidades dos seus próprios poderes, como também seria inusitado permitir-lhes promover uma alteração da própria natureza e substância do investimento realizado pelos acionistas.

É natural, por conseguinte, que a lei tenha colocado grande ênfase no procedimento de aprovação da convenção pelos sócios de todas as sociedades por ela afetadas. $\mathrm{O}$ artigo 270 determina, com efeito, que a convenção de grupo deve ser aprovada de acordo com os mesmos procedimentos que regem a alteração dos atos constitutivos de cada uma das convenentes - incluindo a sociedade de comando, até porque, a este respeito, o legislador não fez qualquer distinção.

Em relação às sociedades anônimas, o critério geral é aquele estatuído no artigo 136, inciso V, da Lei 6.404/1976, correspondente ao voto afirmativo da maioria qualificada de acionistas titulares de, ao menos, metade das ações com direito a voto. Para as companhias fechadas, o estatuto social pode validamente fixar quórum de deliberação mais elevado (artigo 136 caput). No que diz respeito às companhias abertas, nas quais (i) é presumível maior dispersão do capital e (ii) seriam mais graves as consequências de eventual imobilidade decisória, o referido quórum não apenas não pode ser elevado por meio de disposição estatutária, como pode inclusive ser reduzido, mediante expressa autorização da Comissão de Valores Mobiliários ${ }^{583}$, nos termos do $\S 3^{\circ}$ do artigo 136 da lei acionária, desde que as assembleias recentes da respectiva sociedade sejam marcadas pela presença de poucos acionistas.

Para as sociedades limitadas, a decisão deverá ser tomada nos termos do artigo 1.071, V, combinado com o artigo 1.076, I, do Código Civil de 2002, com votos correspondentes a, no mínimo, três quartos do capital social.

Quando se reflete sobre o objeto de tal deliberação - permitir a sujeição da sociedade aos interesses da sociedade de comando - resta evidente que está presente um conatural e estrutural conflito de interesses. Poderia se cogitar, ademais - na tentativa de atrair a regra do impedimento de voto, típica do conflito de interesses formal, para esta hipótese -, a respeito da eventual subsunção da celebração da convenção de grupo ao conceito de "benefício particular" ${ }^{584}$ previsto no $\S 1^{\circ}$ do artigo 115 da Lei 6.404/1976, sob

583 Conforme anotado anteriormente, possibilidade não refletida na Instrução Normativa DNRC nº 73/1998. 584 E. VALLADÃO FRANÇA, Conflito de Interesses e Beneficio Particular: Uma Distinção que se Impõe 
os argumentos de que a formação do grupo representa uma vantagem lícita - tanto que prevista em lei - e atribuível à sociedade de comando em função de sua qualidade de acionista - tanto que necessário o controle interno para a validade da avença.

Contudo, mesmo sem adentrar no sempre intrincado e tormentoso campo da interpretação do $\S 1^{\circ}$ do artigo 115 , não parece possível ou adequado considerar que a sociedade controladora esteja impedida de votar na deliberação de aprovação da convenção de grupo. São aplicáveis, neste caso, essencialmente os mesmos argumentos relativos ao voto do acionista controlador na incorporação de controlada ${ }^{585}$. Em primeiro lugar, trata-se de operação expressamente prevista pela lei, sem que a norma levante qualquer objeção ao voto da sociedade controladora ${ }^{586}$. Ademais, em todas as hipóteses de controle majoritário - a mais frequente na realidade brasileira e a mais apta a conferir estabilidade ao controle no grupo de direito - jamais se conseguiria atingir o quórum de deliberação previsto no artigo 136, V, se a acionista preponderante fosse impedida de votar, nem mesmo se a formação do grupo de direito fosse aprovada unanimemente pelo conjunto dos minoritários. Além disso, se a sociedade controladora não pudesse votar na deliberação de apreciação da adesão ao grupo de direito, dificilmente se explicaria o direito de recesso previsto nos artigos 270 , parágrafo único, e 137 da lei acionária ${ }^{587}$.

Mesmo no que tange a análise ex post do conteúdo da decisão da sociedade controladora, a regra do conflito substancial deve ser aplicada cum grano salis no que diz respeito à decisão de integrar o grupo de direito. Com efeito, pelo seu próprio conteúdo, tal

Definitivamente Dirimir, p. 45.

585 São, de fato, notáveis as semelhanças entre as duas hipóteses, inclusive pela questão da absorção da estrutura da controlada na atividade desenvolvida pela sociedade controladora. A diferença no grupo de direito é que a sociedade filiada continua a existir como ente juridicamente separado. Convém recordar que, nos termos do Parecer de Orientação CVM n 34/2006, a autarquia não buscou construir argumento de que existiria impedimento de voto para incorporações de controlada em geral - o que seria inviável diante das disposições do artigo 264 da lei acionária - mas se limitou a apontar possível impedimento de voto em deliberações mais agressivas, que tratassem, por exemplo, de relação de troca desigual, conforme as ações pertencessem ou ao não ao bloco de controle.

586 "Sendo o grupo de direito instituto expressamente autorizado na LSA, não há que se falar em conflito formal, ou a priori." in M. VARGAS, Grupo de Sociedades, p. 2064.

587 Perfeitamente aplicáveis, portanto, as conclusões do Professor Erasmo Valladão França a respeito da incorporação de controlada: "Na incorporação de companhia controlada, a maioria controladora é que decide a operação por ambas as companhias. E, no entanto, mesmo assim, nessa situação de evidente conflito formal de interesses, a lei permite que a acionista controladora exerça o direito de voto. Se não pudesse exercê-lo, aliás, não se atingiria o quórum previsto para incorporação [...] e não se justificaria, minimamente, o direito de recesso concedido aos acionistas minoritários no $\S 3^{\circ}$, do art. 264, supracitado." in E. VALLADÃO FRANÇA, Conflito de Interesses e Beneficio Particular: Uma Distinção que se Impõe Definitivamente Dirimir, p. 41. 
deliberação sempre envolverá potenciais efeitos negativos para a filiada. O sentido fundamental da formação do grupo de direito é afastar as operações intragrupo do perímetro da comutatividade obrigatória e necessária, que deve prevalecer nos grupos de fato nos termos dos artigos 245 e 246 (com suas remissões aos artigos 116 e 117) da Lei 6.404/1976. Trata-se de exclusão tópica e circunscrita de uma proteção legal. O grupo de direito representa um instrumento drástico (pode-se mesmo dizer brutal) para a superação do conflito de interesses pela via da subordinação de interesses. Seria, portanto, contraditório impedir que a sociedade controladora votasse na deliberação de aprovação da convenção orientada pelo interesse da controlada - frise-se, o interesse que se quer subordinar por meio do grupo de direito.

Ainda assim, não se pode afirmar que não há limites à conduta da sociedade controladora por ocasião da deliberação de formação do grupo. Por exemplo, conforme discutido a seguir, pode ser considerada abusiva a proposta de formação do grupo que tenha como único ou principal escopo compelir os minoritários a exercer direito de recesso e, assim, evitar que ganhos futuros esperados para a companhia sejam com eles compartilhados.

$\mathrm{O}$ artigo 271, inciso II, trata ainda do registro de atas ou "instrumentos de alteração contratual" de todas as sociedades convenentes. A provável razão para essa referência à necessidade de alteração do contrato social de uma integrante do grupo é a aposição da designação do grupo à própria denominação, consoante o $\S 3^{\circ}$ do próprio artigo 271, pois a formalização da convenção não parece, por si só, exigir outras modificações formais dos atos constitutivos das sociedades que integram o grupo.

O artigo 268 se refere a "companhias" - mas, parece mais adequado compreender a expressão como menção imprópria a "sociedades" em geral - cujo funcionamento dependa de autorização para funcionar ${ }^{588}$. A exigência é razoável, pois o grupo de direito poderia facilmente ser utilizado para contornar restrições regulamentares setoriais. A norma, contudo, não esclarece se a concessão da autorização impede a própria formação do grupo ou apenas a extensão de seus efeitos à convenente sujeita à respectiva

588 A Instrução Normativa DNRC $n^{\circ} 114 / 2011$, conforme alterada pela Instrução Normativa DNRC $\mathrm{n}^{\circ}$ 121/2012, que contém "quadro enumerativo dos atos empresariais sujeitos à aprovação prévia de órgãos e entidades governamentais', não parece ter levado em consideração a formação ou a alteração do grupo de direito. O requisito legal, no entanto, é repetido pelo artigo $4^{\circ}, \S 1^{\circ}$, da Instrução Normativa DNRC n ${ }^{\circ} 73 / 1998$. 
regulamentação especial.

\subsubsection{Registro e Publicidade}

De acordo com o artigo 271 da Lei 6.404/1976, é necessário arquivar no registro da sede da sociedade de comando ${ }^{589}$ : (i) a convenção, (ii) os atos das convenentes por meio dos quais se aprovou a formação do grupo e (iii) alternativamente, (a) declaração autenticada da titularidade de ações ou quotas detidas pelas integrantes do grupo no capital social, umas das outras, ou (b) cópia do "acordo de acionistas" - pareceria mais adequado dizer "acordo de voto" - que assegura o controle da sociedade de comando sobre as filiadas ${ }^{590}$.

O caput do artigo 271 se refere expressamente a "registro de comércio" - na dicção do Código Civil de 2002, passa a ser Registro Público de Empresas Mercantis (artigo 1.150). A esse respeito, é de se questionar se a sociedade de comando pode ser uma sociedade simples e, em caso afirmativo, se o registro da convenção deverá em tal caso ser realizado perante o competente Registro Civil das Pessoas Jurídicas.

A lei não especifica se as atas e instrumentos de alteração contratual que tratam da aprovação do grupo devem ser apresentados já registrados em nome de cada uma das convenentes - o que tornaria o processo ainda mais moroso e circular - ou se podem ser entregues para registro simultaneamente.

Também não é clara a situação do registro relativamente às filiadas, conforme estejam ou não baseadas no mesmo local da sede da sociedade de comando, nos termos do $\S 1^{\circ}$ do artigo 271. O próprio conceito de "local" é dúbio. A lei se refere à mesma localidade (município) ou à competência territorial da respectiva autoridade de registro do comércio o que, tratando-se das Juntas Comerciais, poderia compreender as próprias unidades da federação do país? Deixada de lado tal questão, qual é a extensão da expressão "as atas de assembléia ou alterações contratuais"? Considerando que a obrigação de arquivar os seus próprios atos de deliberação relativos à aprovação da convenção caberia, de toda forma, também às filiadas com sede no mesmo local da sociedade de comando, o

589 "O registro tem, na hipótese, caráter constitutivo" in E. TEIXEIRA, A. GUERREIRO, Das Sociedades Anônimas no Direito Brasileiro, vol. II, p. 772.

590 A Instrução Normativa DNRC nº 73/1998 acrescenta a essa lista os formulários e guias de recolhimento de praxe. 
disposto no $\S 1^{\circ}$ do artigo 271 parece (pouco razoavelmente; bastaria cópia da convenção) exigir das filiadas com sede em lugar diverso o registro dos atos de todas as demais sociedades integrantes do grupo de direito.

Nos termos do artigo 32, II, alínea "f", combinado com o artigo 33, caput, do Decreto 1.800/1996, o registro de atos relativos aos grupos passou a se beneficiar também da retroatividade de trinta dias, típica do arquivamento dos atos empresariais ${ }^{591}$.

As companhias abertas que aderirem a grupo de direito deverão enviar cópia da respectiva convenção à Comissão de Valores Mobiliários - CVM, por meio de sistema eletrônico, dentro do prazo de sete dias, a contar da data da respectiva assinatura, nos termos do artigo 30, IX, da Instrução Normativa $n^{\circ}$ 480/2009. Além disso, conforme observa Nelson Eizirik, é difícil imaginar cenário em que a celebração de uma convenção de grupo - pela potencial amplitude e profundidade de seus efeitos - não possa influir de modo ponderável na cotação das ações de companhia aberta ou nas decisões de investidores relativamente a tal título, pelo que seria também necessária a publicação de fato relevante, nos termos da Instrução Normativa CVM n ${ }^{\circ} 358 / 2000^{592}$.

\subsubsection{Direito de Recesso}

Nos termos dos artigos 270, parágrafo único, e 136, V, da Lei 6.404/1976, os sócios dissidentes da deliberação de adesão da respectiva sociedade ao grupo de direito têm a prerrogativa de se retirar da companhia, consoante o regime previsto no artigo 137 . No caso das sociedades limitadas, o direito de recesso estará duplamente fundamentado, uma vez que a alteração do contrato social, por si só, já enseja a retirada do quotista, conforme o previsto no artigo 1.077 do Código Civil de 2002.

O direito de recesso foi claramente colocado pelo legislador brasileiro como a principal linha de defesa ${ }^{593}$ - e, essencialmente, a única moeda de troca - dos acionistas externos, por ocasião da formação do grupo de direito. Com efeito, ao lado do direito de informação, os "direitos patrimoniais de saída" representam um dos mecanismos de

591 Perderam, portanto, atualidade, as oportunas observações de Lacerda Teixeira e Tavares Guerreiro a respeito da ausência do efeito da retroatividade para os atos relativos aos grupos, ainda no regime da Lei 4.726/1965. E. TEIXEIRA, A. GUERREIRO, Das Sociedades Anônimas no Direito Brasileiro, vol. II, p. 780-781.

592 N. EIZIRIK, A Lei das S/A Comentada, vol. II, p. 527.

593 F. COMPARATO, Os Grupos Societários na Nova Lei de Sociedades por Ações, p. 100. 
proteção mais frequentemente utilizados pela lei acionária brasileira ${ }^{594}$, tal como se verifica, por exemplo, em relação à incorporação de sociedade controlada (artigo 264, $\left.\S 3^{\circ}\right)$.

De acordo com o artigo 137, II - que contém remissão ao artigo 136, V -, não caberá o direito de recesso para os titulares de ações de companhia aberta que apresentem, cumulativamente, liquidez e dispersão no mercado. Os conceitos de liquidez e dispersão, a seu turno, estão respectivamente definidos nas alíneas "a" e "b" de tal inciso como os fatos de: (i) a ação em questão integrar índice geral representativo de carteira de valores mobiliários, definido pela Comissão de Valores Mobiliários ${ }^{595}$ e (ii) de os acionistas controladores não deterem mais da metade da respectiva espécie ou classe de tal ação.

Sob certo ponto de vista, a retirada representa uma solução eficaz, pois permite ao sócio externo que esteja cético quanto à tutela de sua posição no âmbito do grupo de direito desvincular-se imediatamente do risco da atividade da empresa plurissocietária, desmobilizando o investimento que realizou naquela sociedade que anteriormente estava sob a proteção do disposto no artigo 245 da Lei 6.404/1976. Além disso, não deixa de ser um mecanismo extremamente pragmático, pois prescinde de qualquer valoração a respeito da conveniência ou razoabilidade - ou mesmo boa-fé - da sociedade controladora na celebração da convenção de grupo.

Por outro lado, não deixa de ser uma resposta demasiadamente drástica e sujeita a limitações. Drástica, porque, conforme sublinhado por Anne Pietpierre-Sauvain, busca resolver o problema do conflito de interesses entre maioria e minoria por meio da supressão desta última ${ }^{596}$. Limitada, por duas principais questões. A primeira reside no fato

594 A esse respeito, assevera o Professor Calixto Salomão Filho: “As consequências desse tipo de tendência são óbvias: o incentivo ao minoritário é no máximo um incentivo de liquidez no momento que quiser se desfazer do investimento. Não há qualquer garantia de solidez durante sua permanência” in C. SALOMÃO FILHO, O Novo Direito Societário, p. 55-56.

595 A esse respeito, o item 6.5 do Ofício-Circular/CVM/SEP/n ${ }^{\circ}$ 01/2013, de 28 de fevereiro de 2013, esclarece que: "Considerando que, atualmente, inexiste regulamentação acerca da matéria na CVM, entende-se que os indices considerados para efeito de liquidez devem ser aqueles admitidos à negociação em bolsas de futuros, atualmente, Ibovespa e IBrX-50".

596 "Entretanto, tal resultado é obtido por meio altamente radical (suprime-se o conflito ao se suprimir a minoria) e será exagerado se toda a divergência entre majoritários e minoritários puder ensejar a retirada ou a recompra, equivalentes a uma expropriação". Tradução livre de: "Cependant, ce résultat est obtenu par un moyen fort radical (on supprime le conflit en supprimant la minorité) et qui le serait trop si toute divergence entre intérêts majoritaires et minoritaires pouvait entraîner le retrait ou un rachat équivalent à une expropriation." in A. PETITPIERRE-SAUVAIN, Droit des Sociétés et Groupes de Sociétés, p. 231. 
de o recesso criar ônus financeiro para a própria companhia (artigo 45 caput da Lei 6.404/1976), prejudicando indiretamente os acionistas minoritários remanescentes e os credores sociais, cuja garantia é reduzida. Pode-se dizer que, neste caso, existe uma solidarização dos custos decorrentes da decisão tomada pelo controlador de colocar a sociedade a serviço do grupo de direito que ele próprio comanda. Por se tratar de crédito oponível à companhia, o valor do reembolso deverá ser sempre fixado prudencialmente e os pagamentos efetuados - se realizados à conta de capital - estarão sujeitos à ação revocatória, nos termos do artigo $45, \S 8^{\circ}$. Ou seja, o ex-minoritário pode, de todo o modo, ser negativamente afetado pelos riscos futuros de sociedade na qual deixou de ter qualquer influência ou direito de fiscalização.

Parece muito mais adequada, nesse sentido, a solução alemã (lei acionária de $1965, \S 305)$ que prevê o direito do acionista externo de exigir a aquisição de suas ações pela empresa dominante em troca de uma compensação adequada (Abfindung), em dinheiro ou na forma de ações da própria sociedade controladora, dependendo do local da sede, da natureza jurídica e da sujeição ou não desta última ao controle de outras sociedades $^{597}$.

O outro aspecto negativo relevante que se pode identificar na solução baseada no direito de recesso reside no fato de que a contabilidade da sociedade e os respectivos critérios de apuração do valor do reembolso previstos no estatuto social podem não refletir adequadamente elementos já conhecidos pela administração, que ensejem uma forte expectativa de rentabilidade e valorização para a companhia (por exemplo, a saída de um concorrente do mercado ou a informação privilegiada sobre resultados positivos em prospecções geológicas). Em tais casos, o controlador pode, de maneira oportunista, propor a celebração de convenção de grupo particularmente gravosa - dada a ausência de limites ou restrições a esse respeito na lei acionária - com o objetivo de compelir os minoritários ao exercício de direito de recesso, de forma a reter para si parcela maior dos futuros ganhos esperados para a companhia.

É importante observar que o artigo 269 determina a aprovação da convenção de grupo por todas as "sociedades que o componham". Além disso, os artigos 136, V, e 270, parágrafo único, não fazem qualquer distinção entre sociedade de comando e filiadas.

597 V. EMMERICH, M. HABERSACK, Konzernrecht, p. 343-346. 
Nesse sentido, a prerrogativa de exercício do direito de retirada se aplica também aos sócios minoritários da sociedade de comando, cujos interesses podem efetivamente ser negativamente afetados pela convenção.

O inciso VIII do artigo 269 da lei acionária prevê como parte do conteúdo obrigatório da convenção a declinação das condições para a sua alteração ${ }^{598}$. A lei, porém, não trata da hipótese de recesso em caso de modificação da convenção, caso esta última, bem como os atos constitutivos das convenentes, sejam silentes a esse respeito. De qualquer forma, como bem observa Manoel Vargas, o direito de recesso deve, de toda forma, ser assegurado sempre que houver alteração substancial da convenção ${ }^{599}$. Caso contrário, seria demasiadamente simples para a sociedade de comando neutralizar o mecanismo do direito de recesso, propondo uma convenção amena, que seria aprovada pelos acionistas externos, com a consequente preclusão de seu direito de retirada, apenas para em seguida aditá-la, impondo termos mais severos.

Questão extremamente interessante, mas que não parece ter sido explorada pela doutrina brasileira, nem tampouco enfrentada pelos tribunais nacionais, seria a aplicação da doutrina do grupo de fato qualificado (qualifizierter faktischer Konzern), construída pelo direito alemão, para fins de incidência do direito de recesso. A referida doutrina diz respeito à hipótese em que o grupo de fato é pautado por tão densa integração de atividades e tão profunda subordinação de interesses que já não é mais possível reconstruir a situação da sociedade controlada enquanto empresa independente, frustrando-se assim a eficácia do mecanismo de pagamento compensatório adequado ${ }^{600}$.

Nesses casos, uma vez que o grupo de fato qualificado opera de uma maneira que, legalmente, apenas seria possível na esfera do grupo convencional, a jurisprudência alemã admite a possibilidade de aplicação excepcional a tal estrutura das regras típicas do grupo de direito ${ }^{601}$. Tal extensão das regras do grupo de direito ao grupo de fato é normalmente

598 Também em relação a esse ponto, o legislador brasileiro foi mais generoso com a sociedade de comando do que o alemão, pois a lei acionária de 1965 prevê que a alteração do acordo de domínio em relação a questões estratégicas, como a compensação de perdas e direito de retirada, exige aprovação dos acionistas externos em conclave separado ( $\$ 295$, subparágrafo 2 ).

599 "O direito de recesso, no caso é o instrumento por excelência de proteção aos acionistas minoritários, mas só existe na constituição do grupo; é razoável sustentar, porém, que se houver alteração substancial na convenção do grupo deve também ser assegurado." in M. VARGAS, Grupo de Sociedades, p. 2065.

600 Conceitos discutidos no ponto 5.1.6 deste trabalho.

601 M. HOFFMANN-BECKING, Der qualifizierte faktische AG-Konzern - Tatbestand und 
buscada na praxe alemã com o objetivo de fazer recair sobre a empresa dominante determinadas obrigações relativas à absorção e compensação de perdas (lei acionária de 1965, $\S \S 302$ e 304), típicas dos grupos sujeitos a acordo de domínio. Conforme se assinala mais adiante, a timidez da lei brasileira em matéria de compensação de perdas nos grupos de direito torna tal assimilação dos grupos de fato à disciplina do grupo convencional essencialmente inócua em nossa realidade, ao menos no que se refere a esse efeito específico de composição de danos e absorção de prejuízos.

Entretanto, o mesmo raciocínio poderia ser aplicado, no direito brasileiro, para se reconhecer o direito de retirada ao acionista externo de sociedade integrante de grupo de fato sujeita a formas de subordinação de interesse não mais corrigíveis ou contornáveis pelo mecanismo do adequado pagamento compensatório (Lei 6.404/1976, artigo 245) e que, portanto, nos termos da lei acionária, apenas seriam lícitas se expressamente amparadas por convenção. Ora, se a sociedade de comando que busca às claras formalizar e legitimar o próprio domínio por meio da celebração de convenção de grupo está sujeita ao ônus do exercício do direito de recesso pelos minoritários, consoante o parágrafo único do artigo 270 da Lei 6.404/1976, seria injusto excluir tal possibilidade no grupo de fato qualificado. Entre outras considerações, tal distinção de tratamento significaria colocar em posição mais vantajosa a sociedade controladora que opta por agir, de fato, como sociedade de comando, mas o faz ao total arrepio da lei.

\subsection{Efeitos da Convenção de Grupo}

Nos termos do caput do artigo 271, considera-se constituído o grupo a partir da data de arquivamento no registro da sede da sociedade de comando da convenção de grupo, dos atos que atestem sua aprovação por todas as sociedades que o integrarão, bem como de declaração com a indicação das participações societárias ou acordos de voto que assegurem a posição de controle da sociedade de comando.

É de se questionar qual seria a eficácia de tal instrumento anteriormente ao seu registro. Para fins de incidência do disposto no artigo 1.154 do Código Civil de 2002 - que determina, mediante interpretação a contrario sensu, a eficácia imediata dos atos empresariais ainda não registrados entre os sujeitos que tomaram parte em sua celebração

Abwehransprüche, p. 69. 
-, quem seriam exatamente os terceiros e qual seria, ao revés, o perímetro inter partes no caso da convenção de grupo?

Não parece razoável, em primeiro lugar, considerar que a convenção não registrada seja oponível, desde logo, aos acionistas externos da sociedade de comando e das filiadas. Ainda que tenham participado da deliberação interna relativa à celebração de tal ato e independentemente da forma como tenham votado, tais sujeitos não têm como formalmente ter ciência da aprovação da convenção pelas demais sociedades do (futuro) grupo de direito antes que o processo de registro tenha se completado. Essa consideração parece, por si só, lançar relevante dúvida sobre qualquer possibilidade de legítima subordinação de interesses com base em convenção não registrada.

É também extremamente questionável a eficácia erga omnes da representação coletiva das sociedades integrantes do grupo de direito anteriormente ao registro da convenção. Poder-se-ia discutir a respeito de sua validade temporária na forma de simples mandato, mas nem sempre as regras para a outorga de procuração constantes dos atos constitutivos das diversas filiadas - é praxe, por exemplo, a limitação do prazo máximo dos mandatos ad negotia - serão compatíveis com tal conclusão. Nesse sentido, pode-se concluir que os efeitos práticos mais relevantes da convenção de grupo estão, de todo modo, condicionados ao seu registro.

\subsubsection{Legítima Subordinação de Interesses}

O fato de que o legislador de 1976 tenha julgado necessário ressalvar expressamente a manutenção da personalidade jurídica das sociedades filiadas, consoante a parte final do artigo 266, dá a dimensão do grau de integração econômica e de subordinação de interesses que se pretendeu oferecer por meio dessa estrutura.

A referência à "subordinação" dos administradores constante do próprio artigo 266, associada ao disposto no artigo 276, que trata da oponibilidade da "subordinação de interesses" apontam claramente na direção de uma desaplicação, nos limites e nos termos expressamente fixados na respectiva convenção de grupo, do disposto no artigo $245^{602}$ e em algumas passagens do artigo $117^{603}$. No grupo de direito, desde que assim seja

602 "[...] não se aplica ao grupo de direito a vedação de favorecimento a sociedade controladora ou controlada que existe no grupo de fato (LSA, art. 245)." in M. VARGAS, Grupo de Sociedades, p. 2056. 603 Por exemplo, uma desaplicação do disposto no artigo 117, $\S 1^{\circ}$, alíneas "a" e "f", na medida em que 
expressamente pactuado, a comutatividade obrigatória cede o passo à legítima subordinação de interesses ${ }^{604-605}$.

Trata-se, evidentemente, de significativa subversão dos princípios gerais aplicáveis à gestão das sociedades. O grupo de direito representa uma mutilação contratual - evidentemente, admissível apenas em função de expressas disposições legais - dos deveres fiduciários atribuíveis à sociedade controladora e aos administradores de todas as sociedades convenentes. Seu significado teórico e conceitual não deve ser minimizado com base no argumento de que, mesmo nos grupos não convencionais, a subordinação é corriqueira e disseminada. No grupo de direito, a subordinação de interesses é elevada do plano dos fatos para a própria deontologia da norma.

É importante enfatizar, porém, que a simples celebração da convenção de grupo não afasta integral e automaticamente a disciplina do grupo de fato. Conforme discutido, o grupo de direito está sempre contido em um grupo de fato. Mesmo no grupo de direito, o

tratam, respectivamente, do não favorecimento de outras sociedades e da vedação de contratação em condições não equitativas.

604 “[...] divisamos incompatibilidade lógica entre suas disposições [do artigo 245 da Lei 6.404/1976] e as constantes do art. 276, relativos aos grupos. Assim, se de um lado, o art. 245 veda o favorecimento de sociedades, e exige comutatividade nas operações entre elas, o art. 276 admite a subordinação dos interesses de uma sociedade aos de outra e participação em custos, receitas ou resultados de atividades ou empreendimentos. Dai entendermos que a conduta dos administradores no grupo de sociedades (e conseqüentemente suas responsabilidades) deve reger-se por regras próprias, que levem em consideração a existência e os interesses do grupo, de acordo com a convenção aprovada pelas partes." in E. TEIXEIRA, J. GUERREIRO, Das Sociedades Anônimas no Direito Brasileiro, vol. II, p. 709. "Com efeito, não se aplica aos grupos de direito a exigência constante do artigo 245, de que as relações comerciais entre as sociedades associadas apresentem natureza estritamente comutativa. [...] os atos praticados em benefício do grupo ou de alguma sociedade em particular e que venham a prejudicar os interesses de outra somente serão legítimos, e deverão ser aceitos por seus acionistas minoritários, na medida em que estejam previstos na convenção (artigo 276)." in N. EIZIRIK, A Lei das S/A Comentada, vol. II, p. 526. "A lei é clara ao dispor que, pela convenção, as sociedades integrantes do grupo se obrigam a 'combinar recursos ou esforços para a realização dos respectivos objetos'. Abre-se, desse modo, uma exceção ao princípio contido no art. 245 [...]” in F. MARTINS, R. PAPINI (atualiz.), Comentários à Lei das Sociedades Anônimas, p. 1112.

605 Como raro exemplo de decisão, ainda que em âmbito administrativo, em que a estrutura do grupo de direito cumpriu sua função de exonerar os administradores de responsabilidade pela realização de operações não comutativas: "10. Ao dispor sobre a responsabilidade dos administradores e das controladoras nas operações com sociedades ligadas, relativamente a grupos não convencionais, ou de fato, o art. 245 da lei societária exige a observância de condições estritamente comutativas ou com pagamento compensatório adequado, para que possam ser realizadas, sob pena de responderem pelas perdas e danos que resultarem do não atendimento desses pressupostos. 11. Já, nos grupos de direito, como o caso que ora se nos apresenta, tais operações podem ser admitidas, ainda que em condições não eqüitativas, desde que previstas na convenção de grupo. Isto se dá porque, no momento em que as sociedades resolvem entrar no grupo, é conferida a oportunidade de recesso aos minoritários discordantes." conforme voto do Diretor Relator, Wladimir Castelo Branco Castro, Comissão de Valores Mobiliários, Processo Administrativo Sancionador n 09/03, 25 de janeiro de 2006. 
afastamento da incidência do disposto nos artigos 245 e 246 será sempre excepcional e limitado ao que a convenção dispuser a respeito.

Existem, outrossim, limites na condução das sociedades filiadas que nem mesmo diante de expressa previsão convencional devem ser superados. A convenção evidentemente não implica superação de imposições decorrentes de normas cogentes de caráter público. Assim, por exemplo, o estabelecimento do grupo de direito não isentará o administrador da filiada de responsabilidade caso siga instruções da sociedade de comando que consubstanciem fraude fiscal. Mesmo em âmbito puramente societário, não parece possível vislumbrar na convenção exclusão de responsabilidade pela nomeação de administrador sabidamente inapto, pela indução de representante da sociedade a cometer ato ilícito ${ }^{606}$, pela aprovação de contas irregulares ou pela omissão na apuração de denúncias fundadas (artigo 117, § 1, alíneas “d”, "e" e "g", cujas disposições são "internalizadas" na disciplina dos grupos de fato por força da remissão constante do artigo 246).

Ademais, cumpre recordar que a sociedade filiada continua a ser sociedade e, como tal, encontra sua definição e razão de existir na alocação de recursos para a realização de atividade econômica e partilha dos resultados. Nesse sentido, mesmo no âmbito de grupo de direito, a sociedade filiada não deve ser completamente desnaturada, a ponto de se tornar permanentemente inviável a obtenção de qualquer forma de resultado econômico positivo em benefício de seus acionistas ${ }^{607}$.

Com isso não se quer dizer que a sociedade filiada deva necessariamente produzir ganhos para os acionistas externos, uma vez que o legislador brasileiro não reproduziu o comando constante do $\S 304$, subparágrafo 2, da lei acionária alemã. Contudo, não é admissível, nem mesmo em face de disciplina expressa prevista na convenção de grupo, que ela seja privada da perspectiva de lucro, pois isso representaria o seu total desvirtuamento enquanto sociedade.

606 E. TEIXEIRA, J. GUERREIRO, Das Sociedades Anônimas no Direito Brasileiro, vol. II, p. 709.

607 "É bem de ver, no entanto, que a convenção constitutiva do grupo não pode contrariar a lei, deformando a própria índole societária. Assim, se toda a sociedade mercantil tem, necessariamente, por objetivo a produção e partilha de lucros entre os sócios, a convenção grupal não pode estabelecer um pacto leonino, segundo o qual uma sociedade filiada seria perpetuamente condenada a atuar sem lucros, ou obrigada a transferi-los integralmente à controladora." in F. COMPARATO, Os Grupos Societários na Nova Lei das Sociedades por Ações, p. 100. 
Questão diretamente vinculada à subordinação de interesses e discutida mais detalhadamente no tópico a seguir é a da vinculação dos administradores das sociedades filiadas às instruções recebidas pelos administradores do grupo, que estejam em linha com a convenção. Se estão legalmente obrigados a seguir tais orientações, é evidente que os administradores das filiadas não poderão ser responsabilizados se o fizerem. Neste caso, verifica-se não apenas uma derrogação tópica das disposições do artigo 245 da lei acionária, mas também de muitos outros deveres fiduciários fixados nos artigos 153 e seguintes de tal diploma.

\subsubsection{Administração, Representação e Fiscalização}

Nos termos do artigo 272, bem como do artigo 269, VI, da Lei 6.404/1976, a convenção deve obrigatoriamente disciplinar a estrutura de administração e representação do grupo de direito. Contudo, não se trata de supressão ou substituição da administração das sociedades convenentes, fato, aliás, ressaltado pelo próprio inciso VI do artigo 269, que se refere a "relações entre a estrutura administrativa do grupo e as das sociedades que $\underline{O}$ componham" como uma das matérias que devem, necessariamente, ser abordadas pela convenção. A manutenção da estrutura de administração das sociedades individualmente consideradas também é confirmada tanto pelo parágrafo único do artigo 272 - que prevê o fato de que, no silêncio da convenção, as sociedades filiadas serão representadas exclusivamente pelos seus próprios administradores - quanto pelo artigo 273 - que fixa o dever de obediência dos administradores das sociedades às diretrizes e instruções recebidas da administração grupal. Se a formação do grupo de direito eliminasse a administração das sociedades que o compõem, tal dispositivo não teria qualquer sentido. As sociedades que integram o grupo de direito mantêm, portanto, não apenas a sua personalidade jurídica e individualidade, bem como a própria estrutura orgânica de administração.

Conforme parecer da Procuradoria Regional da Junta Comercial de São Paulo, de 1980, comentado pelo Professor Mauro Rodrigues Penteado, a composição dos órgãos sociais das sociedades filiadas não pode ser diretamente delegada à administração grupal $^{608}$. Assim, por exemplo, se a sociedade de comando $A$ controla a sociedade $B$, que por sua vez controla $C$, tendo todas elas firmado convenção para a constituição do grupo $A B C$, não poderão os administradores de $A$, nem tampouco os administradores grupais de

608 M. PENTEADO, Eleição de Administradores em Sociedades Filiadas a Grupos Societários, p. 164. 
$A B C$ nomear diretamente os administradores de $B$ e de $C$, avocando para si prerrogativa típica das assembleias e dos conselhos de administração destas duas últimas companhias. Nesse sentido, o percurso para o preenchimento, de acordo com os desígnios do grupo, dos cargos de administração de $C$, por exemplo, será o fornecimento de instruções vinculantes por parte dos administradores grupais (administradores do grupo $A B C$ ) - nos termos do artigo 273 da Lei 6.404/1976 - ao administrador de $B$ que exercerá o direito de voto em nome de tal sociedade na assembleia de $C$.

O já citado parágrafo único do artigo 272 autoriza ainda a convenção a disciplinar expressamente a representação conjunta das sociedades integrantes do grupo de direito perante terceiros. Neste caso, trata-se de representação coletiva e unificada das sociedades agrupadas - filiadas e de comando - e não de representação do grupo, em si mesmo, que, como se argumentou, não é sujeito de direito ${ }^{609}$, não reúne elementos de subjetividade e não tem como assumir direitos ou obrigações perante terceiros em nome próprio ${ }^{610}$.

Não se pode deixar de observar que muitos dos efeitos originalmente pretendidos como típicos da convenção de grupo foram alcançados na prática por um uso e uma interpretação marcadamente ampliativos do instituto do acordo de acionistas, que acabaram reforçados e sancionados pela reforma da lei acionária de 2001. De fato, os "acordos em cascata" têm sido frequentemente utilizados como mecanismos de formalização e regulação da projeção do poder de controle ao longo da cadeia societária ${ }^{611}$. Existe, por outro lado, evidente paralelo entre o artigo 273, que vincula o administrador às instruções da administração do grupo, e o disposto nos parágrafos $8^{\circ}$ e $9^{\circ}$ do artigo 118 , com a redação atribuída após a reforma de 2001, que prevê sujeição de membros de órgãos colegiados da administração ao acordo de acionistas.

Nas sociedades filiadas, a instalação do conselho fiscal que não opere em caráter

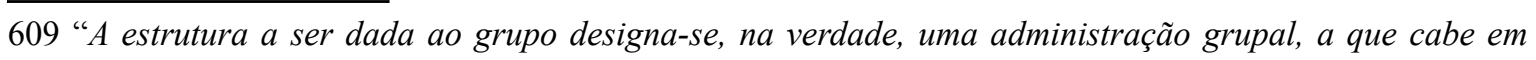
princípio, tomar deliberações de ordem geral; não se trata, contudo, de uma pessoa moral, mas de simples caso de representação do conjunto das sociedades que constituem o grupo, inclusive a sociedade de comando." in F. MARTINS, R. PAPINI (atualiz.), Comentários à Lei das Sociedades Anônimas, p. 1114.

610 “Não tem o grupo representação legal, nem se preocupou o legislador como defini-la, [...] Daí, ter-se limitado a lei a disciplinar a representação das sociedades perante terceiros, o que fez no parágrafo único do art. 272. Ainda quando essa representação caiba convencionalmente aos administradores do grupo, é sempre em nome das sociedades que eles agem." in E. TEIXEIRA, A. GUERREIRO, Das Sociedades Anônimas no Direito Brasileiro, vol. II, p. 783.

611 J. PEDREIRA, Acordo de Acionistas sobre Controle de Grupo de Sociedades, p. 245-246. 
permanente é facilitada, consoante o artigo 277, uma vez que se exige pedido formulado por acionistas titulares de cinco por cento - ao invés de dez por cento, nos termos do artigo $161, \S 2^{\circ}$ - das ações com direito a voto. O percentual de ações sem direito a voto (cinco por cento) não é afetado pela formação do grupo de direito. Uma outra diferença entre os artigos 161 e 277 é que, no âmbito do grupo de direito, os acionistas não controladores titulares de ações com direito de voto podem eleger um representante para o conselho fiscal independentemente do percentual de participação que detiverem na companhia. Tendo em vista a limitada eficácia do conselho fiscal nas sociedades isoladas, não é de se imaginar que ele teria muito sucesso no âmbito do grupo de direito. De qualquer modo, é digna de nota a disposição do $\S 2^{\circ}$ do artigo 277 , que autoriza os membros do conselho fiscal de filiada a solicitar informações aos órgãos da sociedade de comando e de outras convenentes, na medida em que as julgar necessárias à fiscalização do cumprimento da convenção de grupo.

\subsection{Compensação das Perdas}

Ao contrário da legislação alemã, a disciplina brasileira foi extremamente lacônica em matéria de compensação de perdas verificadas no âmbito do grupo de direito, como resultado das políticas adotadas pela sociedade de comando ${ }^{612}$.

Como barreira de proteção à integridade patrimonial da sociedade dependente, o $\S 302$ da lei acionária alemã de 1965 determina que a empresa dominante deve assumir as perdas líquidas anuais apuradas pela contraparte signatária do acordo de domínio, desde que tais resultados negativos não sejam absorvidos por reservas de lucros constituídas durante a vigência do próprio acordo ${ }^{613}$. No que diz respeito especificamente à posição dos acionistas externos, o $\S 304$ estabelece a obrigatoriedade de pagamentos compensatórios adequados (Angemessener Ausgleich) e periódicos, tendo como piso o montante estimado de dividendos que seriam distribuídos a tais sócios, calculados com base no desempenho

612 Em referência à vaga menção a compensação constante do $\S 2^{\circ}$ do artigo 276 da Lei 6.404/1976, o Professor Eduardo Munhoz assevera que: "Esse sistema de compensação, ainda que admitido, tem pouca eficácia, pois em vez de discipliná-lo claramente a lei atribuiu tal tarefa à convenção grupal, deixando, portanto, à vontade dos controladores, cuja orientação é preponderante nas deliberações sociais, a definição da proteção aos minoritários. Sob esse aspecto, a lei brasileira é de uma timidez surpreendente, em face dos rigorosos mecanismos de proteção aos minoritários concebidos no direito comparado em relação aos chamados grupos de direito (modelo contratual)." in E. MUNHOZ, Empresa Contemporânea e Direito Societário: Poder de Controle e Grupos de Sociedades, p. 284.

613 V. EMMERICH, M. HABERSACK, Konzernrecht, p. 311. 
pregresso da companhia ${ }^{614}$.

O direito português vai ainda mais longe e, em presença do contrato de subordinação (equivalente mutatis mutandis à convenção de grupo do direito brasileiro), não apenas assegura aos acionistas externos (denominados "sócios livres") uma garantia de lucros (Código das Sociedades Comerciais, artigo 500), mas determina ainda a responsabilidade da sociedade de comando (denominada "sociedade directora") em face dos credores da sociedade filiada ("sociedade subordinada", consoante o artigo 501), algo que mesmo no direito alemão apenas teria lugar com a operação de integração (Eingliederung). Além disso, a sociedade directora também é responsável perante os sócios livres pelas perdas anuais apuradas pela sociedade subordinada durante o período de vigência do contrato de subordinação (artigo $\left.502^{\circ}\right)^{615}$.

Não há nada semelhante na lei brasileira, que de forma tímida se limita a uma tênue referência a "compensações" entre as sociedades do grupo, consoante o $\S 2^{\circ}$ do artigo $276^{616}$, relativo à contabilização de operações grupais, sem esclarecer, entretanto, se a expressão é utilizada no sentido de indenização pelas perdas causadas em função da política de grupo ou simplesmente representa uma referência à extinção recíproca de obrigações contrapostas, nos termos do artigo 386 do Código Civil, o que seria natural quando se trata da gestão centralizada de fundos do grupo.

Cabe recordar que o artigo 269, que trata do conteúdo mínimo obrigatório da convenção grupal, faz referência, em seu inciso III, às "condições de participação das diversas sociedades", mas em nenhum momento cita expressamente qualquer forma de

614 V. EMMERICH, M. HABERSACK, Konzernrecht, p. 324-325.

615 A. ALMEIDA, Sociedades Comerciais, p. 570-573.

616 Em 1998, o Professor Calixto Salomão Filho argumentou que: "Ao contrário do que tem recorrentemente afirmado a doutrina, o direito positivo brasileiro contém uma regra de responsabilidade (estrutural) para os grupos de direito. Trata-se do próprio art. 276, frequentemente utilizado para argumentações no sentido inverso. Se é verdade que o caput afirma com todas as letras que é possivel a subordinação de interesses da sociedade controlada à controladora, é igualmente verdade que o $\S 2^{\circ}$ do mesmo dispositivo dispõe que: 'a distribuição de lucros, receitas e resultados e as compensações entre sociedades, previstas na convenção de grupo, deverão ser determinadas e registradas no balanço de cada exercício social das sociedades interessadas'. Evidente o objetivo da lei. Não é admissivel subordinação de interesses sem compensação. [...] $\underline{O \text { dispositivo não apenas permite }}$ a inclusão de regras sobre compensação, mas deve ser interpretado no sentido de impor que isso seja feito [...]" (sem grifo no original) in C. SALOMÃO FILHO, O Novo Direito dos Grupos, p. 196-197. Em obra mais recente, sua posição é diversa e mais pessimista a esse respeito: "No caso brasileiro, nos grupos de direito, há a possibilidade legal de subordinação de interesses. Não há qualquer previsão de compensação." (sem grifo no original) in C. SALOMÃO FILHO, O Novo Direito Societário, p. 46. 
proteção econômica ou compensação. O legislador brasileiro de 1976 parece ter depositado exagerada confiança no direito de recesso, como instrumento de barganha dos acionistas externos para a negociação, com a sociedade controladora, de adequados mecanismos de proteção e compensação de perdas no momento de estipulação da convenção de grupo. Tal opção, contudo, não parece ter dado o devido peso (i) às dificuldades de coordenação entre os acionistas externos (sobretudo porque dispersos entre diferentes sociedades) por ocasião da negociação da convenção e (ii) ao caráter incompleto (em sentido econômico) dos vínculos de grupo e de sociedade, cujas inúmeras contingências desafiam a capacidade de previsão das partes e, portanto, a possibilidade de adequada tutela contratual. O resultado final é um baixíssimo nível de proteção dos interesses dos acionistas externos ${ }^{617}$.

É exatamente essa ausência de mecanismos de compensação e absorção de perdas no grupo de direito que explica porque no Brasil nunca emergiu qualquer tentativa de atrair a aplicação de tal regime para o grupo de fato, tal como se fez na Alemanha com a doutrina do grupo de fato qualificado (qualifizierter faktischer Konzern) ${ }^{618}$.

\subsection{Conclusões Preliminares}

A análise do sistema brasileiro de regulamentação do grupo de direito permite contextualizar e relativizar o tão repisado papel inspirador da disciplina alemã para o legislador de 1976. É evidente que a lei alemã serviu de modelo para a lei brasileira quanto ao próprio conceito fundamental de estrutura dual, ou seja, de repartição dos grupos conforme a formalização, ou não, do vínculo de domínio exercido pela controladora. Quanto a todo o resto, porém, a abordagem da norma brasileira é radicalmente diferente daquela alemã.

O sistema alemão aproximou o acordo de domínio do campo dos contratos bilaterais e deu grande ênfase à proteção de credores e acionistas externos. A leitura brasileira do sistema dual - vale dizer, da divisão dos grupos nas categorias de fato e de

617 "Não há porém, no grupo de sociedades de direito substancial diferença quanto ao amparo dos interesses dos minoritários daquele existente no grupo de sociedades de fato. Com efeito, tal proteção aos minoritários aparece apenas no momento da constituição do grupo, uma vez que a lei reconhece aos acionistas dissidentes da deliberação de se associar ao grupo, o direito de recesso [...]” in A. WALD, N. EIZIRIK, A Designação "Grupo de Sociedades" e a Interpretação do Art. 267 da Lei das S/A, p. 63.

618 C. SALOMÃO FILHO, O Novo Direito Societário, p. 47. Como discutido acima, porém, a noção de grupo de fato qualificado poderia ter utilidade prática na realidade brasileira em relação ao direito de recesso. 
direito - é, ao revés, marcada por (i) forte tendência concentracionista, privilegiando-se a propagação sem embaraços do poder da sociedade controladora e (ii) uma tentativa de construir a formalização do grupo à imagem e semelhança da sociedade personificada ${ }^{619}$. Como consequência dessas escolhas, verifica-se um quase desconcertante contraste entre o detalhismo do legislador brasileiro no que se refere a questões relativamente secundárias, tais como a designação do grupo, e seu laconismo em relação a um ponto tão central quanto a responsabilidade da sociedade de comando e a compensação das perdas causadas.

619 "A inclusão na lei desse novo regime [grupo de direito] foi considerada conveniente porque àquela época havia a perspectiva de aumento do número e dimensão dos conglomerados e era tradição do direito comercial a enumeração taxativa dos tipos de sociedades comerciais." (sem grifo no original) in M. VARGAS, Grupo de Sociedades, p. 2055. 


\section{PARTE III - Crise da Disciplina Brasileira dos Grupos e Alternativas}

\section{Crises Conexas}

Como discutido nos capítulos anteriores, um dos pontos menos polêmicos no que diz respeito aos grupos de sociedades é a profunda insatisfação da doutrina com o atual estado do regramento do fenômeno no direito societário brasileiro ${ }^{620}$. Outra conclusão amplamente compartilhada se refere ao insucesso do modelo dual de regulamentação do fenômeno por meio das categorias contrapostas dos grupos de fato e de direito.

O presente capítulo busca amparar com dados empíricos as referidas impressões, como pressuposto para a construção do argumento de que a crise de desuso dos grupos de direito está diretamente relacionada com a inefetividade dos mecanismos de contraste do conflito de interesse nos grupos de fato.

\subsection{Crise de Desuso dos Grupos de Direito}

\subsubsection{Efetiva Difusão dos Grupos de Direito}

Parece claro que, na concepção original do legislador de 1976, o grupo de direito deveria representar um instrumento essencial da macroempresa, a forma para a qual naturalmente convergiriam as grandes estruturas plurissocietárias, em busca da segurança jurídica resultante da formalização do domínio sobre as sociedades controladas ${ }^{621}$. Não fosse assim, não se teria dedicado um amplo e articulado capítulo da Lei 6.404/1976 (Capítulo XXI) especificamente para estatuir uma disciplina própria para esse instituto.

À luz de tais ambições iniciais, parece evidente que o grau de difusão e acolhimento dos grupos convencionais na praxe empresarial brasileira é ínfimo. Não é difícil encontrar advogados de primeira linha, com experiência de décadas em matéria de direito societário, que nunca se depararam com qualquer questão atinente às convenções de

620 "Não é exagerado dizer que o direito grupal brasileiro enfrenta momento de séria crise. Do modelo original praticamente nada resta." in C. SALOMÃO FILHO, O Novo Direito dos Grupos, p. 169. Viviane Muller Prado fala de "falência do modelo grupal brasileiro" (V. PRADO, Conflito de Interesses nos Grupos Societários, p. 77).

621 "O grupo de sociedades é uma forma evoluida de inter-relacionamento de sociedades [...]" conforme Exposição de Motivos n 196, de 24 de junho de 1976, do Ministério da Fazenda. Notas ao Capítulo XXI, Seção I, do Projeto. 
grupo. Mesmo algumas notórias iniciativas pioneiras de adoção do modelo do grupo de direito - tais como os grupos Real, Cindumel, Rosager e Pão de Açúcar ${ }^{622}$ - tiveram como resultado a reversão das estruturas assim criadas, com o retorno à organização das relações intersocietárias na forma do grupo de fato.

Se, de um lado, não há dúvida sobre o fato de que os grupos de direito restaram figura raríssima na realidade brasileira ${ }^{623}$, de outro, é significativamente difícil obter dados oficiais que corroborem tal unânime impressão ${ }^{624-625}$. O Departamento Nacional de Registro do Comércio informa não possuir estatísticas consolidadas a respeito do registro dos grupos de direito ${ }^{626}$. Por sua vez, a coleta de dados diretamente perante as várias Juntas Comerciais das unidades federativas brasileiras esbarraria na diversidade de critérios adotados pelos departamentos responsáveis pelo armazenamento de dados em cada uma delas, além de mecanismos de pesquisa e levantamento de informações (compreensivelmente) voltados para a prática empresarial e não para a análise acadêmica $^{627}$.

A esse respeito, cabe observar que o artigo $5^{\circ}$, inciso III, da Instrução Normativa da Receita Federal do Brasil n 1.183/2011, em linha com a já discutida (imprópria) opção

622 M. CARVALHOSA, Comentários à Lei de Sociedades Anônimas, $4^{\circ}$ vol., tomo II, nota de rodapé n 28 , p. 359.

623 "Embora os grupos de fato existam em grande número, praticamente não há, em nossa prática de negócios, grupos de direito, cuja disciplina legal é raramente utilizada; pode-se dizer que as disposições legais que tratam do grupo de direito, na realidade, 'não pegaram' [...]" in N. EIZIRIK, A Lei das S/A Comentada, vol. II, p. 519-520.

624 "No Brasil, infelizmente, a pobreza dos dados estatísticos, que assola os mais variados campos, em prejuizo da compreensão de sua realidade social e econômica, não deixa de se verificar em matéria de grupos de sociedades." in E. MUNHOZ, Empresa Contemporânea e Direito Societário: Poder de Controle e Grupos de Sociedades, p. 119.

625 São poucas e desencontradiças as informações colacionadas pela doutrina a esse respeito. Citando estudo do Professor Comparato, de 1981, Wald e Eizirik asseveraram: "Foi notado, a propósito, em recente estudo, que há apenas oito grupos de sociedades com seus atos de constituição levados ao registro de comércio de São Paulo, número insignificante se comparado ao total de grupos de fato existentes." in A. WALD, N. EIZIRIK, A Designação "Grupo de Sociedades" e a Interpretação do Art. 267 da Lei das $S / A$, p. 63. A Professora Viviane Muller Prado cita informação recebida em aula do Professor Fábio Konder Comparato, em 1996, de acordo com a qual haveria menos de 30 grupos registrados perante o Departamento Nacional de Registro de Empresas - DNRC. V. PRADO, Conflito de Interesse nos Grupos Societários, nota de rodapé $\mathrm{n}^{\circ} 101$, p. 69. Rodrigo de Castro relata a identificação de informações a respeito de apenas dez grupos, em busca realizada em 2011 no banco de dados da Junta Comercial do Estado de São Paulo - JUCESP. R. CASTRO, Controle Gerencial e o Grupo de Sociedades, p. 161-162.

626 Conforme correio eletrônico enviado em 23 de fevereiro de 2011, pela Coordenadoria de Atos Jurídicos do Departamento Nacional de Registro do Comércio, em resposta a solicitação do autor deste trabalho.

627 Nesse sentido, oportuno o agradecimento aos representantes da Junta Comercial da Bahia que prontamente confirmaram, por correspondência eletrônica de 28 de fevereiro de 2011, a ausência de registros de grupos de direito naquele Estado. 
do legislador brasileiro de regrar o grupo convencional nos moldes de uma sociedade personificada, estabelece a obrigatoriedade de registro dos grupos de direito (bem como dos consórcios de sociedades) no Cadastro Nacional da Pessoa Jurídica - CNPJ. Além disso, nos termos da Resolução da Comissão Nacional de Classificação - CONCLA n ${ }^{\circ}$ 2/2011, cuja "Tabela de Natureza Jurídica" é amplamente utilizada na administração pública federal, os grupos de direito estão catalogados sob o código 215-1.

Com base em tais premissas, foi possível formular, no âmbito do esforço de coleta de dados para o presente trabalho, pedido de acesso à informação amparado pelas disposições da Lei Federal 12.257/2011, dirigido à Receita Federal do Brasil, por meio do qual se verificou que, em outubro de 2012, constavam dos bancos de dados de tal órgão 428 inscrições ativas, duas inscrições suspensas e 330 inscrições baixadas relativas a grupos de direito ${ }^{628}$.

Se confrontados com o fato de que, entre 1985 e 2005, foram constituídas mais de quatro milhões e meio de sociedades comerciais-empresárias no país ${ }^{629}$, tais números atestam amplamente o insucesso do modelo dos grupos de direito na realidade econômica brasileira. Por outro lado, eles também demonstram que, apesar de serem poucos, os grupos de direito efetivamente existem na realidade brasileira e não podem ser, de plano, desconsiderados.

De fato, se excluirmos da comparação as sociedades limitadas (e as antigas sociedades por quotas de responsabilidade limitada), parece possível, quando menos, relativizar a suposta total insignificância da quantidade de grupos de direito existentes. Com efeito, nas referidas duas décadas compreendidas entre 1985 e 2005, foram constituídas apenas cerca de vinte mil sociedades anônimas no Brasil ${ }^{630}$. A mesma solicitação de informações que permitiu confirmar o número de grupos convencionais existentes apontou também que a situação dos consórcios de sociedades (código de

628 Pedido de acesso à informação protocolado sob o ${ }^{\circ} 16853.007164 / 2012-17$, atendido por meio de mensagem eletrônica de 09 de outubro de 2012, cujo teor é parcialmente transcrito a seguir: " $E m$ atenção a solicitação SIC do presente processo, informo os totais de Consórcios de Sociedades e Grupos de Sociedades, naturezas jurídicas respectivamente, 215-1 e 216-0, por situação cadastral, conforme abaixo: Consórcio de Sociedades (Ativas: 6.365; Suspensas:82; baixadas: 948; nulas: 3); Grupo de Sociedades: (Ativas: 428; Suspensas: 2; Baixadas: 330). As informações foram extraídas do banco de dados DW/CNPJ no dia 2/10/12".

629 Conforme estatísticas do Departamento Nacional de Registro do Comércio - DNRC. Dados disponíveis em: $<$ http://www.dnrc.gov.br/Estatisticas/caep0101.htm>. Acesso em: 07out2012.

630 Dados disponíveis em: <http://www.dnrc.gov.br/Estatisticas/caep0101.htm>. Acesso em: 07out2012. 
natureza jurídica 216-0) - instituto frequentemente utilizado em licitações e que não costuma ser apontado pela doutrina como em desuso - perante o CNPJ correspondia a apenas 6.365 inscrições ativas $^{631}$. É evidente que não existe relação direta entre a quantidade de companhias abertas e o número grupos de direito, mas considerando que ambos são instrumentos concebidos precipuamente para a macroempresa, cumpre lembrar também que, em março de 2013, havia apenas 452 sociedades listadas na BM\&FBovespa $^{632}$.

Para além das estatísticas e como exemplos práticos de uso da forma convencional por grupos empresariais relevantes, pode-se mencionar a experiência do Grupo WEG, que tem como sociedade de comando a companhia aberta WEG S.A., cuja convenção está arquivada perante a Junta Comercial do Estado de Santa Catarina ${ }^{633}$, bem como o Grupo Itautec, cuja sociedade de comando é a Itautec S.A. - Grupo Itautec, com sede em São Paulo $^{634}$ e que também é listada na BMF\&Bovespa.

Importante sublinhar que, com estas considerações, não se quer negar o insucesso do modelo dual e do instituto do grupo de direito na realidade brasileira. Experiências como as do Grupo WEG e do Grupo Itautec parecem ser somente as exceções que confirmam a regra do ocaso a que foram relegados os grupos de direito. Por outro lado, parece oportuno, em face dos dados ora disponíveis, quanto menos redimensionar a medida de tal fracasso ${ }^{635}$.

Uma vez confirmada a limitada difusão dos grupos de direito, é necessário indagar a respeito de suas possíveis causas, o que se faz no tópico a seguir.

631 Pedido de acesso à informação protocolado sob o $\mathrm{n}^{\circ} 16853.007164 / 2012-17$, atendido por meio de mensagem eletrônica de 09 de outubro de 2012, já transcrita acima.

632 Conforme BM\&FBovespa, Boletim Empresas, Ano 12, $\mathrm{n}^{\circ}$ 191, Abril 2013. Dados disponíveis em: $<$ http://www.bmfbovespa.com.br/empresas/download/Boletim-49-Marco-2013.pdf $>$. Acesso em: 10 jun2013.

633 Conforme $7^{\text {a }}$ alteração da convenção de grupo, firmada em 25 de novembro de 2010, registrada perante a Junta Comercial de Santa Catarina e disponível em: <http://www.weg.net/ri/wpcontent/uploads/2011/03/Grupo-WEG-7-Conven\%C3\%A7\%C3\%A3o.pdf>. Acesso em: 20jun2012.

634 Convenção de grupo registrada perante a Junta Comercial do Estado de São Paulo e disponível em: $<$ http://www.itautec.com.br/media/764768/20120516\%20-\%20d\%C3\%A9cimo\%20segundo\%20aditame nto $\% 20 \mathrm{a} \% 20$ conven $\% \mathrm{C} 3 \% \mathrm{~A} 7 \% \mathrm{C} 3 \% \mathrm{~A} 3 \mathrm{o} \% 20 \mathrm{do} \% 20$ grupo $\% 20$ itautec.pdf $>$. Acesso em 08 set 2013 .

635 Não se pode, portanto, concordar inteiramente com a afirmação de que: "Os grupos de direito no Brasil são letra absolutamente morta na realidade empresarial brasileira.” in C. SALOMÃO FILHO, O Novo Direito dos Grupos, p. 169. 


\subsubsection{Possíveis Causas da Limitada Difusão dos Grupos de Direito}

Dentre as possíveis causas para o insucesso do modelo dos grupos de direito na realidade brasileira, a doutrina costuma citar: (i) a ausência de flexibilidade e dinamismo de tal modalidade de organização dos grupos ${ }^{636}$, (ii) a artificialidade de tal instituto, que teria sido importado sem encontrar correspondência na tradição nacional e na realidade de nossa economia ${ }^{637}$, (iii) a possibilidade de direito de recesso concedida aos acionistas minoritários $^{638}$, (iv) a ausência de benefícios fiscais decorrentes da celebração da convenção de grupo $^{639} \mathrm{e}$, enfim, (v) a suposta facultatividade dessa modalidade de formalização do grupo ${ }^{640}$. Com a devida vênia, tais argumentos não parecem inteiramente

636 "O grupo de direito não se mostra como o instrumento jurídico flexivel o suficiente para a configuração dos grupos, pois exige que as relações entre empresas e a estrutura administrativa estejam expressamente disciplinadas na convenção grupal, aprovada por assembléia [...]" in V. PRADO, Conflito de Interesses nos Grupos Societários, p. 74. V. PRADO, Grupos Societários: Análise do Modelo da Lei 6.404/1976, p. 358. "Outros aspectos negativos a serem considerados dizem respeito à perda de flexibilidade, em razão da necessidade de alterar o texto da convenção sempre que uma mudança da estrutura administrativa se fizer necessária [...]" in L. AZEVEDO, O Paradoxo da Disciplina Legal dos Grupos de Direito no Brasil: sob uma Perspectiva de Direito e Economia, p. 189.

637 M. CARVAlHoSA, Comentários à Lei de Sociedades Anônimas, 4 vol., tomo II, p. 358. "A artificialidade está relacionada com a importação parcial de um modelo de disciplina dos grupos que não tinham [sic] qualquer tradição no Brasil, sem a concessão de nenhum incentivo econômico." in V. PRADO, Conflito de Interesses nos Grupos Societários, p. 71.

638 "Por outro lado, se o sistema legal aparece, prima facie, como autoritário para os sócios nãocontroladores, atribuindo-lhes apenas o remédio do recesso, a experiência destes primeiros tempos de aplicação da lei revela que esse remédio tem sido bastante enérgico a ponto de inibir praticamente a criação de grupos de direito que incluam sociedades com minoria acionária expressiva." in F. COMPARATO, Os Grupos Societários na Nova Lei de Sociedades por Ações, p. 100. "Disciplinados recentemente entre nós pela Lei acionária de 1976, os grupos de sociedades, cuja constituição tem sido em muito inibida pelo direito de recesso previsto no art. 270 [...]" in M. PENTEADO, Eleição de Administradores em Sociedades Filiadas a Grupos Societários, p. 164.

639 O Professor Manoel Vargas considera o instituto do grupo de direito "letra morta" e atribui tal insucesso, principalmente, à disciplina fiscal, em particular, à revogação do Decreto-Lei 1.598/1977: in M. VARGAS, Grupo de Sociedades, p. 2057. Tal norma havia instituído, em seu artigo 2, I, o regime de tributação conjunta da renda das sociedades integrantes do grupo de direito - a mesma prerrogativa era conferida ao grupo de fato com sociedades ligadas por um vínculo de controle qualificado, definido como a titularidade de mais de oitenta por cento das ações com direito a voto. Tratava-se de uma espécie de Organschaft à brasileira, em que apuração do imposto de renda se daria com base no resultado do balanço consolidado e, portanto, com a compensação e neutralização dos lucros e prejuízos intragrupo. Contudo, a referida disposição do Decreto-Lei 1.598/1977 foi revogada pelo Decreto-Lei 1.648/1978 no final do exercício fiscal de 1978, antes que o regime de tributação conjunta pudesse ser posto em prática. Cumpre observar que se tratava de norma fortemente concentracionista, com elementos preocupantes de regressividade fiscal. Ainda sobre a questão: “[...] não houve recepção do novo modelo pelas autoridades fazendárias, que impuseram dupla tributação no que respeita às convencionadas transferências de recursos e de lucros" in M. CARVALHOSA, Comentários à Lei de Sociedades Anônimas, $4^{\circ}$ vol., tomo II, p. 359. "[...] a ineficácia do instituto do grupo de direito relaciona-se - ou se relacionaria - diretamente com as normas de natureza tributária. Mais do que exigir consolidação, o que deveria ocorrer, caso se pretendesse dar vida ao instituto, seria a integração fiscal e contábil das sociedades." in R. CASTRO, Controle Gerencial e o Grupo de Sociedades, p. 163.

640 "Note-se que a constituição dos grupos de direito e, por conseqüência, a aplicação do regime jurídico excepcional fica a depender da vontade dos próprios empresários. Para estes, basta não adotar um dos 
convincentes.

No que diz respeito à suposta ausência de flexibilidade, é de se reconhecer que a forma como os grupos de direito foram disciplinados no Brasil, buscando aproximá-los das sociedades e, sobretudo, das sociedades personificadas, cria gravames burocráticos que desencorajam a sua adoção, tais como a necessidade de registro de diversos atos societários e de alteração da denominação das sociedades convenentes. Por outro lado, como anotado no capítulo anterior, o legislador brasileiro foi extremamente generoso com a sociedade de comando, deixando-lhe os horizontes mais largos possíveis para a livre formatação da ordem interna do grupo, sem sequer impor exigências mínimas de compensação e absorção de perdas, divergindo assim, significativamente, da experiência comparada ${ }^{641}$. Além disso, a consolidada praxe brasileira com os acordos de acionistas e, em particular, com os acordos em cascata, comprova a viabilidade da regulação contratual e parassocial, por parte de agentes sofisticados, de questões extremamente complexas da sempre mutável realidade da atividade empresarial. Nesse sentido, se a formalização das relações de grupo fosse realmente medida necessária ou oportuna, não parece razoável argumentar que os empresários brasileiros não teriam sabido lançar mão, de maneira eficiente e eficaz, da convenção de grupo como instrumento de organização da empresa plurissocietária.

Hipótese interessante levantada por Luís André Azevedo, que também diz respeito à flexibilidade e aos entraves burocráticos do grupo de direito, é aquela segundo a qual a necessidade de divulgar a terceiros aspectos sensíveis do modus operandi da empresa plurissocietária por meio do registro da convenção poderia explicar, ao menos em parte, a resistência das sociedades controladoras em formalizar o grupo de direito ${ }^{642}$. Também neste caso é possível recorrer à comparação com os acordos de acionistas arquivados na sede da sociedade, para recordar que a exigência de divulgação de informações a seu respeito,

instrumentos legalmente previstos que a disciplina legal especifica não é aplicada, fato que, [...], tem suscitado críticas severas, ao que parece justas, quanto à inefetividade desse sistema regulatório." (sem grifo no original) in E. MUNHOZ, Empresa Contemporânea e Direito Societário: Poder de Controle e Grupos de Sociedades, p. 119. "Ademais, trata-se de um mecanismo facultativo, no qual cabe à controladora decidir se vai utilizar a figura do grupo contratual ou não." in V. PRADO, Conflito de Interesses nos Grupos Societários, p. 71.

641 Como discutido no capítulo anterior, é gritante o contraste entre a referência ambígua e en passant a compensação constante do artigo $276, \S 2^{\circ}$, da Lei 6.404/1976 e os deveres de absorção e compensação de perdas constantes dos $\S \S 302$ e 304 da lei acionária alemã de 1965 e dos artigos $500^{\circ}$ a $502^{\circ}$ do Código das Sociedades Comerciais português.

642 L. AZEVEDO, O Paradoxo da Disciplina Legal dos Grupos de Direito no Brasil: sob uma Perspectiva de Direito e Economia, p. 188-189. 
imposta pela Comissão de Valores Mobiliários ${ }^{643}$, não parece ter desencorajado a sua celebração por parte das companhias abertas. Em um e em outro caso, uma redação cuidadosa do respectivo documento (acordo ou convenção) poderia assegurar os efeitos desejados, resguardando-se ao máximo os dados confidenciais da empresa. Cumpre recordar, também, que a convenção não é um plano de negócios; deve apenas conter as regras e princípios gerais para a subordinação de interesses ${ }^{644}$, não detalhes operacionais.

$\mathrm{O}$ argumento da artificialidade se desdobra em duas premissas distintas, mas diretamente relacionadas. Vale dizer, os grupos de direito teriam fracassado no Brasil (i) por consistirem "em direito sem fato", já que não existia em nossa realidade econômica uma figura análoga ao zaibatsu japonês ${ }^{645}$, e (ii) por representarem a importação acrítica de institutos que não correspondiam à nossa tradição jurídica.

É evidente, e já foi ressaltado em mais de uma passagem deste trabalho, a reprovável inclinação concentracionista da lei acionária de 1976. Em linha com o espírito da época, a norma buscou declaradamente fortalecer a grande empresa nacional e a posição dos acionistas controladores. Não o fez, entretanto, baseada em substratos da realidade então completamente ausentes do panorama nacional, nem tampouco buscando transplantar acrítica e inteiramente modelo estrangeiro de organização da empresa plurissocietária, tanto que colheu inspiração em diferentes fontes para distintos institutos ${ }^{646}$. De fato, como se discutiu no Capítulo 2, tanto o fenômeno das relações intersocietárias, quanto os grandes grupos familiares já eram, há muito, partes integrantes da realidade econômica brasileira no momento em que se promulgou a Lei 6.404/1976 ${ }^{647}$.

643 Instruções Normativas CVM n ${ }^{\circ} 480 / 2009$, artigo 30, VII, e n 358/2008, artigo $2^{\circ}$, parágrafo único, II.

644 Como se depreende, por exemplo, da já mencionada convenção do Grupo Itautec, que - bastante sintética - contém apenas oito cláusulas.

645 “E, em 1975, não existia o fato, não preexistia o Zaibatsu brasileiro, o Konzern brasileiro. Não podendo, portanto, institucionalizar o que não havia, o legislador, cioso dos planos de política econômica em voga (II PND), resolveu fazer com que a lei criasse entre nós o Zaibatsu com roupagem de Konzern." in M. CARVAlHOSA, Comentários à Lei de Sociedades Anônimas, $4^{\circ}$ vol., tomo II, p. 358.

646 Apenas como exemplo da importação seletiva de ideias de fontes diversas pelo legislador de 1976, o modelo dual foi certamente baseado na experiência alemã, mas o prêmio atribuível ao minoritário autor da ação social foi colhido na praxe americana: "Quanto à estruturação jurídica dos grupos, nas legislações européias a que tomou a iniciativa foi a alemã, havendo tendência de outras se lhe seguirem (como fez a legislação brasileira, no art. 265)."; e "[...] o Anteprojeto, no art. 255, $\S 2^{\circ}$ (art. 246 e $\S 2^{\circ}$ da Lei), para permitir melhor apuração desse abuso, adota norma, vigente em alguns Estados americanos, de premiar o advogado e o acionista que ganharem ação em que tal abuso fique comprovado." in A. LAMY FILHO, J. PEDREIRA, A Lei das S.A., vol. I, respectivamente, p. 89 e 167.

647 I. DE SOUSA, Autobiografia: Visconde de Mauá, nota de rodapé no 35, p. 131-132 e 219-220. "Ao se alcançar a década de 1970, as empresas dominantes na maioria dos setores no Brasil pertencia a 
É, ademais, inegável que, em meados da década de 1970, os grupos de direito não pertenciam à tradição jurídica brasileira. Esse fato, porém, decorre unicamente do caráter então absolutamente inovador do instituto, que havia sido concebido ex novo pouco mais de uma década antes na Alemanha. Pode-se reconhecer que, neste ponto específico, ao contrário de tantos outros, o vanguardismo do legislador de 1976 não foi recompensado ${ }^{648}$. Contudo, não parece justa ou adequada a crítica de artificialismo. Quando foi promulgada a Lei 6.404/1976, a experiência alemã com a lei acionária de 1965 ainda estava em plena maturação - não estava claro o insucesso do modelo dos acordos de domínio (Beherrschungsverträge) - e, até então, despontava como o modelo de referência para a futura disciplina do tema pelos países da região e pela própria Comunidade Europeia. Uma vez que o Brasil foi apenas o segundo país no mundo a buscar a implementação do sistema dual, é evidente que o grupo de direito, como figura então recentíssima no panorama jurídico, não poderia encontrar elementos correspondentes na tradição jurídica nacional, como também - e pelas mesmas razões - não pertencia à tradição de nenhum outro país, nem mesmo da própria Alemanha. Assim, pedindo-se vênia pelo jogo de palavras, parece haver notável artificialidade no argumento da artificialidade.

Em relação ao direito de recesso, não há dúvida de que a maciça retirada de acionistas externos pode comportar ônus econômico relevante, existindo inclusive relatos históricos de situações em que a decisão de se constituir o grupo de direito foi revertida especificamente em função do impacto que o exercício de tal prerrogativa teria sobre as finanças das sociedades convenentes ${ }^{649}$. Seria, contudo, impensável permitir a formação do grupo convencional sem conceder aos acionistas externos o direito de recesso. Conforme já

conglomerados de diversas empresas ou grupos, altamente diversificados, normalmente sob o controle direto de uma família ou de uma sociedade controladora detida por uma família". Tradução livre de: "By the 1970s, the dominant firms in most sectors in Brazil belonged to multifirm, largely diversified conglomerates or grupos, usually under the direct control of a familiy or family-owned parent company." in A. MUSACCHIO, Experiments in Financial Democracy - Corporate Governance and Financial Development in Brazil - 1882-1950, p. 243.

648 A própria Exposição de Motivos da lei acionária reconhece abertamente o caráter experimental da disciplina dual dos grupos de fato e de direito, assinalando que esta foi construída "em forma tentativa a ser corrigida pelas necessidades que a prática vier a evidenciar" (Exposição de Motivos n 196, de 24 de junho de 1976, do Ministério da Fazenda, notas ao Capítulo XX do Projeto). Se não se permitisse ao legislador experimentar institutos não inteiramente consolidados na praxe internacional, o Brasil não teria, por exemplo, adotado já em 1919 forma simplificada e não acionária de sociedade com responsabilidade limitada de todos os sócios, enquanto que a Itália o fez apenas em 1942.

649 O Professor Manoel Vargas cita, a esse respeito, o exemplo do Banco Real, cujos controladores foram obrigados a reconsiderar a decisão de formação de grupo de direito, em função do elevado valor de reembolso que deveria ser pago aos acionistas que optaram por exercer direito de retirada. in $\mathrm{M}$. VARGAS, Grupo de Sociedades, p. 2058. 
se sublinhou no capítulo anterior, a retirada representa o único efetivo mecanismo de defesa colocado à disposição dos sócios minoritários pelo legislador. Suprimi-lo significaria converter o grupo de direito em instrumento para uma discricionária e desenfreada expropriação das minorias sociais, devidamente sancionada pelo legislador. Não se pode, tampouco, deixar de considerar que, também em relação a esta matéria, a lei acionária brasileira de 1976 foi mais condescendente que a norma alemã, ao estabelecer que a retirada se dá na forma de recesso, oponível à própria companhia convenente, e não como opção de venda ou permuta de ações exercível diretamente em face da sociedade de comando (conforme $\S 305$ da lei acionária alemã de 1965).

Em face dessas ponderações, atribuir ao direito de recesso a limitada difusão dos grupos de direito, soa em certa medida como uma inversão de leitura dos fatos. Seria mais razoável concluir que as sociedades controladoras não souberam negociar mecanismos adequados de tutela da posição dos acionistas externos a serem inseridos na própria convenção, que assegurassem a sua adesão ao grupo de direito. De resto, cumpre observar que o direito de recesso também é aplicável a diversas outras deliberações e operações societárias das companhias, tais como a incorporação ou a incorporação de ações de sociedade controlada, que nem por isso deixam de ser realizadas rotineiramente.

Por sua vez, a tese de que o modelo dos grupos de direito não prosperou em função da ausência de benefícios fiscais também é merecedora de ressalvas. É verdade que a solução de tributação conjunta da renda das sociedades convenentes, inicialmente prospectada por meio do artigo $2^{\circ}$, I, do Decreto-Lei $1.598 / 1977$, jamais chegou a ser implementada. Esta seria, contudo, uma medida extremamente concentracionista, implicando potencialmente tributação regressiva. A formação dos grupos de direito não representa, ademais, um fim em si mesmo; não traz per se benefícios para a coletividade que justifiquem uma renúncia fiscal ou qualquer forma de subsídio público. O seu objetivo é formalizar e legitimar a subordinação de interesses no âmbito do grupo e é em tais termos e em tal âmbito que ela deve ser explicada e justificada, sem a necessidade de se lançar mão de artificiais incentivos extrassocietários.

É justamente em função da questão da subordinação de interesses que se pode refutar também a afirmação de que o estabelecimento do grupo de direito, na disciplina da Lei 6.404/1976, seria uma mera faculdade atribuída à sociedade controladora. Na mens 
legis da norma acionária, a par do pagamento compensatório adequado previsto no artigo 245 - que seria, no mais das vezes, uma solução inaplicável em relações continuadas e de profunda integração -, a celebração de convenção de grupo representa a única via lícita para a subordinação de interesses de sociedade controlada. Na concepção original da lei, toda subordinação de interesses fora dessas duas hipóteses seria antijurídica e sujeita a severos mecanismos de responsabilização, até então desconhecidos na praxe brasileira ${ }^{650}$. Considerando-se, ainda, as dificuldades práticas de se preservar a plena e rigorosa comutatividade de todas as operações intragrupo nas hipóteses de forte entrelaçamento das atividades das sociedades sob controle comum, a conclusão que exsurge da análise dos artigos 245 e 246 da Lei 6.404/1976 é que a celebração de convenção seria, em princípio, requisito obrigatório e indispensável para a condução de qualquer empresa plurissocietária efetivamente coesa e integrada.

Haveria real faculdade jurídica se a lei permitisse a subordinação de interesses fora do grupo de direito sem cominar sanção a tal conduta. Como se viu, não é isso o que prevê a norma. Se, em termos práticos, as sociedades controladoras que violam tais preceitos não costumam ser responsabilizadas por isso, ao menos não na grande maioria dos casos de abuso, se a constituição do grupo de direito foi assim, de fato, degradada a mera (e substancialmente inútil) opção para o empresário, tal resultado não se deve a uma suposta facultatividade ínsita aos comandos legais, mas sim à sua inefetividade em termos concretos.

A inefetividade da regra de conflito nos grupos de fato no Brasil - argumenta-se derruba o pilar fundamental da justificação prática para a formação dos grupos de direito, que seria justamente a legitimação da subordinação de interesses e, portanto, a proteção em relação à responsabilização de administradores e da sociedade controladora, prevista nos artigos 245 e 246 da Lei 6.404/1976. Parece residir nesse ponto a efetiva razão para o desuso dos grupos de direito. Existe, portanto, um elemento de conexão entre a crise de desuso dos grupos de direito e a inefetividade da disciplina dos grupos de fato, tema que é abordado no próximo subcapítulo.

650 Tal como, apenas exemplificativamente, o prêmio de cinco por cento sobre o valor da indenização atribuído ao minoritário autor da ação social, nos termos do artigo $246, \S 2^{\circ}$. 


\subsection{Crise de Efetividade da Disciplina dos Grupos de Fato}

A demonstração da existência de uma relevante e profunda crise de efetividade nos mecanismos brasileiros de tutela do conflito de interesse no âmbito dos grupos de fato - uma das principais hipóteses deste trabalho - parece ter como pressuposto a prévia verificação de três cruciais dados empíricos: (i) a ampla difusão dos grupos de fato na realidade brasileira, (ii) a significativa disseminação do abuso de controle (notadamente da prática de tunnelling ou desvio de recursos da sociedade para o acionista controlador) e (iii) a tendência a que tais lesões aos direitos e interesses legítimos dos acionistas minoritários (a) não encontrem respostas adequadas no Judiciário ou (b) sequer sejam levadas aos tribunais. Esses três aspectos da realidade dos grupos de fato representam, respectivamente, os objetos de cada um dos tópicos deste subcapítulo, a seguir.

\subsubsection{Difusão e Relevância Econômica dos Grupos de Fato}

Justamente por representarem situação de fato, não formalizada diretamente por meio de convenção ou por outros atos solenes, nem expressa e diretamente refletida em registros e cadastros públicos, é árdua a tarefa de coletar dados empíricos estatisticamente relevantes a respeito da difusão dos grupos de fato.

A legislação brasileira, de forma bastante inovadora, quase ousada, permite que as companhias mantenham registro privado sobre a titularidade das ações e respectivos ônus. Esse mecanismo enseja agilidade e flexibilidade na circulação das ações, mas também reduz significativamente a transparência quanto à sua titularidade, especialmente no que diz respeito à identificação do controle indireto ${ }^{651}$.

Em relação às sociedades limitadas, o acesso à informação é facilitado pela declinação das participações societárias no corpo do próprio contrato social. Ainda assim, a identificação das cadeias de controle indireto - e, portanto, da própria estrutura do grupo de fato - resta bastante complexa, uma vez que ainda são poucas as Juntas Comerciais que colocam seus bancos de dados à disposição para acesso público e irrestrito sem a necessidade de burocrática solicitação de cópias-certidão de atos específicos.

651 Nos termos do $\S 1^{\circ}$, do artigo 100, da Lei 6.404/1976, o acesso ao Livro de Registro de Ações Nominativas de uma sociedade anônima é assegurado apenas a quem demonstre a necessidade de defesa ou esclarecimento de interesse pessoal - e é bastante fácil dessumir que se trate de interesse patrimonial e não meramente acadêmico. 
Nesse sentido, parte significativa dos estudos que se dedicaram à análise da estrutura de propriedade das sociedades brasileiras se focaram nas companhias abertas ou, de todo modo, em grandes empresas, justamente em função da maior disponibilidade e comparabilidade de dados.

Dante Aldrighi e Roberto Mazzer Neto, por exemplo, ao analisarem os dados de companhias abertas que entregaram formulários de informações anuais (IAN) à Comissão de Valores Mobiliários durante o período compreendido entre 1997 e 2002, concluíram que, em média, 50,5\% delas possuíam uma "estrutura de propriedade piramidal”, definida pelos autores como uma cadeia societária com ao menos uma outra companhia de capital aberto interposta entre a sociedade prestadora das informações e o sujeito definido como "maior acionista último". Entre tais sociedades, o "grau da estrutura piramidal" - definido como o número de entidades interpostas entre o acionista último e a controlada de capital aberto - era de 2,06 652 . Assim, a despeito do emprego de um conceito extremamente restritivo de estrutura piramidal, com a exigência de que ela seja intermediada por companhia de capital aberto, e não obstante o fato de reconhecerem como "acionistas últimos" não apenas pessoas naturais e cenários de capital pulverizado, mas também sociedades anônimas de capital fechado, sociedades limitadas, sociedades estrangeiras, fundos de investimento e blocos de controle regulados por meio de acordo de acionistas ${ }^{653}$ - fatores que obviamente subestimam fortemente o número total de grupos de fato e o respectivo grau de piramidação na amostra analisada -, Aldrighi e Mazzer Neto identificaram a estrutura indireta de domínio como sendo a prevalente.

A publicação anual "Valor Grandes Grupos", não obstante a sua natureza jornalística e não acadêmica, é também extremamente interessante por trazer informações ricas e detalhadas, incluindo organogramas das estruturas societárias dos 200 maiores grupos empresariais brasileiros. Na edição de $2012^{654}$, cujos dados têm como referência informações contábeis relativas à data de 31 de dezembro de 2011, todas as duas centenas de grandes empresas citadas adotam a forma plurissocietária. Há casos notáveis, como o da

652 D. ALDRIGHI, R. MAZZER NETO, Evidencias sobre as Estruturas de Propriedade de Capital e de Voto das Empresas de Capital Aberto no Brasil, p. 141.

653 D. ALDRIGHI, R. MAZZER NETO, Evidências sobre as Estruturas de Propriedade de Capital e de Voto das Empresas de Capital Aberto no Brasil, p. 131.

654 "Valor Grandes Grupos", Dezembro de 2012, Ano 11, n 11, p. 322. Pode-se afirmar que o próprio nome da publicação já é sugestivo quanto à prevalência da estrutura plurissocietária, posto que não foram utilizadas as fórmulas "grandes empresas" ou "grandes sociedades". 
Marfrig Alimentos S.A., que controla, direta e indiretamente, 84 sociedades distintas ${ }^{655}$ e que, ainda assim, é eclipsada pela Odebrecht S.A., cujo grupo compreende mais de 350 controladas diretas e indiretas ${ }^{656}$. Atestando a onipresença do grupo de fato entre as macroempresas brasileiras, pode-se observar que mesmo no caso da Weg S.A. - signatária de convenção de grupo, conforme mencionado anteriormente -, verifica-se que a maioria de suas controladas não integra a estrutura convencional formada pelo Grupo WEG ${ }^{657}$. Ou seja, também neste caso estamos diante de grupo de fato, muito mais amplo, aliás, do que o grupo de direito que nele está contido.

Pode-se argumentar, e em parte com razão, que esses dados são pouco representativos, posto que grandes empresas e companhias abertas possuem forte tendência à adoção de estruturas societárias mais complexas do que a média nacional, uma vez que podem mais facilmente arcar com os custos transacionais decorrentes dessa estratégia. Por desconsiderarem as pequenas e médias empresas, essas informações ofereceriam, portanto, um retrato incompleto da realidade ${ }^{658}$. De fato, por exemplo, em recente pesquisa, a Professora Mariana Pargendler verificou que entre as 53 sociedades limitadas com registro na Junta Comercial do Estado de São Paulo cujo capital social excedia a cifra de R 1 bilhão, 94,3\% delas tinha pessoas jurídicas como quotistas ${ }^{659}$. Em contraste, no âmbito da mesma pesquisa, mas lidando com amostra diversa, composta por 200 sociedades limitadas, também com assento na Junta Comercial do Estado de São Paulo, mas selecionadas aleatoriamente, Mariana Pargendler apurou que apenas 16\% delas possuíam

655 Conforme campo 8.1 ("Descrição - Grupo Econômico") do Formulário de Referência apresentado à Comissão de Valores Mobiliários, por meio do sistema EmpresasNet, em 15 de outubro de 2013, protocolo de entrega $\mathrm{n}^{\circ}$ 020788FRE201320130700031864-78.

656 "Valor Grandes Grupos", Dezembro de 2012, Ano 11, n 11, p. 160-169.

657 Nos termos da $7^{\text {a }}$ alteração da convenção do Grupo, firmada em 25 de novembro de 2010 (referida no subcapítulo anterior), apenas sete sociedades integram tal grupo de direito. Por outro lado, a Weg S.A. (sociedade de comando do Grupo WEG) controla um total de 48 sociedades, conforme campo 8.1 ("Descrição - Grupo Econômico") do Formulário de Referência apresentado pela companhia à Comissão de Valores Mobiliários, por meio do sistema EmpresasNet, em 10 de outubro de 2013, protocolo de entrega $\mathrm{n}^{\circ}$ 005410FRE201320130800031788-70.

658 Efetivamente, oportuno lembrar que, entre 1995 e 2005, foram constituídas no Brasil mais firmas individuais do que sociedades sujeitas a registro nas Juntas Comerciais (somando todos os tipos societários). Conforme dados do Departamento Nacional de Registro do Comércio - DNRC, entre 1985 e 2005, foram constituídas (i) 4.300.257 sociedades limitadas (ou sociedades por quotas de responsabilidade limitada), (ii) 21.731 sociedades cooperativas, (iii) apenas 20.080 sociedade anônimas e (iv) 4.534 sociedades classificadas sob a rubrica de "outros tipos", perfazendo o total de 4.346.602 sociedades. No mesmo período, foram registradas 4.569.288 novas firmas individuais. Dados disponíveis em: <http://www.dnrc.gov.br/Estatisticas/caep0101.htm>. Acesso em: 20set2013.

659 M. PARGENDLER, O Direito Societário em Ação: Análise Empírica e Proposições de Reforma, p. 239. 
sócias pessoas jurídicas ${ }^{660}$ - cifra que, de todo modo, não é absolutamente irrelevante ou desprezível.

Não se pode, entretanto, deixar de levar em conta o fato de que somente os 200 grandes grupos abarcados pela referida publicação anual da editora Valor Econômico S.A. - frise-se, todos eles organizados na forma de grupos de fato e que se desdobram em milhares de sociedades individuais - auferiram no exercício de 2011 uma receita bruta total de $\mathrm{R} \$ 2,707$ trilhões $^{661}$, correspondente, portanto, a cerca de $65,33 \%$ do produto interno bruto brasileiro (equivalente a R\$ 4,143 trilhões $^{662}$ ) apurado no mesmo período. Nesses termos, não parece possível colocar em dúvida a ampla difusão e a extrema relevância dos grupos de fato para a realidade econômica brasileira.

\subsubsection{Evidências do Abuso de Controle nos Grupos de Fato}

Se a obtenção de dados oficiais sobre o uso e a difusão dos grupos de fato já não é tarefa simples, cioso salientar que a coleta de informações sobre o abuso de tal estrutura será missão ainda mais ingrata. Neste caso, existe amplo e evidente incentivo para que os atos tendentes à ilegítima captura, pela sociedade controladora, de ganhos atribuíveis a controladas e coligadas sejam associados a estratégias de ocultação dos vestígios de tais práticas $^{663}$. A discrição e a ausência de transparência são fatores-chave para o sucesso da fraude e do abuso. A escassez de informações é ainda mais aguda quando se tenta passar do plano dos relatos sobre episódios específicos de fraude para a análise de dados estatísticos, quantificáveis e comparáveis.

660 O estudo não especifica, contudo, se eram sociedades ou não. M. PARGENDLER, O Direito Societário em Ação: Análise Empírica e Proposições de Reforma, p. 238.

661 "Valor Grandes Grupos", Dezembro de 2012, Ano 11, n 11, p. 13.

662 Fonte: Instituto Brasileiro de Geografia e Estatística - IBGE. Dados disponíveis em: $<\mathrm{http} / /$ saladeimprensa.ibge.gov.br/noticias? view $=$ noticia\&id=1\&busca=1\&idnoticia=2093>. $\quad$ Acesso em: 10abr2012.

663 "A ausência de provas não é acidente. Pela sua própria natureza, os benefícios privados do controle são dificilmente observáveis e ainda mais dificilmente quantificáveis de uma maneira confiável. $O$ controlador pode se apropriar de valor apenas quando tal valor não é verificável (ou seja, passivel de prova em juizo). Se o fosse, seria relativamente fácil para os acionistas não controladores impedir o controlador de realizar tal apropriação. Os beneficios privados do controle são, portanto, inerentemente dificeis de se medir". Tradução livre de: "The lack of evidence is no accident. By their very nature, private benefits of control are difficult to observe and even more difficult to quantify in a reliable way. A controlling party can appropriate value for himself only when this value is not verifiable (i.e., provable in court). If it were, it would be relatively easy for non-controlling shareholders to stop him from appropriating it. Thus, private benefits of control are intrinsically difficult to measure." in A. DYCK, L. ZINGALES, Private Benefits of Control - An International Comparison, p. 537-538. Questão mencionada em trabalho anterior do candidato: D. VIO, Prova Dificil e Inadimplemento da Obrigação de Contratar em Condições Equitativas nos Termos da Lei das S.A., p. 235-236. 
Em reação a essas dificuldades, o melhor mecanismo desenvolvido até hoje pelos pesquisadores da área econômica para tentar dimensionar o nível de abuso e de benefícios privados capturados por acionistas controladores em cada realidade econômica tem sido a análise da precificação da própria posição de controle em comparação com o valor médio das demais ações emitidas pela mesma sociedade. Tais investigações partem da premissa de que, em princípio, os frutos econômicos decorrentes da qualidade de acionista deveriam ser proporcionais à participação detida no capital da referida companhia, ajustada meramente em função de direitos especiais expressamente fixados no estatuto, tais como dividendos prioritários. Assim, a existência de significativas diferenças de preço entre o valor de ações emitidas pela mesma companhia, conforme integrem ou não um bloco de controle, é tomada como forte indício da possibilidade de utilização do poder de controle para a obtenção de benefícios privados - ganhos não compartilhados com os demais acionistas -, pois um agente racional, motivado pela maximização do próprio retorno econômico não pagaria relevante sobrepreço por determinado ativo sem ter sólida expectativa de retorno para o investimento realizado ${ }^{664}$.

A aplicação de tal concepção à realidade das companhias abertas brasileiras - as únicas nas quais existe ampla disponibilidade de informação sobre o valor médio das ações detidas pelos minoritários e os prêmios de controle pagos em reestruturações societárias traz alarmantes evidências de elevadíssimos benefícios privados de controle. Em estudo envolvendo 18 países diferentes, Tatiana Nenova utilizou dados referentes a operações de compra e venda de participações societárias realizadas em 1997, todas relativas a companhias que possuíam ao menos uma classe de ações sem direito a voto. A pesquisadora buscou, desse modo, identificar o valor pecuniário do poder de influência nas decisões das companhias. O Brasil apresentou um dos prêmios de controle mais elevados da amostra analisada, com a atribuição ao bloco de controle de um sobrepreço correspondente a $23 \%$ do valor médio de capitalização em bolsa das companhias em

664 "Em resumo, argumentamos que, uma vez que o preço de transferência reflete o valor dos beneficios societários que correm em favor de todos os acionistas, na proporção das frações de capital de que são titulares, qualquer diferença entre o preço do bloco de ações e a cotação de transferência reflete beneficios que favorecem apenas o detentor do bloco de controle - os beneficios privados do controle". Tradução livre de: "In short, we argue that because the exchange price reflects the value of corporate benefits that accrue to all shareholders in proportion to their fractional ownership, any difference between the block price and the exchange price reflects benefits that accrue to the blockholder alonethe private benefits from control." in M. BARCLAY, C. HOLDERNESS, Private Benefits from Control of Public Corporations, Journal of Finance Economics, p. 372. E. GORGA, Direito Societário Atual, p. 59. 
questão $^{665}$. Para que se tenha uma base de comparação, os índices mais altos foram verificados na Coreia do Sul (48\%) e no México (36\%), mas a média para a Dinamarca, Suécia e Finlândia foi de apenas um por cento, de 4\% para os Estados Unidos e 7\% para o Canadá66.

Alexander Dyck e Luigi Zingales, retomando método utilizado por Barclay e Holderness, compararam o valor das ações em negociações privadas de transferência de controle com as cotações dos mesmos títulos em bolsa imediatamente após o anúncio ao mercado das respectivas operações. A pesquisa compreendeu 39 países e operações realizadas entre os anos de 1990 e 2000. O estudo identificou prêmios de controle no Brasil correspondentes à assombrosa cifra média de $65 \%$ do valor da companhia, a mais alta entre todos os países investigados. O valor pareceu tão elevado que, inclusive, criou perplexidade entre os próprios pesquisadores, levando Dyck e Zingales à coleta de dados adicionais que substancialmente corroboram a conclusão original ${ }^{667}$. A média entre todos os países analisados foi de apenas 14\%, apurando-se um índice negativo - ou deságio de controle - de 4\% para o Japão ${ }^{668}$.

Parece, portanto, haver sólida evidência de disseminada utilização da posição de controle no Brasil para auferir ganhos - no mais das vezes ilegítimos - não compartilhados com os demais acionistas.

665 "No Brasil, por exemplo, o titular de 50\% dos votos pode deter tão pouco quanto o direito a um sexto dos resultados positivos distribuiveis [cash flow rights], mas o beneficio esperado decorrente do controle é, em média, ao menos o dobro de tal valor (33,3\% do valor da empresa).". Tradução livre de: "In Brazil, for example, a 50\% vote-owner can hold as little as one-sixth of the total cash flow rights, but the expected benefit from control is at least double that amount (33.3\% of the value of the firm) on average." in T. NENOVA, The Value of Corporate Votes and Control Benefits: A Cross-country Analysis, p. 327. A referência da autora à titularidade de apenas um sexto do capital social pressupõe a emissão de ações preferenciais até o limite de dois terços do capital total, conforme então facultado pela Lei 6.404/1976, anteriormente às reformas introduzidas pela Lei Federal 10.303/2001.

666 T. NENOVA, The Value of Corporate Votes and Control Benefits: A Cross-country Analysis, p. 340.

667 “No Brasil, nós estimamos que os beneficios privados correspondam a 65\% do valor das ações. $O$ valor dos beneficios privados poderia realmente ser tão alto, ou essa conclusão é o resultado de um problema na maneira pela qual nós inferimos os benefícios privados? [...] Em resumo, estimativas independentes levam a uma conclusão muito similar: os beneficios privados do controle no Brasil são extremamente elevados". Tradução livre de: "In Brazil, we estimate private benefits to be 65 percent of the value of equity. Could private benefits really be this large, or is this finding the result of some problems in the way we infer private benefits? [...] In sum, independent estimates lead to a very similar conclusion: Private benefits of control in Brazil are extremely high." in A. DYCK, L. ZINGALES, Private Benefits of Control: An International Comparison, p. 570-571.

668 A. DYCK, L. ZINGALES, Private Benefits of Control: An International Comparison, p. 538. 


\subsubsection{Ineficácia da Tutela Judicial}

Convém, neste ponto, recapitular algumas das observações preliminares deste trabalho. Conforme se argumentou anteriormente, pode-se afirmar com segurança que (i) os grupos de fato são numerosos e difusos na realidade brasileira, desempenhando papel econômico relevante (item 9.2.1, acima); (ii) o país é marcado por elevados índices de captura de benefícios privados do controle (item 9.2.2), reflexo de disseminadas práticas de abuso de poder e desvio de finalidade e, enfim, (iii) nosso direito societário material veda categoricamente a subordinação do interesse de sociedades controladas e coligadas e impõe a comutatividade ou o pagamento compensatório adequado como requisito essencial para a legitimidade das operações realizadas no âmbito do grupo de fato (Capítulo 7).

À luz dessas premissas, seria de se esperar que nossos tribunais enfrentassem uma enxurrada de ações ajuizadas por acionistas minoritários tendo por objeto a apuração de responsabilidade de administradores e controladores, em razão de operações ilegítimas levadas a cabo nos grupos de fato; enxurrada esta que se traduziria em uma correspondente avalanche de condenações. Afinal, se são generalizados o uso e o abuso dos grupos de fato, deveriam ser igualmente numerosos os indícios de funcionamento dos mecanismos judiciais de contraste às condutas irregulares. A despeito das dificuldades inerentes à demonstração de um fato negativo, não é isso, porém, o que parece ocorrer em termos práticos. Muito pelo contrário. A impressão que emerge da análise dos dados disponíveis é a de quase total inefetividade do aparato judicial, com poucas ações formuladas e número ainda menor de decisões imputando responsabilidade aos acionistas controladores.

É opinião difusa na doutrina o fato de que as ações sociais reguladas pelos artigos 159 e 246 da Lei 6.404/1976 são, em termos práticos, pouquíssimo utilizadas e substancialmente ineficazes $^{669}$. Além disso, a despeito das décadas de vigência da lei acionária e do enorme número de sociedades que estão, direta ou indiretamente, sujeitas às suas disposições, é notavelmente acanhada a quantidade total de ocasiões em que os

669 "Toda a energia e toda a eficiência que o sistema do acionariato acalentava imprimir à ação social, originária ou derivada, se frustram nos meandros de uma prática forense a que falta, no mínimo, equilibrio. A quase absoluta ausência de casos registrados nos repertórios jurisprudenciais pátrios de ações derivadas é, aliás, a prova mais gritante desse lamentável desencontro." in L. LEÃES, A Prévia Deliberação Assemblear Como Condição de Legitimatio ad Causam na Ação Social, p. 706. "Em termos empíricos aliás, a realidade do foro demonstra que o principal problema das ações sociais não está no seu exercício abusivo, mas simplesmente, na completa falta de exercício" in M. VON ADAMEK, Responsabilidade Civil dos Administradores de S/A e as Ações Correlatas, p. 376. 
tribunais superiores se dedicaram especificamente à disciplina societária do conflito de interesse nos grupos de fato ${ }^{670}$.

As mesmas pesquisas de cunho econômico, mencionadas anteriormente, que apontam o elevado grau de captura de benefícios privados de controle na realidade brasileira, assinalam como principais causas para tal lamentável estado de coisas a ausência de adequada tutela dos investidores e a ineficiência dos mecanismos de aplicação e cumprimento coativo de normas e contratos ${ }^{671}$.

Um outro relevante indício da incapacidade dos nossos tribunais de oferecer respostas adequadas aos conflitos societários, incluindo os de natureza grupal, pode ser colhido no papel central e fundamental que se conferiu à arbitragem na modernização do mercado de capitais brasileiro. Com efeito, ao contrário de outras realidades em que o procedimento arbitral possui um papel marginal no mercado de capitais ${ }^{672}$ ou é até mesmo expressamente repudiado pelo ordenamento nesse âmbito específico ${ }^{673}$, a arbitragem

670 "Constata-se que a preocupação da dogmática jurídica, em especial do direito comparado, para identificar os elementos que caracterizam os grupos societários, seja apenas o controle seja os critérios para identificar a unidade de direção, não está presente na jurisprudência do STJ, o que nos leva a afirmar a não judicialização do tema em nosso país." in V. PRADO, M. TRONCOSO, Grupos de Empresas na Jurisprudência do STJ, p. 87-120.

671 "A aplicação da lei, a proteção aos investidores, a regulamentação das operações de aquisição de controle e disposições estatutárias explicam, conjuntamente, 68\% das diferenças sistemáticas no valor dos votos dos blocos de controle". Tradução livre de: "Law enforcement, investor protection, takeover regulations, and corporate charter provisions together explain $68 \%$ of the systematic differences in the value of control-block votes." in T. NENOVA, The Value of Corporate Votes and Control Benefits: A Cross-country Analysis, p. 348-349. Dyck e Zingales enfatizam a importância dos elementos (i) ambiente legal, (ii) padrões de divulgação de informação e (iii) execução dos contratos em juízo, mencionando especificamente o fato de que: "A capacidade que o acionista controlador tem de se apropriar do valor criado é limitada pela possibilidade de ser processado. Portanto, uma maior possibilidade de iniciar processos deveria se traduzir em menores beneficios privados do controle". Tradução livre de: "The ability of a controlling shareholder to appropriate some of the value generated is limited by the possibility of being sued. Thus, a greater ability to sue should translate into smaller private benefits of control." in A. DYCK, L. ZINGALES, Private Benefits of Control: An International Comparison, p. 576. Na tabela de "variáveis institucionais" (Institutional Variables), construída por Dyck e Zingales para confrontar os resultados dos prêmios do controle com a qualidade da tutela dos direitos dos investidores em cada país, coube ao Brasil a nota 6,32, acima de México e Argentina $(5,35)$, mas significativamente abaixo da Alemanha $(9,23)$ e de Canadá e Estados Unidos (nota máxima, 10) (A. DYCK, L. ZINGALES, Private Benefits of Control: An International Comparison, p. 580).

672 O Professor Eduardo Munhoz cita, por exemplo, a importância da qualidade e reputação dos tribunais de Delaware como um dos fundamentos do papel destacado para tal Estado no âmbito do mercado de capitais americano: E. MUNHOZ, A Importância do Sistema de Solução de Conflitos para o Direito Societário: Limites do Instituto da Arbitragem, p. 83.

673 É o caso da Itália, por exemplo. O $\S 1^{\circ}$, do artigo 34, Decreto Legislativo de 17 de janeiro de 2003, $n^{\circ} 5$, excepciona expressamente as companhias que recorrem ao mercado de capitais, conforme a definição do artigo 2.325 bis do Código Civil italiano, do rol de sociedades que podem validamente incluir cláusulas compromissórias em seus atos constitutivos. 
consiste em um dos pilares fundamentais para o bom funcionamento dos segmentos especiais de listagem da BM\&FBovespa ${ }^{674}$. Em muitos casos, a arbitragem representa, efetivamente, a única maneira possível de se discutir questões societárias de grande complexidade perante julgadores devidamente especializados e de forma minimamente célere $^{675}$. O instituto, porém, possui algumas limitações, muitas das quais restam evidenciadas em âmbito societário ${ }^{676}$ - especialmente no que diz respeito aos grupos de sociedades $^{677}$-, e não está, de toda a forma, disponível para a maioria das sociedades empresárias, que não se valeram da faculdade constante do artigo $109, \S 3^{\circ}$, da Lei $6.404 / 1976$.

A própria duração média dos processos judiciais no Brasil é, ao mesmo tempo, causa e expressão da impossibilidade, para a vasta maioria dos casos, de se contar com a autoridade judiciária para a resolução de disputas societárias. Os diversos anos necessários à obtenção de uma decisão transitada em julgado ${ }^{678}$ são, no mais das vezes, incompatíveis com a realidade empresarial. A morosidade agrava sobremaneira a situação do minoritário que se aventura a perseguir a responsabilização do acionista controlador em juízo, pois entre outras consequências negativas - aumenta as despesas com o procedimento e facilita o ocultamento de bens e a dissipação dos meios de prova.

674 Conforme Seção XIII do Regulamento do Novo Mercado em vigor desde maio de 2011.

675 Dentre as boas práticas que uma companhia de capital fechado deve adotar para se habilitar a receber investimentos de um Fundo de Investimento em Participações - FIP, está a adesão a câmara de arbitragem para a resolução de conflitos societários, nos termos do artigo $2^{\circ}, \S 4^{\circ}$, IV, da Instrução CVM $n^{\circ} 391 / 2003$. A referida exigência não deixa de representar um reconhecimento, pela própria Comissão de Valores Mobiliários (ou seja, pelo próprio Estado), da incapacidade de se oferecer um mínimo de segurança jurídica aos investidores pela via judicial.

676 E. MUNHOZ, A Importância do Sistema de Solução de Conflitos para o Direito Societário: Limites do Instituto da Arbitragem, p. 88-97.

677 A vinculação ao procedimento arbitral de sociedades do mesmo grupo não signatárias da cláusula compromissória é problema antigo e complexo. A. WALD, A Teoria dos Grupos de Sociedades e a Competência do Juízo Arbitral, p. 22.

678 "A solução de uma ação pelo procedimento ordinário no Judiciário paulista (até o segundo grau de jurisdição - Tribunal de Justiça) não costuma levar menos que cinco anos." in E. MUNHOZ, A Importância do Sistema de Solução de Conflitos para o Direito Societário: Limites do Instituto da Arbitragem, p. 83-85. A despeito de toda a discussão em torno do tema da duração razoável do processo - inclusive com a Emenda Constitucional ${ }^{\circ} 45 / 2004$, que acrescentou o inciso LXXVIII ao artigo $5^{\circ}$ da Carta Magna -, e não obstante os esforços do Conselho Nacional de Justiça, há pouca disponibilidade de informações estatísticas e oficiais sobre a duração dos processos judiciais no Brasil. Ainda que se trate de processos sobre matéria específica, é relevante e ilustrativa a informação relatada pelo Instituto de Pesquisa Econômica Aplicada - IPEA sobre a duração média de oito anos, dois meses e nove dias para as execuções fiscais federais (IPEA, Custo Unitário do Processo de Execução na Justiça Federal, p. 6). Relatório do Banco Mundial, de 2012, estimava que eram necessários 731 dias para se obter o cumprimento judicial de um contrato comercial simples no Brasil (WORLD BANK, Doing Business 2012 - Economy Profile: Brazil, p. 94). 
Extrapola em muito as possibilidades e ambições deste trabalho catalogar todos os sintomas e as causas da inefetividade do Judiciário enquanto mecanismo de proteção de investidores e acionistas minoritários. Para os fins deste ponto da análise, basta constatar que a soma dos indícios e elementos mencionados anteriormente corroboram a conclusão de que a disciplina do conflito de interesse no direito societário, em geral, e nos grupos de fato, em particular, é pouquíssimo efetiva no Brasil. Esse fato, por sua vez, tem desdobramentos determinantes sobre a utilidade prática do regime do grupo de direito, conforme se discute a seguir.

\subsection{A Conexão das Crises}

A principal razão para a constituição do grupo de direito, já se teve a ocasião de argumentar anteriormente, é a busca da exclusão de responsabilidade da sociedade controladora e dos administradores pela subordinação de interesses, notadamente na forma da realização de operações intragrupo que não tenham caráter comutativo. O grupo de direito é um instrumento que autoriza a redução das sociedades filiadas a mero instrumento da atividade empresarial capitaneada pela sociedade de comando, permitindo que suas políticas e instruções sejam mais amplas, profundas e gravosas do que seria possível nos estreitos limites fixados pelos artigos 245 e 246 da Lei 6.404/1976.

Contudo, se o mesmo resultado que a lei pretendeu atribuir exclusivamente aos grupos de direito - ou seja, a ausência de responsabilização - é, em termos práticos e pragmáticos, corriqueiramente alcançado também nos grupo de fato, ainda que apenas graças à inefetividade do sistema de contraste a abusos do poder de controle, a celebração de convenção na forma do artigo 265 da Lei 6.404/1976 resta quase inteiramente desprovida de sentido ${ }^{679}$. O grupo de direito representa, assim, uma forma de proteção relativamente onerosa para um risco que, na prática, é baixo ou praticamente nulo, seja para o acionista controlador, seja para os administradores da sociedade grupada ${ }^{680}$. Em

679 Se a realidade brasileira torna, de fato, irrelevante a função exoneratória da convenção de grupo, restariam ainda seus efeitos de representação coletiva e unificada das convenentes - que pode, ainda que imperfeita e mais burocraticamente, ser reproduzido pela outorga de mandatos - e de vinculação dos administradores das sociedades filiadas às instruções da sociedade de comando - efeito este que é geralmente obtido pelo simples poder de controle, que permite à sociedade dominante prontamente substituir administradores que não se ajustem aos seus desígnios. Nesse sentido, pode-se argumentar que os demais efeitos da convenção são secundários e replicáveis por meio de outros instrumentos.

680 Ao indagar a respeito das razões pelas quais os grandes grupos empresariais não adotam a forma convencional no Brasil, Danilo de Araujo levanta essa hipótese: "A resposta pode estar ou na identificação de uma eventual inconveniência ou inadequação da própria estrutura do grupo de direito 
nossa realidade, a perspectiva de efetiva responsabilização pela violação ao disposto nos artigos 245 e 246 simplesmente não é forte o suficiente para tornar necessária ou desejável a estrutura do grupo de direito.

Parece residir exatamente nesse ponto a principal razão para o ocaso dos grupos de direito na praxe brasileira. A crise de desuso de tal estrutura é, sobretudo, uma expressão da crise de inefetividade dos mecanismos de contraste ao conflito de interesse nos grupos de fato.

Não se deve vislumbrar nessa linha de argumentação uma tentativa de defesa do modelo dual ou do próprio conceito dos grupos de direito - técnica legislativa implementada apenas por alguns poucos países que, como o Brasil, seguiram o exemplo alemão e nos quais, ao que consta, não se registra sequer um único relato de ampla difusão e sucesso dos grupos de direito. O ponto que se quer salientar é que é impossível não identificar na falência do grupo de direito também uma derrocada do grupo de fato. Falar somente em crise do grupo de direito no Brasil significa analisar, de forma artificial e ilógica, apenas uma faceta de um problema mais amplo e mais profundo. Na verdade, mais do que uma crise do direito grupal, a análise das relações intersocietárias traz à tona uma grave crise de efetividade dos mecanismos de tutela dos bens sociais que afeta igualmente a própria sociedade isolada.

É possível viver sem grupos de direito. Porém, o preço - em termos de custos de oportunidade e de alternativas ao financiamento da atividade empresarial - de continuarmos a não dispor de adequados instrumentos de proteção aos investidores parece ser alto demais para ser tolerado.

brasileiro, tornando-o desinteressante ou frágil para alcançar esse objetivo, ou - e aqui se divulga apenas uma hipótese que certamente exigiria maior investigação - na fragilidade da sanção de responsabilidade prevista nos arts. 245 e 246, que não teria suficiente força dissuasória para impedir que os administradores das sociedades agrupadas e a sociedade controladora agissem em conformidade com os preceitos ali previstos." in D. ARAUJO, A Doutrina Rozenblum do Direito Francês; o Reconhecimento do Caráter Exoneratório dos Grupos de Sociedades em Matéria de Crimes de Abus de Biens Sociaux e a Consequente Influência do Direito Penal na Estruturação e no Funcionamento dos Grupos de Sociedade, p. 113. 


\section{Anotações sobre Alternativas para a Disciplina dos Grupos}

Após a análise das principais características da disciplina brasileira dos grupos de sociedades e a tentativa de identificação daquelas que parecem ser as suas deficiências mais relevantes, impõe-se breve discussão sobre possíveis ajustes no sistema de regulação do fenômeno intersocietário. O objetivo - até mesmo porque o diagnóstico, como visto, aponta para questões transversais a todo o direito societário - é apenas discutir rumos gerais da disciplina dos grupos e sua relação com alguns outros institutos, em caráter exemplificativo e sem qualquer pretensão de enunciar um receituário exaustivo de soluções completas e acabadas, que mereceriam, cada uma delas, monografia própria.

Apenas para fins de argumentação, pode-se iniciar este ponto da discussão colocando em questão a própria necessidade de regras sobre o conflito de interesse no direito societário, em geral, e no direito dos grupos, em particular. Afinal, uma vez que, conforme se anotou no Capítulo 4, os principais credores vulneráveis da sociedade trabalhadores, consumidores e vítimas de dano ambiental - encontram proteção em leis especiais e, além disso, o direito societário versa predominantemente sobre direitos patrimoniais disponíveis, por que não deixar às partes - empreendedores, investidores e credores - a livre estipulação dos mecanismos contratuais de tutela que julguem oportunos?

Existem, contudo, argumentos relevantes que permitem refutar uma posição extremada nesse sentido ${ }^{681}$, muitos dos quais também já foram articulados no Capítulo 4. Como ressalta Wymeersch, os grupos podem se formar pelas mais diversas razões herança, incorporação, compra de participação, dação em pagamento, penhora de ações, etc. - e, na maioria dos casos, sem que acionistas minoritários e credores disponham de qualquer instrumento para se opor a esse fato ${ }^{682}$. Quando muito, aos acionistas externos é

681 “A principal argumentação contrária à necessidade do aparato regulatório é a de que as forças do mercado por si só providenciariam mecanismos suficientes para a revelação de informações ao público investidor num nível social ótimo e, além disso, os custos do sistema regulatório de disclosure minariam quaisquer benefícios que dele pudesse advir. Os elevados custos de transação provavelmente impedem uma negociação entre acionistas majoritários e minoritários, de forma que o problema da assimetria informacional não será internalizado de maneira suficiente pelo próprio mercado de capitais, que não é eficiente [...]" in E. GORGA, Direito Societário Atual, p. 86-87.

682 "Esperar-se-ia destes acionistas [minoritários de sociedades de capital fechado] que pudessem cuidar de 
concedido o direito de retirada - seja na forma de recesso pela formação de grupo de direito, seja em função de oferta pública pela alienação de controle.

Ademais, já se teve a oportunidade de ressaltar o caráter incompleto (em termos econômicos) do contrato de sociedade, no sentido de que é inviável, em função de altos custos de transação, prever no momento de sua celebração todas as contingências que podem incidir sobre a relação. Mesmo agentes sofisticados e em boa-fé não seriam capazes de estipular, desde logo e em todos os seus detalhes, todos os aspectos da condução das atividades sociais. É justamente por essa razão que a sociedade é, necessariamente, uma avença aberta e inclui mecanismos que não costumam estar presentes em contratos bilaterais de curto prazo, tal como o próprio regime de deliberação e as regras para a alteração do capital social. Ou seja, existem limites estruturais para a eficiência de uma regulação puramente contratual do fenômeno dos grupos, o que justifica plenamente o fato de que o legislador se debruce sobre a questão ${ }^{683}$.

Uma vez que se aceite a necessidade de regramento estatal neste campo, o passo sucessivo é tentar compreender a magnitude das eventuais mudanças no direito societário exigidas pelos atuais problemas dos grupos de sociedades. Para tanto, parte-se de uma análise crítica da tese de que o direito posto estaria inteiramente desconectado da realidade dos grupos. Em seguida, são discutidas propostas doutrinárias para os grupos julgadas inadequadas ou insuficientes para, enfim, se construírem possíveis sugestões de melhoria do sistema.

si mesmos ao ingressar na sociedade: teoricamente, a lei não deveria oferecer nenhuma proteção especial. Na prática, esse é um consolo precário: posições minoritárias não surgem apenas no momento de formação da companhia, mas são frequentemente o resultado de fusões que são aprovadas sem o consentimento do minoritário, ou ainda ações podem ser herdadas. Ou o negócio pode ter mudado, fazendo com que a antiga família seja superada em astúcia por um grupo mais poderoso". Tradução livre de: "These shareholders [minoritários de sociedades de capital fechado] are supposed to have been able to fend for themselves upon entering the company: theoretically the law should not provide for any special protection. In practice this is often a meagre consolation: minority stakes arise not only at formation of the company but often are the result of mergers that were approved without the minority's consent, or shares may have been inherited. Or the business may have changed causing the former family to be outwitted by a more powerful group." in E. WYMEERSCH, Do We Need a Law on Groups of Companies?, p. 579.

683 Como bem ressalta Natalino Irti, a discussão não diz respeito a ter ou não ter Estado, ter ou não ter uma intervenção jurídica (N. IRTI, L'Ordine Giuridico del Mercato, p. 11-14). O mercado é em si mesmo um espaço artificial, político, pautado pela juridicidade, constituído (e não meramente conformado) por regras; não existe fora do Direito, ou sem ele. O ponto da discussão é meramente que tipos de regras mais ou menos detalhadas, mais ou menos rigorosas, cogentes ou dispositivas - seriam os mais adequados. 


\subsection{Crítica à Tese do Divórcio da Realidade}

$\mathrm{Na}$ doutrina sobre os grupos de sociedades, um argumento recorrente é o de que o direito societário contemporâneo seria ainda inteiramente baseado na ideia da sociedade isolada, que persegue de forma autônoma um interesse próprio ${ }^{684}$. Essa concepção, supostamente ainda arraigada nos mais diversos ordenamentos, quando aplicada a uma realidade em que prevalece a empresa plurissocietária, daria - de acordo com os partidários desta tese - ensejo a um grave desajuste, a uma crise estrutural e sistêmica ${ }^{685}$, decorrente de um arcabouço normativo que, argumentam, teria permanecido quase imutável enquanto as suas premissas econômicas eram engolidas pela marcha impiedosa da História.

A impressão que tais comentários transmitem - com a devida vênia aos seus ilustres formuladores que tanto contribuíram para o estudo dos grupos - é a de que o legislador societário seria completamente desatento ou imóvel. Desatento porque simplesmente não teria se dado conta de que o mundo mudou, de que o perfil das empresas

684 "[...] todo o edifício jurídico-societário arranca dum modelo pressuposto da sociedade comercial como uma entidade económica e juridicamente autónoma, que desenvolve a sua actividade económicoempresarial na execução de uma vontade social e de um interesse social próprios, definidos soberanamente pela colectividade social. Ora, a irrupção dos grupos societários estava condenada a vir abrir uma crise sem precedentes nos quadros jurídicos-societários tradicionais, dado que o postulado de referência em que estes assentam - o estatuto 'ideal' (Gesetztypus) da sociedade isolada e autónoma - está em total oposição com aquele que constitui afinal o traço distintivo daquela nova forma de organização empresarial - o estatuto 'real' (Lebentypus) de sociedade coligada e controlada. Tal discrepância entre norma e realidade arrisca-se assim a criar uma perigosa lacuna para o sector mais importante da vida económico-empresarial do século XXI [...]" (sem grifo no original) in J. ANTUNES, Estrutura e Responsabilidade da Empresa: O Moderno Paradoxo Regulatório, p. 33-34. J. ANTUNES, Liability of Corporate Groups - Autonomy and Control in Parent-Subsidiary Relationships in US, German and EU Law - An International and Comparative Perspective, p. 52 e ss. "Ao afetar gravemente as estruturas patrimonial e organizacional autônomas, nas quais se assenta a sociedade isolada personificada, com responsabilidade limitada, o fenomeno dos grupos abre uma crise sem precedentes no modelo societário. $O$ divórcio entre o direito e realidade chegou, nesse campo, a um nivel jamais imaginado [...]" (sem grifo no original) in E. MUNHOZ, Empresa Contemporânea e Direito Societário: Poder de Controle e Grupos de Sociedades, p. 70-71.

685 "Certamente não é por coincidência que um dos bordões mais frequentes da moderna doutrina relativa ao fenômeno dos grupos de sociedades tenha por base precisamente o divórcio entre 'norma e realidade', entre 'forma jurídica e realidade econômica', entre 'direito societário e realidade societária' [...] Mais do que a mera crise temporária relativa a alguns de seus aspectos específicos, eu argumento que os grupos de sociedades simplesmente explodiram toda a estrutura clássica de regulamentação das sociedades". Tradução livre de: "It is certainly not by chance that one of the most common sobriquets of modern corporate literature dealing with the phenomenon of corporate group lies precisely in the divorce between 'norm and reality', between 'legal form and economic reality', between 'corporation law and corporate reality' [...] More than a mere temporary crisis related to some of its specific aspects, I submit that corporate groups simply exploded the entire classical regulatory framework of the corporation." in J. ANTUNES, Liability of Corporate Groups - Autonomy and Control in ParentSubsidiary Relationships in US, German and EU Law - An International and Comparative Perspective, p. 64. 
e o modo de utilização das formas societárias se alteraram profundamente no último século e meio. Imóvel porque teria pecado pelo excesso de conservadorismo, faltando-lhe a coragem de abandonar os seus pilares conceituais mais tradicionais, a despeito de a realidade econômica clamar fortemente por isso.

Essa visão, porém, não parece corresponder a um retrato fiel do desenvolvimento do direito societário a partir da primeira metade do século XX. Desde o início, parece ter havido certa clareza quanto à magnitude dos potenciais efeitos da admissão da estrutura plurissocietária - comparável à abertura de uma caixa de pandora. De outro modo, não se explicaria a tenaz resistência à afirmação desse fenômeno ao longo do século XIX.

Tampouco soa justo afirmar que as relações intersocietárias e os seus desdobramentos tenham sido ignorados pelo ordenamento hodierno. Os aspectos particulares da empresa plurissocietária que geravam as distorções mais gritantes foram disciplinados em normas especiais. É o caso, por exemplo, das regras a respeito de participações recíprocas, avaliação de investimentos pelo método do patrimônio líquido (equivalência patrimonial) e consolidação contábil. Por outro lado, as facetas mais inespecíficas do fenômeno - e, portanto, mais insidiosas -, tal como o conflito de interesse, já estavam de algum modo sujeitas a princípios e institutos de amplitude geral, como a fraude, a simulação ${ }^{686}$, o abuso de direito e o dever de lealdade do acionista, mesmo antes da introdução de dispositivos como os artigos 115, 116, 117, 245 e 246 da Lei 6.404/76. Se o legislador não tivesse claramente reconhecido o fato de que a sociedade personificada não é - e, aliás, nunca foi - um ente autônomo, independente e autointeressado, não teria reconhecido e definido a figura do acionista controlador.

Isto para não mencionar os diversos microssistemas jurídicos - normas trabalhistas, bancárias, consumeristas e ambientais - que, em paralelo à lei acionária, adotaram regras próprias sobre a questão. Vivemos em uma abundância de regras grupais societárias e não societárias -, fato que torna inviável argumentar sobre um desconhecimento pelo legislador desse fenômeno. Conforme se argumentou no Capítulo 6, o grupo pode ser visto não apenas como estrutura normatizada, mas como forma tipificada de condução da atividade empresarial.

686 T. VALVERDE, Sociedades por Ações, Vol. II, p. 325. 
Passados mais de 30 anos da promulgação da Lei 6.404/1976, que bem ou mal buscou disciplinar específica e detalhadamente a questão dos grupos, é simplista ou reducionista a afirmação de que vivemos um total descompasso ou assincronia entre a emergência do fenômeno econômico dos grupos e o tempo de reação do legislador ${ }^{687}$.

O que se vê é uma determinada escolha política, resultado de específica ponderação de valores e necessidades, com a qual se pode obviamente concordar ou não e é escopo do presente trabalho criticar muitas de suas facetas. Não parece cabível, porém, acusar o ordenamento atual de ignorar o fenômeno dos grupos ${ }^{688}$. Em resumo, não há um vácuo normativo a ser preenchido necessariamente por meio da total reformulação do sistema. Existe um determinado e amplo "conteúdo" de normas, que possui graves deficiências $\operatorname{sim}$ - algumas das quais foram apontadas ao longo deste trabalho -, mas que não pode ser sumariamente rejeitado e substituído por algo inteiramente novo sem maiores cuidados, o que significaria desprezar os seus vários méritos, além de décadas de amadurecimento nos tribunais e na praxe empresarial.

Há, sem dúvida, uma crise de efetividade do aparato brasileiro de contraste ao conflito de interesse nas relações societárias, não uma crise sistêmica de um ordenamento que não teria tomado consciência da existência da empresa plurissocietária. Nesse sentido, pode-se concluir que o direito societário dos grupos deve efetivamente ser ajustado, reformulado, aprimorado, porém não é necessário criá-lo ex novo ou refundá-lo.

\subsection{Propostas e Mecanismos Julgados Inadequados}

Nos termos dos Capítulos 2 e 6, deste trabalho, parece possível afirmar que estão historicamente superadas as posições que propugnavam pela vedação da participação de sociedades em outras sociedades - e, portanto, do controle interno de uma sociedade sobre outra -, ou ainda que vislumbravam em tal fenômeno uma fraude ou simulação ${ }^{689}$.

687 “A verdade é que esse discurso, que atribui aos grupos a culpa pela crise do direito societário, tem a marca de uma retórica própria dos anos de 1960, já ultrapassado à época, no particular, diante do que acontecia na economia americana desde os fins do século XIX"; e "Quer se dizer: o direito societário, há um bom tempo, já vem se acostumando com a realidade grupal, acomodando, cada vez mais, por especialização (ou, eventualmente, por meio de outras estratégias), antigas tensões, sem se descuidar das novas, desafios próprios de um fenômeno cambiante e em constante evolução." in D. ARAUJO, W. WARDE JR., Os Grupos de Sociedades: Estado Atual da Técnica, respectivamente p. 13 e 14.

688 Os Capítulos XX e XXI da Lei 6.404/1976 são, por si só, testemunho da relevância atribuída à matéria pelos autores do respectivo anteprojeto, que também se ocuparam do tema em diversos outros escritos. Por exemplo: A. LAMY FILHO, J. PEDREIRA, A Lei das S.A., vol. I, p. 88-89.

689 "Tais regras proibitivas não são mais hoje em dia discutidas seriamente, porque precluem as 
Isso não significa que não existam, na atualidade, normas setoriais que têm como escopo o desincentivo à formação de estruturas de grupo ou mesmo a sua proibição. Já se mencionou, anteriormente, a Lei Complementar 123/2006, que contém notáveis restrições no campo das micro e pequenas empresas, mas um outro ótimo exemplo é a disciplina das sociedades de advogados. De fato, a exigência de que todos os sócios sejam advogados (artigos 15 e 16 da Lei Federal 8.906/1994) ${ }^{690}$ afasta, desde logo, qualquer possibilidade de estruturas piramidais entre sociedades dessa natureza. Ademais, a vedação de participação do mesmo advogado em mais de uma sociedade no território do mesmo Conselho Seccional da Ordem dos Advogados do Brasil (artigo 15º $\S 4^{\circ}$ ), também implica que o mesmo sujeito apenas poderá controlar um número limitado de sociedades - em princípio, uma em cada unidade da federação, até o número máximo de 27 , o que não deixaria de ser uma temeridade, à luz da regra de responsabilidade ilimitada constante do artigo 17 do mesmo diploma, a qual também representa uma restrição à formação dos grupos.

Ao contrário de tantas outras áreas de atividade econômica e profissional, a advocacia é capaz de conviver com tais vedações por não ser intensiva em capital. Na verdade - e trata-se de aspecto que tem de ser considerado ao se buscar aplicar propostas semelhantes em outros campos -, o objetivo precípuo de tais limitações é manter a pessoalidade nas relações entre o cliente e o advogado, evitando - ou almejando evitar que este último se organize de forma demasiadamente empresarial. Ou seja, tais normas antigrupo são também normas reconhecidamente contrárias à afirmação da empresarialidade nessas organizações.

Existem, contudo, propostas de caráter geral que também representariam, em termos práticos, graves entraves à formação e à operação dos grupos de sociedades, sem porém estarem amparadas e justificadas por princípios éticos bem delineados ou necessidades específicas, tal como ocorre nos exemplos acima, relativos a empresas de pequeno porte e sociedades de advogados. O objetivo dos dois próximos subcapítulos é analisar algumas de tais teses, partindo daquelas que tratam da estrutura patrimonial e da

reconhecidas vantagens econômicas do agrupamento de empresas, sem garantir benefícios do ponto de vista das estruturas do mercado". Tradução livre de: "Derart prohibitive Regeln werden indes heute ernsthaft nicht mehr diskutiert, weil sie die anerkannten wirtschaftlichen Vorteile eines Unternehmensverbundes versage, ohne die markstrukturellen Vorteile garantieren zu können" in $\mathrm{H}$. WIEDEMANN, Die Unternehmensgruppe im Privatrecht, p. 60-61. 690 A. GONÇALVES NETO, Sociedades de Advogados, p. 12. 
responsabilidade das integrantes do grupo, para em seguida abordar aquelas preponderantemente voltadas para a tomada de decisões na estrutura plurissocietária.

\subsubsection{Exclusão ou Relativização da Limitação da Responsabilidade}

Mesmo após a afirmação histórica e o reconhecimento legislativo das relações intersocietárias, parece haver remanescido algum preconceito e certa resistência em relação à limitação da responsabilidade da sociedade sócia. Conforme já assinalado anteriormente, Blumberg entende que a limitação da responsabilidade surgiu para proteger os investidores que não tomavam parte nas atividades do negócio e que a extensão de tal benefício à sociedade sócia significaria afastar indevidamente dos credores da empresa parte dos bens $\operatorname{desta}^{691}$.

Essa visão conservadora transparece em numerosas propostas formuladas tanto para o enquadramento conceitual e dogmático quanto para a regulamentação dos grupos de sociedades; propostas que têm como ponto convergente o agravamento das hipóteses de responsabilização da sociedade controladora pelos débitos da controlada - com diversas nuances, que variam da responsabilidade solidária à meramente subsidiária - em função do simples fato de ser uma sociedade ${ }^{692}$. Ou seja, sugere-se uma modulação dos efeitos da limitação da responsabilidade unicamente em razão de atributos subjetivos da acionista ${ }^{693}$.

691 P. BLUMBERG, The American Law of Corporate Groups, p. 306-307. Porém, como apontou Ascarelli, com a usual precisão, a compartimentação patrimonial não significa que os bens deixam de servir como garantia aos credores da controladora, mas simplesmente que são substituídos por "bens de segundo grau" - a própria participação detida na controladora, formando-se uma distinção entre diversas séries de credores (T. ASCARELLI, Saggi di Diritto Commerciale, p. 239-243).

692 Antes de defender uma aproximação do regime do grupo de fato à doutrina Rozenblum, o Professor Eduardo Munhoz sugeriu a atribuição de responsabilidade subsidiária automática à controladora totalitária e de presunção de responsabilidade da controladora majoritária, que poderia ser elidida apenas na hipótese de prova de ausência de subordinação ou de nexo causal. E. MUNHOZ, Empresa Contemporânea e Direito Societário: Poder de Controle e Grupos de Sociedades, p. 298-300.

693 O Professor Carlos Zanini, mencionando especificamente os grupos, sustenta que a (i) projeção de imagem de unidade no mercado e (ii) a unidade de comando imposta pela controladora justificariam um regime diverso de responsabilidade (C. ZANINI, A Responsabilidade da Sociedade Controladora pelas Dívidas da Controlada, p. 394). O primeiro aspecto já é enfrentado, ao menos no que diz respeito à vasta maioria dos sujeitos hipossuficientes que por ele podem realmente ser afetados, pela legislação consumerista e trabalhista; em âmbito empresarial, ou estaremos diante de hipótese de aplicação da teoria da aparência ou diante de um empreendedor tão inábil ao ponto de não saber discernir a sociedade do grupo a que pertence e que, portanto, não deveria se dedicar a atividade complexa e de risco. Quanto à segunda questão, o autor escora boa parte de seu raciocínio na doutrina italiana e no artigo 2.632 do Código Civil daquele país, que realmente atribuía responsabilidade ilimitada, por ocasião da falência, ao acionista único pelas dívidas da controlada. É importante considerar, contudo, que a redação de tal dispositivo foi alterada nos termos da reforma de 2003 (Decreto Legislativo $n^{\circ}$ 6, de 17 de janeiro de 2003), para assegurar a responsabilidade limitada do sócio único, desde que cumpridas específicas exigências de publicidade: "Admite-se, portanto, a sociedade por ações unipessoal, seja em sede de 
Tal conceito é explícito nas visões unitaristas do grupo ${ }^{694}$ bem como na doutrina da responsabilidade estrutural de grupo ${ }^{695}$, mas também está presente na qualificação do grupo, em si, como uma sociedade de sociedades, já analisada criticamente no Capítulo 6 deste trabalho. De fato, um dos principais efeitos que se parece buscar por meio da tentativa de caracterização do grupo em si como uma sociedade é justamente a responsabilidade subsidiária de suas integrantes pelos débitos decorrentes das atividades da empresa grupal ${ }^{696}$.

Os defensores de tais posições não parecem, contudo, dar o devido peso para o fato de que a limitação da responsabilidade - e a consequentemente compartimentação patrimonial do grupo - ensejam benefícios para a coletividade que vão além do mero incentivo ao investimento e à assunção de riscos, por si só, aspecto fundamental para a economia contemporânea. De fato, conforme acenado no Capítulo 3, a divisão do grupo em unidades autônomas do ponto de vista patrimonial permite que os terceiros que estabelecem relações com cada uma das sociedades agrupadas façam uma análise de risco

constituição seja sucessivamente, sem que se altere a responsabilidade do sócio ou dos sócios pelas obrigações da sociedade. A regra da responsabilidade limitada vale, de fato, do mesmo modo tanto para as sociedades por ações pluripessoais quanto para aquelas unipessoais". Tradução livre de: " $E$ pertanto ammessa la s.p.a. unipersonale sia in sede di costituzione che successivamente, senza che muti la responsabilità del socio o dei soci per le obbligazioni della società. La regola della responsabilità limitata vale infatti allo stesso modo tanto per le società per azioni pluripersonali, quanto per quelle unipersonali." in M. NOTARI, Disposizioni Generali. Conferimenti. Azioni, p. 121. Além disso, a despeito de, aparentemente, defender uma regra geral de responsabilidade subsidiária da sociedade controladora - pelo simples fato de ser sociedade e ser controladora - Zanini faz referência à doutrina americana, citando elementos de responsabilização que estão claramente vinculados à conduta do sócio (capitalização insuficiente e confusão patrimonial; C. ZANINI, A Responsabilidade da Sociedade Controladora pelas Dívidas da Controlada, p. 398-402). Ao buscar amparo às suas proposições no texto da lei acionária, o autor cita a referência a "comunidade" constante do artigo 116 e a ressalva quanto à ação individual pelo dano direto constante do artigo 159, $\S 7^{\circ}$. Contudo, em ambos os casos, estamos diante de hipóteses de responsabilidade delitual e, como tal, atrelada a condutas ilícitas e não ao mero fato da relação intersocietária.

694 “A teoria unitarista clássica [...] pretende orientar o direito privado pelo modelo da empresa unitária do antigo direito do imposto sobre o faturamento, dado que a sociedade isolada dependente estaria aniquilada enquanto empresa autônoma. Em termos de política legislativa, essas reflexões conduzem a tornar o grupo em si um sujeito de direito [...]". Tradução livre de: "Die klassische Enheitstheorie [...] möchte nach dem Vorbild des alten Umsatzsteuerrechts auch das Privatrecht am Einheitsunternehmen ausrichten, weil die abhängigen Einzelgesellschaften als eigenständige Unternehmen vernichtet seien. Rechtspolitisch führen diese Gedanken dazu, den Konzern zum eigenen Rechtssubjekt zu machen [...] H. WIEDEMANN, Die Unternehmensgruppe im Privatrecht, p. 15. Já a versão moderna da teoria unitarista não coloca em discussão a autonomia jurídica das sociedades grupadas, mas coloca ênfase na construção de órgãos e instituições grupais (H. WIEDEMANN, Die Unternehmensgruppe im Privatrecht, p. 16-17).

695 “Com a expressão 'responsabilidade estrutural' quer-se exprimir a responsabilidade privativa dos grupos, aplicável em função da simples existência de uma determinada estrutura grupal." C. SALOMÃO FILHO, O Novo Direito dos Grupos, p. 182.

696 E. PEREIRA NETO, Anotações sobre os Grupos de Sociedades, p. 32. S. VACRATE, La Société Créée de Fait, Essai de Théorisation, p. 151-152. 
de crédito mais circunscrita, simples e menos custosa, comparada a uma investigação da solvabilidade do conglomerado como um todo ${ }^{697}$. Além disso, em época de notável concentração econômica, a compartimentação patrimonial decorrente da adoção de estruturas de grupo é certamente um instrumento irrenunciável para a gestão do risco sistêmico das macroempresas contemporâneas. Considerando as dimensões que alguns conglomerados alcançaram e o número de pessoas diretamente afetados por suas atividades, o fato de que a derrocada de uma parte da empresa plurissocietária não implique o fracasso do todo é extremamente relevante para a própria comunidade e não apenas para os investidores ${ }^{698}$. Na verdade, na hipótese de falência da sociedade controladora, alguns dos principais beneficiários da separação patrimonial serão justamente os credores - incluindo os empregados - das sociedades controladas cujo patrimônio de garantia representa apenas bem de segundo grau para a massa falida e, portanto, não pode ser diretamente agredido pelos credores desta.

Além disso, mesmo em termos de incentivo a investimentos, cumpre recordar que a limitação de responsabilidade não é relevante apenas no momento da decisão de se aportar recursos em uma dada sociedade em constituição, mas sobretudo quando se avalia a aquisição do controle sobre sociedade existente. Para o adquirente, é essencial ter razoável segurança de que não está “comprando dívida" e que, na pior das hipóteses, perderá apenas o que investiu. Assim, se a posição de controle estiver automática e estruturalmente atrelada a uma responsabilidade subsidiária (ou pior, solidária) pelas dívidas da controlada, dificilmente se formará um mercado do controle acionário - o qual, porém, representa uma ferramenta importantíssima para a alocação eficiente de recursos e para o adequado reaproveitamento de empresas mal geridas ou subcapitalizadas.

No que tange especificamente à estrutura do grupo, é importante recordar, como já se argumentou no Capítulo 3, que a compartimentação patrimonial - que tem como pressuposto a limitação da responsabilidade do acionista, inclusive do controlador -

697 D. PRENTICE, A Survey to the Law Relating to the Corporate Groups in the United Kingdom, p. 307.

698 A questão é especialmente relevante em função das instituições financeiras que se tornaram tão grandes, ou tão interconectadas com o resto do sistema financeiro que a sua quebra não pode ser tolerada pelas autoridades governamentais: "'Grande demais para falir' é, atualmente, um problema maior do que antes, em parte porque os bancos se fundiram de uma maneira que cria instituições bancárias ainda maiores [...]". Tradução livre de: "Too-big-to-fail is now a larger problem than before, in part because banks have merged in a way that creates even larger banking institutions [...]" in F. MISHKIN, From the Subprime to the Global Financial Crisis, p. 66. 
representa a principal função prática dessa forma de organização empresarial, a mais determinante e a que mais dificilmente poderia ser replicada por meio de outros instrumentos jurídicos. Assim, tocar na limitação da responsabilidade do acionista representa tocar na principal razão de existir dos grupos.

Contudo, não se pretende, evidentemente, que a responsabilidade limitada seja um dogma absoluto ou que deva ser preservada mesmo quando se preste a abusos. O que se argumenta, porém, é que tanto a concessão de tal benefício quanto a sua supressão não devem estar atreladas às características pessoais do sócio - ao fato de que seja sociedade e seja controlador ou esteja sob controle comum -, mas sim, ao respeito ou à violação, respectivamente, de preceitos claros e objetivos que tutelem a separação e a adequada gestão dos bens da própria sociedade controlada, assegurando-lhe um grau mínimo de solidez patrimonial. Com isso, também não se quer dizer que a circunstância da existência do grupo é irrelevante para a responsabilização do acionista. Há, por exemplo, diversas operações e muitíssimos abusos que apenas podem ser realizados no âmbito do grupo, tal como a incorporação de controlada com relação de troca de ações injusta.

Porém, mesmo nestas hipóteses, é a conduta que releva, não a pertinência ao grupo per se. Caso contrário, corre-se o risco - já presente na aplicação, por vezes, pouco criteriosa pelos tribunais brasileiros da desconsideração da personalidade jurídica ${ }^{699}-$ de se lançar em uma vala comum tanto o acionista-empreendedor desafortunado quanto aquele efetivamente desonesto, substituindo desse modo o efeito pedagógico da norma por enorme insegurança jurídica.

699 O Professor Eduardo Munhoz ressalta o "caráter excessivamente casuístico" da aplicação da teoria da desconsideração no Brasil. E. MUNHOZ, Desconsideração da Personalidade Jurídica e Grupos de Sociedades, p. 36. A questão porém, não parece ser exclusividade da praxe brasileira: "Há pouco a ser obtido da análise detalhada desses casos. Eles não são capazes de articular quaisquer princípios claros dos quais seja possível prever quando os tribunais desconsiderarão ou não a personalidade jurídica. Por exemplo, existem diversos casos, virtualmente idênticos em seus fatos subjacentes, nos quais os tribunais alcançaram resultados opostos". Tradução livre de: "Little would be gained from analysing these cases in any detail. They fail to articulate any clear principles from which it is possible to predict when the courts will or will not pierce the corporate veil. For example, there are a number of cases, virtually identical on their facts, where the courts have reached contrary results." in D. PRENTICE, A Survey to the Law Relating to the Corporate Groups in the United Kingdom, p. 309. De fato, a desconsideração da personalidade jurídica parece ser uma espécie de expressão "coringa" usada para descrever as mais variadas situações em que, por imperativos de equidade, opta-se por imputar responsabilidade ao sócio. Pela variabilidade de seu conteúdo e de seus pressupostos, é difícil analisá-la e, mais difícil ainda, considerá-la uma possível solução para os problemas verificados nos grupos. 


\subsubsection{Vedação de Operações Intragrupo e Impedimento de Voto}

Considerando os fatos de que (i) as operações e contratos entre sociedades controladas e coligadas estão sujeitas a permanente e conatural conflito de interesse e que (ii) representam os típicos instrumentos para a constituição dos já mencionados "vasos comunicantes" por meio dos quais são transportados os ganhos e perdas entre as diversas sociedades agrupadas, conforme a melhor conveniência do titular do poder de controle, não se pode deixar de analisar medidas que tenham por objeto restringir ou condicionar tais negócios jurídicos intragrupo.

Para fins de argumentação, convém indagar a respeito da mais radical e extrema entre elas, que seria a pura simples vedação das operações entre partes relacionadas, ao menos no que se refere aos grupos de fato. Seria, contudo, solução drástica e altamente ineficiente, pois amiúde as operações intragrupo são aquelas mais oportunas e vantajosas não apenas para a controladora, mas inclusive para controladas e coligadas ${ }^{700}$. Com efeito, um dos grandes custos transacionais em qualquer operação é a obtenção de informações a respeito da contraparte. Sempre haverá alguma dúvida sobre as intenções e a honestidade da outra parte contratual e esse risco tende a ser precificado como custo do negócio. Entre sociedades integrantes do mesmo grupo, tende a haver conhecimento recíproco muito maior. Além disso, a sociedade controladora não tem dúvidas a respeito das intenções da controlada, pois em última análise trata-se de expressão indireta de sua própria vontade - e, se por qualquer razão assim não for, a controladora dispõe dos meios para fazer com que seja. Por essas razões, por exemplo, um empréstimo intragrupo pode ser realizado em condições convenientes para ambas as partes, por uma taxa mais elevada do aquela obtida pelos regulares investimentos da sociedade mutuante, mas, de qualquer modo, mais baixa do que aquela que um banco ofereceria para a sociedade tomadora.

Além dessa questão da eficiência potencial dos contratos individualmente

700 "[...] uma coletividade pode proibir totalmente operações em conflito de interesse: todas as operações entre a companhia e os seus controladores - ou qualquer outra entidade que tais controladores também controlem - poderiam ser banidas pela lei. Ainda assim, nenhuma coletividade considera, tampouco, prático utilizar essa abordagem; porque em muitas situações as operações entre partes relacionadas fazem sentido economicamente.". Tradução livre de: "[...] a society can prohibit conflicted transactions altogether: all dealings between a corporation and its controllers - or any other entity these controllers also control - could be banned by law. Yet no society finds it practical to use this approach either, perhaps because in many instances related-party transactions actually make economic sense." in S. DJANKOV, R. LA PORTA, F. LOPEZ-DE-SILANES, A. SHLEIFER, The Law and Economics of SelfDealing, p. 431. 
analisados, é importante considerar que uma proibição total das operações entre partes relacionadas, independentemente de qualquer análise de sua comutatividade, tornaria o grupo de fato um espaço de não coordenação e de não integração econômica. Significaria em relevante medida um desmantelamento da empresa plurissocietária.

Opção mais amena e razoável do que a simples proibição, seria a sujeição de todas as operações entre partes relacionadas à aprovação prévia por acionistas ou administradores desinteressados e independentes. Contudo, mesmo em relação a esta alternativa é necessário cuidado, conforme se infere das acirradas discussões relativas à natureza formal ou substancial do conflito de interesse. De fato, uma ampliação desmesurada das hipóteses de impedimento de voto criaria toda a sorte de possibilidades de abuso de minoria e de paralisia decisória, uma vez que a intervenção judicial pode desconstituir votos ilegítimos, mas não impor um conteúdo positivo a uma deliberação que não atinja os quóruns exigidos pela lei ou pelo estatuto ${ }^{701}$. Também nesta hipótese, estaríamos diante da inviabilização da empresa plurissocietária.

Naturalmente, versões mais delimitadas e circunscritas da técnica de legitimação de medidas por meio da aprovação de acionistas desinteressados podem representar instrumentos importantes para lidar com situações específicas de conflito de interesse particularmente grave. Pode-se colher no direito alemão um exemplo bastante razoável de aplicação desta técnica. O subparágrafo 2 do $§ 295$ da lei acionária alemã determina que a alteração do acordo de domínio que tenha por objeto alterações na compensação devida aos acionistas externos ou na obrigação de aquisição das ações que possuem deve ser aprovada em conclave separado, formado apenas por tais sócios.

\subsection{Alternativas para o Desenvolvimento do Direito dos Grupos}

Nos termos do Capítulo 9, pode-se argumentar que o ponto fulcral da crise de efetividade dos grupos de fato, que se traduz e se propaga como crise de desuso no campo dos grupos de direito, reside na ineficiência dos mecanismos de contraste ao conflito de interesse constantes da Lei 6.404/1976.

O legislador de 1976 declaradamente buscou atribuir aos acionistas controladores

701 E. VALLADÃO FRANÇA, Conflito de Interesses e Benefício Particular: Uma Distinção que se Impõe Definitivamente Dirimir, p. 42. Vide também parágrafo 81 do voto do Diretor Luiz Antonio de Sampaio Campos, no Inquérito Administrativo CVM n TA-RJ 2002/1153, de 06 de novembro de 2002 
a maior margem de manobra possível ${ }^{702}$, deixando-lhe as mãos desatadas e o caminho desembaraçado para emitir uma ampla variedade de títulos, impor o seu domínio sobre os órgãos sociais e realizar operações entre partes relacionadas, mesmo em situações de conatural e estrutural conflito de interesse. Como contrapeso a tais generosas prerrogativas, transformou os direitos políticos do acionista controlador em poder-função, elevando-o a órgão da companhia. Ademais, atribuiu aos administradores minuciosos deveres fiduciários.

O grande vício desse sistema é que, tendo em vista a intencional timidez dos mecanismos estruturais e preventivos de "controle do controle" quase inteiramente na revisão ex post dos atos dos administradores e do acionista controlador $^{704}$, fazendo com que esse extenso e grave ônus do recurso à autoridade judiciária recaia sempre sobre os acionistas minoritários. Estes, porém, como já apontado anteriormente, enfrentam toda a sorte de dificuldades para fazer valer em juízo as suas razões. Pode-se argumentar, portanto, que o país não possui um sistema judicial de resolução das disputas societárias à altura da missão reivindicada pela própria estrutura da lei acionária. Como consequência, o sofisticado sistema de direito material que imputa rigorosos deveres fiduciários a controladores e administradores restou um gigante de pés de barro.

Face a esse diagnóstico, ou seja, de que o cerne das dificuldades enfrentadas reside na deficiência dos mecanismos de cumprimento coercitivo dos comandos da lei acionária, pode-se concluir que (i) estamos diante, fundamentalmente, de um problema de natureza geral - que incide transversalmente sobre todas as relações societárias - e não especificamente grupal e (ii) as eventuais medidas voltadas a mitigar as suas consequências negativas devem ter por escopo e prioridade (a) a diminuição do peso relativo da regra de conflito no sistema da lei acionária e (b) o aprimoramento da posição do acionista minoritário em juízo.

Em relação ao primeiro ponto, parece legítimo colocar em questão a própria necessidade de um articulado sistema de direito societário que expressamente defina os grupos como tal. É evidente que existem particularidades das relações grupais que exigem

702 A. LAMY FILHO, J. PEDREIRA, A Lei das S.A., vol. I, p. 135.

703 F. COMPARATO, C. SALOMÃO, O Poder de Controle na Sociedade Anônima, p. 29.

704 C. SALOMÃO FILHO, O Novo Direito Societário, p. 98. 
tratamento legal específico - a consolidação contábil e as regras sobre participações recíprocas são exemplos disso -, mas como já se argumentou no item 6.2.4 deste trabalho, os problemas fundamentais do controle societário e do conflito de interesse parecem ser apenas mais complexos nos grupos do que nas sociedades isoladas, mas não são ontologicamente distintos. É discutível a conveniência de se alterar estruturalmente nosso regime de desdobramento das noções de sociedade controladora e de acionista controlador, que já foi absorvido pela tradição brasileira. Contudo, não se pode deixar de observar que a experiência de diversos países - a maioria aliás, conforme discutido no Capítulo 2 - que não possuem uma definição legal dos grupos societários ${ }^{705}$, mas lidam com seus efeitos negativos tão bem ou melhor que Alemanha e Brasil, parece confirmar claramente a prescindibilidade de uma estrutura jurídica dessa natureza.

No que se refere a medidas estruturais e preventivas, potencialmente capazes de diminuir o peso relativo da (inefetiva) regra de interesse em nosso sistema, é possível citar, apenas como exemplos: (i) a submissão obrigatória de operações significativas entre partes relacionadas à prévia aprovação pelo conselho de administração ${ }^{706}$, (ii) regras mais rigorosas a respeito da manutenção do capital social e publicidade dos registros contábeis $^{707}$ e (iii) o aprimoramento do acesso do acionista à informação, inclusive com a obrigação de clara identificação do acionista controlador ${ }^{708}$ e de variações relevantes nas

705 D. PRENTICE, Some Comments on the Law of Groups, p. 371-372.

706 V. PRADO, Transações com Partes Relacionadas: Estratégias Jurídicas, p. 89-90. O fato de que a posição do acionista controlador, que por definição nomeia a maior parte dos integrantes de tal órgão, tenda a prevalecer, não torna a deliberação inócua, pois assegura acesso à informação aos representantes nomeados pela minoria social (ex artigo 141 da Lei 6.404/1976) e exige dos administradores a documentação e formalização de seu processo decisório.

707 Seria impensável em outras legislações que uma sociedade anônima pudesse operar, por diversos exercícios sociais consecutivos (evidente sinal de subcapitalização, com aportes camuflados como crédito), sem publicar demonstrações financeiras e com patrimônio líquido negativo. Apenas como exemplo, é possível citar os artigos 2.446, 2.497 quinquies, 2.467, 2.630 do Código Civil italiano, que tratam da redução obrigatória do capital social para a absorção de perdas, das restrições à concessão de crédito às sociedades controladas e da sanção pela omissão no registro tempestivo do balanço social. Ambas as hipóteses, contudo, são frequentes entre as companhias brasileiras de capital fechado e a segunda delas não deixa de se verificar também entre companhias abertas (tanto que é hipótese expressamente prevista na Instrução CVM n ${ }^{\circ} 361 / 2002$, artigo 34, $\S 1^{\circ}$, IV). Provavelmente contribuíram para esse estado de coisas décadas de inflação elevada e regimes fiscais baseados no faturamento das sociedades, não em seu lucro, que são compatíveis, portanto, com uma menos rígida disciplina contábil. Um maior rigor nessa área não impediria por si só a realização de operações em conflito de interesse. Porém - retomando a paráfrase de Champaud - se os vasos continuariam comunicantes, ao menos seus fluxos seriam mais visíveis e seria mais difícil esvaziá-los por completo.

708 Não faz sentido transformar o poder de controle em poder função e elevar o controlador a órgão da companhia, como mencionado anteriormente, e não identificá-lo clara e publicamente como tal, de modo a facilitar a sua responsabilização, bem como o mapeamento das cadeias de controle indireto. Além disso, a regra constante do artigo $277, \S 2^{\circ}$, da Lei $6.404 / 1976$, relativa ao poder de fiscalização 
participações detidas no capital social, mesmo nas companhias fechadas ${ }^{709}$.

No que diz respeito ao aprimoramento da defesa dos interesses dos sócios em juízo - aspecto absolutamente crítico para a disciplina do conflito de interesses, conforme discutido anteriormente -, cabe mencionar como algumas entre tantas possíveis sugestões: (i) de lege lata uma interpretação mais restritiva para os efeitos do quitus, nos termos do artigo 134, $\S 3^{\circ}$, da Lei 6.404/1976 e de lege ferenda uma aproximação do regime brasileiro às regras do direito comparado a esse respeito ${ }^{710}$; (ii) extensão do prêmio de cinco por cento previsto no $\S 2^{\circ}$ do artigo 246 às ações sociais $u t$ singuli propostas em face dos administradores ${ }^{711}$; (iii) redução, nos termos de regulamentação a ser promulgada pela Comissão de Valores Mobiliários consoante o artigo 291 da lei acionária, do percentual de participação que autoriza a propositura de ação social contra a sociedade controladora sem a necessidade de caução; e, provavelmente o ponto mais importante de todos, (iv) facilitação da prova em juízo das hipóteses de responsabilização consignadas nos artigos 116,117 e 245 da Lei 6.404/1976.

Pela sua relevância, a questão da prova merece algumas poucas ponderações adicionais $^{712}$. O legislador de 1976 incorporou na lei acionária um sistema de padrões de conduta e de deveres fiduciários claramente inspirado nos ordenamentos da tradição de common $l a w^{713}$. Porém, ao fazê-lo, deixou de também importar um sistema processual apto à apuração dos elementos fatuais que permitem apurar o inadimplemento de tais deveres ${ }^{714}$.

“intersocietária" do conselho fiscal da sociedade convenente, poderia ser estendida ao grupo de fato (ao menos no que diz respeito às próprias sociedades controladoras, diretas e indiretas) e a outros órgãos das companhias.

709 De modo similar, por exemplo, ao que determina o direito italiano em relação à identificação do ente que exerce a atividade de direção e coordenação de sociedades (artigo 2.497 bis) e ao que prevê a lei acionária alemã, em seus $\S \S 20$ a 22 , a respeito da divulgação de participações superiores a um quarto do capital social.

710 M. VON ADAMEK, Responsabilidade Civil dos Administradores de S/A e as Ações Correlatas, p. 508509.

711 M. VON ADAMEK, Responsabilidade Civil dos Administradores de S/A e as Ações Correlatas, p. 509.

712 “Mas o problema mais sério, na prática (em particular, em âmbito judicial), é representado pela aquisição da prova [...]". Tradução livre: "Ma il problema più grave, nella prassi operativa (in particolare giudiziaria), è costituito dall'acquisizione della prova [...]” in F. ABATE, A. DIMUNDO, L. LAMBERTINI, L. PANZANI, A. PATTI, Gruppi, Trasformazione, Fusione, Scissione, Scioglimento e Liquidazione, Società Estere (artt. 2484-2510), p. 249. Sobre a natureza diabólica da prova da violação do dever de correta administração no direito italiano: R. SANTAGATA, Autonomia Privata $e$ Formazione dei Gruppi nelle Società di Capitali, p. 811.

713 E. SALOMÃO NETO, Trust e Deveres de Lealdade e Sigilo na Sociedade Anônima Brasileira, p. 309310. L. SPINELLI, Conflito de Interesses na Administração da Sociedade Anônima, p. 67.

714 "Contribui, ainda, para a ineficácia do sistema, a dificuldade em comprovar o ato abusivo de controle, dada a complexidade de dos sistemas de transferência de recursos entre as sociedades. $O$ minoritário, 
Justamente por se tratar de obrigações baseadas, necessariamente, em conceitos abertos e indeterminados, a aferição de sua violação é operação que muitas vezes exige a verificação da intenção dos agentes e de detalhes de seu processo de tomada de decisões.

Enquanto nos Estados Unidos o sistema da discovery corriqueiramente permite aos advogados do autor da derivative suit ${ }^{715}$ - equivalente à ação social por substituição processual de nossa legislação - o mais amplo acesso à correspondência interna da companhia e a todos os seus arquivos ${ }^{716}$, nos países de tradição continental-europeia, como o Brasil, ainda prevalece uma visão supostamente garantista do processo, com o inadequado transplante de conceitos do processo penal ${ }^{717}$ para o âmbito civil, tal como o preceito de acordo com o qual ninguém deve produzir prova contra si mesmo ${ }^{718}$. Em nossa realidade, a escassez de informações e documentos aos quais os potenciais autores de ações sociais possam ter acesso, somada com uma postura formalista e rígida dos tribunais na aplicação do ônus da prova enquanto regra de julgamento, parece ser uma das mais importantes - senão mesmo a principal - causa de inefetividade do aparato de contraste ao abuso do poder de controle $\mathrm{e}^{719}$.

que não participa da condução dos negócios sociais, tem pouca, ou nenhuma, possibilidade de identificar como se dá a subordinação dos interesses da sociedade controlada nas complexas relações desenvolvidas no âmbito do grupo, tornando diabólica a exigência atual de se comprovar tal situação" in E. MUNHOZ, Empresa Contemporânea e Direito Societário: Poder de Controle e Grupos de Sociedades, p. 280.

715 Sobre a importância estrutural do acesso aos meios de prova para o funcionamento não apenas do sistema judicial, mas do próprio mercado de capitais americano, vide o excelente trabalho, ainda em versão preliminar, dos Professores Halberstam e Gorga. E. GORGA, M. HALBERSTAM, Litigation Discovery and Corporate Governance: The Missing Story About the "Genius of American Corporate Law" [no prelo], p. 29.

716 Ressalvadas pouquíssimas exceções, como as correspondências trocadas com advogados.

717 Perfeitamente justificados em sua esfera de origem, na qual costuma estar em jogo a liberdade individual, mas pouco adequados para uma realidade em que se lida quase que exclusivamente com direitos patrimoniais disponíveis e relações fiduciárias.

718 Clamoroso a esse respeito, o exemplo de processos movidos por investidores na Alemanha e nos Estados Unidos contra a Deutsche Telekom pela prestação de informações errôneas. Enquanto o tribunal alemão - cujo sistema é provavelmente dos mais eficazes no âmbito do civil law - excluiu a responsabilidade dos administradores, uma vez que os autores da ação não tiveram como demonstrar a intencional omissão ou distorção de dados, documentos obtidos no processo estadunidense - frise-se, relativo aos mesmos fatos - obrigaram a companhia a celebrar uma transação no valor de US\$ 120.000.000,00. E. GORGA, M. HALBERSTAM, Litigation Discovery and Corporate Governance: The Missing Story About the "Genius of American Corporate Law" [no prelo], p. 69-71.

719 Tratando da experiência italiana, mas com ponderações que se aplicam perfeitamente à realidade brasileira, Ventoruzzo assevera que: “[...] não há nada comparável à ampla coleta de provas [discovery] controlada pelas partes no estilo americano. Como consequência, em qualquer ação por substituição processual [derivative suit], os acionistas minoritários encontram-se em significativa desvantagem em termos de informação em relação aos administradores-réus, que possuem melhor acesso à informação relevante e podem, portanto, mais facilmente se defender de alegações de conduta imprópria. Enfim, a duração média de um processo civil na Itália desencoraja seriamente o recurso aos tribunais como um 
Para fazer frente a essa situação, não parece razoável cogitar a importação em bloco de sistema tão diverso da tradição brasileira quanto o discovery ${ }^{720}$. Existem, porém, diversas medidas cuja adoção seria menos traumática e que podem mitigar as dificuldades probatórias dos acionistas minoritários, tais como, apenas como exemplos: a inversão ${ }^{721} \mathrm{ou}$ a dinamização do ônus da prova, leitura e aplicação mais rigorosa dos deveres de colaboração e veracidade (Código de Processo Civil, artigos 14, I e 339) no âmbito processual civil, uma postura de maior flexibilidade em relação à prova indiciária e a criação de varas e câmaras judiciais especializadas em questões empresariais ${ }^{722}$.

meio para a proteção dos minoritários". Tradução livre de: “[...] there is nothing comparable to U.S. style extensive, party-controlled discovery. As a consequence, in any derivative action, minority shareholders are at a significant disadvantage in terms of information in relation to the directordefendants, who have better access to the relevant information and can therefore more easily defend against allegations of misconduct. Finally, the average length of a civil lawsuit in Italy seriously discourages resort to the courthouse as a means for protecting minorities." in M. VENTORUZZO, Experiments in Comparative Law: The Recent Italian Reform and the Dubious Virtues of a Market for Rules in the Absence of Effective Regulatory Competition, p. 197.

720 Para um relato da tentativa japonesa de reformular seu sistema probatório incorporando mecanismos típicos da experiência estadunidense: E. GORGA, M. HALBERSTAM, Litigation Discovery and Corporate Governance: The Missing Story About the "Genius of American Corporate Law" [no prelo], p. 73-74.

721 O direito alemão, por exemplo, se vale amplamente da inversão do ônus da prova no âmbito dos grupos, tal como nos casos dos $\S \S 309$ (subparágrafo 2), 310 (subparágrafo 1) e 318 (subparágrafo 1) da lei acionária de 1965.

722 Algumas dessas estratégias já foram discutidas em trabalho anterior do candidato: D. VIO, Prova Difícil e Inadimplemento da Obrigação de Contratar em Condições Equitativas nos Termos da Lei das S.A., p. 249-259. 


\section{Considerações Conclusivas}

Aspecto particular do desenvolvimento do direito dos grupos é o fato de que, como apontado na análise histórica constante deste trabalho, a presença de um conjunto orgânico e detalhado de regras e definições, tanto na experiência alemã quanto naquela brasileira, não representou - como poderia parecer à primeira vista - expressão da intenção legislativa de reprimir, restringir ou disciplinar o fenômeno em margens estreitas, mas, ao contrário, foi tradução do objetivo anseio de se assegurar maior liberdade e margem de manobra para o exercício da empresa plurissocietária.

No caso brasileiro, porém, a praxe societária acabou por zombar da mão estendida pelo legislador, de forma que a liberdade de ação concebida para existir apenas no âmbito do complexo e burocrático grupo regulado por convenção acabou sendo alcançada no próprio grupo de fato, não com fundamento em uma elegante explicitação e formalização das operações em que se admitiria expressamente a subordinação de interesses, mas sim pelo atalho espúrio da ausência de efetivas consequências em decorrência da sistemática violação da lei. Trata-se da subordinação de interesses sem legitimação, mas sem sanção.

Conforme se espera ter demonstrado por meio dos limitados dados empíricos à disposição, os grupos de direito são bastante raros no Brasil; existem, provavelmente em número mais elevado do que antes se imaginava, mas certamente estão muito aquém do papel que lhes reservou a mens legislatoris de 1976. Por outro lado, há indícios igualmente fortes de que o abuso é altamente disseminado nos grupos de fato. Analisadas as possíveis hipóteses alternativas que explicariam a restrita difusão dos grupos convencionais, amplamente eclipsados pelos grupos de fato, a que desponta como mais convincente é a da inefetividade de nosso sistema judicial de cumprimento coercitivo dos deveres fiduciários imputados ao controlador e aos administradores.

Dessas circunstâncias, derivam duas principais conclusões. A primeira é a de que é necessário encontrar, no direito posto material, critérios para, em face da falência do modelo do grupo de direito, viabilizar juridicamente a empresa plurissocietária - cujo papel essencial para a economia contemporânea e cuja natureza tipificada se buscou ilustrar ao longo deste trabalho - no próprio grupo de fato e discernir o abuso da coordenação e da integração legítimas de atividades. Como apontado anteriormente, uma 
das estratégias mais promissoras nesse sentido é a adoção de uma visão menos estreita tanto em termos temporais quanto de número de operações consideradas - ao se aferir a comutatividade dos contratos intragrupo. Contudo, para que não represente uma neutralização dos comandos constantes dos artigos 117 e 245 da Lei 6.404/1976, tal abordagem deve, necessariamente, estar associada a uma rigorosa exigência de documentação, mensuração e comprovação das vantagens comparativas, que é natural incumbência dos administradores e do acionista controlador.

A segunda questão diz respeito à transversalidade e magnitude do problema. Uma vez que se identifique a raiz profunda das dificuldades experimentadas na inefetividade do sistema judicial de resolução de controvérsias societárias, não estamos mais diante de uma questão típica do direito dos grupos, mas sim de um desafio maior, com impacto sobre todo o direito societário. É evidente que, no grupo, tais dificuldades são engrandecidas de forma exponencial e têm nuances particulares, como, por exemplo, os problemas de legitimação e de acesso à informação em relações de participação societária apenas indireta. De qualquer forma, trata-se de um problema do controle societário em geral, que tem as mesmas feições fundamentais, seja na sociedade isolada (ressalvada a subsidiária integral) seja no grupo, pois em ambos os casos se verifica o alto risco de que o abuso ou o desvio de finalidade restem sem consequências. 


\section{Bibliografia}

ABATE, Francesco, DIMUNDO, Antonio, LAMBERTINI, Lamberto, PANZANI, Luciano, PATTI, Adriano, Gruppi, Trasformazione, Fusione, Scissione, Scioglimento e Liquidazione, Società Estere (artt. 2484-2510), in LO CASCIO, Giovanni (cur.), La Riforma del Diritto Societario, Milano, A. Giuffrè, n. 9, 2003, p. 582.

ALDRIGHI, Dante, MAZZER NETO, Roberto, Evidências sobre as Estruturas de Propriedade de Capital e de Voto das Empresas de Capital Aberto no Brasil, Revista Brasileira de Economia, v. 61, $\mathrm{n}^{\circ}$ 2, 2007, p. 129-152. Disponível em: $<$ http://www.scielo.br/pdf/rbe/v61n2/a01v61n2.pdf >. Acesso em: 12 set2013.

ALDRIGHI, Dante Mendes, POSTALI, Fernando Antonio Slaibe, Propriedade Piramidal das Empresas no Brasil, EconomiA Revista da ANPEC, Brasília, v. 12, n 1, 2011, p. 27-48. Disponível em: <http://www.anpec.org.br/revista/vol12/vol12n1p27_48.pdf? frbrVersion $=2>$. Acesso em: 08set2013.

ALVIM, Arruda, Notas Atuais sobre a Figura da Substituição Processual, Revista de Processo, 106, Ano 27, p. 18-27.

ARAUJO, Danilo Borges dos Santos Gomes de, WARDE JR., Walfrido Jorge, Os Grupos de Sociedades: Estado Atual da Técnica, in (orgs.), Os Grupos de Sociedades - Organização e Exercício da Empresa, São Paulo, Saraiva, 2012, p. 1121.

ARAUJO, Danilo Borges dos Santos Gomes de, A Doutrina Rozenblum do Direito Francês; o Reconhecimento do Caráter Exoneratório dos Grupos de Sociedades em Matéria de Crimes de Abus de Biens Sociaux e a Consequente Influência do Direito Penal na Estruturação e no Funcionamento dos Grupos de Sociedades, in ARAUJO, Danilo Borges dos Santos Gomes de, WARDE JR., Walfrido Jorge (orgs.), Os Grupos de Sociedades - Organização e Exercício da Empresa, São Paulo, Saraiva, 2012, p. 83-113.

ALMEIDA, António Pereira de, Sociedades Comerciais, $4^{\mathrm{a}}$ ed., Coimbra, Coimbra Editora, 2006, p. 804.

ALMEIDA, Heitor V., WOLFENZON, Daniel, A Theory of Pyramidal Ownership and Family Business Group, The Journal of Finance, Vol. 61, No. 6, 2006, p. 2.637-2.680.

ANTUNES, José Engrácia, Os Grupos de Sociedades, Almedina, Coimbra, 1993, p. 842.

, Liability of Corporate Groups - Autonomy and Control in ParentSubsidiary Relationships in US, German and EU Law - An International and Comparative Perspective, Deventer, Kluwer Law and Taxation, 1994, p. 550.

, Estrutura e Responsabilidade da Empresa: O Moderno Paradoxo Regulatório, in CUNHA, Alexandre dos Santos, $O$ Direito da Empresa e das 
Obrigações e o Novo Código Civil Brasileiro - Anais do Congresso Ítalo-Brasileiro de Direito Civil (2004), São Paulo, Quartier Latin, 2006, p. 18-64.

, The Governance of Corporate Groups, in ARAUJO, Danilo Borges dos Santos Gomes de, WARDE JR., Walfrido Jorge (orgs.), Os Grupos de Sociedades Organização e Exercício da Empresa, São Paulo, Saraiva, 2012, p. 23-59.

ANTUNES, José Engrácia, BAUMS, Theodor, CLARKE, Blanaid J., CONAC, PierreHenri, ENRIQUES, Lucas, HANAKA, Andras I, HANSEN, Jesper Lau, DE KLUIVER, H.J., KNAPP, Vanessa, LENOIR, Noële, LINNAINMAA, Leena, SOLTYSINSKI, Stanislaw, WYMEERSCH, Eddy, Report of the Reflection Group on the Future of EU Company Law (April 5, 2011), Comissão Europeia, 2011, p. 82. Disponível em: $<\mathrm{http}: / /$ ssrn.com/abstract $=1851654>$. Acesso em: $15 \mathrm{set} 2013$.

ARAGÃO, Paulo Cézar, Aspectos Processuais da Legislação Societária, Revista dos Tribunais, Ano 78, Vol. 641, 1989, p. 61-71.

O Parecer de Orientação 35/2008 da CVM e a Incorporação de Companhia Fechada por sua Controladora Companhia Aberta, in VON ADAMEK, Marcelo Vieira (coord.), Temas de Direito Societário e Empresarial Contemporâneos, São Paulo, Malheiros, 2011, p. 522-535.

ASCARELLI, Tullio, Studi in Tema di Società, Milano, Giuffrè, 1952, p. 1168.

, Saggi di Diritto Commerciale, Milano, Giuffrè, 1955, p. 620.

Corso di Diritto Commerciale - Introduzione e Teoria dell'Impresa, Milano, Dott. A. Giuffrè, 1962, p. 463.

Problemas das Sociedades Anônimas e Direito Comparado, 2a ed., São Paulo, Saraiva, 1969, p. 544.

ASQUINI, Alberto, I Profili dell'Impresa, in Rivista del Diritto Commerciale e del Diritto Generale delle Obbligazioni, Anno XLI, Parte Prima, Volume 41, Milano, Dottor Francesco Vallardi, 1943, p. 1-20.

ASSOCIATION FRANÇAISE DES JURISTES D'ENTREPRISE, CENTRE DE DROIT DES AFFAIRES DE RENNES, Droit des Groupes des Sociétés - Analyse Propositions, Paris, Librairies Techniques, 1972, p. 260.

AZEVEDO, Luís André N. de Moura, O Paradoxo da Disciplina Legal dos Grupos de Direito no Brasil: sob uma Perspectiva de Direito e Economia, in ARAUJO, Danilo Borges dos Santos Gomes de, WARDE JR., Walfrido Jorge (orgs.), Os Grupos de Sociedades - Organização e Exercício da Empresa, São Paulo, Saraiva, 2012, p. 177193.

BARBI, Celso Agrícola, Comentários ao Código de Processo Civil, 13a ed., Rio de Janeiro, Forense, 2008, vol. I, p. 484. 
BARCLAY, Michael J., HOLDERNESS, Clifford G., Private Benefits from Control of Public Corporations, Journal of Finance Economics, n. 25, 1989, p. 371-395.

BECHT, Marco, DELONG, Bradford J., Why has there been so little Block Holding in America?, in MORCK, Randall K. (ed.), A History of Corporate Governance Around the World, Chicago, The University of Chicago Press, 2007, p. 613-666.

BERLE, Adolf A., MEANS, Gardiner C., The Modern Corporation \& Private Property, New Brunswick, Transaction, 1991, p. 380.

BLOSS, Henning, Die Unternehmensgruppe im englischen und deutschen Recht der Kapitalgesellschaften, Frankfurt am Main, Peter Lang, 1999, p. 177

BLUMBERG, Philip I., The American Law of Corporate Groups, in MCCAHERY, Joseph, PICCIOTTO, Sol, SCOTT, Colin (editores), Corporate Control and Accountability Changing Structures and the Dynamics of Regulation, Oxford, Claredon, 1994, p. 305-342.

BOBBIO, Norberto, Teoria dell'Ordinamento Giuridico, Torino, Giappichelli, 1960, p. 219.

, Eguaglianza e Libertà, Torino, Einaudi, 1995, p. 98.

BRAUDEL, Fernand, Espansione Europea e Capitalismo - 1450-1650, Bologna, Il Mulino, 1999, p. 88.

BUONOCORE, Vincenzo, Le Nuove Frontiere del Diritto Commerciale, in Napoli, Edizioni Scientifiche Italiane, 2006, p. 162-236.

CANELlAS, Thiago Costa, LEAL, Ricardo Pereira Câmara, Evolução e Estrutura de Controle das Empresas Ligadas na Bovespa entre 2004 e 2006, Rio de Janeiro, UFRJ, COPPEAD, 2009, p. 20.

CARDOSO, Luiz Philipe Tavares de Azevedo, A Onerosidade Excessiva no Direito Civil Brasileiro, Dissertação de Mestrado, Faculdade de Direito da Universidade de São Paulo, 2010, p. 202. Disponível em: <http://www.teses.usp.br/teses/disponiveis/ 2/2131/tde-19112010-082708/publico/A_onerosidade_excessiva_no_direito_civil_ brasileiro_Luiz_P.pdf $>$. Acesso em: 05nov2013.

CARNELUTTI, Francesco, Teoria Generale del Diritto, Roma, Foro Italiano, 1940, p. 480.

CARVAlHOSA, Modesto, Sociedade "Holding" - Bens Excluídos do Giro de seus Negócios, in Revista de Direito Mercantil, Ano X, n. 2, 1971, p. 37-39.

168. , A Nova Lei de Sociedades Anônimas, Rio de Janeiro, Paz e Terra, 1976, p. 
, Comentários ao Código Civil - Parte Especial do Direito de Empresa, in AZEVEDO, Antonio Junqueira de (coord.), Comentários ao Código Civil, São Paulo, Saraiva, Vol. 13, 2003, p. 840.

, Comentários à Lei de Sociedades Anônimas, $3^{\mathrm{a}}$. ed., São Paulo, Saraiva, 2003, $3^{\circ}$ Vol., p. 826.

, Comentários à Lei de Sociedades Anônimas, 5a . ed., São Paulo, Saraiva, 2011, $2^{\circ}$ Vol., p. 1082.

, Comentários à Lei de Sociedades Anônimas, 5ª ed., São Paulo, Saraiva, 2011, $3^{\circ}$ Vol., p. 982.

, Comentários à Lei de Sociedades Anônimas, 4a . ed., São Paulo, Saraiva, 2011, $4^{\circ}$ Vol., Tomo II, p. 608.

CASTELLÕES, Leonardo de Gouvêa, Grupos de Sociedades, Curitiba, Juruá, 2008, p. 256.

CASTRO, Rodrigo R. Monteiro de, Controle Gerencial e o Grupo de Sociedades, in ARAUJO, Danilo Borges dos Santos Gomes de, WARDE JR., Walfrido Jorge (orgs.), Os Grupos de Sociedades - Organização e Exercício da Empresa, São Paulo, Saraiva, p. 151-175.

CHAMPAUD, Claude, Le Pouvoir de Concentration de la Société par Actions, Paris, Sirey, 1962, p. 350.

CLARK, Robert Charles, Corporate Law, Boston, Little Brown, 1988, p. 838.

COASE, Ronald Harry, The Nature of the Firm (1937), in WILLIAMSON, Oliver E., WINTER, Sidney G. (ed.), The Nature of the Firm - Origins, Evolution, and Development, New York, Oxford University Press, 1993, p. 18-33.

COMPARATO, Fábio Konder, Anteprojeto de Lei de Sociedade por Ações, Revista de Direito Mercantil, São Paulo, n. 17, 1975, p. 118-126.

, Os Grupos Societários na Nova Lei das Sociedades por Ações, Revista de Direito Mercantil, n. 23/93, 1976, p. 91-107.

, Consórcios de Empresas, Revista Forense, vol. 256, 1976, p. 5-10.

, O Direito de Subscrição em aumento de Capital, no Fideicomisso Acionário, Revista da Faculdade de Direito da Universidade de São Paulo, v. 76, 1981 , p. 123-144. Disponível em: <http://ojscurso.fflch.usp.br/index.php/ rfdusp/article/view/ 3349/2073>. Acesso em: 05out2013.

, Titularidade do Poder de Controle e Responsabilidade pela Concessão Abusiva do Crédito, in , Direito Empresarial - Estudos e Pareceres, 
São Paulo, Saraiva, 1990, p. 65-74.

, Controle Conjunto, Abuso no Exercício do Voto Acionário e Alienação

Indireta de Controle Empresarial, in

e Pareceres, São Paulo, Saraiva, 1990, p. 81-102. , Direito Empresarial - Estudos

, Na Proto-História das Empresas Multinacionais: o Banco Medici de Florença, in Saraiva, 1990, p. 261-269. , Direito Empresarial - Estudos e Pareceres, São Paulo,

, Grupo Societário Fundado em Controle Contratual e Abuso de Poder do Controlador, in , Direito Empresarial - Estudos e Pareceres, São Paulo, Saraiva, 1990, p. 270-291.

Cabivel, in

, Abuso de Controle em Grupo Societário de Fato: Remédio Jurídico Saraiva, 1990, p. 292-312. , Direito Empresarial - Estudos e Pareceres, São Paulo,

, Die Konzerne in brasilianischen Aktiengesetz, in LUTTER, Marcus (herausg.), Konzernrecht im Ausland, ZGR Sonderheft 11, Berlin, 1994, p. 32-54.

COMPARATO, Fábio Konder, SALOMÃO FILHO, Calixto, O Poder de Controle na Sociedade Anônima, Rio de Janeiro, Forense, 2005, p. 597.

CONAC, Pierre-Henri, Groups of Companies and the Current European Company Law Framework, 2011, p. 4. Disponível em: <http://ec.europa.eu/internal_market/ company/docs/modern/onference201105/conac_en.pdf $>$. Acesso em: 15 set2013.

CORSI, Francesco, FERRARA JR., Francesco, Gli Imprenditori e le Società, 12 ${ }^{\mathrm{a}}$ ed., Milano, Dott. A. Giuffrè, 2001, p. 911.

DAVIES, Paul Lyndon, Gower and Davies' Principles of Modern Company Law, $8^{\text {th }}$ ed., London, Sweet \& Maxwell, 2008, p. 1258.

DERANI, Cristiane, Direito Ambiental Econômico, 2ª ed., São Paulo, Max Limonad, 2001, p. 302.

DETTLING, Heinz-Uwe, Die Entstehungsgeschichte des Konzernrechts in Aktiengesetz von 1965, Tübingen, J.C.B. Mohr (Paul Siebeck), 1997, p. 430.

DINE, Janet, The Governance of Corporate Groups, Cambridge, Cambridge University Press, 2000, p. 208.

DRUERY, Jean Nicolas, Das deutsche Konzernrecht aus der Sicht des übrigen Europa, in GOERDELER, Reinhard, HOMMELHOFF, Peter, LUTTER, Marcus, ODERSKY, Walter, WIEDEMANN, Herbert (herausg.), Zeitschrift für Unternehmens und Gesellschaftsrecht, Sondernheft 11, Berlin, Walter der Gruyter, 1994. p. 310-368. 
DYCK, Alexander, ZINGALES, Luigi, Private Benefits of Control: An International Comparison, The Journal of Finance, vol. 59, No. 2, 2004, p. 537-600. Disponível em: <http://www.jstor.org/stable/3694907>. Acesso em: 27jun2012.

EASTERBROOK, Frank H., FISCHEL, Daniel R., The Economic Structure of Corporate Law, Cambridge, Harvard University Press, 1991, p. 370.

EISENBERG, Melvin Aron, Megasubsidiaries: The Effect of Corporate Structure on Corporate Control, Harvard Law Review, vol. 84., No. 7, 1971, p. 1577-1619. Disponível em: <http://scholarship.law.berkeley.edu/facpubs/2018/>. Acesso em: 18jul2013.

, The Structure of the Corporation - A Legal Analysis, Washignton, Beard Books, 2006, p. 334.

EIZIRIK, Nelson, A Lei das S/A Comentada, São Paulo, Quartier Latin, 2011, vol. II, p. 662.

, A Lei das S/A Comentada, São Paulo, Quartier Latin, 2011, vol. III, p. 662.

EMMERICH, Volker, HABERSACK, Mathias, Konzernrecht - Ein Studienbuch, 9. Auflage, München, C.H. Beck, 2008, p. 556.

FERRI, Giuseppe, Le Società, Torino, Unione Tipografico-Editrice Torinese, 1971, p. 776.

FERRO-LUZZI, Paolo, I Contratti Associativi, Milano, Dott. A. Giuffrè, 1976, p. 392.

FRANÇA, Erasmo Valladão Azevedo e Novaes, Conflito de Interesses nas Assembléias de S.A., São Paulo, Malheiros, 1993, p. 109.

, A Natureza Jurídica dos Fundos de Investimento, Conflito de Interesses Apurado pela Própria Assembleia de Quotistas. Quorum Qualificado para Destituição de Administrador de Fundo, in , Temas de Direito Societário, Falimentar e Teoria da Empresa, São Paulo, Malheiros, 2009, p. 185-215.

, Dever de Informar dos Administradores de Companhias Abertas. Inexistência de Submissão ao Acionista Controlador, in , Temas de Direito Societário, Falimentar e Teoria da Empresa, São Paulo, Malheiros, 2009, p. 361-377.

, Conflito de Interesses e Benefício Particular: Uma Distinção que se Impõe Definitivamente Dirimir, Revista de Direito Mercantil, n§ 161/162, 2012, p. $38-46$.

, A Sociedade em Comum, São Paulo, Malheiros, 2013, p. 192.

FRANÇA, Erasmo Valladão Azevedo e Novaes, VON ADAMEK, Marcelo Vieira, Sociedades de Grande Porte (Lei 11.638/2007, art. $3^{\circ}$ ), in FRANÇA, Erasmo 
Valladão Azevedo e Novaes, Temas de Direito Societário, Falimentar e Teoria da Empresa, São Paulo, Malheiros, 2009, p. 119-146.

, O Novo Conceito de Sociedade Coligada na Lei Acionária Brasileira, in ESTEVEZ, André Fernandes, JOBIM, Marcio Felix (orgs.), Estudos de Direito Empresarial - Homenagem aos 50 Anos de Docência do Professor Peter Walter Ashton, São Paulo, Saraiva, 2012, p. 365-385.

, Empresa Individual de Responsabilidade Limitada (Lei $n^{\circ}$ 12.441/2011): Anotações, in AZEVEDO, Luís André N. de Moura, CASTRO, Rodrigo R. Monteiro (coords.), Sociedade Limitada Contemporânea, Quartier Latin, São Paulo, 2013, p. 40-77.

FRANCO, Vera Helena de Mello, Concentração de Poder Econômico e Grupos não Acionários perante a Ótica do Código Civil, Revista dos Tribunais, Ano 100, vol. 908, 2011, p. 205-229.

GALGANO, Francesco, Lex Mercatoria, Bologna, Il Mulino, 2001, p. 263.

, Direzione e Coordinamento di Società - Art. 2497-2497 septies, in (cur.), Commentario del Codice Civile Scialoja-Branca, Bologna, Zanichelli, 2005, p. 232.

, La Forza del Numero e la Legge della Ragione - Storia del Principio di Maggioranza, Bologna, Il Mulino, 2007, p. 266.

GÉGOUT, Maurice, Filiales et Groupements de Sociétés, Paris, Recueil Sirey, 1929, p 380.

GIERKE, Otto Von, Das Wesen der menschlichen Verbände, Berlin, Gustav Schande (Otto Francke), 1902, p. 32.

, Über die Geschichte des Majoritätsprinzips, in SCHMOLLER, Gustav (herausg.), Schmollers Jarbuch für Gesetzgebung, Verwaltung und Volkswirtschaft im Deutschen Reich, München-Leipzig, Duncker \& Humblot, 1915, 39 J., 2. H, p. 7-29.

GOLDSCHMIDT, L., Universalgeschichte des Handelsrechts, Meisenheim am Glan, Anton Hain, 1957, p. 469.

GONÇALVES NETO, Alfredo de Assis, Sociedade de Advogados, $2^{\mathrm{a}}$ ed., Juarez de Oliveira, 2002, p.

, Direito de Empresa - Comentários aos Artigos 966 a 1.195 do Código Civil, $4^{\mathrm{a}}$ ed., São Paulo, Revista dos Tribunais, 2012, p. 779.

GORGA, Érica, Changing the Paradigm of Stock Ownership from Concentrated towards Dispersed Ownership? Evidence from Brazil and Consequences for Emerging Countries, Cornell Law Faculty Working Papers, 2008, p. 106. Disponível em: $<$ http://scholarship.law.cornell.edu/clsops_papers/42>. Acesso em: $15 \mathrm{abr} 2012$. 
, Direito Societário Atual, Rio de Janeiro, Elsevier, 2013, p. 300.

GORGA, Érica, HALBERSTAM, Michael, Litigation Discovery and Corporate Governance: The Missing Story About the "Genius of American Corporate Law", Columbia Law and Economics Working Paper No. 447, 2013, p. 81. No prelo. Disponível em: $<$ http://ssrn.com/abstract=2239322 >. Acesso em: 01set2013.

GRUNEWALD, Barbara, Gesellschaftsrecht, Tübingen, Mohr Siebeck, 6. Auflage, 2005, p. 436.

GUERREIRO, José Alexandre Tavares, Responsabilidade dos Administradores das Sociedades Anônimas, Revista de Direito Mercantil, no 42, 1981, p. 69-88.

GUYON, Yves, Das Recht der Gesellschaftsgruppe in Frankreich, in LUTTER, Marcus (herausg.), Konzernrecht im Ausland, ZGR Sonderheft 11, Berlin, 1994, p. 76-114.

HANNOUN, Charley, Le Droit et les Groupes de Sociétés, Paris, Librarie Générale de Droit et de Jurisprudence, 1991, p. 322.

HANSMANN, Henry, KRAAKMAN, Reinier, The End of History for Corporate Law, Yale School of Management, 2000, p. 33. Disponível em: $<$ http://ssrn.com/abstract $=204528>$. Acesso em: 30set2011.

, Agency Problems and Legal Strategies, in KRAAKMAN, Reinier, DAVIES, Paul, HANSMANN, Henry, HERTIG, Gerard, HOPT, Klaus J., KANDA, Hideki, ROCK, Edward B., The Anatomy of Corporate Law - A Comparative and Functional Approach, Oxford, Oxford University Press, 2004, p. 21-31.

,Reflections on the End of History for Corporate Law, Yale Law \& Economics Research Paper No. 449, 2012, p. 14. Disponível em: $<\mathrm{http}: / /$ ssrn.com/abstract $=2095419>$. Acesso em 20set2013.

HARRIMAN, Edward Avery, Voting Trusts and Holding Companies, The Yale Law Journal, Vol. 13, No. 3, 1904, p. 109-123. Disponível em: $<$ http://www.jstor.org/stable/783089>. Acesso em: 04fev2012.

HART, Oliver, MOORE, John, Incomplete Contracts and Renegotiation, in Econometrica, Vol. 56, No. 4, 1988, p. 755-785. Disponível em: $<\mathrm{http}: / /$ www.jstor.org/stable/1912698>. Acesso em: 10mai2010.

HERTIG, Gerard, KANDA, Hideki, Creditor Protection, in KRAAKMAN, Reinier, DAVIES, Paul, HANSMANN, Henry, HERTIG, Gerard, HOPT, Klaus J., KANDA, Hideki, ROCK, Edward B., The Anatomy of Corporate Law - A Comparative and Functional Approach, Oxford, Oxford University Press, 2004, p. 71-99.

, Related Party Transactions, in KRAAKMAN, Reinier, DAVIES, Paul, HANSMANN, Henry, HERTIG, Gerard, HOPT, Klaus J., KANDA, Hideki, ROCK, 
Edward B., The Anatomy of Corporate Law - A Comparative and Functional Approach, Oxford, Oxford University Press, 2004, p. 101-128.

HICKS, J. R., The Foundations of Welfare Economics, in The Economic Journal, vol. 49, No. 196, 1939, p. 696-721. Disponível em: <http://www.jstor.org/stable/2225023>. Acesso em: 10abr2013.

HOBSBAWN, Eric, The Age of Capital - 1848-1875, New York, First Vintage Books, 1996, p. 354.

HOFFMANN-BECKING, Michael, Der qualifizierte faktische AG-Konzern - Tatbestand und Abwehransprüche, in ULMER, Peter (hrsg.), Probleme des Konzernrechts: Symposion zum 80. Geburtstag von Wolfgang Schilling, ZHR Beiheft, Heft 62, Heidelberg, Recht und Wirtschaft, 1989, p. 68-86.

HOMMELHOFF, Peter, Die Konzernleitungspflicht, Köln, Carl Heymanns, 1982, p. 545.

HOPT, Klaus J., Legal Elements and Policy Decisions in Regulating Groups of Companies, in SCHMITTHOFF, Clive M., WOOLDRIDGE, Frank, Groups of Companies, London, Sweet \& Maxwell, 1991, p. 81-110.

HOUIN, Roger, Les Groupes des Sociétés en Droit Français, in HOPT, Klaus J., Groups of Companies in European Laws, Walter de Gruyter, Berlin, 1982, p. 45-58.

Instituto de Pesquisa Econômica Aplicada - IPEA, Custo Unitário do Processo de Execução na Justiça Federal, Comunicados do IPEA, n 83, 2011, p. 12. Disponível em: <http://www.ipea.gov.br/portal/images/stories/PDFs/comunicado/110331_comu nicadoipea83.pdf $>$. Acesso em: 10set2013.

IRUJO, José Miguel Embid, Algunas Reflexiones sobre los Grupos de Sociedades y su Regulación Juridica, Revista de Direito Mercantil, n 53, 1984, p. 18-40.

IMMENGA, Ulrich, The Law of Groups in the Federal Republic of Germany, in WYMEERSCH, Eddy (editor), Groups of Companies in the EEC - A Survey Report to the European Commission on the Law relating to Corporate Groups in various Member States, Berlin, Walter de Gruyter, 1993, p. 85-121.

IRTI, Natalino, L'Ordine Giuridico del Mercato, Roma, Laterza, 2001, p. 138.

JAEGER, Pier Giusto, L'Interesse Sociale, Torino, Dott. A. Giuffrè, 1977, p. 250.

, L'Interesse Sociale Rivisitato (Quarant'Anni Dopo), Giurisprudenza Commerciale, vol. 27, fasc. 6, 2000, p. 795-812.

JOHNSON, John G., MILBURN, John G., United States of America vs. Standard Oil Company and Others - Brief on Behalf of Defendants Standard Oil Company and Others, New York, C.G. Burgoyne, 1909, p. 188. Disponível em: <http://ia700409.us.archive.org/32/items/cu31924030066835/cu31924030066835.pd 
f>. Acesso em: 03abr2013.

JOHNSON, Simon, LA PORTA, Rafael, LOPEZ-DE-SILANES, Florencio, SHLEIFER, Andrei, Tunnelling, in The American Economic Review, Vol. 90, No. 2, Papers and Proceedings of the One Hundred Twelfth Annual Meeting of the American Economic Association, 2000, p. 22-27. Disponível em: <http://www.jstor.org/stable/117185>. Acesso em: 22 set2013.

KALDOR, Nicholas, Welfare Propositions of Economics and Interpersonal Comparisons of Utility, in The Economic Journal, Vol. 49, No. 195, 1939, p. 549-552. Disponível em: <http://www.jstor.org/stable/2224835>. Acesso em 07 out2013.

KHANNA, Tarun, YAFEH, Yishay, Business Groups in Emerging Markets: Paragons or Parasites?, in Journal of Economic Literature, Vol. 45, No. 2 (Jun., 2007), p. 331372. Disponível em: <http://www.jstor.org/stable/27646796> . Acesso em: $27 j u n 2012$.

LAMY FILHO, Alfredo, PEDREIRA, José Luiz Bulhões, A Lei das S.A., $3^{\mathrm{a}}$ ed., Rio de Janeiro, Renovar, Vol. I, 1997, p. 508.

, Estrutura da Companhia, in LAMY FILHO, Alfredo, PEDREIRA, José Luiz Bulhões (coords.), Direito das Companhias, Rio de Janeiro, Forense, vol. I, 2009, p. 775-870.

LAMY FILHO, Alfredo, Responsabilidade do Acionista Controlador Estrangeiro, in LAMY FILHO, Alfredo, PEDREIRA, José Luiz Bulhões, A Lei das S.A., $2^{\mathrm{a}}$ ed., Rio de Janeiro, Renovar, 1996, vol. II, p. 204-216.

, O Acionista Controlador na Nova Lei de S.A., in Temas de S.A. - Exposições Pareceres, Rio de Janeiro, Renovar, 2007, p. 149-165.

, Financiamentos Bancários a Empresa Associada, in , Temas de S.A. - Exposições Pareceres, Rio de Janeiro, Renovar, 2007, p. 329-334.

, Responsabilidade do Administrador por Ato Praticado no Exercício da Função - A Dificil Caracterização do Risco Envolvido, in S.A. - Exposições Pareceres, Rio de Janeiro, Renovar, 2007, p. 409-414.

LA ROSA, Antonio Pavone, Le Società Controllate - I Gruppi in COLOMBO, G. E., PORTALE, G. B., Trattato delle Società per Azioni, Torino, UTET, Vol. 2, Tomo II, 1991, p. 581-664.

LAZZARESCHI, Alfredo Sérgio Lazzareschi Neto, Lei das Sociedades por Ações Anotadas, $4^{a}$ ed., São Paulo, Saraiva, 2012, p. 914.

LAZZARINI, Sérgio Giovanetti, Capitalismo de Laços: Os Donos do Brasil e suas Conexões, Rio de Janeiro, Elsevier, 2011, p. 184.

LEÃES, Luiz Gastão Paes de Barros, Sociedades Coligadas e Consórcios, Revista de 
Direito Mercantil, São Paulo, n. 12, 1973, p. 137-148.

, Proibição de Voto e Conflito de Interesse nas Assembléias Gerais, in , Pareceres, São Paulo, Singular, 2004, v. 1, p. 175-184.

, A Prévia Deliberação Assemblear Como Condição de Legitimatio ad Causam na Ação Social, in p. 461-470. , Pareceres, São Paulo, Singular, 2004, v. 1,

, Ação Social Derivada de Responsabilidade Civil dos Administradores, in , Pareceres, São Paulo, Singular, 2004, v. 1, p. 705-714.

LOBO, Carlos Augusto da Silveira, Conflito de Interesses entre a Companhia e seu Administrador, in , Advocacia de Empresas, Rio de Janeiro, Renovar, 2012, p. 19-36.

LOBO, Jorge Joaquim, Grupos de Sociedades, Rio de Janeiro, Forense, 1978, p. xxiv, 140.

, Direito dos Grupos de Sociedades, Revista de Direito Mercantil, Industrial, Econômico e Financeiro, São Paulo, v.36, n.107, jul./set. 1997, p. 99-122.

LUCENA, José Waldecy, Das Sociedades Limitadas, 6a ed., Rio de Janeiro, Renovar, 2005 , p. 1.142 .

, Das Sociedades Anônimas - Comentários à Lei, Rio de Janeiro, Renovar, 2012, vol. III, p. 1.272.

MACEDO, Ricardo Ferreira de, Limites de Efetividade do Direito Societário na Repressão ao Uso Disfuncional do Poder de Controle nas Sociedades Anônimas, Revista de Direito Mercantil, São Paulo, n. 120, Ano XXXIX, 2000, p. 195-227.

MARANHÃO, Délio, TEIXEIRA FILHO, João de Lima (atualiz.), Sujeitos do Contrato de Trabalho, in SÜSSEKIND, Arnaldo, MARANHÃO, Délio, VIANNA, Segadas, TEIXEIRA, Lima, Instituições de Direito do Trabalho, São Paulo, LTr, vol. I, 2005, p. 290-326.

MARCELO, Paulo Lopes, A Blindagem da Empresa Plurissocietária, Coimbra, Almedina, 2002, p. 123.

MARCONDES, Sylvio, Questões de Direito Mercantil, São Paulo, Saraiva, 1977, p. 300.

MARTINS, Fran, PAPINI, Roberto (atualiz.), Comentários à Lei das Sociedades Anônimas, $4^{\mathrm{a}}$ ed., Rio de Janeiro, Forense, 2010, p. 1128.

MAXIMILIANO, Carlos, Hermenêutica e Aplicação do Direito, 19ª ed., Rio de Janeiro, Forense, 2006, p. 342.

MENGONI, Luigi, Conflitto di Interessi in Materia Sociale, Rivista delle Società, Anno I, 
Fascicolo 1, 1956, p. 434-464.

MESSINEO, Francesco, Le Società di Commercio Collegate (c.d. Società a Catena), Padova, Cedam, 1932, p. 48.

MICKLETHWAIT, John, WOOLRIDGE, Adrian, The Company - A Short History of a Revolutionary Idea, New York, Modern Library, 2005, p. 230.

MIRANDA, Francisco Cavalcanti Pontes de, Tratado de Direito Privado, Campinas, Bookseller, 2000, tomo I, p. 670. III, p. 716

, Tratado de Direito Privado, São Paulo, Revista do Tribunais, 2012, tomo

MISHKIN, Frederic S., From the Subprime to the Global Financial Crisis, The Journal of Economic Perspectives, vol. 25, n. 1, 2011, p. 49-70. Disponível em: $<$ http://www.jstor.org/stable/23049438>. Acesso em: 27 out2013.

MORCK, Randall, WOLFENZON, Daniel, YEUNG, Bernard, Corporate Governance, Economic Entrenchment, and Growth, Journal of Economic Literature, Vol. 43, No. 3, 2005, p. 655-720. Disponível em: <http://www.jstor.org/stable/4129473>. Acesso em: $12 \mathrm{abr} 2013$.

MUNHOZ, Eduardo Secchi, Empresa Contemporânea e Direito Societário: Poder de Controle e Grupos de Sociedades, São Paulo, Juarez de Oliveira, 2002, p. 344.

, Desconsideração da Personalidade Jurídica e Grupos de Sociedades, Revista de Direito Mercantil, Industrial, Econômico e Financeiro, São Paulo, v. 43, n.134, abr./jun. 2004, p.25-47.

, A Importância do Sistema de Solução de Conflitos para o Direito Societário: Limites do Instituto da Arbitragem, in YARSHELL, Flávio Luiz, PEREIRA, Guilherme Setoguti J. (coords.), Processo Societário, São Paulo, Quartier Latin, 2012, p. 77-99.

, Estrutura de Governo dos Grupos Societários de Fato na Lei Brasileira: Acionista Controlador, Administradores e Interesse de Grupo, in CASTRO, Rodrigo R. Monteiro, WARDE JÚNIOR, Walfrido Jorge, GUERREIRO, Carolina Dias Tavares (coords.), Direito Empresarial e Outros Estudos em Homenagem ao Professor José Alexandre Tavares Guerreiro, São Paulo, 2013, p. 267-291.

MUSACCHIO, Aldo, Experiments in Financial Democracy - Corporate Governance and Financial Development in Brazil - 1882-1950, New York, Cambridge, 2009, p. 298.

NENOVA, Tatiana, The Value of Corporate Votes and Control Benefits: A Cross-country Analysis, Journal of Financial Economics, vol. 68, 2003, p. 325-351. Disponível em: $<\mathrm{http}: / /$ dx.doi.org/10.1016/S0304-405X(03)00069-2>. Acesso em 02jul2012. 
NEVES, A. Castanheira, A Distinção entre a Questão-de-Facto e Questão-de-Direito e a Competência do Supremo Tribunal de Justiça Como Tribunal de "Revista", in. , Digesta - Escritos acerca do Direito, do Pensamento Jurídico, da sua Metodologia e Outros, Coimbra, Coimbra Editora, 1995, vol. 1, p. 483-513.

NOTARI, Mario, Disposizioni Generali. Conferimenti. Azioni, in ABRIANI, Niccolò (et ali), Diritto delle Società - Manuale Breve, Milano, Giuffrè, 2004, p. 117-156.

PARGENDLER, Mariana, O Direito Societário em Ação: Análise Empírica e Proposições de Reforma, Revista de Direito Bancário e do Mercado de Capitais, vol. 59, 2013, p. 215-255.

PEDREIRA, José Luiz Bulhões, Dispositivos da Lei das S.A. Revogados pela Lei $n^{\circ}$ 7.958/89, in LAMY FILHO, Alfredo, PEDREIRA, José Luiz Bulhões, A Lei das S.A., $2^{a}$ ed., Rio de Janeiro, Renovar, 1996, vol. II, p. 352-376.

, Acordo de Acionistas sobre Controle de Grupo de Sociedades, Revista de Direito Bancário e do Mercado de Capitais, vol. 15, 2002, p. 226-248.

, Sociedades Coligadas, Controladoras e Controladas, in LAMY FILHO, Alfredo, PEDREIRA, José Luiz Bulhões (coords.), Direito das Companhias, Rio de Janeiro, Forense, vol. II, 2009, p. 1921-1998.

PENNISI, Roberto, La Disciplina delle Società soggette a Direzione Unitaria ed il Recesso nei Gruppi, in ABBADESSA, P., PORTALE, G. B., Il Nuovo Diritto delle Società, Torino, UTET, Vol. 3, 2007, p. 889-944.

PENTEADO, Mauro Rodrigues, Consórcio de Empresas, São Paulo, Pioneira, 1979, p. 176.

, Eleição de Administradores em Sociedades Filiadas a Grupos Societários, Revista de Direito Mercantil, n. 40, 1980, p. 164-166.

p. 315.

, Dissolução e Liquidação de Sociedades, 2a. ed., São Paulo, Saraiva, 2000,

PEREIRA NETO, Edmur de Andrade Nunes, Anotações sobre os Grupos de Sociedades, Revista de Direito Mercantil, Industrial, Econômico e Financeiro, São Paulo, v. 30, n. 82, abr./jun. 1991, p. 30-38.

PETITPIERRE-SAUVAIN, Anne, Droit des Sociétés et Groupes de Sociétés, Genève, Georg, 1972, p. 262.

PICCIOTTO, Sol, Regulating Global Corporate Capitalism, Cambridge, Cambridge University, 2011, p. 572.

PRADO, Viviane Muller, Grupos Societários: Análise do Modelo da Lei 6.404/1976, 
Revista Direito GV, Vol. 1, n. 2, p. 05-28, jun.-dez. 2005, p. 05-27.

2006, p. 271.

, Conflito de Interesses nos Grupos Societários, São Paulo, Quartier Latin, , Transações com Partes Relacionadas: Estratégias Jurídicas, Revista de Direito Bancário do Mercado de Capitais, Ano 12, n 46, 2009, p. 80-102.

PRADO, Viviane Muller, TRONCOSO, Maria Clara, Grupos de Empresas na Jurisprudência do STJ, Revista de Direito Bancário e do Mercado de Capitais, $\mathrm{n}^{\circ} 40$, 2008, p. 87-120.

PRENTICE, Dan D., A Survey of the Law Relating to Corporate Groups in the United Kingdom, in WYMEERSCH, Eddy (editor), Groups of Companies in the EEC - A Survey Report to the European Commission on the Law relating to Corporate Groups in various Member States, Berlin, Walter de Gruyter, 1993, p. 279-329.

, Some Comments on the Law of Corporate Groups, in MCCAHERY, Joseph, PICCIOTTO, Sol, SCOTT, Colin (editores), Corporate Control and Accountability - Changing Structures and the Dynamics of Regulation, Oxford, Claredon, 1994, p. 371-374.

RATHENAU, Walther, Vom Aktienwesen - Eine Geschäftliche Betrachtung, in , Gesammelte Schriften, Berlin, Fischer, 1918, Fünfter Band, p. 123177.

REALE, Miguel, História do Novo Código Civil, São Paulo, Revista dos Tribunais, 2005, p. 272.

REQUIÃO, Rubens, Anteprojeto de Lei de Sociedades por Ações, Revista de Direito Mercantil, São Paulo, n. 17, 1975, p. 111-118.

RIPERT, Georges, Aspects Juridiques du Capitalisme Moderne, Paris, Librairie Générale de Droit et Jurisprudence, 1946, p. 348.

ROITMAN, Horacio, Francesco Galgano y su obra, in GALGANO, Francesco (trad. ROITMAN, Horacio), Grupo de Sociedades - Dirección y Coordinación de Sociedades, Buenos Aires, La Ley, 2007, p. 189-194.

, Los Grupos en el Derecho Argentino, in GALGANO, Francesco (trad. ROITMAN, Horacio), Grupo de Sociedades - Dirección y Coordinación de Sociedades, Buenos Aires, La Ley, 2007, p. 195-212.

ROOVER, Raymond de, The Medici Bank Organization and Management, The Journal of Economic History, Vol. 6, No. 1 (May, 1946), p. 24-52. Disponível em: $<$ http://www.jstor.org/stable/2112995>. Acesso em: 03mar2012.

, The Medici Bank Financial and Commercial Operations, The Journal of 
Economic History, Cambridge, Cambridge University Press, Vol. 6, n 2, nov. 1946, p. 153-172. Disponível em: <http://www.jstor.org/stable/2113081>. Acesso em 14 out2010.

SALOMÃO FILHO, Calixto, A Sociedade Unipessoal, São Paulo, Malheiros, 1995, p. 242. , O Novo Direito dos Grupos, in , O Novo Direito Societário, $1^{\text {a }}$. ed., São Paulo, Malheiros, 1998, p. 169-197. , O Novo Direito Societário, $3^{\mathrm{a}}$ ed., São Paulo, Malheiros, 2006, p. 279.

SALOMÃO NETO, Eduardo, Trust e Deveres de Lealdade e Sigilo na Sociedade Anônima Brasileira, in CASTRO, Rodrigo Rocha Monteiro de, WARDE JÚNIOR, Walfrido Jorge, GUERREIRO, Carolina Dias Tavares (coords.), Direito Empresarial e Outros Estudos em Homenagem ao Professor José Alexandre Tavares Guerreiro, São Paulo, Quartier Latin, 2013, p. 293-335.

SANTAGATA, Renato, Autonomia Privata e Formazione dei Gruppi nelle Società di Capitali, in ABBADESSA, P., PORTALE, G. B., Il Nuovo Diritto delle Società, Torino, UTET, Vol. 3, 2007, p. 799-830.

SCHMIDT, Karsten, Gesellschaftsrecht, 4. Auflage, Köln, Carl Heymanns, 2002, p. 1964.

SCONAMIGLIO, Giuliana, Danno Sociale e Azione Individuale nella Disciplina della Responsabilità da Direzione e Coordinamento, in ABBADESSA, P., PORTALE, G. B., Il Nuovo Diritto delle Società, Torino, UTET, Vol. 3, 2007, p. 947-971.

SILVA, José Afonso da, Curso de Direito Constitucional Positivo, 33 ${ }^{\text {a }}$ ed., São Paulo, Malheiros, 2010, p. 926.

SIMONSEN, Mario Henrique, A Imaginação Reformista, SIMONSEN, Mario Henrique, CAMPOS, Roberto de Oliveira, A Nova Economia Brasileira, Rio de Janeiro, J. Olympio, 1974, p. 119-150.

, Os Desafios do Desenvolvimento, in SIMONSEN, Mario Henrique, CAMPOS, Roberto de Oliveira, A Nova Economia Brasileira, Rio de Janeiro, J. Olympio, 1974, p. 175-209.

SOUSA, Irineu Evangelista de (Visconde de Mauá), Autobiografia: Visconde de Mauá, Brasília, Conselho Editorial do Senado Federal, 2011, p. 334.

SPINELLI, Luis Felipe, Conflito de Interesses na Administração da Sociedade Anônima, São Paulo, Malheiros, 2012, p. 310.

TOMBARI, Umberto, Diritto dei Gruppi di Imprese, Milano, Giuffrè, 2010, p. 216.

TEIXEIRA, Egberto Lacerda, GUERREIRO, José Alexandre Tavares, Das Sociedades Anônimas no Direito Brasileiro, São Paulo, José Bushatsky, 1979, vols. I e II, p. 885. 
TEIXEIRA, Egberto Lacerda, Das Sociedades por Quotas de Responsabilidade Limitada, $2^{a}$ ed., São Paulo, Quartier Latin, 2006, p. 448.

TEUBNER, Gunther, Die „Politik des Gesetzes“ im Recht der Konzernhaftung - Plädoyer für einen sektoralen Konzernduchgriff, in JÜRGEN, Baur F., HOPT, Klaus J., MAILÄNDER, Peter K. (Herausg.), Festschrift für Ernst Steindorff Zum 70. Geburtstag, Berlin, Walter de Gruyter, 1990, p. 261-279.

, The Many-Headed Hydra: Networks as Higher-Order Collective Actors, in MCCAHERY, Joseph, PICCIOTTO, Sol, SCOTT, Colin (editores), Corporate Control and Accountability - Changing Structures and the Dynamics of Regulation, Oxford, Claredon, 1994, p. 41-60.

VACRATE, Sabine, La Société Créée de Fait, Essai de Théorisation, Paris, Librarie Générale de Droit et de Jurisprudence, 2003, p. 408.

VAlZER, Amedeo, Il Potere di Direzione e Coordinamento di Società tra Fatto e Contratto in ABBADESSA, P., PORTALE, G. B., Il Nuovo Diritto delle Società, Torino, UTET, Vol. 3, 2007, p. 833-885.

VAMPRÉ, Spencer, Das Sociedades Anonymas, São Paulo, Pocai-Weiss, 1914, p. 682.

VARGAS, Manoel, Grupo de Sociedades, in Alfredo, PEDREIRA, José Luiz Bulhões (coords.), Direito das Companhias, Rio de Janeiro, Forense, vol. II, p. 2051-2072.

VENTORUZZO, Marco, Experiments in Comparative Law: The Recent Italian Reform and the Dubious Virtues of a Market for Rules in the Absence of Effective Regulatory Competition, in VENTORUZZO, Marco (org.), Nuovo Diritto Societario e Analisi Economica del Diritto, Milano, Egea, 2005, p. 165-213.

VERÇOSA, Haroldo Malheiros Duclerc, Teoria Geral das Sociedades Comerciais, in , Curso de Direito Comercial, São Paulo, Malheiros, Vol. 2, 2006, p. 560.

VIO, Daniel de Avila, Prova Difícil e Inadimplemento da Obrigação de Contratar em Condições Equitativas nos Termos da Lei das S.A., Revista de Direito Privado, Ano 14, vol. 55, 2013, p. 227-262.

VIVANTE, Cesare, Trattato di Diritto Commerciale, $5^{\text {a }}$ ed., Milano, F. Vallardi, 1923, vol. II, p. 577.

, Proposte per la Riforma delle Società Anonime, Il Foro Italiano, Anno LX. Vol. LX, XIII, Parte Quarta, Monografie e Varietà, Roma, 1935, p. 1-24. Disponível em: <http://www.jstor.org/stable/23133928>. Acesso em: 28 out2013.

VON ADAMEK, Marcelo Vieira, Responsabilidade Civil dos Administradores de S/A e as Ações Correlatas, São Paulo, Saraiva, São Paulo, 2010, p. 618. 
WALD, Arnoldo, A Teoria dos Grupos de Sociedades e a Competência do Juizo Arbitral, Revista de Direito Mercantil, n. 35, n. 101, 1996, p. 21-26.

, Caracterização do Grupo Econômico de Fato e suas Consequências quanto à Remuneração dos Dirigentes de suas Diversas Sociedades Componentes, Revista de Direito Bancário e do Mercado de Capitais, vol. 25, p. 145, Jul/2004 (versão RT Online), p. 12.

WALD, Arnoldo, EIZIRIK, Nelson, A Designação "Grupo de Sociedades" e a Interpretação do Art. 267 da Lei das S/A, Revista de Direito Mercantil, Ano XXIII, n. 54, 1984, p. 51-66.

WARDE JR., Walfrido Jorge, O Fracasso do Direito Grupal Brasileiro: a Institucionalização do Controle Oculto e de sua Sub-Reptícia Transferência, in ARAUJO, Danilo Borges dos Santos Gomes de, WARDE JR., Walfrido Jorge (orgs.), Os Grupos de Sociedades - Organização e Exercício da Empresa, São Paulo, Saraiva, 2012, p. 115-150.

WIEDEMANN, Herbert, Gesellschaftsrecht - Ein Lehrbuch des Unternehmens- und Verbandsrecht - Band I-Grundlagen, München, Beck'sche, 1980, p. xxxii, 905.

, Die Unternehmensgruppe im Privatrecht, Tübingen, J.C.B. Mohr (Paul Siebeck), 1988, p. 153.

, The German Experience with the Law of Affiliated Enterprises, in HOPT, Klaus J., Groups of Companies in European Laws, Walter de Gruyter, Berlin, 1982, p. 21-44.

WORLD BANK, Doing Business 2012 - Economy Profile: Brazil, 2012, p. 106. Disponível em: <http://www.doingbusiness.org/ /media/fpdkm/doing business/ documents/ profiles/country/BRA.pdf.>. Acesso em: 12abr2012.

WYMEERSCH, Eddy, The Groups of Companies in Belgian Law, in WYMEERSCH, Eddy (editor), Groups of Companies in the EEC - A Survey Report to the European Commission on the Law relating to Corporate Groups in various Member States, Berlin, Walter de Gruyter, 1993, p. 1-83.

, Do We Need a Law on Groups of Companies?, in HOPT, Klaus J., WYMEERSCH, Eddy (eds.), Capital Markets and Company Law, Oxford, Oxford University Press, 2003, p. 575-600.

ZANINI, Carlos Klein, A Responsabilidade da Sociedade Controladora pelas Dívidas da Controlada, in ESTEVEZ, André Fernandes, JOBIM, Marcio Felix (orgs.), Estudos de Direito Empresarial - Homenagem aos 50 Anos de Docência do Professor Peter Walter Ashton, São Paulo, Saraiva, 2012, p. 387-420. 